\author{
Universidad Nacional de La Plata \\ Facultad de Humanidades y Ciencias de la Educación \\ Secretaría de Posgrado
}

\title{
Una articulación de arte y política: dislocaciones y rupturas en la poética de Edgardo Antonio Vigo (1968-1975)
}

\author{
Lic. Ana Liza Bugnone \\ Tesis para optar por el grado de Doctora en Ciencias Sociales \\ Director: Dr. Miguel Ángel Dalmaroni, UNLP - CONICET
}

La Plata, 24 de septiembre de 2013 



\section{RESUMEN}

Esta tesis, que integra los estudios de la Sociología del Arte, se centra en la vinculación de la poética del artista Edgardo Antonio Vigo (1928 - 1997) con la política y lo político, así como con los procesos sociales más generales entre 1968 y 1975. Vigo ocupó una posición emergente en el desarrollo del arte platense y desplegó producciones que emprendieron una poética rupturista con lo establecido por algunos de los cánones tradicionales del arte y sus instituciones, y elaboró propuestas estéticas innovadoras que abarcaban las artes visuales en sus diversas formas.

Se analizan en esta tesis los modos por los que Vigo al mismo tiempo que apunta a cuestionar las estructuras y manifestaciones de las Bellas Artes, lo hace con las formas dominantes de la cultura a través de obras y textos que tendían a desestabilizar los roles de autor, espectador y obra, así como a involucrarse de distintos modos en los acontecimientos políticos de la época. Se estudian, además, las producción de acciones artísticas en el espacio público, que Vigo llamó señalamientos, la utilización y apropiación del discurso y aspectos materiales de lo judicial-administrativo y la edición de la revista ensamblada Hexágono '71 (1971 -1975). En estas zonas de la poética de Vigo se consideran las diversas relaciones entre arte y política, las cuales no han sido lineales ni unidireccionales, sino modos de distorsionar y disentir con las jerarquías, lugares y funciones de los sujetos y objetos del entramado social.

Para la realización de la tesis se produjo un diseño metodológico cualitativo, se utilizaron fuentes documentales y entrevistas. Se desarrolla un análisis de las obras del artista, más que remitiéndolas a una corriente artística particular, haciendo foco en su relación con la situación social y política, especialmente en sus vinculaciones con el particular proceso de subjetivación política de la época. Se procuró para ello realizar una investigación que se detenga de manera pormenorizada en el trabajo artístico y sus particularidades (materiales, técnicas, formas, estrategias de intervención), así como en sus discursos escritos, plasmados en ensayos, artículos y otros textos, para avanzar desde allí hacia un análisis interpretativo y comprensivo de las conexiones y de los efectos que perseguía tal trabajo con los procesos políticos.

Se presentan en los Anexos matrices de datos de los señalamientos y de Hexágono '71, así como un índice razonado de la misma.

\section{Palabras clave:}

ARTE - POLÍTICA - EDGARDO ANTONIO VIGO - SEÑALAMIENTOS HEXÁGONO '71 - DISCURSO JUDICIAL. 


\section{ABSTRACT}

This dissertation is part of the field of Sociology of Arts and focuses on the relationship between the poetics of the artist Edgardo Antonio Vigo (1928-1997) and politics and the political, as well as the general social processes between 1968 and 1975. Vigo occupied an emerging position in the development of local art and carried out productions that undertook a poetics which broke with some traditional canons of art and their institutions, and he also made innovative aesthetic proposals in visual arts.

We analyze the ways in which Vigo, while questioning structures and manifestations of Beaux Arts, did it with the dominant culture forms through works and texts that tended to destabilize the roles of author, spectator and work, as well as to be involved in political events. We also study the production of artistic actions in the public space, which Vigo called señalamientos [signalings], the use and appropriation of the judicialadministrative discourse and materials, and the publication of the assembling magazine Hexágono '71 (1971-1975). In these zones of Vigo's poetics we consider diverse relationships between art and politics, which were not linear or one-way, but means of distorting and dissenting from hierarchies, places and roles of subjects and objects in society.

To prepare this dissertation we produced a qualitative research design and used documental sources and interviews. We developed an analysis of Vigo's works, focusing on the relationship with the social and political situation and the process of political subjectivation of that time, rather than following a specific artistic movement. The research discusses in detail the artistic work and its distinctive features (materials, techniques, forms, strategies of intervention), as well as Vigo's written discourses expressed in essays, articles and other texts, to progress from there to an interpretative and comprehensive analysis of the connections and effects pursued by those works with regard to the political process.

In the Appendix we include data matrices of señalamientos and Hexágono '71, and an index of this magazine.

\section{Key words}

$$
\begin{aligned}
& \text { ART - POLITICS - EDGARDO ANTONIO VIGO - SENALAMIENTOS } \\
& \text { [SIGNALINGS]-HEXÁGONO '71 - JUDICIAL DISCOURSE. }
\end{aligned}
$$




\section{ÍNDICE}

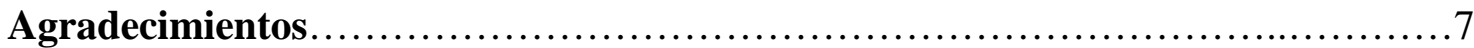

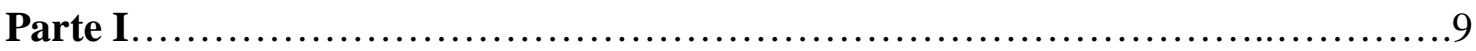

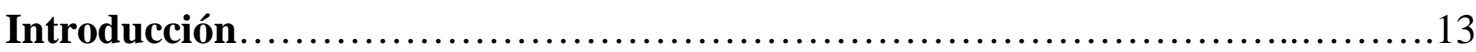

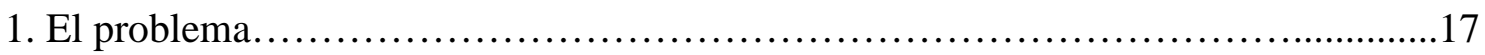

2. Las hipótesis ............................................................ 20

2. Estado de la cuestión y proposiciones teóricas generales.............................22

4. Trama histórico-social y artística del problema..............................................................45

4.1. Cultura, arte y revolución.................................................... 49

4.2. Un acercamiento a la biografía de Vigo.....................................55

5. Definiciones metodológicas y dispositivos de investigación.......................65

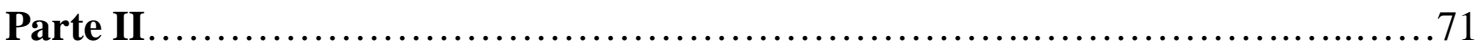

Capítulo 1. Los sujetos del arte trastocados................................... 75

1.1. Obra, artista, público, institución: "un arte contradictorio".........................75

1.2 La participación del espectador............................................ 81

1.2.1. Algunos casos de propuestas participativas y "clavesmínimas"....................91

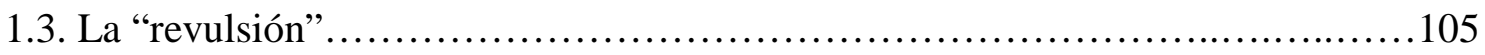

1.4. "El artista es el opio del arte" ................................................ 108

1.5. Las instituciones en crisis................................................... 114

1.5.1. Maniobras estratégicas: intervenciones en el Di Tella y el

CAYC.

1.5.2. El paradojal Museo de la Xilografía: del "MuseoMuselina"

a la valija itinerante.

1.5.3. "Medios de comunicación novísimos” y crítica

institucional 
2.1. Espacio público, arte y política........................................... 147

2.2. "Un arte en la calle no es sacar lo viejo a tomar sol" ............................150

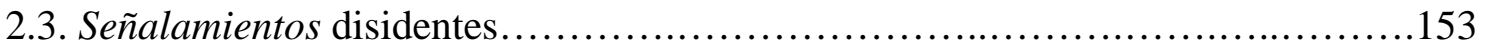

2.3.1 Manojo de semáforos..............................................156

2.3.2 Poema demagógico...................................................161

2.3.3. Un paseo visual por la plaza Rubén Darío...................................172

2.3.4. 5' de filmación en el monumento de B. Mitre y Tres actos

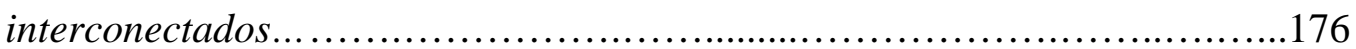

2.3.5. Souvenir del dolor.................................................. 179

2.4. Serie y ritualización......................................................... 191

2.5. “El 'señalamiento' desencadena, no limita".................................... 195

Capítulo 3. Usos y dislocaciones del discurso judicial............................201

3.1. "Puedo ser un burócrata y sin embargo ser libre" ................................201

3.2. Lenguaje técnico y discurso judicial.......................................205

3.3. La justicia descentrada.................................................. 209

3.3.1. Terminología, certificación y prueba................................211

3.3.2. Los temas jurídicos..............................................235

3.4. Deshilvanar el orden social................................................. 241

Capítulo 4. Distorsiones de un soporte: la revista................................251

4.1. Soporte, materialidad y ensamblaje..........................................252

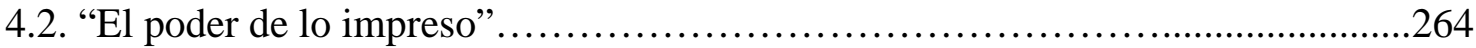

4.3. Voluntad programática..................................................... 265

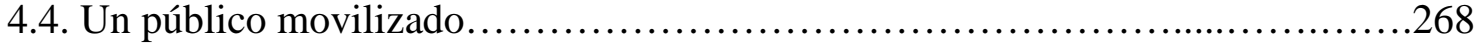

4.5. Primeros seis números.................................................270 
4.6. Últimos siete números................................................228

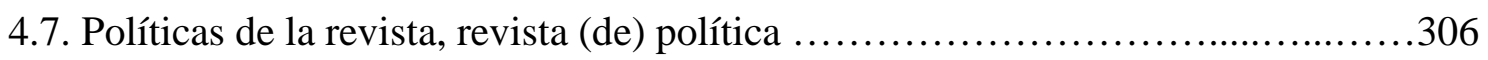

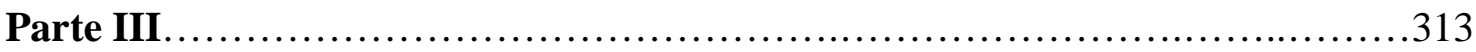

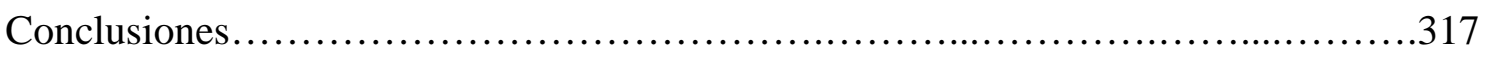

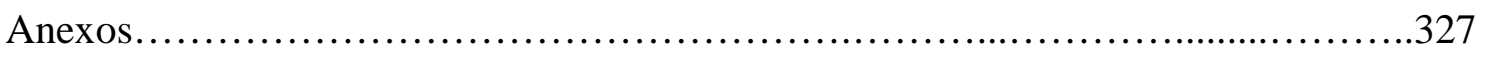

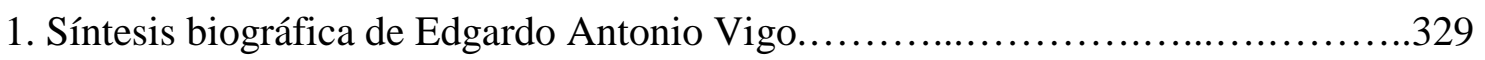

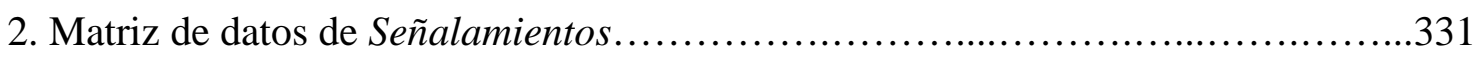

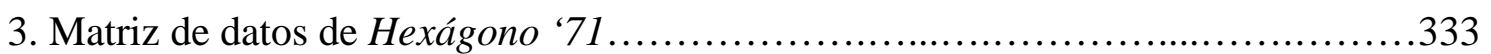

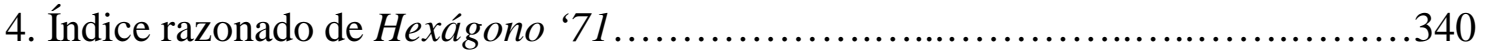

5. Archivo del Centro de Arte Experimental Vigo.....................................360

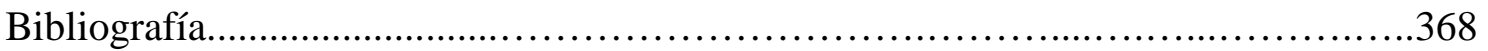

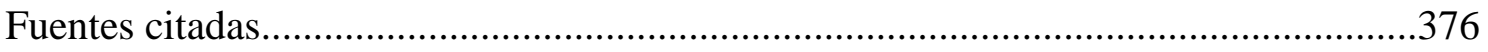




\section{AGRADECIMIENTOS}

Quiero agradecer, en primer lugar, a Miguel Dalmaroni, por su apoyo, sus lecturas lúcidas y su dedicación en el proceso de realización de esta tesis. Debo mucho a su enorme generosidad intelectual y rigurosidad, así como a su mirada crítica que ayudó a que las primeras preguntas que me formulé acerca del arte de los sesenta y setenta se hayan convertido en la investigación que aquí presento. Me gratificó, también -y que no es menos- con su amistad y paciencia.

Agradezco enormemente a Ana María Gualtieri, Mariana Santamaría y Mariana Fuks, del Centro de Arte Experimental Vigo, sin cuyo soporte, apertura e ingenio esta tesis no hubiera sido posible. Pusieron a mi disposición el Archivo de Vigo, permitieron su utilización sin restricciones, brindaron información tanto sobre el acervo documental como sobre la vida artística de Vigo. Me ayudaron, además, a pensar, dudar e interpretar importantes aspectos de la tesis.

También, al Centro de Estudios de Teoría y Crítica Literaria del Instituto de Investigaciones en Humanidades y Ciencias Sociales, a sus directivos, investigadores y becarios, que incorporaron a una socióloga en el mundo de las letras. Asimismo, a mis compañeros del proyecto de investigación Resistencias de la teoría, estados de la crítica (literatura, arte, cultura: Argentina, 2000-2011), por sus lecturas atentas, ideas y sugerencias. Agradezco a Graciela Goldchluk por el estímulo y la provocación a seguir pensando, a Laura Lenci y a Mora González Canosa, del Centro de Investigaciones Socio Históricas, quienes con sus comentarios nutrieron parte de la tesis, detectaron problemas y apuntaron soluciones.

A la Comisión Nacional de Investigaciones Científicas y Técnicas (CONICET) que financió con becas mis estudios doctorales y el desarrollo de la tesis, así como a Harvard University, cuyo Program for Latin American Libraries and Archives facilitó la digitalización y acceso al Archivo de Vigo.

Agradezco a las personas que he entrevistado para esta tesis, que me brindaron sus recuerdos, historias y vivencias.

Finalmente, a mis padres y hermanas, a Cecilia, Valeria y Victoria, y muy especialmente a Mariano, Blas y Ciro, por el apoyo, la contención y el amor de todos los días. 
PARTE I 
"Las características formales de esas presentaciones (happening, entornos, recorridos, señalamientos) también exigen el abandono físico de esos espacios cerrados (galerías, museos, instituciones consanguíneas del arte), porque indudablemente ya no se adecuan a las necesidades reales de la 'cosa'. Es de ahí pues que el 'artista' (...) busca quemar la etapa de exposición y por sucesivas acciones demuele el uso de las instituciones citadas. Hoy nadie duda de que hay un lugar importante para el creador, el espacio abierto, natural, ya sea de contacto directo con la naturaleza natural o la naturaleza arquitectónica, urbanística (la calle). Además, carguemos el índice en esto, hay razones socio-políticas de compromiso por parte del creador. Este ya no duda de que los 'encierros tradicionales' responden a un sistema económico que exige ciertas reglas que ya no está dispuesto a respetar; por el contrario, son esas reglas las que aceleran la reacción opositora.

La comercialización del arte a través de enjuagues no muy limpios, la inalcanzable economía exigida para exponer, las círculos cerrados de una seudo-cultura oficial que responde al pavoneo de valores intrascendentes y sobre todo no peligrosos para el 'establishment' (léase mensaje directo de la obra o posición del creador) más el alejamiento cada vez más palpable de y hacia la comunidad, son elementos poderosos que juegan en un momento determinado y exigen respuesta a dar por el creador a sí mismo y para con la sociedad".

Vigo. "Hacia una nueva terminología" (Carpeta Poesía visual, s/f). 


\section{INTRODUCCIÓN}

Las representaciones de la cultura de los sesenta y setenta se constituyeron sobre un cúmulo de acontecimientos y discursos que van desde la transformación de diversos ámbitos de la sociedad y la cultura hasta el uso de la violencia política. Como parte de ese proceso, el arte desarrolló su politicidad mediante prácticas históricas particulares, en consonancia con algunos de los cambios sociales y políticos que implicaron un proceso de politización y radicalización social, así como por energías surgidas en el interior del campo. Para el contexto histórico que nos ocupa, el modo en que esa politicidad tomó forma consistió en una compleja articulación de relaciones entre el arte y la política.

Esta investigación se centra en la vinculación de la poética del artista Edgardo Antonio Vigo (1928 - 1997) con la política y lo político, así como con los procesos sociales más generales. Vigo ocupó una posición emergente en el desarrollo del arte platense y desplegó producciones que emprendieron una poética rupturista con lo establecido por algunos de los cánones tradicionales del arte y sus instituciones, y elaboró propuestas estéticas innovadoras que abarcaban las artes visuales en sus diversas formas.

En 1968 puede hallarse en Vigo una teorización más o menos acabada sobre las diversas relaciones del arte con lo social, especialmente en sus críticas a las ideas "burguesas" de autor como genio único e inspirado, la obra como inaccesible e inmutable y el espectador en tanto pasivo receptor de un trabajo terminado. Estas críticas lo llevan a organizar un programa de acción que distorsionará o alterará significativamente los status de los sujetos y la obra. Vigo al mismo tiempo apunta a cuestionar las estructuras y manifestaciones tradicionales de las Bellas Artes, así como las formas dominantes de la cultura a través de obras y textos que tendían a desestabilizar los roles de autor, espectador y obra, como modos de distorsionar y disentir con las jerarquías, lugares y funciones de los sujetos y objetos del entramado social.

Se realiza en esta tesis un análisis de las obras del artista, más que remitiéndolas a una corriente artística particular, haciendo foco en su relación con la situación social y política, especialmente en sus vinculaciones con el particular proceso de subjetivación política de la época. Se procurará para ello realizar un análisis que se detenga de manera pormenorizada en el trabajo artístico y sus particularidades (materiales, técnicas, 
formas, estrategias de intervención), para avanzar desde allí hacia un análisis interpretativo y comprensivo de las conexiones y de los efectos que perseguía tal trabajo con los mencionados procesos políticos.

Esta investigación involucra una perspectiva de análisis no desarrollada previamente para el estudio de la obra de Vigo, cuyo punto de partida es la Sociología, especialmente la Sociología del Arte ${ }^{1}$. Si bien esta rama abarca diversos objetos de estudio, la tesis que aquí se presenta se centra en analizar e interpretar objetos y sujetos del arte en íntima conexión con la sociedad, pensada esta no como contexto externo que estructura y determina el fluir del arte y la cultura, sino más bien en interrelación problemática, coconstructiva y no siempre aislable, fija o estipulable. De allí que más que juicios cerrados, se proponga como resultado de este trabajo abrir nuevas preguntas que avancen en el indeterminable (histórico y a la vez anacrónico) vínculo entre arte y sociedad.

Una cuestión aún no profundizada en los trabajos sobre Vigo, y que nos proponemos abordar, es un análisis de las múltiples vinculaciones de su obra con la política y lo político. La política entendida como una relación de mutua exterioridad entre dos esferas diferenciadas, y lo político, vinculado a la politicidad de la obra, producto del cuestionamiento a los sentidos disponibles no solo del lenguaje artístico sino también del orden social en general. De este modo, una de las razones que vuelven productivos los trabajos precedentes sobre Vigo que se señalan abajo, reside precisamente en que organizan algunas de las bases que nos han conducido a formular interrogaciones pendientes: de qué modos particulares (artísticos, procedimentales, compositivos) se efectúa la "revulsión" de la obra de Vigo y, a la vez, en qué sentido tales prácticas singulares implican una relación con la política.

La investigación abarca el período comprendido entre 1968 y 1975, e incorporamos al análisis zonas aún no trabajadas, aprovechando los avances que se han realizado hasta el momento en el estudio de la obra. En el primer capítulo se analizan las relaciones entre artista, público e instituciones en la poética de Vigo, y se indaga este problema bajo una mirada sociológica que tenga en cuenta el papel de estos, tanto en sus discursos y textos como en sus obras y acciones. El eje sobre el que se articula el capítulo es la forma en

\footnotetext{
${ }^{1}$ Sobre la historia y los problemas de los que se ocupa la Sociología del Arte, ver Bourdieu $(1971,2005)$; García Canclini (1979); Heinich (2010); De la Fuente (2000, 2007); Milner, A. (2010); Zangwill, N. (2002).
} 
que Vigo se propuso trastocar la presencia de los sujetos del arte, desviando, modificando o distorsionando los roles asignados tradicionalmente.

Si bien la insistencia de Vigo sobre estos temas fue señalada en diversos trabajos (Herrera, 2004; Pérez Balbi, 2006; Davis, 2007ª 2009c; Cadabón, 2007; Davidson, 2010, 2011), se procura en esta tesis avanzar sobre una interpretación global que considere el conjunto de los "sujetos del arte" en simultáneo y como parte imprescindible del análisis de sus producciones artísticas en vinculación con la sociedad. Asimismo, se profundiza, desde un punto de vista analítico, en el tipo de trabajos en el que Vigo intentó llevar a cabo su propuesta

En el segundo capítulo se estudian los señalamientos ${ }^{2}$, para lo que partimos del análisis material pormenorizado y completo de las acciones, y los relacionamos con una teorización sobre el espacio público que las vincule, de un modo preciso y particularizado, con la situación histórico-social de la época y con una indagación sobre los modos en que operan en la desarticulación de la organización sensible dominante. Si bien estudios anteriores mencionan los señalamientos y describen algunas de sus características y vinculaciones con la política (Herrera, 2004; Davis 2007a, 2009c; Davidson, 2011), no se había realizado un estudio completo de la totalidad de los presentados en el espacio público ni desde el eje problemático que guía esta tesis.

El tercer capítulo se centra en un aspecto de las producciones de Vigo que aún no ha sido abordado en otras investigaciones: el uso del lenguaje judicial-administrativo en las obras y escritos, así como de materiales procedentes de las prácticas de ese ámbito. Estas presencias, que pueden remitirse al trabajo que mantenía el artista en los Tribunales Judiciales para ganarse la vida, le otorgan una particularidad (técnica, formal) y son utilizadas específica y conscientemente a lo largo de su obra. Proponemos pensar que en esas apropiaciones, Vigo pone en cuestión algunos procesos de exclusión que regulan los lenguajes especiales, fundamentalmente, el judicial, donde los sujetos autorizados para utilizarlos, así como los objetos sobre los cuales puede decirse algo, se encuentran fuera del alcance del lego.

El estudio de la revista Hexágono '71, editada y dirigida por Vigo, conforma el cuarto capítulo. Avanzamos en el análisis e interpretación de la totalidad de los números publicados, e identificamos nuestro problema de investigación tanto en la conexión de

\footnotetext{
${ }^{2}$ Señalamientos es el nombre que Vigo dio a una serie de acciones que consistían en destacar algún hecho u objeto artísticamente.
} 
la revista con los temas políticos como en la combinación que se produce entre estos y una materialidad específica que pone en cuestión modelos del género y de la comunicación. Nuestro trabajo incluye también la organización de un índice razonado completo de la revista. En trabajos previos (De Rueda, 2003b; Davis, 2007a, 2009c; Davidson, 2011) se ha realizado una enumeración de las características fundamentales de la revista, y un análisis de su cercanía con las "urgencias políticas" por el uso de temáticas vinculadas a algunos acontecimientos políticos importantes, sin avanzar más allá de esta afirmación común a otras manifestaciones de artistas e intelectuales de la época. Asimismo, aspectos de la materialidad de la revista han sido señalados por Gradin (2011), quien se centró en el problema de la comunicación.

Para realizar el análisis se realizó un estudio empírico de la poética de Vigo en el período mencionado (es decir, un análisis de las obras en tanto objetos y/o acontecimientos en sus dimensiones técnicas, procedimentales, compositivas, formales, discursivas, etc.), así como de las repercusiones que provocó en la crítica y en menor medida, en el público (en los casos en que estas han podido relevarse). Este estudio ha sido puesto en consonancia con una posición teórica que permita encontrar los puntos claves que pongan en evidencia los modos en que se dan las relaciones entre el arte de Vigo, la política, lo político y algunos aspectos del orden social general.

Desde el concepto de poética -que abarca tanto las obras producidas como los posicionamientos de los artistas en relación con un programa- se analiza la obra artística y ensayística de Vigo, por lo que las ideas del artista vertidas en textos y entrevistas no se utilizarán, como en investigaciones precedentes, a modo de claves interpretativas de la propia obra, sino como objetos de investigación retórica, ideológica y sociológica. Esta decisión metodológica permitió, en primer lugar, tener un acceso científicoanalítico a sus discursos y en segundo lugar, interrogar críticamente algunas afirmaciones que el propio Vigo hizo de su obra y del arte en general, contrastándolas y poniéndolas en tensión con su propia producción artística. De este modo se pudieron establecer e interpretar las contradicciones y vaivenes en el interior de su poética y construir, por tanto, objetivaciones relativas a la densidad y la complejidad de sus prácticas.

Se organizó analíticamente la obra de Vigo en series o grupos de acuerdo con sus características materiales, en lugar de analizarla como un todo indeterminado, o según criterios predominantemente o únicamente cronológicos, para lograr un examen e 
interpretación que tienda a la comprensión de la misma como conjunto, pero considerando las particularidades de su producción que den cuenta de trayectos discrónicos, itinerarios discontinuos o relaciones internas no unidireccionales ${ }^{3}$. Asimismo, esta organización permitió tomar decisiones de periodización suficientemente fundadas, pensar en fases o agrupar prácticas en relación con determinada coherencia material o temática al interior de la obra de Vigo, sin anteponer a tales decisiones la necesaria consideración de la cronología. Se considera que, teniendo un acceso complejo a la obra de Vigo en el período de estudio, esta puede vincularse con aspectos del proceso social que aparecen tanto al interior de la misma como en su relación con lo social y político.

\section{EL PROBLEMA}

Comprender las relaciones entre arte y política, en particular en el caso de la poética de Edgardo Antonio Vigo, resulta problemático si se considera que estas no son lineales ni unidireccionales. Si bien desde la Historia del Arte se ha supuesto en general que esas relaciones obedecen a las influencias que el contexto político ejerció en las producciones artísticas, esta investigación pretende complejizar esa vinculación, teniendo en cuenta que las diferentes formas de encuentro entre la obra de Vigo y la política constituyen un entramado en el que estas no son fijas ni estructuradas. Se considera por ello que el estudio de la poética del artista Edgardo Antonio Vigo, a través de la exploración de sus producciones realizadas en el mundo artístico y las diversas relaciones mantenidas con la política del período, ampliará el análisis y la comprensión del tema.

Vigo forjó una relación tensa y no siempre homogénea con las convenciones más generalizadas acerca de la obra de arte, sus relaciones con la política y la vida, el nexo entre artista y público y las vinculaciones con las instituciones artísticas: premios, museos, galerías, circuitos y agentes de circulación, exposición, valoración y consagración. Sus prácticas emergieron en un contexto de cambios sociales y culturales que marcaron las décadas de los sesenta y setenta a nivel nacional e internacional.

\footnotetext{
${ }^{3}$ Como señala Daniel Link en relación con la periodización de la década de los setenta, "los analistas y críticos de la cultura y el arte se enfrentan (...) con el peligro de articular mecánicamente procesos fácticos y producciones simbólicas, que no tienen los mismos ritmos ni admiten las mismas determinaciones" (2004: 35)
} 
Asimismo, la idea del compromiso con la sociedad y la política iba adquiriendo peso en todos los ámbitos a medida que se asistía a una progresiva radicalización política. Junto al carácter vanguardista en lo estético, los acontecimientos políticos y la politización de la sociedad generaron diversas relaciones del artista con la política que es necesario indagar.

Para ello se tomarán en consideración dos dimensiones: en primer lugar, las prácticas, es decir, acciones llevadas a cabo por Vigo dentro del mundo del arte, tanto visuales como escritas, así como las reacciones de la crítica y del público; en segundo lugar, los discursos sobre la idea de arte y su relación con la sociedad y la política. Además de obras y acciones, este artista generó discursos plasmados en escritos, programas, artículos periodísticos, manifiestos y publicaciones que se referían a la idea de obra de arte, su relación con el público, con las instituciones, así como con la política y con la vida en general. Asimismo, mantuvo relaciones con otros artistas e instituciones artísticas.

Como se dijo arriba, el recorte temporal de esta investigación abarca desde 1968 hasta 1975. Ese período, que no coincide con la idea de década ni con un lapso determinado por los tiempos políticos institucionales, se centra en momentos claves de la poética de Vigo. Hemos considerado que ese recorte se incluye dentro de la "época" de los sesenta y setenta, constituida por un "haz de relaciones institucionales, políticas, sociales y económicas fuera de las cuales es difícil pensar cómo podría haber surgido la percepción de que el mundo estaba al borde de cambiar y de que los intelectuales tenían un papel en esa transformación, ya fuera como sus voceros o como parte inseparable de la propia energía revolucionaria" (Gilman, 2003: 37), producido por eventos tales como la Revolución Cubana, guerra de Vietnam y el antirracismo de Estados Unidos. El año 1968 da comienzo a lo que puede considerarse un período dentro de la vasta obra de Vigo, dado que en ese año produce el primero de sus señalamientos, lo que marca o hace visible un interés específico por vincularse con la realidad social y política de su época de un modo no convencional, y en el que la utilización del espacio público para la concreción de sus obras o acciones excede al interés propio del arte moderno en general, intentando poner en cuestión ciertos hábitos y registros del espacio, lo político y lo social. $^{4}$

\footnotetext{
${ }^{4}$ En cuanto al inicio del período en 1968, han quedado fuera de nuestro objeto la conformación del grupo "Movimiento Diagonal Cero" y la revista Diagonal Cero (1962 y 1969). La revista, de referencia obligada en los estudios de las revistas experimentales de América Latina y el mundo, contiene poesías,
} 
La elección del año 1975 para marcar la finalización del período obedece a que desde ese momento Vigo se ocupó casi centralmente de hacer arte-correo. En el análisis de los documentos de archivo de Vigo y de las entrevistas, se observa a partir de ese año un aumento sistemático del interés por el arte-correo y una disposición menor hacia un tipo de obras en que la participación del público era fundamental. Por ello se consideró que el período iniciado en 1968 finaliza entre los años 1974 y 1975. La gran mayoría de los trabajos realizados por Vigo a partir de esos años mantienen una relación esencial con el arte-correo, ya sea por producciones propias o a pedido de otros artistas para realizar cadenas de cartas. Además, participa de exposiciones de este tipo de arte y él mismo con Horacio Zabala organiza en 1975 la Última exposición internacional de arte correo en la Galería Arte Nuevo de Buenos Aires, en la que intervinieron doscientos artistas de veinticinco países. Vigo consideró relevante desde ese momento trabajar de lleno en el envío de postales o cartas y registrar pormenorizadamente el circuito recorrido por estas. Si bien ya venía desarrollando un interés por el arte-correo, es en este año que se produce un corte en relación con el tipo de trabajos que se encontraba realizando. Aunque Vigo no ha abandonado su interés en el problema del rol del espectador como sujeto activo, ha desplazado desde mediados de los setenta la centralidad de su poética desde la problemática de la acción concreta sobre la obra hacia el medio de comunicación. Así, a partir de aquel momento el problema está enfocado en el modo de circulación del arte, lo que Vigo llamó "circuitos marginales de circulación". La posición anti-institucional que adoptó en aquel momento se centró en el interés sobre un dispositivo de comunicación alternativo que permitiera el movimiento de productos artísticos -en especial, postales y estampillas- por fuera de la organización de museos y galerías tradicionales.

Es posible que el aumento de los niveles de represión general sobre la sociedad y en particular sobre la cultura, especialmente desde el inicio de la dictadura cívico militar en 1976, haya incidido en la decisión de continuar en el arte-correo y no en otro tipo de

grabados, poesías visuales, fónicas y diferentes formas artísticas, y constituyó una marca en la historización del arte contemporáneo. Ambas cuestiones han sido analizadas en diversos trabajos (Davis, 2006, 2007a, 2007b, 2009; Pérez Balbi, 2006; Gradin, 2010; Davidson, 2011; Dolinko, 2008, 2010, 2012a, 2012b). Si bien esta tesis inicia el estudio de la poética de Vigo en 1968, se consideró que la producción de la revista y del grupo (con los que solo coincide por un breve lapso) corresponden a un período anterior. Esta decisión se sustenta, también, en la idea expresada arriba de que las decisiones metodológicas que hemos tomado exceden al recorte cronológico como único elemento a tener en cuenta para la conformación del objeto de investigación. Esto da cuenta, además, de la porosidad y solapamiento de los procesos de producción que conforman una poética artística, donde los cortes temporales y programáticos no pueden ser considerados como rígidas definiciones estancas y unidireccionales. 
acciones u obras artísticas, dado que la vía postal le permitió mantener vinculaciones con otros artistas del mundo y denunciar, a su modo, los resultados del terrorismo de Estado, especialmente, la detención y desaparición de su hijo Abel ("Palomo"). A partir de este evento, Vigo comenzó a hacer una serie de intervenciones (especialmente por arte-correo, pero también a través de otros medios) con la frase "Set free Palomo" y lo convirtió en uno de los temas principales de su producción. Sin embargo, las teorizaciones y propuestas que Vigo venía desarrollando desde 1974 y 1975 hacen hincapié en una decisión programática de involucrarse con un tipo de comunicación "marginal", por lo que los sucesos políticos no pueden considerarse la causa de ese cambio de rumbo, sino una razón más para continuar en él.

\section{LAS HIPÓTESIS}

En un proceso de progresiva politización en el que una ética del compromiso social y político emergía como imperativo para intelectuales, artistas y actores sociales en general, Vigo -como otros artistas de la época- se vinculó con la política a través de la tematización de los acontecimientos políticos más relevantes del período a nivel nacional e internacional (entre ellos, la masacre de Trelew, la figura del Che, la Revolución, la guerra de Vietnam), así como acercándose ideológicamente a organizaciones políticas y cruzando su discurso con el de la nueva izquierda. La relación entre el arte y la política también se dio en la poética de Vigo de un modo menos explícito, en tanto no se trató solo de una dependencia temática. Así, podemos identificar en su obra lo político del arte como generador de un disenso (desequilibrio, disimetría, disidencia) con el orden social dominante, cuyo tenor puede calificarse de político en tanto implicaba modos de abandonar, reemplazar o perturbar el orden de las cosas y las compartimentaciones y ubicaciones de sujetos y funciones. Se trata de una tensión con los sentidos disponibles, "normales" o dominantes de la sociedad que puede identificarse en su poética a través del análisis de sus producciones.

Teniendo en cuenta que para esta investigación no es solo el tema sino también la forma y la materialidad trabajada las que definen sus conexiones con la política, consideramos que la poética de Vigo puede generar un desplazamiento desestabilizante: a la par que con su arte pretendía cumplir una función comunicativa (en un camino más o menos directo que va de la obra a la politización de la sociedad), planteaba una relación donde 
el arte provoca un movimiento que, desencajando las reglas de los lenguajes y la experiencia, configura posibilidades para el surgimiento de nuevas miradas sobre el mundo.

Estos cruces diversos dan cuenta de la politicidad de sus prácticas en el marco de un proceso de politización general de la sociedad. Las dos dimensiones (la vinculación con los acontecimientos de la política y lo político del arte), serán, para esta investigación, parte fundamental de la poética desarrollada por Vigo.

La situación histórica estaba marcada por cambios culturales generacionales, que incluían la liberalización de las relaciones y formas sociales, de la sexualidad, el juvenilismo, los movimientos feministas y contestatarios en general, y allí la obra de Vigo construyó también una nueva mirada del mundo estableciendo contradicciones con el carácter social dominante de la época, a través de obras y discursos que cuestionan los valores, las formas de vida, la represión y la reproducción sociales. Estas rupturas se traducen en intentos de movilizar la experiencia sensible hacia la emergencia de situaciones que no encajen en la totalidad significativa común. Sus producciones artísticas constituyeron una poética que actuaba en dos niveles: en el primero, contradecía los cánones más tradicionales del arte, retomando las prácticas de las vanguardias históricas de las primeras décadas del siglo XX (especialmente, el dadaísmo), y llevando a cabo acciones, producciones y discursos que desafiaban las reglas del mismo; en otro nivel se ubica su relación con el orden social dominante, a través del cual sus producciones se presentan no como reflejo, sino en contraste con el mismo desde diversas politicidades. En este último nivel, si bien pueden identificarse analíticamente los dos modos predominantes referidos arriba (la política y lo político), éstos actuaban en vinculación compleja y en muchos casos superpuesta. Es por ello que la idea de articulación deberá considerarse no como una conjunción homogénea, sino en la producción de un desajustado encuentro de múltiples elementos no siempre perfectamente compatibles que actuaban en registros, formas y materialidades diversos. Así, como hipótesis general se afirma que en la práctica artística y la poética de Vigo convivían la política del arte, donde la política es el tema de la obra y pretende comunicar algo acerca del mundo para lograr una toma de conciencia o acción en el público, y lo político del arte en su confrontación con el carácter social dominante del período. De este modo, la poética de Vigo, además de vincularse con los sentidos políticos previamente instituidos en otros campos, es decir, las ideologías en disputa, también se constituyó como uno de los territorios donde el desequilibrio entre sus 
acciones y las convenciones del orden social tuvo un carácter que puede calificarse como político.

Así, es posible pensar la relevancia de su poética a través de las rupturas que plantea no solo con los cánones del arte sino también con las posiciones que ocupan sujetos y objetos, tiempos y espacios en una determinada red de relaciones sociales. En ese disenso invita a un desborde, más allá de las reglas del campo artístico, de las reglas sociales y culturales.

Esta politicidad no surge a través de un modelo que intente enseñar sobre las desigualdades, inequidades e injusticias del mundo, un patrón que fue arquetípico en algunos artistas de la época (el ejemplo más claro es la obra de Ricardo Carpani), sino de un modo menos explícito y más complejo que Vigo figura a partir de la idea de "revulsión". Este tipo de relación entre arte y política es, entonces, siempre móvil e inestable, porque depende de las normas sociales, culturales y políticas de un momento dado y de las relaciones que se establezcan entre ellas. En ese sentido, puede ubicarse en sus obras una política que no solo cuestiona el orden por la utilización de una temática y un discurso políticos, sino por la forma de su propia construcción.

Los señalamientos realizados en el espacio público, las obras que incorporan el discurso y la materialidad de lo judicial-administrativo y la revista Hexágono ' 71 son tres zonas privilegiadas para analizar la pertinencia de nuestra hipótesis general.

\section{ESTADO DE LA CUESTIÓN Y PROPOSICIONES TEÓRICAS GENERALES}

En cuanto a los trabajos que se han ocupado de un modo general sobre los cambios culturales y artísticos de la época, citaremos los más relevantes.

El rol de los intelectuales frente a la politización y radicalización social de los sesenta y setenta que en algunos casos corría en paralelo al papel de los artistas, ha sido abordado por, Terán (1991, 2004, 2007), Sarlo (1998, 2007), Sigal (1991), Gilman (2003), Casullo (2004). Estos trabajos han indagado los modos por los cuales los cambios culturales y sus sujetos se encontraron inmersos en un clima en que la política parecía ser el centro tanto de las reflexiones como de las acciones (afirmaciones sobre las que volveremos más adelante). Centrado en la modernización del campo intelectual de los sesenta, Terán señala la introducción de nuevas teorías sociales y filosóficas (el estructural funcionalismo, el existencialismo sartreano, la teoría de la dependencia, etc.), así como una relectura del marxismo y del peronismo. En el marco de 
instituciones y publicaciones modernizadoras, las nuevas posiciones teóricas estaban influenciadas por dos hechos de fuerte impacto: la Revolución Cubana, que representaba un ejemplo concreto de cambios profundos, al mismo tiempo que un horizonte posible para países como el nuestro, y la reinterpretación del peronismo, que implicó un abandono de la crítica opositora mantenida por gran parte de la fracción intelectual. Terán ubica las vinculaciones entre intelectuales y política en un triple cruce entre modernización cultural, radicalización política y fuerzas tradicionalistas. En ese entramado el autor se plantea el problema de la creciente pérdida de autonomía del intelectual y del artista frente a una política dadora de sentido y presentada como principal fuente de legitimidad. Al mismo tiempo, una fuerte corriente antiintelectual, alimentada por las visiones de corte populista, proponía a la política como el lugar privilegiado para la construcción de saberes y acciones. En un análisis de las transformaciones en la ideas desde mediados de los cuarenta hasta 1973, Sarlo dice que en la literatura y las artes hubo un pasaje "del compromiso al arte político, de la modernidad y la vanguardia a la revolución" (2007: 17) y, en ese sentido, sostiene que la frase "toda obra de arte es siempre política" define el tono de la época (140). La autora señala la presencia de debates acerca de los modos en que los intelectuales y artistas formarían parte del esperado proceso revolucionario y sobre la necesidad de abandonar el reformismo. Entre fines de los sesenta y principios de los setenta, según Sarlo, la cuestión para los intelectuales -y en todos los campos- era la lucha de clases y la función primordial del proletariado o del pueblo: su especificidad se había "disuelto" en la política. En cuando a los artistas, la autora apunta que la película La hora de los hornos, de Pino Solanas y Octavio Getino y la instalación Tucumán Arde son una muestra de la unión entre prácticas estéticas y políticas, donde la vanguardia estaba puesta al servicio de la revolución.

Casullo se pregunta por las subjetividades creadas entre los sesenta y setenta, la forma en que los ideales de la modernidad parecían realizarse a través de las luchas revolucionarias y los modos en que la cultura respondió a las peticiones de una política que reclamaba heroicidad. En cuanto a las vanguardias artísticas, sostiene que la política "contrae" a la sensibilidad estética, y finalmente la borra, de modo que un "fondo estético-político" deviene en "ético-político" (2004: 16). Sigal afirma que los intelectuales rechazaron la distinción entre esfera política y esfera cultural en una convergencia de vanguardias artísticas y políticas. Si bien decidieron "supeditar las prácticas culturales a los objetivos políticos", ello no significó la pérdida de su 
autonomía, sino, por el contrario, una de sus prácticas más autónomas (2002: 205). Más próxima a la tesis de Terán, Gilman sostiene que durante los sesenta y setenta "la política constituyó el parámetro de la legitimidad de la producción textual y el espacio público fue el escenario privilegiado donde se autorizó la voz del escritor, convertido así en intelectual" (2003: 29). En esa "época" la problemática central fue la valorización de la política y la expectativa revolucionaria, cuyo desenlace parecía inminente.

Preocupados principalmente por los cambios en los intelectuales, estos autores han desarrollado escasamente hipótesis sobre los artistas, por lo que hemos considerado más pertinente desplegar en este apartado las perspectivas de otras investigaciones en estrecha vinculación con nuestro problema de investigación.

Los trabajos de Longoni (1995, 2001, 2004, 2005a, 2005b, 2006), Longoni y Mestman (2000), Giunta (1994a, 1994b, 1997, 1999, 2005, 2008), Fantoni (1993, 1994, 1998) y García Canclini (1973, 1977), realizan registros de los desarrollos de movimientos artísticos de esas décadas y analizan los modos por los cuales la crítica a los cánones tradicionales del arte y un clima de rupturas culturales y generacionales fueron gestando neovanguardias artísticas en Buenos Aires, Rosario y La Plata.

Investigaciones como la de Longoni y Mestman (2000), y Giunta (2008) han profundizado en el estudio de las manifestaciones artísticas que planteaban una ruptura con la institución arte ${ }^{5}$ (Bürger 1997). Entre los hechos más relevantes, se encuentra la producción e instalación colectiva emplazada en la CGT de los Argentinos de Rosario y en Buenos Aires, Tucumán Arde, en 1968. Esta instalación (que refería al progresivo empobrecimiento y exclusión en la provincia de Tucumán) y el proceso previo que incluyó varios eventos durante 1968 implicaron el paso de la situación de “compromiso" a la imbricación directa con la nueva izquierda, así como la ruptura de sus relaciones con las instituciones artísticas que hasta ese momento los había cobijado, especialmente el Instituto Torcuato Di Tella. Luego de la presentación en ambas ciudades, "la política obtura la dimensión artística" y se plantea el paso de la acción artística a la militancia política.

Longoni y Mestman proponen las siguientes características de las vanguardias de los sesenta: experimentación continua, ampliación de los límites del arte, obra serial,

\footnotetext{
${ }^{5} \mathrm{Si}$ bien nos concentraremos en el problema de las instituciones artísticas en el capítulo 1, adelantamos aquí que este concepto, que Bürger (2010) toma de Marcuse, implica las relaciones de producción, distribución y recepción del arte, especialmente puestas en cuestión por las vanguardias históricas, que dejaron en evidencia la entidad de las vinculaciones entre arte y sociedad.
} 
procesual y no artesanal, un nuevo público (participante activo), creación colectiva (cuestionamiento al status del "arte" y del "artista"), actuación por fuera del mercado del arte. Como podrá verse, esta caracterización es coincidente en lo fundamental con la poética desplegada por Vigo en el período de estudio.

También se ha señalado el proyecto de internacionalización del arte argentino y de desarrollo de una vanguardia local en los sesenta, caracterizada por el grado de compromiso asumido por artistas e instituciones con sus proyectos (Giunta, 2008). Esta década estuvo marcada por "la necesidad de borrar las fronteras entre el arte y la vida, de fusionar el arte y la política, el antiintelectualismo, el antiinstitucionalismo, el rediseño y la ampliación del concepto tradicional de 'obra de arte' (a través de happenings, collages, assemblages), la búsqueda de un nuevo público" (Giunta 2008: 18).

Los setenta presentaron diferencias en relación con los años previos (Longoni y Mestman, 2000; Longoni, 2001, 2004, 2006; Giunta 1994a, 2008; Fantoni 1994, 1998): por una parte, los artistas retornaron (críticamente) a las instituciones; y por otra, establecieron vínculos más estrechos con organizaciones y acontecimientos políticos. Así, se modificaron las posiciones adoptadas por los artistas en relación con la política y su vínculo con la violencia.

La obra de Edgardo Antonio Vigo en particular ha sido recientemente estudiada desde el ámbito académico, especialmente a través de las investigaciones desarrolladas en la Universidad Nacional de La Plata. También han escrito ensayos diversos curadores y artistas, así como antiguos compañeros de ruta, que reseñaremos brevemente. Sin perjuicio de ello, hemos privilegiado en este estado de la cuestión los resultados producto del trabajo académico, por sus cualidades científicas fruto de la investigación empírica y reflexión teórica.

En la investigación que llevó a cabo Fernando Davis se historizan las "prácticas críticas en el conceptualismo argentino de finales de los 60 y primera mitad de los 70" (Davis 2009c: 1) Su perspectiva, que puede encuadrarse en la Historia del Arte, enfoca el objeto desde la noción de "conceptualismo". Orientado principalmente por ese encuadre, releva parte de la obra de Vigo como uno de los artistas que forman parte de una historia del tema, y proporciona una valiosa contextualización. En los artículos publicados sobre Vigo, Davis (2002, 2005, 2006, 2007b, 2009a, 2009b, 2009c, 2010) ha relevado, organizado y presentado en un relato historiográfico bien informado, y con una amplia base empírica que abarcó las acciones de Vigo como grabador y como 
creador del Museo de la Xilografía, su participación en el Movimiento Diagonal Cero, su producción de poesía visual y otras obras conceptuales así como su vinculación con el arte-correo. El extenso relevamiento de archivo realizado por el investigador ha sido una de las bases de los posteriores estudios sobre la obra de Vigo, incluyendo esta tesis. ${ }^{6}$

Uno de los énfasis de los trabajos de Davis está en la idea de "revulsión", central y recurrente en los textos del propio Vigo para referirse a su propuesta para hacer y pensar el arte. De allí que este investigador utilice las categorías de "poéticas de la 'revulsión"” y "prácticas "revulsivas" como ejes para describir la obra y sobre todo la poética manifiesta de Vigo. Se refiere con ello al carácter disruptivo de su obra, que resume como "activar la contradicción" (Davis 2007a: 9). Davis hace mención a la relación desestabilizada entre artista y público tomando como referencia la idea de "participación” que Vigo planteó en sus ensayos como clave interpretativa para sus obras. En este mismo sentido, Davis destaca la posición que tomó Vigo a través de sus ensayos sobre el proceso de realización de la obra: "estética de la participación" y "un arte a realizar" son ideas de Vigo que el relato de este investigador permite visualizar y seguir durante el transcurso en que se van manifestando. Ha descripto la vinculación del artista con la poesía visual, como creador y gestor en el campo del arte, tanto a través de la organización de exposiciones como por medio de la revista Diagonal Cero, dirigida y editada por Vigo. Así, ha analizado las poesías visuales de Vigo, interpretando que se trata de desbordes de los límites de la propia poesía. Sobre los señalamientos, Davis sostiene que los realizados en la calle apelan a la "apuesta utópica de conciliar los ámbitos escindidos de arte y vida" (2007b: 5). Para el investigador, la opción radical de la apuesta revulsiva de Vigo ataca el valor "arte", así como los roles tradicionalmente asignados al artista y al público (2007a) y a los circuitos legitimados de circulación. Davis menciona la relación de Vigo con la política, especialmente en la publicación Hexágono '71, así como en algunos señalamientos realizados en la época, en los que, por ejemplo, Vigo hace referencia a la masacre de Trelew. Sobre esto dice Davis que se trata de "conflictuar el espacio del arte con las marcas de la urgencia de la política", por

\footnotetext{
${ }^{6}$ La recurrencia en esta tesis a fuente documentales coincidentes con algunas de las ya utilizadas por Davis y Davidson en sus respectivas investigaciones ha redundado ciertas veces en repeticiones respecto de esos trabajos, especialmente porque ambos han utilizados el fondo documental del archivo de Vigo. La reiteración en nuestra investigación de citas de artículos de diarios y documentos de archivo se justifica, sin embargo, por la decisión metodológica de atender tanto a la materialidad de las obras, como a la ubicación temporal, cultural y social de la obra del artista que permita su adecuada interpretación.
} 
lo que para el investigador la relación entre el arte y la política se da al paso de las necesidades políticas coyunturales.

De Rueda (1997, 2003a, 2003b, 2007), que ha trabajado sobre Vigo también desde la Historia del Arte, realizó un análisis de algunas de sus obras y mencionó su producción entre otros artistas y grupos de la ciudad de La Plata. La investigadora ubica a Vigo en el conceptualismo platense. Se refiere al carácter experimental de la obra de Vigo, y describe su trabajo en la revista Diagonal Cero, así como en la organización de la Expo Internacional de Novísima Poesía '69, y se refiere a algunos señalamientos. En relación con la poesía, De Rueda la vincula con los concretos y dadaístas, que deriva en la poesía proceso y en la vinculación entre autor y espectador. Menciona los cambios ocurridos en el transcurso de la publicación de Hexágono '71, los relaciona, como Davis, con la "politización del medio" (2003a: 17), e interpreta que se enmarca en un proceso más general de toma de conciencia de la realidad por parte de los artistas.

Desde la misma perspectiva, Magdalena Pérez Balbi (2006) realizó un trabajo sobre el "Movimiento Diagonal Cero", historizando sus acciones y producciones entre 1966 y 1969. Analiza las actividades del grupo, describe también la organización y características de la Expo Internacional de Novísima Poesía '69, así como las acciones de cada uno de sus miembros. Pérez Balbi muestra las particularidades de la poesía visual y su utilización en la publicación Diagonal Cero. La mencionada exposición también fue objeto de estudio de Barisone (2012), y la enfoca desde la presencia de la poesía concreta en ese evento. En cuanto a la relación de Vigo con el grabado y sobre Diagonal Cero, Silvia Dolinko (2008, 2009, 2010a, 2010b, 2012a, 2012b) desarrolló un estudio que le permitió afirmar que el artista participó de una red contracultural a través de dicha revista. La extensión de lazos con otros artistas le permitió "generar un polo de irradiación cultural continental, ampliando y complejizando el programa inicial de orgullosa difusión localista" (2012b: 270). La revista, en consonancia con los cambios operados en el campo cultural, tuvo un giro latinoamericanista, que incluye contactos con chilenos, brasileños, uruguayos y mexicanos, entre otros. Dolinko señala que si bien Diagonal Cero no presenta un discurso político explícito, la inclusión de referencias a hechos políticos o poetas relacionados con ellos significa una actitud de compromiso con la situación social y política de su tiempo. El grabado, además, se presenta como un tipo de obra "popular" que le permitía una reproducción sencilla; además, la producción de Vigo en xilografías era novedosa por su rasgo experimental, especialmente por el trabajo que realiza con perforaciones, plegados y tridimensionalidad. La autora destaca 
también el rol de Vigo en la creación del Museo de la Xilografía. Gradin (2010), y ha realizado una descripción de la revista y sus modos de comunicación.

En el Institute of Fine Arts de la Universidad de New York, Vanessa Davidson (2011) presentó su tesis doctoral Paulo Bruscky and Edgardo Antonio Vigo: Pioneers in Alternative Communication Networks, Conceptualism, and Performance (1960s-1980s), y se ocupó de analizar las relaciones entre ambos artistas. Davidson (2009, 2010, 2011) sostiene que, aún con grandes diferencias entre sus producciones, Vigo y Bruscky convergen en proponer el arte como una forma de vida a través de lo que designan como "poéticas del desplazamiento": en el caso de Vigo, mediante el llamado a la participación del público que denominó "Proyectos a realizar", y en el de Bruscky, a través del uso de su propio cuerpo para desplazar la hermeticidad de la obra de arte. Davidson ha estudiado la correspondencia mantenida entre ambos y con Leonhard Frank Duch, y es allí donde encuentra sus puntos de contacto, así como a través del artecorreo. Para la investigadora, "Proyectos a realizar" de Vigo, vinculado a la obra de Duchamp, es un paradigma de participación de arte conceptual enraizado en la poesía y lo lúdico. Davidson también ha estudiado los señalamientos de Vigo y la edición de sus revistas, todo lo cual ha conformado un antecedente productivo para otros trabajos que, como el nuestro, aborden temáticas similares, aunque desde otra perspectiva.

El trabajo que Gradowczyk (2009) realizó para el catálogo de la exposición Maquinaciones. Edgardo Antonio Vigo: trabajos 1953 - 1962 consiste en un pormenorizado estudio de los trabajos de Vigo pertenecientes a lo que reconoce como una primera época de su producción. A través del análisis de las obras producidas por Vigo en el período mencionado, Gradowczyk encuentra vinculaciones permanentes con el dadaísmo y ciertas conexiones con el surrealismo, así tanto como un contacto fundamental -y temprano- con la obra y los ensayos de Marcel Duchamp. El autor ubica el viaje de Vigo a París como un punto de inflexión que da origen a esta etapa, y sostiene que la influencia de estas corrientes es clara en su obra, aunque las reformula y adopta formas y materiales propios. Gradowczyk incluye en su estudio pinturas, collages, y Relativusgir's, nombre que dio Vigo a objetos, collages y dibujos realizados en este período. Para el autor, las series de las "máquinas imposibles" se vinculan con el concepto de repetición de Deleuze, y poseen una relación con las ideas de inestabilidad, disimetría y abertura. Gradowczyk analiza el interés de Vigo en el problema del rol del espectador desde sus comienzos y lo relaciona con el papel social del arte, en la educación del observador por el absurdo y el corrimiento de los límites. Finalmente, el 
autor concluye en que no es posible ofrecer un modelo que explique de forma acabada el desarrollo creativo de Vigo; sin embargo, ofrece una hipótesis de lectura de las "máquinas imposibles" de corte psicologista, en la que identifica cambios en el yo del artista.

Hay, además de los mencionados, otros artículos o notas que analizan algún aspecto de la obra de Vigo, pero de índole ensayística (por ejemplo, Cignoni, 1999), periodística, (como Pacheco, 1997 y Battistozzi, 2008), o bien trabajos académicos que no lo abordan como un objeto de estudio específico sino en el contexto de investigaciones más amplias. Nessi (1982) incluye a Vigo en la Historia del Arte de La Plata, especialmente al referirse a Diagonal Cero, sobre la que afirma que tiene una cuidada presentación y reproducciones, y destaca la presencia de corresponsales en Europa y América Latina; con respecto al Museo de la Xilografía, historiza su creación, explica su funcionamiento y subraya la divulgación que produce de la técnica en diversos espacios. Glusberg (1985) menciona la tarea de Vigo en vinculación con el Centro de Arte y Comunicación (CAYC); López Anaya (1997, 1999) describe brevemente algunos trabajos de Vigo, especialmente los vinculados con el conceptualismo. Longoni (2001, 2008) también lo ubica en el marco de obras conceptualistas y en consonancia con los trabajos de otros artistas del período, mientras que $\operatorname{Kozak}(2007,2012)$ se interesa en el aspecto vinculado con la técnica, la producción de las "máquinas inútiles", la poesía y el arte-correo, y destaca el rol fundamental que tuvo Vigo es esas áreas. Fajole (2003) establece relaciones entre parte de la obra de Vigo y otros artistas vanguardistas, especialmente europeos. Perkins, S. (2005) y Perneczky, G. (1993, 2003) se han ocupado del trabajo editorial de Vigo, sus revistas -que consideran pioneras en el género de las "revistas ensambladas"- y su activa participación en el arte-correo; el segundo destaca también la labor de Vigo en el arte con sellos, y sostiene que él y Clemente Padín son los dos grandes iniciadores de la tendencia de arte alternativo en Sudamérica.

Se han incluido trabajos visuales y escritos de Vigo en numerosos volúmenes y revistas, sin que signifique por ello un estudio de su poética. Encontramos, así, una biografía sumaria e imagen de una de sus obras en el catálogo del Museo Macro editado por Farina, Echen y Rojas (2004) (publicado en ocasión de la donación de dicha obra al museo), información sobre su actuación como "pionero" del arte-correo en García Delgado y Romero (2005), reproducciones y descripción de Diagonal Cero en Aarons y Roth (2009), inclusión de sus poesías en la compilación realizada por Monteleone 
(2010), imágenes del Señalamiento I en el marco del conceptualismo latinoamericano en López (2010), diversas referencias a sus trabajos en relación con los de Juan Carlos Romero en Romero, Davis y Longoni (2010), sucinta reseña de su labor artística en Storr (2010), imagen y referencia a una de sus obras en Plante (2013).

Diversos textos se han escrito sobre Vigo para exposiciones nacionales e internacionales en las que se expusieron obras suyas, tanto colectivas como individuales. ${ }^{7}$ Zabala (1987) resumió en tres términos su observación de los trabajos de Vigo: "transgresión, irregularidad, incertidumbre", y se refirió a la obra del artista para la exposición curada por el propio Vigo donde, además de sus obras, expuso las de otros que intervinieron xilografías suyas; Álvarez Martín (1991) afirmó que el artista logró “moverse marginalmente con respecto al sistema comercial y ser congruente en forma total con la idea de la creatividad sin pautas"(3), y sostuvo que incita a la libertad de acción sobre la obra y a la sublevación reflexiva. El propio Vigo escribió sobre algunos señalamientos e incluyó fotografías de obras en el catálogo de la exposición que compartió con Claudia del Río y Mario Gemin (1993). Ángel Nessi (1994) realizó una entrevista a Vigo para el catálogo de 1954 - 1994, Farina (1995) hizo un breve recorrido por algunas obras de Vigo y afirmó sobre el artista que "como investigador de las reglas del gran juego (del que el arte es parte), su misión (si la tuviera) sería desnaturalizar las normas para mostrar su arbitrariedad, su historicidad" (5). Álvarez (1997) se refirió a su trayectoria y destacó que había producido una obra "no aurática". Morais reprodujo la fotografía de una de las obras que Vigo envió y un texto breve en el catálogo de la I Bienal de Arte Visuales del Mercosur (1997). Gutiérrez Marx (2002), su compañera artística de la dupla "G.E.MarxVigo", compuso una original biografía del artista. Davis (2004), como curador de una muestra de xilografías y ediciones de Vigo, afirmó que en sus grabados “des-construye los signos que componen su sintaxis, los sitúa en los bordes, los dessistematiza". Casanegra (2004) incluyó reproducciones de algunas de sus obras y una breve biografía. Santanera (2009), para la exposición sobre arte-correo de Vigo, expresó que las motivaciones del artista "pionero" para producir ese tipo de trabajos eran la comunicación, la democratización y la circulación de obras fuera de los museos y galerías. Sarmiento (2009) sumó poesías visuales e imágenes de su publicación

\footnotetext{
${ }^{7}$ El listado que sigue no pretende ser exhaustivo de las exposiciones de Vigo, sino una mención de los textos escritos en ellos que hagan referencia su obra.
} 
Diagonal Cero, así como un breve recorrido histórico de su obra. Noorthoorn y Yáñez (2009) publicaron imágenes de objetos, proyectos y otras obras. Battistozzi y Giudici (2010) hicieron lo propio con tarjetas, postales y poesías. Alonso (2011) reunió fotografías de señalamientos y la reproducción de su ensayo “De la 'poesía proceso' a la ‘poesía para y/o a realizar'”. Marín (2012), al igual que Dolinko (2013), incluyó a Vigo entre los artistas grabadores, resaltando la creación de la revista Diagonal Cero y el Museo de la Xilografía.

Fruto de la exposición Arte y política en los '60, se publicó el catálogo homónimo, editado por Giudici (2002). Incluye el período que va desde 1958 hasta 1973. Su curador sostiene que 'afirmar que el arte fue 'reflejo' de esos tiempos trepidantes es simplificar, con una categoría secundarizante propia de las décadas previas a la que nos ocupa. Haciendo parte del torrente de actos e ideas, el arte también intensificó su ritmo, acompasando el de la historia" (9). De esa manera entiende Giudici la relación entre arte y política, y remarca los cambios en los lenguajes y formas estéticas, así como la conjugación de arte y vida. En relación con Vigo, dice que es considerado uno de los padres del arte experimental del país, e incluye un artículo donde menciona algunas de sus obras y acciones, la publicación de "Un arte a realizar" y un breve curriculum vitae. El catálogo editado por Besoytaorube (2004) contiene tres textos sobre la obra de Vigo e imágenes de sus obras, objetos, publicaciones, ediciones, en un período que va desde mediados de los sesenta hasta los noventa. En el primer texto Herrera sostiene que Vigo siempre fue un "libero" y que "entendió el arte como la habilidad de perturbar nuestras propias experiencias del mundo" (2004: 13). La autora realiza un recorrido histórico por los distintos momentos de su trabajo, donde describe la producción de máquinas, objetos, revistas, los libros de artistas, algunos señalamientos y el arte-correo, así como las obras políticas, que Herrera vincula con el "conceptualismo ideológico" y con la politización de artistas e intelectuales. El mismo catálogo reproduce un ensayo de Basualdo (1994), que había sido elaborado para la XXII Bienal Internacional de São Paulo, en la que Vigo participó como uno de los tres artistas argentinos -los otros dos son Libero Badii y Pablo Suárez-, convocados por su curador, Jorge Helft. Según Basualdo, el centro de la obra de Vigo es la comunicación. Así, tanto el arte-correo como la participación del espectador y las obras de corte político se vinculan directamente con el interés por demostrar que "toda actividad artística pertenece fundamentalmente al orden de los fenómenos comunicacionales" (1994: 10). 
Besoytaorube sumó también el mencionado texto de uno de los compañeros de ruta de Vigo, Horacio Zabala (1987).

El referido texto de Gradowczyk (2008) se encuentra en el catálogo que se realizó para la exposición Maquinaciones. Edgardo Antonio Vigo: trabajos 1953 - 1962, donde, además de imágenes, se incorporó una completa cronología de su obra.

Como Zabala, otros colegas de Vigo publicaron ensayos sobre su obra. Entre ellos, Padín $(1997,2007)$ realiza una breve reseña de sus trabajos y destaca su "vocación libertaria"; Romero (1999) dice que Vigo fue un "creador de un estilo de trabajo propio, un militante de la vida, un experimentador y un hombre comprometido con su tiempo" $(\mathrm{s} / \mathrm{p})$.

En la revista $X u l$ se prestó especial atención a los trabajos de Vigo: Rivero (1981) publicó una nota sobre poesía concreta donde Vigo aparece como uno de los iniciadores en Argentina, especialmente por su edición de Diagonal Cero: "reconocida mundialmente aunque ignorada en Argentina" (46); Carrera (1981) también se refirió a Vigo en una historización del concretismo y en relación con el grupo de platenses que publicaban en la mencionada revista; en 1993 Xul presentó un análisis de sus acciones, poesías y objetos.

El grupo "La grieta” organizó y publicó en su folleto La Náusea (1997) conversaciones entre Vigo, Alfredo Bedoya y el público. Allí Vigo plantea algunas impresiones sobre el arte, la comunicación y la necesidad de la Historia del Arte de poner nombre o clasificar las manifestaciones artísticas, situación a la que renuncia por su posición "anarquista". La revista ramona también se ocupó de Vigo, ya que con la presentación y edición de Davis, publicó cinco textos fundamentales del artista ("Hacia el arte del 'objeto"”, "Manifiesto Primera No-Presentación Blanca. Manojo de Semáforos", "Declaración de Edgardo Antonio Vigo entregada a Ángel Osvaldo Nessi el 23 de enero de 1969”, "La calle: escenario del arte actual" y "Sellado a mano") (2007); seguidamente publicó una biografía de Vigo producida por el Centro de Arte Experimental Vigo; y a ello se suman diversas referencias a su obra en relación con el conceptualismo y el arte correo.

En la revista Manglar, editada en Francia, Fajole (2002) dedicó un dossier (en español y francés) a Vigo donde reprodujo textos, manifiestos, artículos, documentos de archivo y ensayos del artista, así como fotografías de sus obras y acciones y una entrevista que se le realizó en Radio Universidad en 1956. Fajole publicó allí un ensayo en el que analiza los Relativuzgir's de Vigo, de la década de los cincuenta, las poesías visuales y su especial relación con el lenguaje matemático, así como las vinculaciones que mantuvo 
con su par francés, Julien Blaine. Realiza menciones a alguna de sus obras, máquinas, acciones y revistas, así como a sus textos y declaraciones; en el mismo dossier sumó también un texto de Sergio Elbuan publicado en 1969 sobre Vigo.

Como se ha visto, trabajos pioneros sobre la obra de Vigo (los citados de De Rueda, Davis, Longoni) han centrado su atención en el carácter conceptualista de la obra de Vigo. En esta tesis, sin embargo, se sostiene que más que la adscripción a una corriente particular, Vigo puede ser estudiado bajo el concepto de poética, que excede las características del conceptualismo. Sin embargo, los resultados de aquellas investigaciones han resultado altamente productivos para el análisis de su obra y, específicamente, en la identificación de rasgos comunes del conceptualismo en América del Sur, en los que la obra de Vigo ha tenido gran relevancia. Es por ello que reseñamos aquí brevemente los resultados de esas definiciones teóricas, enmarcadas en amplios debates sobre su conceptualización y pertinencia para estas latitudes, para vincularlas especialmente con los rasgos de la obra de Vigo que han sido analizados a la luz de dichas teorizaciones.

A los fines de hacer comprensible en qué fenómeno específico del cono sur ha sido incluido Vigo en los trabajos citados, más que una pesquisa de diferenciación e historización sobre el conceptualismo lingüístico y el latinoamericano -que Ana Longoni y otros ya han desarrollado productivamente en nuestro país junto con el grupo que conforma "Red Conceptualismos del Sur" ${ }^{\circ}$ y que excede los objetivos de este trabajo- nos centraremos aquí en una breve referencia de sus múltiples dimensiones.

Imbuidos del giro lingüístico, los pioneros angloamericanos (el grupo británico "Art \& Language", el estadounidense Joseph Kosuth) sostuvieron que el arte conceptual está hecho de conceptos y por ello utiliza fundamentalmente el lenguaje, lo que llevaría a conflictuar la producción de sentido y destacar el carácter inobjetual de sus obras. Lejos de constituir un "estilo coherente y cohesionado", el conceptualismo en que se incluyó a Vigo se trata, según la Red de Investigadores sobre Conceptualismos en América

\footnotetext{
8 "La Red Conceptualismos del Sur se postula como una posibilidad diferente de pensar, hacer, intervenir, concebir, exhibir e historiar políticamente la fuerza disruptiva y la capacidad crítica de las prácticas artísticas 'conceptuales' latinoamericanas". Según esta red "El uso táctico de los términos 'conceptualismos' y 'prácticas conceptuales'. (...) reconoce que dichos términos vienen sirviendo en los últimos veinte años para acometer una tarea historiográfica, teórica y crítica de desjerarquización, impugnación y descentramiento de los relatos canónicos en torno al 'arte conceptual', entendiéndolo no como una tendencia artística específica y acotada sino como una manera diferente de practicar el arte y de comprender su función social." (Red Conceptualismos del Sur, 2009: 2) Ver también Freire, Cristina y Ana Longoni (2009).
} 
Latina, de "un giro radical y definitivo cuyo momento de inflexión puede ubicarse en los años sesenta" (Longoni 2008: 21), distanciándose de la definición más canónica y angloamericana, que "sólo podía concebirse en los términos de una operación lingüística y autoreflexiva" (Davis 2008: 31). Esa mirada fue establecida por Joseph Kosuth de este modo: "la definición 'más pura' del arte conceptual sería decir que constituye una investigación de los cimientos del concepto 'arte"” (Davis 2008: 31). Las reflexiones en torno al abandono de esta lectura inaplicable para muchas producciones del cono sur, han dado lugar a la categoría de "conceptualismo ideológico" o "político". Si bien esto ha generado amplios debates ${ }^{9}$, una de las primeras aproximaciones a esta diferenciación fue realizada en 1974 por Marchán Fiz. Ambas clasificaciones han sido puestas en duda por estrechas o limitadas. Sin embargo, es posible, según Longoni (2007), definir otros rasgos específicos: "su abierta y radical condición política (que no se restringe a una mera cuestión de contenido), así como también su ruptura con el espacio de exhibición institucional, y los intentos de inscribirse en circuitos de comunicación de masas apostando a generar condiciones de recepción colectiva que exceden largamente el público de elite habitual del circuito artístico"; y agrega que más que una crítica a las instituciones artísticas, se han centrado en la esfera pública. Asimismo, este conceptualismo cuestiona la separación entre arte y vida, así como la relación convencionalizada entre arte y política (2007: 156).

En la medida en que Vigo ha sido asumido por los autores mencionados como un conceptualista en ese marco teórico, diferenciándose de sus pares norteamericanos y europeos, es evidente para aquellos que su inserción excede el aspecto lingüístico.

Si bien en los últimos años se ha avanzado en la definición de un conceptualismo propio de la periferia o "descentrado" y distanciado de su homónimo lingüístico emergente en los grandes centros mundiales, algunos aspectos de la obra de Vigo, especialmente los que tratamos en el capítulo 3, pueden ser vinculados con rasgos que evidencian una utilización del lenguaje incluida en aspectos de la primigenia intención del conceptualismo lingüístico. Sin embargo, y considerando la importancia de que otros trabajos profundicen en ese sentido, hemos hecho hincapié en otra caracterización de su obra, que más allá de su carácter conceptualista, adquirió formas expresivas particulares que deben ser analizadas en conjunto y la luz de una interpretación sociológica.

\footnotetext{
${ }^{9}$ Ver, por ejemplo, el debate suscitado entre Jaime Vindel, Ana Longoni, Fernando Davis y Miguel López en Ramona, 82, julio de 2008.
} 
Como queda expresado, el conjunto de las investigaciones desarrolladas y publicadas tanto como las aún en proceso que se ocupan de la trayectoria y la obra de Vigo en general representan un valioso aporte de relevamiento, sistematización, descripción e historización de una parte de la base empírica y de las fuentes disponibles, de especial interés para la prosecución de investigaciones que, como esta tesis, privilegien otros enfoques y preocupaciones desde los que el tema no ha sido explorado más que de modo incidental o preliminar. Desde allí se propone esta investigación plantear temas y la construcción de un objeto particular que implique tanto el trabajo de observación y análisis minuciosos sobre la materialidad de las obras de Vigo, como su vinculación con el procesos histórico y social, acompañados por una reflexión teórica que indague acerca de las especificidades de las vinculaciones del arte con la política en el caso de estudio. Las preguntas acerca de la politicidad de la obra de Vigo, considerada como la política y lo político es, en este sentido, una novedad no abordada anteriormente desde esta perspectiva teórica, conceptual y empírica.

De acuerdo con esto último, resulta productivo presentar las bases teóricas generales que sostienen el desarrollo de la tesis. Es posible afirmar que el arte, como otras esferas de la sociedad, debe ser considerado parte del conjunto del proceso social (Williams, 2003). En este sentido, si bien esta investigación propone el estudio del arte en un lugar y tiempo acotados, no perderá de vista esta definición fundamental que, lejos de concebirlo aisladamente, lo ubica en su contexto global. Sin embargo, es posible considerar que "el arte, aunque claramente relacionado con las otras actividades, expresa ciertos elementos de la organización que, de acuerdo con los términos de esta, sólo podrían haberse expresado de ese modo" (Williams, 2003: 55), lo cual apunta a identificar lo específico de la esfera del arte en un momento y sociedad determinados tanto como su carácter productivo y no meramente reflejo. En esto coincide también la idea de que "el arte, en su forma y producción, provee un lugar desde el cual podemos observar y experimentar aspectos de la vida política a los que no podemos acceder de otro modo", porque se vincula con la agencia humana. Además, es un medio privilegiado que puede ofrecernos información sobre la vida política $y$, junto con la literatura, un lugar para los discursos políticos, dado que pertenece a las circunstancias históricas de tiempo y espacio (Negash, 2004: 188. Traducción nuestra)

Un orden social, y que aparece como "natural”, se trata, según Rancière, de un régimen policial: "el conjunto de los procesos mediante los cuales se efectúan la agregación y el 
consentimiento de las colectividades, la organización de los poderes, la distribución de los lugares y funciones y los sistemas de legitimación de esta distribución" (Rancière, 2007: 43). Asimismo, en ese orden hay un carácter social dominante que "es el resumen de un grupo dominante" (Williams, 2003: 68), y se relaciona con las creencias, valores, virtudes e instituciones centrales de un período. Su existencia no implica, sin embargo, la ausencia de otros caracteres sociales alternativos que se encuentran en relación y tensión con el dominante. Se considerará que entre esos caracteres sociales alternativos, la producción artística moderna y contemporánea adquiere la potencialidad de convertirse en uno de los modos a través de los cuales emerge lo novedoso en relación a los usos, prácticas y discursos usuales, con valores materiales y simbólicos desde los cuales pueden plantearse otros modos de representar, pensar el mundo y hasta de intervenir en él.

Estos modos artísticos se vuelven más o menos manifiestos, en algunos casos, a través de poéticas. Entenderemos por poética "los programas de arte propuestos, discutidos o combatidos por los artistas no sólo en sus obras de arte, sino con escritos y tomas de posición teóricas" (Vattimo 1993: 47). En el siglo XX, que para Vattimo es "el siglo de las poéticas", la enunciación programática ha prevalecido sobre la producción de obras, de modo que las obras son ejemplos o ilustraciones provisorias de las poéticas. Por ello, más que fundar estilos, las poéticas han tendido a responder a problemas de índole más filosóficos -como el significado del arte, la posición del artista en el mundo y su relación con el espectador-. Según Vattimo, en formulaciones próximas a las que tomamos de Rancière, "la obra de arte funda un mundo en cuanto que funda un nuevo sistema de significados (...), no se inserta simplemente en el mundo tal cual es, sino que representa una propuesta de nueva y distinta sistematización del mundo" (1993: 80). En esta investigación hemos considerado que la poética abarca tanto las formulaciones discursivas y programáticas como la producción material del $\operatorname{artista}^{10}$. Ambas permiten considerar las relaciones múltiples que establece con las instituciones, sujetos y objetos artísticos y al mismo tiempo, con el orden social general.

\footnotetext{
${ }^{10}$ En la tesis haremos uso de los términos "obra de arte", "arte" y "artista" para referirnos a lo que comúnmente aluden dichos vocablos. No es nuestro propósito preguntarnos qué es el arte ni distinguirlo de lo que no es. Si bien analizamos las propuestas de Vigo para utilizar otros conceptos que reemplacen a los de uso tradicional, como recaudo metodológico, consideramos que no debe confundirse el programa poético de Vigo y sus categorías "nativas" con las utilizadas en la investigación, excepto cuando hagamos referencia a ellas. Para una reflexión sobre los cambios producidos en la obra de arte a partir de las vanguardias, ver Bürger (2010).
} 
Históricamente y para nuestro caso, se considerará apropiado caracterizar a las vanguardias de posguerra con el concepto de neovanguardias: agrupamientos de artistas que retomaron los procedimientos de vanguardistas de principios del siglo $\mathrm{XX}$, tales como el collage, el ensamblaje, el readymade, la retícula, la pintura monócroma y la escultura construida (Foster, 2001). Para este autor, a diferencia de Peter Bürger (1997), más que restaurar pobremente las prácticas de las vanguardias históricas, las neovanguardias se encargan de "desafiar su status en el presente, las ideas recibidas que deforman su estructura y restringen su eficacia (...) clarificar su estrategia contingente, que es la de reconectar con una práctica perdida a fin de desconectar de un modo actual de trabajar que se siente pasado de moda, extraviado cuando no opresivo" (Foster, 2001: 5). ${ }^{11} \mathrm{Si}$ bien se señalarán algunas salvedades en los capítulos siguientes, es posible hacer un uso estratégico del término neovanguardia para agregar a las características mencionadas el conjunto de prácticas artísticas que tuvieron lugar entre la décadas de los cincuenta y los setenta, cuyos aspectos más sobresalientes son la crítica al estatuto de la obra de arte, de las instituciones artísticas y del artista. ${ }^{12}$

A partir de nuestra definición de poética, uno de los centros de interés de este trabajo está dado por la relación entre arte y política. Sin desconocer el tipo de análisis sociohistórico que suele vincular los dos términos como campos de prácticas reconocidas institucionalmente, es decir como la relación entre dos actividades sociales diferenciadas (Bourdieu 1983, 1990, 2005; Giunta 2008), optaremos por uno integrador que considere también la politicidad propia del arte. Según el enfoque bourdeano, la política es un campo externo al arte, que influye de diversas maneras sobre él. Así, por ejemplo, al analizar las relaciones entre arte y vanguardia artística en los sesenta, Giunta

\footnotetext{
${ }^{11}$ Hemos asumido en esta tesis que la poética de Vigo fue vanguardista. La discusión generada acerca de la productividad de las vanguardias y neovanguardias excede a nuestros intereses. Sobre la emergencia de las vanguardias a partir de los años sesenta y la utilidad del término, remitimos, una vez más a Giunta (2008), Longoni y Mestman (2000) Longoni (2006) y Richard (1990, 2005) En cuanto a la caracterización que realiza Richard, la planteamos en el capítulo 1. El principal crítico de las neovanguardias, Bürger, sostuvo que "pese a que los objetivos que se plantearon las neovanguardias fueron, en parte, los mismos que los movimientos históricos de vanguardia, la pretensión de que el arte regrese a la praxis cotidiana no tiene asidero en la sociedad actual, luego de que fracasaran los movimientos históricos de vanguardia”. De este modo, lo que Duchamp había generado como oposición a la institución arte, más tarde se convirtió en su contrario, un intento de ingreso al museo (Bürger, 2010: 24). Foster, sin embargo, propuso rescatar la noción de neovanguardia y reflexionar sobre su potencialidad crítica. Así, afirma que el retorno por parte de artistas a los modelos anteriores ocurrió "para elaborarlos mediante una práctica reflexiva, para convertir las auténticas limitaciones de estos modelos en una conciencia crítica de la historia, artística o no (2001: 5-6).

${ }^{12}$ Sobre este tema, ver, además de Foster (2001), Buchloh (1990) y una reseña de las teorías sobre las neovanguardias en Del Río (2006).
} 
hace referencia a que en la politización de los artistas hubo "determinantes externos", como el golpe de 1966 y el Mayo Francés, y otros “internos" al campo artístico argentino. Esta conceptualización es la que permite a Giunta pensar en la transformación de los artistas en intelectuales comprometidos, elección en la que Vigo no participó. Según Giunta, antes de 1968 era posible pensar en la noción de autonomía del arte en términos bourdeanos, aunque esta separación se desbarata después de ese año. Así, la autora sostiene que los desplazamientos ocurridos en el campo del arte son "una respuesta a la radicalización política de la sociedad" (1995: 60, subrayado nuestro).

En nuestro caso, en cambio, sostenemos que era posible mantenerse en el marco de una producción artística específica y, al mismo tiempo, vincularse de modos diversos y no lineales y reflejos con los problemas y discursos políticos, aún después de 1968. La cuestión de la autonomía y heteronomía de los artistas más que coadyuvar a la comprensión del tema, resulta limitante ${ }^{13}$. En cambio, el concepto de poética que hemos construido permite visualizar, analizar e interpretar múltiples relaciones entre arte y política.

En este sentido, nos apoyaremos en la distinción que realiza Richard (2005) entre la consideración de "arte y política", como dos esferas separadas y donde emerge el arte militante y de compromiso, y "lo político en el arte" entendido como "una articulación interna a la obra que reflexiona críticamente sobre su entorno social desde su propia

\footnotetext{
${ }^{13}$ Una de las formas de poner en cuestión el viejo dilema de la autonomía y heteronomía es la teoría que desarrolla Rancière (2005). La problemática de la autonomía del arte refiere a dos cuestiones: a la existencia de una esfera autónoma, con criterios y reglas propias, y al supuesto derrumbe de esa autonomía a fines del siglo XX, producido por la caída de los límites que la separan del resto de mundo social. Rancière intenta dar por tierra con la oposición entre autonomía del arte y su contrario, así como terminar con la idea de dicotomía entre arte moderno y postmoderno. Su propuesta supone los amplios debates que han surgido al respecto, así como el fuerte cuestionamiento que se ha realizado a la noción de autonomía del arte, vinculado originalmente con la idea de "arte por el arte", es decir, un arte ajeno al mundo social, libre de condicionamientos y dedicado exclusivamente a la creación. La propuesta de fusionar arte y vida de las vanguardias históricas, y retomado luego por el arte "comprometido" de los años '60, pusieron en jaque esa diferenciación tajante. Frente a esto, y retomando parte de la teoría adorniana, Rancière se propone rescatar la idea de autonomía del arte, pero tensionándola con su opuesta, la heteronomía. Interesa destacar aquí una diferenciación sustantiva que realiza el autor: la esfera de la estética es autónoma en tanto está separada de otras, pero en esa esfera se producen obras de arte que, por el contrario son heterónomas: sus objetos no pueden distinguirse de los de las otras esferas. Para Rancière, este encuentro de autonomía y heteronomía definen el lugar de la política de la estética. Es por ello que no hay oposición entre arte y política, o entre "la pureza del arte y su politización" (2005: 23). Para Rancière, el conflicto está en el seno de su pureza, es decir en el arte como forma de experiencia autónoma. Es desde este lugar que el arte puede instituir nuevas divisiones de lo sensible, justamente porque se propone como una reconfiguración de las formas habituales de esa partición y su representación. Esto es lo que le permite redibujar un espacio común diferente del establecido por el orden, actuando como arte (experiencia específica), pero también como no-arte (promesa de comunidad).
} 
organización de significados y su propia retórica de los medios, desde sus propios montajes simbólicos", que se distingue de la anterior en que aquí no hay una correspondencia dada entre forma artística y contenido social (2005: 17). Partiendo de esta última definición, trabajaremos con una noción de politicidad que permita conceptualizar los modos en que el arte desestructura las convenciones y las expectativas sociales del campo a través de sus producciones, acciones y discursos. Es decir que, además de relacionarse más o menos deliberadamente con la política, el arte será considerado en su capacidad de ejercer presiones, impulsos y energías: a) política y socialmente formativas o productivas; b) cuyos efectos resultan tales porque son disconformes, "disidentes" y "disensuales". Lo que interesa del arte para una mirada sociológica es no solo la historia acontecimental de sus vínculos con la política, ni únicamente sus iniciativas deliberadamente opositoras, sino también su politicidad, esto es, su capacidad no reproductiva, ajena a los insatisfactorios sentidos disponibles y por tanto conflictual, para configurar "experiencia". ${ }^{14}$

Encontramos la matriz teórica general de nuestro enfoque en los trabajos de Rancière (2002a, 2002b, 2005, 2006a, 2006b, 2007a, 2007b, 2008, 2010). Las producciones artísticas, por fuera de las convenciones y expectativas más generalizadas, pueden

\footnotetext{
${ }^{14}$ Además de las conocidas teorizaciones sobre arte y política desarrolladas por la Escuela de Frankfurt (Adorno, 2003, 2005; Marcuse, 1978; Benjamin, 1989, 1990), y por Williams (2002), otros trabajos se han ocupado también de las relaciones entre ambos, especialmente de la forma en que transcurren en la actualidad. Entre ellos, Achugar reflexiona sobre las diferentes formas de concebir lo estético y su relación con la esfera pública y afirma que, más allá de la explicitación del compromiso político, "toda obra de arte por su enunciación en una determinada situación histórica y en una particular situación estética entra en diálogo en otras producciones a las que de hecho, voluntaria o involuntariamente, responde" (1991: 125). Bokina señala que si bien la cuestión de la política del arte parece para la Ciencia Política un asunto periférico o caprichoso, de Platón a Hegel, muchos se han ocupado del arte como un factor crucial de la política. Así, cree conveniente pensar no tanto en las relaciones externas que influyen sobre el arte, sino en "el significado político interno de las obras de arte en sí mismas" (1991: 3). Lukes (1991), preocupado por los efectos políticos del arte en el público, clasifica cuatro tipo de relaciones entre arte y público: el arte del público, el arte en el público, el arte sobre el público y el arte más allá del público. Foster (2003) se pregunta dónde y cómo puede situarse el arte político si ya no puede concebirse en el marco de la lucha de clases. Frente a ello sugiere que no hay una forma específica en que se constituya el arte político, sino que depende de las condiciones socioculturales, ya que lo cultural sería el lugar privilegiado de contestación, y las interferencias que allí se producen pueden afectar los códigos hegemónicos del orden social. Según Negash (2004), la relevancia del estudio de las relaciones entre arte y política se debe a que el arte puede brindar una explicación de las intenciones y motivaciones de la acción humana -que no es posible hacer de otro modo-, así como es un medio privilegiado que brinda información sobre la vida política. Además, cree que es fundamental el rol jugado por intelectuales y artistas en la construcción de sentidos compartidos, dado que le da forma a las ideas políticas. Aznar Almazán e Iñigo Clavo (2007), trabajaron, a partir de la noción de "arte activista", sobre dos formas de relación entre arte y política, la actividad que realiza el artista en el espacio público con fines políticos (o "democráticos") y la de grupos de artistas que se vinculan con colectivos sociales y se alejan de las tradicionales fronteras del arte. Para estas autoras, en el "arte activista", los artistas funcionan como "ciudadanos activistas", vinculados con sus comunidades, y producen un tipo de manifestaciones caracterizadas por lo radical, lo urgente y lo procesual, así como de naturaleza pública y colectiva.
} 
adquirir un carácter político cuando rompen con el normal funcionamiento del régimen de la sensibilidad. Rancière propone pensar la politicidad del arte como "eficacia de un disenso", es decir por un conflicto entre diversos regímenes de sensibilidad que se efectúa por "la discontinuidad de las formas sensibles de la producción artística y las formas sensibles a través de la cuales es aprehendida. (...) [El arte opera] como experiencia de ruptura con la distribución jerárquica de lo sensible" (Rancière 2005: $\mathrm{s} / \mathrm{p}$ ), y reenmarca "la red de relaciones entre espacios y tiempos, sujetos y objetos, lo común y lo singular" (Rancière 2006b: 3 ). ${ }^{15}$

Rancière llama a este modo histórico "régimen estético el arte", que se define por su pertenencia a un sensorium específico, es decir que se trata de una forma sensible heterogénea que se opone a las formas sensibles de la experiencia ordinaria, pertenecientes al orden policial. Se vincula con una nueva forma de comunidad (y de ahí su politicidad), porque define al arte por lo que concierne a ese sensorium que es diferente al de la dominación (2006b, 2010). Se impone, así, una separación entre las formas del arte y las formas por las cuales es aprehendida por el público. Aquí no hay un mensaje, sino una distancia respecto de lo que el arte debe transmitir hacia la comunidad. Por eso se trata de una "disyunción" y una separación. En este régimen opera una experiencia estética que transmuta el orden social, trastocando la división de lo sensible, pero desde su propia especificidad artística, sin fundirse en la comunidad. Allí se encuentra su potencia: es necesaria esa separación estética que libra al arte de todo deber particular. Esta actividad rompe la configuración sensible -es decir lo que se establece como "ley" y que determina el orden de los cuerpos, sus tareas asignadas, así como lo visible y lo decible- y que se manifiesta "por una serie de actos que vuelven a representar el espacio donde se definían las partes, sus partes y las ausencias de partes" (Rancière, 2007: 45, subrayado nuestro), deshaciendo las divisiones sensibles -que también son una construcción, una ficción- del orden policial.

Este régimen se diferencia, para Rancière, de otros dos modos de vinculación entre arte y sociedad, el "mimético" y el "archiético" (2010). En el "régimen de representación

\footnotetext{
${ }^{15}$ Si bien los trabajos del Rancière presentan la base teórica para la construcción del concepto de lo político del arte en nuestra indagación teórica y empírica, su obra abarca otra serie de afirmaciones que exceden o no proceden en la construcción de este marco teórico. Me refiero especialmente a lo que posee de normativo en su descripción del arte en el régimen estético y la particular cualidad de emancipatorio, cuestiones que no abordaremos en esta tesis por resultar ajenas a los términos en que se ha construido nuestro problema. Es por ello que hemos echado mano también a otras herramientas teóricas que permitan conceptualizar la complejidad de lo que llamamos una articulación de cruces entre arte y política.
} 
mimético" el arte se trata de una imitación, una apariencia verosímil y se considera, además, que una obra de arte representa una intención del autor, y que trasmite un mensaje que es captado claramente por el público y que lleva, por ende, a un tipo de acción determinada. Hay una continuidad que va del autor a la obra, y de allí a la comunidad. De este modo, mantiene una intencionalidad pedagógica hacia quienes la reciben.

Frente a este, se propone el régimen "archiético" o "ético", en el que las imágenes se juzgan en función de sus efectos sobre el modo de ser de los individuos y la colectividad. Consiste en la disolución del arte, que se convierte en la comunidad en acto. Ya no hay separación entre el arte y la vida, porque el arte ha traspasado sus barreras para incorporarse directamente a ella.

Si bien este filósofo se encarga de diferenciar los tres regímenes -aunque resalta la productividad del régimen estético y expresa luego que son tres lógicas que trabajan entrelazadas-, en nuestro caso lo que interesa es la distinción analítica específica del estético, que permite conceptualizar a lo político de la poética de Vigo, y la afirmación de que este régimen no actúa solo, sino en vinculación con los otros dos. Ello nos dará pie para avanzar en la conceptualización de que lo político actúa en combinación con la política. $^{16}$

En la política se producen actividades que "dependen inmediatamente de los intereses que giran alrededor del reparto, de la conservación o del traspaso del poder" (Weber, 2000: 6), es decir, se trata de la actividad que se constituye como la lucha por el acceso al poder (en general, del estado) y que en el período trabajado se caracteriza por la emergencia de grupos políticos más o menos radicalizados que enfrentaban el modelo de dominación social vigente a partir de discursos y prácticas políticas definidas y cuyo horizonte, en términos generales, era revolucionario.

En nuestro caso, la política más que la búsqueda del poder por los medios del sistema de representación eleccionario, se trató de la oposición a las diferentes formas de represión que caracterizaron al sistema político argentino desde mediados de los cincuenta con el golpe de estado que desalojó a Perón y su consiguiente proscripción

\footnotetext{
${ }^{16} \mathrm{Si}$ bien hay puntos de encuentro entre Laclau y Rancière, dado que para el primero "lo político está asociado al momento de subversión de lo instituido, de aparición del antagonismo que muestra el carácter contingente del orden social y de la superación de esta dislocación a través de relaciones de poder" (Muñoz, 2006), su aplicabilidad al campo del arte es problemática. Es por ello que no se ha considerado pertinente, así tampoco como la teoría de Schmitt (1999) y se ha creado una herramienta teórica más adecuada al tema y al momento histórico en que se desarrolla.
} 
(Cavarozzi, 1997). Así, cuando definimos a la política como los intereses y las luchas por el reparto del poder, nos referimos al contexto específico de las diferentes formas de disputarlo caracterizadas por una mirada crítica respecto del capitalismo y sus modos de funcionamiento político (O’ Donnell, 1977, 1982). Ello ocurría especialmente en el proceso de constitución de organizaciones políticas y sociales, algunas de ellas decididas a practicar la lucha armada, la militancia barrial, la cercanía con los más desposeídos, seguido de prácticas como la proletarización y movilización, cuyo objetivo final se presentaba cercano al proceso revolucionario según los modelos cubano, chino o soviético (De Riz, 2000; Terán, 1991).

En este sentido, la política del arte se presenta en vinculación con este horizonte de ideas y prácticas, así como con sus discursos críticos del "sistema" y reivindicativos de la lucha política más o menos combativa. La función de la denuncia -que veremos repetidamente en algunos trabajos de Vigo- se ubica en esta forma de arte que critica los modos represivos y disputa una mirada del mundo en el marco de un proyecto político más general, que genéricamente puede llamarse de izquierda.

La conceptualización que hemos realizados de la política y lo político del arte en la poética de Vigo, además de basarse en la referida distinción de Richard, converge con la de otros dos autores que han considerado similares caracterizaciones para pensar el arte y la literatura. Suely Rolnik (2010), señaló dos modos de enfrentarse el arte de los sesenta y setenta con la violencia del estado: la "macropolítica" y la "micropolítica". La primera, más ligada a la figura del militante,

Consiste en insertarse en las tensiones que se producen entre polos en conflicto en la distribución de los lugares establecida por la cartografía dominante en un determinado contexto social (conflictos de clase, de raza, de religión, de etnia, de género, etc.). (...) La acción macropolítica se inscribe en el corazón de estos conflictos, en un combate por una redistribución de lugares y sus agenciamientos con miras a lograr a una configuración social más justa (2010: 123)

Es decir, se trata del tipo de prácticas que se han llamado "políticas" o "ideológicas" de los "artistas militantes" y que nosotros hemos conceptualizado como la política. Por otro lado, la acción "micropolítica" consiste en insertarse en la tensión de la dinámica paradójica ubicada entre la cartografía dominante, con su relativa estabilidad, de un lado, y la realidad sensible en permanente cambio del otro lado, producto esta de la presencia viva de la alteridad como campo de fuerzas que no cesa de afectar a nuestros cuerpos." (2010: 123). 
Estos casos de "micropolítica" -que la autora intenta rescatar dado que sostiene que la Historia del Arte los ha dejado de lado- son "acciones artísticas que tienen lo político como aspecto de su propia poética y que por eso mismo alcanzan potencialmente la dimensión sensible de la subjetividad y no su conciencia" (2010: 122). Allí, como en nuestro concepto de lo político, existe una tensión entre la organización dominante y el plano de lo "sensible, invisible e indecible". Según Rolnik, esta separación entre "micro" y "macropolítica" fue, sin embargo, perdiendo sus límites entre los sesenta y los setenta, lo que para nosotros configuró el cruce múltiple entre diversas politicidades del arte.

Giordano (2001) propuso una distinción de similares características, y se basa fundamentalmente en la teoría de Barthes, quien clasifica los poderes de la literatura como institución y como acto (1983, cit. por Giordano, 2001). Según Giordano,

Desde el punto de vista de la institución, la literatura, en tanto práctica cultural específica, puede participar en distintos debates que agitan la vida de una sociedad, puede intervenir en ellos representando una de las posiciones en conflicto o bien manifestando su existencia (...). Desde el punto de vista del acto (...), la literatura aparece "más allá y al lado" (Barthes, 1982: 27) de los conflictos en los que se oponen valoraciones establecidas, debilitando o suspendiendo las fuerzas de sujeción que animan a los valores. (Giordano, 2001:

En sintonía con nuestro concepto de la política y la idea de "macropolítica" de Rolnik, Giordano asume que la literatura en su poder como institución se vincula con una selección de valores a los que llama a adherir. En el segundo, que "excede" a lo institucional, la literatura "interroga las morales en conflicto, las sacude, las inquieta nada más que por afirmarse como una experiencia de lo diferente” (2001: 23). Así, la literatura como acto, de un tenor semejante al del concepto de lo político y "micropolítica", contribuye a ampliar la mirada que queremos desarrollar en el análisis de la poética de Vigo y sustenta la pertinencia de nuestras hipótesis.

Esta conceptualización de la política y lo político del arte en la obra de Vigo permite desafiar la idea de que "el imán de la política como herramienta capaz de modificar radicalmente el mundo y la vida atrajo de tal modo a sectores relativamente amplios, (...) [que] dicho proceso de politización tendía a negar autonomía a la práctica artística e intelectual", cuyo ejemplo paradigmático sería Tucumán Arde, donde "la política devoraba la autonomía del arte tras la sincera creencia de que se había saturado el 
universo de la denuncia y que el pasaje a la acción tenía de su lado al huracán de la historia" (Terán, 2004: 11). Afirmaciones como esta -altamente productivas para algunos casos- han tendido a ser reproducidas en los estudios históricos del arte del período y, si bien no puede negarse su veracidad, no agotan las múltiples posibilidades de vinculaciones entre arte y política, y, por ello, resultan inaplicables a nuestro caso de estudio tal cual fueron formuladas. Es posible que la idea de que la entrega a la causa revolucionaria, como única opción positiva, haya sido enunciada especialmente para el caso de los intelectuales -justamente porque su condición de tales implica un necesario involucramiento directo con los avatares políticos-, lo cual no significa su aplicación llana y directa a los artistas y escritores, considerando los modos específicos e históricos de sus prácticas creativas. Además, la idea de que el arte como práctica particularizada termina en 1968 (Giunta, 2008), dado que de allí en adelante solo funcionaría la opción de la entrega a la lucha política, se contradice con un estudio de la poética de Vigo que, como el nuestro, inició el período justo en aquel año. Longoni (2001), sin embargo, plantea que desde los setenta, los artistas no solo participan de instituciones, como el caso del CAYC, sino que entre las opciones posibles para los artistas existían tanto la de sumarse a la organizaciones armadas como la de tener afinidad con las posiciones de esas organizaciones, aunque sin involucrarse orgánicamente con ellas.

Por ello, uno de los puntos principales de nuestra tesis pretende ampliar o complementar esta sentencia a partir de la investigación empírica de la obra de Vigo en el período mencionado. Si bien es cierto que los acontecimientos políticos son parte de la obra y los discursos de Vigo, no se trata de una práctica excluyente en la medida en que no negó las productividades de lo político del arte, es decir que apostó a intervenir en la situación del arte y social general desde sus trabajos vanguardistas, y mantuvo sus intenciones de participar de los procesos de cambios culturales a partir de la práctica artística, al mismo tiempo. Esto no significa un desdén por la actuación en relación con la comunidad, dado que lo hizo tanto en su rol de artista, docente, divulgador y director del Museo de la Xilografía, como a partir de una serie de trabajos artísticos que tienden a producir desajustes en la comunicación y los estándares de lectura, recepción y representación de las obras de arte, así como de algunos caracteres sociales dominantes. 


\section{TRAMA HISTÓRICO-SOCIAL Y ARTÍSTICA DEL PROBLEMA}

Para una mayor comprensión de la situación política y social de nuestro país en el período estudiado, y una correcta ubicación del concepto de la política, hemos considerado conveniente reseñar las principales características del proceso históricosocial y artístico, teniendo en cuenta que sus particularidades favorecerán una interpretación compleja de nuestro caso de estudio. ${ }^{17}$

Nuestro problema de investigación se ubica en el contexto de la Revolución Argentina, iniciada el 28 de junio de 1966, con la expulsión de Illia de la Presidencia de la Nación y el golpe de estado propulsado por Juan Carlos Onganía. El proyecto de la Revolución Argentina consistía, principalmente, en el desarrollo, la industrialización, la tecnificación y la modernización del país, conformando un proyecto desarrollista autoritario (O’Donnell, 1982). Todo ello sería posible a través de un sistema que planteara el abandono del modelo agroexportador del siglo XIX, dependiente y anacrónico. En cambio, sus dirigentes sostenían que era necesaria la industrialización del país, partiendo del reconocimiento de que la Argentina era un país en vías de desarrollo. La Revolución Argentina llegó al poder invocando metas de "transformación estructural", lo que lo diferenció de otras intervenciones militares. Los objetivos de este gobierno de facto se estructuraban en los "tres tiempos": un primer tiempo económico, luego el tiempo social, y finalmente el tiempo político. El primero consistiría en un reordenamiento económico, con el fin de distribuir bienes y oportunidades en forma supuestamente equitativa -lo que en realidad significaba quitarle poder a los trabajadores-; el segundo, social, sería una consecuencia de los logros del primero y posibilitaría la implantación de la justicia distributiva; el tercero abriría paso a lo político, para que paulatinamente se fueran incorporando las instituciones representativas de la sociedad. La política, identificada con divisiones sectarias, egoísmos y desorden, ocuparía el último lugar del proyecto. El aumento de la racionalización y la eficiencia del Estado se encontraban entre los primeros objetivos.

Este proceso significó la concentración de poder económico y político en el estado. En este "estado burocrático autoritario" (O’Donnell, 1977, 1982), la doctrina que guiaba el

\footnotetext{
${ }^{17}$ Para una mayor profundización de los principales temas señalados aquí, ver O’ Donnell $(1977,1982)$, Portantiero (1977), De Riz (2000), Pucciarelli (1999), Cavarozzi (2004).
} 
plan implantado por Onganía se sustentaba en la organización de las Fuerzas Armadas. Allí, la corriente liderada por Onganía estaba basada en ideas de cohesión interna y disciplina, apoyada en la doctrina de la seguridad nacional, el nacionalismo y el "cursillismo" cristiano. Según esta visión arquitectónica del Estado y la sociedad, la nación debía ser estructurada y corregida mediante un sistema de organizaciones funcionalmente especializadas y jerárquicamente articuladas. A ello debe sumarse que los militares temían que el clima de libertad que vivían los jóvenes fuera un caldo de cultivo para la "subversión" de los valores occidentales y cristianos (De Riz, 2000), por lo que debían extremar sus medidas de control, censura y represión.

Dentro de este proyecto "neocapitalista", las Fuerzas Armadas iniciaron alianzas con el establishment y el gran capital monopolista industrial, dejando de lado el aporte de los partidos políticos -hasta suprimir sus derechos, lo que luego será determinante en la crisis de la Revolución. Estos últimos verán vedada su intervención legítima en la competencia por el poder, concentrado en la burocracia estatal, las Fuerzas Armadas, y, en menor medida, en una participación de la burocracia sindical.

En lo económico, este modelo suponía la hegemonía, dentro de la clase dominante, de un sector en particular: la burguesía urbana asociada al capital monopolista, en detrimento de otros sectores propietarios como la burguesía agraria pampeana y la pequeña y mediana burguesía urbana. Asimismo, los asalariados se vieron desfavorecidos por las políticas económicas implementadas, y por esa razón formaron parte del grupo de tensiones que acorralaban al gobierno.

A pesar de los logros económicos, la Revolución Argentina entró en crisis y según Portantiero (1977), su causa radicaba en la imposibilidad de superar la debilidad crónica del estado y la falta de eficacia para impedir ser desbordado por la sociedad. El descontento generalizado hizo su aparición, especialmente cuando las "62 Organizaciones del Pie”, dirigidas por José Alonso, y las “62 Organizaciones”, guiadas por Augusto Vandor, pasaron a la oposición, desilusionados por las políticas que poco favorecían sus intereses. A ello se sumó la influencia de Perón que comenzó a enviar directivas de oposición. Es por ello que la CGT declaró un paro nacional para el $1 \mathrm{de}$ diciembre de 1966 y se fue perfilando el enfrentamiento del gobierno -que cada vez más favorecía a los intereses de un sector de la burguesía- con los sectores populares. Los costos sociales y el desplazamiento de los sectores agrarios, pequeños y medianos urbanos y asalariados, sumados a la acentuación de los desequilibrios regionales y la disconformidad de la clase media por el autoritarismo ejercido desde el gobierno, 
hicieron de contrapeso al intento del gobierno de dominar social y políticamente, lo que fue generando un nivel alto de presión sobre el mismo. Los partidos -que habían sido ilegalizados-, los sindicatos y las organizaciones políticas en general aparecían en la sociedad con fuerza, canalizando demandas e iniciativas postergadas.

Los avatares que sufrieron los asalariados -disminución del salario, inflación- fueron un impulso para la intensificación de las protestas, huelgas y descontento. A partir de una ruptura en la organización de los trabajadores, en 1968 se creó la disidente CGT de los Argentinos, liderada por Raimundo Ongaro, cuyo periódico CGT estaba dirigido por Rodolfo Walsh.

A partir de 1969, con el Cordobazo, creció el número de conflictos hasta 1972. En ese año las crisis económica y política alcanzaban niveles altos y ello hacía cada vez más difícil el salvataje de Alejandro Lanusse -quien reemplazó a Roberto Levingston en el cargo de presidente- y la continuidad del proyecto de la Revolución Argentina.

Estas crisis se desarrollaba en un contexto caracterizado, en primer lugar, por los problemas que acaecían en el Estado y la sociedad; segundo, por la complejidad que iba adquiriendo la cuestión del peronismo, que ya no podía ser pensado como un actor, sino que estaba formado por múltiples líneas a veces antagónicas y contradictorias entre sí; tercero, por el uso indiscriminado de la violencia (O’Donnell, 1982). Se fue generando un proceso de agudización de la lucha de clases y colapso del estado, donde se ponía en jaque a la dominación social y a las relaciones sociales.

En ese mismo proceso, se fue conformando la "nueva izquierda". Este repertorio de ideas, prácticas y representaciones políticas no fue unívoco ni lineal. Sin embargo, es posible identificar ciertos rasgos comunes: provenían de tradiciones diversas como el peronismo, la militancia cristiana, el nacionalismo y la izquierda; sus acciones y discursos convergían en oponerse a la dictadura y al "sistema"; compartían objetivos y metodologías de tipo radical (Tortti, 1999). Entre estos grupos se encontraban desde organizaciones militarizadas hasta prácticas obreras y estudiantiles de protesta. Influidos por el ascenso de la idea de revolución, que se transformó, según Gilman (2003) en la palabra, los acontecimientos del Mayo Francés de 1968, la expansión del antiimperialismo, el rechazo a la Guerra de Vietnam, la exaltación de la lucha política y de la idea de "compromiso", así como una revalorización del peronismo en clave marxista, los que participaron de la radicalización política estaban en consonancia con un juvenilismo apoyado en lo que Terán (1991) y Sarlo (2007) llaman "sentimiento de la inminencia", es decir que jóvenes dispuestos a cambios radicales en lo social, lo 
cultural, lo político, eran protagonistas de tiempos rápidos y actuaban en relación con algo que estaba por venir: la revolución, la vuelta de Perón, un mundo/sistema nuevo. El activismo estudiantil fue uno de los blancos de la política represiva de Onganía, pero lejos de desmantelarlo, este fue fortaleciéndose y radicalizándose hasta estallar, junto con los trabajadores, en los sucesos de Córdoba en 1969. Este proceso viene engarzado a la falta de canales institucionales por los cuales expresar el descontento o las propuestas alternativas a las del gobierno. Prohibidos los partidos políticos, la represión fue en ascenso y la violencia surgida del Estado y de la sociedad comenzó a transformarse en el medio más común de manifestación de las tensiones. Además, apareció una nueva generación de cuadros sindicales y dirigentes combativos que proclamaban la resistencia. La idea de revolución a partir de la Revolución Cubana y la formación de los primeros grupos guerrilleros marcan el comienzo de una nueva etapa en la política argentina. Con el Cordobazo se hiere de muerte al gobierno, y el desenlace de la Revolución Argentina ya estaba preanunciado.

Las Fuerzas Armadas, luego del fracasado intento de Levingston, en medio de una crisis de legitimidad, y asediadas por todos los flancos, diseñaron un nuevo programa que consistía en la "reconciliación" con los partidos políticos. El Gran Acuerdo Nacional (GAN), estaba inmerso en un proceso a cargo de Lanusse, caracterizado por la búsqueda de un consenso político que, a diferencia de lo planteado por los tres tiempos, no sería ya la consecuencia natural del desarrollo económico. La salida negociada estaría dada por la convergencia de las Fuerzas Armadas, los partidos y la burocracia sindical, y se basaba en el retorno del proceso electoral y el funcionamiento de los partidos. Sin embargo, la búsqueda de acuerdo no funcionó.

Con la llegada de Perón a la Argentina en 1972, quedó en claro el alto grado de convocatoria e identificación que provocaba, así como su capacidad de generar adhesiones, y se hizo visible que quien realmente arbitraba el acuerdo era él, y no Lanusse con su propuesta del GAN. Se tornó utópico un acuerdo entre las Fuerzas Armadas y los partidos políticos. La candidatura de Lanusse se hizo imposible.

En los setenta, los procesos vividos en la década anterior -la resistencia a la proscripción del peronismo, las luchas anticolonialistas y antiimperialistas, la influencia de la revolución cubana, la modernización y el experimentalismo- fueron dando lugar a nuevos acontecimientos sociales y culturales. Los más relevantes son: la aguda conflictividad social, la creciente radicalización política y el aumento de los niveles de confrontación (Terán, 2004), así como el proceso de formación del estado terrorista, que 
converge en una particular articulación entre estado y sociedad (Lenci: 2013). El asesinato del General Aramburu por parte de Montoneros en 1970 y la conformación del Ejército Revolucionario del Pueblo (ERP) del Partido Revolucionario de los Trabajadores (PRT) que decidió iniciar la "guerra revolucionaria", el fusiliamiento de dieciséis militantes en la cárcel de Trelew dos años más tarde por parte de las fuerzas represivas, el enfrentamiento entre las alas de derecha e izquierda del peronismo, condensado en la violencia ejercida en la espera de la llegada de Perón a Ezeiza en 1973, la vuelta del peronismo al poder ese año con la elección de "Cámpora al gobierno y Perón al poder" y la liberación de presos políticos con el "Devotazo", y luego, el esperado regreso del líder peronista a la presidencia, su muerte en 1974 y el avance de la derecha y la Triple A (Alianza Anticomunista Argentina) en el gobierno de su sucesora, Isabel Martínez de Perón, dan cuenta de los grados de conflictividad social y de la velocidad de los hechos en el lapso de media década.

De allí en adelante, las intervenciones para limitar a los sectores más radicalizados en universidades e instituciones culturales y religiosas, así como la represión directamente ejercida desde el sector paramilitar del gobierno, fueron dificultando el camino de cualquier proyecto transformador.

\subsection{CULTURA, ARTE Y REVOLUCIÓN}

Como señalamos antes, el ascenso de la idea de revolución es uno de los elementos clave para comprender este proceso (Altamirano, 2001; Terán, 1991, 2004). A partir de la Revolución Cubana en 1959 dicha idea cobró fuerzas en Argentina -y en toda Latinoamérica-, y se diferencia del proceso anterior en que se proponían cambios de tipo "reformista" y alejados de un proyecto que incluyera un cambio total en el sistema. Cuba emergió como un modelo alternativo a la dependencia imperialista en que estaba inmersa la Argentina, y los sectores de la nueva izquierda consintieron en la necesidad de contactarse con ese mundo que posibilitaba la ruptura abrupta con el presente, para pasar a transitar el camino de la revolución. Lo que antes de 1959 parecía inalcanzable para los militantes de la izquierda tradicional en Argentina florece como posibilidad plena a partir de dicha revolución. Tanto el Partido Comunista como el Partido Socialista sustentaban sus propuestas en reformas de tipo graduales y aceptaban la vía democrática como medio para alcanzarlas. Recién después de 1960 la idea de Revolución se hace presente como una propuesta más real, más próxima. Es en la nueva 
izquierda que esta posibilidad se hace fuerte y aflora con ímpetu en sectores universitarios y católicos de la juventud que se vinculaban a la política con esperanzas transformadoras. Además, su influencia se dejó ver en grupos intelectuales, artísticos y políticos progresistas.

El clima ideológico de la época incluía también el optimismo de la década, el voluntarismo de la acción transformadora, las teorías dependentistas, antiimperialistas, antietapistas, el proceso de progresiva politización de la cultura que incorporaba en la labor del intelectual una acción política directa y no puramente teórica (Terán, 1991). Ese panorama implicaba también para los artistas un marco de referencia ideológico, así como de elecciones prácticas.

Los acontecimientos políticos locales, como los enfrentamientos desde el golpe de estado de 1955 que llevaron al borde de la guerra civil, los poderes formales de Frondizi e Illia que eran frágiles al lado de los poderes reales de otros grupos, especialmente las Fuerzas Armadas, el conflicto peronismo/antiperonismo que impidió la estabilidad de algún sistema político y el golpismo, que formaba parte de la vida política (Altamirano, 2001) fueron elementos ineludibles de los procesos previos al período de nuestro estudio. Todo esto conformaba el espectro revolucionario a partir del cual los jóvenes de la época captaban la política, la democracia, y las formas de modificar lo que vivían. Es decir que la revolución como posibilidad no solo surgía de la importación de la Revolución Cubana sino que además lo que acontecía políticamente se conjugaba para lograr que esa posibilidad se proyectara cada vez más cercana.

En ese clima de modernización y rupturas el arte a partir de los sesenta -y quizá antescomenzó a causar "desconcierto" porque había abandonado sus tradiciones centrales (Giunta, 2004): las técnicas, los temas y las formas que se habían ido consolidando en los últimos cinco siglos fueron negados progresiva y sostenidamente por parte de los artistas. ${ }^{18}$ Lo que veían tanto críticos como público en una muestra confrontaba muchas veces con las expectativas que habían albergado durante largo tiempo acerca de lo que era el arte, las funciones que debía cumplir -especialmente las ligadas al goce estético y

\footnotetext{
${ }^{18}$ En cuanto a la Historia del Arte del período, los libros de Giunta (2008) y Longoni y Mestman (2000), cuyas líneas principales hemos reseñado en el estado de la cuestión, parecen fundamentales para su comprensión. Asimismo, la cronología realizada por Dolinko (2004), que incluye acontecimientos de la vida política, cultural y artística de la Argentina entre 1965 y 1983, resulta de gran utilidad para conocer un panorama de los eventos y procesos más relevantes. No reproduciremos aquí los términos y condiciones de los cambios producidos y sus actores, dado que remitimos allí para adentrarse en los principales hechos de la época. Procuraremos, sin embargo, apuntar en cada capítulo referencias a artistas, obras o acciones vinculadas con nuestro objeto de investigación, cuando ello aporte a la interpretación y comprensión del problema.
} 
la exposición de lo bello- y los modos en que debía mostrarse. Se multiplicaron los lenguajes, proliferaron los objetos, las formas espaciales, los happenings y performances; algunos se apartaron de la pintura y utilizaron otros medios como la fotografía, el cine, los documentos y los materiales efímeros. Primera Plana tituló una tapa en 1969 "Argentina: la muerte de la pintura", un signo de la magnitud de los cambios producidos en las artes visuales como consecuencia de la experimentación y la búsqueda de nuevas formas de manifestación artística. Como se sabe, las ideas de movimiento, juego y producción de objetos habían crecido en los años cincuenta, especialmente con el arte Madí y Concreto-invención, que tuvieron una fuerte influencia en las producciones de Vigo y de otros artistas.

El arte figurativo y la representación parecían alejarse cada vez de los objetivos de los artistas, aunque no mucho después reaparecían -aunque con formas e intencionalidades renovadas- para denunciar, mostrar e indagar en la realidad social. Entre la seducción de la vanguardia estadounidense, que funcionaba como imán de algunos sectores artísticos, y el latinoamericanismo de carácter solidario y contestatario, se desarrollaron múltiples estrategias artísticas y comunicativas que combinaban elementos de uno y otro. En ese espectro diverso se movió Vigo, ligado también a la vertiente europea de las primeras vanguardias. El pop, el arte de los medios, el arte ecológico y la denuncia política podían convivir en la misma época, lo que no significaba la ausencia de posiciones críticas hacia la tendencia de acercar cada vez más el arte al mercado internacional. Esto se vincula también con la ampliación del mercado del arte, así como de la circulación de productos artísticos dentro y fuera del país, tanto para ser expuestos y reconocidos como para ser comercializados.

Muchos de los artistas que vivieron en los años sesenta y setenta no se posicionaron en un punto fijo con respecto a las tendencias o corrientes artísticas, sino que fueron modificando sus preferencias de acuerdo con sus gustos, intereses, expectativas o necesidades y en vinculación con la situación social y política más general.

Dos instituciones resultaron claves en esas décadas: el Instituto Torcuato Di Tella y el Centro de Arte y Comunicación (CAYC). Sobre el primero, basta leer los estudios de King (1985), Longoni y Mestman (2000) y Giunta (2008) para comprender el altísimo grado de influencia y atracción que generó en los artistas. Las exposiciones, premios y cursos del Di Tella dan cuenta de los objetivos que se planteaba, ligados tanto con la experimentación como con la internacionalización. Es hacia las postrimerías de su liderazgo que comienza nuestra tesis. El CAYC fue una institución relevante desde fines 
de los sesenta. Con la dirección de Jorge Glusberg, apoyó trabajos conceptualistas, así como los basados en la idea de "sistema" y otros de raigambre "científica" e investigativa. En ese espacio, bajo la mirada cómplice y oportunista de su director, se desarrollaron charlas, reuniones, exposiciones y debates sobre el arte contemporáneo, la vanguardia y su vinculación con la política. Vigo se vinculó con el Di Tella y el CAYC de modos diversos, y utilizó esos espacios de acuerdo con sus objetivos de divulgar su obra y las de otros colegas, así como para intervenir críticamente en el panorama de las artes visuales de la época y en los modos de funcionamiento de las propias instituciones. En esos años se concentraron en La Plata y en otros puntos del país, especialmente en Rosario y Buenos Aires, artistas que se abocaron a renovar el campo con propuestas estéticas que los mismos protagonistas llamaron "nuevas" o "novísimas", y que se presentaban como ajenas a las reglas más habituales de las Bellas Artes. Las instituciones más relevantes en el campo del arte platense del período fueron la Escuela Superior de Bellas Artes, dependiente de la Universidad Nacional de La Plata, y el Museo Provincial de Bellas Artes, además de otros espacios más pequeños o informales donde circulaban, exponían y debatían los artistas. Vigo y los artistas que lo rodeaban mantuvieron con esas instituciones distintas relaciones, enfrentamientos, disputas, así como vínculos variables, de acuerdos y rechazos con la crítica.

En cuanto a la concepción de los trabajos de algunos de los artistas de la época -entre ellos, los de Vigo- como "vanguardias" y "neovanguardias", es claro que desde los sesenta hubo una vuelta a los gestos, críticas y propuestas de las vanguardias de principios del siglo $\mathrm{XX}$, además de una proliferación de manifiestos y programas que se proponían "atacar" el arte tradicional, sus instituciones y sujetos. Incluso se generó entre algunos de ellos la idea de que el trabajo individual debía ser reemplazado por el colectivo, ya sea en conjunto con otros artistas o con el público. Proponían una dinámica que no respondía solo a los cambios que venían ocurriendo en el campo del arte sino también en relación con las propuestas de trabajo grupal o asociativo que imperaban en los sectores jóvenes y contestatarios en general, como parte de una cultura solidaria y contrapuesta al individualismo que se identificaba con el aislamiento generado por el "sistema". Como señalaremos más adelante, Vigo intervino en diversos grupos de artistas, aunque muchas veces prevaleció en él el carácter de un trabajo individual y asociado a un rol de liderazgo. Esto conllevó, por un lado, la enorme influencia que ejerció sobre sus colegas, pero por otro lado, la dificultad del 
sostenimiento de esas relaciones en momentos en que los cambios y renovaciones se presentaban como imperiosos para la vivencia y experimentación de nuevos caminos.

Para nombrar solo algunos de los artistas más relevantes del período, citaremos a León Ferrari cuya La civilización occidental y cristiana (1965), enviada para el Premio Di Tella de ese año y censurada, marcó el camino de la crítica política desde la práctica artística para los posteriores trabajos de sus colegas; Oscar Bony presentó en 1968 La familia obrera, que indicaba un punto crucial de crítica institucional y social al interior de Experiencias 68 del Di Tella; en la misma muestra Margarita Paksa presentó las huellas de dos cuerpos en la arena y la grabación de los sonidos de una pareja haciendo el amor; Juan Carlos Distéfano se centró en el sufrimiento corporal, identificado en algunos casos con una denuncia de la tortura; Aldo Paparella producía sus Monumentos inútiles y Objetos fantasmales como una crítica a los monumentos y esculturas oficiales y nacionalistas; Luis Benedit produjo obras a partir de la investigación sobre el comportamiento de plantas y animales para comprender el mundo social; Horacio Zabala creó obras críticas hacia las instituciones artísticas y con expreso contenido político: sus elocuentes proyectos arquitectónicos de cárceles buscaban poner en evidencia los propósitos represivos y autoritarios de los gobiernos de América Latina; Juan Carlos Romero, con su instalación Violencia en 1973 mostró que su raigambre conceptualista estaba engarzada en un discurso de denuncia con un alto contenido político; Alberto Heredia creó objetos escultóricos en base a materiales no convencionales y de desecho, además trabajó en Amordazamientos (1972 - 1974) sobre la represión violenta ejercida en la época.

La opción del "compromiso" del artista con su realidad social, de conocida raigambre sartreana, fue el camino que muchos de ellos eligieron como modo de involucrarse políticamente con la idea de un cambio revolucionario más o menos radical. El renombrado caso de Tucumán Arde, así como los eventos de denuncia política e institucional producidos entre 1967 y $1968^{19}$, y fuera de él, son algunos de los ejemplos más claros de esa elección, en vinculación con los procesos sociales de radicalización mencionados antes. De este modo, términos como "vanguardia", "compromiso",

\footnotetext{
${ }^{19}$ Nos referimos a los conocidos hechos de 1968 que van desde la acción de Eduardo Ruano sobre el cuadro de Kennedy en Ver y Estimar del Museo de Arte Moderno; la censura de Baño de Roberto Plate, la renuncia de Pablo Suárez en Experiencias 68 del Di Tella y la posterior destrucción de obras; las renuncias, proclamas y actos contra la censura en el Museo Nacional de Bellas Artes durante el Premio Braque. Estos hechos y otros, terminaron por decidir a un grupo de artistas a renunciar a la institución en agosto de ese año. Un año más tarde, Vigo estaría inaugurando la muestra Expo Internacional de Novísima Poesía en el Di Tella. Volveremos sobre este tema en el capítulo 1.
} 
"politización" y "arte revolucionario" funcionaron como "artefactos verbales de alta disponibilidad" (Giunta, 2008: 22), es decir que circulaban frecuentemente entre los artistas más involucrados en aquellos procesos sociales.

Sin embargo, como demostraremos en esta tesis, esos no fueron los únicos modos por los cuales el arte participó y contribuyó a los procesos de subjetivación política de la época. ${ }^{20}$ Las formas, materialidades y discursos programáticos de Vigo muestran que la renovación estética podía ir más allá del mundo del arte para interferir críticamente en los sentidos dominantes, culturalmente aceptables y disponibles de la sociedad. Sin desdeñar la ligazón con los problemas políticos del momento, y asumiendo aspectos de las argumentaciones, propuestas y convicciones de la ideología de izquierda, era posible permanecer en la producción artística vanguardista.

De este modo, en los años que van desde 1968 hasta 1975, Vigo intervino en el campo del arte sin abandonar su posición crítica tanto hacia ese ámbito como hacia el "sistema" dominante en general. Formó parte del grupo de artistas que continuó produciendo desde su práctica específica en conexión con los mencionados problemas sociales y políticos. La forma de sus obras y acciones, a veces de difícil legibilidad para los estándares y sentidos culturales compartidos o dominantes, además de la moderada visibilidad de sus trabajos, alojados en espacios no convencionales y de escasa circulación, impidieron la censura sistemática y directa sobre su obra y le permitieron mantener un sentido que desafiaba el orden social.

El golpe de estado que implantó la dictadura cívico-militar en 1976, liderado por Jorge Rafael Videla, significó, como se sabe, el comienzo de uno de los capítulos más oscuros de la historia argentina para la sociedad en general, y especialmente para el propio Vigo. No solo por la intensa represión que el gobierno de facto ejerció sobre el arte y la cultura (Funes, 2007a, 2007b), que paralizó la libre expresión (pública), sino también porque la desaparición de su hijo fue una impronta tanto para su producción artística como para su vida personal, que jamás pudo resignar.

\footnotetext{
${ }^{20}$ Como señala Giunta, con la recuperación de la experiencia de Tucumán Arde, después del regreso de la democracia, "terminó convertida en el paradigma del arte de acción y algo así como un manual del arte de activismo social" (2004: 17)
} 


\subsection{UN ACERCAMIENTO A LA BIOGRAFÍA DE VIGO}

La prolífica y multifacética tarea de Vigo (1928-1997) parece, hasta el momento, inabarcable. Es prácticamente imposible realizar un detalle de sus múltiples actividades, y esta dificultad aumenta a medida que nos adentramos en las miles de hojas que conforman su archivo personal. Listados interminables de participaciones en charlas, envíos a muestras, realizaciones de acciones, producciones de objetos, poesías visuales y arte-correo, artículos y ensayos escritos, revistas y otras ediciones, organización de exposiciones, impiden un recorrido exhaustivo de su vida. Los hechos más relevantes para el tema y período de nuestra investigación son referidos en cada capítulo.

Se han escrito biografías breves y extensas sobre Vigo (referidas en el estado de la cuestión), por lo que remitimos a ellas para un panorama más o menos abarcativo de su obra. ${ }^{21}$ Será útil, sin embargo, una descripción general de sus obras y actividades, la mayoría anticipadas en el mencionado apartado de esta tesis a modo de breve acercamiento a sus principales actividades y producciones, y como justificación de la relevancia de la elección de parte de su extensa obra como tema de la tesis.

Tomando como base un documento de archivo realizado por el propio Vigo y que incluye el período de nuestro interés, (s/f, Archivo CAEV) podemos observar la intensa labor que tuvo en su rol de teórico y docente, ofreciendo charlas sobre arte contemporáneo, poesía, arte conceptual, historieta, xilografías, fotografías, arte-correo. Además de su función como docente en el Colegio Nacional "Rafael Hernández" de la Universidad Nacional de La Plata desde 1961, dictó diferentes cursos, como "La plástica y su límite" por la radio de dicha universidad durante 1962, "Panorama del arte contemporáneo" en Chascomús en 1973 y 1983, entre otros tantos.

Sus publicaciones más importantes son, en primer lugar, los Poemes Mathematiques Barroques en 1967, en París por la editorial Contexte bajo de dirección de Jean Françoise Bory y Brian Lane y por Agentzia, del mismo país, al año siguiente. Este "libro experimental de poesía matemática", como lo calificó el propio Vigo, tiene una importante influencia del concretismo y se trata de hojas sueltas, caladas y de distintos espesores y colores, que el "lector" puede intercalar para crear nuevas formas espaciales y visuales. En segundo lugar, De la poesía proceso a la poesía para y/o a realizar fue

\footnotetext{
${ }^{21}$ Especialmente, la realizada por el equipo del Centro de Arte Experimental Vigo, publicada en 2008 en el catálogo de Maquinaciones. Edgardo Antonio Vigo: trabajos 1953 - 1962. Se reproduce en el Anexo una síntesis biográfica de su vida realizada por el mismo equipo.
} 
publicado en 1969 por la editorial Diagonal Cero. Este libro, que también posee hojas sueltas, tiene un formato artesanal, con partes que componen un montaje de textos e imágenes. Como se verá más adelante, Vigo expuso allí su teoría acerca de los cambios producidos en el arte y la poesía en particular que van desde la caducidad de los roles tradicionales del artista y el espectador, hasta la forma obra de arte. Incluyó allí, además, textos de Moacy Cirne, Álvaro y Neide de Sà, Jean Calude Moineau, Claude Portal, Yves Charnay, Georges Aperghis, imágenes de Dennis Williams, el grupo Zaj, Gérald Rocher, Andy Suknasky, Julien Blaine, Jochen Gerz, Alain Arias Misson, y parte de su propio artículo "Un arte a realizar" (1969).

En cuanto a las revistas, Vigo creó y editó $W$. $C$. (cinco números, en grupo con Miguel Ángel Guereña, Osvaldo Gigli y Elena Comas) entre 1958 y 1960, DRKW'60 (tres números) en 1960, Diagonal Cero (veintiocho números) entre 1962 y 1968 y Hexágono '71 (trece números) entre 1971 y 1975, todas de factura artesanal y que incluían textos sobre diversas formas de arte y poesía, imágenes y grabados. Vigo pretendió a través de ellas difundir sus ideas y obras, y también de otros artistas argentinos y extranjeros. Editó entre 1979 y 1993 veinte números de Nuestro libro internacional de estampillas y matasellos "bajo el concepto de filatelia marginal, creativa y paralela" (Vigo, "Publicaciones") y tres volúmenes del Libro internacional (1976, 1977, 1978-1980) de poesía visual y arte-correo.

Publicó, además, numerosos artículos desde 1961 como columnista del diario El Argentino de La Plata y como colaborador de El Día y El Atlántico, este último, de Bahía Blanca. También, en revistas de divulgación y especializadas, como "Formalismo sugerente" en la revista Realizaciones en 1962, "Libertad, dinámica y atemporalidad del arte" en Escala dos años más tarde, otro artículo sobre poesía visual argentina publicado en la belga Historische Anthologie Visuelle Poezie durante 1976, y numerosas intervenciones y comunicaciones sobre arte-correo.

Ganó premios en salones de artes plásticas y grabado, además de menciones especiales y de honor; también fue convocado como jurado de diversos eventos artísticos. Participó en innumerables exposiciones en Argentina, Chile, Uruguay, Brasil, Inglaterra, Bélgica, Francia, Italia, Puerto Rico, Alemania, entre otros, sobre poesía visual, arte de acción, proyectos, arte en el espacio público, "arte de sistemas", arte conceptual, arte-correo, etcétera. En los últimos años de su vida recibió un reconocimiento al participar de la XXII Bienal de San Pablo en 1994 y la I Bienal del Mercosur en Porto Alegre en 1997. 
Desplegó una red de relaciones profesionales y de amistad con artistas de diversos puntos del mundo (Julien Blaine, Paulo Brusky, Horacio Zabala, Carlos Ginzburg, Jochen Herz, Luigi Ferro, Fernando Millán, Juan Carlos Romero, Luis Benedit, Clemente Padín, Klaus Groh, Hugh Fox, por solo citar algunos), con los que intercambiaba obras, correspondencias, teorías y reflexiones.

Creó el Museo de la Xilografía en 1967, un excéntrico resguardo de xilografías que itineraban en valijas de madera por colegios, clubes y otras espacios. Organizó muestras como la Expo Internacional de Novísima Poesía en el Instituto Torcuato Di Tella en 1969 y la Última exposición internacional de arte correo en 1975 junto a Horacio Zabala en la Galería Arte Nuevo de Buenos Aires.

Formó parte de diversos grupos a lo largo de su vida. Los más relevantes fueron el "Movimiento Diagonal Cero" (1966-1969) (junto con Luis Pazos, Jorge de Luján Gutiérrez y Omar Gancedo, y más tarde, Carlos Ginzburg); el "Grupo de los Trece" del CAYC (con Jacques Bedel, Luis Benedit, Gregorio Dujovny, Jorge Glusberg, Carlos Guinzburg, Víctor Grippo, Jorge González Mir, Vicente Marotta, Luis Pazos, Alfredo Portillos, Juan Carlos Romero, Julio Teich y Horacio Zabala) -del que participó entre 1973 y 1974, aunque nunca fue un integrante formal-; y la dupla artística "G.E.Marx Vigo" con la escultora, poeta visual y arte-correísta Graciela Gutiérrez Marx entre 1977 y 1984. Si bien Vigo teorizó sobre la importancia del trabajo en equipo, mantuvo siempre cierta independencia o "individualismo" -según su colega y amigo Juan Carlos Romero (comunicación personal, 19/03/2013)- que lo llevó a establecer, en varias ocasiones, relaciones en las que ejercía un liderazgo, muchas veces resistido y problemático.

Parece imprescindible mencionar un hecho que él mismo se encargó de señalar como uno de los más relevantes para su formación y apertura de nuevas ideas: la estadía en Francia durante el año 1953 junto a Miguel Ángel Guereña, donde se puso en contacto con Jesús Soto, Carlos Cáceres (pintor riojano) y un artista chileno de apellido Contreras, así como con diferentes grupos y artistas de la vanguardia parisina, además de asistir a exposiciones y eventos. Se sabe que el viaje a Europa, especialmente a Francia, era considerado por los propios artistas como uno de los procesos casi obligados para ponerse a tono con los últimos movimientos de arte contemporáneo. Más allá de las consideraciones que hoy podamos hacer desde una perspectiva crítica del centro-periferia acerca del imaginario eurocentrista que funcionó entre artistas y escritores -al menos hasta los sesenta, desplazándose luego a Nueva York o hacia una 
mirada crítica latinoamericanista-, lo cierto es que Vigo fue categórico en asegurar que aquella estadía implicó para él una renovación en cuanto a la formación que había recibido en la Escuela de Bellas Artes de la Universidad Nacional de La Plata, de la que había egresado con el título de Profesor de Dibujo. Sin embargo, como afirma su colega cubano Pedro Gutiérrez, a pesar de esa insistencia, "París lo que hizo fue remover dentro de Vigo, agitar un poco lo que ya estaba a punto de germinar. París logró que ese material fermentara y creciera hasta reventar" (2004: 2).

Otro hecho crucial en su vida fue su trabajo como empleado de los Tribunales del Poder Judicial Provincial, en el que decidió trabajar desde 1950 por más de cuatro décadas, para ganarse la vida. Las relaciones que allí desarrolló, los conocimientos y prácticas que adquirió fruto de su labor diaria fueron especialmente influyentes en el desarrollo de su práctica artística.

El tercer suceso que marcó su vida fue la exposición que realizó a su regreso de Francia, en 1954, en la Asociación Sarmiento junto a su esposa, también artista y luego colaboradora en las tareas que emprendió Vigo, Elena Comas. Los objetos que presentó allí, de raigambre concreta y algunos de ellos manipulables por el público, aparecieron al día siguiente destruidos (aparentemente) por concurrentes a la muestra. Vigo sintió aquella reacción contra sus trabajos como una expulsión de la institución arte, y al mismo tiempo, funcionó como disparador de la idea de que su propuesta efectivamente era radical, había logrado la "revulsión". Esta muestra quedó grabada en su memoria casi como un trauma y aprovechaba para citarla cada vez que hacía referencia a los problemáticos inicios de su carrera.

De allí en adelante se sucedieron elecciones en las que la provocación y el desvío de los cánones de la Bellas Artes operaron como senderos irreductibles. Así creó las máquinas imposibles o inútiles (como el Cargador eléctrico de 1957 o la Bi-tricicleta ingenua (con ruedas incapaces de rodar) de 1960), la serie de los Relativuzgir's (imagen 1) ${ }^{22}$, los grabados (imagen 2), los objetos (que llamó "cosas") (imagen 3), las poesías visuales (imágenes 4 y 5), las revistas (imágenes 6), las acciones (imagen 7), las exposiciones. Según Casanegra, con la presentación de Cargador eléctrico, "Vigo fue uno de los precursores de una avanzada anti-arte y nihilista que se estrenaba para el arte argentino por ausencia hasta esa fecha" (2004: 27). Asimismo, destaca la versatilidad de

\footnotetext{
22 Todas las imágenes que se reproducen en la tesis pertenecen al Archivo del Centro de Arte Experimental Vigo.
} 
Vigo "constituyendo una figura que al mantenerse al margen de lo institucional transitó canales alternativos de incidencia social y política a través de una intencionalidad estética" (27).
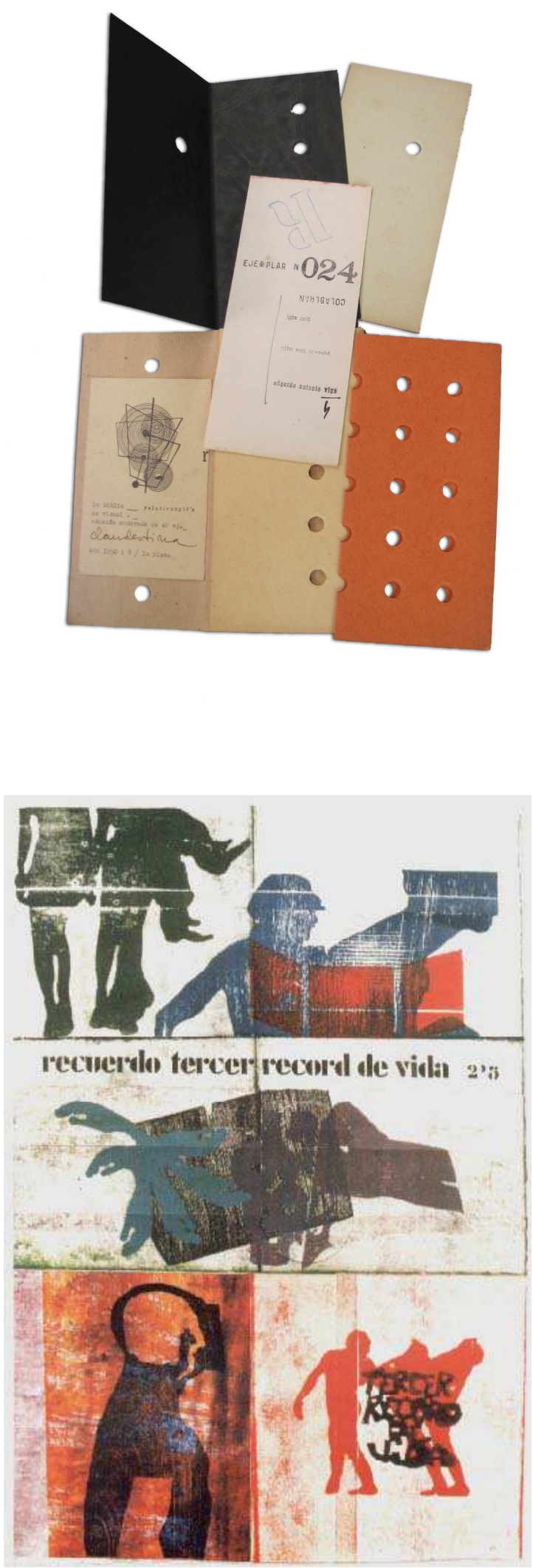


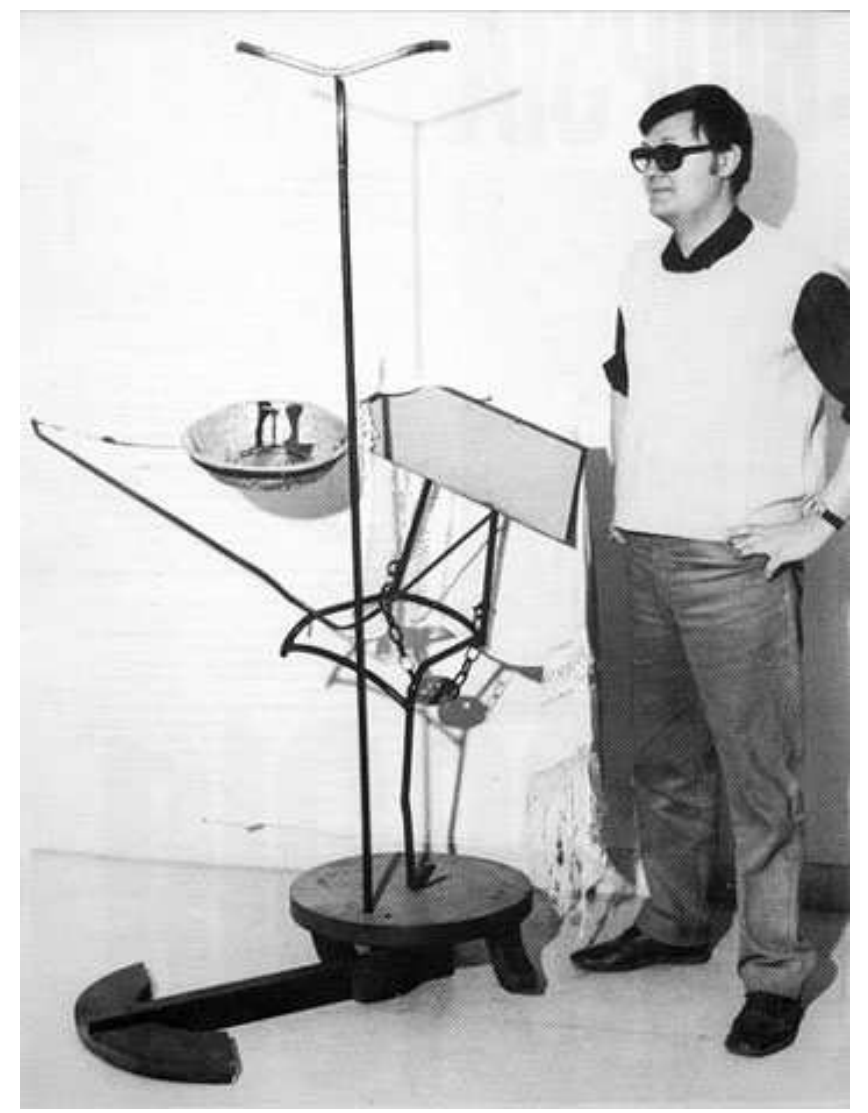

Imagen 3. Vigo, Palanganómetro mecedor (que no se mece) para críticos de arte. 1963.

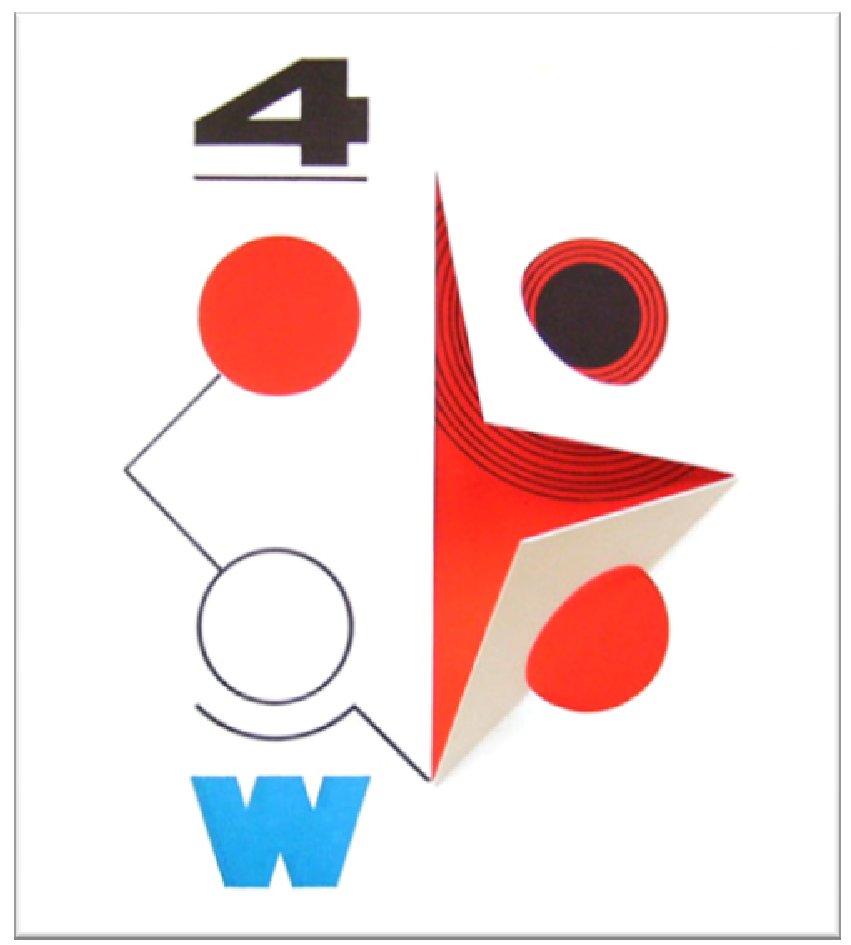

Imagen 4. Vigo, Poemes

Mathematiques Barroques. 1967.

Dos hojas superpuestas 


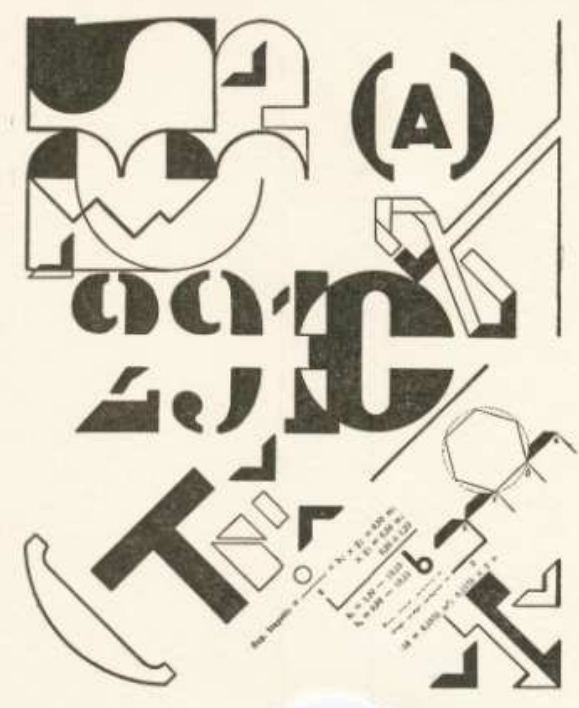

Imagen 5. Vigo, P/Mat. Eunuco. 1967.
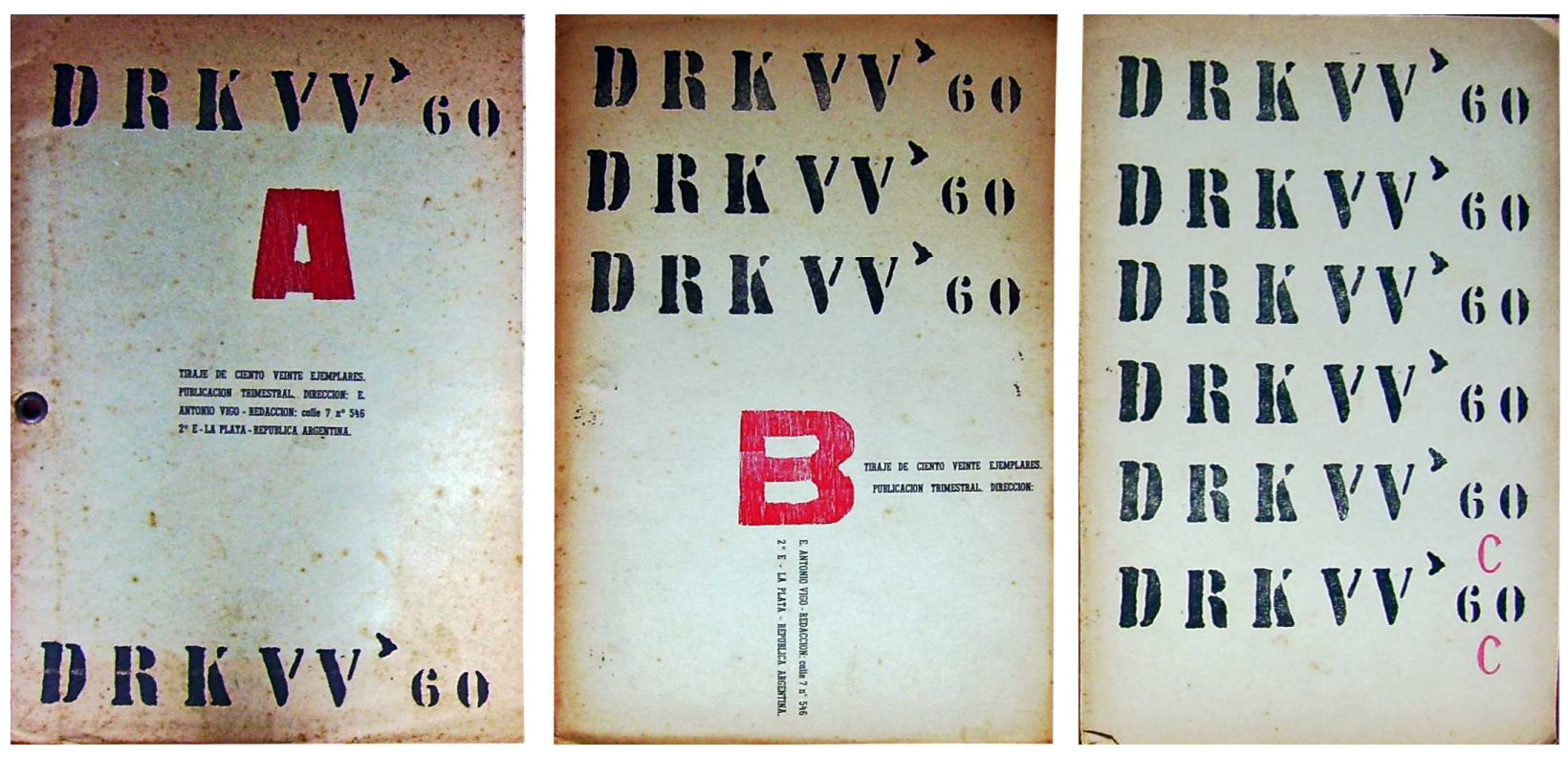

Imágenes 6. Vigo, Revistas DRKW'60 y Diagonal Cero. 

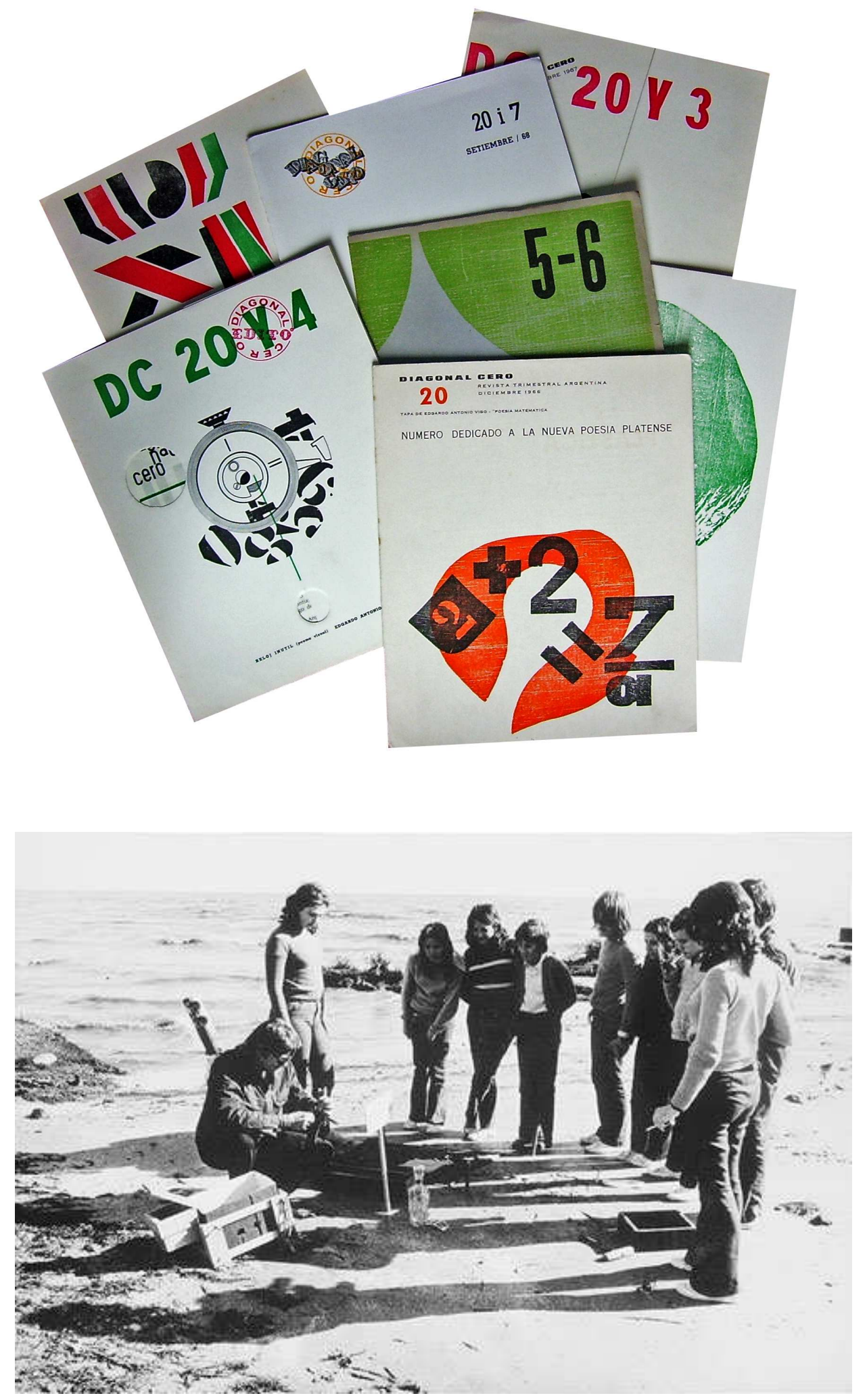

Imagen 7. Vigo, Señalamiento XII. Almácigo de arena. 1972. 
Su revista Diagonal Cero fue calificada como emblemática o mítica, iniciadora de una nueva forma de producir revistas artísticas de vanguardia experimental a nivel internacional, por lo que Vigo es considerado actualmente uno de los precursores y referente mundial del arte-correo, actividad que desarrolló durante treinta años. Fue ese el medio que utilizó durante la dictadura cívico-militar iniciada en 1976 para denunciar el secuestro y desaparición de su hijo "Palomo" (imagen 8). En los ochenta y noventa continuó su trabajo artístico, para lo que aprovechó las diferentes experimentaciones que había realizado en las décadas precedentes y, en muchos casos, en tono de denuncia contra las injusticias y desigualdades sociales y políticas (imagen 9).

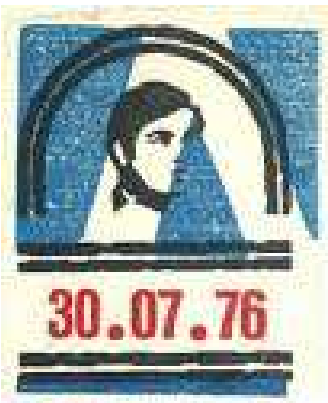

SET FREE $\star$ PALOMO FIRST DAY COVER

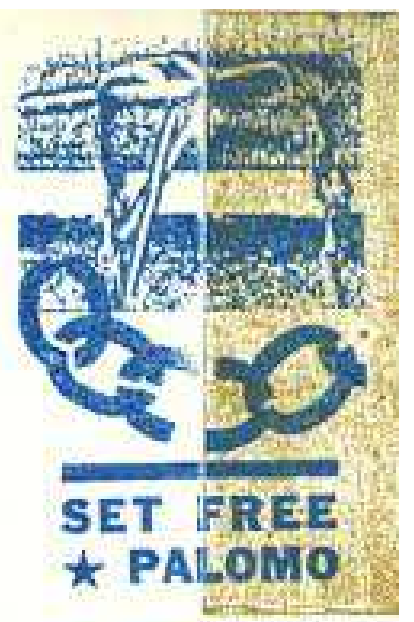

Imagen 8. Vigo, estampilla y matasello Set free Palomo. 1981.

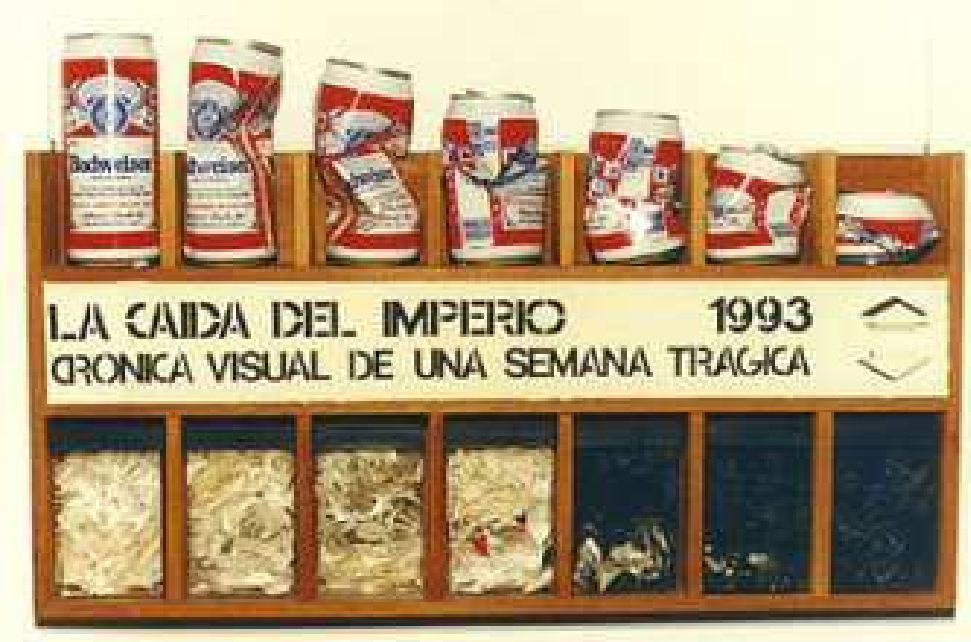

Imagen 9. Vigo, La caída del imperio. Crónica visual de una semana trágica. 1993.

Es posible considerar, como Davidson (2011), que las operaciones textuales son el corazón de las prácticas de Vigo. Influencias del dadaísmo, el surrealismo, el 
concretismo y el constructivismo aparecen a lo largo de su vida artística. Las figuras de Marcel Duchamp, Macedonio Fernández, Lucio Fontana y Leonardo Da Vinci fueron señaladas por Vigo como sus principales mentores. Como sostiene Basualdo, "se extenderá en su obra el campo prolífico del enigma, bajo las formas cambiantes del acertijo, del juego de palabras, de la broma o del absurdo" (1994: 10). En cuanto al influjo que ejerció Duchamp, se ve en la "irreverencia lúdica hacia los cánones tradicionales del arte", y en relación con Macedonio, por incluir al espectador en el juego estético, por su afición por los textos absurdos y la posibilidad de producir obras no cerradas a la modificación. Duchamp, que con sus prácticas cincuenta años antes se había encargado de cuestionar profundamente a las instituciones artísticas y a la misma entidad de la obra, funcionó como un modelo a seguir por los artistas que deseaban contestar a la mercantilización del arte y los patrones de artista, público e institución. Los cortes de Fontana y las máquinas de Da Vinci fueron estímulos que Vigo reconoció entre sus mayores influencias. Además de ellos, es evidente la proyección que tuvo el arte concreto sobre su obra, de modo que trabajos como los de Arden Quin o Gyula Kosice con figuras geométricas, tienen un sello que Vigo retomará en sus poesías visuales. Asimismo, el Dadá y el constructivismo, con su rechazo a la representación y la figuración, y la búsqueda de nuevas formas que llevó a experimentar con diversos materiales, buscando borrar las barreras entre pintura y escultura, aparecen como resonancias constantes en la poética de Vigo.

El encasillamiento definitivo de la multifacética obra de Vigo en cualquier género o movimiento sería erróneo y restrictivo. Sin embargo, podemos apuntar que se vinculó con la poesía concreta y poesía proceso brasileña, la poesía visual, el arte ecológico, el arte de acción, el conceptualismo, los happenings y performances, el arte-correo. El grabado, especialmente la xilografía, fue una actividad constante en su vida, así como su relación con la madera, iniciada desde niño en el taller de carruajes de su padre.

La mayoría de sus obras, textos, objetos y correspondencia se encuentran en el Centro de Arte Experimental Vigo - Fundación Arte Visuales. Importantes coleccionistas y museos poseen obras suyas.

Antes de finalizar este acercamiento a la biografía de Vigo, dos anécdotas y una frase pueden dar cuenta de su programa. Cuenta Ginzburg que "Vigo llevaba en su muñeca un reloj que él llamaba 'reloj inútil' o 'reloj de verano' (porque en verano, como no 
utilizaba saco, el reloj estaba visible). A veces, cuando íbamos juntos por la calle con él y Pazos, un transeúnte le preguntaba la hora. Vigo le mostraba su reloj: solo se veía el engranaje del reloj roto y deconstruido, y la pobre persona quedaba estupefacta". El mismo artista relata que a fines de los sesenta, una noche, "Vigo presentó una performance-conferencia con el tema "La nada" (yo diría que fue una versión, la más interesante, del manifiesto de la oquedad): de improvisto, en medio del baile endiablado en la oscuridad y de la música a pleno volumen, la sala se ilumina un poco, la música se interrumpe y todos dejan de bailar. Sobre una pantalla blanca se proyecta una diapositiva donde no hay nada, es blanca luminosa. Vigo con un puntero de escuela señaliza la superficie de la pantalla blanca de la diapositiva vacía. Después de algunos minutos de silencio, de inmovilidad y de vacío, todo vuelve a la normalidad" (Ginzburg, (comunicación personal, 2012).

Soy anarco total, no pretendo ponerme a la cabeza de un movimiento ni generarlo.

[Quiero] tener un diálogo con la gente a través de mi obra (Vigo, entrevistado por Curell, 1995).

\section{DEFINICIONES METODOLÓGICAS Y DISPOSITIVOS DE INVESTIGACIÓN}

Para esta investigación se llevó a cabo un diseño flexible con metodología cualitativa, que se sustenta en el tipo de problema planteado en este proyecto. Se emplearon dos técnicas para la recolección de datos, orientadas por las dimensiones de nuestro objeto y el desarrollo teórico realizado. En primer lugar, la recolección de fuentes documentales escritas y fotográficas y obras de arte ha sido la base del trabajo empírico, ya que permitieron el acceder a las producciones realizadas por Vigo en el período estudiado, tanto de sus obras visuales como escritas: obras presentadas dentro y fuera de los museos, manifiestos, declaraciones, publicaciones, ensayos, notas mimeográficas. Para ello se utilizó el Archivo del Centro de Arte Experimental Vigo (CAEV), donde se concentra un enorme acervo documental sobre su trayectoria artística. De este fondo, se ha accedido a:

1. Fondo documental: 
a. Serie Documentos Personales de Edgardo Antonio Vigo: Cajas Biopsia (años 1953 a 1997): estas cajas, organizadas por año por el propio artista, contienen diversos documentos sobre su tarea como artista. Incluyen, entre otros, los siguientes tipos documentales:

- Curriculum Vitae con descripciones de las actividades llevadas a durante cada mes de los años 1953 a 1997;

- recortes de diarios y revistas de Argentina y el mundo sobre exposiciones organizadas o en las que participó Vigo;

- críticas artísticas y reseñas realizadas sobre sus trabajos;

- catálogos;

- ensayos ;

- correspondencias;

- fotografías;

- grabados, diseños, tarjetas realizadas por el artista.

b. Revistas, publicaciones y ediciones producidas por Vigo:

c. Carpeta "Archivo Marx Vigo".

d. Carpeta "Dibujos infantiles".

e. Carpeta "Diccionario mío y 44 trabajos dibujos 61/62"

f. Carpeta "Exposición Radio Universidad de La Plata 1961".

g. Carpeta "París - Verona 1953".

h. Carpeta "Poesía Visual".

i. Carpetas "Relativuzgir's".

j. Carpetas "Señalamientos" I al XIX.

k. Carpeta "Xilografías a la témpera (1963 - 1965) y Poemas y notas periodísticas sobre Diagonal Cero".

1. Objetos, poesía visual

m. Manuscritos no clasificados

2. Hemeroteca de Edgardo Antonio Vigo

3. Biblioteca de Edgardo Antonio Vigo 
Se han analizado mil setecientos documentos aproximadamente, pertenecientes a este centro documental. En al apartado Fuentes se listan solo aquellos que han sido citados en la tesis.

Sobre este material se ha realizado un trabajo de digitalización con el objetivo de protegerlo y acceder con mayor facilidad. También se ha realizado la digitalización de la colección completa de las revistas Hexágono '71, tanto para la producción de la tesis como para contribuir para futuras investigaciones interesadas en ellas. Una referencia a este trabajo se encuentra en los Anexos de la tesis.

Para las producciones artísticas se utilizó la técnica de recolección de información documental. El término documento se refiere a "una amplia gama de registros escritos y simbólicos (...) incluyendo relatos históricos o periodísticos, obras de arte, fotografías, memoranda, registros de acreditación, transcripciones de televisión, periódicos, objetos, agendas y notas de reuniones, audio o videocintas (...)" (Erlandson et al. en Valles, 1997:120). Las producciones artísticas fueron consideradas como documentos visuales, según la clasificación realizada por MacDonald y Tripton (1993), que los distingue de los documentos escritos. Estos autores sostienen que los documentos se refieren a ciertos aspectos del mundo social: algunos tienen la intención de registrar el mundo social, otros intentan provocar reacciones como diversión, admiración, orgullo o goce estético, y que "sin embargo, nos dicen algo sobre los valores, intereses y propósitos de aquellos que los encargaron o produjeron. Tales creaciones pueden ser consideradas 'documentos' de una sociedad o grupo, que pueden ser leídos, si bien en un sentido metafórico" (1993: 188. Traducción nuestra).

De acuerdo con nuestros propósitos, si bien se realizaron entrevistas, estas no agotan el acceso a este tipo de producciones, dado que la información que brinda el encuentro con los documentos visuales, ya sea a través del contacto directo o de fotografías, incorpora otros datos para nuestro trabajo interpretativo con el beneficio de la no reactividad. El análisis estará centrado en las características materiales de las producciones artísticas, a lo que se sumará el contexto en que fueron producidas y expuestas, producto tanto de la investigación histórica, como de la mirada global que permite el trabajo de archivo de gran parte del fondo documental.

En el análisis de los discursos (orales y escritos) de Vigo se tuvieron en cuenta los supuestos básicos del enfoque sociológico relativos a la referencialidad y a las determinaciones sociales de los discursos, en función de situar los textos en contextos y, al mismo tiempo, darle un lugar privilegiado al sujeto, considerando sus discursos como 
prácticas (Alonso 1998; Pollak y Heinch 2006), además de evitar el riesgo de sobreinterpretación de la intención del texto (Alonso, 1998).

En segundo lugar, se trabajó con fuentes orales: la realización de entrevistas en profundidad a integrantes de los grupos integrados por Vigo o a testigos vinculados con sus producciones permitió dar cuenta de las experiencias vividas e interpretadas por actores claves del período (artistas), así como reconstruir parcialmente prácticas de arte de carácter efímero. Se realizaron entrevistas para la tesis (comunicación personal) y se utilizaron otras producidas por diversos investigadores:

a) Entrevistas personales a: Gustavo Sager, en relación con su padre, Julio Sager (2010), Graciela Gutiérrez Marx (2010), Antonio Miranda (por correo electrónico, 2010), Carlos Ginzburg (por correo electrónico, 2012), Clemente Padín (2012), Juan Carlos Romero (2013).

b) Entrevistas realizadas a Vigo:

- producidas por Mónica Curell (1995-1997), de las que hemos tenido acceso a los videos (VHS) en crudo y a la transcripción.

- transcriptas y publicadas: tanto las que se encuentran en las Cajas Biopsia entre los años 1955 y 1997 como las que se hallan en publicaciones más recientes.

c) Registros y desgrabaciones de entrevistas realizadas por otros investigadores: a Luis Pazos (Gualtieri, 2004; Pérez Balbi, 2006), Jorge D’Elía (Gualtieri, 2005), Jorge De Luján Gutiérrez (Santamaría y Pérez Balbi, 2006) y Carlos Ginzburg (por correo electrónico, Gualtieri, 2010).

d) En una primera etapa de la investigación hemos efectuado entrevistas exploratorias para el relevamiento de información sobre las artes en la ciudad de La Plata en los sesenta a: Eduardo Painceira (2010), Gonzalo Cháves (2010), Héctor Puppo (2010), Lida Barrgán (2010) y Néstor Mux (2010).

Las entrevistas en profundidad, de tipo flexibles y dinámicas, están dirigidas a la comprensión de las perspectivas de los informantes con respecto a sus experiencias o situaciones (Taylor y Bogdan, 1986), así como de sus creencias, valores, ideas y 
discursos arquetípicos (Alonso, 1998). Cabe destacar que se tuvieron en cuenta los riesgos metodológicos usuales de los relatos lineales de informantes, que procuraremos evitar en el sentido que lo advierten Bourdieu (1995) o Geertz (1992), entre tantos. En el análisis se destacaron secciones de los relatos que ofrecían información relevantes para nuestro trabajo, aunque no siempre se reflejaron en citas textuales a los largo de la tesis, sino que se incorporaron a los análisis e interpretaciones.

Para el análisis de los datos cualitativos basado en las fuentes utilizadas, hemos producido matrices de datos sobre:

1. Las nociones de artista, obras de arte, participación del espectador e instituciones.

\section{Señalamientos.}

3. Las apariciones de elementos de discursos y materialidades de lo judicial.

4. Hexágono '71.

Además, en base a un relevamiento previo realizado por Ana María Gualtieri en el Centro de Arte Experimental Vigo sobre la mencionada publicación, confeccionamos un índice razonado de la totalidad de sus números. Por la utilidad que pueden presentar para la tesis y para investigaciones futuras, hemos incorporado a los Anexos de la tesis matrices de los señalamientos, Hexágono '71 y el índice de esta última. 
PARTE II 
"No busco la perfección de mi obra, lego la perfectibilidad de los caminos que uno abre para posibilitar la eternidad del arte. No he pretendido nunca la obra que apabulle, que pretenda enterrar un ciclo, aparte de no estar dentro de mí, esa posición me parece idiota. Mi credo está basado en dos artistas de muy diferentes épocas. Leonardo Da Vinci y Marcel Duchamp, el primero por su búsqueda científica y orgánica de la cosa y la poética que toman sus trabajos no realizados por la falta de apoyo de una técnica que no permitió la construcción de sus inventos. La visualización de sus dibujos de máquinas se cargan de ese halo que permite la imaginación de lo que hubieran sido trastocando toda la imagen que uno tiene del arte de su tiempo. Duchamp porque trabajando también muy adelantado a todos los mensajes de su época permitió por su valentía y estado irónico la construcción ingenua de sus objetos, concretándose éstos bajo una técnica de grado perfectible. En ellos veo la constante que me domina: la experimentación. Nunca temo a la negrura de la incomunicación que a veces incluso se produce entre mi obra y yo. Dejo brotar mis elementos, el tomar conciencia de la existencia de los mismos no me preocupa, busco el sedimento vital que el trabajo anterior dejó, los ubico y pretendo tener ese hilo que una, sin cronología pero dentro de mí lo que yo puedo concretar. Mi taller plagado de formas iluminadas por mi propio quehacer, ya sacado del Misterio sé que presentan un panorama negro para los demás, así como guardan todavía para ellos recónditos interrogantes. No niego que en oportunidades, esos mismos trabajos se vuelven incomunicables conmigo mismo."

Vigo. Texto grabado en cinta magnética para "El archivo de la palabra" en la Dirección de Cultura de la Municipalidad de La Plata, 5/9/67. (Biopsia 1967) 


\section{CAPÍ́TULO 1 \\ LOS SUJETOS DEL ARTE TRASTOCADOS}

Durante las dictaduras de Onganía, Levingston y Lanusse, mientras se vivía un clima represivo y de ebullición política, crecieron los cuestionamientos e intentos de renovación en clave cultural y social. Entre ellos se incluían modificaciones en los patrones de conducta en relación con la autoridad en los ámbitos públicos y privados, así como en la moral sexual y familiar, y controversias sobre la doctrina católica tradicional y la cultura burguesa capitalista. Vigo vivió ese mundo, puso en cuestión algunas concepciones, prácticas e instituciones artísticas y se insertó, al mismo tiempo, en las disputas político-ideológicas de la época.

En su poética diversa, un interés especial ocupó a Vigo en el período de estudio de esta tesis: la participación del espectador. Esa idea, compartida por otros artistas locales y de diversos lugares del mundo fue la matriz que gestó en Vigo una serie de prácticas artísticas y discursos. Asimismo, atendió a otros problemas relacionados, como la idea tradicional de artista y la vinculación con instituciones artísticas. Veremos en este capítulo de qué modo Vigo planteó sus definiciones en torno a esos temas a través de escritos teóricos y trabajos artísticos.

\subsection{OBRA, ARTISTA, PÚBLICO, INSTITUCIÓN: "UN ARTE CONTRADICTORIO"}

Los cambios proclamados en la obra de arte, el artista y el público eran moneda corriente entre las vanguardias de los sesenta (Longoni y Mestman, 2000). Las ideas que desarrolla Vigo sobre estos temas parten de un cuestionamiento al estatuto del público como sujeto pasivo y distante respecto de la obra, del artista como único autorizado a tomar parte en el proceso creativo y de obra de arte como objeto cerrado, terminado de una vez y para siempre, intocable y auratizado. Cuando escribió sobre estos temas, lo hizo en el contexto de una perspectiva más o menos compartida con otros artistas del momento y que encuentra su origen en las operaciones de las vanguardias históricas. Así, la búsqueda de conmover la conducta, la conciencia o la sensibilidad del espectador, la propuesta de una creación colectiva -ya sea en grupos o con el espectador- en oposición a la del artista individual, la producción de obras no 
destinadas a la comercialización, ni a museos o galerías, y presentadas en espacios públicos, son algunas de las características de la vanguardias de la época (Longoni y Mestman, 2000). Si en ese sentido no es tanto la originalidad de Vigo lo que puede destacarse, son relevantes, en cambio, el interés que demostró por tomar parte en la discusión crítica acerca del nuevo estatuto del arte a través de sus ensayos, y la forma en que combinó esos textos escritos con sus trabajos artísticos y editoriales, dejando en evidencia vaivenes y transformaciones a través del tiempo y al calor de las circunstancias sociales y políticas. Asimismo, su actitud estudiosa respecto de las últimas novedades sobre estos temas, especialmente por la información que recibía de sus contactos con el extranjero, se evidenciaba no solo a través de sus clases en el Colegio Nacional y de las charlas que brindaba en diferentes instituciones, sino también en la marcada disposición a mostrar estas nuevas tendencias tanto en sus propios textos como en la publicación de ensayos -que en algunos casos él mismo hacía traducir- en la revista Hexágono '71.

Cuando Vigo y otros artistas se oponen a las instituciones, lo hacen a ese conjunto que implica un "selecto rango de significados, valores y prácticas que (...) constituyen los verdaderos fundamentos de lo hegemónico" (Williams, 2009:162) y que, en el caso del arte, refiere -como adelantamos en la parte I- a las relaciones que implican la producción, distribución y recepción del arte, así como la definición de lo que se considera arte en un momento determinado (Bürger, 2010). Estas instituciones están basadas en "tradiciones selectivas" de una visión del pasado que se reconfigura en el presente, lo cual supone la producción histórica de las figuras de artista, público y obra de arte desde el siglo XVIII, pero especialmente desde el Romanticismo en adelante.

La figura del artista, como la de autor, refiere primeramente a la autoridad ejercida sobre una obra de arte, y en segundo lugar, a su creador como genio individual (Williams, 2009; Bürger, 2010). Lo que convienen en cuestionar los artistas del período de nuestro estudio -en tanto reactivan las críticas realizada por las vanguardias históricas- es la identificación del artista con esa función de autoridad creativa, individual y burguesa. El artista, en este sentido, es también quien puede intercambiar en el mercado, como propietario, su obra, es decir, el resultado de su creación, por otro bien. Con esta figura se vincula la crítica de Vigo también a la noción de un público pasivo, como contracara de ese "individuo como creador de la obra" (Bürger, 2010: 74). La reprobación que desarrolló Vigo no incluye, sin embargo, la noción de "nombre de autor", tal como fue desarrollada por Foucault (2000) y que se define por una referencia 
al nombre que organiza, clasifica, agrupa y delimita los discursos, no al individuo. Veremos más adelante que la oposición a la figura de artista por parte de Vigo fue más compleja que la simple negación, y si bien cuestionó la idea de artista como creador individual, no implicó, en el desarrollo material de su poética, un impedimento para mantener su nombre como "nombre de autor", para invocar su "función-autor", en un sentido similar al que Barthes (1987) se refiere al autor como "sujeto" y no como "persona". 23

En el editorial de una de sus primeras revistas, $W C$, el número 2 de 1958, Vigo apuntaba a una crítica a los sujetos del arte:

Realizando nuestro trabajo individualmente trataremos de cargar al mismo de dinámica social (...). Contamos en que las distintas manifestaciones (nada de estilo) de los trabajadores expresivos (nada de artistas) lleguen al pueblo (nada de público) y no retrasmitidos (nada de críticos) sino palpados directamente. (Vigo, 1958).

Vigo fue desarrollando a lo largo de los años esta visión -que ya ponía en funcionamiento con sus producciones artísticas y ediciones tempranas, aunque de otro modo ${ }^{24}$ - y uno de los textos en que presenta su visión crítica respecto del arte tradicional es un artículo que publicó en 1968 titulado "La revolución en el arte" (Vigo, 15/12/68). Analiza allí distintos cambios producidos en el arte referidos a modificaciones en las condiciones de producción y de recepción, y en los materiales y técnicas empleados. Comienza destacando dos aspectos de ese proceso: "la participación activa del observador y la 'simultaneidad' del suceso [que] socavan el concepto de exposición". Sostiene que el público también ha sufrido transformaciones, en tanto el arte para las elites de las galerías y los museos ha dado paso a uno destinado a la comunicación. También destaca los cambios producidos en las obras ("elementos"), especialmente por su integración al espacio y el tiempo, al eliminar la distancia y negar lo inalterable de la obra. Eso se debe, según el artista, a que en el momento el ambiente modifica la propia obra. Al mismo tiempo, desde esa mirada, el observador rompe su posición "antidinámica, lenta y contemplativa"; aunque no debe exigírsele un cambio de

\footnotetext{
${ }^{23}$ Por ello la idea de "muerte del autor" de Barthes no coincide con lo que Vigo pretende provocar cuando dice que renuncia a la idea de "artista".

${ }^{24}$ Ver Gradowczyk (2008).
} 
conducta $^{25}$ para que la relación obra-público sea "más natural y efectiva". Para Vigo, el arte contemplativo respondía a un tipo de sociedad que ya no existe, y hoy el arte se ha dinamizado porque también lo ha hecho la sociedad.

En este ensayo, cita un texto de 1960 en el que Alan Kaprow -un artista pionero del happening- propone abandonar los elementos permanentes o inalterables en el arte y utilizar en su lugar otros perecederos. Vinculado con ello, Vigo menciona, también del artista estadounidense, la idea de "presentación", que reemplaza a la de "exposición". La principal diferencia entre ambas -según Kaprow- es que en la "presentación" se permiten variaciones, mientras que en la "exposición" todo se mantiene inalterado ${ }^{26}$. Vigo agrega a esto que la presentación se logra por "la irrupción de lo insólito"27, y ofrece ejemplos, entre ellos una performance que realizó en octubre de 1968 en la Alianza Francesa para la exposición Remember... Grupo Sí, como festejo del cumpleaños del grupo informalista. Vigo mostró el objeto Bi-tricicleta ingenua - 1961 mod. 1968, e hizo la presentación de la muestra: el público, sentado en el piso, debía pasarse una vela encendida dentro de un artefacto creado por Vigo, y finalmente todos cantaron el "Feliz cumpleaños": "aclarando que la presentación de una Expo/ contemporánea debía romper los cánones tradicionales, invité al público a sentarse en el suelo", dice Vigo en sus manuscritos, y destaca la intención de la activa participación del público (Biopsia 1968) ${ }^{28}$. Otro ejemplo que anota son las poesías fónica ${ }^{29}$ y visual

25 Esta idea de no exigir un cambio de conducta en el espectador es coincidente con el manifiesto del primer señalamiento que se verá en el capítulo 2 .

${ }^{26}$ Kaprow propone la "presentación" en lugar de utilizar el término "suceso", por ser la traducción de la palabra inglesa "happening".

${ }^{27}$ En diversos textos repite esta la idea de "presentación”, en general basado en el concepto de Kaprow. Por ejemplo, también hace referencia al reemplazo de la exposición por la presentación en alusión al desarrollo de la vanguardia platense de los sesenta en su artículo "No-arte-Si" (Vigo, 25/08/69). Sin embargo, como se verá más adelante, introduce una variación en "La calle: escenario del arte actual", publicado en su revista Hexágono '71, be (1971), oponiendo presentación a representación.

${ }^{28}$ Los documentos contenidos en las Caja Biopsia del Archivo del Centro de Arte Experimental Vigo (manuscritos), se citan "Biopsia" seguido del año de producción del documento. En los casos en que ha sido necesario informar sobre el documento específico al que se refiere la cita, este dato se ha incorporado luego del nombre del autor. Todas las citas textuales conservar el énfasis del original, excepto cuando es aclarado expresamente. En algunos casos no ha podido identificarse la fecha de producción del documento (s/f), el número de página (s/p) o carecen de título (s/t).

${ }^{29}$ Padín, uno de los artistas y teóricos de la vanguardia uruguaya, explica que "la poesía sonora o fónica se vale de las posibilidades expresivas de los sonidos y articulaciones vocales que hacen posible la dimensión sonora del lenguaje verbal. La poesía fónica fluctúa entre la música y la literatura, entre el habla y el canto, entre la experimentación fono-verbal y el juego glososemántico. No se trata de la lectura padronizada por la declamación o recitado de los poemas sino de investigar las posibilidades expresivas de la oralidad en todas sus dimensiones. (...) Hasta la aparición de las técnicas de grabación electrónica, 
que, según Vigo, “cambian la destinación del 'lector'. Este, hasta entonces, era preciso. El poema se cerraba sobre él.". En cambio, "la poesía visual es un excitante para el psiquismo, a partir de las palabras propuestas y de su arquitectura, debe hacer trabajar su cuerpo y su espíritu; debe proponerse él mismo como contenido". También menciona como ejemplo el uso de expresiones cercanas a la publicidad. En estos casos, dice, "el clima resultante quiebra toda previsión y status".

Para Vigo el arte contemporáneo lucha contra el mercado del arte, exige el abandono del curriculum y los premios, "que han alejado la sociedad de su 'derecho' a la libre elección".

Arrojar el lastre será para el artista la apertura al vacío, el 'derrumbe' de Galerías y museos en un deseo de ganar la calle, la muerte de las elites exigentes, dueñas de creadores al servicio de sus intereses. La utilización de materiales que permiten la destrucción del religioso espacio separatista entre obra-público, indican una dirección hacia un arte 'tocable', signo de calidez comunicativa. Complementa un público predispuesto a entregarse a lo colectivo, cuando la participación permite en alguna de sus secuencias la aparición de la personalidad individual puesta al servicio del 'logro de la cosa'. (Vigo, 15/12/68, s/p)

Vigo articula así una nueva idea de obra, el cambio en la concepción sobre el artista, el público y las instituciones y delinea su propia posición como artista-teórico entre los colegas y demás lectores no expertos, ya que el medio en que publicó es el diario local. ${ }^{30}$ Otro texto crucial para comprender qué relaciones pretendía establecer entre las figuras de artista, obra y público, es el manifiesto que entregó al crítico Ángel Nessi en 1969, que citamos completo:

Hacia un arte "tocable" que quiebre en el artista la posibilidad del uso de materiales "pulidos" al extremo de que produzcan el alejamiento de la mano del

se refugió, escrita, en la poesía visual, resurgiendo con las vanguardias históricas de comienzos de siglo XX a lo que hoy se conoce como poesía fonética. Luego en los 50s., con la aparición de la cinta electromagnética, la poesía sonora se diversificó notablemente, en virtud del amplio abanico de posibilidades que ofrecía el nuevo medio y, aún más, hoy día, con la tecnología digital y sus posibilidades multimedias." (Padín, 1992, s/p )

\footnotetext{
${ }^{30}$ Vigo expuso estas ideas reiteradamente en diversos escritos, todos de un tenor similar. Hemos tomado aquí los que consideramos más representativos de sus tesis respectos de las renovaciones en el arte que él ha querido expresar. En otros textos, por ejemplo, "No-arte-Si", Vigo (25/08/69) señaló que las novedades son "la decadencia de la obra de arte inerte", la aparición del objeto, la participación del observador, cambios en la crítica, el pasaje de la exposición a la presentación, y del artista individual al agrupamiento, el arte en la calle, entre otros. Esto se repite en diversos ensayos publicados en general en periódicos o revistas, los cuales pueden consultarse en el enorme acervo documental de su archivo personal.
} 
observador -simple forma de atrapar- que se quedará en esa posición sin participar "epidérmicamente" de la cosa.

Vía uso de materiales "innobles" y por un contexto cotidiano delimitador del contenido.

Un arte "tocable" que se aleja de la posibilidad de abastecer a una "élite" que el artista ha ido formando a su pesar, un arte "tocable" que pueda ser ubicado en cualquier "hábitat" y no encerrado en Museos y Galerías.

Un arte con "errores" que produzca el alejamiento del "exquisito". Un aprovechamiento al máximo de la estética del "asombro", vía "ocurrencia" -acto primigenio de la creación- para convertirse, ya por forma masiva -movimientos envolventes- o por la individualidad -congruencia de intencionalidad- en "actitud".

Un arte de expansión, de atrape por vía lúdica que facilite la participación-activa del espectador, vía absurdo.

Un arte de "señalamiento" para que lo cotidiano escape a la única posibilidad de lo funcional.

No más “contemplación” sino "actividad".

No más “exposición” sino "presentación”. Donde la materia inerte, estable y fija tome el movimiento y el cambio necesario para que constantemente se modifique la imagen.

En definitiva: un arte contradictorio. (Vigo, 1968-1969) ${ }^{31}$

La idea de contradicción, que actúa como corolario de unas definiciones antagónicas a las nociones y funciones tradicionalmente ejercidas por los sujetos del arte, funciona aquí como perturbación, distorsión o disenso con las posiciones y jerarquías normalmente asignadas a ellos. Vigo apunta, así, a intervenir en la articulación entre arte y sociedad, de modo que aún refiriéndose al campo específico de su accionar, adquiere un carácter político por la forma en que combinó estas declaraciones con las prácticas efectivamente llevadas a cabo tanto en la producción artística como en las instituciones.

\footnotetext{
${ }^{31}$ En cuando a la "no contemplación”, en la misma sintonía, Rubén Santantonín había propuesto en 1963 que "el arte-cosa (...) intenta denodadamente que el hombre no contemple más las cosas, que se sienta inmerso en ellas, con su asombro, su inquietud, su dolor, su pasión” (Santantonín en Giunta, 2008: 136).
} 
A partir del artículo citado y del manifiesto podemos resumir lo que serán las principales líneas de su trabajo en este período:

- Participación "activa" del espectador: observador dinámico, aunque no forzado; público "dispuesto a entregarse a lo colectivo" gracias a la participación.

- Arte para la "comunicación", no para las "elites" ni para "exquisitos".

- Provocación de "asombro", a través de la "ocurrencia".

- Cambios en la relación obra-público: "destrucción del religioso espacio separatista entre obra-público".

- Obras como "elementos", integrados al espacio y tiempo.

- “Presentación” en lugar de exposición: permite variaciones y la "irrupción de lo insólito".

- Cambio de relación con las instituciones artísticas: galerías, museos y gestores ("elites exigentes", "creadores al servicio de sus intereses”), así como con el mercado del arte (para lograr el “'derecho” a la libre elección” de la sociedad).

- Incorporación de trabajos en el espacio público: "ganar la calle".

- Modificaciones en la obra: materiales, dispositivos y formas nuevos.

Vigo propone un programa que desarrollará a lo largo de su vida, pero cuya especial densidad entre fines de los sesenta y mediados de los setenta, hace necesario un análisis detallado de su producción textual y artística.

\subsection{LA PARTICIPACIÓN DEL ESPECTADOR}

Como sabemos, la idea de que el público no fuese un simple observador pasivo, cómo solía serlo de un cuadro colgado en una pared, tuvo su origen en las vanguardias de principios del siglo XX. El dadaísmo, el surrealismo, el futurismo, reclamaron una participación más activa por parte del espectador, "a quien trataban de provocar con tal de que reaccionaran ante la situación que estaban denunciando" (Cervantes, 2000: 105). Esta búsqueda dio un giro en la relación entre arte y público y generó distintos grados de involucramiento en los procesos de creación, que van desde la participación en la producción de la "obra" hasta su rechazo. De allí en adelante, distintos movimientos han ido interesándose en esta cuestión, hasta que en los cincuenta aparecieron las primeras 
performances, entre las que se destacan las realizadas en 1952 por John Cage. Con influencia Dadá, especialmente del espíritu de Duchamp, así como de la filosofía Zen, Cage esperaba que la ubicación del público en círculo, mirando hacia afuera, y la actuación, recitado, baile y música de varios artistas (entre los que se encontraban Robert Rauschenberg reproduciendo música de Edith Piaf y Merce Cunningham danzando), todo ello con un alto grado de indeterminación e improvisación, generasen más atención que un concierto convencional. La herencia de Duchamp parece haber sido fundamental para pensar en un nuevo tipo de público, dado que el modelo de sus ready made, especialmente de la Boîte en Valise (caja-valija) ${ }^{32}$ "había desafiado al espectador a encontrar una reflexión nueva para ese objeto a través de la eliminación de la intervención del autor" (Hopkins, 2000: 41. Traducción nuestra).

A estas performances se suman, entre otras, las de Klein a partir de 1960, hasta que apareció el happening como forma en que el público fuese la "razón de ser" de la obra. A partir de los intentos de cerrar lo que Rauschenberg llamó la "brecha" (gap) entre arte y vida, surgieron los happenings y las acciones de Fluxus, los cuales desde la interdisciplinariedad artística desafiaron la pintura convencional y la escultura, basados en la herencia de Cage, Rauschenberg y las performances de principios de los cincuenta, así como en la tendencia Dadá, enfocados en el "descentramiento del ego del artista, favoreciendo la interacción viva artista-audiencia (...) a través de transgresiones desorientadoras de los límites de los medios" (Hopkins, 2000: 104. Traducción nuestra). George Maciunas, de Fluxus había escrito sobre la importancia de demostrar que, contrariamente a lo que sucede en el arte tradicional, el artista no es imprescindible, desafiando su status elitista y profesional, y que el público tiene autonomía o autosuficiencia. Todo ello apuntaba a establecer relaciones de igualdad entre ambos (DeRoo, 2006).

Inspirado en Pollock y Cage, Allan Kaprow inició una serie de acciones participativas, que definió como "una forma de arte distinta de las disciplinas preexistentes (...), un arte de naturaleza abstracta, sin intriga ni historia, que ocupa un lugar en el tiempo, y debe ser realizado de manera activa por el artista y los espectadores, que pasan a convertirse en cocreadores de la obra, anulando así las barreras entre el público y la creación" (Kaprow en Cervantes, 2000: 109). En los happenings cobra especial relevancia la relación del público a través de entornos sensorialmente complejos, en los

${ }^{32}$ Ver el capítulo 4 
que, lindando con aspectos teatrales, se utilizan propuestas de participación de los espectadores.

Las mismas preocupaciones asaltaron a artistas argentinos, quienes buscaban que el público pasara a ser un colaborador activo e imprescindible para que la obra tuviera una existencia completa (Giunta, 1999). Santantonín escribía en 1965: “nos preocupa el espectador, no en trance de evasión. Quisiéramos darlo vuelta como se da vuelta un guante. Que tenga sensaciones diferentes a todas las vivencias estéticas que ha experimentado en su vida (...) Un arte de compromiso vital (...) Provocar en el participante una sensación inédita" (Santantonín en Giunta, 2008: 160-161). El Di Tella avalaba un tipo de trabajos, como los de Marta Minujín o Emilio Renart, que hacían hincapié en el espectador, y hasta implicaban su propio cuerpo, mientras Le Parc subrayaba sobre este asunto que querían un "espectador consciente de su poder de acción" (Le Parc en Giunta, 2008: 161). En 1965 se llevó a cabo La Menesunda, un happening ideado por Minujín y Santantonín que generó una asistencia masiva de público, la reacción de la crítica y un salto en el desarrollo del arte local.

Asimismo, la búsqueda de alterar los sentidos, nuevas experiencias y la introducción de lo subjetivo y lo orgánico en el arte estaban en el centro de trabajos de artistas brasileños, como Lygia Clark, Helio Oiticica y Lygia Pape. Los espectadores, transformados en partícipes sensibles, eran la clave de sus producciones artísticas.

El conjunto de las proposiciones renovadoras desarrolladas en el arte de la época en diferentes puntos del mundo, de las que hemos mencionado solo algunas, se centraban en mayor o menor medida en los mismos puntos cruciales referidos al artista, al público, a la obra de arte y a las instituciones. La modificación parecía imprescindible, y alterar o desviar el curso de las prácticas artísticas se presentaba como una necesidad que tomaba parte de los cambios sociales y culturales que variaban las condiciones del mundo contemporáneo. No se trataba solo del reemplazo de unas formas por otras, sino de un proceso que pretendía una transformación absoluta de la vida social.

En esta atmósfera, Vigo se interesó no solo en llevar a cabo la participación del público sino también en teorizar acerca de su pertinencia para el arte de vanguardia, aunque no acotada a la presentación de happenings. Como vimos antes, Vigo había escrito en "Un arte a realizar" una proclama en la que proponía ir "hacia un arte tocable", donde lo lúdico fuera una de las formas de participación, para pasar de la "contemplación" a la "actividad". 
Estas premisas son las que Vigo desarrolló a lo largo de su poética, tanto en sus ensayos como en sus producciones artísticas. Veremos a lo largo de la tesis diversas obras en las que puso en práctica esta teoría.

La idea de la obra como proyecto o propuesta a realizar por el público se encuentra en consonancia, como ya hemos mencionado, con otros artistas de la época. Al acudir a los términos "propuesta" o "proyecto" Vigo estaba utilizando una categoría empleada, entre otros, por Joseph Kosuth, quien afirmaba a fines de los sesenta que reemplazaba el término "obra" por el de "arte de proposición" (art proposition), dado que "una obra de arte conceptual en el sentido tradicional es una contradicción" (Kosuth en Buchloh, 1990: 108. Traducción nuestra.)

En su ensayo "Desde la poesía proceso a la poesía para realizar. La vanguardia poética" (Vigo, 23/10/70; 1970 ${ }^{33}$ ) el problema principal que aborda Vigo es la participación del público. Allí dice que el fenómeno que enriquece el desarrollo de la "novísima poesía" es esa participación, al contrario de la idea de "objeto intocable, misterioso, fuera del contacto de nuestros sentidos", que responde a la lógica tradicional. Explica que luego de haber pasado por una "participación condicionada", en la que había intencionalidades no cumplidas, se ha llegado a la poesía proceso, donde se promueve el desarrollo de "imágenes poéticas por intermedio de "claves", a través de un "participante activo". Este pasa de ser "recreador (interpretación de la cosa) a creador (modificante de la imagen)", y genera así un producto final, agregando o quitando elementos cuyo resultado no puede ser "computado" con anterioridad por el artista. Además,

la retención visual, el acostumbramiento por lo repetido, el conocimiento del objeto transcripto en su diseño y no en su concepto caligráfico, la acumulación de información de 'señalamientos' cotidianos (tránsito, vías peatonales, etc.) producen una lectura diferente a la habitual (...), torpedean el costumbrismo cotidiano, producen facetas nuevas (visión caleidoscópica), crean la revulsión. $(23 / 10 / 70, \mathrm{~s} / \mathrm{p}$.$) .$

Vigo plantea la existencia de un proceso ascendente, donde se va desde lo menos auténtico en la participación del espectador hasta lo que sugiere como un punto de llegada, la transformación del participante en un verdadero "creador".

\footnotetext{
${ }^{33}$ Vigo publicó este ensayo en el diario El Popular de Montevideo con fecha 23/10/1970 y en el mismo año en un libro de su editorial Diagonal Cero con el título "De la poesía/proceso a la poesía para y/o a realizar". Al cotejar ambos textos, aparecen algunas diferencias que no modifican lo sustancial del contenido. La opción de publicarlo en un periódico refleja la idea de hacer circular sus ideas hacia un público más amplio que excediera al de los circuitos artísticos, amistades y colegas.
} 
Vigo desarrolla aquí la idea, expresada antes, de "presentación", que reemplaza a la "exposición", y define esta última como "todo aquello que permanece inalterable a la contemplación del público (perennidad de las formas)", a diferencia de la primera, donde "todo aquello que, ya sea por la participación del espectador, o por el movimiento de la obra, o por la señalada metamorfosis de los elementos componentes, produce sucesivos cambios de la obra, en su estructura, contexto o imagen". También se refiere a la "desaparición de la obra", es decir su consumo o destrucción luego de ser presentada. Define tres etapas de la poesía:

1. El "poema proceso": quiebra la utilización de la palabra (contrapuesto a dadaístas y surrealistas), usando un lenguaje espacial - visual.

2. El "poema para armar": hay un participante pero su acción está limitada por un "programador" -idea que suplanta a la de "artista".

3. El "poema para realizar": es el resultado de una progresión de los modelos anteriores (y que Vigo propone como superación) e implica una "participación activa" hasta llegar al objetivo de la realización del poema por el participante, "su poema". El poema a realizar, dice Vigo, se opone al "arte de consumo", si se tiene en cuenta que este último se trata de una necesidad creada artificialmente. Es por ello que se debe tomar una posición claramente contraria a aquel. Con el arte de consumo se niega al hombre, masificándolo por la vía del espectáculo al que hay que contraponer un arte "intercomunicativo - lúdico - individual”.

Con respecto a esto último, dice que

Lo lúdico [funciona] como puente de contacto en diferenciadas formas de encarar el arte, porque está comprobado que es la única vía posible para que la sociedad retome interés y participación en el fenómeno del arte. Procedimiento válido y accesible que se basa en la solución de una participación activa para llegar a la activación más profunda del individuo: la realización por él del poema (Vigo, 1970: 9)

Como puede verse, aquí Vigo centraliza la idea de participación en la creación de la poesía, aunque se refiere también a otro tipo de trabajos, como los señalamientos, y en general, a los cambios que se producen en la "presentación" de una obra. Se interesa especialmente por la posibilidad de que el espectador se transforme en un sujeto activo, lo que conduciría a dejar atrás modelos que consideraba superados.

Luego de la acción en el espacio público del señalamiento $I V$ en 1970 -en que el público debía emitir un voto a modo de poesía, al mismo tiempo que se exponían 
objetos de Vigo dentro de la tienda Tomatti (ver capítulo 2)- se publicó una nota sobre esa presentación (Ritmo, 1970). Allí se hacía hincapié en la cuestión de la participación como eje, reemplazando a "la obra" por "el acto". Una vez más, Vigo refiere al abandono de la idea de "exposición" por el de "presentación" y sostiene que, a diferencia de una "contemplación", en este acto se trató de una "presentación". Si bien allí expuso algunos objetos, el artista explica que la presentación se logró a partir de una "ambientación" que diera al lugar un aspecto conocido a través a algunas "obra-tipo" suyas. Vigo expresó: "además quiero dejar establecido otro hecho fundamental para la 'quebradura definitiva' y es el que representa el abandono al concepto de religioso, intocable y único de la obra de arte al permitir que cada una de las obras asimile lo 'rodeante' y este a su vez se introduzca en la imagen de aquella transformándola" (1970: 4). Llamó a esto "integraciones impuras", en oposición a las obras de arte tradicionales, las que no pueden sufrir este proceso porque perderían su unidad e integración. De este modo, con tono benjaminiano, Vigo parece referirse al aura y a su destrucción. Así como para Benjamin (1989) en el conocido texto "La obra de arte en la época de su reproductibilidad técnica", el aura es el "aquí y ahora" de la obra de arte (1989: 20), "una presencia irrepetible" $(20,22)$ o la "manifestación irrepetible de una lejanía" $(26,75)$, Vigo, cuando se refiere al "religioso espacio separatista entre obrapúblico" (15/12/68) identifica lo intocable, lo siempre igual, con lo viejo y desvinculado del público en tanto este no tiene nada que hacer allí para modificarlo.

Asimismo, Benjamin vincula al aura con la "unicidad" de la obra de arte (1989: 25), mientras que Vigo refiere a la "unidad" e "integración", en lo que, para ambos, aparece la fuerza de la tradición. Benjamin dice que la destrucción del aura permite "acercar espacial y humanamente las cosas" (24), y si bien para él esto ocurre especialmente por la reproducción técnica, esa posibilidad de acercamiento es lo que le interesa a Vigo a través no solo de sus múltiples (que pueden reproducirse), sino también a través de la participación directa del público. El acercar las cosas actúa para Vigo no solo como posibilidad de acceder a una reproducción, sino como potencia de acción por parte del espectador, lo que, igual que para Benjamin, implica también una modificación en la forma de exhibición de la obra de arte. Esto se vincula con que "la orientación de la realidad a las masas y de estas a la realidad es un proceso de alcance ilimitado tanto para el pensamiento como para la contemplación" (Benjamin, 1989: 25), en el mismo sentido en que Vigo exalta la vinculación entre arte y vida de diversas formas, especialmente, la producción de obras participativas, la utilización de un tipo especial 
de "presentación" de sus trabajos y acciones artísticos -y que implicó también el uso del espacio público-, el empleo de formas discursivas y materiales del mundo judicial y, en algunos casos, la incorporación de aspectos del discurso de la izquierda política en momentos de amplia politización de la sociedad. De este modo, destrucción del aura, cambio de posición del público y vinculación con la vida, emergen de la propuesta de Vigo, así como de sus trabajos artísticos y editoriales.

En cuanto a los trabajos de Vigo que pueden analizarse a la luz de esta perspectiva, podría decirse que todos los presentados a lo largo de esta tesis se encuentran contenidos en este planteo, ya que es el eje estructurante que hemos identificado para este período en torno a su poética. Solo propondremos algunos ejemplos que adelantarán los casos analizados más adelante.

El momento en que la propuesta de Vigo tuvo su auge, tanto por la envergadura de la exposición como por las críticas en la prensa local, nacional e internacional, fue en la Expo Internacional de Novísima Poesía realizada en el Instituto Torcuato Di Tella entre el 18 de marzo y el 13 de abril de 1969. (imagen 10).

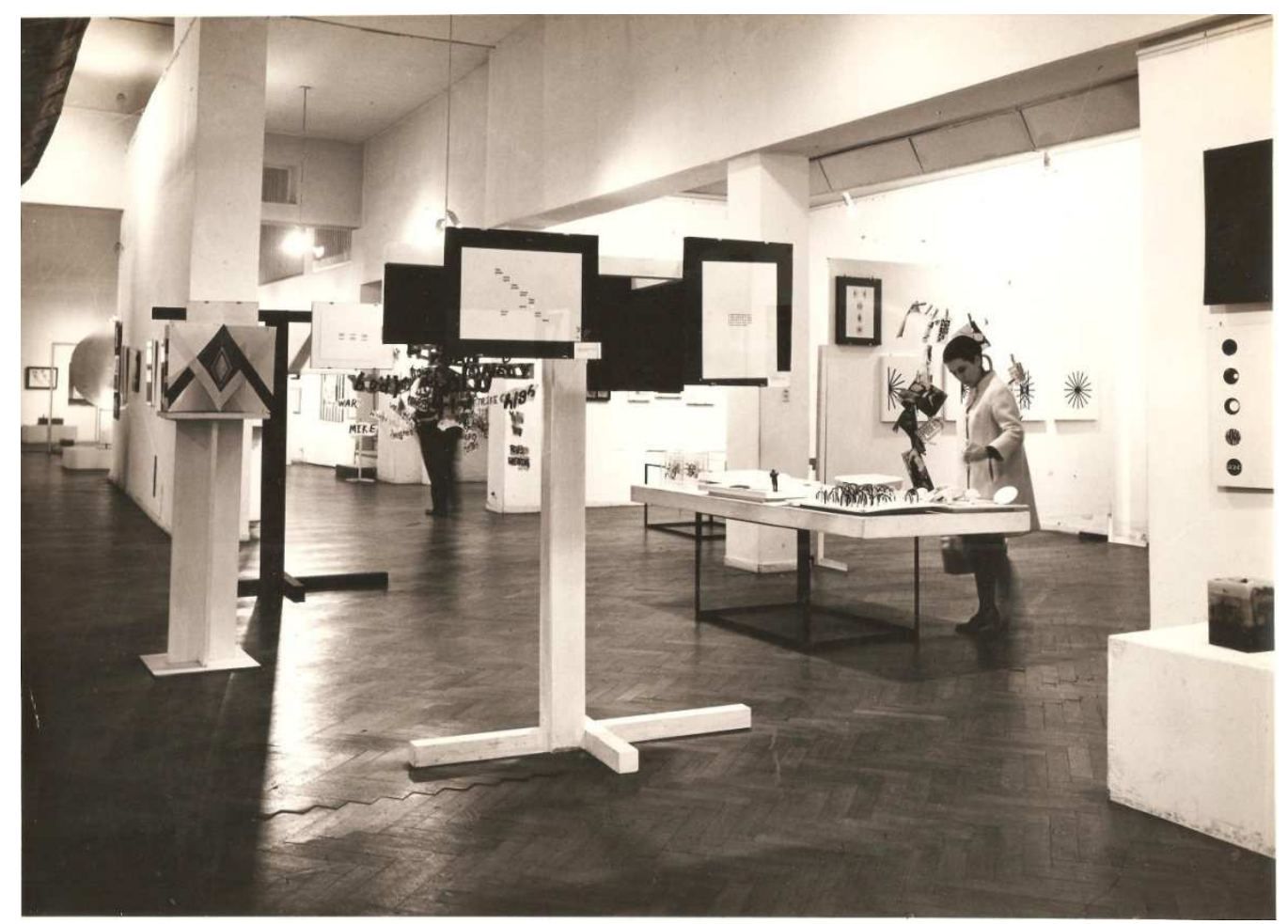

Imagen 10. Expo/Internacional de Novísima Poesía. ITDT, 1969. 
Aquel suceso, organizado y dirigido por Vigo, lo hizo conocido en los ámbitos artísticos, y demostró su capacidad operativa para generar eventos de gran envergadura. Ciento catorce artistas de quince países presentaron más de ciento cincuenta obras, lo que da cuenta de la red de conexiones nacionales e internacionales que movió Vigo para concretarla, con la anuencia y el apoyo de Jorge Romero Brest.

Esta exposición de "novísima poesía" cubría, en realidad, un abanico de obras, revistas y acciones que implicaban diversos modos de presentar y reflexionar sobre las posibilidades de combinación entre poesía y plástica hasta exceder sus propios límites. Si bien no describiremos aquí los detalles de los trabajos presentados, dado que no nos hemos ocupado de la reconocida labor de Vigo como gestor de exposiciones, grupos de artistas y diversos eventos ${ }^{34}$, debemos mencionar que en cuanto al tema que nos ocupa, generó opiniones, diversas críticas y reseñas, en las cuales la gran mayoría hace referencia a que la idea rectora de la exposición es la de participación del público.

En relación con los artistas participantes, Álvaro de Sá realizó una entrevista a Vigo, Jorge Gutiérrez, Carlos Ginzburg y Ana María Gatti sobre la Expo Internacional y sus propias obras: todos se refirieron a la centralidad de la participación del público, involucrado de distintas maneras. Ginzburg -que había realizado unos avioncitos de papel para que el público los lanzara y una lata para ser pateada- destaca la importancia de lo lúdico y señala que el problema ahora es la participación: "lo importante es que los juegos (avión y lata) presentados, coinciden con los impulsos del público y se transforman en actos de participación que los objetos desencadenan" (De Sá, 1969: s/p. Traducción nuestra). Gatti había realizado unas cabinas transparentes en las que se activaban luces y sonidos por medio de un control central operado por el público. La artista señaló que "mi máxima ambición es trabajar con las conexiones cerebrales del espectador. El tiempo es el límite, dado que el espectador no puede perderlo. En general todos están ocupados (...). Se trata del elemento humano puro sin condicionamientos estéticos determinados y sería bueno realizar trabajos donde encuentre las vías (una especie de cabina telefónica de poesía) en los trenes, los colegios, donde en fin, cada uno haga poesía"; sostuvo, además, que su intención es "cambiar cualitativamente la relación entre el actor y el espectador” (De Sá, 1969: s/p. Traducción nuestra).

\footnotetext{
${ }^{34}$ Sobre la Expo internacional de Novísima Poesía remitimos a los trabajos de Pérez Balbi (2006), Davis (2009) y Barisone (2012). Allí se encuentran reconstrucciones descriptivas de los trabajos expuestos, sus autores, y análisis de sus vinculaciones con el concretismo y el grabado.
} 
En la misma sintonía, otros artistas que se presentaron en la exposición, el "Grupo Proceso do Brasil” (Álvaro de Sá y Neide, su esposa) dicen: "nuestras creaciones, nuestros poemas son procesos. En ellos el espectador participa libremente completando o modificando la propuesta del artista. Si alguien quita algo de un poema, este se desvirtúa. En este caso, en cambio, no ocurre. Por el contrario, con la intervención del lector, se crea una nueva posibilidad de creación. El objeto es vitalizar la obra de arte y, especialmente, la relación entre público y artista" (El Día, 13/04/69). Ambos habían presentado poemas lúdicos, compuestos por distintos objetos (recortes de diarios, un soldado de plomo, botones, una cuerda y broches en el caso de Neide; una caja de madera, cinco bolitas que formaban la palabra caos en portugués, en el de Álvaro de Sá) para que el público pudiera manipularlos.

Las notas publicadas en diferentes medios locales, nacionales e internacionales sobre la Expo internacional revelan la trascendencia de la concepción de un público activo: Corriere del Giorno (21/01/69); El Día (13/04/69 y 16/03/69); La Razón (19/03/69); Clarín (20/03/69); La Nación (29/03/69); Primera Plana (1 al 7/04/69); Análisis (1 al 7/04/69); El Diario (22/04/69), Jornal do escritor (octubre 1969), hacen referencia a la importancia que adquiere el espectador al involucrarse en los trabajos allí expuestos.

Si bien la gran mayoría de las notas son auspiciosas respecto de la exposición y destacan la relevancia de la misma a nivel nacional e internacional, algunas expresan reparos. Una ellas merece ser mencionada porque se centra en el problema de la participación. En el diario Los Andes, el crítico Hugo Enrique Sáez, además de reprobar la exposición en general y de expresar que da la "impresión desconcertante" de "haber entrado en el Gran Supermercado del Arte", donde se encontraban "los clásicos atuendos estruendosos, las ya clásicas melenas y barbas de los clásicos anti-clásicos”, dice que la idea de participación del público no es nueva. Y se pregunta por la eficacia de esa intención:

La actitud para que el espectador cree (una estética tachada de tradicional diría que este recrea) a una con el propio artista, ¿se produce o es una imagen social de la obra que ha imaginado nada más que el artista? Esta desconfianza por la participación y creación es notoria sobre todo cuando uno ve las excesivas explicaciones en los creadores de esta exposición se ocupan. Creo que los estímulos que se le brindan al espectador pueden actuar sólo como tales (Sáez, 23/05/69: s/p). 
El exceso de explicaciones y la ausencia de una participación autónoma por parte del espectador, señaladas por el crítico, son observaciones que harían tambalear el logro de la propuesta participativa, y ponen en entredicho una suposición aparentemente incuestionable. En este planteo, Sáenz aparece como uno de los pocos que se adentra en la conjetural posición de Vigo y otros pares, cuyo planteo participativo aparece muchas veces como un ideal utópico, basado en presupuestos no siempre verosímiles. Volveremos sobre este punto problemático más adelante, al hacer un balance de la propuesta de Vigo.

A pesar de esta mirada, finalmente Sáenz rescata que "algo hay en todo esto de inconcluso, de expectativa, de apertura en esos trabajos, más allá de la pose o de la buscada originalidad. Esto es positivo." (23/05/69: s/p).

La concepción acerca de un público que interactúa, produce u opera sobre diversos materiales para construir, a partir del ofrecimiento realizado por un artista, algo nuevo, inexistente antes de su acción, fue central para Vigo -y, como hemos visto, para otros artistas contemporáneos- y la Expo internacional no hizo sino reforzar su posición pública con respecto a esta elección teórica y práctica.

En tanto para Romero Brest en esta muestra se evidenció que "indudablemente las viejas formas están caducas. Aunque ahora es imposible definir nada al respecto, porque estamos en un período de transición (...) no alcanzaremos a vislumbrar que estamos a las puertas de una nueva cultura. Esto significa que estamos a punto de cambiarlo todo" (El Día, 13/04/69), y se hizo claro que el objetivo de la exposición fue "informar" sobre esta nueva tendencia en la poesía, lo fue así tanto para los artistas como para el público general que asistió. Parecía que ya no podía volverse atrás o ignorar que el receptor del nuevo arte estaba convocado a la acción, la interpretación y la creación conjunta con el artista. Vigo estaba, pues, llamando la atención acerca de varios objetivos que desbordaban la presentación de la "nueva poesía", dado que esta presencia ineludible del público conllevaba también una pregunta acerca del status del artista y de la entidad de la propia obra de arte. El modo en que Vigo propuso redireccionar las funciones de esos sujetos intervinientes y del objeto -que, si bien tenía los antecedentes mencionados arriba, no dejaba de ser innovador en su contexto- se dio en un momento en que culturalmente se resignificaban los roles de la autoridad y las instituciones públicas y domésticas, así como los movimientos políticos proponían un cambio total sobre la estructura del sistema de dominación. Esa combinación de situaciones hace del proyecto 
de Vigo un elemento más en la conjunción de hechos sociales, culturales y políticos que potenciaban una expectativa de modificación general del mundo.

\subsubsection{ALGUNOS CASOS DE PROPUESTAS PARTICIPATIVAS $Y$ "CLAVESMÍNIMAS"}

En cuanto a los trabajos de Vigo presentados o publicados en diversas ocasiones, además de los que analizaremos a lo largo de la tesis, examinaremos aquí algunos casos como muestra de lo que efectivamente llevó a la práctica a partir de su opción participativa. Estos ejemplos servirán como demostración de las formas que adoptó el artista para llevar a cabo su propuesta en cuanto al espectador y como introducción a los modos en se vinculó con la política y lo político, tal como se verá en los capítulos siguientes.

Vigo diseñó en 1969 una serie de cuatro etiquetas para que el público pudiera pegarlas donde quisiera (imágenes 11 y 12).
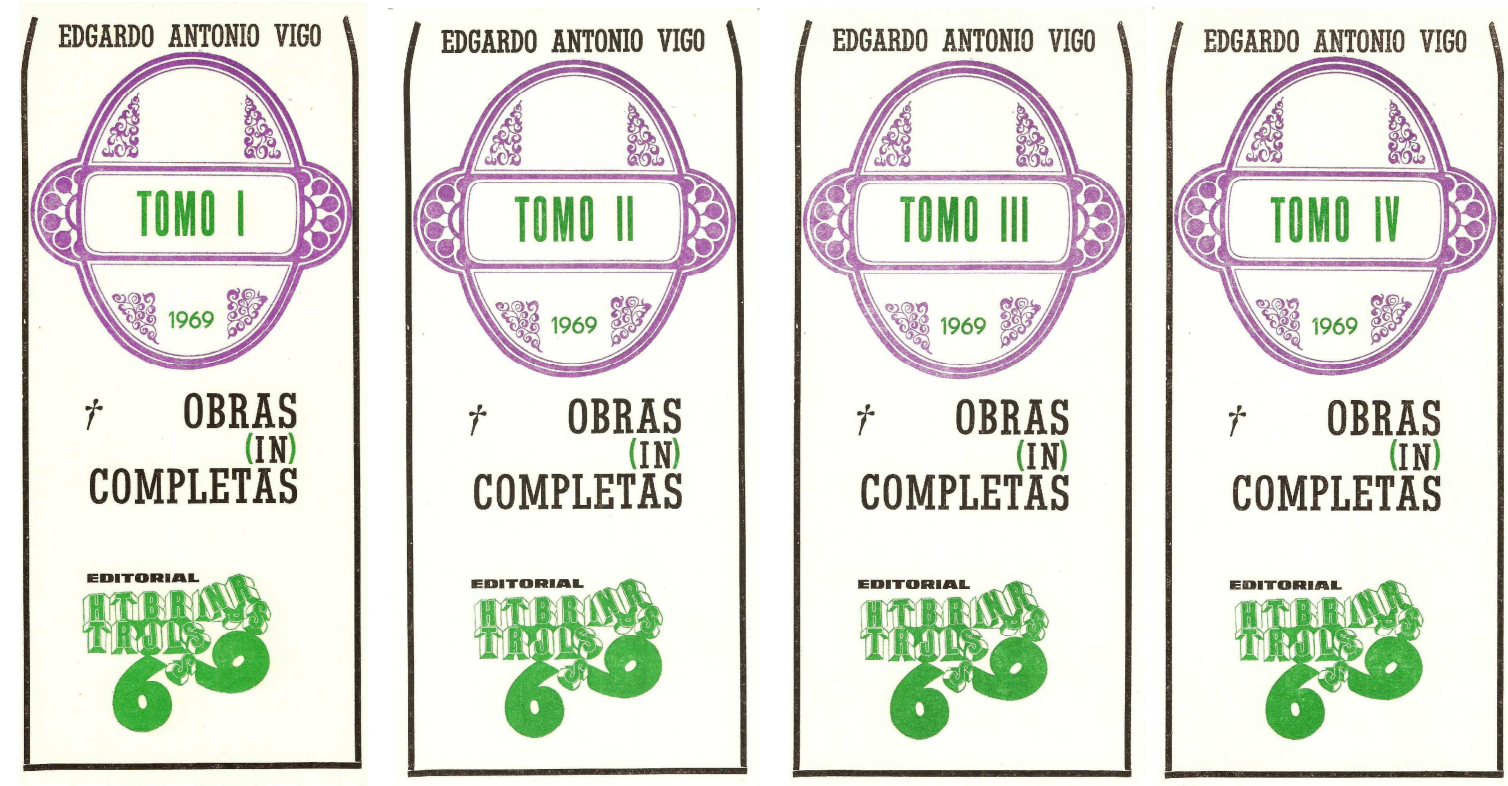

Imagen 11.Vigo, Obras

(in)completas. Etiquetas. 1969 


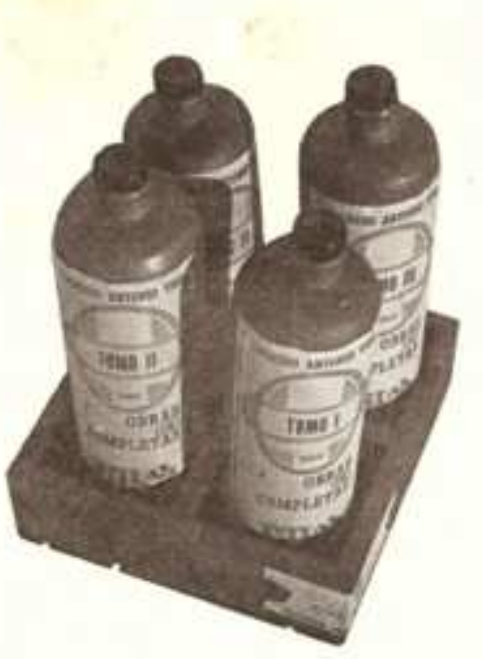

IWSTHUCCIONES: Ud. recfbe estoe cuatro membroton de las "OBRAS (IN) COMPLETAS" respetando la tooria de un Arte de partleipación $\gamma$ una traslación de algunce porcentales de la crocactón ublque donde Ud. desee loe mismos. Como elecapio el urabado de arriba lo llintra.
Imagen 12. Vigo, Obras

(in)completas. Tarjeta. 1969.

Las etiquetas que forman las Obras (in)completas, divididas en "tomos" del I al IV tienen un aspecto de formalidad: el nombre del "autor" en la parte superior, debajo, un marco decorado rodea la palabra "Tomo", su número correspondiente en romano y el año. Más abajo colocó una cruz y el nombre de la Editorial, cuyas letras y el número 69 se encuentran fuera de la línea base. Este trabajo fue presentado en De la figuración al arte de sistemas, exposición organizada por el Centro de Arte y Comunicación (CAYC) en 1970.

En uno de los ejemplos que realizó y fotografió, Vigo adhirió las etiquetas a cuatro botellas (que pasaron a ser las "obras"), las puso en los compartimentos de un cajón de madera, y pegó sobre él un papel con la siguiente leyenda: "Faja de honor de la Sociedad Argentina de Escritores" y un escudo. Como señala Davidson (2011), el uso de las botellas puede evocar al Bottle Rack (secador de botellas) de Duchamp. En su 
archivo personal, Vigo colocó la foto y agregó lo siguiente de modo descriptivo: "Un arte a realizar. 4 etiquetas para pegarse en superficies a elegir por el propio observadorparticipante" (Vigo, Biopsia 1969).

Estos rótulos repetían -a contramano- los que había hecho un año antes con el texto Obras completas. Las Obras (in)completas dan cuenta de que además de poner el foco en la participación del público, se trató de un juego con la frase referida a compilaciones de textos de un autor, utilizada en este caso como ironía, ya que no se trata de "obras completas" en el sentido literario, sino de etiquetas que pueden colocarse en cualquier objeto. Además, la negación “(in)", utilizada por Vigo para diferentes objetos o acciones, determina la contraposición al sentido normal del texto. La presencia de la firma de Vigo haría que al ser colocadas en diferentes lugares, él se convirtiese, en virtud de una decisión del público, en autor de los objetos más inverosímiles.

Acompañó la entrega de las etiqueta con una tarjeta de "Instrucciones":

"Ud. recibe estos cuatro membretes de las 'Obras (in)completas' respetando la teoría de un Arte de participación y una traslación de algunos porcentajes de la creación [,] ubique donde Ud. desee los mismos. Como ejemplo el grabado de arriba lo ilustra". Si bien las etiquetas fueron realizadas para que el receptor las coloque del modo y donde desee, culminando el proceso de creación comenzado por Vigo, a partir de las "Instrucciones" da a conocer explícitamente al destinatario qué es lo que se espera de él, y aún más, le informa sobre la teoría a la que adhiere el artista. Finalmente, el ofrecimiento de un ejemplo con imagen incluida (en ese caso, se han colocado en cuatro botellas), restringe las libertades interpretativas de quien recibe las etiquetas.

Sin embargo, la radicalidad en la propuesta de una obra sin terminar, sumado al componente de burla irónica sobre la literatura y la figura del artista, generó críticas favorables que lo calificaron como "revolucionario". En "Las 'Obras (in)completas' de Edgardo Antonio Vigo", un artículo publicado en el diario uruguayo El popular (1969), se analizan los productos de la "vanguardia", entre los que se incluyen a las Obras (in) completas de Vigo. El crítico realiza un análisis de la obra mientras afirma que ese trabajo es un ataque a la aspiración de cualquier poeta: la publicación de sus obras completas. Obras (in) completas, según el articulista, pone al desnudo la hipocresía del arte en la construcción de un autor como una "estrella de cine", y de la obra, adaptada a los requerimientos del mercado. Así,

Esta manifestación de Vigo es revolucionaria porque, aunque no declare verbalmente su compromiso político-social por la nueva sociedad como se estila 
con demasiada frecuencia en la poesía tradicional, su acción apunta directamente a uno de los puntos neurálgicos de una de las estructuras más importantes del sistema: la cultura. (El popular, 1969: s/p).

Según el autor, la obra de Vigo no cae en el vacío porque apunta a la participación del público, exigiéndole que pegue las etiquetas donde crea conveniente. Finaliza diciendo que

Este nuevo acto de Vigo quien, pese a ser acusado de estar demasiado imbuido de la cultura y corrientes vanguardistas europeas, nos demuestra, con responsabilidad artística y coherencia intelectual, cómo debe manifestarse el verdadero compromiso del artista latinoamericano: atacar en todos los frentes, aún en el aparentemente prescindible de la cultura, los fundamentos de la opresión imperialista con hechos que destruyan sus factores determinantes ( $E l$ popular, 1969: s/p).

El análisis de este artículo revela, por un lado, lo "revolucionario" que resultaba en aquel momento la producción de obras participativas (también destacado en las críticas mencionadas arriba sobre la Expo Internacional), y por otro, el significado que adquiría Obras (in)completas como crítica al funcionamiento del sistema de publicación y consagración del mundo literario. Además, resulta interesante la relación que encuentra el autor del artículo entre esta obra, un ataque a la cultura dominante y una posición política de compromiso del artista, dado que ese vínculo no se manifiesta de modo explícito. Entendemos que, sin asumirlo expresamente, Vigo ironiza sobre el mundo literario y del arte en general, y con ello, sobre un aspecto de la cultura que venía criticando desde hacía tiempo, como es la relación entre artista y espectador, así como respecto de la propia entidad de la obra de arte, desvinculada de los cánones que la ubicaban en relación con las elites y alejada de la gente común.

En (in) conferencia, del mismo año, Vigo realizó una invitación particular, donde artista, espectador y espacio artístico aparecen desvirtuados en su función tradicional (imágenes 13 y 14). 
de la serie "ACTOS A REALIZAR" no 0001/69

(in) CONFERENCIA

La calle invita a ud. a su propia (in) conferencia

a dictarse en lugau, fecha y hara a designar.

Enstucciones: Decida un dia alejnise a acercarse a un lugax partanda la presente invitación y proceda dictax, mascullax, cantar, silbar, agitar o hamboleax su cuerpo, etc. no decir su propia conferencia. PPar rasones solidarias se nuega asistir a las demás (in) conferencias.

Vigo realizó ciento cincuenta sobres que en su interior contenían la invitación y el "ticket", y los envió por correo postal a diferentes personas, algunas de ellas elegidas "al azar", a través de la guía telefónica. ${ }^{35}$ Una tarjeta blanca, realizada en imprenta y con aspecto de invitación formal en cuanto a la tipografía, ubicación del texto, tamaño y papel, contiene la invitación cuyo autor es "la calle", en concordancia con la declaración que realizó Vigo ese año sobre la realización de trabajos en el espacio público, ya no en museos o galerías, por ser instituciones cerradas y apartadas de los lugares de contacto

\footnotetext{
${ }^{35}$ También lo publicó en Enflin Plot, 8, editado en Canadá por Andrew Suknasky en 1971.
} 
con la gente (ver capítulo 2). Se le ofrece al destinatario que pronuncie su propia "(in) conferencia" y le propone que se acerque o aleje de "un lugar" con la invitación y "proceda dictar, mascullar, cantar, silbar, agitar o bambolear su cuerpo, etc. no decir su propia conferencia”. A esta tarjeta la acompaña otra, de menor tamaño, con el texto “Ticket - invitación", que sugiere la posibilidad de ser entregada en el momento de la (in) conferencia .

Vigo calificó este trabajo como "de revulsión convulsiva y colectiva, a nivel de correspondencia (...) basado en la teoría de Un arte a realizar" (Biopsia 1969). La idea de "revulsión convulsiva y colectiva" puede interpretarse en el marco del juego de palabras, la parodia de invitación y la ironía sobre la existencia de una conferencia imposible o no dicha, que apuntan a la sorpresa del público, tanto como insinúan un modo de anulación de la palabra o del discurso como modo formal de presentación de una idea o proyecto. Asimismo, se presume que el desconcierto aumenta en los receptores que no conocían a Vigo y recibían la invitación a una (in) conferencia por correo.

En 1971 presentó la Historieta para armar, en la casa Tomatti, una boutique de ropa que pertenecía a amigos de Vigo (ver capítulo 2). La Historieta para armar está conformada por varias piezas. Le entregaba al público un sobre que contenía una plantilla para realizar una historieta junto con una tarjeta que poseía las instrucciones (imagen 15).

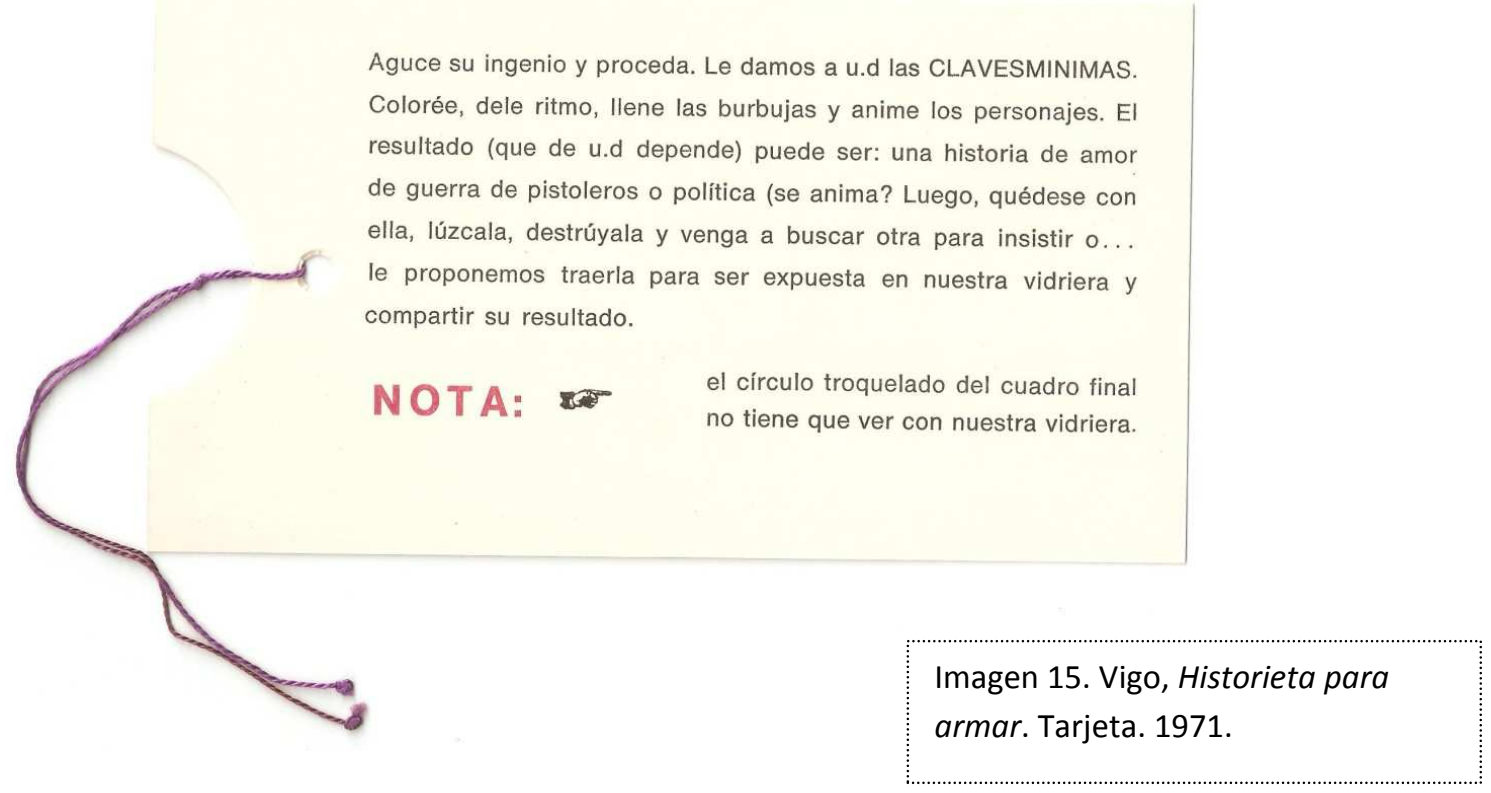


La plantilla consiste en una cartulina dividida en seis partes, cada una de las cuales contiene un cuadro de historieta no totalmente blancos, sino con imágenes ya realizadas por Vigo, pero diseñadas para ser completadas por el receptor. ${ }^{36}$ Las "clavesmínimas" para componer una historieta, cuyo resultado puede ser "una historia de amor, de guerra, de pistoleros o política (se anima?", indican que esta luego puede destruirse y buscar otra, o bien ser llevada para que sea expuesta en la vidriera. Dice que el resultado "de u.d depende", colocando al espectador, nuevamente, en un lugar privilegiado. Más tarde, expuso los resultados de las intervenciones del público sobre estos cuadros de historieta.

En relación con las "clavesmínimas", es decir, la forma en que Vigo conceptualizó y materializó su intención de participación del público, se hace necesario profundizar en la dimensión que adquieren en su programa. Otros artistas, especialmente los vinculados al conceptualismo, también apuntaban al uso de las instrucciones destinadas a generar algún tipo de acción por parte del receptor o lector. Algunos ejemplos de ello son: el trabajo de Ben Vautier, miembro de Fluxus, quien había colocado instrucciones sobre una caja de fósforos para quemar las obras de arte en su Total Art Matchbox from Flux Year Box 2 de 1968; la caja Games and Puzzles (Bead and Swim Puzzles) from Flux Year Box 2 de George Brecht, donde un texto señala la forma en que se juega ${ }^{37}$; el paradigmático caso de Sol Lewitt, que daba instrucciones para que otros pintaran murales, sus Wall Drawing. Por otro lado, Yoko Ono había publicado en 1964 un libro con indicaciones, Grapefruit, en cuyos textos, tales como Pintura para construir en la propia cabeza, Pieza para martillar un clavo o Pintura para ver los cielos, proponía acciones. Vigo utilizó este tipo de estrategias para la producción de la obra. En su ensayo "La calle: escenario del arte actual", publicado en Hexágono '71 (1971), Vigo dice que el "proyectista" -término con el que reemplaza al de "artista"- es quien ofrece las "clavesmínimas" para que el receptor desarrolle la acción.

\footnotetext{
${ }^{36}$ El sobre dice "Historieta para armar. CASATOMATTISRL '51 / 692'LA PLATA. S/N '51 / EA’VIGO '71”. El primero de los seis cuadros tiene las letras SN, el número 51 y círculos concéntricos, jugando con las referencias de la dirección del local y haciendo uso de los círculos que no sólo se vinculan con las producciones de Vigo, sino también con una ventana circular que hacía de vidriera en el local. El siguiente, dedos de un pie. Al lado, una mano que sostiene un sobre. Abajo, la silueta de una cabeza humana con una boina con estrellas. Seguido, diferentes figuras y por último, una burbuja con un círculo troquelado.

${ }^{37}$ Pueden verse otros casos en la antología de imágenes de Fluxus en Thing/Thought: Fluxus Editiones / 1962 - 1968 del Museum of Modern Art de New York (2011).
} 
[La proposición del proyectista] deberá ser concretada por la participación posterior y enjuiciamiento, uso o descarte de las someras claves propuestas (...) [En cuanto a las clavesmínimas] La función del "proyectista" será la de indicar simples elementos que permitan un "hacer" posterior legando al receptor las mayores posibilidades de desarrollo. Acá no hay detención del transeúnte para volcarles elementos de re-creación, sino proponerle, exigirle que haga. (Vigo, 1971: s/p). ${ }^{38}$

A través de estas proposiciones que realiza el "proyectista", según Vigo, quien recibe las instrucciones de acción, más que ser "corregido", es inducido a que -a través de su propia construcción de la experiencia- realice una acción. Veremos que similares declaraciones acompañarán sus señalamientos.

La idea de "proyectos a realizar", que titula el cuarto apartado del ensayo, había sido desarrollada anteriormente en "De la poesía/proceso a la poesía para y/o realizar" (1970). Aquí, retomando parte de la argumentación, Vigo explica que consiste en que el receptor realice su propio acto a partir de las mencionadas "clavesmínimas", lo que tiene $-\mathrm{o}$ al menos se propone- unas consecuencias potentes: la destrucción de la obra, la posibilidad de ausencia del artista, el carácter efímero de la acción y la posibilidad abierta de que cada receptor concrete actos distintos. Vigo colocaba estas claves en tarjetas que usualmente entregaba en la mano de los peculiares espectadores convertidos en participantes, o que enviaba por correo. Las tarjetas tenían, en general, una información clara y más o menos precisa de lo que el receptor podía realizar, por lo que pasaron a conformar una parte destacada de la acción. Sobre esto, dice Vigo (1971) que "un tarjetón indicando una 'clavemínima' y un elemento (que puede ser sustituido), nos invita a realizar un acto que podemos simplemente modificar por otro. Basado en su lectura, la realización de nuestro 'propio acto'." Como se ve, Vigo enfatiza que el objetivo de las indicaciones es que el trabajo colaborativo que realiza el receptor se convierta en su obra, su propio acto. Apunta así a que las claves se transformen en una guía que más que imposibilitar la libertad de acción, la promueva.

Manual e instrucciones para realizar una "obra de arte" (occidental y cristiana), de 1969, es un sobre cerrado con ojalillos metálicos que impiden su apertura (imagen 16).

\footnotetext{
${ }^{38}$ Todas las citas textuales de la revista Hexágono '71 carecen de números de páginas dado que la revista traía hojas sueltas y sin numerar.
} 
En el reverso hay un hilo del que cuelga una tarjeta con la letra "V", llamada La marca de Vigo.

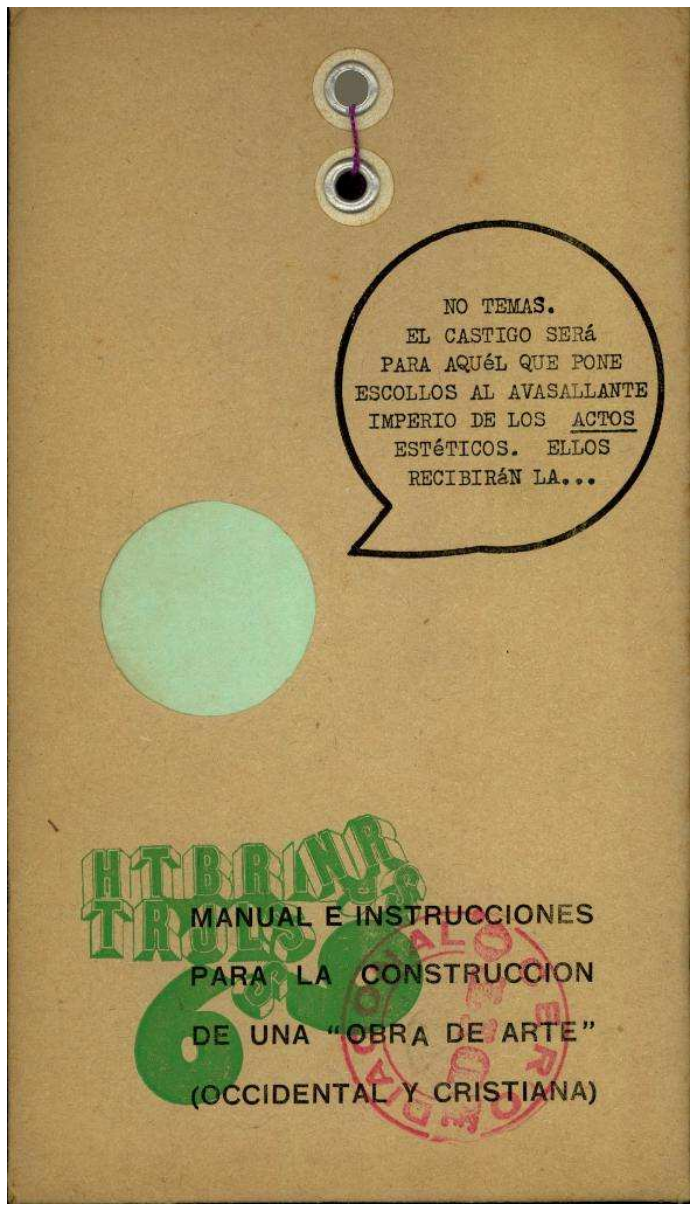

En esta edición de Diagonal Cero, el supuesto "manual" y sus "instrucciones" no son accesibles, solo pueden percibirse a través del troquelado circular que deja entrever o meter la mano para tocarlos. Desafiante de la lógica de funcionamiento de un manual, así como de la propia "obra de arte" que en la poética de Vigo no puede contenerse en indicaciones formularias, implica, por un lado, mantener el secreto sobre el modo de realizarla (dado que el sobre no puede abrirse) y, por otro lado, una ridiculización de su propia idea de "clavesmínimas" en los "proyectos a realizar".

Suma a ello un globo de historieta que emerge de la perforación con el texto: "No temas. El castigo será para aquel que pone escollos al avasallante imperio de los actos estéticos. Ellos recibirán la...". Con un tono bíblico, la idea de no temer un castigo apuntado a quienes pongan límites a los "actos", y su final inconcluso, no dejan en claro el sentido de la frase que tanto puede ser una referencia a la función del poder institucional o político sobre el arte, castigando a quienes se salgan de sus lugares 
estipulados (donde el "no temas" funciona como ironía), o bien su contrario, la premonición de una penalidad hacia los que intenten frenar las acciones artísticas novedosas o vanguardistas.

Esto se vincula con un título que configura la politicidad manifiesta de la obra en una posición crítica. Por un lado, es posible que Vigo conociera el suceso ocurrido en la presentación de la conocida obra de León Ferrari de 1965 titulada La civilización occidental y cristiana, que fue censurada y retirada del Premio Nacional Di Tella. Esa obra, en la que se vinculaban dadaísmo y surrealismo, se constituyó como una "imagenmanifiesto" (Giunta, 1997), de modo que la institución no soportó su presencia y decidió su retiro. Cuatro años más tarde, Vigo produjo el sobre aludiendo en su título a los mismos términos que Ferrari. Por otro lado, como señala Davidson (2011), el uso de la frase se vincula, además, con el discurso que pronunció Onganía en 1964 en West Point, en la Conferencia de Estados Americanos, donde sostuvo que la misión fundamental de las Fuerzas Armadas era la preservación de los valores “occidentales y cristianos". Esta alusión a un modo de vida que se deseaba defender se hizo presente en la política llevada a cabo por el militar cuando llegó al poder: esos valores se presentaron como la guía política y espiritual de sus acciones. Su pertenencia no solo al poder armado y represivo, sino también al "cursillismo" católico, evidenció que esa posición estaba fundamentada desde las entrañas de la derecha conservadora.

Vigo conjuga ambos planos, la crítica política desde el arte por parte de Ferrari, quien debió soportar la censura de la institución más importante del momento del arte contemporáneo local y la alusión a términos comunes del discurso de la Seguridad Nacional. Se suman a ello las comillas que Vigo ubicó en la frase "obra de arte", indicando su distanciamiento con respecto a la idea que ella conlleva y la factura del sobre, cerrado y perforado.

Vinculado con esto último, Quién no es nadie?, producido en 1972, es otro de los ejemplos de su propuesta participativa en que las claves adquieren un cariz particular (imagen 17). 


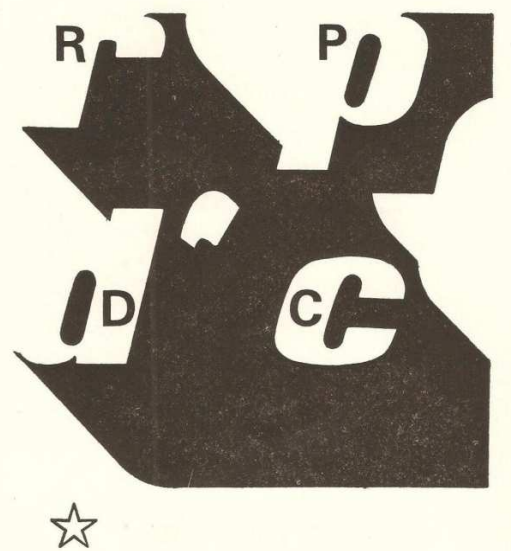

Ante la comunicación eléctrica (WALTER BENJAMIN \& MARSHALL MiLLUHAN) anteponemos Ia
"COMUNICACION BOCA A BOCA"
es decir, trasmisión por contacto dire BENJAMIN \& MARSHALL McLUHAN) anteponemos Ia
"COMUNICACION BOCA A BOCA"
es decir, trasmisión por contacto directo. Ejemplo más típico de las bondades del método: el AMOR.
Frente al peligro de la esterilización de
este último y la problemática de la recepción de una cultura trasmitida por medios técnicos, proclamamos la necesidad del "CONTACTO DIRECTO"

Por ello usamos como sistema de esta "ACCION SENALADA"

"GUIA TELEFONICA", en ella debemos encontrar no a los abonados, sino a los que no figuran en ella. stos serán los propuestos para figurar en

QUIEN NO ES NADIE. En ellos podemos

cifrar la esperanza de la necesidad comunicativa vía contacto, vivenciado y enriquecido, en los datos recibidos; po-

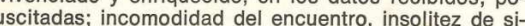
tuaciones.

\section{Fe.}

\section{ACCION SENALADA}

partir del 10 de setiembre de 1972 realizar una LECTURA (a) SISTEMATICA de la "GUIA TELEFONICA", no regimentando hora ni dia, pero sí constantemente tratando de retener los abonados para conseguir por ese metodo, la automática eliminación de todos aquellos que figuren en ella. La no figuración dr

" COMUNICACION BOCA A BOCA".

La búsqueda, el descarte (los enemigos dio), la revalorización, serán

ATr indicado todas aquellas posibilidades que nazcan en cada uno de los receptores de la presente.

\footnotetext{
NO OLVIDE, la consigna es :

" TRASMISION DIRECTA BOCA A BOCA",

PONGALA EN PRACTICA!!!
} 
Vigo realizó un sobre firmado como "Fund(i)ción Vigo" y colocó debajo la imagen de unos hombres semidesnudos y un sello con la fecha 18/08/1972. Dentro del sobre se encuentra la tarjeta. Vigo realizó doscientos cincuenta ejemplares de este trabajo y, según escribió en su archivo, está "basado en un principio de ironización de Quién es quién en La Plata, publicación editada que reúne las aparentes figuras más importantes del medio local, la idea se fue madurando y permitió la puesta de una teoría de la comunicación boca a boca" (Biopsia 1972). El contenido de la tarjeta se centra en la transmisión de la "comunicación boca a boca", donde propone el contacto directo, utilizando la "acción señalada" sobre la guía telefónica. Se le propone al receptor realizar una lectura (a)sistemática de la 'guía telefónica', no regimentando hora ni día, pero sí constantemente tratando de retener los abonados para conseguir por ese método la automática eliminación de todos aquellos que figuren en ella. La no figuración denunciará una posibilidad más de los practicantes de la 'comunicación boca a boca' (...) Agregar, con plena libertad, al método indicado todas aquellas posibilidades que nazcan en cada uno de los receptores de la presente (Vigo, 1972).

En el texto cita a Walter Benjamin y a Marshall MacLuhan, y formula la necesidad de acceder a un tipo de relación más personal y alejada de "comunicación eléctrica" o transmitida por "medios técnicos". Vigo formaba parte así del clima de análisis y críticas de los medios de comunicación de la época, como el caso de Tucumán Arde, el llamado Happening de la participación total, Happening para un jabalí difunto o antihappening (inexistente en los hechos, solo creado para la prensa) y las teorizaciones sobre la relación entre arte y medios realizada por Oscar Masotta (Longoni, 2005a). ${ }^{39}$ En relación con la utilización de los medios de comunicación, Vigo también reflexionó críticamente a través de un texto que acompaña al comic-strip La (in)comunicación de los medios de comunicación masivos (por caso la TV) (1972), donde analiza la soledad en la que queda el hombre frente a la incomunicación que producen los medios. En ese texto dice que si bien la soledad es una reacción a la incomunicación que generan los

\footnotetext{
${ }^{39}$ No sólo se hacían críticas a los medios masivos de comunicación, por ejemplo, Masotta, confiado en las posibilidades de su uso, había arriesgado en Conciencia y estructura que tenían un carácter "potencialmente revolucionario" (Link, 2004: 39). En relación con el antihappening, Eduardo Costa, Raúl Escarri y Roberto Jacoby escribieron "Un arte de los medios de comunicación (manifiesto)", donde afirmaban: "nosotros pretendemos construir la obra en el interior de dichos medios" (Costa, Escarri y Jacoby en Alonso, 2011:70)
} 
medios, el "systema" utilizará otros medios de persuasión, y atacará la resistencia que se ofrece en busca de la liberación. Propone, entonces, al igual que en Quién no es nadie?, como medio alternativo la "comunicación de boca en boca", centrado en la comunicación del "amor". El "diálogo" es la fórmula más apropiada: "por contacto, por mirada, por sobreentendimiento, por silencios cómplices de una vertical seguridad" (Vigo, Biopsia 1972).

En Quién no es nadie? parte de un rechazo a la impersonalización de las relaciones humanas, y sostiene que el "boca a boca" favorecerá el "diálogo transmitido por contacto, vivenciado y enriquecido, en los datos recibidos", así como las "polémicas", "incomodidad del encuentro" y la "insolitez de situaciones". Es decir que sus intereses no son solo el medio directo de comunicación, sino también lo que esta puede generar. De ese modo, el llamado a la "lectura (a)sistemática" sustenta la idea de señalar pero no regimentar, lo que coincide con el concepto de "revulsión", a diferencia del de "revolución" -tal como se verá más adelante-, así como con la idea principal del I señalamiento, centrado en movilizar, pero no "corregir" (ver capítulo 2). Esta incitación se refuerza sobre el final de la tarjeta, cuando afirma que hay una apertura a que el receptor pueda utilizar con plena libertad otros métodos. ${ }^{40}$

En relación con esta proposición -que puede resultar de difícil factibilidad-, surge un trasfondo crítico y reflexionado sobre las relaciones humanas y su estado de alienación. Así, Vigo escribió en "Tenth happening also called From the lemon tree":

Sin querer retornar totalmente al pasado, consciente de que el artista debe necesariamente amar su propia época, deseamos volver a una forma de individualidad que participe del diálogo directo 'comunal' -boca a boca. El vertiginoso desarrollo de las nuevas técnicas y el redescubrimiento de las viejas nos ha presionado precipitadamente a estados de extrema alienación personal. Nuestro propósito puede ser resumido mejor simplemente como 'amor'. (Vigo, 1974: 3. Traducción nuestra).

En estas propuestas, que se presentan como superadoras de un momento crítico que requiere una vuelta a las relaciones humanas más simples, la participación del espectador, si bien en términos materiales parece de imposible concreción, aparece como un llamado a un cambio en una dirección más humana y menos mecánica o

\footnotetext{
${ }^{40}$ Un antecedente de este trabajo puede encontrarse en el primer número de Hexágono ' 71 , donde Jochen Gerz propone realizar una intervención sobre la guía telefónica: la acción de "paralizar el código de la guía de París".
} 
mediada. En Quién no es nadie apela, una vez más, al vacío o al sentido no del todo determinado, proponiendo al espectador una acción que más que ser elaborada tal cual se la expone, implique una reflexión sobre el mundo.

A la luz del trabajo de investigación de esta tesis que ha pretendido tomar a los discursos de Vigo como materia de análisis, en lugar de una reproducción de sus intenciones o clave de lectura de su propia obra, interesa desmontar que en esa propuesta -que no deja de ser renovadora en términos de desubicación de los roles de artista y espectador, tal como se señaló arriba- hay una vacilación, un problema irresuelto adelantado por el crítico Sáenz (23/05/69). Además del interés en que el público realice tal o cual acción con la poesía u objeto, de la formulación de esa intención y del desarrollo teórico que realizó el propio Vigo, aparece una necesidad inherente de presencia del autor. Esta participación está siempre condicionada por las indicaciones, materiales o intenciones que proporcione el artista. Así, la ilusión de una participación en la que el público cree $s u$ obra -como lo plantea en el citado "La revolución en el arte"-, que va de la mano de una crítica radical a la figura del artista como genio inspirado, si bien se asume como ideal a seguir, puede suponerse que nunca llega a ser plena, y no podría serlo por la propia condición de que la obra de arte producida por el público requiere que alguien presente como mínimo las condiciones para que se realice; de otro modo, no podría distinguirse una acción artística de un acto espontáneo cualquiera. Es decir que la presencia de una "intencionalidad" del artista parece insuprimible. ${ }^{41}$ Esta situación, más que hacer caer en el vacío la propuesta de Vigo, problematiza su propio ideal y, posiblemente, el del muchos otros artistas interesados simultáneamente en la participación del espectador. La presentación de instrucciones como "clavesmíninas", así como la idea de "consigna” y la necesidad de su justificación o explicación, denotan que Vigo integró esos conceptos al armado teórico y a los trabajos que realizó con la convicción de que ese era el medio más propicio para provocar el cambio de status del espectador. Volveremos sobre este problema al referirnos al cuestionamiento a la figura del artista.

Para sumar complejidades a esta cuestión, es posible afirmar que, si bien las instrucciones parecen ser en algunos casos estrictas normas de cumplimiento obligado que restringirían la búsqueda de libertad creativa expresada por Vigo, él también

\footnotetext{
${ }^{41}$ Esta cuestión puede ser abordada también desde el punto de vista de la discusión filosófica sobre los términos intencionalidad artística e institución artística. Ver Pérez Carreño, 2001.
} 
consideró la posibilidad de que el receptor de las instrucciones no ejecute lo propuesto por el "proyectista", sino que simplemente lo descarte. Ese grado de indeterminación sobre lo que sucederá a posteriori de la recepción de las claves fue concebido por Vigo como uno de los avances del arte actual en relación con otro tipo de propuestas que intentaban incorporar al espectador, pero no le concedían libertades expresivas (Vigo, 23/10/70).

Como hemos visto y se analizará en otras partes de la tesis, esas "clavesmínimas" en algunos casos eran indicaciones realizables, pero en otros no eran factibles. En estos últimos, funcionaron más como incitadores al extrañamiento sobre lo que se estaba leyendo, tanto por la formulación circunspecta y lindante con el discurso judicial -lo que se verá en el capítulo 3-, como por el uso de frases e ideas insólitas. Así como en el happening la participación se buscaba a través de la creación de un entorno que estimulara los sentidos, en el caso de Vigo se trataba principalmente del desconcierto a través de propuestas irónicas, lúdicas o, a primera vista, insensatas para los códigos culturales de comunicación convencional.

\subsection{LA "REVULSIÓN"}

Un término utilizado por Vigo en diversos textos e intrínsecamente vinculado con la idea de participación y de renovación del rol del artista es el de "revulsión"42.

En el manifiesto del primer señalamiento, se refirió a la "revulsión" como parte de lo que esa acción pretendía generar: "Se propone: (...) Una revulsión para que el hombre 'despersonalizado' que la construyó observe 'personalizado' al ser señalada esa construcción" (Vigo, 1968). En ese caso, se refería al cambio que proponía generar a través del extrañamiento con respecto al objeto señalado, el semáforo, cuyo eje estaba puesto en la posibilidad de experimentar una "divagación estética" que se encontrara alejada tanto de la tradicional forma de observar una obra de arte como de la mirada técnica y utilitarista sobre su funcionalidad (ver capítulo 2).

Sin embargo, el texto en que desarrolla el sentido del concepto es "La calle: escenario del arte actual”, publicado en Hexágono '71, be (1971). Este ensayo se concentra en el uso de espacios alternativos a los museos y galerías -que analizaremos más adelante-, y

\footnotetext{
${ }^{42}$ Davis (2007) ha señalado la importancia de la idea de "revulsión" en la poética de Vigo. Según Davis, “'Revulsionar', en el proyecto del artista, supone incomodar el orden naturalizado, introducir un desvío en la percepción ordinaria, desarreglar la cotidiana adecuación a prácticas y normas instituidas.” (2007: 1)
} 
reflexiona también sobre otros aspectos de la relación artista-obra-espectador. Allí Vigo sostiene que la idea de "obra" ha caducado porque implica una limitación al incentivar el consumo, la acumulación y la contemplación, todas ellas, conductas del "pequeño burgués". Para renovar este viejo paradigma, propone la "revulsión". Citamos in extenso su definición, donde deja planteado, además, gran parte de los fundamentos de su programa estético:

'Revulsionar' es la palabra para la actitud límite del arte actual, y para ello, insistimos, la 'obra' se perime para dar paso a otro elemento: la acción. Ésta está basada preferentemente en despertar actitudes de tipos generales por planes estéticos abiertos, y que buscan dentro de ese terreno expandir su acción revulsiva a otros campos. No hay otro método posible que batallar dentro del plano estético (por supuesto dentro del campo del arte) para conseguir ese cambio, pero el cambio 'revulsivo' no debe ser únicamente en las formas de la cosa, sino en la profundidad y propio interior de la misma, y si buscamos lo interior llegaremos a lo mental, es decir a la propuesta más que a la realización. (...) Ésta, a su vez, no se convierte en un tirano condicionador de libertades de acción sino, por el contrario, promueve asistemáticamente. (Vigo, 1971, s/p)

Para producir cambios "revulsivos" se busca evitar un trabajo cerrado, y producir uno que apele a liberar la acción. Esto significa, dice Vigo, que las acciones se convierten en heterogéneas porque queda en manos de cada receptor su resolución, quien actuará en función de esas pautas o bien tendrá la posibilidad de dejarlas de lado.

Vigo afirma que el cambio radical parte del "campo del arte", pero debe ir más allá de la propia obra para sumergirse en la subjetividad del receptor. Esta matriz resulta coincidente con nuestro concepto de lo político del arte, en que los trabajos artísticos intervienen en el orden social no solo a través de una temática comprometida o denuncialista, sino también a partir de su configuración interna como obra que apunta a distorsionar funciones, jerarquías o lugares, dado que se transforma en disidente con respecto a las normas o convenciones sociales, y se dirige a estimular nuevas miradas del mundo. En este sentido, se verá en los capítulos siguientes de qué modos funciona en la poética de Vigo lo político (o bien, lo "revulsivo") -en combinación con otras modalidades de la política- ya sea al sobresignificar los espacios públicos, al utilizar espuria y desjerarquizadamente el discurso judicial, o bien al distorsionar un género de la comunicación, la revista, donde alude a acontecimientos y formas de la política radicalizada al mismo tiempo que sostiene una estética vanguardista. 
Vigo explica:

[Utilizo] el término revulsionar porque la direccionalidad del mismo nos denuncia una actitud y a ésta la demarcamos dentro de lo individual-interior, por el contrario el perimido término, para este caso, revolución, nos denota y contacta con actos-exteriores que produzcan cambios de actitudes. (Vigo, 1971, $\mathrm{s} / \mathrm{p})$

Resulta interesante aquí que la idea de "revulsión" aparezca como reemplazo del término revolución, el cual, tal como lo indicó en otros ensayos, le resulta anticuado o desgastado por el uso ${ }^{43}$. Pero, además, existe una diferencia conceptual, dado que la primera implica, para el autor, un cambio de actitud interna y la segunda, externa. Vigo está remitiendo su explicación a una idea de revolución dirigida desde fuera del sujeto o que no transforma ni altera las subjetividades sociales ya disponibles, tal como podían pensarse en ese momento las diferentes acciones que estaban llevando a cabo las organizaciones políticas que se consideraban vanguardias de un movimiento revolucionario. Vigo opone, entonces, esta idea a la "revulsión", que refuerza en otra parte de este ensayo cuando dice que el transeúnte no debe ser corrido de rumbo -desde fuera- sino implicado en un cambio a partir de propuestas. Asimismo, el uso de la palabra "actitud" conlleva una intencionalidad de modificación subjetiva que rompa con las estructuras "heredadas". Puede verse aquí la yuxtaposición de una propuesta de modificación en lo estético y en lo subjetivo, un deslizamiento de la primera sobre la segunda, lo que podría pensarse como parte de una idea más general de Vigo que resumimos como un deseo de cambio o ruptura general a través de la subjetividad, mediado por una desestructuración provocada desde la experiencia estética. De este modo, la subjetividad que la "revulsión" se propone modificar o reemplazar es una madeja de determinaciones culturales y sociales internalizada, asimilada y naturalizada en muchos individuos a la vez (aunque nunca se internalice de modo idéntico en unos y otros).

Esta distinción que realizamos entre las ideas de "revolución" y "revulsión", basada en el discurso de Vigo pero analizada a la luz de nuestro armado teórico y nuestras preguntas de investigación, se vuelve central para diferenciar politicidades (la política /

\footnotetext{
${ }^{43}$ Debemos anotar que, sin embargo, el propio Vigo había titulado en 1968 el artículo que publicó en el diario El Día "La revolución en el arte" (15/12/68).
} 
lo político) en el programa declarado y formulado, y ya no solo en una forma o en la "obra" del artista.

\section{4. "EL ARTISTA ES EL OPIO DEL ARTE"}

Como venimos mostrando, el programa de Vigo incluyó una crítica a los status tradicionales de la obra y del espectador. Ello implicó también una oposición a la idea tradicional de artista, en tanto los tres términos (artista, obra y espectador) están mutuamente involucrados y conforman un único nudo problemático. En consonancia con esto, ya mencionamos que Vigo propuso la noción de "proyectista": quien propone un trabajo artístico para su realización o culminación, en reemplazo del "artista". Este último, en cambio, se presenta en su programa como una figura vetusta, tradicional o burguesa que debe abandonarse en función del establecimiento de una nueva concepción en el arte en general y en cada una de las tres partes que lo componen. Vigo, que también utilizó "programador" como sinónimo de "proyectista", define este nuevo rol del siguiente modo:

El término 'programador' suple al de 'artista'. Este ya está perimido por la acción y relación que mantiene con la sociedad. Si hablamos de un arte seriado, tecnológicamente realizable, con formas de fácil reproducción y anexiones técnicas es obvio seguir utilizando este término. Programador de proyectos (así lo define Neide de Sá) encierra en su significación una 'conducta' diferente. Un programador no necesariamente debe cumplimentar las exigencias de práctica artesanal y encerrarse en un 'vedettismo' propio de la etapa individualista perfectamente identificada desde el punto de vista histórico, mientras existió el concepto de 'obra única'. (Vigo, 1970: 8)

Vigo busca así conceptualizar una situación deseable desde el punto de vista programático y al mismo tiempo factible tanto en sus trabajos como en los de sus colegas que estaban ligados a los mismos intereses. La afirmación de que el "programador" tiene nuevas relaciones con la sociedad se sostiene también en la idea de que ha modificado su propia posición en el mundo del arte, dejando de lado actitudes consideradas como "vedettismo" e "individualismo". Asimismo, sostiene que la "obra única" se contrapone al "arte seriado", producido tecnológicamente, aludiendo nuevamente a la tesis de Walter Benjamin sobre la reproductibilidad técnica. La visión benjaminiana de que la obra firmada e irrepetible está vinculada con una experiencia 
estética del modelo burgués se ajusta a la propuesta de Vigo y resulta coherente con el resto de sus posiciones con respecto a las figuras de artista y espectador. Para el artista, la posibilidad de producir trabajos seriados permite la generación de nuevas relaciones con el público y un acceso amplio y no elitista al arte. Se evidencia aquí una conexión artista-obra-público eminentemente desestructurada con relación al modelo tradicional e institucional, y donde sujetos y objeto dejan de ostentar ubicaciones y jerarquías inmutables para adquirir una flexibilidad transformadora.

"Lo que ha sido descartado es la utilización del término 'artista'. Este es el representante individual de un arte de "pieza única", repite Vigo en "La calle: escenario del arte actual" (1971). Explica que lo colectivo funciona mejor que lo individual,y cita a otros artistas para contextualizar la mirada sobre este cambio: "Neide de Sá propone el nombre de 'programador', los italianos el de 'operatori', Julien Blaine los clasifica como 'provocadores para hacer' (luego por el de 'agitadores del día y de la noche')" (Vigo, 1971, s/p). Finalmente, define: "Proponemos el término 'proyectista' pues el mismo es una derivación directa (de algo a realizar) del 'proyecto'. Y para completar llamaríamos 'proyectista programador' a la conjunción en equipo para la realización de complejos no individuales" (Vigo, 1971, s/p). De la mano de Julien Blaine, esto implicó para Vigo "una nueva actitud" que excediera el problema del artista y se transformara en un "revulsivo interno". Esa "revulsión" es la que estructura el modelo de nuevas relaciones entre sujetos y objeto que decíamos arriba, un plus ultra que avanza sobre los acuerdos y convenciones culturales.

En la citada entrevista que realizó Álvaro de Sá para el Jornal do Escritor (octubre de 1969), Vigo dice que el artista, como parte de la sociedad, "debe convertirse en un trabajador-creador asimilado a un concepto de masa" (traducción propia). De Sá le pregunta sobre el poeta actual, a lo que Vigo responde que cree que se ha cumplido un ciclo y que él fue un "artista" hasta la exposición actual -se refiere a la Expo Internacional de Novísima Poesía-, pero ya no lo será más. "El concepto de exposición no cumple con los requisitos exigidos por mi trabajo, y está irremediablemente caduco todo hábitat que encierra una obra." El artista, en lugar de ocupar un lugar de elite, debe aprovechar el "contacto directo con las masas y como mejor medio para esta comunicación postulo el espacio abierto (calles, plazas, etc.)". Puede verse aquí las relaciones que establece Vigo entre el "proyectista" o "trabajador-creativo", la ocupación del espacio público como reemplazo de la exposición y el público entendido 
como masas. A ello se suma la afirmación de que no vale la pena identificar géneros en el arte, sino hacer lo que cada creador considere en libertad. De este modo, los cambios en el artista se encuentran intrínsecamente vinculados con las demás renovaciones y apuntan a un nuevo contacto del arte con la sociedad. Sin embargo, en otra parte de la entrevista, Vigo sostiene que no le interesan los modos artísticos folclóricos o realistas como forma de relacionarse con lo nacional, sino que aparecen una serie de coincidencias entre artistas de diversos países, que trabajan simultáneamente, a pesar de las distancias.

Estas propuestas referidas a una nueva figura del artista dejan entrever también sus tensiones. Vigo había declarado que para cortar la relación distante y estática con la obra, proponía el "anonimato": respecto de los señalamientos, decía: "he querido que el creador vuelva al anonimato" (julio de 1972), como una forma de ruptura radical con la función del artista en tanto genio, único creador.

El caso más extremo de cambio en la figura del artista que Vigo llevó a cabo es el del Señalamiento I, Manojo de semáforos, en el que Vigo convocó por distintos medios al público y entregó invitaciones en forma personal, pero sin embargo no se hizo presente en el momento del señalamiento (veremos con mayor detenimiento este trabajo en el capítulo 2). La acción, en sentido estricto, debían llevarla a cabo los presentes a través de su experiencia estética, lo que hizo posible la ausencia de Vigo. Otro caso destacado es la falta de firma en sus obras publicadas en Hexágono 71; en la propia revista tampoco aparece su nombre como director y editor. Sin embargo, en Diagonal Cero hacía figurar su nombre en los rangos de "director" y "editor". En otras obras suyas vemos firmas claramente identificatorias de autor, tensionando su propia afirmación con relación al anonimato y a la producción colectiva en reemplazo de la individual. A esto se suma un tipo nuevo de firma que utilizó frecuentemente: el uso del sello de goma personal. Este aparece como una "marca" de autor. Sin embargo, al mismo tiempo que ofrece un dato concreto de su autoría, muestra un tipo de firma particularizada que ha reemplazado la habitual hecha a mano. Complejizando el asunto, el sello personal, aunque diseñado por él mismo, puede ser reproducido infinidad de veces con la misma validez y, en casos extremos, utilizado por otras personas que puedan hacerse pasar por el artista. Así como el sello deniega el anonimato, paradójicamente, hace eco de la utilización de una modalidad vinculada al múltiple que tiende, en el caso de Vigo, a negar el aura de la irreproductibilidad que tiene toda obra original firmada. Sellar una 
obra en lugar de firmarla no solo se vincula estrechamente con la asunción de elementos del discurso judicial (ver capítulo 3), sino también con evitar la significación específica que tiene en el arte la firma del original como dato irrefutable de autoría y autenticidad. Así, lo que el propio Vigo llama "autor anónimo", no es -a pesar de su enunciación- un elemento constante u homogéneo en su poética, aunque sí una variación de la idea de artista que podemos llamar inestable. Un artista que a veces firma, otras no y en ciertas situaciones, lo hace a través de un sello.

En primer lugar, esa inestabilidad se sustenta en que la falta de firma no implica su anonimato, ya que el público puede tener conocimiento de antemano sobre la identidad del autor. En el caso de las acciones o señalamientos, la inmaterialidad de la obra -o materialidad compleja, compuesta por acciones, objetos y espacios- conlleva la dificultad de la firma en un sentido clásico, como es el caso de una pintura. Sin embargo, las convocatorias hechas por el propio Vigo -sea a través de invitaciones personales o de los medios de comunicación- implicaban desde el comienzo el conocimiento de su autoría. A esto se suma que en los casos de apropiación de aspectos formales del discurso judicial, Vigo hizo un uso de su firma como certificación de la existencia de una acción u obra.

En segundo lugar, como hemos mencionado, en otros casos Vigo siguió firmando sus obras y, más aún, hizo de su firma, su sello o su nombre parte del objeto poético: por ejemplo, la tarjeta que utilizó en diversas acciones que llamó La marca de Vigo (imágenes 18 y 19), los sellos de Vigo en Hexágono '71 y la certificación que él mismo hizo de sus trabajos con firma y estampa (como el caso de la tarjeta sumergida en Punta Lara que se verá en el capítulo 3). También desplegó un interés especial en la aparición de su nombre en la elaboración de catálogos, edición de libros, organización de distintos eventos, así como en la prensa y en revistas nacionales e internacionales. Aquí funciona lo que Foucault llamó el "nombre del autor", que excede a la identificación de un individuo y "ejerce un cierto papel con relación al discurso: asegura una función clasificatoria; tal nombre permite reagrupar un cierto número de textos, delimitarlos, excluir algunos, oponerlos a otros" (2000: 13). El "nombre de autor" para Vigo funcionó como una marca de autoría en relación con una estructuración semejante entre sus obras, acciones, ediciones, eventos, que se identificaran, más que con la persona, con lo que Vigo como nombre significaba. Mantuvo, así, a pesar del cuestionamiento a la idea de autor como creador individual, su "función-autor". 

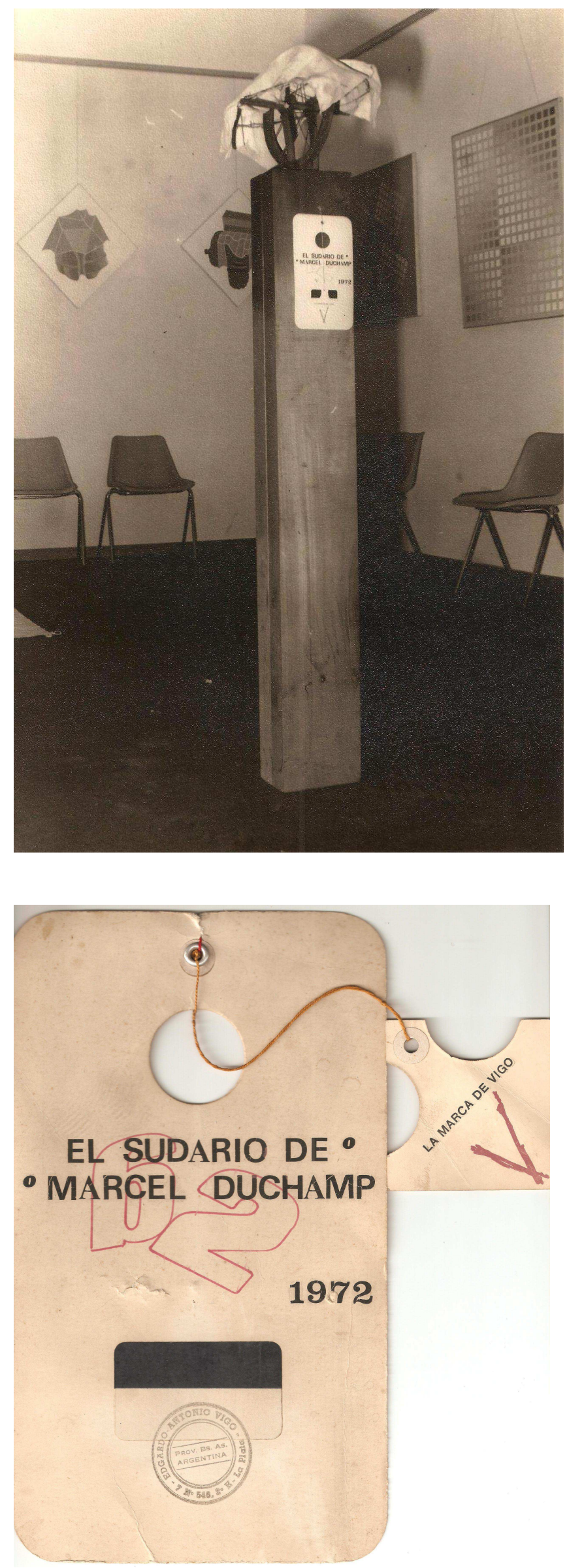

Imagen 18. Vigo, El sudario de

Marcel Duchamp. 1972.
Imagen 19. Vigo, El sudario de Marcel Duchamp (detalle con sello y La marca de Vigo). 1972. 
En tercer lugar, el anonimato del artista no garantiza per se la participación del público, a pesar de haber sido una de las formas por las que Vigo intentó fortalecer esta última. En el marco de su razonamiento, ambos elementos están interrelacionados, de modo que si el artista no estaba presente o se desconocía, atraería la actividad de los receptores de la obra. Sin embargo, podría pensarse que más que el desconocimiento del autor, son los medios y estrategias empleadas por él los que movilizan de un modo más o menos eficaz dicha participación.

La utopía de un autor inexistente que deje en manos de los espectadores toda la acción es una idea que se matiza a la hora de analizar la poética de Vigo. Se ha dicho que Vigo se refiere a las "clavesmínimas" como escuetas instrucciones que ofrece el artista para que una acción sea realizada. En este aspecto, Vigo parece consciente de que su presencia como artista es ineludible, ya que sin estas indicaciones y sin los elementos materiales necesarios para la confirmación de la acción no habría obra u acción artística. Es decir, si no hay un artista que planifique -en mayor o menor medida- el desarrollo de una acción y que ofrezca los elementos materiales o conceptuales o ambos al público, lo que resulta es cualquier acción común desvinculada del arte. Por ejemplo, en el caso de Paseo Visual -que veremos en el capítulo siguiente-, donde se propone que el transeúnte realice un "paseo visual" a partir de marcar en el suelo un círculo y girar en él, sin la tiza y la tarjeta con instrucciones; el paseante por la plaza sigue su curso normal sin desvíos, realiza solo un itinerario sin ser interferido ni interpelado en su experiencia sensorial.

Estas tensiones no desmantelan la intensidad de la propuesta en términos de ruptura con los acuerdos institucionales del arte. Esto se condensa en la frase que Vigo utilizó en una tarjeta colocada en Hexágono '71 (bc): "El artista es el opio del arte". Parafraseando la conocida sentencia de Marx sobre la religión, es aquí el artista quien mantiene el control y el sometimiento del arte. Si la religión cumple una función política en la teoría marxista haciendo lo propio con el pueblo, para Vigo el artista mantiene una ilusión, velando la verdad sobre las condiciones materiales del arte y su valor político libertario. 


\subsection{LAS INSTITUCIONES EN CRISIS}

Uno de los rasgos del programa de Vigo vinculado con las críticas a las posiciones tradicionales de los sujetos y objeto del arte es la reprobación a las instituciones artísticas. Si bien esta actitud no fue permanente ni idéntica a lo largo del tiempo -por lo cual no puede hablarse aquí de antiinstitucionalismo radical-, aparece como telón de fondo de diversas intervenciones discursivas y materiales que ponían en cuestión los modos de funcionamiento, las premisas y los roles de los museos, galerías y organizadores. Destacaremos de qué forma y en qué circunstancias Vigo hizo circular esta crítica que ocupó un lugar relevante en su poética y que abre el camino a la interpretación de los problemas de investigación de esta tesis, aunque sin profundizar en las actuaciones que tuvo como gestor o curador, las cuales exceden el marco de este trabajo. ${ }^{44}$

Sabemos que la emergencia de neovanguardias artísticas no fue un fenómeno exclusivamente argentino. Pueden hallarse denominadores comunes con otros procesos latinoamericanos. Conociendo las diferencias entre los procesos chileno y argentino, es posible, sin embargo, hacer extensiva la caracterización que realiza Nelly Richard (1990) de la "avanzada chilena" al caso argentino, con algunas salvedades que se precisarán más abajo. En concordancia con la realizada por Longoni y Mestman (2000) para las vanguardias de los sesenta (que enumeramos en la Parte I), según la autora, los rasgos distintivos más relevantes son: el desmontaje del sistema de representación pictórica y el cuestionamiento a su unidad-cuadro, el enjuiciamiento al sistema institucional de validación y consagración artísticas y la transgresión de las fronteras entre géneros artísticos. Interesa destacar aquí la segunda cuestión señalada por Richard, quien apunta que las neovanguardias tienen la posibilidad de utilizar otros espacios y medios para la producción de obras que desestabilicen los mecanismos de recepción y consumo dominantes. Si bien en Argentina la relación de las vanguardias con las instituciones no ha sido de crítica absoluta y tajante (Longoni, 2006), y los museos y galerías han acogido por períodos la producción vanguardista, las acciones por afuera de las mismas -en nuestro caso, interesa especialmente el uso del espacio público- se han constituido como una de las posibles expresiones de ruptura con las tradiciones del arte

\footnotetext{
${ }^{44}$ Esto no significará restar importancia a esas participaciones institucionales, las cuales se proponen como futuras líneas de investigación abiertas a partir de esta tesis.
} 
referidas a la utilización de las instituciones como espacios que permiten la consagración y la incorporación al mercado. Es decir que, por un lado, las neovanguardias $-\mathrm{y}$ especialmente el caso de Vigo- no fueron siempre contrarias a la utilización de las instituciones, pero en algunos casos aprovecharon la potencialidad de la intervención en otros espacios (plazas, calles, zoológico) como medio de búsqueda de nuevos contactos con el público, fuera de los circuitos más o menos cerrados y estables. El caso particular de Vigo es un ejemplo de ese ida y vuelta permanente a las instituciones: si en un momento se oponía a los salones y galerías que, según sus palabras, "mercantilizan" la obra de arte, apuntando a otro tipo de espacios, se lo ve luego participando nuevamente de exposiciones preparadas por organizaciones reconocidas. Esta relación inestable con las instituciones no significó un abandono de la crítica y la reflexión acerca de las características elitistas y comerciales de estos circuitos. Por el contrario, en muchos casos Vigo y otros artistas aprovecharon esas circunstancias para mostrar trabajos no convencionales o vanguardistas que implicaban una convocatoria a la participación del público o que requerían de una actitud reflexiva y atenta por parte del mismo, o bien que al interior de la exposición cuestionaban el propio sistema de selección y premios de obras y artistas.

Desde 1966 en adelante algunos artistas venían señalando en diversos manifiestos sus decisiones de abandonar las instituciones, tales son los casos de "A propósito de la cultura mermelada”, producido por el grupo de artistas de Rosario en 1966, el cual denuncia a las "entidades pseudo-culturales" (Renzi, 1966); "Siempre es tiempo de no ser cómplices" del Grupo de Artistas de Vanguardia de Rosario en 1968, que declara "NO PARTICIPAR de ningún acto (oficial o aparentemente no oficial) que signifique una complicidad con todo aquello que represente a distintos niveles el mecanismo cultural que la burguesía instrumenta para absorber todo proceso revolucionario" (Renzi y otros en Katzenstein, 2007: 303), y las diversas expresiones individuales de artistas como Jacoby o Ferrari, críticas de las posiciones institucionales. ${ }^{45}$ Asimismo, en Europa y Estados Unidos se manifestaba una atmósfera de crítica institucional en la que se formulaban cambios en el mismo sentido del señalado en Argentina. En Francia -país con el que Vigo tuvo una constante relación desde su primer viaje a mediados de los cincuenta- los artistas, especialmente inmersos en los movimientos sociales y políticos

\footnotetext{
45 Sobre el contexto y significación de estas declaraciones pueden verse Fantoni (1994, 1998), Giunta (2008), Longoni y Mestman (2000). Otras declaraciones afines se compilaron en Katzenstein (2007).
} 
de mayo de 1968, tomaron a las instituciones como uno de los espacios donde podía operarse la transformación revolucionaria que se proponían. Allí, la politicidad de sus prácticas puede interpretarse a través de la exploración de los objetos y la vida cotidiana, dado que el museo como representación de la cultura nacional "había llegado a parecer elitista, anticuado, y desconectado de las experiencias cotidianas, personales y políticas de los diversos grupos que componían el pueblo francés" (DeRoo, 2006: 5. Traducción nuestra).

En este clima de "enjuiciamiento al sistema institucional" (Richard, 1990), puede citarse la decisión de Vigo en 1969, aparentemente indeclinable, de no exponer de ahí en adelante en espacios tradicionales. Cuando realizó la exposición 15 años al encuentro del tiempo perdido (por cumplirse ese tiempo desde su primera exposición en la Asociación Sarmiento en 1954), anunció que era

La "exposición última desde el punto de vista personal (...). La vía exposición no es la realmente comunicativa para el estado actual de la relación artistasociedad. Negada la contemplación, el vedettismo del artista y puesto en duda el carácter de este último, exponer es mantener la forma clásica de buscar esa comunicación.” (Biopsia 1969)

Agregó luego que a partir de ese momento realizaría presentaciones al aire libre (El Día, 7/12/69). Este planteamiento parece centrarse más en la crítica a la figura del artista que a la institución; sin embargo, en el rechazo al modelo de artista y al tipo que comunicación que entabla con la sociedad, está implícito que el sistema institucional es el que objetiva esta relación a través de los dispositivos de exposición tradicional que implican: un público pasivo que se limita a observar, un artista que expone una obra cerrada y una institución que consagra o premia al que queda incluido en los parámetros establecidos por la academia o el mercado.

En consonancia con esta declaración, durante el año siguiente la mayoría de sus actividades se centraron en acciones, propuestas y ediciones alejadas de ámbito institucional. Por ejemplo, en marzo se presentó en la boutique Tomatti con algunos objetos y la "urna erótica" -una acción que analizaremos más adelante-; en abril editó 180 ejemplares del Análisis (in) poético de $1 \mathrm{~m}$. de hilo y renunció a su carácter de socio de la Asociación de Críticos de Arte; tres meses más tarde envió por correo a 150 personas el (in) acto a realizar- Creación del silencio asistemático, y programó la Invitación a rasgar, acción que estaba proyectada para realizarse en la Plaza Libertad de Montevideo, pero que no pudo hacerse por falta de permiso policial. En octubre realizó 
Continuidad de lo discontinuo, en el Colegio Nacional, charla sobre la poesía visual y fónica, que también incluyó una acción y una ambientación.

En los pocos casos de participación en eventos más o menos formalizados e institucionalizados, incluyó obras desestabilizantes de la mirada tradicional, ya sea porque son resultados de acciones, o bien que implican una acción por parte del público. Un ejemplo de ello es la Exposición Internacional de Ediciones de Vanguardia (Montevideo, Uruguay), realizada en 1970, en la que participó con revistas y ediciones, entre ellas, Análisis poético/matemático (1967), Poemas (in) comestibles (1968), Manojo de semáforos (1968); o bien, en la Audición Internacional de poesía fónica. Exposición internacional de la nueva poesía. Exposición de ediciones de vanguardia, desarrollada en el Museo Genaro Pérez de Córdoba y organizada por Ovum/10 de Uruguay, donde envió trabajos, números de la revista Diagonal Cero y concretó el proyecto Poema demagógico. También formó parte de la Primera Bienal de San Juan de Puerto Rico del Grabado Latinoamericano: Homenaje a la lucha de liberación de los pueblos de Latinoamérica. Continuó participando en los meses siguientes en las actividades del CAYC, que incluyeron exposiciones en diferentes países de Europa. Todas estas intervenciones de Vigo se caracterizaron -como ocurrió en general en todo el período estudiado- por tratarse de posiciones vanguardistas, críticas respecto del arte como actividad masiva o dependiente de los requerimientos del mercado, así como alejadas de la producción artística ligada directamente con las Bellas Artes en tanto modelo único y canónico. A esto se suma una participación singular que merece atención porque se vincula con la crítica al sistema institucional de un modo directo y original.

En mayo de 1971 se organizó la exposición Delmar en el arte, que ofreció a los artistas que mostraran sus colecciones privadas. Vigo fue invitado, y unos días antes le solicitaron que enviaran las obras, ante lo que remitió un poster con el texto "No tengo obras". El día de la inauguración asistió y repartió entre el público una comunicación con el texto: "La fund(i)ción Vigo saluda a la Fundación Delmar" y debajo, adosado un papel amarillo con la frase "No tengo obras" (imagen 20). 


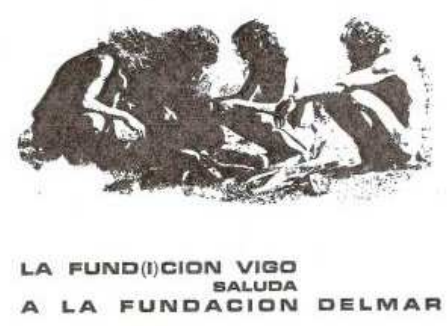

Imagen 20. Vigo, No tengo obras.

Tarjeta. 1971.

NO TENGO OBRAS

La aceptación a participar de la exposición y luego la decisión de enviar el poster y repartir la tarjeta constituye un acto disruptivo de la lógica de funcionamiento de las exposiciones y de la suposición de que los artistas -especialmente aquellos que, como Vigo, demostraban frecuentemente su conocimiento de la Historia del Arte y su interés en el análisis crítico de obras y artistas- debían poseer una colección de obras digna de ser expuesta en un evento cultural. Vigo no niega la invitación, decide participar para intervenir en esa trama de expectativas y reglas, desvirtuando su presencia en la exposición y poniendo en cuestión esas mismas lógicas. Primero a través del afiche y luego, de la tarjeta, la frase "no tengo obras" apela al desconcierto del público, pero también de los propios organizadores, transformándose en una crítica institucional al interior de la institución.

Vigo había participado en abril de 1973 del "Grupo de los Trece", perteneciente al CAYC e integrado por Jacques Bedel, Luis Benedit, Gregorio Dujovny, Carlos Ginzburg, Víctor Grippo, Jorge González Mir, Jorge Glusberg, Vicente Marotta, Luis Pazos, Alfredo Portillos, Juan Carlos Romero, Julio Teich y Horacio Zabala. Este grupo 
(incluyendo a Vigo) ${ }^{46}$ había demostrado interés en hacer conocidas sus críticas a la Bienal de San Pablo. Su director, Jorge Glusberg, había sido invitado como colaborador, pero luego renunció. Vigo adhirió a la denuncia que realizaron dos grupos de artistas e intelectuales reunidos en Nueva York: "Museo Latinoamericano" y “Movimiento de Independencia Cultural Latinoamericano". Además, como parte del "Grupo de los Trece”, publicó una solicitada en el diario La Razón (31/06/73) con el título "El Grupo de los Trece frente a la Bienal de San Pablo", dirigida al Ministro de Relaciones Exteriores y Culto, Juan Carlos Puig. Allí, los integrantes del grupo dicen que fueron seleccionados para participar en la mencionada exposición, avalados por el gobierno anterior a mayo -es decir durante la presidencia de facto de Alejandro Lanusse-, pero solicitan que no se envíen trabajos a la Bienal por ser Brasil un país con dictadura y lugar de ejercicio de la censura, torturas y muertes. "No queremos avalar con nuestra presencia las aspiraciones de un país que es testaferro del imperialismo en Latinoamérica", dicen. Si bien aquí el centro de la crítica se dirige hacia los gobiernos dictatoriales de Brasil y Argentina, la Bienal aparece como un modo concreto de representación del poder represivo. Esto implica una lectura según la cual las instituciones artísticas no se encuentran aisladas, dedicadas al cultivo del arte, sino inmersas en la trama de relaciones políticas más generales. Es por ello que pueden ser repudiadas o boicoteadas al igual que una empresa o un gobierno.

Unos meses más tarde se dio otro caso de mayor envergadura, y por ello con amplias repercusiones. En agosto, el Museo de Arte Moderno de la Municipalidad de Buenos Aires albergó al cuarto "Salón Premio Artistas con Acrílicopaolini". Vigo integró un grupo formado por Perla Benveniste, Eduardo Leonetti, Luis Pazos y Juan Carlos Romero, quienes presentaron Proceso a nuestra realidad. Ese trabajo, ya descripto y analizado en investigaciones precedentes ${ }^{47}$, invita a reflexionar acerca del posicionamiento que adoptaron algunos artistas en relación con una crítica al salón y al otorgamiento de premios. Construyeron un muro de ladrillos de tres metros de alto y siete metros de largo dentro de uno de los salones. De un lado, le pegaron afiches sobre los fusilados de Trelew y del otro, carteles con fotos del la violencia desplegada en

\footnotetext{
${ }^{46}$ Más abajo se detallará la relación de Vigo con el "Grupo de los Trece”, el CAYC y su director.

${ }^{47}$ Sobre esta exposición, remitimos a los trabajos de Andrea Giunta (1995) Ana Longoni (2001, 2011). Giunta ofrece un completo análisis de la exposición y Longoni realiza una descripción detallada del proceso de construcción de la obra e interpreta sus implicancias como un "copamiento" de instituciones por parte de los artistas.
} 
Ezeiza; también escribieron frases con aerosol, entre las que se destaca "Ezeiza es Trelew". El efecto de inmersión en la realidad callejera se logró hasta el punto en que, como señalan Giunta y Longoni, uno de los críticos describe el muro por su llamativa semejanza con la vida real: sus inscripciones, carteles y siglas son los que frecuentemente se ven en las calles, dijo Hugo Monzón desde el diario La Opinión (10/08/73). Acompañaron al muro con un manifiesto que se pronunciaba por un "Arte no elitista, no selectivo, no competitivo, no negociable, ni al servicio de intereses mercantilistas", y entregaron un texto que exigía la "democracia cultural". Este texto, formado por dos columnas, dice "Ante la Burocracia cultural" "exigimos la Democracia cultural", y debajo de cada una de las frases, una caracterización de ambos sistemas. Se tomaron párrafos del reglamento para participar en el concurso Acrilicospaolini y se compararon con lo que propusieron como "democracia cultural". Así, se refieren a que el reglamento invita "especialmente a un grupo de artistas", a lo cual contraponen la "participación plena de todos los artistas", y "denuncian" que se trata de una invitación selectiva, que impone a los artistas el acatamiento del reglamento o la autocensura. En segundo lugar, citan que la empresa entregará el material a los artistas, ofreciéndose un descuento, frente a lo cual condenan "el carácter de dependencia económica y material de quien instituye el salón", limitando las posibilidades expresivas. Luego señalan uno de los puntos más problemáticos del salón, el otorgamiento de premios, a lo que responden que ese sistema fortalece la competencia entre los artistas, en lugar de evaluar sus trabajos por sus resultados. Finalmente, en el párrafo en que el reglamento anuncia la formación del jurado, afirman "que por nuestro grado de conciencia y compromiso no necesitamos ser juzgados ni premiados por unos pocos, pues nuestra obra será válida en tanto ella represente la realidad social en que vivimos" (Biopsia 1973). Se cuestiona aquí la lógica -y su reflejo discursivo en el reglamento- que sostiene la institución arte respecto de la consagración de los artistas a través del reconocimiento de la obra por valores más o menos vinculados con la validez, expresividad, factura de la obra o bien por las posibilidades de afirmación en el mercado del arte. Oponen a esto una escala de valoraciones que se mida en relación con la representatividad que tiene la obra de la realidad social, la cercanía que posea con citando el final del documento- "un arte que esté al servicio de los verdaderos intereses del pueblo". Esto supone también que el jurado no podrá valorar esta característica de la obra, sino atarse a las formas de funcionamiento de los concursos, museos y premios. 
En el salón esta obra no estaba aislada, hubo otras presentaciones de un tenor similar, lo que conformaba un clima de protesta, con un repertorio de temas concordante con los que circulaban en los distintos modos de acción política contestataria. Ejemplos de ello son las presentaciones "Audiohistoria” de Eduardo Rodríguez en las que se proyectaban sobre una pared imágenes de los jóvenes masacrados en Trelew, manchas de sangre y textos alusivos; "Gráfico de una estrategia imperialista" de César Fioravanti y otra obra del mismo que consistió en disponer en el piso una silueta sangrante de un "compañero inocente"; "Ausencias" de Juan Bercetche, hecho con ropas, tierra, placas negras y un cubo truncado; "Una urna funeraria de los caídos por la liberación latinoamericana" de Alfredo Portillos, formada por una caja transparente en la que se encerró una escenografía; Ricardo Roux denunció la violencia y el crimen político; Horacio Zabala realizó una secuencia didáctica para graficar el "Proceso latinoamericano"; Carlos Ginzburg, asumiendo la necesidad de revelar el proceso de producción de la obra y criticando al mismo tiempo la posición de la empresa organizadora, decidió informar el origen y costo de los acrílicos que utilizó en la muestra.

El jurado estaba compuesto por Jorge Glusberg, Julio Le Parc y Osvaldo Svanascini. Los dos primeros se reunieron con un grupo de artistas que se oponían al sistema de premios utilizados en esta muestra. Los artistas querían visibilizar la injusticia sostenida por la forma de organización y otorgamiento de premios, así como la falta de libertad y democracia que generan estos concursos, por lo que proponían hacer un fondo común con el dinero de los premios entregados y resolver una forma de repartirlo. Glusberg y Le Parc aceptaron la propuesta, pero estuvo en desacuerdo el tercer miembro del jurado. La empresa, que tampoco estaba conforme con la decisión de los artistas y parte del jurado, decidió otorgar una nueva suma de dinero para que Svanascini entregue cinco premios más, unilateralmente, a quien deseara y así lo hizo con quienes no habían adherido al reclamo. Los artistas presentaron allí otro documento en el que convocaron a una nueva asamblea para analizar el proceso y tomar decisiones. Hernández Rosselot, del diario La Razón (18/08/73), luego de mencionar las que a su criterio son las obras más destacadas -todas ellas pertenecientes a quienes no formaron parte del reclamodice que "varias de las restantes piezas presentadas se particularizan por un marcado cariz político social, algunas de discutible carácter artístico y en ciertos casos desvirtuando el exclusivo empleo del acrílico, que da sentido al concurso."

Los artistas volvieron a reunirse y resolvieron que donarían los fondos de los premios a la Comisión de Familiares de las víctimas de Trelew. También debatieron sobre 
cuestiones ligadas a la censura y la libertad de expresión, tomando como ejemplo el caso del Salón de Experiencias Visuales $1971^{48}$. Se trató el tema de la creación de un sindicato -se había conformado uno durante la segunda presidencia de Perón-, se discutió si hacerlo dentro de la SAAP (Sociedad de Artistas Plásticos) o fuera de ella y su incorporación a la CGT.

La presencia de Vigo en el desarrollo de estos hechos es evidente por conformar el grupo que decide cuestionar al sistema de premios. Pero también en la producción de la obra. El mencionado manifiesto estaba incluido en una tarjeta elaborada por él, en la que se encontraba el acrílico utilizado, un recorte con forma de gota en color rojo que colgaba de la tarjeta (producido por Perla Benveniste), sujeto con un hilo y bajo la leyenda "Castigo a los culpables. Esta 'gotadesangre' denuncia que el pueblo no la derrama inútilmente" (imagen 21)

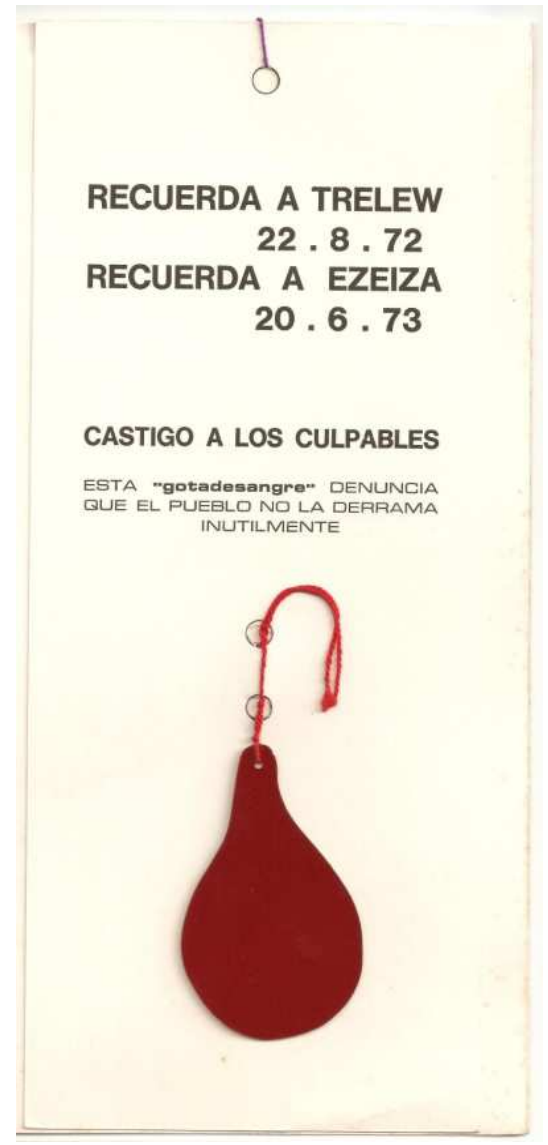

Imagen 21. Vigo, Proceso a nuestra realidad. Tarjeta. 1973.

\footnotetext{
${ }^{48}$ En ese momento, tras el decreto 5696/71 del Poder Ejecutivo ocupado por Lanusse, se censuraron las obras premiadas (Made in Argentina de Ignacio Colombres y Hugo Pereyra; Celda, de Gabriela Bocchi y Jorge de Santa María) en el Certamen de Experiencias Visuales de 1971 por su contenido ideológico. Sobre estos hechos y sus repercusiones, ver Longoni (1999).
} 
Sobre la frase, las menciones a Ezeiza y Trelew con sus respetivas fechas, reiteran las intenciones del muro, haciendo visible la relación entre ambos hechos en los que fueron asesinados militantes de izquierda por fuerzas vinculadas a la derecha. La frase que comenzó a circular luego de la masacre de Trelew, "la sangre derramada no será negociada" está implícita en el texto sobre el acrílico con un juego de palabras que agrega la conjunción "gotadesangre" y el pedido de castigo a los culpables. La utilización del término "denuncia", si bien se encuentra a tono con el tema y la época, está asignado a la "gotadesangre", no a los artistas: es la obra la que querella a los asesinos a través de una gota de acrílico rojo, que incluye también el muro con sus inscripciones y afiches provenientes del espacio público.

Luego de la censura institucional, el grupo, sin embargo, se presentó nuevamente en la Galería Arte Nuevo, donde mostraron fotografías y otros trabajos relacionados con la crítica a la represión y a la violencia del Estado (ver capítulo 4). Como señala Longoni, "ese retorno es vivido no sin contradicciones, como se evidencia en el texto que presenta la muestra firmado por el crítico Horacio Safons: 'La propuesta en esta galería, de este grupo de artistas (...) abastecerá con las mejores intenciones todo aquello que desean combatir, y propone la alternativa de llegar al "corazón de las villas"” (2011, s/p). Volveremos sobre esta muestra al referirnos a la revista Hexágono '71, pero interesa apuntar aquí la relación poco estructurada, no esquemática ni absolutamente desafiante a las instituciones artísticas, aunque hábilmente incisiva sobre sus modos de funcionamiento, y que usufructúa las posibilidades de presentar obras que reprobaban las condiciones generadas por la represión, el capitalismo, la dominación ${ }^{49}$. Como señala Romero al referirse a las experiencias y desafíos vividos en las instituciones, donde había además de un rechazo, una ambigüedad: "uno quería estar y no estar, las dos cosas" (Comunicación personal, 2013).

Como se verá en el capítulo 2, la crítica al sistema institucional implicó para Vigo el desarrolló de acciones en el espacio público. Según su visión,

Las características formales de esas presentaciones (happening, entornos, recorridos, señalamientos) también exigen el abandono físico de esos espacios cerrados (galerías, museos, instituciones consanguíneas del arte) porque

\footnotetext{
${ }^{49}$ Según Longoni (2001), con este y otros trabajos artísticos, se trata de la operación contraria a la que habían realizado los artistas a fines de los sesenta, ya que ahora se instalaron en las instituciones artísticas "en el afán de generar ecos amplificados de las denuncias políticas". La autora se refiere también a la pérdida de autonomía del arte, que queda "al servicio" de la política, como sostenía Perla Benveniste.
} 
indudablemente ya no se adecuan a las necesidades reales de la 'cosa'. Es de ahí pues que el 'artista' (...) busca quemar la etapa de exposición y por sucesivas acciones demuele el uso de las instituciones citadas. (Vigo, Carpeta Poesía Visual, s/f: 1)

La utilización de la calle como medio privilegiado para la actividad artística va de la mano, en la poética de Vigo, con el alejamiento de las instituciones y con el complejo de relaciones a las que se oponía -que ya hemos señalado-, formadas por las exposiciones, el artista en su rol tradicional y el público pasivo. A ellos se suma una idea de contemporaneidad entre las transformaciones del arte y los cambios sociales: de allí que ya no se adecuen a las necesidades reales y sea necesario "demolerlas".

Vigo continúa en el mismo texto refiriéndose a la trama de relaciones que involucran las instituciones:

La comercialización del arte a través del enjuagues no muy limpios, la inalcanzable economía exigida para exponer, los círculos cerrados de una seudocultura oficial que responde al pavoneo de valores intrascendentes y sobre todo no peligrosos para el 'establishment' (léase mensaje directo de la obra o posición del creador), más el alejamiento cada vez más palpable de y hacia la comunidad, son elementos poderosos que juegan en un momento determinado y exigen respuesta a dar por el creador a sí mismo y para con la sociedad" (Vigo, Carpeta Poesía Visual, s/f: 1-2.)

Todo ello se vincula para Vigo con su relación con la sociedad: lejos de darse por la representación figurativa de su situación o sus problemas, se trata de "presentaciones" que, como hemos mencionado, implicaban para el artista una estrategia diferenciada de las prácticas elitistas o burguesas del arte tradicional, intocable, aurático y referencial.

Conjuntamente con las acciones y ensayos críticos hacia el sistema institucional, y en una tensión que impide ubicarlo en una posición fija y lineal, Vigo no abandonó la participación en diversas exposiciones. En el año 1971 su sumó a la exposición Grabadores Argentinos Contemporáneos, en el Art Gallery International de Buenos Aires, organizado por el Ministerio de Relaciones Exteriores y Culto de la Nación, en el que se contó con un jurado de selección. Además, formó parte de la exposición Arte joven platense en el Museo Provincial de Bellas Artes. Sin embargo, ese año fue fructífero para Vigo en la producción de acciones dentro y fuera del espacio público, los señalamientos 5' de filmación en el monumento de B. Mitre, De tu mano, Devolución 
del agua del '70, Tres actos interconectados '71, Enterramiento y desenterramiento de un taco de madera de cedro.

En diciembre de 1973 la Galería Arte Nuevo ubicada en Buenos Aires presentó la muestra colectiva Investigación de la realidad nacional en la que participaron Perla Benveniste, Eduardo Leonetti, Luis Pazos, Juan Carlos Romero, Horacio Zabala y Vigo. Allí Vigo mostró El tapón del Río de La Plata (objeto y documentación); Allende/Neruda $=$ Chile, innecesidad de los 'Homenajes después de...', llamado a la activa militancia 'Antes de...'; Trasplante uno / '73 - Área Dependencia (correspondencia); Trasplante dos / '73 - Área Liberación (correspondencia); Frustración por azar (tres actitudes). Estos trabajos -con excepción de "El tapón..."presentan un alto grado de politicidad explícita. Allende/Neruda... cuyo título termina con un "llamado a la activa militancia", es un caso claro de temática política, incorporando un asunto de alto impacto en América Latina, como fue el golpe de estado en Chile y el asesinato del presidente Salvador Allende en ese mismo año. Los Trasplante uno y dos también contienen en su título significantes alusivos a uno de los problemas más debatido en la izquierda en relación con el subcontinente, el de la "liberación" o la "dependencia" respecto de los centros de poder del primer mundo.

\subsubsection{MANIOBRAS ESTRATÉGICAS: INTERVENCIONES EN EL DI TELLA Y EL CAYC}

En esa relación de inestabilidad con las instituciones que incluyó una fuerte oposición y al mismo tiempo intervenciones críticas, Vigo decidió organizar en 1969 la Expo Internacional de Novísima Poesía (a la que nos referimos antes) en el Instituto Torcuato Di Tella, justamente cuando este ya entraba en una crisis después de la retirada de los grupos que habían decidido cortar sus lazos, rechazar la censura y organizar el proceso colectivo Tucumán Arde en la CGT de los Argentinos en Rosario y luego en Buenos Aires $^{50}$. Como se señaló en la Parte I, una serie de hechos durante el año 1968 que van desde la censura a Baños de Roberto Plate en Experiencias 68 del Di Tella, hasta la acción de denuncia en el Museo Nacional de Bellas Artes durante el Premio Braque, implicaron los posicionamientos de un grupo de artistas, cada vez más intransigentes con las instituciones artísticas, que los llevaron a renunciar a la participación en instituciones en agosto de ese año.

\footnotetext{
${ }^{50}$ Sobre este proceso ver Longoni y Mestman (2000) y Giunta (2008).
} 
Vigo había iniciado una relación con Romero Brest unos años antes, cuando en 1966 el crítico escribió la introducción para una carpeta de grabados hecha por el platense. Allí, Romero Brest ve en Vigo un encuentro del gráfico con el poeta: "Vigo es un extraño creador que talla la madera como si buscara formas con significado independiente, a semejanza de palabras, y que compone poemas disponiendo las palabras como si fuese un grabado". Agrega que "para él, como para mí, 'el arte no es una teoría, es un acto de libertad" (Biopsia 1966). Parte del texto fue citado luego como justificación de la relevancia de la exposición de Vigo realizada en Asunción, en la Galería de Arte 'Ilari' en 1968.

Vigo aceptó la invitación de Romero Brest para organizar la exposición del año siguiente, utilizando tácticamente una institución de renombre nacional (e internacional) para difundir una práctica disonante de los cánones de lectura y visión: la "novísima poesía”, que incluía poesía visual, concreta, de objetos y propuestas de acción.

En el Boletín informativo $\mathrm{N}^{\circ} 1$ sobre la organización de la Expo, publicado por el Di Tella, Centro de Artes Visuales, se informaba sobre los orígenes de la muestra: partió de una idea de los brasileños de "Grupo de Poesía Concreta de Sao Pablo" (Haroldo y Augusto de Campos y Decio Pignatari), que invitó al Di Tella, y este hizo lo propio con Vigo y su grupo "Diagonal Cero". Según el boletín, aparentemente escrito por Vigo,

Recibirá así Argentina un testimonio de la actual nueva visión poética y podrá 'ver' y 'oír' las últimas experimentaciones que se realizan en este campo. Se pretende con ello desatar la polémica, crear el revulsivo necesario y enriquecer la práctica del arte en nuestro país respondiendo a las necesidades vitales y tecnológicas de nuestros días. Una poesía para 'ver' y otra para 'oír' son las dos características fundamentales en que se dividen los logros de estas experiencias. No se trata de plástica ni de música, sino en definitiva la utilización de géneros arbitrariamente dominados y que mermaban la posibilidad de ampliar la recepción de nuestras 'fibras poéticas' (Boletín informativo, 1969.)

Como se ve, la propuesta de Vigo apuntaba a un tipo de creaciones artísticas que poco tenían que ver con las obras de arte y poesías en sentido tradicional, así como con la idea de exposición que tanto había criticado: "crear el revulsivo" a través de esta muestra era parte de su programa poético, aún en una institución consagratoria.

En un artículo del diario La Razón (19/03/69), sintomáticamente titulado "Estalló la Revolución en la Poesía”, Vigo decía sobre esta exposición: 
Nuestra intención fue traer al país todo lo que se hace en la nueva poesía, quebrando una línea tradicionalista. En este caso, el poema es un objeto en sí y no lo ilustra, por eso se diferencia del surrealismo. Acá los elementos los pone el espectador y se recrean los elementos que nosotros les brindamos (...) Partimos, indudablemente, del objeto y vamos a la expresión poética. (Vigo, 19/03/69, $\mathrm{s} / \mathrm{p}$.

La Expo, además de ser coherente con su proyecto "revulsivo", le posibilitaba hacer conocida en nuestro país a la "novísima poesía", en la ciudad más importante tanto por ser la capital como por su rol preeminente en el arte contemporáneo local. Si bien Vigo no acordaba con muchos de los artistas que habían participado del Di Tella y sus posiciones, que leía como tendientes a producir para el mercado, no rechazó la propuesta. Como dijimos antes, Vigo puso a funcionar su amplia red de contactos con artistas de diversos países del mundo y encontró en esa oportunidad una forma privilegiada de estrechar lazos con ellos y poder hacer visible también su propia producción en otros lugares.

Vigo se interesó por las Experiencias 69 del Di Tella (desarrolladas en septiembre de ese año), tanto porque había guardado recortes de diario sobre ella en su archivo, como porque él mismo escribió una crítica. En la revista Ritmo (7/7/69) reseñó y describió los trabajos presentados, y los vinculó con la idea de participación del público, que era uno de los centros de su interés. Resaltó la importancia de la comunicación, se refirió a la relación de arte y vida y a la centralidad de un "arte libre", no encasillado. Además, comparó estas Experiencias con las ocurridas en 1967 y 1968, demostrando conocimiento y disposición para informar lo que ocurría en dicha institución.

En 1970 se evidencia la ruptura de Vigo con Romero Brest, dado que le había entregado su ensayo "De la poesía proceso a la poesía para y/o a realizar" para ser publicado por Paidós bajo la dirección del crítico. Sin embargo, se le informó luego que había sido rechazado, según escribió Vigo en su archivo, por "razones técnicas (?)”, preguntándose por la veracidad de tal justificación. ${ }^{51}$

El mismo año Vigo dirigió una carta a Romero anunciándole su renuncia a la Asociación Argentina de Críticos de Arte. Allí, llamativamente, explica que renuncia

\footnotetext{
${ }^{51}$ Este trabajo, como ya vimos, fue publicado luego por Vigo por su Editorial Diagonal Cero, en 1970. Sobre este explicó el autor que se trataba de un "ensayo sobre una teoría que parte de los procesos brasileros a una amplia posibilidad de re-creación contra una política de consumo dirigido y un ataque hacia la posibilidad del individuo a desarrollar su poema en base a claves sucintas". (Vigo, Biopsia 1970)
} 
por la "distancia que no me permite cumplir con mis tareas" y por "razones económicas" (Biopsia 1970).

Al mismo tiempo que concluyó su vinculación con esta institución clave y su principal mentor (además del cierre del Centro de Arte Visuales del Di Tella), Vigo fue acercándose paulatinamente al CAYC.

Este centro se había creado en 1969 con el objetivo de "promover la ejecución de proyectos y muestras donde el arte, los medios tecnológicos y los intereses de la comunidad se conjuguen en un intercambio eficaz", con una "vocación interdisciplinaria" y una "meta de integración cultural" (Glusberg, 1985: 94). El CAYC se vinculó con diferentes organizaciones e instituciones del extranjero, donde llevó muestras, artistas y novedades.

Vigo comenzó a tener relación con este centro en abril de 1970, a partir de la invitación que le hizo su director, Jorge Glusberg, a participar de una exposición a realizarse en Praga. En noviembre fue invitado a Escultura, follaje y ruidos, una muestra/experiencia organizada por el CAYC, donde presentó el $V$ Señalamiento Un paseo visual a la plaza Rubén Darío (ver capítulo 2). Recibió también una convocatoria para participar como panelista de las "Jornadas Intensivas de discusión 1970", organizadas por el mismo centro y la Galería Bonino. Se trató de cinco reuniones de discusión sobre arte dictadas por un grupo interdisciplinario y coordinadas por Gregorio Klimovsky. Vigo participó de la primer jornada, “Arte y Estructura social”, junto con Martha Berlín (psicóloga), los artistas Ernesto Deira, Lea Lublin, Felipe Noé, Juan Pablo Renzi y la socióloga Marta Slemenson. En esa oportunidad partieron de las preguntas que planificó Klimovsky para desarrollar. Estas eran:

¿Cuáles serán los lenguajes artísticos de la década del setenta?

¿Es el artista un elemento de cambio social?

¿Existen expresiones artísticas independientes de la ideología? (Forma y contenido estético, forma y contenido ideológico).

¿Cabe la expresión artística dentro de un proceso de cambio?

Desde ese año se sucedieron participaciones de Vigo en exposiciones -especialmente en otros países del mundo-, paneles y mesas redondas, publicaciones de ensayos en la gacetilla de la institución, etc. Vigo comenzó a ocupar un lugar cada vez más destacado en las actividades del CAYC, de modo que Glusberg en ocasiones le propuso no solo participar como artista, sino también como organizador de exposiciones. En 1970 Vigo fue uno de los tres artistas que intervino en De la figuración al Arte de Sistemas, 
coorganizada por Glusberg y el Museo Emilio Caraffa de Córdoba. Esta exposición luego fue ampliada y enviada al año siguiente al Camden Arts Center de Londres. Esta, según Glusberg, fue la primera gran muestra del CAYC en el exterior.

En 1971 intervino en exposiciones organizadas por el CAYC en Puerto Rico, Checoslovaquia, Inglaterra, Italia. En relación con esto, Charles Spencer envió una carta con membrete de "Art and artists" de Londres, a Jorge Glusberg. Se refiere a la muestra organizada en esa ciudad con artistas del CAYC. Dice que el embajador objetó una escultura fálica y un poster, pero que sin embargo la inauguración fue un éxito y que está encantado con la presentación y la selección realizada por Glusberg: "Aunque a cada artista se le dio un pequeño espacio, la presentación de Vigo es, en particular, la más efectiva" (correspondencia de Charles Spencer a Jorge Glusberg, 1971. Traducción nuestra.)

En julio avanzó en su relación con el CAYC y su director, dado que Vigo organizó la Expo/Internacional de propuestas a realizar ("investigaciones poéticas") con la colaboración de Elena Pelli y Clemente Padín en la misma institución. Vigo, además, presentó allí sus trabajos Contempla y vota, con el Suero (in) estético para contemplar y una votación para realizar un "gesto poético" (todo ello en momentos en que el voto estaba suprimido por el gobierno dictatorial) (ver capítulo 2). Esta exposición internacional tuvo repercusiones en la crítica y se basó en la presentación de proyectos para ser realizados por los asistentes o artistas, en clara sintonía con el interés de Vigo por la participación del espectador.

Ese mismo año intervino en las Segundas Jornadas de "Investigaciones poéticas" del CAYC, organizadas por Glusberg, y en las que compartió el panel con invitados de Brasil, Chile, Uruguay y Argentina. Fue en ese contexto que Vigo participó de la renuncia a la Bienal de San Pablo (referida arriba), debido a la dictadura represiva que gobernaba Brasil. A raíz de esta suspensión, Glusberg armó la muestra del CAYC en el Museo de Arte Moderno de Buenos Aires (MAM), en la que participaron los artistas convocados para la Bienal.

Como apuntamos antes, a comienzos de 1973 participó del "Grupo de los Trece" que funcionó en el CAYC, dirigido por Glusberg, aunque su integración al grupo no fue total y mantuvo siempre cierta independencia. Este grupo se había conformado a partir de una convocatoria del director de la institución en 1971 e hizo su primera presentación al año siguiente en Colombia; luego mostró sus trabajos en Arte de sistemas y su primera exhibición individual fue en el CAYC: El Grupo de los Trece en Arte de 
Sistemas entre diciembre de 1972 y marzo de 1973. Según escribió Glusberg en un texto que presentaba al grupo: "no hay dudas acerca [del papel] (...) del artista en la sociedad contemporánea como hacedor de lo artificial, pero es evidente que ya no opera solo; acciona en un entorno social -aunque al servicio del individuo- y se prepara -a través de la discusión y el diálogo- para entrar en los umbrales de un nuevo tipo de sociedad" (1985: 130). Sin embargo, Juan Carlos Romero asegura que si bien los miembros conformaban un "grupo", no se producían debates o intercambios profundos, sino los necesarios para la organización de las muestras, dado que entre ellos no había una convergencia ideológica que permitiera una plataforma de acción común, razón por la cual finalmente se alejó del grupo (comunicación personal, 2013).

Con ellos, Vigo formó parte de la exposición Arte en cambio (en mayo de 1973), donde presentó Secuencia cotidiana: el aburrimiento (una serie de fotos de su camino hacia el trabajo). ${ }^{52}$ Ese año Vigo realizó Acción de investigar una acción (envió un sobre a circular por correo y luego lo retuvo definitivamente, convertido en un "objeto investigado"). Esta acción, que fue luego presentada en el CAYC junto con un texto explicativo y fotos de Juan José Estéves, refleja el interés que fue creciendo en Vigo por coleccionar y organizar la correspondencia recibida, lo que luego se transformará en su práctica del arte-correo. De este modo, su inserción en el CAYC le permitió editar postales e historietas (por ejemplo: Armas para mate $\cos (c)$ ido, Historieta hermética $n^{\circ}$ $2)^{53}$ y lanzarlas a su circulación como forma de construcción de nuevos objetos de arte. También envió trabajos a pedido del CAYC para Voces y formas para Chile. Poemas ilustrados para el pueblo chileno. Se realizó luego una subasta pública para ayudar al "pueblo chileno", lo cual se planteó desde la institución como un "apoyo moral”.

Una de las exposiciones de mayor envergadura en las que Vigo participó junto al Grupo es El Grupo de los Trece en Arte de sistemas. Vigo escribió un texto publicado tanto en la gacetilla de la institución (19/03/73) (por error, salió publicado sin firma y posteriormente aclarado), en Hexágono ' $71, c d$, con el título "Un arte de sistemas

\footnotetext{
${ }^{52}$ Esta obra tiene claras similitudes con trabajos de otros artistas, como Segmento de línea recta (1972) de Romero en Argentina -aunque este contenía un alto contenido político- y New York - Boston Exchange Shape (1968) de Douglas Houebler en Estados Unidos.

53 Además de ser presentados en muestras, estos trabajos de Vigo editados por el CAYC fueron publicados: en Art Power $\mathrm{n}^{\circ}$ 16, Suiza, se reprodujo Historieta hermética $n^{\circ} 2$, y en D’Ars $\mathrm{n}^{\circ} 71 / 72$, noviembre - diciembre 1974, Milán, se copió Armas para mate cos(c)ido. Téngase en cuenta el título de esta última obra, refiriéndose a las "armas", de clara vinculación con la violencia política, pero remitiéndolo a un objeto que nada tiene que ver con ello, sino con la popular infusión. El juego de palabras que incluyó el término "armas" se verá en el capítulo 2.
} 
concretado como objeto" y con pequeñas variaciones en el diario El Día (25/03/73). El artículo consiste en una reseña crítica de la muestra. El grupo ${ }^{54}$ que expuso se formó a partir de miembros de ese centro y otros que habían participado allí anteriormente. Según este texto, si bien mantienen diferencias, todos trabajan desde la idea de "arte de sistemas", partiendo de un concepto de Jorge Glusberg. Según este crítico, las dos características principales son las siguientes: están producidos de un modo que pueden ser seriados o reproducidos, y toman elementos de sistematizaciones de otras disciplinas. En el texto de Vigo destaca que estas producciones se suman a la vanguardia internacional, aunque descarta que ello sea en un tono colonialista. Otra de las características descriptas es la vinculación "espectador-obra-realizador-entornosociedad" que, como es claro, es uno de los temas de reflexión y producción de las vanguardias de la , y que el mismo Vigo tomó como uno de los centros de su poética.

En este ensayo, Vigo realiza un análisis de las categorías de arte conceptual y arte de sistemas, a la luz de algunas definiciones teóricas (de Marchan Fiz y de Catherine Millet) y centrado en la muestra. Toma también parte del texto firmado por Glusberg sobre ese evento, como creador de la categoría. Según Vigo, con "Arte de sistemas"

[Argentina se] suma a la vanguardia internacional de un arte que, sin dudas, ha modificado con sus propias propuestas novísimas las relaciones espectador-obrarealizador-entorno-sociedad. Y por primera vez en la vanguardia argentina aparecen nombres que en sus curriculum-vitae no denuncian antecedentes académicos o estrictamente artísticos, un avance que posibilita la ampliación del campo activo rompiendo así la pasividad de hasta no pocos años y a la cual estaba sentenciado apriorísticamente el observador. (Vigo, 25/03/73)

Sobre la relación entre arte conceptual y de sistemas, dice que no son lo mismo, pero que tienen aspectos en común.

[Una de las diferencias es que en el de sistemas aparece] "una necesidad de objetivar lo propuesto por la vía literaria (...). [Esto] "se encadena resueltamente en las últimas tendencias vistas en Europa (apuntamos Europa no con sentido colonialista sino con carácter nacional, porque de las comparaciones muchas

\footnotetext{
${ }^{54}$ Lo conformaron en esta muestra quince personas: Jacques Bedel, Luis Benedit, Gregorio Dujovny, Carlos Ginzburg, Víctor Grippo, Jorge González Mir, Jorge Glusberg, Vicente Marotta, Luis Pazos, Alberto Pellegrino, Alfredo Portillos, Juan Carlos Romero, Julio Tech, Horacio Zabala y Hebe Conte.
} 
veces comprobamos la antelación argentina a muchas experiencias vanguardistas internacionales).

Más abajo, sostiene que el Arte de sistemas nunca negó el objeto en algunas de sus experiencias y que ese arte

no es proposición única para leer, sino que es un intercambio, un apuntalamiento entre propuesta literaria y propuesta documentada (fotografía, filmes, reproducción, afiche-poster) o plástica (objeto), lo que genera una nueva lectura dentro del fenómeno de las actuales propuestas de creación. Un lenguaje a descifrar y un tomar elementos que desarrollan otra instancia espacial y que obliga al 'lector' a un juego incesante de detenciones, participaciones, modificaciones y mediaciones constantes que darán un resultado final, su resultado final.

La coincidencia de intereses entre esta muestra y Vigo no parece ser azarosa. La clasificación que divide entre conceptualismo y arte de sistemas, más que absorber sin más la teoría de Glusberg, es un refinamiento del propio programa artístico poético de Vigo. Vemos allí, además, elementos de lo que efectivamente el platense estaba llevando a cabo en sus actividades artísticas más allá del mencionado grupo. Una de las características del arte de sistemas para Vigo, las propuestas literarias y documentadas, es lo que hemos considerado en nuestra tesis como una apropiación del discurso judicial administrativo, es decir, uno de los rasgos más sobresaliente de su trabajo en el período (ver capítulo 3).

La intervención teórico-crítica de Vigo en esta muestra, así como la posibilidad de haber organizado la Expo/Internacional de proposiciones a realizar, la renuncia a participar en la Bienal de San Pablo, el envío de materiales para la muestra a favor del "pueblo chileno", entre otras, dan señales de que el acercamiento al "Grupo de los Trece" y el afianzamiento de sus relaciones con el CAYC y Glusberg no significó un desdén de sus posicionamientos estéticos y políticos, sino, por el contrario, un modo de sostener su programa artístico poético en otros ámbitos ampliados que dieran visibilidad, reconocimiento y estímulo al tipo de trabajos que él estaba interesado en realizar y difundir. Si, como argumenta Longoni (2006), la teoría de la vanguardia de Bürger funciona como un "corset", ya que solo puede ser aplicada a unos pocos casos aislados de nuestro país, la identificación entre vanguardia y antiinstitucionalismo absoluto es aquí inaplicable. Por el contrario, sus vinculaciones con el Di Tella y el CAYC pueden considerarse maniobras estratégicas, de las que sacó provecho, sobre todo en cuanto a 
las posibilidades que brindaron ambas a sus propios fines: la "revulsión", la participación del espectador y la desconfiguración de los géneros artísticos tradicionales. Asimismo, como dijimos antes, le proporcionaron oportunidades de que lo conocieran en el exterior, de estrechar lazos con otros artistas y de difundir su programa.

Su relación con el CAYC continuó hasta 1974. En enero de ese año se presentó junto a otros miembros en Alternative Video, en el Museum of Modern Art, Study Conference Open Circuits - The future of televisión, New York. Allí Vigo mostró 1971 - 10', bajo Ediciones Tercer Mundo. A los pocos meses envió su Comic-strip hermético número dos al International Cultureel Centrum de Amberes, Bélgica, en una muestra organizada por Glusberg llamada Arte de sistemas en Latinoamérica. Para esa muestra Vigo escribió un texto en francés sobre los comics, publicado en la gacetilla de CAYC y presentado en Bélgica. Glusberg también invitó a Vigo a participar de una muestra del "Grupo de los Trece" que recorrería un itinerario por Argentina, Montreal, Yugoeslavia; además de otras dos en Londres y París. La última presentación con el grupo se produjo en Arte en cambio II (1974) en el CAYC, donde exhibió Latinoamericano culto, desde el punto de vista europeo / '74, un conjunto de fotos sobre los modales de un latinoamericano, Vigo, bebiendo de diferentes latas. Finalmente, en septiembre de 1974 renunció a formar parte del "Grupo de los Trece" con una carta remitida a Jorge Glusberg.

\subsubsection{EL PARADOJAL MUSEO DE LA XILOGRAFÍA: DEL "MUSEOMUSELINA" A LA VALIJA ITINERANTE}

Otra de las incursiones estratégicas de Vigo fue la creación del Museo de la Xilografía. En aparente contradicción con su posicionamiento crítico hacia las instituciones, especialmente los museos (recuérdese su definición de exposición como lo inmutable, siempre igual, opuesta a la presentación, variable a los cambios), decidió, sin embargo, ampliar su proyecto personal -y colectivo- a través de este paradójico espacio dedicado a mostrar grabados en una valija itinerante (imágenes 22 y 23). 

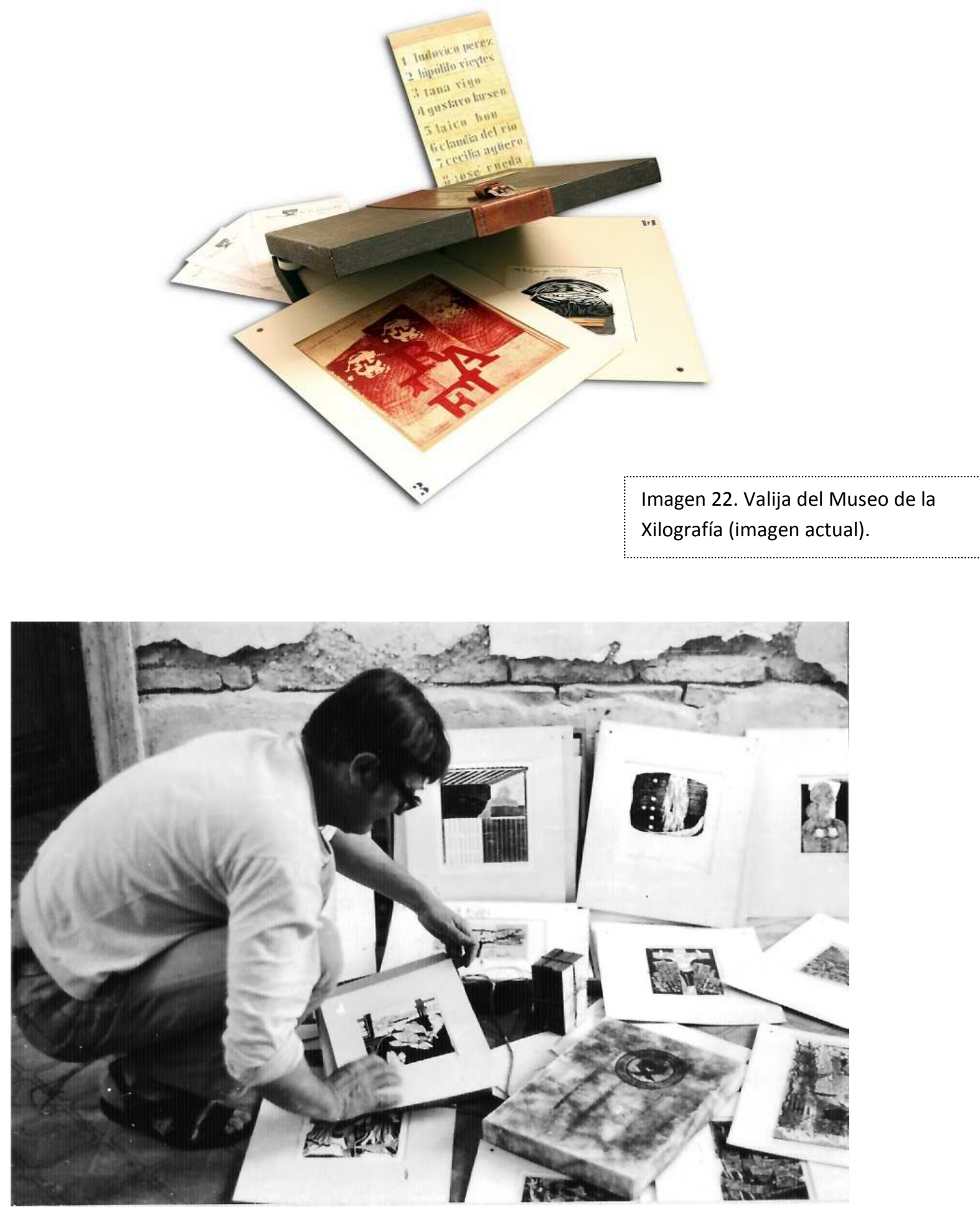

Imagen 23.Vigo con obras del Museo de la Xilografía. s/f

Vigo se había vinculado con el grabado desde los comienzos de su carrera, y la impronta del trabajo con la madera fue crucial en el resto de su producción artística, 
hasta el final de sus días. Ese desarrollo fue visible en diferentes tipos de trabajos, tanto en las xilografías como en poesías visuales, tarjetas, ilustraciones y sus primeras revistas experimentales, pero fue en Diagonal Cero donde explotó su relación con el grabado, colocando estampas tanto en sus portadas como en el interior, intercaladas entre textos, poesías visuales y dibujos.

Comenzó la planificación del Museo de la Xilografía en 1967. La idea surgió a partir de una propuesta de Carlos Pacheco sobre la posibilidad de organizar un museo con las colecciones de grabados que ambos poseían. A partir de las obras que tenía coleccionadas y canjeadas, "trataba de hacer una circulación, un conocimiento" (Vigo, entrevistado por Curell, 1995), tarea en la que colaboró Sixto García. Esa intención se plantea en consonancia con los cambios que venían produciéndose en la práctica del grabado, especialmente en cuanto a la ampliación de su difusión y el acercamiento al "pueblo" (Davis, 2005; Dolinko, 2012b). Así, la fundación del Museo del Grabado en 1963, del Club de la Estampa de Buenos Aires en 1965, la creación del Gabinete de Estampas del Museo Provincial de Bellas Artes un año más tarde y la proliferación de certámenes, charlas y exposiciones, enmarcan la creación del Museo de la Xilografía en un contexto especialmente favorable para la divulgación del grabado ${ }^{55}$.

En 1967 organizó la exposición Grabadores de La Plata, en la que el Museo del Grabado patrocinó el Museo de la Xilografía “(en formación)”. Esa fue la primera presentación pública, pero aún no funcionaba como tal.

La primera muestra del Museo de la Xilografía de La Plata se realizó en la Galería de Arte del Cine Teatro Ópera, que pertenecía al centro literario israelita Max Nordeau. Vigo tenía amigos que formaban parte de la Comisión de Cultura de dicho centro, y así consiguió el apoyo que necesitaba. Además, le resultaba interesante que la gente pudiera circular por la galería que se encontraba en el Teatro porque allí se reunía en los intervalos de una película o una obra de teatro. El diario local informó sobre la inauguración (El Día, 30/11/1967 y 10/12/1967) y destacó que la "exposición incluye figuras de relieve internacional en la técnica en madera, incluyéndose a maestros".

El catálogo contenía un listado de las obras de su acervo, un grabado de Vigo (producido con taco original) y un texto revelador de la mirada del artista sobre la creación del museo:

\footnotetext{
${ }^{55}$ Sobre la relación de Vigo con el grabado, pueden verse: Davis $(2002,2005)$ y Dolinko $(2008,2010$, 2012a, 2012b).
} 
Fundar un Museo en nuestros días es contradictorio.

Cuando el arte en su eterna rebusca clama la calle, la cotidianeidad, la comunicación directa, es una acción gratuita hablar del 'encierro' característico que el 'MuseoMuselina' nos da.

Pero cobijar para no permitir las disgregaciones de obras, cuidar un 'acervo' siempre será constante tarea.

La realidad que nos marca una línea, los acontecimientos que nos ubican, y las acciones que nos exigen, han hecho variar el concepto de Museo. Si este abarca la suficiente dinámica, captará esa 'nueva forma estructural' y seguirá cumpliendo la tarea fundamental de mostrar y acercar por medio del arte a distintas personalidades acuñadas por distintas posiciones estéticas.

El Museo de la Xilografía de La Plata pretende captar esa dinámica de acción contemporánea y bregará como Institución actual, ser la cabeza de una nueva toma de posición para el enfrentamiento obra-comunidad.

La creación del museo incluye el interés de posicionarse en el arte contemporáneo y, como expresa la cita, establecer un rol de vinculación con la comunidad. Esto último implicó que Vigo mostrara sus trabajos en sitios vinculados a la educación, como el Hall del Colegio Nacional (octubre de 1969) o en la Escuela Nacional de Educación Técnica $N^{\circ} 1$ de Ensenada (agosto de 1972). En esta última muestra participó como organizador y expositor; dio una charla informativa cuyo objetivo fue "la experiencia de contacto con el público, [por lo que se] inicia una serie de actos programados a ese nivel". Allí participaron para estos fines la grabadora platense Hebe Redoano, con su prensa impresora, así como Lidia Kalibatas, Mercedes Quiroga y Graciela Gutiérrez Marx y Pereira, los que "tiraron con la prensa impresiones para informar al público de todo el proceso de impresión" (Vigo, Biopsia 1972). Como apunta Dolinko (2012b), la idea de establecer un museo en vinculación con la comunidad ya había sido adelantada cuatro años antes, cuando en uno de sus textos de archivo señalaba la importancia de salir de las galerías hacia la calle y de emprender la educación visual a través de "cursos en bibliotecas populares" y "exposiciones", las que "podrían dar una apertura interesantísima para abrir los grifos de ese interés popular (Vigo, Biopsia 1964).

$\mathrm{Al}$ año siguiente, participó de la muestra La violencia vista por grabadores de La Plata como artista y como auspiciante a través del Museo de la Xilografía. Expuso junto con el grupo de grabadores de La Plata en el Club de la Estampa de Buenos Aires. Este grupo venía desarrollando una labor de exposición pero también de difusión y 
enseñanza de la técnica del grabado sobre madera, haciendo crear al público sus trabajos (El Día, 13/05/73).

También produjo un tríptico sobre el Museo de la Xilografía que contenía información y una explicación para divulgación de la técnica de la xilografía. En ocasión de la inauguración de una muestra del Museo de la Xilografía en la Galería Pequeño Formato de la Escuela de Artes de Luján, un periodista del diario El Civismo recogió la frase de Vigo: la muestra está presentada en una "Caja de xilografías" "que es su característica esencial", por lo que puede ser solicitada por otras instituciones para ser exhibida (18/10/75). Si la cualidad principal del Museo es su ubicación en la caja-valija itinerante, también destacó que lo propio del grabado es la negación de la obra única. Así, en el tríptico que creó para la divulgación de la técnica del grabado y del Museo en 1974 (imagen 24), señaló que "todas las disciplinas artísticas construyen obra única, luego el mercado del arte se reduce a una élite, mientras que el grabado abre un amplio camino" (Vigo, 1974). La unión de estos dos elementos (un museo producido en una valija y el grabado como obra múltiple), fue la combinación que permitió a Vigo intervenir críticamente en dos sentidos: por un lado, a través de la itinerancia de la valija en su función de divulgación y acercamiento de la técnica y sus obras a algunos sectores que suponía no vinculados a los museos; por otro lado, el empleo de un medio que proporciona un tipo de obra multiplicable. 


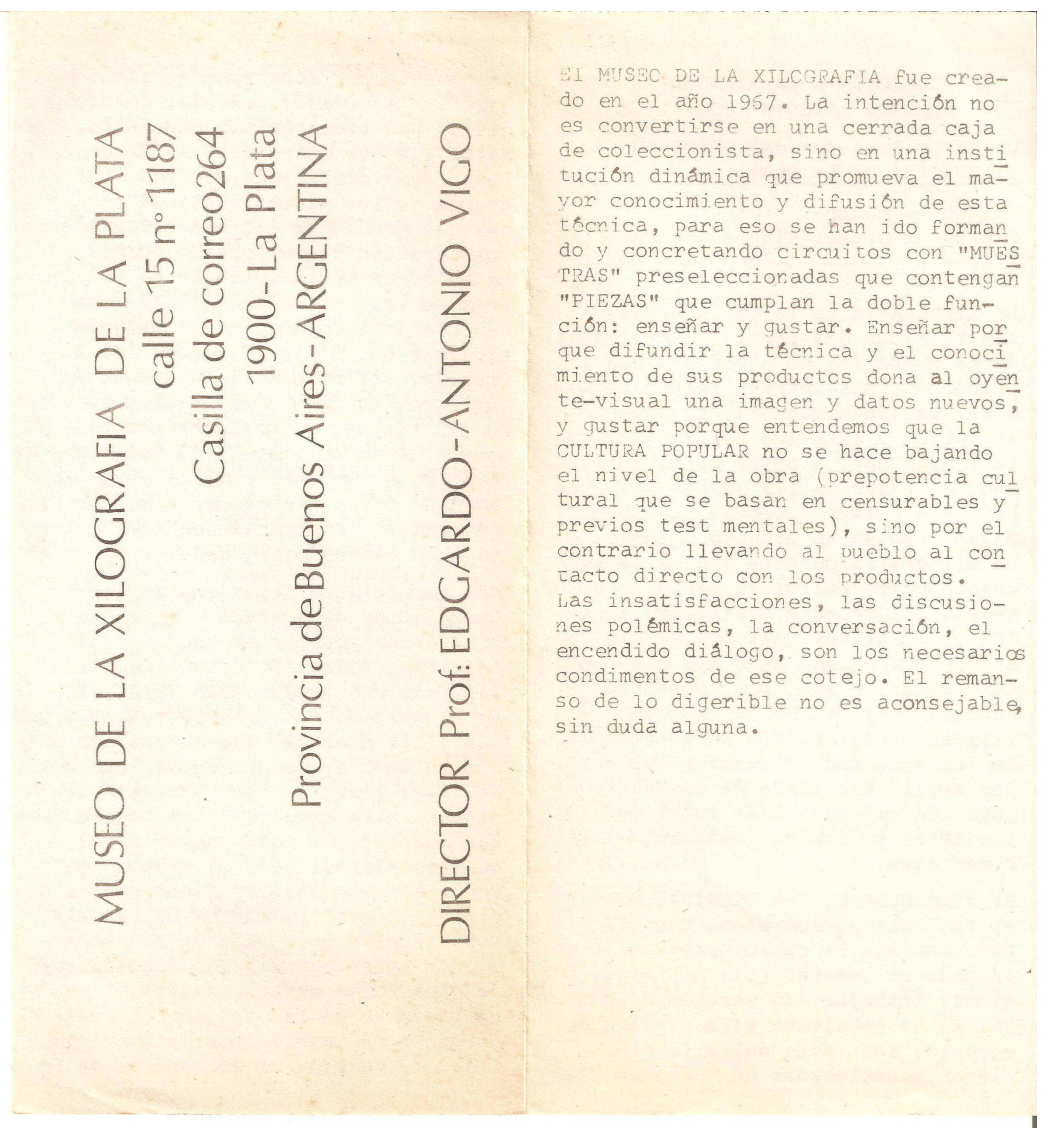

Imagen 24. Vigo, "Museo de la Xilografía”. Tríptico. 1974.

En el mismo tríptico describió al Museo de la Xilografía:

La intención no es convertirse en una cerrada caja de coleccionista, sino en una institución dinámica que promueva el mayor conocimiento y difusión de esta técnica, para eso se han ido formando y concretando circuitos con 'muestras' preseleccionadas que contengan 'piezas' que cumplan la doble función: enseñar y gustar. Enseñar porque difundir la técnica y el conocimiento de sus productos dona al oyente-visual una imagen y datos nuevos, y gustar porque entendemos que la cultura popular no se hace bajando el nivel de la obra (preponderancia cultural que se basa en censurables y previos test mentales), sino por el contrario llevando al pueblo el contacto directo con los productos. Las insatisfacciones, las discusiones polémicas, la conversación, el encendido diálogo, son los necesarios condimentos de este cotejo. El remanso de lo digerible no es aconsejable, sin duda alguna.

Con esta afirmación aparece nuevamente la idea de un espectador activo y alerta, aunque aquí no se trate de la culminación de la obra por una acción. Y es, paradójicamente, también desde la proposición de un museo que Vigo intenta apelar a 
esas actitudes descentradas y contrarias a las jerarquizaciones en que público y pueblo aparecen en los lugares más bajos. En cuanto a la oposición a lo "digerible", refiere probablemente- a los propósitos de transferencia pedagógica asociados a ciertas variantes politizadas del realismo o bien, tal como apuntó en otro texto, a lo "folklórico", los cliché repetidos.

La presencia del término "exposición” en los catálogos del Museo, así como la charla que dio Vigo en Rotary Club en 1975 sobre la xilografía y el museo, hacen aparecer las contradicciones que emergen en el funcionamiento de la institución. Sin embargo, más que quitarle potencialidad o desactivar su propuesta crítica, dejan entrever los vericuetos de la función de Vigo como organizador y al mismo tiempo como artista "revulsivo". La actividad didáctica que desplegó desde allí no puede aislarse de nuestra interpretación, sino que más bien hace vislumbrar las capacidades movilizantes que Vigo proponía desde ese espacio, así como en su rol de docente secundario. Según Vigo, el método que encontró de contacto con la comunidad fue a través de la docencia, de allí que el Museo de la Xilografía ocupara ese lugar dentro de su programa: "había que buscar una forma de que este material que tenía en mi casa cumpliera una función de comunicación, que lo conocieran los demás y a la vez una divulgación de los artistas y de la obra" (entrevistado por Curell, 1995). La relación que Vigo estableció con la docencia como medio de estrechar sus lazos con la comunidad tiene una resonancia política, especialmente enmarcada en las críticas que realizaba al arte "elitista", accesible a unos pocos. En tanto la comunidad es la destinataria principal de su actividad docente y en el Museo. No es solo la forma vanguardista de las creaciones artísticas lo que contribuye a eliminar el elitismo en el arte -es decir, el arte "tocable", de materiales "innobles", no representativo-, sino también las relaciones sociales que se construyen a través de los canales institucionales, tanto en la difusión del grabado y de sus técnicas como en sus clases del Colegio Nacional. De allí que la fundación de un museo no sea, para el caso de Vigo, en sí misma una traición a sus ideales rupturistas, sino otra de las formas por las cuales era posible realizar acciones políticas.

Así como en el análisis de las obras de Vigo nos concentraremos en su materialidad, asimismo debemos valorar la constitución del Museo de la Xilografía a partir de una valija o una "caja de xilografías", una posible reminiscencia de la Boîte en Valise (cajavalija) de Duchamp. Si algo hace posible la existencia de un museo, en principio, son dos elementos: una colección y un espacio físico, un edifico donde exponerla. El de la xilografía no cumplía con el segundo de los requisitos: consistía en una caja con manijas 
de cuero donde se trasladaban los grabados, conseguidos por intercambio o donaciones, a diversos sitios, donde se la abría para mostrar su contenido (imagen 22). El museo era la valija, la itinerancia, lo nómade, el cambio. Lejos de convertirse en un centro de exposiciones, el Museo de la Xilografía carecía de edificio que lo fijara, tanto como las obras que lo componían carecían de paredes apropiadas y especialmente planificadas para su exposición. "No tengo un espíritu institucional, me revienta, mi definición filosófica, política, sociológica, es totalmente anárquica”, decía Vigo sobre su relación con este Museo (entrevistado por Curell, 1995). Es por ello que asegura que las obras no le pertenecen, sino que funciona "como un albergue, es una especie de hostería de paso". Y continúa:

Yo no puedo institucionalizar. ¿Se imaginan, yo como director del Museo, haciendo una muestra y dando un discurso y que venga el intendente? (...) Yo no voy, no tengo estómago, me descompongo, porque veo (...) un tipo que viene (...) porque quizá le sirva para ganar tres votos en un sector. No me pude armar para sobrepasarlo, no me pude educar para eso, quizá no tuve tampoco intención ni interés, pero no lo pude hacer. (...) Sé que tengo algo que está en tránsito.

La valija se prestaba a docentes o a casas particulares y permitía trasladar una muestra entera, ya sea de un artista o de una ciudad. La simplicidad era su aspiración: "La valija, el paquete, está preparada de tal manera que parece que llevara un paquete de alimentos", dice. Así, se puede ceder para realizar charlas, clases o también dejarla instalada como muestra. Vigo afirma que nunca realizó una selección, sino que todo lo que se le entregaba pasaba a formar parte del acervo del Museo y señala que esa selección se realizará algún día "cuando el Museo se institucionalice".

\subsection{3. "MEDIOS DE COMUNICACIÓN NOVÍSIMOS" Y CRÍTICA INSTITUCIONAL}

Alejado ya de las dos grandes instituciones del arte a las que había estado ligado temporalmente, Vigo asumió un rol crítico respecto de ellas y sus directores.

En el ensayo "Sellado a mano", publicado en la última Hexágono '71 (e, 1975), Vigo analiza el fenómeno de la utilización de los sellos de goma en el arte -que se verá con mayor profundidad en el capítulo 4-, y hace referencia a su posición respecto de las 
instituciones y al libro de sellos (ideado y editado por Vigo en 1974), igualmente titulado Sellado a mano.

Bajo el subtítulo "Una forma del 'real' arte pobre”, hace una crítica a las instituciones que con intenciones de "internacionalizar", en lugar de "universalizar", el arte, condicionan su accionar por los "grandes intereses" que garantizan su rápida recepción y limitan el trabajo de los artistas. Estas instituciones, "zares de la creación", seleccionan ideológicamente a los "investigadores creativos", están "interesadas al máximo en hacernos aceptar por constancia de mensaje y su repetición, slogan, posiciones, técnicas, movimientos" y restringen el arte a la modalidad de "exportación" e "importación". En este contexto,

Para conseguir apoyo y permiso, el investigador debe aceptar una serie de imposiciones, las más comunes, vigilancia de su mensaje, potabilidad, conveniencia o no a nivel de política de ciertas presencias, caprichosas actitudes de selección y una serie de condicionamientos que acaban por ser una lamida imagen de lo latinoamericano. O, en última instancia, un concepto de lo latinoamericano internacionalizado.

De este modo, para Vigo, el arte pobre o marginal se enriquecerá en la medida en que se aparte del "circuito hábilmente tejido por el sistema-lógico-tradicional que conforman los factores actuales, encargados de difundir y valorar, tasando, la creatividad". Así, podrá prosperar el uso de un tipo de "medios de comunicación novísimos", entre los que destaca el arte por correspondencia, las tarjetas postales, las cintas grabadas y las películas de $8 \mathrm{~mm}$. El "investigador-creativo-latinoamericano" se encuentra, así, alejado de los circuitos del "sistema-lógico-tradicional" en los que circula y se comercializa el arte, da cuenta de una búsqueda "no-conformista", en la que también aparecen lo popular y lo kitsch, y los medios utilizados son simples. Es la creatividad desplegada lo que diferencia a estos trabajos de otros.

Hay, según Vigo, dos formas de desarrollar el arte de investigación: una que utiliza medios inaccesibles y que responde a los intereses de los centros de arte limitantes de la creación; otra que acude a formas al alcance del creativo, un "real arte pobre" sin apoyo estatal o privado. De este modo,

Los medios instrumentales de las comunicaciones novísimas admiten una libertad mayor, puesto que su circulación se realiza por canales no-tradicionales alejados del organizado aparato de represión y censura y lejos de la peligrosa direccionalidad impuesta por los Centros estatales o privados. 
(...) El uso de las técnicas novísimas -la mayoría a nivel manual-posibilita un encuentro de arte investigaciones-creativas-latinoamericanas.

Si hasta aquí el texto de Vigo parecía aludir a las instituciones locales más reconocidas, más abajo decide dar un nombre a ese sistema de dominación en el arte, enfrentándose abiertamente con Romero Brest, sus criterios de selección y apoyo, así como su posición institucional e internacional. Según Vigo, el ex director del Centro de Artes Visuales del Di Tella, con su "mentalidad dependiente", es un "aplicador del método de selección, digitado por premoldeados arbitrarios y desde ya indiscutibles (para ellos)" que responden a las lógicas internacionales Para el platense, Romero Brest es un defensor de las corrientes de lo aceptado por los mass media, denostando todo lo que surja por fuera de ellas. Y sigue,

El Poder es tal en la medida que nosotros creamos en él. Si el investigador contemporáneo acepta la carrera profesionalizada sin cuestionar, el Poder detentado por los Centros no será nunca cuestionado. En la medida que el investigador-creativo acepte otros medios de comunicación, entre sí y con la sociedad, que no respondan rígidamente a-lo-aceptado por Popes digitados, el Poder cambiará de mano, o [será] compartido.

Haciendo hincapié en el carácter universalista y no internacionalista -que marca jerarquías y divisiones de campos- dice que también en Europa han utilizado estos medios de "instrumental paupérrimo": tarjetas postales, intercambios de trabajos, montajes de muestras en lugares no tradicionales, xerox, multicopiados, arte como idea, sellos de goma, collages manuales seriados.

El texto está ilustrado por algunos sellos: el título del mismo está escrito en un sello, y en la hoja siguiente, refrendando el contenido político que Vigo quiso darle a este trabajo, se encuentra impreso un sello que dice "29 de mayo de 1969. Insurrección popular en Córdoba. 29 de mayo 'Día del Ejército Argentino"”.

El libro-objeto editado por Vigo, Sellado a mano (1974), no solo tiene la particularidad referida arriba, es decir que se trata de un libro enteramente realizado con sellos, sino que las hojas sueltas y el formato de caja atada con hilo sisal remiten a un tipo de edición desconvencionalizada, desmembrable y "pobre" o "marginal". Estas cualidades, que Vigo aplicó también en otros trabajos -veremos especialmente el caso de Hexágono '71- dan una señal de autoría y factura artesanal (imagen 25). 


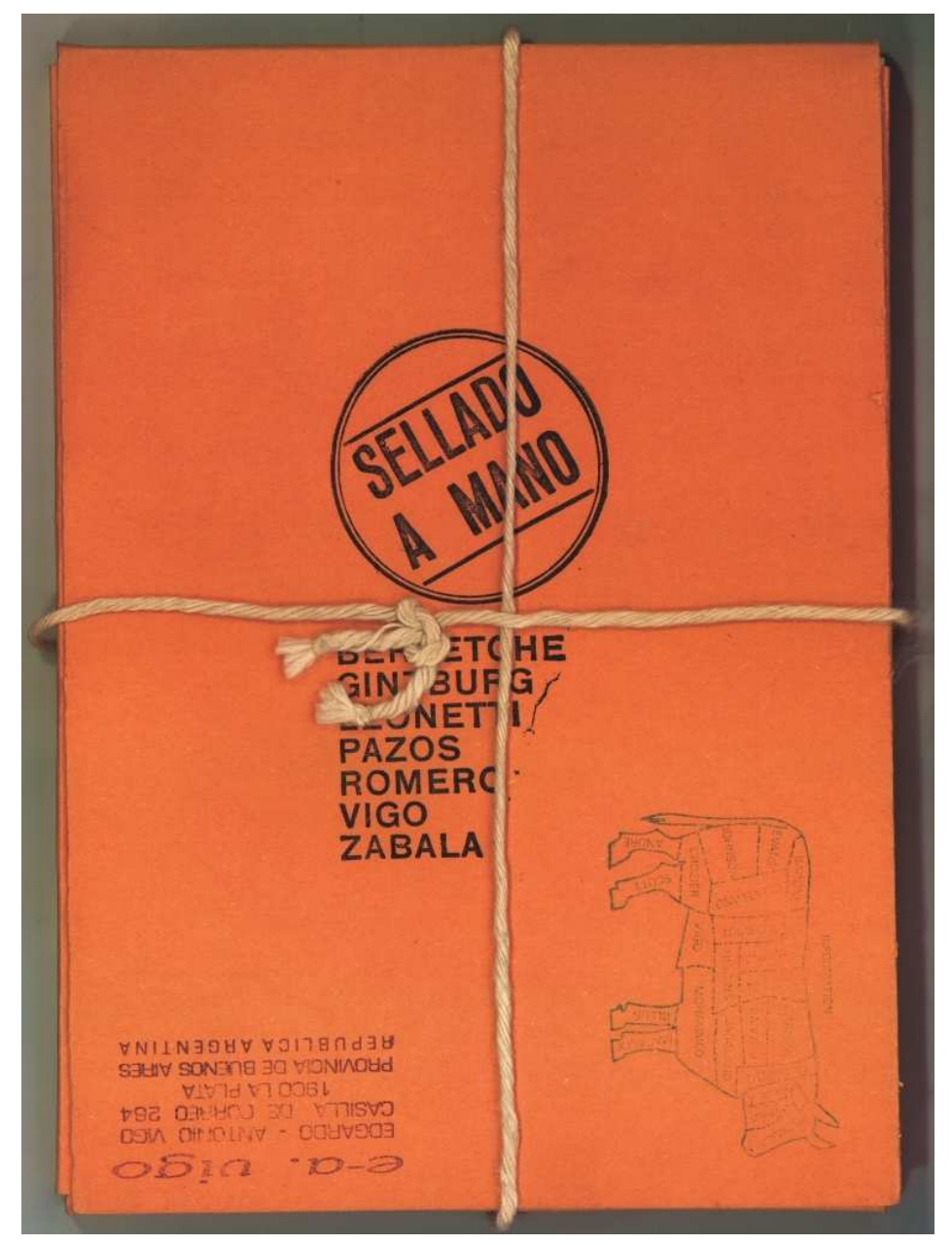

Imagen 25. Vigo, Sellado a mano. 1974.

Las temáticas que abordan casi todos los trabajos -a excepción de los de Ginzburg- son políticas. Lo componen sellos que refieren a la libertad (Vigo), a personas "ejecutadas" (Bercetche), las frases "Libres o muertos jamás esclavos" y "Perón o muerte Viva la patria" que se superponen (Romero), textos de Platón, Pascal y Shakespeare (Ginzburg); tres sellos que juegan con la fecha "29 de mayo" colocando en la parte superior un hecho político y en la inferior "Día del Ejército Argentino": el primero, citado arriba, sobre el Cordobazo; el segundo, "29 de mayo de 1970. Montoneros secuestran al General Aramburu"; el tercero, "29 de mayo de 1972. Muere el Montonero Jorge Escribano" (Leonetti); la censura en el Arte Latinoamericano actual (Zabala) y dos términos caros a las ideas y discursos de la izquierda: "Liberación" y "Dependencia" (Pazos).

En su artículo "Sellado a mano" al referirse al libro, Vigo afirma que se trata de "una clara línea política" y que sus trabajos se encuentran "inmersos en una realidad que presenta problemas urticantes". Demuestra, de este modo, tanto él como los demás artistas del libro, que se encontraban inmersos en un clima ideológico y político más o 
menos generalizado entre los intelectuales y militantes en que se reflexionaba acerca de esa realidad. La mención de los problemas del tercer mundo o de Latinoamérica en particular, la dominación del sistema y los poderosos, el colonialismo, la censura, la violencia, eran temas casi obligados entre aquellos que se dispusieran a considerar aspectos problemáticos de la vida social. La afirmación de que estos problemas "deben ser contestados también desde el punto de vista creativo", asume que la forma corriente de deliberar sobre ellos se da en otros ámbitos y es por ello que refuerza la idea de que "también" debe hacerse en el arte.

El libro carece de datos con respecto a la fecha de publicación, editor o coordinador, así como números de páginas. La combinación de un tipo de producción que anula los criterios editoriales normalizados, la impresión en sellos (que apuntaba a un arte desligado de los circuitos comerciales e internacionalizados) y la política de sus trabajos terminan de configurar una posición que reprueba las instituciones tradicionales y las comerciales, así como una intervención crítica respecto de la realidad que se estaba viviendo, y que daba cuenta tanto de los procesos represivos que llevaban adelante el Estado y organizaciones de la derecha como de la radicalización política de distintos sectores de la sociedad. En esta apuesta, cuya politicidad explícita no invalida formas y métodos vanguardistas, Vigo mostró hasta qué punto esa articulación particular de arte y política era posible.

Como recapitulación de lo analizado en este capítulo, podemos afirmar que en las críticas a los sujetos del arte Vigo pretendió desorganizar y desjerarquizar las funciones tradicionalmente asignadas a ellos. La participación del público, la desacralización de la obra de arte y la presencia de un "proyectista" en lugar de un artista, son los modos por los cuales intentó llevarlo a cabo. La crítica institucional, cuyos vaivenes hemos mostrado, si bien no implicó una oposición total y sostenida, apuntó a ocupar otros espacios -como el espacio público-, a crear una forma institucional novedosa que rehusaba convertirse en museo tradicional e intervenir en las instituciones, cuando ello conviniera con sus objetivos personales y concordantes con su programa poético.

En cuanto a la figura del artista, Vigo planeaba la invención de un nuevo sujeto creativo, opuesto al tradicional genio. Esa oposición a la forma que adquirió el artista en la sociedad burguesa no lo llevó a convertirse en el sujeto histórico de la época, el "militante, de izquierda, combatiente, peronista, marxista", ligado con una heroicidad y 
"una donación sacrificial de la vida" (Casullo, 2004: 10). Eso distaba de su programa poético, así como de su plan de vida: no se involucró en la lucha política organizada. Posiblemente, su identificación como "anarquista" y la búsqueda de respuestas en la experimentación estética coincidieron en la decisión de mantenerse al margen de la entrega total a la vida revolucionaria. Ello no implicó rehusar el encuentro con los problemas sociales y políticos. Como señala Richard (2000) para el caso chileno, la crítica de Vigo a los sujetos del arte se sostuvo en el "anhelo de fusión entre arte y vida". La vieja idea de las vanguardias reaparece y se presenta como posibilidad en el cuestionamiento a la institución artística, en tanto se propone "revulsionar" los mecanismos que regulan la obra, el artista, el público y las formas de consagración y regulación, lo que implica "revolucionar el significado y la función del arte haciendo explotar las fronteras que lo divorcian de la vida" (Richard, 2000: 42-43). De este modo, la vinculación entre arte y vida reaparecía en la propuesta de participación activa del espectador en un "arte tocable", en la idea de que estuviera alejado de todo "elitismo" y en una crítica institucional a las formas de funcionamiento que implicaban un destinatario privilegiado, sectorizado y pasivo. Asimismo, operaba un cuestionamiento a las jerarquías en la proposición de que la figura del artista como autoridad fuera al menos cuestionada.

Uno de los modos en que esa aspiración de fusión entre arte y vida pudiera llevarse a la práctica fue a través de la intervención directa del arte en el espacio público, ya que el uso de la calle y la cotidianeidad permitían idear la disolución de barrera que separaban los espacios diferenciados -como museos y galerías- de los públicos. 


\section{CAPÍTULO 2 \\ SOBRESIGNIFICACIÓN ARTÍSTICA DEL ESPACIO PÚBLICO}

Las acciones artísticas en el espacio público a fines de los sesenta comenzaron a acrecentarse y destacar en algunos sectores neovanguardistas. Entre ellos, Vigo desarrolló como parte de una poética más amplia, una serie de acciones que llamó señalamientos. Se abordará en este capítulo la significación de esas acciones realizadas desde 1968, considerando que han formado una parte fundamental de su poética en el período estudiado. Si Vigo planteó una nueva configuración del arte a través de la participación del público y la presencia inestable del artista, así como el abandono de las prácticas canónicas de circulación de las obras de arte en museos, premios y galerías, los señalamientos fueron una forma amalgamada más o menos estable de ese programa, un modo particular de cumplimiento de ese propósito. La presencia de esos elementos en estas acciones se hace evidente cuando se analizan las características de cada señalamiento, su relación con el medio en que fueron realizados y las repercusiones en la crítica. Asimismo, Vigo teorizó sobre ellos, los definió y ubicó en el marco de su poética, así como ensayó respuestas a los acontecimientos políticos del momento.

La complejidad del tema requiere de un comienzo que se pregunte por la entidad del espacio social y luego, pasando por el concepto de espacio urbano, de un segundo momento del análisis que nos aproxime al significado de las acciones artísticas en el espacio público. Se tendrá en cuenta la circunstancia histórica: que estas acciones ocurrieron en el contexto particular de plena dictadura, durante gobierno de la llamada "Revolución Argentina”. Esta consideración otorga al análisis un elemento ineludible para la comprensión de la dimensión política de las mismas.

\subsection{ESPACIO PÚBLICO, ARTE Y POLÍTICA}

El espacio es un producto social (Lefebvre, 1991), ya que no se trata solo de aspectos físicos o materiales, sino que es una construcción compleja en la que existe siempre una relación con la vida social; de este modo, se trata de una síntesis entre el contenido social y las formas espaciales (Santos, 2000).

La organización del espacio está dada tanto por las prácticas como por los relatos, los cuales imponen divisiones que lo estructuran. Estas divisiones separan al sujeto de su 
exterioridad, a los objetos entre sí y operan sobre el funcionamiento del tejido urbano y del rural (De Certeau, 2007). Además, hay una condición política del espacio, ya que existen disputas de poder para intervenir en él como producto social $\mathrm{y}$, aunque no siempre son evidentes, le quitan cualquier neutralidad aparente (Lefebvre en Vázquez Romero, 2009: 10). En estas disputas políticas y estratégicas, queda abierto el camino para acciones contrarias al orden que impone el poder dominante sobre ese espacio.

Lo vivido en el espacio forma parte de su producción (que Lefebvre ha llamado “espacios de representación”): “espacios vividos que representan formas de conocimiento locales y menos formales; son dinámicos, simbólicos y saturados con significaciones, construidos y modificados en el transcurso del tiempo por los actores sociales" (Oslender, 2002: 6). Éstos no son homogéneos ni autónomos y se desarrollan en una relación dialéctica con las representaciones dominantes del espacio; en este sentido, están sujetos a la dominación, pero pueden convertirse en fuente de resistencia (Oslender, 2002).

Fruto de la resistencia al espacio hegemónico surge, para Lefebvre, el "espacio diferenciado", aquel que acentúa las diferencias frente al intento de homogeneización del primero: un “contra-espacio". Se trata, entonces, de la dimensión política del espacio, la cual se particularizará en este trabajo a través de las acciones artísticas en el espacio público. Puede señalarse, además, que, siguiendo a Rancière (2007), una de las formas de vinculación del arte con lo político -que este filósofo llama el "régimen estético del arte"- es aquélla en que el arte disiente con el orden "normal" o policial, de modo que puede entrar en contradicción con el régimen de la sensibilidad, es decir, el que establece los lugares y jerarquías de sujetos y objetos. En este sentido, la intervención en el espacio público, desestabilizando funciones preestablecidas tanto del arte como de ese espacio, así como de las acciones posibles y de los sentidos habituales y disponibles, desestructura el régimen normal de la sensibilidad y por ello, también es política.

Dentro de las diferentes formas del espacio social, el espacio urbano tiene particularidades que es necesario destacar, dado que las acciones que se analizarán tuvieron lugar allí. Dice Lefebvre que "la ciudad concentra la creatividad y da lugar a los más altos productos de la acción humana, en la ciudad se expresa la sociedad en su conjunto (...); la ciudad proyecta sobre el terreno a la totalidad social; es económica pero también es cultural, institucional, ética, valorativa, etc." (Vázquez Romero, 2009: 8). Por lo tanto, el espacio urbano además de ser el espacio construido socialmente, 
condensa las principales características de la sociedad moderna, donde se desatan las contradicciones sociales, las pujas por el poder, pero también conduce a la expresión cultural y a la creatividad. Si el espacio social es político, la ciudad, específicamente, es el resultado de múltiples decisiones, maniobras, gestiones que tienen consecuencias no solo a nivel material de su conformación, sino también sobre la vida cotidiana de las personas. Allí las pujas por la apropiación del espacio, en términos materiales, pero también simbólicos, son evidentes. Es en la ciudad donde los grupos dominantes pueden expresar su hegemonía sobre el conjunto y donde, a través de sus decisiones, ejercen un poder político que afecta a un gran número de personas.

Esto no significa que la ciudad solo sea objeto del dominio del estado que la administra, ordena y controla, sino que existe allí una relación dinámica entre resistencia y dominación, normas más o menos explícitas y usos entre lo prescrito y lo practicado. Así, en el terreno simbólico, en la ciudad se juegan relaciones de poder que influyen en esa construcción social del sentido. Todo lo que se produce en la ciudad puede convertirse en información que, al mismo tiempo, es pasible de ser interpretada por sus mismos habitantes.

En las ciudades, cobra relevancia el espacio público. Este es un orden de visibilidades con una pluralidad de usos y perspectivas y es un orden de interacciones y encuentros (Joseph, 2002). Allí es requisito que exista una accesibilidad universal. A pesar de que en el período estudiado, había una espacialización represiva, las acciones en el espacio público fueron posibles porque había un resto -producto histórico de las democracias de masas anteriores- que había cristalizado ciertos acuerdos mínimos sobre la existencia de un espacio propio de lo público en que era posible accionar con otros, comunicar y hacer visible una perspectiva sobre el mundo. En este sentido, estos espacios están especialmente dotados de significaciones culturales, memoria e identidad (Oslender, 2002), porque allí la intencionalidad de las acciones se convierte en resultados hacia la colectividad; así, aún las pequeñas acciones individuales emplazadas en lo público tienen un significado que siempre puede ser interpretado socialmente.

A partir de estas definiciones, resulta fundamental indagar en las acciones que allí realizó Vigo. El arte ecológico, definido como "el conjunto de procedimientos estéticos que buscan resignificar y/o transformar nuestras relaciones sensibles y operativas con medio" (García Canclini, 1977: 189) puede realizarse tanto sobre la naturaleza como sobre espacios urbanos. En el segundo caso, se trata de aprovechar las potencialidades de utilización o modificación del espacio público, tanto en términos concretos como 
simbólicos, y una intervención sobre las disputas de poder que allí se dirimen. Las acciones en el espacio público de Vigo se vinculan con el arte ecológico y conceptual, y si bien, no pueden enmarcarse de modo fijo en uno de ellos, se insertan en el mismo horizonte de preocupaciones que sus contemporáneos.

\section{2. "UN ARTE EN LA CALLE NO ES SACAR LO VIEJO A tOMAR SOL"}

En 1968 Vigo recibió una invitación para participar del $2^{\circ}$ Incontro Internazionale d'avanguardia "Parole sui muri", que iba a desarrollarse entre julio y agosto en la ciudad de Fiumalbo, Italia. La invitación contiene un texto que es una apuesta a la ocupación del espacio público con las obras de arte enviadas por los artistas, ya que los cuadros se colocarían en las casas de los campesinos, las películas se proyectarían sobre los muros, las esculturas se colocarían en las calles. Dice:

El encuentro se basa en la participación 'activa' de poetas, pintores, escultores, gráficos, cineastas, actores, personajes... En las casas, en las calles, en las plazas de Fiumalbo será posible inventar un nuevo mundo. Estamos todos invitados a trabajar para construir 'objetos' en este pueblo. No hay límites a este juego. Caminar por estas calles significa construir el poema más grande $\left(2^{\circ}\right.$ Incontro Internazionale d'avanguardia, 1968. Traducción nuestra).

Es posible pensar que esta particular invitación -guardada por Vigo en su archivo como otras tantas que recibía- haya inquietado su deseo de seguir experimentando en una dirección que tomara el espacio público como punto de partida ${ }^{56}$.

Años más tarde, Vigo dijo: "He hecho muchas cosas en la calle. El arte busca comunicación, es necesidad de mostrar. Mi pretensión es llegar [a] lo más, poner el trabajo delante del transeúnte. Después armamos un diálogo muy lindo porque me gusta que el público se exprese, busco alternativas de comunicación", sumado a que el artista tiene una necesidad de diálogo, "no está en una pompa de jabón". Sin embargo, esa necesidad -dice Vigo- no se resuelve en las exposiciones, por lo que debe buscar otros modos de hacerlo y la calle es uno de ellos (entrevistado por Curell, 1995). Con esta idea general, pero con especificaciones que remiten a otras cuestiones, en 1971 Vigo produjo un texto clave para entender su teorización respecto del uso de la calle como espacio habilitado para la producción artística. Se trata del ya referido ensayo "La calle:

\footnotetext{
${ }^{56}$ Vigo participó de este encuentro enviando poemas matemáticos y Composición “609”.
} 
escenario del arte actual" (1971). A cuatro años de haber comenzado sus primeras acciones en el espacio público, Vigo construyó una teoría sobre la relación entre el arte, el artista y la calle. Como adelantamos en el capítulo anterior, en una búsqueda por explicar la importancia de modificar algunos parámetros establecidos en el arte, critica en ese texto la utilización de museos y galerías para exposiciones, así como la idea de “exposición", proponiendo la "presentación" en su reemplazo, y alternativas como la utilización de la calle y el concepto de "proyectista" en lugar del de "autor". Además, realiza una reflexión crítica sobre la idea de "revolución", formulando su sustitución por la de "revulsión".

Este ensayo, como otros de Vigo, comienza con un epígrafe, donde una cita de Les Levine parece resumir la idea central del texto: “...los museos y las colecciones están saturados; pero el espacio real aún existe...". A modo de introducción, Vigo comienza por enmarcar su propuesta en la afirmación de que el arte de mediados del siglo XX se caracteriza por la "pretensión constante de quebrar lo heredado", así en el momento actual el arte da por finalizado el uso de la terminología pasada -un "no va más!!!"57, dice- abriendo paso al "espacio real, abierto, cotidiano". Para el autor, esta ruptura exige también un "quebrantamiento interno de su propia actitud" para poder utilizar el "nuevo espacio ambiental", convirtiéndose en "proyectista".

Para explicar los principales conceptos de su argumento teórico y tomando una idea de Julien Blaine sobre la nueva actitud de los artistas, Vigo declara que uno de los objetivos es "variar el sistema que nos rige y cambiar las estructuras clásicas en cuanto a [los] medios que movieron el arte hasta nuestros días, romper con los habitáculos, salir y ganar la calle", de modo que se genere "una 'revulsión' que no sea únicamente formal y estética sino un cambio real de vida". Es en "Proposiciones" -el tercer apartado del texto- donde aparece el tema de la ocupación de la calle. Allí dice que "a la calle hay que proponerle. No es más que eso, señalarla. No debemos corregir al transeúnte, ni cambiar su rumbo (...) pero debe ser "revulsionado"”. Una de las formas de la revulsión que podrá habilitar esos cambios es, pues, la ocupación de la calle.

Para lograr una definición de lo que quiere plantear como un nuevo vínculo con la calle, se distancia de otro tipo de acciones que considera "viejas" o "ancianas":

\footnotetext{
${ }^{57}$ Utilizó la frase "no va más!!!" también como idea de límite de un proceso pasado en el último número de Diagonal Cero. Allí lo hizo en una tarjeta colgada de la portada que dice "Señalamiento III", es decir que señala a la propia revista informando sobre su cierre.
} 
La calle no acepta ideas ni teorías extrañas a ella misma, un arte en la calle no es sacar lo viejo a tomar sol (acercamiento pedagógico del arte tradicional enclaustrado) ni tampoco 'armar formas nuevas que disfrazan su ancianidad', sino una nueva actitud (lúdica) que concilie todos los elementos inherentes a ella misma. (Vigo, 1971)

Esta nueva actitud se opone aquí a la idea de llevar obras que respondan al modelo clásico a un espacio abierto, como un modo de hacer descender la alta cultura a una accesibilidad más general, pero respetando los cánones tradicionales de obra y autor. ${ }^{58}$ En relación con esto, Vigo dice en una entrevista que se le realizara años más tarde que "hay que priorizar el elemento calle" (entrevistado por Curell, 1995) ya que existe una diferencia entre este tipo de acciones y trasladar una escultura, que está hecha para un lugar cerrado, a uno abierto. En este sentido, el texto refiere a que mostrar lo viejo se ata a un sentido pedagógico sobre un público pasivo al que hay que instruir o enseñar, frente a lo cual formula la búsqueda de una actitud distinta o novedosa. Aparece también aquí, como en tantos otros lugares, la idea de lo lúdico o el juego como forma privilegiada en el arte: a partir de allí es posible lograr la nueva actitud en el receptor.

En la última parte de "La calle: escenario del arte actual", para definir el término señalamiento cita parte del manifiesto que produjo para la acción Manojo de semáforos ${ }^{59}$. Allí dice que lo que se propone con la acción es "no construir más imágenes alienantes sino señalar aquellas que no teniendo intencionalidad estética la posibiliten". También utiliza la idea de "revulsión" que se aplica, según el autor, a la despersonalización del hombre y por la "activación de la sociedad hacia el proceso estético". Así, la calle contiene los elementos cotidianos que, al ser señalados, muestran las estructuras estéticas del hombre, testimoniando, además, lo colectivo y lo demográfico. Todo esto no debe realizase, según este manifiesto, "representando" la realidad, sino "presentándola".

En similares términos, otros artistas cuestionaban las instituciones cerradas y auspiciaban las acciones en el espacio público. Por ejemplo, en un programa similar al de Vigo, Rubén Santantonín proponían los "salones abolidos" y "la calle, vibrante y

\footnotetext{
${ }^{58}$ Coincidente con la diferenciación entre "lo viejo y "lo nuevo", Santantonín decía en 1965: "Queremos que el hombre sienta la vejez de su anterior actitud ante la cosa artística, que se sienta complicado" (Santantonín en Giunta, 2008: 161).

${ }^{59}$ Un análisis de este señalamiento se realiza en el apartado 2.3.1.
} 
único ámbito del gesto artístico", donde se privilegie "lo insólito" y "la sorpresa" de "los que perciben" (Santantonín en Giunta, 2008: 135); Juan Pablo Renzi, renunciando a participar de las instituciones decía: "los que quieran ser entendidos en alguna forma, díganlo en la calle o donde no se los tergiverse" (Katzenstein: 2007: 299).

Esas ideas compartidas, asimilaban que los límites de las instituciones debían superarse en el contacto con un público más amplio y con obras o acciones que no permitieran su comercialización. Como señala Giunta -basada en una idea de Giroux-, "la necesidad de ampliar la esfera de influencia de sus prácticas (...) los llevó a romper los límites de sus actividades específicas y a buscar situarse entre las instituciones y el espacio urbano, entre la alta cultura y la cultura popular, entre lo público y lo privado" (199: 134).

La idea de "presentación", como se vio en el capítulo 1, ya había sido desarrollada por Vigo en "La revolución en el arte" (1968), donde toma el concepto de un ensayo de Alan Kaprow en el que lo opone a exposición. Para Vigo, la presentación da lugar al "suceso" a diferencia de la exposición, situación en que "todo se mantiene inalterado". En "La calle...", en cambio, Vigo modifica su posición y lo contrario a la presentación no es la "exposición", sino la "representación", dado que esta última vuelve a mostrar algo que ya estaba presentado. En esta oposición, Vigo incorpora otra idea: la situación de mostrar algo que efectivamente existe (por ejemplo, el señalamiento de un objeto o un hecho político), antagoniza no solo con la representación en términos del arte figurativo, sino -entendemos- con todo el arte anterior a los ready made, es decir, con la producción de obras de arte resultado de la factura de un cuadro o una escultura por el propio artista. Serán, entonces, los señalamientos, los que darán forma y materialidad a este programa.

\subsection{SEÑALAMIENTOS DISIDENTES}

A partir de 1968, la resistencia a la dictadura de Onganía aumentó, así como el nivel general de las protestas tanto en las calles como en las fábricas y universidades (O’Donnell 1982). El espacio público se convirtió, cada vez más, en sitio de expresión del descontento social. Las medidas represivas y altamente impopulares desplegadas por el gobierno iban generando reacciones de obreros, estudiantes y ciudadanos disconformes. Este proceso, que se condensaría en mayo del '69 con el Cordobazo, tuvo su correlato en el campo artístico, aunque con elementos que provenían de su propia dinámica. 
El antecedente más destacado de las acciones en el espacio público son los vivo-dito de Alberto Greco. Éstos consistían en indicar con el dedo un objeto o persona en la calle y luego marcar con tiza un círculo alrededor de los mismos, para considerar que allí se había realizado una acción artística $^{60}$. Vigo había identificado a los vivo-dito en los orígenes del arte en la calle. Así, cuando proyectó en junio de 1970 la acción Invitación a rasgar en la Plaza Libertad de Montevideo, aunque no pudo realizarse por falta de permiso policial, Vigo expresó que consistía en un homenaje a Greco, recordando sus vivo-dito, que "había adelantado en la Argentina la idea de un arte en la calle". (Vigo, Biopsia 1970)

A medida que se acercaba la mitad de la década de los sesenta y la experimentación adquiría un lugar destacado en el arte, las presentaciones en el espacio público se hicieron posibles. En La Plata, el Grupo de los Elefantes, formado por Lida Barragán, Raúl Fortín y Omar Gancedo y el grupo La voz del tiempo integrado, entre otros, por Néstor Mux, Osvaldo Ballina y Rafael Oteriño habían pegado poesía mural en las paredes de la ciudad. Este acto de confrontación con los cánones tradicionales del arte, especialmente en cuanto a la utilización de soportes y espacios para su difusión, logra concretar una apropiación del espacio público, lo que generó rechazos y debates entre los vecinos de la ciudad (Bugnone, 2012). Artistas del Di Tella e independientes habían sacado sus obras a la calle o directamente, programado acciones allí (Giunta, 2008; Longoni y Mestman, 2000). Es por ello que en 1973 García Canclini decía que "Llevar el arte a la calle" es una "consigna reiterada" y agregaba que instituciones como la UNESCO o el CAYC se preocupaban por sacar el arte de los museos, así como diferentes artistas realizaban trabajos artísticos en el espacio público. Entre los casos que menciona, se encuentran la acción que realizaron Roberto Jacoby y Eduardo Costa en 1966, en que pintaron con color verde diversas partes de la ciudad; la presentación de Carlos Ginzburg de un terreno baldío en la muestra Arte de sistemas del CAYC; el teñido de canales y ríos por Nicolás García Uriburu. Este autor, consideraba en aquél momento que la opción de producir arte en la calle

Exige, sobre todo, replantearse la concepción estética, social y comunicacional de las obras en función del ámbito urbano y de la cultura popular; hay que preguntarse qué significa exponer en una calle o una plaza, qué se quiere decir

\footnotetext{
${ }^{60}$ Sobre el artista argentino Alberto Greco y sus vivo-dito ver Giunta (2008) y Longoni (2005a).
} 
allí, qué mensajes son transmisibles en cada lugar, qué necesita la población que lo usa (García Canclini, 1973: s/p.; 1977: 186) ${ }^{61}$

Desde 1968, Vigo realizó señalamientos ${ }^{62}$, los cuales consistían en identificar, demostrar o marcar objetos, espacios, hechos. El artista los denominó y numeró sistemáticamente del 1 al $18^{63}$, y los definió como una "serie" con "rituales" cuya constante es la utilización de una banderola con una flecha ${ }^{64}$. Lo que interesa destacar aquí sobre esas acciones es que algunas de ellas se produjeron en el espacio público. El artista realizó diecinueve señalamientos: los primeros dieciocho fueron realizados entre 1968 y 1975, y luego de casi dos décadas produjo el último, en 1992. De los primeros, consideraremos para el análisis las acciones que intervinieron el espacio público. La separación entre éstos y los señalamientos que se realizaron en el ámbito privado o sin convocatoria de público, se justifica en lo que hemos considerado para esta investigación una característica fundamental: el espacio en que se han desarrollado, donde convergen, como decíamos antes, disputas políticas por su apropiación y regimentación, así como estrategias de resistencia a la dominación, cuyo contenido puede interpretarse socialmente.

Si bien tanto los señalamientos público como los privados (su registro fotográfico u objetos utilizados en los mismos) fueron enviados luego por el artista a exposiciones o publicados en revistas, con lo cual se hicieron públicos, es la ocupación y consiguiente sobre-significación del espacio público lo que converge con una idea más o menos definida de intervención en el orden público a través de la experiencia estética. A esto se suma que el propio artista clasificó a los señalamientos en públicos y privados, haciendo

\footnotetext{
${ }^{61}$ En el desarrollo de análisis del arte en la calle, García Canclini hace una referencia temprana a Vigo, citando su texto "Un arte a realizar" de 1969, aunque sugiere que estos casos quedan reducidos a obras aisladas anárquicas o dadaístas "cuyo carácter esporádico y lúdico es digerible sin molestias por el sistema cultural" (1977: 191). La solución estaría, para este autor, en una crítica política de la función del arte en la estructura social y sostiene que el carácter lúdico de las acciones, si bien es necesario, difícilmente pueda transformar las condiciones sociales de producción, difusión y consumo de obras de arte. Esta crítica hacia la posición de Vigo se refiere posiblemente al primer señalamiento, que es el que García Canclini cita en su libro de 1973, por lo que no considera la serie completa de las acciones, los significados de su intervención en el espacio público y el contenido político de algunas de ellas, así como tampoco el conjunto de obras, acciones y discursos de Vigo que responden a su programa poético.
}

\footnotetext{
${ }^{62}$ Un análisis de los señalamientos puede encontrarse en el texto inédito de Davis (2007a).

${ }^{63}$ Ver en los Anexos la matriz de datos con los datos de los diecinueve señalamientos.

${ }^{64}$ Este punto se desarrolla más adelante.
} 
una lista de los ubicados en cada una de las categorías ${ }^{65}$. Se analizarán en este capítulo los Señalamientos $I, I V, V, V I, I X$ bis y $X I$ (utilizamos la numeración original) y, en algunos casos, otras acciones, objetos o exposiciones que se encuentran vinculados estrechamente con los mismos y que permiten realizar una interpretación más completa.

\subsubsection{MANOJO DE SEMÁFOROS}

Manojo de semáforos, el primero de los señalamientos, se realizó en 1968 y consistió en "una experiencia estética con aprovechamiento de elemento cotidiano" (Vigo, Biopsia 1968) para la que realizó una convocatoria a la esquina de las calles 1 y 60 a observar un semáforo que se encontraba allí. ${ }^{66}$ Para ello, Vigo preparó una invitación o catálogo que repartió entre sus conocidos (imagen 26), también utilizó la prensa escrita durante el mes previo para difundir la acción y generar cierta incertidumbre sobre lo que sucedería ese día ${ }^{67}$. El artista no concurrió a la cita, por lo que el señalamiento no implicó siquiera una acción de su parte en aquel momento, aunque se reunió allí un grupo de ochenta personas aproximadamente. ${ }^{68}$ Para comprender la intención del artista con esta acción, conviene citar in extenso parte del manifiesto que estaba incluido en la invitación, al que llamó "Primera no presentación Blanca" (cuyo título es una posible alusión al "Manifiesto Blanco" de Lucio Fontana de 1946):

La funcionalidad del carácter práctico-utilitario de algunas construcciones deben ser señaladas y así producir interrogantes que no surgen del mero y

\footnotetext{
${ }^{65}$ Vigo (1971) “Acción de señalar”; Vigo, s/f, “Señalamiento”.

${ }^{66}$ Este señalamiento es el más renombrado y descripto en la bibliografía sobre la obra de Vigo. Lo que se intenta aquí es profundizar en el análisis en la potencialidad política de esa acción y vincularlo con su planteo programático poético más general.

67 "Manojo de semáforos: experiencia estética con aprovechamiento de elemento cotidiano. Se citó a las 20 horas al público pero no me hice presente en esa cita. Una declaración y una utilización de los medios de comunicación, periodístico y radial, fomentaron durante 20 días la duda de lo que iba a pasar" (Vigo, Biopsia 1968). Entre los medios que anunciaron la acción se encuentran en Primera Plana (24/09/1968) "No tanta risa" y el diario Gaceta de la tarde (6/10/68) "Manojo de semáforos". En este último se reproduce el manifiesto redactado por Vigo y se anuncia próxima la realización de la acción. El diario El Día, (19/10/68) anuncia la realización del señalamiento. Dice "Según su autor, el acto iniciará una serie de 'señalamientos' destinados a aprovechar al máximo las posibilidades de los medios comunicativos". Luego se copia parte del manifiesto. En otra nota de El Día (25/10/68) se informa sobre el señalamiento que se llevará a cabo ese mismo día.

${ }^{68}$ Es preciso apuntar que López Anaya (1999) sostiene erróneamente -contrastado por los registros orales y escritos de la acción- que Vigo alteró el funcionamiento de los semáforos. Por el contrario, Vigo convocó al señalamiento pero no sólo se ausentó, sino que tampoco realizó modificaciones en el normal movimiento de las luces. Giudici (2010) comete la misma equivocación.
} 
vertical planteo utilitarista sino de la 'divagación estética' (...). Los señalamientos producirán: un detenerse ante el 'acto gratuito de divagación estética’ y el anonimato de los constructores (...) Se propone: no construir más imágenes alienantes sino señalar aquellas que no teniendo intencionalidad estética como fin, la posibilitan (...) Una vuelta a lo urbanístico cotidiano como activación de la sociedad hacia el proceso estético (...) La liberación está en que el hombre se desprenda de los bagajes del concepto posesivo de la cosa para ser un observador-activo participante de un 'cotidiano y colectivo elemento señalado'. (Vigo, “Manifiesto”, 1968) ${ }^{69}$

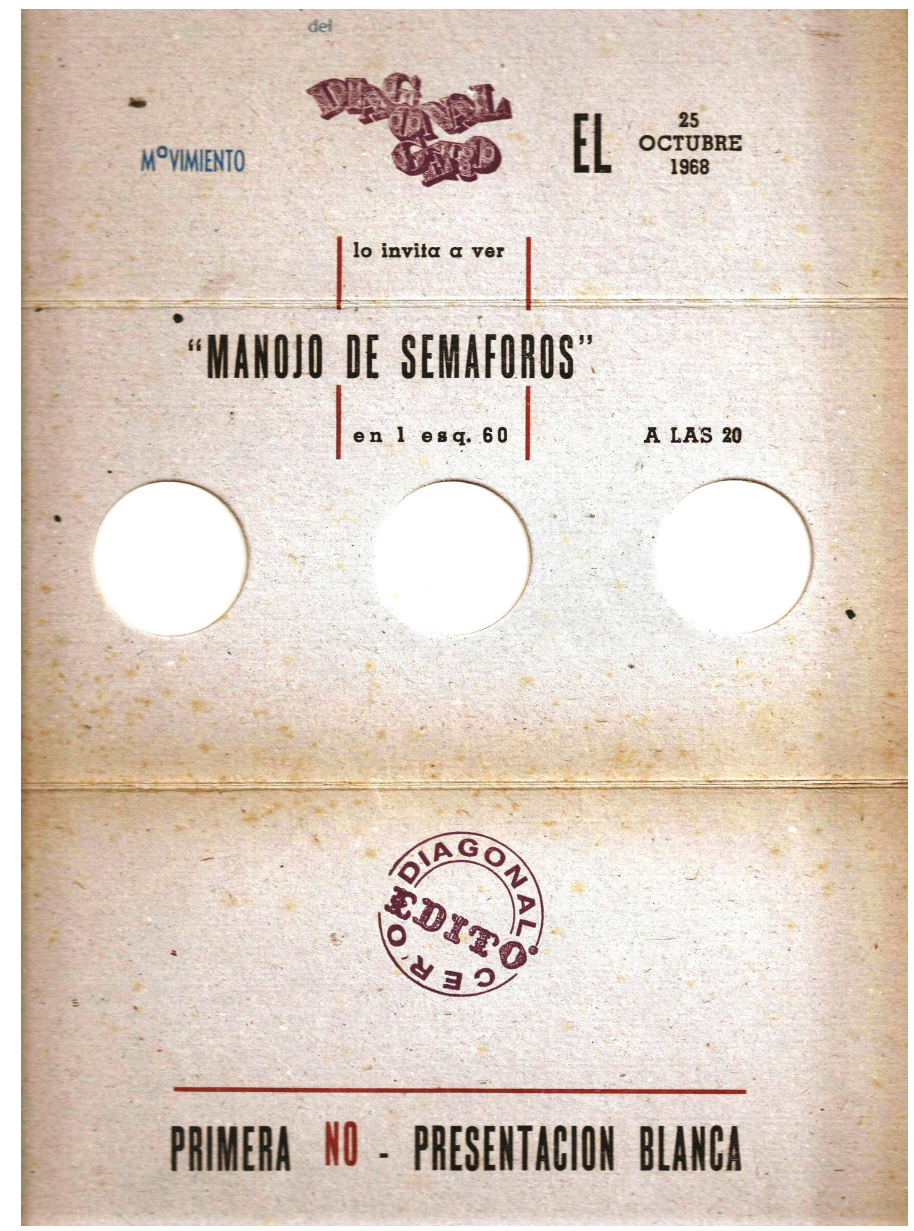

Imagen 26. Vigo, Invitación a Manojo de semáforos. 1968.

\footnotetext{
${ }^{69}$ Este manifiesto también se publicó en el diario Gaceta de la Tarde (6/10/68). En consonancia con el interés desplegado por Vigo por difundir sus reflexiones en torno al uso del espacio público y los cambios necesarios en el arte, publicó en el diario El Día (15/12/68) el citado artículo "La revolución en el arte". Este ensayo, que contiene elementos de un tenor similar al del manifiesto del Señalamiento I, analiza como ya mencionamos- distintos cambios producidos en el arte, todos referidos a modificaciones en las condiciones de producción y de recepción, así como en los materiales y técnicas empleados.
} 
Desde una perspectiva, en cercanía con el situacionismo (Herrera, 2004), Vigo apuntaba a desconfigurar la vivencia del espacio público, así como buscaba un extrañamiento en relación con la cosa señalada, en este caso un semáforo, que pasaba de ser objeto cotidiano a formar parte de una experiencia estética, desencajado de su normalidad funcional ${ }^{70}$.

En un artículo de Vigo publicado antes de la realización de este señalamiento, podemos encontrar elementos discursivos que formaron parte de su poética en el espacio público y que anticiparon sus intenciones de trabajar en la calle. En "No-arte-Si" (Vigo, 1968), un ensayo que, como hemos referido, analiza y propone los principales aspectos de su programa poético, desarrolla también contenidos y un tono similares al manifiesto de Manojo de semáforos. Allí, entre otros, menciona al Señalamiento I y al arte en la calle en general como uno de los cambios que demuestran las rupturas que se estaban produciendo en el arte.

En ese artículo, Vigo se basa en un texto de Jean Clay publicado en su revista Robho en 1967, sugerentemente titulado "La peinture est finie", donde se refiere a una jornada en que los hombres dejaron sus hábitos y rutinas para producir arte en la calle. Si esta idea de Clay, así como los textos (que Vigo conocía) de Allan Kaprow sobre el happening, y la invitación recibida para participar en "Parole sui muri", sumados al conocimiento que tenía de los vivo-dito de Greco, entre otros, fueron la matriz que despertaron la fascinación por el uso del espacio público, el desarrollo específico que hizo de este señalamiento, no solo lo conecta con cierto clima de experimentación en la calle presente en los artistas vanguardistas argentinos y del mundo, sino que da cuenta de los intereses que tenía para llevar a cabo, en sus modos particulares, la acción propuesta por Clay y una teorización sobre el asunto.

Este señalamiento sobre el espacio público significó no solo un acto fuera de los cánones de la institución artística, en el sentido de ser efímero, no museificable, no firmable, ni mercantilizable, en el que el autor no realizó otro acto más que la convocatoria y sus instrucciones, es decir que no había "obra" expuesta en el sentido tradicional del término; sino que además implicó una ocupación del espacio público y la

\footnotetext{
70 Entre las ideas de las vanguardias históricas, la de “extrañamiento" o "desafamiliarización” (la "ostranenie" de los formalistas rusos) tiene cierta coincidencia con la figura del señalamiento de Vigo. En el extrañamiento el efecto sacrílego querría presentarse como consecuencia de una incompetencia o descompetencia cultural: se pueden "ver" las cosas fuera de las convenciones, con ajenidad respecto del sentido común y de lo previsto-previsible; o confundir, ignorar funciones previstas, refuncionalizar sin notarlo: extrañar, extrañificar, sacar de lugar y función. Ver Shklovski (2004) y Erlich (1974).
} 
construcción de un modo particular de representación del mismo: ese espacio y su máquina podían convertirse ahora en escenario y objeto de una acción artística, y por eso, desubicada de su lugar "natural".

En relación con la utilización específica del semáforo y la puesta en tensión de su funcionalidad, Vigo ya había incursionado desde mediados de los '50 en la construcción de "Máquinas inútiles", producidas a partir de ensamblajes de distintos artefactos u objetos $^{71}$. En 1957 realizó la exposición Maquinaciones inútiles, “en la cual -dice Vigoel juego de humor negro se sumaba con las imágenes sacadas de su propio "contexto",, y donde esas "imágenes no juegan funcionalmente de acuerdo a lo que ellas representan realmente" (La Tribuna, 25/06/1968). Con ese interés que, en oposición al futurismo, se burlaba de las máquinas y sus funciones, las convertía en objetos artísticos formados a partir de restos. Con el Señalamiento I retoma la idea de sacar de "contexto" y de burlar la funcionalidad, pero en lugar de construir un nuevo objeto a partir de otros, decidió tomar uno ya producido.

Si bien hasta aquí las consecuencias de esta acción parecen desprenderse de un acto más simbólico que material, las derivaciones de la convocatoria en plena dictadura, fueron de otro tipo. A la hora señalada, comenzaron a concurrir algunos de los alumnos y amigos que habían sido invitados por el artista, quienes, desconociendo que Vigo no asistiría, lo esperaron durante algún tiempo. La policía que se encontraba allí, por la cercanía con la Dirección de Infantería, ubicada frente al semáforo, sospechó de esa reunión de personas y los detuvieron, tras lo cual tuvo que asistir Vigo para aclarar la situación y explicar que se trataba de una experiencia estética (entrevistas Graciela Gutiérrez Marx, 2010 y Jorge D’Elia, 2005).

La particularidad de esta experiencia entraña una cuestión que interesa doblemente: por un lado, se trató de una acción artística en el espacio público que utilizó un elemento propio de ese espacio para evadir la funcionalidad del mismo, modificar la experiencia cotidiana acerca del semáforo y transformarlo en un objeto artístico. El trayecto que va del semáforo a la obra ocurre porque Vigo convierte a ese objeto en otra cosa en la medida que lo dice en el manifiesto y en la invitación y que los asistentes acuden al lugar en calidad de público. Cuando Vigo actúa como artista, "firmando" la obra, traslada la carga autoral sobre un objeto que él no creó y que ni siquiera reubicó, con

\footnotetext{
${ }^{71}$ Ver Gradowczyk (2008).
} 
claras reminiscencias de Greco y de Duchamp. A diferencia de este último, no desplazó el objeto, sino que lo señaló justo en el lugar en que se encontraba, como una de las variantes más extremas de aquel gesto fundacional de un nuevo tipo de arte (también, de artista y de relación con la institución arte) que se produjo con Fountain en 1917. Así, Manojo de semáforos se trata de un ready-made literal, donde la intervención material sobre la cosa es nula. Por otro lado, la convocatoria provocó una reunión de personas en la calle que inmediatamente generó sospechas dadas las limitaciones de reunión y expresión establecidas por la dictadura. Paradójicamente, la intención expresada por el autor de apartarse del aspecto funcional y pragmático de la cosa, para volverlo "divagación estética", terminó convirtiendo a los concurrentes en sospechosos de un activismo político no deliberado, entre otros aspectos, en correlación con el hecho de que el suceso o episodio no ofrecía ningún rasgo que permitiese distinguirlo como estético o diferenciarlo de una manifestación o reunión vecinal, política o de otro tipo. El manifiesto expresa que lo que se busca es "producir interrogantes", desnaturalizar el orden cotidiano y, a través de la experiencia estética, conducir a la "liberación". Lejos de cualquier llamado explícito a la participación política, su estrategia se despliega pasando por una vivencia que, desorganizando elementos de la experiencia sensible, desestructure algunos aspectos de la organización social (Rancière, 2007b). En este caso, lo último apunta a dos cuestiones: por un lado, al orden propio de la institución arte, en el que autor, público y obra cumplen roles bien definidos y diferenciados, pero que aquí se presentan desdibujados: un autor que no hace la obra; la ausencia de la obra en sentido tradicional; un público que construye su propia experiencia en virtud de indicaciones ofrecidas por el autor ausente; la falta de un espacio específico para que la obra sea mostrada. Por otro lado, la "liberación" se refiere a las ataduras que genera la propiedad de la obra ("que el hombre se desprenda de los bagajes del concepto posesivo de la cosa", dice el manifiesto), con lo que se propone una limitación a la idea de que la obra puede ser vendida, convirtiéndose en mercancía. En esta acción, por el contrario, se apunta a una experiencia en la que no sea posible esa mercantilización, con lo cual no solo expresa un cuestionamiento al ámbito del comercio del arte, sino de la propiedad privada en general. Esto último se relaciona también con el interés específico de que la acción se lleve a cabo en el espacio público, como espacio compartido que se presenta abierto a las interacciones y visibilidades (Joseph, 2002), da lugar a una vivencia también compartida, en la que la construcción social de ese espacio, se encuentre intervenida -entre otras- por la acción estética. 
Como ocurrió con sus otros señalamientos, Vigo saltó la barrera del adentro-afuera de la institución, al menos de aquellas lo suficientemente despegadas del canon tradicional, y envió materiales que formaron parte de sus acciones a exposiciones. Así, por ejemplo, lo presentó en 1970 en la Exposición Internacional de Ediciones de vanguardia (Montevideo), junto con otros trabajos; y en diversas circunstancias, especialmente en el exterior, aún años después de su realización, como el caso del envío de la invitación y manifiesto de Manojo... en 1971 a Alemania, Estados Unidos y Perú para ser expuestos en esos países.

\subsubsection{POEMA DEMAGÓGICO}

El Señalamiento IV se denominó Poema demagógico y se realizó entre 1969 y 1971. Consistía en una acción en la que el público emitía un voto en una urna cuya parte superior podía cambiarse. Antes de votar, el participante realizaba un dibujo, escribía o tachaba sobre una tarjeta que se le entregaba. En todos los casos en que se llevó a cabo este señalamiento había dos cuestiones centrales: que el público siempre llevaba a cabo una acción primero sobre la hoja y luego la introducía de ciertos modos específicos dentro de la urna, de acuerdo al tipo de apertura.

La urna que construyó Vigo para estas acciones, estaba hecha en madera y tenía otras cuatro cajas con diferentes tipos de ranuras para la colocación del voto, que llamó "cabezales intercambiables". Éstos se colocaban en la parte superior de la urna y se adosaban a través dos ganchos que se unían con un candado. Fruto del trabajo artesanal y prolijo que realizaba Vigo en cada una de sus obras, las cuatro cajas tienen un acabado liso, pintadas y con los ganchos puestos en la misma posición y altura. Cada cabezal daba un nombre a la urna: "urna electoral", "urna erótica", "urna místico religiosa", "(in) urna". La primera tenía la ranura longitudinal tradicional de las urnas electorales; la segunda, un corte en forma circular, que obligaba a los votantes a formar un cilindro con el papel -según Vigo, con un fuerte contenido fálico-sexual-; la tercera, un corte en forma de cruz para lo cual se debía doblar en papel con esa forma; y la última, sin ranura, imposibilitaba el voto. Estos cabezales podían ponerse sobre la misma urna y en cada ocasión Vigo utilizaba uno de los cuatro.

La primera de estas acciones se desarrolló en septiembre de 1969. Vigo dio una conferencia con el título “"Arte-hoy” en el Salón Dardo Rocha del Colegio Nacional de la UNLP, para la que había reunido a cinco o seis cursos de los últimos años que 
asistían a Estética y otras materias afines, así como otros conocidos suyos y público en general. Pero la charla comenzaba de un modo particular: en la recepción al salón se le entregaba a cada uno un cartón y la propuesta era tachar el "sí" o "no", pero no se sabía a qué. "Era gratuito", dice Vigo, razón por la cual también lo llamó "plebiscito gratuito", dando a entender que se realizaba sin razón o fundamento (Vigo, Biopsia 1969 y Vigo, entrevistado por Curell, 1995) (imagen 27).

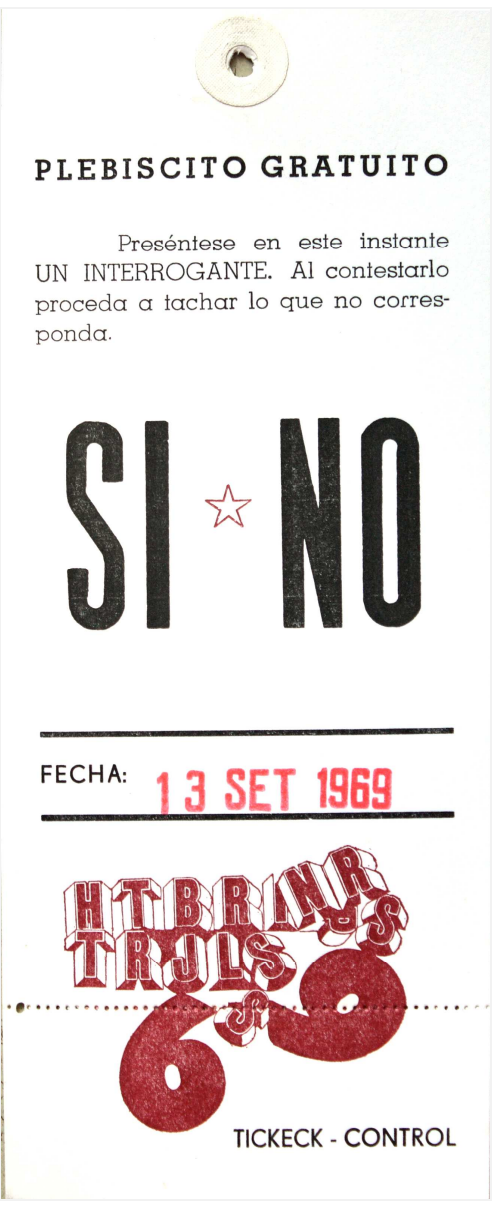

Cuando el votante entraba, el salón estaba oscuro, por lo que para encontrar la urna, había dos ayudantes que lo guiaban y prendían un fósforo o una linterna para iluminar. Pero al llegar, se encontraba con la "(in) urna" y no podía votar. Para continuar con la "conferencia", Vigo reprodujo una cinta grabada con poesía fónica de diversos autores internacionales y además dio la primera presentación a su composición fónica Homenaje a una pensión de estudiantes (1969). En una estimulación de la sorpresa y lo lúdico, así como con un juego polisensorial (de cierto parentesco con los happenings que, como el de Minujín y Santantonín, tenían el objetivo de exacerbar los sentidos de los espectadores), los cambios entre la oscuridad y la luz, así como el camino 
acompañado por otra persona y la audición de poesía fónica, apuntaban a provocar sensaciones extrañas, desconcertantes o novedosas.

Vigo daba a la conferencia en un día lectivo un tono que se alejaba del tipo de charlas escolares corrientes y lo hacía, además, con una acción artística que tocaba a la crítica política sobre el gobierno de Onganía. El título de la conferencia "Arte-hoy" daba cuenta de que para Vigo, referirse al arte de ese momento no significaba solo explicarlo, sino que parecía necesario descolocar al público asistente, tanto por las condiciones físicas del espacio, como porque en este caso, luego de todo el trayecto y las intrigas, el público no podía votar.

Al año siguiente se produjo el señalamiento que interesa particularmente a esta investigación, el que se desarrolló en el espacio público. Se trató de una acción en principio lúdica, pero que, además implicaba una politicidad manifiesta. La acción se desarrolló en la vereda de una boutique llamada Tomatti, ubicada en la esquina de 9 y 51. El negocio era reconocido porque tenía una vidriera en forma circular. Los dueños de la boutique eran Oscar Tomatti y Jorge D'Elia y vendían ropa masculina, según Vigo, "sofisticada", "de onda", "muy exclusiva, no lo masivo". A pesar de caracterizar al negocio también como "elitista", Vigo vio allí una posibilidad abierta, ya que podían convivir en la vidriera las prendas de vestir con objetos suyos. La boutique tenía otra virtud para Vigo, la cercanía con el Teatro Argentino que atraía al público, especialmente por el ballet, así como con la Legislatura provincial y el Automóvil Club, que generaban una amplia circulación de personas. Decidió aprovechar esas circunstancias y planificar el desarrollo de una acción que implicara el voto con la "urna erótica", pero esta vez ubicada en la calle. Los transeúntes pasaban por la vereda de la boutique y eran invitados a participar de la acción cuyo voto consistía en la creación de un poema. Además presentó dentro del local otras obras suyas, como el Palanganómetro mecedor..., la Bi-tricicleta ingenua, las Obras (in)completas, Basura aséptica (primero colocada en la vereda y luego en el interior del probador), Cuna de Ringo Bonavena (igual que la anterior), algunas de ellas entremezcladas con calcetines, calzoncillos o pantalones que colgaban de alguna de sus partes.

Con la utilización, nuevamente, de un medio de comunicación, el artista difundió la acción a través del diario local. Allí se anunciaba la presentación en Tomatti y mencionaba la decisión de Vigo de no exponer más al modo tradicional y, en cambio, 
"abrir la obra a referencias de un público no habitual ni preparado, utilizando como medio un 'habitat' no tradicional" (El Día, 14/03/1970) $)^{72}$.

Así, al cobijo de un negocio amigo, pero en el espacio público, en 1970 bajo la dictadura de Onganía, Vigo propuso la parodia de un acto eleccionario (imagen 28).

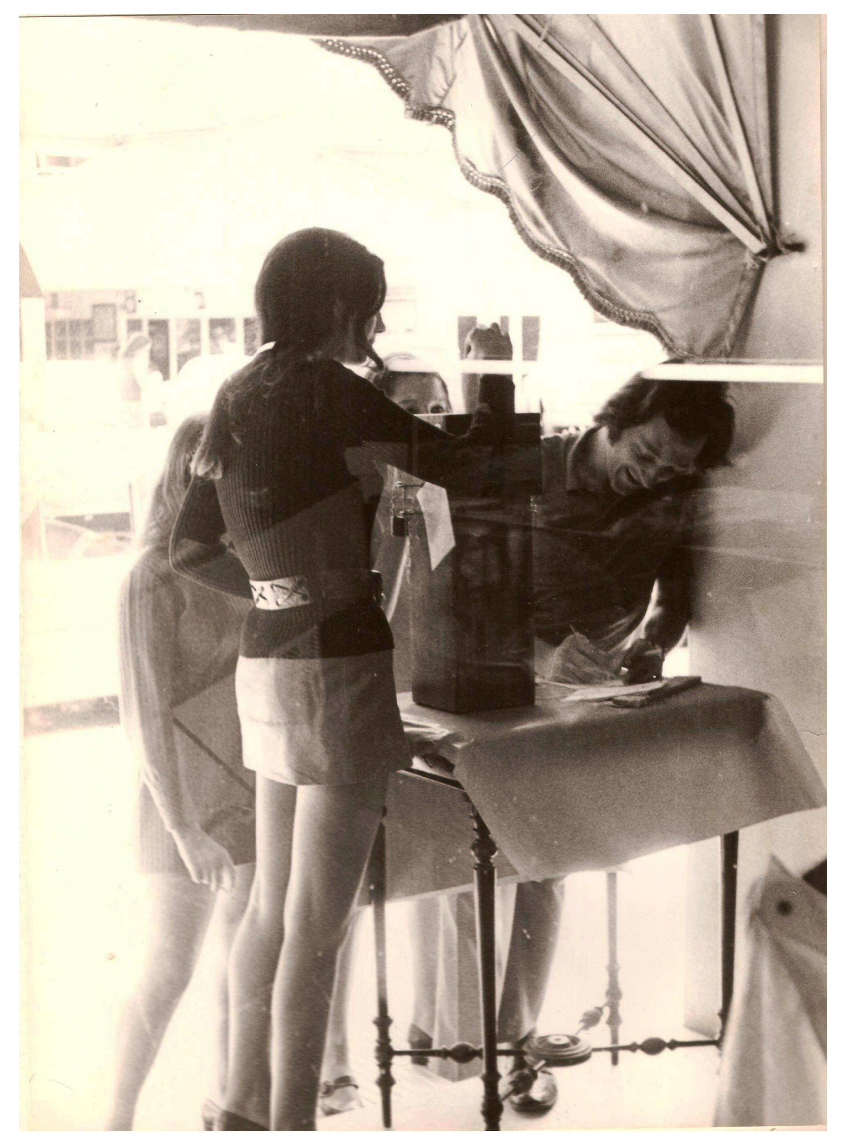

En el frente de la boutique se habían colocado carteles en los que se invitaba a votar. El votante, ya sea un transeúnte o un asistente que había concurrido por el anuncio del diario local, debía leer las instrucciones sobre lo que podía hacer para realizar una "poesía armada", tal como dibujar o escribir. Luego, del "armado de una poesía", pondría el voto en la "urna erótica" y finalmente, aconsejaba "No firme. Mantenga su anonimato" (imagen 29).

\footnotetext{
${ }^{72}$ En el archivo personal de Vigo se encuentra la nota, cuyo título es "Edgardo A. Vigo inaugurará hoy una exposición". Allí de la palabra "exposición" sale una flecha escrita a mano con la palabra "boludos", posiblemente realizada por Vigo en reproche por el título puesto por el diario que se contradecía no sólo con el tipo de acción que proponía Vigo, sino con el propio contenido del artículo.
} 


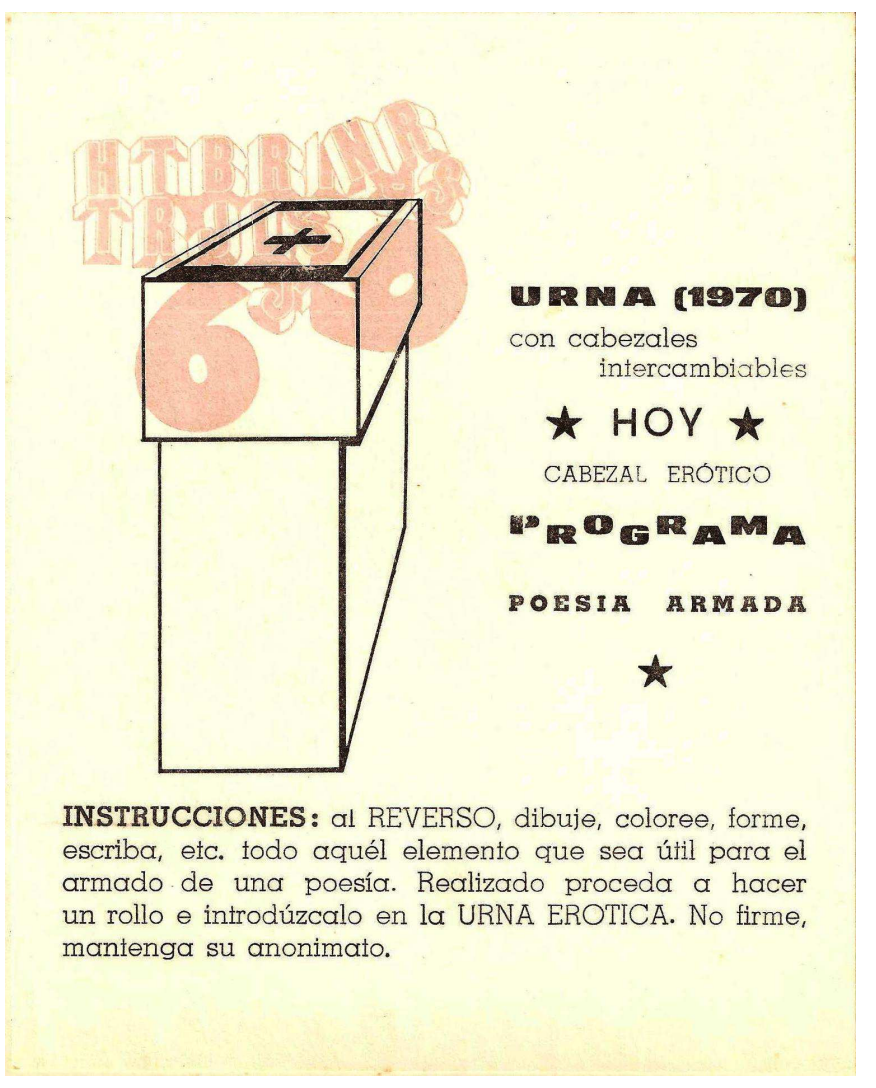

Imagen 29. Vigo, Instrucciones para votar. 1970.

El público, además de votar, podía ingresar al local, ver los objetos allí colocados, comprar prendas de vestir y llevarse las etiquetas de las Obras (in)completas para pegar donde quisiera. Según relata un artículo publicado en la revista Ritmo (1970: 4), la votación duró quince días, con lo que se refuerza la idea de presentación, abierta a los cambios con el transcurso del tiempo, a modificaciones en el espacio y en la ubicación de los objetos (por ejemplo, la Basura aséptica y la Cuna de Ringo Bonavena), lo que da lugar a la "alterabilidad" por el carácter "heterogéneo" de la "obra abierta"; todo ello, contra el "concepto fenecido de obra y artista". Estas alteraciones del espacio, hacen, según Vigo, que cada visita del "observador-participante" sea distinta a la anterior. En relación con esta participación, Jorge D'Elia escribe en el mismo artículo que la gente votaba, entraba al local, veía lo que allí se presentaba y se mostraba asombrada en "una especie de caos general que movía nerviosamente a la búsqueda afanosa de una explicación, o manos extendidas para recibir algunos obsequios que se hicieron, en la creencia que ellos contenían la solución” (Ritmo, 1970: 4). Según sigue el relato, al no encontrar las explicaciones, la gente, sin ataduras, se liberó y divirtió. Dice D’Elia: “se percibía en el aire cierto atrape de lo desconocido, dado por una dimensión no común" (Ritmo, 1970: 4) 
Para retomar el análisis de las instrucciones para el ejercicio del voto, puede apuntarse que el título "Poesía armada", en primer lugar, hace una referencia clara a la actividad y participación del público, que podía componer la poesía a su gusto, al utilizar tanto la escritura como el dibujo y los colores, cuestión que rompe con la idea de poesía escrita e insinúa la producción de la poesía visual. Asimismo, puede ser pensado en vinculación con una de las intenciones de Vigo en cuanto a la "presentación" de objetos o acciones, en reemplazo de la "exposición", considerada imposible de ser penetrada por el ambiente, el público y el paso del tiempo.

Según Vigo, lo que buscó con estas acciones, como la realizada en el Colegio Nacional y la de Tomatti, es un tipo de comunicación que se genere a partir de trabajar con el asombro, la circunstancia nueva que "distienda" y prepare para tener una experiencia distinta, un "clima insólito" (entrevistado por Curell, 1995).

Al mismo tiempo, el significante "armada" tiene para la época otro sentido, ligado a la idea de la organización dispuesta a la lucha violenta contra el gobierno o, más general, el sistema. Así, jugando con la polisemia, la poesía está "armada" tanto por el público que la elabora como porque ella misma está en armas por él, lo cual coincide con el cruce de violencia y literatura, especialmente vigente en la cultura política, literaria y artística de los procesos revolucionarios o de radicalización política. ${ }^{73}$ Esto también apunta al asombro: si bien, como describe el dueño del local, había un clima divertido y caótico, la utilización de ese significante con un alto peso político en el texto para la realización de una acción artística, también descoloca al participante desprevenido.

El acto eleccionario fue el centro de este señalamiento, y sin dudas, más allá del carácter lúdico de la acción, asumía una politicidad en sí mismo. Frente a la suspensión de las elecciones por parte del gobierno dictatorial, la participación política se encontraba vedada. Por eso, la ubicación en el espacio público implicaba la posibilidad

\footnotetext{
73 Como explica Dalmaroni (2011) es importante recordar aquí -aun si Vigo no la hubiese tenido especialmente presente en ese momento- que la cultura a la vez política y literaria de las izquierdas hispanoamericanas disponía de una tradición prestigiosa para el tópico de la poesía armada o de la poesía como arma. Especialmente durante los procesos revolucionarios de la primera mitad del siglo XX y en torno de la Guerra Civil Española primero, a partir de la Revolución Cubana más tarde, las vanguardias poéticas habían dado lugar a textos emblemáticos en este sentido, como La rosa blindada (1936) de Raúl González Tuñón, que junto con otros títulos suyos como "Luna con gatillo" (Canciones del tercer frente, 1941) son expresiones casi intercambiables, formal y semánticamente equivalentes a "poesía armada". En 1955 el español Gabriel Celaya -usualmente considerado uno de los principales "poetas sociales"- había incluido en sus Cantos Íberos el poema "La poesía es un arma cargada de futuro", que desde los años sesenta comenzó a figurar en antologías del género.
} 
de que cualquier transeúnte participase de una votación cuando esta estaba prohibida a nivel político y además representaba una intervención democrática, si bien lúdica, en un ámbito público que se encontraba limitado como espacio de debate y consenso. El citado artículo de la revista Ritmo dice que la nota del diario invitando a la presentación fue un "humorístico aviso comercial", donde decía que algo iba a "suceder": la votación, "fina ironía a nuestro tiempo". Años después, Vigo describió esta experiencia como la que más destaca de las realizadas en la calle "porque nos estábamos olvidando del voto, en un momento en que había un tipo que estaba hablando de un reinado, Onganía", así decidió "llamar a la gente muy modestamente" a través de la invitación a votar (entrevistado por Curell, 1995).

Vigo armó un "(in)forme” con los resultados de las "elecciones", que consiste en una carpeta formada por dos tapas con hojas en su interior, unidas por unos ojalillos de metal que impiden su apertura -al igual que en el caso del Manual de instrucciones... visto en el capítulo 1- y que se encuentran atados con hilos. Las tapas y las hojas tienen, además, una perforación en forma de círculo que las atraviesan en su totalidad (imagen $30)$.

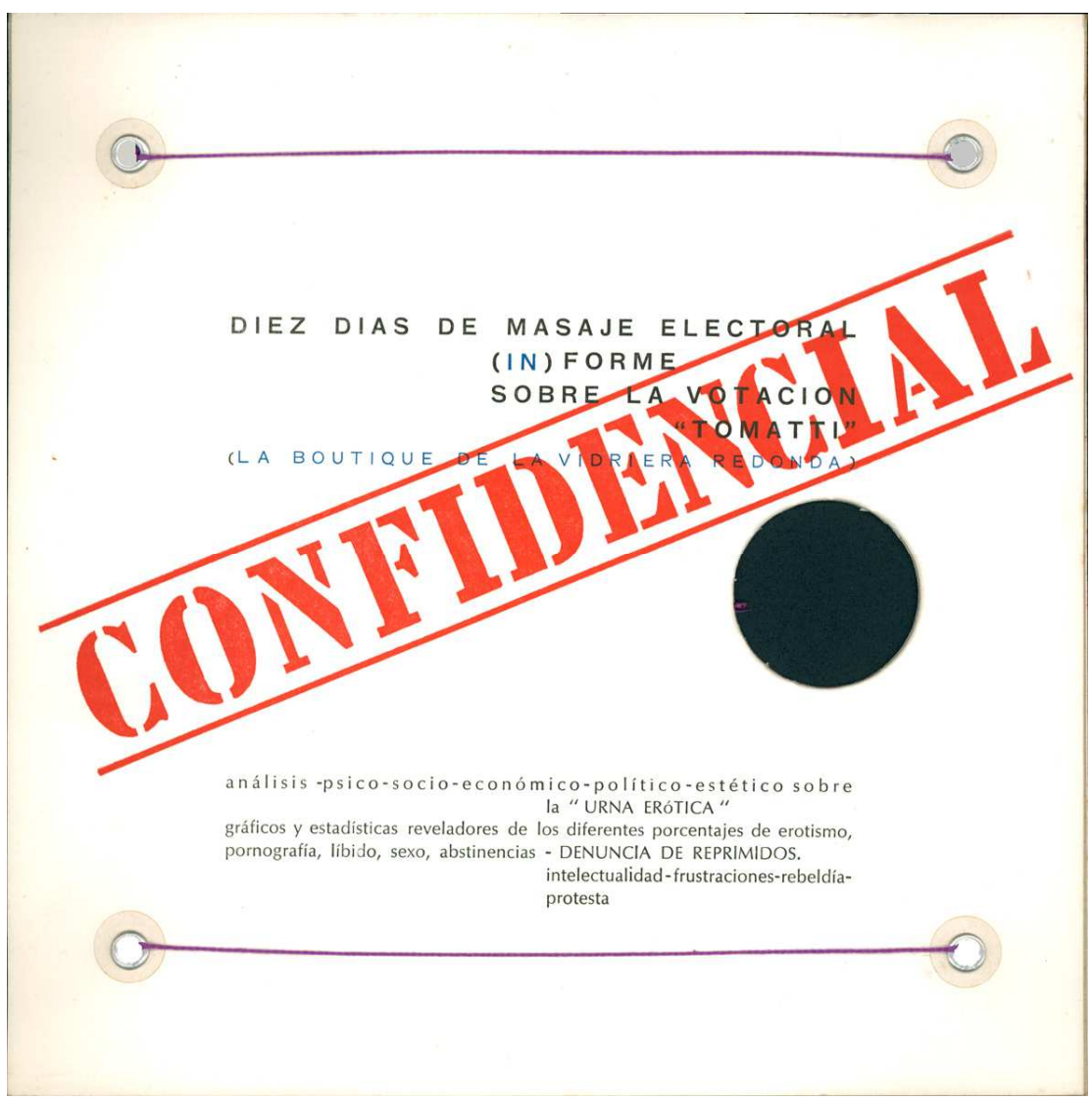


El texto dice "análisis - psico - socio - económico - político - estético sobre la "urna erótica", cruzado por la palabra "confidencial" en color rojo con tipografía y forma de sello oficial. En la parte inferior de la tapa, donde describe las características del informe, tales como "libido", "pornografía” y "sexo", agrega "denuncia de reprimidos", lo cual puede ser leído tanto en un sentido sexual como político. Respecto de la "urna erótica" y la "represión" a la vez política y erótica, puede recordarse con Dalmaroni (2011) que en los sesenta y setenta la superposición o equivalencia "hacer el amor=hacer la revolución" o "erótica=política" es controversial pero intensa y muy presente en el sentido común cultural. Se trata, según el autor, de la erótica de la guerra revolucionaria: una vinculación entre erótica y política como ejercicios libertarios, disconformistas.

En el texto de Vigo, le siguen las palabras "frustraciones, rebeldía, protesta", las cuales pueden identificarse con el momento social y político, dando cuenta de las dos dimensiones de la acción: una estética, que se vincula con la experiencia de la participación y la distinta caracterización que tiene respecto de la obra de arte tradicional en cuanto a inmutabilidad, autor y espacio de exposición; la otra, política, como "protesta" o "rebeldía" frente a la dictadura y la "frustración" por la falta de voto popular; además de la sutil referencia a la violencia política a través de la palabra "armada", tal como se mencionó arriba. Teniendo en cuenta que según Vigo "nos estábamos olvidando del voto", sumado a la idea de "Masaje electoral", puede interpretarse que utilizó ese título y la descripción que colocó debajo como metáfora de una invitación a luchar por el voto político válido.

La perforación que tienen las hojas del informe, además de ser una constante en la producción material de Vigo, puede interpretarse también como el vacío del contenido por lo ficticio de la acción, en tanto ficción artística, pero también por la inverosimilitud política del voto. Asimismo, puede interpretarse que los agujeros sugieren en este y en otros trabajos de Vigo -por ejemplo, Hexágono ' $71 d g$ que se verá en el capítulo 4- un lugar por donde espiar lo clausurado, confidencial. En la contratapa, se lee "Confidencial: Prohibido abrirlo". El informe, imposible de abrir, da cuenta de la misma imposibilidad de la acción de votar, así como hace referencia a la prohibición de acceder a la información secreta en época de dictadura.

Cuando en esta acción el votante debía responder por sí o por no, en respuesta a una pregunta que debía pensar y guardar en secreto, las instrucciones ofrecidas por Vigo hacían referencia a la práctica de la votación y al sistema dictatorial: 
(...) Haga Ud. la práctica de tal sistema democrático, no piense en la gratuidad del mismo y en su falta de resultado positivo para realizar sus anhelos, piense que un acto eleccionario también en sí posee mucho de esa gratuidad (...) Abogamos para que los futuros actos eleccionarios tengan como siempre la característica de la (in)comunicación y mermen la posibilidad de que la voluntad popular nunca se cristalice. Ud. es un elegido, sepa Ud. votar. No nos interesan los problemas que ustedes se plantean, únicamente contesten por sí o por no. Son las opciones. ¿A qué nos lleva esto?, se preguntará. A nada. En la "nada", quizás están todas nuestras soluciones. (Vigo, "Plebiscito gratuito Señalamiento IV", 1969)

Plantea aquí las principales coordenadas para ubicar a esta acción artística en el marco de la política autoritaria de Onganía. Sin mencionarlo explícitamente, pero con evidentes alusiones a la pérdida de la posibilidad de votar en elecciones efectivas, este texto habla de la gratuidad y de falta de resultado positivo de la votación "para realizar sus anhelos". Da por sentado que la voluntad popular no tiene cabida y plantea como uno de los objetivos que "merme" esa situación. Para reforzar la idea de que es imposible votar, identifica al participante de la acción como un "elegido". Finalmente, en una interpelación a la eficacia de la acción, en términos políticos, resume que los resultados no llevarán a nada. Sin embargo, la práctica que Vigo intenta que el público participante vivencie, apela a la función de la desestabilización del acostumbramiento y normalización de la falta de elecciones gubernamentales. Es otra forma de extrañamiento, en este caso, acerca de la experiencia de votar.

En 1970, durante la Exposición de ediciones de vanguardia realizada en el hall de la Universidad de Montevideo, se llevó a cabo el Poema demagógico de Vigo y La poesía debe ser hecha por todos de Padín. En un artículo publicado sin firma ${ }^{74}$ en el diario El Popular, se decía, en relación con estos trabajos, que

Estas experiencias surgen como el resultado de una búsqueda que pretende sustituir los mecanismos habituales de procesamiento y consumo de la obra de arte, en el convencimiento de que éstos se han convertido en un arma más de opresión y de apoyo del sistema y de que la mejor manera de retrovertir los bienes culturales,

\footnotetext{
74 Según Padín este artículo pertenece a Rubén Kanalestein, colaborador de la revista experimental uruguaya Los Huevos del Plata (Padín, comunicación personal, 2012).
} 
ahora en poder y beneficio de unos pocos, es inducir y volcar a las gentes a la creación. (El Popular, 9/10/70, s/p.)

Así, según este artículo, las obras de Vigo y otros como Blaine, Gerz y el grupo de la Poesía Proceso de Brasil, tienden a escapar de la impronta del arte burgués que se impone a través de sus vicios de clase.

Si bien aún no se puede sostener que estas corrientes representen y sean el fruto de una cultura proletaria no determinante y que en el futuro se consagren como el definitivo medio de creación artística lo cierto es que provienen en casi todos los casos de sectores pequeño burgueses que han sabido dar a su condición de explotador una condición revolucionaria: no han 'intentado llegar a las masas' como se acostumbra de una manera demagógica y populista desmereciendo su arte para ponerlo al servicio de una comprensión esclavizada e idiotizada por la 'cultura de masas' sino integrándose a sus propios pueblos para actuar como catalizadores de la imaginación y creatividad de las gentes (...) para que [los individuos] tomen conciencia de sus personalidades tal y como son y posibilitando los cambios indispensables que lo integren grupalmente en las organizaciones de lucha. ( $E l$ Popular, 9/10/70, s/p.)

Este interesante texto que parte de las acciones de Vigo y Padín problematiza la relación entre arte y política desde las prácticas artísticas vanguardistas. En concordancia con lo que dice Vigo sobre el abandono de la idea de revolución y la pedagogía del arte, el articulista sostiene que acciones como las de Vigo pueden ser "catalizadoras" de la creatividad de su pueblo, lo que contribuirá a que tomen conciencia de sí mismos. Según el texto, esto favorecerá su lucha organizada con otros. Sin embargo, la aclaración al comienzo de la cita que refiere a la cualidad de burgueses de los artistas y la duda sobre si este tipo de arte será el arte proletario definitivo, permite pensar que se sugiere como una etapa intermedia o un momento de transición entre el arte plenamente burgués y el futuro proletario. A pesar de ello, y en el marco de una reflexión que intenta combinar de un modo particular vanguardia, arte y política revolucionaria, rescata la actitud de estos artistas que han podido pasar de "burgueses" a "revolucionarios", como si se tratara de un desarrollo progresivo o teleológico.

Al final, reproduce una cita de Maiakowski que dice: "no hay arte revolucionario sin forma revolucionaria", revelando que no es necesariamente el tema del arte lo que lo 
convierte en revolucionario, sino que las formas -como la de la votación de un poema demagógico, que abre a la intervención del público y en la que el autor en mayor o menor medida se hace a un lado para que la construcción poética quede en manos de cada participante- funcionan como experiencia donde pueden emerger la imaginación y la vivencia de la gente común, en función de una práctica libertaria.

La reflexión del articulista puede emparentarse con lo que decía Luis Felipe Noé en una entrevista que se realizó en 1973. Cuando se le pregunta por la identificación entre el artista y el revolucionario y qué es lo que puede aportar la acción artística a la política, Noé responde:

Invención. Pero sucede que los artistas se deforman a tal grado interiormente que más que dominar los mecanismos de la invención son profesionales en la ejecución de obras bien hechas con valores culturales previos y de fácil mercantilización. No es el artista viciado por la sociedad burguesa el que va a servir a un proceso revolucionario. (Noé, 1973: 25)

En esta respuesta, Noé apunta a la misma oposición entre el artista "burgués" y el "revolucionario" y, al mismo tiempo, plantea algunas coordenadas sobre los cambios necesarios en el rol del artista, en coincidencia con lo que plantaba Vigo: la negativa a la inclusión en el mercado del arte y la idea de un "arte tocable" y de materiales “innobles", así como la producción de acciones desestabilizantes del orden espacial y simbólico, los cuales parecen ser caminos posible para esa renovación.

En relación con esto, Vigo afirmaba:

Hoy, nadie duda de que hay un lugar importante para el creador, el espacio abierto, natural, ya sea de contacto directo con la naturaleza natural o la naturaleza arquitectónica, urbanística (la calle). Además, carguemos el índice en esto, hay razones socio-políticas de compromiso por parte del creador. Este ya no duda de que los 'encierros tradicionales' responden a un sistema económico que exige ciertas reglas a las cuales ya no está dispuesto a respetar, por el contrario son esas reglas las que aceleran la reacción opositora. (Vigo, Carpeta Poesía Visual, s/f: 1).

Según Vigo, el "compromiso" del artista, aunque su mención indica un involucramiento en los discursos e imaginarios de los intelectuales y artistas de la época, no es tanto la lucha revolucionaria concebida como participación directa en ella, sino el 
favorecimiento a la modificación de las reglas de comercialización de la institución arte, inmersas en un "sistema económico" más general.

Como se mencionó arriba, en el marco de su intervención mixta entre el afuera y el adentro de la institución, este señalamiento fue repetido en diciembre de 1970 en el Museo "Genaro Pérez" de Córdoba. Como mencionamos antes, allí la revista Ovum/10 de Uruguay organizó la exposición Audición Internacional de poesía fónica. Exposición internacional de la nueva poesía. Exposición de ediciones de vanguardia. En el segundo día de la exposición, propuso la acción del Poema demagógico. Más tarde, en la también referida Expo/Internacional de proposiciones a realizar del CAYC, Vigo presentó la urna con cabezal electoral "en la cual debe ubicarse la votación de un gesto poético" (Vigo, Biopsia 1971). En marzo de 1971 aparecieron en el artículo escrito por Hugh Fox "The pan american review" reproducciones de algunos objetos de Vigo, entre ellos, la urna con cabezales intercambiables. Unos meses más tarde, en la exposición organizada por el CAYC Investigaciones poéticas en el Museo Provincial de Bellas Artes (La Plata), Vigo envió objetos y la urna, pero la votación no se llevó a cabo "por no tener boletas" (Vigo, Biopsia 1971). En el mismo año envió a Estados Unidos uno de los resultados de este señalamiento, el (In) forme sobre la votación en Tomatti.

\subsubsection{UN PASEO VISUAL POR LA PLAZA RUBÉN DARÍO}

En noviembre de 1970 el CAYC organizó la muestra Escultura, follaje y ruidos en la Plaza Rubén Darío de Buenos Aires. La gacetilla de la convocatoria decía "esta exhibición ganará la calle para dialogar con el público, en un intercambio que significará un mutuo acercamiento. Las obras saldrán del ámbito de museos y galerías para alternar con el transeúnte, para convivir con los niños que juegan en las plazas”. El uso de la frase "ganará la calle" se corresponde con el discurso político y militante más usual de la época, bajo la idea de que arte, al igual que la política, puede establecer sus prácticas en ese espacio disputable. Asimismo, es coincidente con la programa de Vigo, decidido a la intervención en la calle como alternativa radical a lo que consideraba la institucionalización burguesa y elitista del arte. 
Los participantes pasaron primero por una acción sonora, a través de silbatos que hacían sonar junto a otros instrumentos al ritmo del "Movimiento Música Más"75 y luego terminaban tocando en una gran jaula.

Vigo, junto a otros artistas, se presentó con una acción que denominó Un paseo visual a la plaza Rubén Darío y que configuró su quinto señalamiento. Vigo entregaba a la gente que se acercaba un volante con indicaciones, una tiza y la Marca de Vigo, junto con una declaración. En las instrucciones se pedía marcar una superficie con la tiza, dar un giro de $360^{\circ}$ y grabar lo visto, para componer así un "paseo visual". Agregó al final de la tarjeta una "nota” en la decía: "reclame la Marca de Vigo. Ésta certificará su paseo" (imágenes 31 y 32).

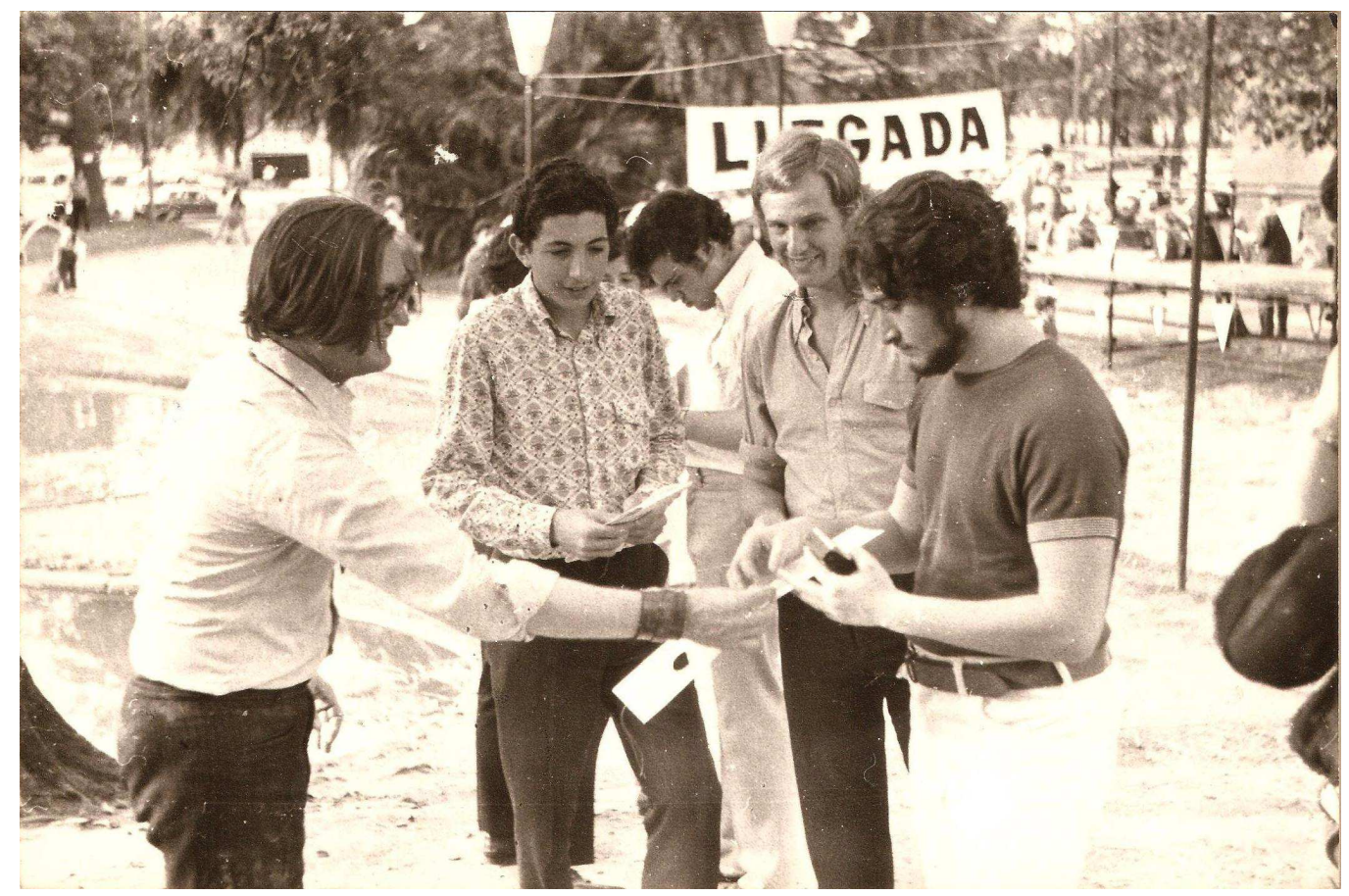

Imagen 31. Vigo entregando las instrucciones y elementos para el señalamiento V. 1970.

\footnotetext{
75 Este grupo estaba conformado por Adrián Barcesat, Norberto Chavarri, Roque De Pedro, Guillermo Gregorio y Margarita San Martín (La Razón, 9/11/70)
} 


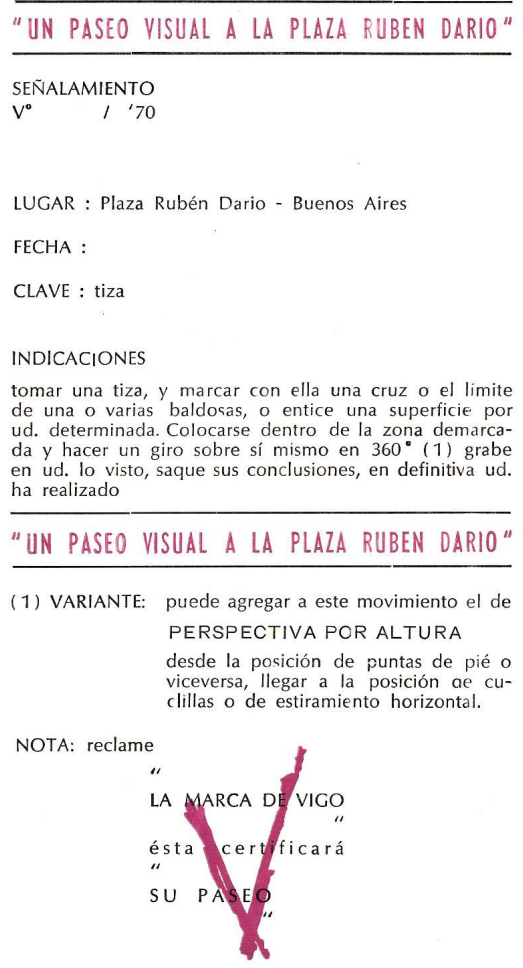

La experiencia propuesta por Vigo apelaba, una vez más, a la acción del transeúnte, para convertirlo luego en poeta. En una progresión que va del simple transeúnte al participante de una acción artística y de allí a la autoría, parecía dejar de lado los aspectos más relevantes de la separación entre autor, obra y público. La búsqueda de que el público pueda vivir su propia experiencia de sensaciones, "grabar" lo visto y realizar luego un "paseo visual", insistía en el carácter esencial que tenía para Vigo el pasaje de lo viejo a lo nuevo, de la obra auratizada y distante a otra donde la experiencia visual y sensorial ocupara un lugar determinante. Implicaba, además, la utilización del espacio público como lugar predilecto para la incorporación del hombre común en estas acciones, alejándose de los espacios privilegiados para la circulación del arte. Esta intencionalidad que estaba dada en la convocatoria a la muestra ofrecida por el CAYC, daba cuenta de que la posición de Vigo en este sentido no era solitaria, sino que tenía lugar en el marco de una idea general que iba estabilizándose en los ámbitos vanguardistas a medida que pasaba el tiempo. En relación con esto, según Glusberg, se trató de una "experiencia hasta entonces inédita en la Argentina, y que era ya común en otros centro culturales de Europa y Estados Unidos (los out door festivals)" (1985: 107). La participación del público fue el suceso de Escultura, follaje y ruidos, dado que "la respuesta del público fue no solo inmediata sino también intensa, alcanzándose la 
participación que buscábamos para esta experiencia (...). Todas las tardes y especialmente, como es lógico, los sábados y domingos, desfilaron centenares de espectadores, de diversas edades" (Glusberg, 1985: 107-108). El organizador de la muestra sostuvo que "no todos reaccionaron con agrado", pero el objetivo no era ese, sino "obtener el concurso de los espectadores”. Glusberg agregó que

los concurrentes a la Plaza Rubén Darío (...) se veían enfrentados a un ensayo que, por su misma índole de tentativa, los colocaba en una posición no menos experimental que la de los artistas convocados (...). El elemento lúdico también se convirtió en un puente para el acceso del público a la exposición (1985: 108).

En este caso, la ocupación del espacio público producida por Vigo estaba sostenida por una muestra organizada institucionalmente, a diferencia de los otros casos en que se lanzó solo a su conquista. Sin embargo, mientras unos presentaron obras que implicaban un público que podía mirar, trepar o tocar, la de Vigo iba más allá: el participante debía armar su poesía, por lo que la obra no existía aún, aunque sí los elementos que la posibilitaban.

La nota al final de las indicaciones, donde ofrece una "certificación" del "paseo" realizado, tal como se verá en el capítulo siguiente, apela al uso de uno de los aspectos del discurso judicial, desenmarcándolo de su lugar "natural" y convencionalizado. Asimismo, la idea de la Marca de Vigo, destaca la importancia de la presencia del autor, aún cuando este no sea el centro de la acción, complejizando su figura y la relación con el espectador, de modo que quien recibe la invitación no se encuentra solo en la creación de la obra, sino que depende en mayor o menos medida del ideólogo de la acción.

Lo insólito de la muestra se expresó también en su finalización. Terminó con la destrucción de las obras "por la concurrencia”, dice el Diario La Razón (9/11/70). Según el cronista, luego del espectáculo musical "los ánimos se caldearon” y comenzó la destrucción de obras, entre ellas el laberinto de Osvaldo Romberg, unas cañas de Alberto Pellegrini (premiada por el jurado), las duchas de acrílico de Lea Lublin y un gato del mismo material de Nicolás García Uriburu. ${ }^{76}$

\footnotetext{
${ }^{76}$ Se mencionan en el mismo artículo como excepción a la destrucción una obra con agua de Antonio Berni, una semiesfera colgante de Gyula Kosice, un trabajo de Ennio Iommi, entre otras.
} 


\subsubsection{5' DE FILMACIÓN EN EL MONUMENTO DE B. MITRE Y TRES ACTOS INTERCONECTADOS}

5' de filmación en el monumento de B. Mitre es el nombre del Señalamiento VI, realizado en el año 1971 y presentado tres años más tarde con el nombre Experiencias. Este video se realizó con Jorge Glusberg, ya que en ese momento Vigo mantenía una fluida relación con el director del CAYC. Por los documentos existentes, consistió en una primera toma de dos minutos alrededor del monumento y luego tres de frente con la indicación "hacia afuera" (imagen 33).

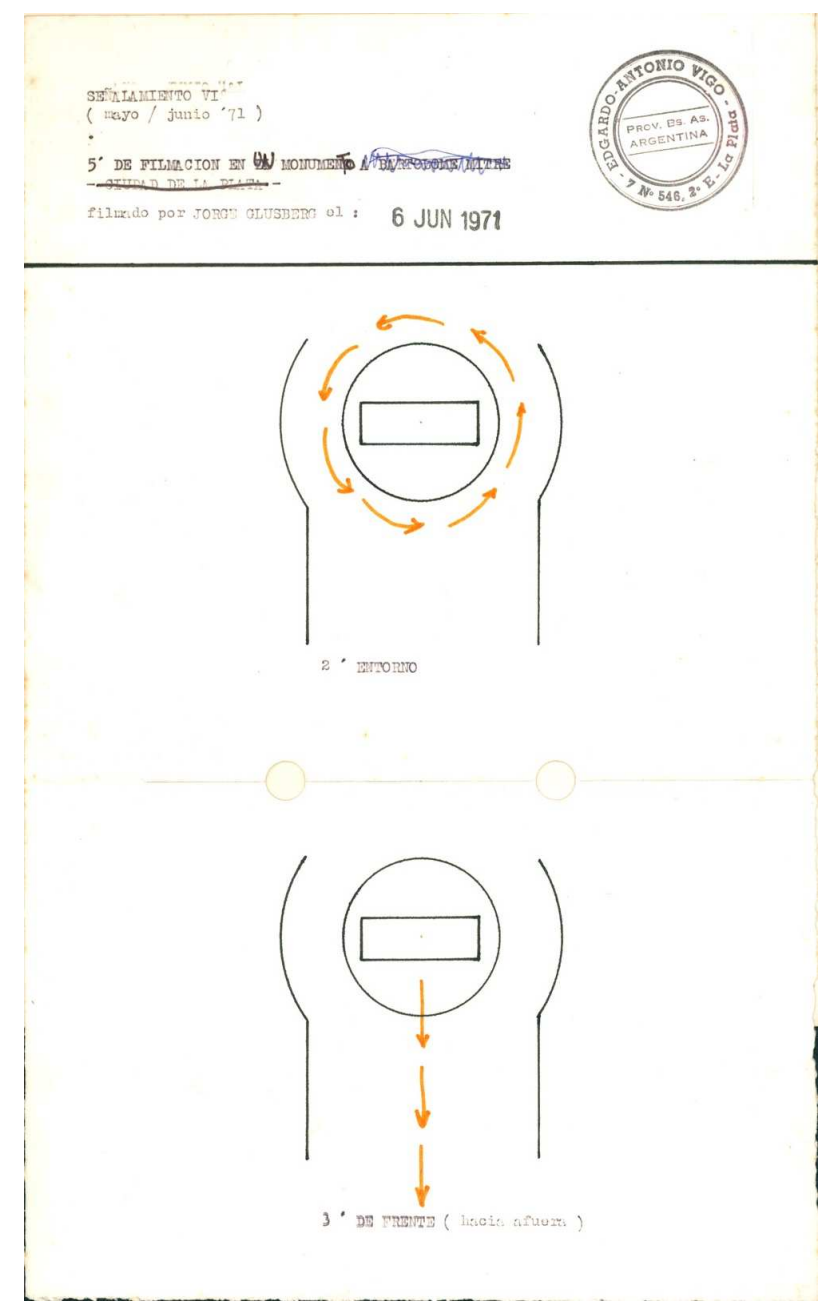

Imagen 33. Croquis del señalamiento VI. 1971.

En la gacetilla del CAYC de 1974 se informa que el video Experiencias, de 10 minutos, se presentó con la edición de Tercer Mundo en Alternative Video, realizado en el Museum of Modern Art de Nueva York, en el marco del Study Conference Open Circuits - The future of television, en enero de ese año. El diario local anunció esta 
presentación (El Día, 14/03/74) y dice que todos los participantes argentinos presentaron videotapes entre 10 y 30 minutos, televisados en circuito cerrado para los visitantes del Museo. Además, agrega que el tema central de los argentinos ha sido, según Glusberg, "una reflexión sobre la situación del hombre de nuestro medio".

En el mes de abril, se proyectó en el Internationaal Cultureel Centrum de Amberes, Bélgica, un espacio donde se dio lugar al desarrollo el arte experimental, especialmente el arte conceptual, las instalaciones, los videos y las performances.

En este caso, Vigo se centró en un elemento existente en el espacio público, provocando una operación similar a la del Señalamiento Manojo de Semáforos, pero aquí, mediado por el ojo de la cámara. El monumento de Mitre, símbolo de respeto a un pasado patriótico y liberal, se convirtió en sitio de la experimentación visual en el que se generó un video alejado de cualquier reivindicación histórica. El uso del monumento, primeramente destacado también en el título del señalamiento, se transformó en objeto de una mirada vinculada a la búsqueda de nuevas sensaciones (¿qué se ve al rodearlo?; ¿qué se observa al alejarse de él?). La acción si bien no ignora el carácter de monumento que la ideología dominante da a la estatua, lo desvirtúa al utilizarlo como objeto pasible de ser convertido en una filmación para ser señalado -en tanto acción artística-, no para ser honrado como tal.

La utilización de ciertos dispositivos ya ubicados en el espacio, con una funcionalidad acotada -en el caso del semáforo, ordenar el tránsito; aquí, homenajear a un presidente e historiador relevante en un período histórico-, para desactivarla, indica que aparece la idea que Vigo desarrolló sobre la ironía, como una forma de desarticular algunos sentidos comunes y estabilizados acerca de esos objetos.

Otro señalamiento en que aparece la ironía, pero de otro tenor es el número IX bis, Tres actos interconectados '71. Era un llamamiento a través de tres tarjetas de cartón a que el público realizara tres pasos: el primero, orinar en la esquina de 7 y 50, luego defecar en el mismo lugar y finalmente, realizar un "llamado a la purificación", alejándose por la calle 7 hasta entrar en "trance poético" (imágenes 34 y 35). Vigo envió las tarjetas por correo y también las distribuyó al azar en la vía pública. 


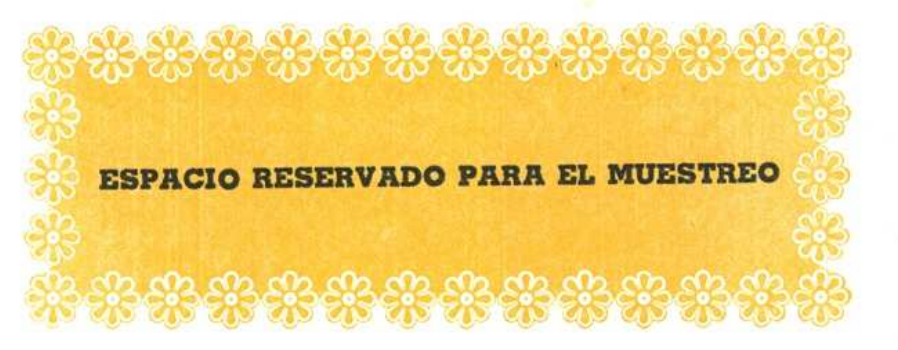

ACto $\mathbf{B}$ : defecá en 7 esq. 50 el lugar señalado " b "

\section{ACTO C :}

llamado de la purificación

alejate por 7 , sigue la flecha diagramada, al final de la misma entra en

"trance poético"

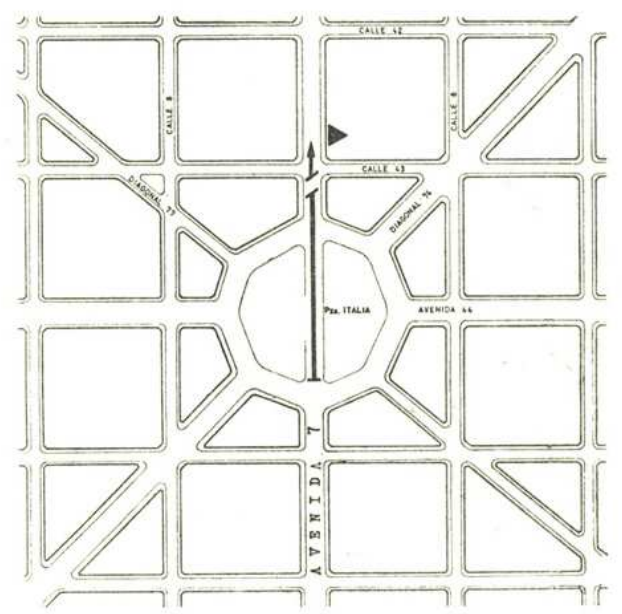

Imagen 35. Vigo, Tres actos interconectados 71. Tarjeta "Acto C". 1971.

Estas acciones resultaban casi imposibles de concretar. La traslación de las acciones de orinar y defecar desde el ámbito más privado e íntimo hacia el espacio público, más que una invitación a llevarlas a cabo, interrumpe, a través de la materialidad de la obra en las tarjetas indicadoras de los tres actos, las reglas de lo que puede imaginarse como 
posible en el espacio público a la vista de cualquier transeúnte. Teniendo en cuenta que el relato -en este caso el texto de las tarjetas- es un acto creador, dado que "la descripción cuenta incluso con una poder distributivo y con una fuerza performativa (hace lo que dice)" (de Certeau, 2007: 135), Vigo interviene sobre esas reglas más por el discurso que por la concreción de las acciones proyectadas. A esto se suma, que la propuesta proviene del arte y que pretende generar un "trance poético" en quien haya vivido la experiencia.

Vigo juega aquí con idea de que el espacio público es allí donde se cruzan las visibilidades -en el que solo lo que puede ser observado por otros es viable-, lo hace al subvertir esa característica esencial de lo público con propuestas de actos eminentemente privados. De este modo se interviene sobre el espacio en la propia condición que determina qué es un espacio público y qué puede hacerse en él. De este modo, tenían, para la época una significación altamente política porque aludían, en lo escatológico, al desprecio a las normas de comportamiento social en el espacio público y, al mismo tiempo, representaba un desafío -inverosímil- al orden político imperante, el cual intentaba reprimir las conductas que se desviaran de la moral, el respeto a las autoridades y a las "buenas costumbres". Como recordamos antes, la "Revolución argentina" se sustentó en ideas de la doctrina de las Fuerzas Armadas y del "cursillismo" católico, cuya orientación conservadora y pacata respecto del comportamiento social, debían cumplirse en los espacios públicos.

Esta experiencia no terminó en las tres tarjetas para la acción en la calle, sino que también las presentó en espacios institucionalizados. Así, en 1972 envió este trabajo a Madrid para Experimenta / 2 y a Nottinhgham (Inglaterra) para la Midland Group Postal Exhibition. Dos años más tarde, decidió llevar a la muestra Signals - messages missions, organizada en Alemania, los tres sobres que contenían estas tarjetas.

\subsubsection{SOUVENIR DEL DOLOR}

La Dirección del Jardín Zoológico de La Plata organizó la muestra Arte Integración, que tendría lugar entre los meses de septiembre y octubre de 1972. Esta muestra estaba planteada por su organizador, Roberto Crowder, con el objetivo de "tener un diálogo directo con un público masivo. Todo el mundo tiene derecho a la cultura y éste no es más que un punto de partida" (El Día, 8/10/72.). Con una política de apertura a la presentación de artistas sin selección previa ni otros requerimientos (es decir, en 
oposición a lo que regularmente ocurre en las exposiciones institucionalizadas), los artistas estuvieron presentes no solo para mostrar sus trabajos, sino para conversar con el público. Se expusieron pinturas, esculturas, grabados y arte conceptual.

En este clima coincidente con las posiciones de Vigo, este decidió comenzar con el Señalamiento XI, que llamó Souvenir del dolor. Este señalamiento se desarrolló en distintas oportunidades a partir de septiembre de ese año, por lo que el artista lo llamó "progresivo",77 (Vigo, Biopsia 1972).

En el zoológico local, Vigo colocó su banderola con la flecha que señala, una estaca de madera con su nombre y el de la obra, y al lado (hacia donde se dirige la flecha) un cartón blanco con un recorte del diario La Razón cuyo titular dice "13 guerrilleros muertos y 6 heridos al intentar fugarse", y la tarjeta denominada "souvenir del dolor". Se trataba, en este caso, de señalar ya no un artefacto o un espacio, sino un hecho -la masacre de Trelew- y su materialización en la prensa escrita (imagen 36).

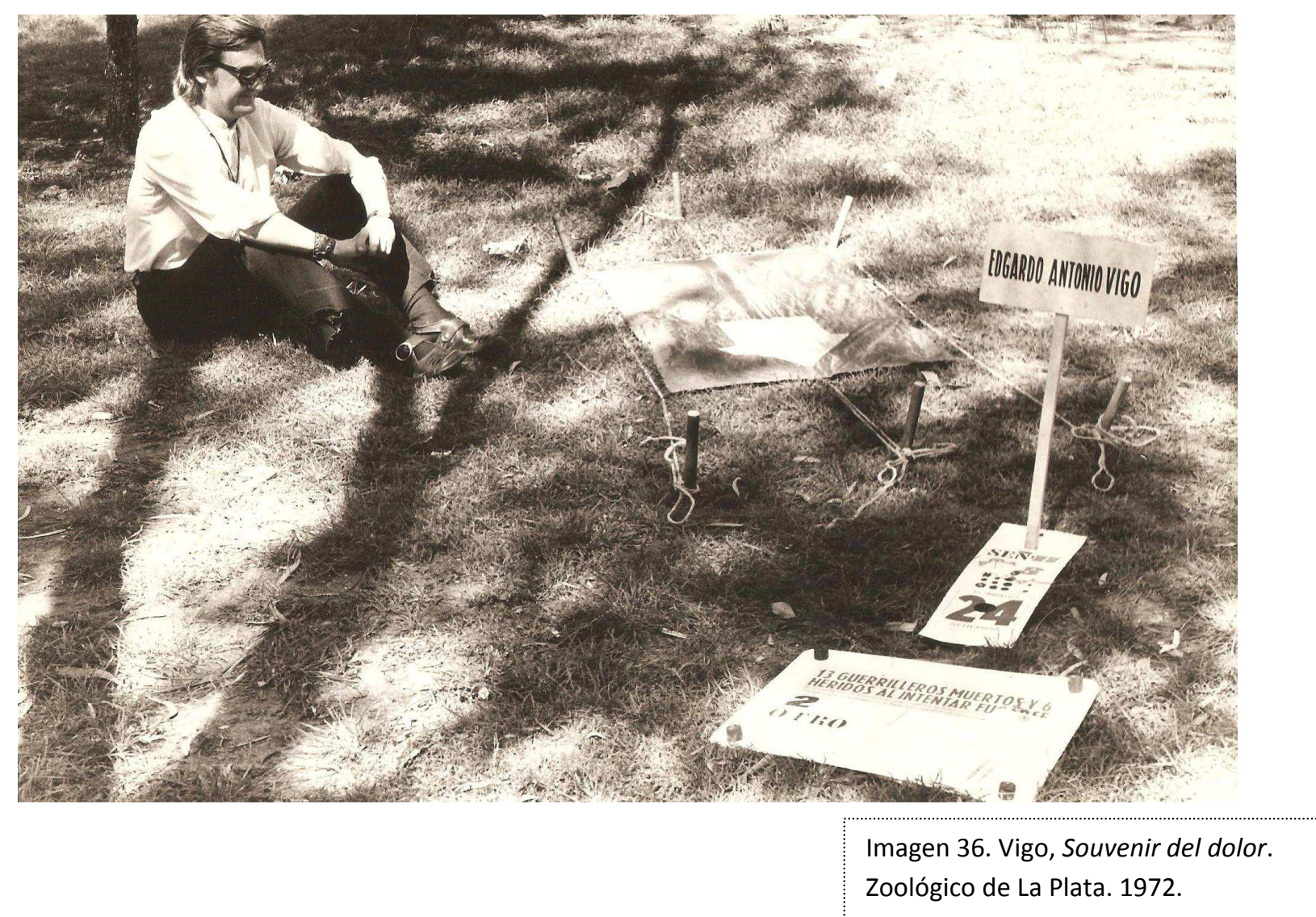

\footnotetext{
${ }^{77}$ Analizaremos aquí todas las fases de este señalamiento, aún cuando parte de ellas se hayan desarrollado en el espacio cerrado, dado que consideramos que no se trata de la repetición del mismo acto, sino que los distintos momentos que lo componen forman un todo que no puede ser estudiado aisladamente.
} 
El "souvenir del dolor" era una tarjeta rectangular de cartulina blanca con una pequeña perforación de la que se ata un hilo rojo y que tiene el título del señalamiento, debajo se encuentra una cruz en forma de $x$ xilografiada en color rojo y la frase "Recuerda!. El 22 de agosto del ' 72 trece más engrosan la lista”. Superpuesto a este texto el número once, que indica el número del señalamiento, en color rojo (imagen 37)

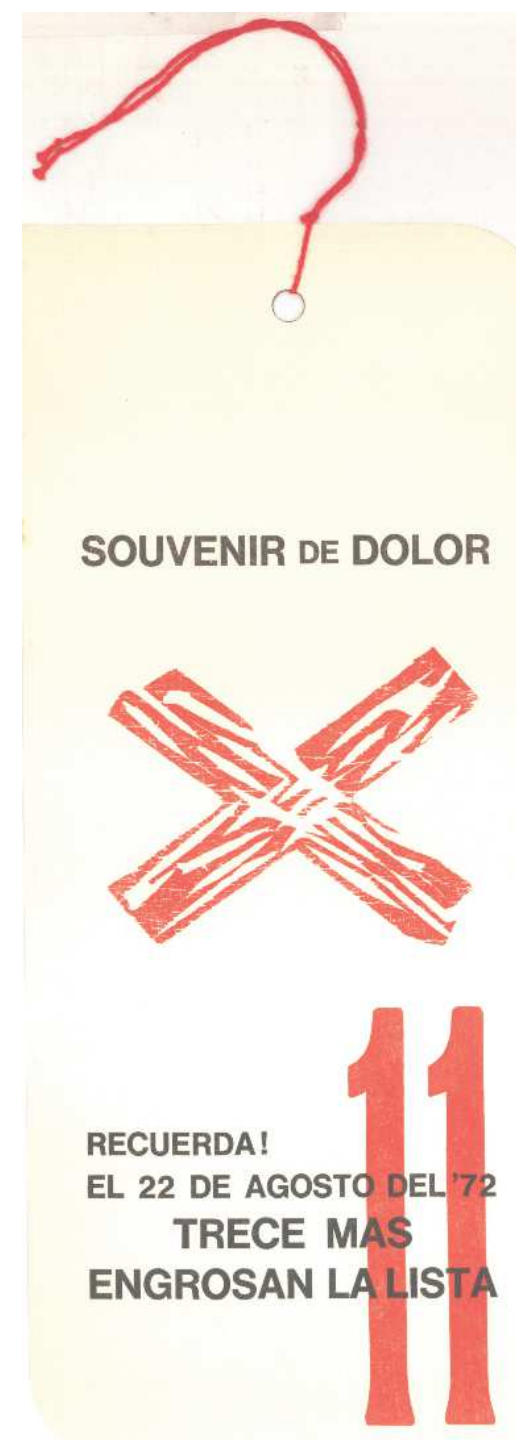

La idea de "souvenir" como recuerdo de un acontecimiento tiene antecedentes en la poética de Vigo. En primer lugar, puede rastrearse en uno de sus textos, un artículo publicado en el diario El Día sobre las "Experiencias 68" en el Di Tella (El Día, 09/06/68) donde destaca que una de las presentaciones consistió en un paquete de revistas del que el observador podía llevarse un ejemplar a modo de "recuerdo", en tanto que la "cosa" (el paquete) quedaba allí. En ese artículo dice Vigo que en ese 
trabajo ocurre una traslación del conjunto a un elemento particular. Puede observarse que en el caso de la "Souvenir del dolor" sucede algo similar, ya que este es parte del Señalamiento XI y funciona como un "recuerdo" en dos sentidos. Por un lado, es una parte la "cosa" del señalamiento, un elemento del conjunto que es la acción artística; por otro, es un recuerdo como forma de fomentar la memoria del hecho mismo de la masacre de Trelew, acaecida un mes y medio antes de la muestra.

Ya en el primer número de Hexágono '71, con el nombre Souvenir de Viet-Nam había colocado un sobre en papel transparente en el que se encontraba la siguiente indicación: "Viaja. Busca una trinchera (de cualquier bando), recoge una vida y guárdala en el sobre transparente" (ver capítulo 4) (imagen 63). Aquí, como en señalamiento, aparece la relación del souvenir como resto de una acción vinculada con un hecho de relevancia política, la guerra de Vietnam. En el Souvenir del dolor, la acción estaba realizada por el artista y en la revista, el de Vietnam, es una propuesta para el receptor. La indicación "recoge una vida" de cualquier trinchera sumado al cumplimiento inverosímil de la búsqueda y su guardado en un pequeño sobre de papel operan como disparador de un cuestionamiento hacia el hecho concreto de la guerra, al mismo tiempo que apela al desconcierto respecto del modo en que esa crítica se realiza en el arte. En el Souvenir del dolor, si bien este ya ha sido realizado por el artista, es decir, ya está acabado en su proceso de producción, la entrega de una tarjeta que contiene una copia del titular del diario La Razón en el que se informa el asesinato de personas, opera -al igual que en el de Vietnam- como denuncia del hecho y como perturbador en la relación masacresouvenir, o mejor, política-arte.

También creó "souvenirs" en diversas ocasiones, siempre ligados a que el público pudiera llevar un elemento que formaba parte de la obra, lo que constituyó una de las formas de participación que Vigo estaba interesado en explotar. En el año 1971, había ideado para presentar en el CAYC un "souvenir" con un sobre idéntico al que utilizara luego para el de Vietnam y un texto que proponía encender un fósforo y guardarlo en el sobre. El texto de la tarjeta, termina "has puesto en práctica la guarda de un recuerdo". Otro ejemplo es Souvenirs de mi sangre extraída el 26 de junio del '72, que repartió en el Centro Cultural Platense ${ }^{78}$.

\footnotetext{
${ }^{78}$ En otros casos, creó tarjetas de invitación con un formato similar al Souvenir del dolor, pero sin utilizar la palabra "souvenir".
} 
Vigo ya había utilizado la prensa en otras ocasiones como parte del proceso de construcción de la obra, como es el caso de la convocatoria a los señalamientos Manojo de semáforos y Poema demagógico, lo que lo colocaba en consonancia con otros artistas que también habían decidido incorporar los medios de comunicación, tal como se apuntó en el capítulo 1.

En Souvenir del dolor, el uso de la prensa se concentra en destacar la forma en que un medio escrito comunica la masacre, un hecho acontecido en la vida política y también como enunciación del señalamiento a través de un texto producido por otros. Aquí no hay instrucciones para el público, sino que al aprovechar la apertura para participar de la muestra, señala, muestra, el acontecimiento político y represivo de la masacre y su consiguiente apropiación por parte de la prensa. Por otro lado, su ubicación en el espacio público, accesible a las interacciones y visibilidades que lo conforman, y su introducción en una muestra artística, le otorgan un carácter específico, muy diferente al del simple ofrecimiento de información. La banderola con la flecha lo hace parte de la serie de los señalamientos que desde el comienzo se planteó como la búsqueda de una experiencia estética.

Durante el transcurso de la muestra, Vigo se presentó varios domingos, cada uno con una intervención sobre el espacio: Área de libertad (1/10/72), Análisis poéticomatemático de 10 m. de soga (15/10/72), Objetivación de la contemplación (29/10/72) y Aquí yace $(11 / 72)^{79}$. De ellos interesa especialmente el que presentó inmediatamente después del referido a la masacre de Trelew, Área de libertad. Se trató de la delimitación de una zona de tierra por cuatro postes clavados, entre los cuales pasaba una cadena. Dentro del rectángulo formado por la cadena se encontraba un cartel con el texto "Área de libertad. Prohibido pasar" (imagen 38). En este trabajo Vigo, en primer lugar, presenta una contradicción entre la primera frase y la segunda, un oxímoron, que, como un juego de palabras, refiere al uso del espacio, intentando despistar al público, confundirlos con un equívoco, desviarlos en su propia relación con el espacio y con la forma narrativa en que comunica una obra de arte. En segundo lugar, contiene un elemento político vinculado a la libertad y la prohibición: la obra muestra que lo que se

\footnotetext{
${ }^{79}$ Análisis poético-matemático de $10 \mathrm{~m}$. de soga constaba de una soga de ese largo dispuesta sobre el suelo atada a unas estacas que la sostenían; Objetivación de la contemplación consistía en la leyenda ubicada también sobre el suelo "hoy 29.10.72 estuve mirando esta cruz"; en Aquí yace, intervino sobre uno de los montículos de tierra existentes en el zoológico, ubicando una tela negra sobre la que colocó un trozo de mármol blanco con el texto que da nombre al trabajo. En este último, según Vigo, la participación se encuentra en que el público debe determinar quién es el que yace (Biopsia 1972).
} 
encuentra vedado es el acceder al espacio de libertad. No se puede llegar a ella-espacial ni simbólicamente- porque está limitada por cadenas. Para completar el sentido del trabajo, Vigo creó una tarjeta con el texto "Espacio de libertad" sobre el que imprimió con un sello la palabra "Perimido": es decir, el espacio de libertad se ha terminado (retomaremos este trabajo en el capítulo 4).

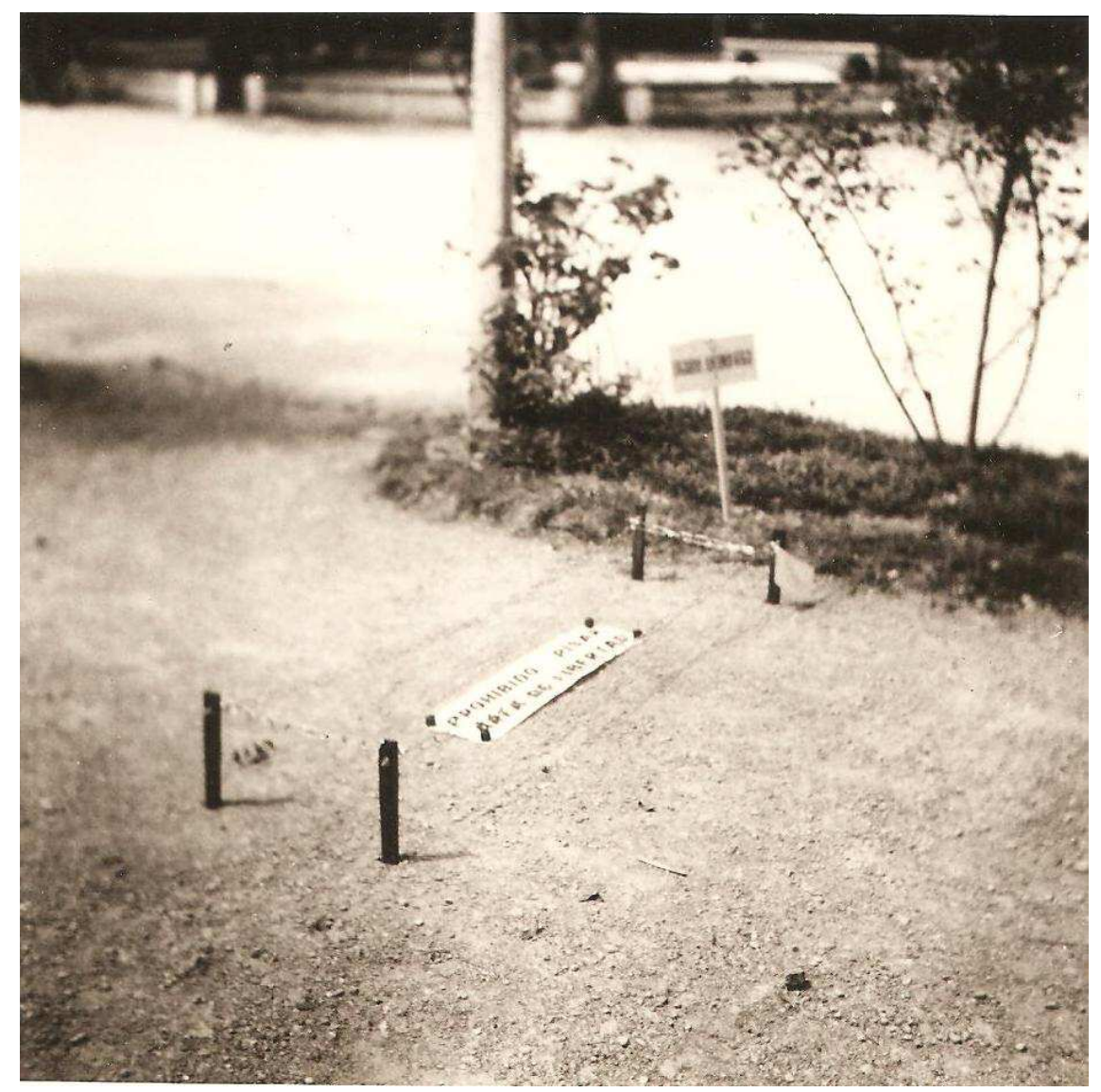

Imagen 38. Vigo, Área de libertad. 1972.

En noviembre del mismo año, continuó con el Señalamiento XI. Se organizó en La cueva del 11 la Exposición de arte platense Panorama 72, en la que participaron dieciocho $\operatorname{artistas}^{80}$.

En una de las salas, enteramente blanca, Vigo armó una ambientación en la que colocó sobre la pared del fondo una xilografía con el rostro del Che que tenía en la parte inferior la palabra "Trelew", y colgado de ella, un rectángulo blanco con el titular del diario La Razón sobre la masacre. En el centro de la sala, ubicó la banderola negra con la flecha dirigida a la imagen del Che, y sobre esta, un trípode con una ametralladora de

\footnotetext{
${ }^{80}$ M. Alzugaray, R. Arcuri, M. Casas, H. De Marziani, E. Gans, C. Ginzburg, G. Gutiérrez, L. Icopetti, H. Khourian, E. Kortsarz, C. López Osornio, C. Pacheco, L. Pazos, H. Redoano, H. Soubielle, B. Uribe, Vigo y E. Zabalet. La muestra estaba organizada por la empresa constructora Giusti.
} 
juguete. Sobre los laterales, colocó divisiones en el suelo con los nombres de los asesinados en la masacre, para lo cual tomó como base el plano de las ubicaciones de las celdas (imagen 39).

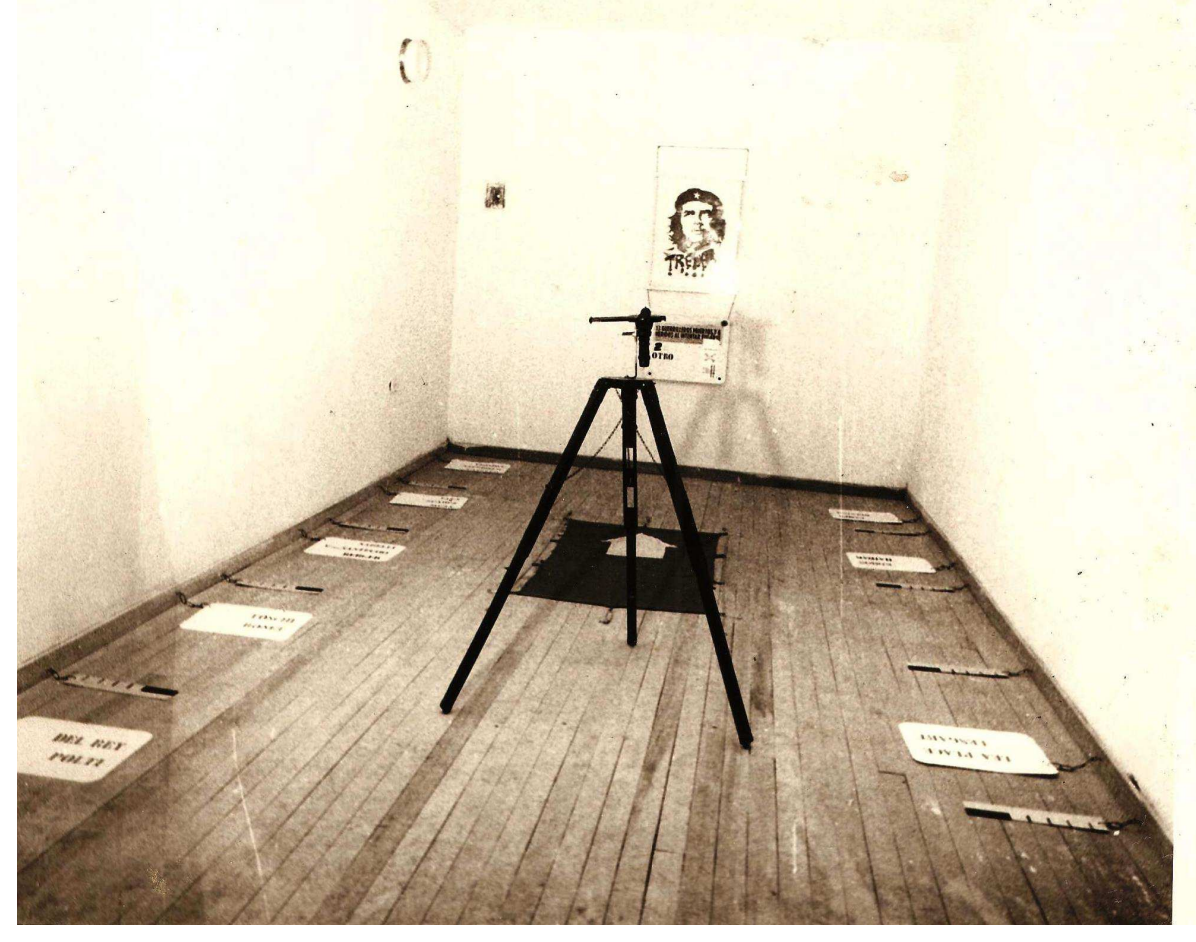

Imagen 39. Vigo, Señalamiento XII. 1971.

El señalamiento, entonces, se dirigía hacia la cara de Guevara y la noticia de los asesinatos e identificaba así a los militantes con el líder de dos maneras: en primer lugar, el ataque que había terminado con la vida de los guerrilleros se simbolizaba en el que había sufrido el Che cinco años atrás (la ametralladora apunta hacia ambos); en segundo lugar, esto implica vincular a la figura del líder con los militantes de la izquierda revolucionaria, ya que la referencia a Trelew no se encuentra solo en el recorte del diario, sino también en la propia xilografía del Che. La ubicación espacial de 
los nombre de los militantes, sobre el suelo y sin volumen, refiere al plano que tomó como modelo, lo que lo vincula con un dato real, la verdadera ubicación de las celdas de cada uno. Encontramos, así, tanto en esta fase del señalamiento como en la del zoológico, una vinculación con la realidad como hecho del mundo, visible tanto por la utilización de un titular de diario -que informa sobre lo sucedido- como por el uso del plano con la localización espacial de las celdas. También, hay una apelación a lo real como horror -en el sentido que le da Badiou (2009)-, las muertes injustas de los militantes, los engaños del gobierno represivo, el desamparo de los sobrevivientes. Una obra hecha de contigüidades semánticas: el Che y los militantes; el arma y la muerte; las celdas y los espacios en el suelo, dejan, sin embargo, un elemento extraño que remite a la presencia del artista, a algo de la vida que aún existe a pesar de lo real, la bandera con su flecha que no es solo una señalización en una dirección y un indicador de la pertenencia a una serie, sino una evidencia de que detrás de todo aquello está el artista, pensando el horror, reflexionando sobre su existencia. La politicidad de esta obra, evidente en cuanto refiere claramente a acontecimientos políticos, representa una de las relaciones establecidas entre arte y política en la poética de Vigo.

El crítico de la revista 7 y 50 dijo que las obras expuestas en La cueva del 11

Sin cuestionar el hecho de que puedan constituir válidamente en auténtico 'Panorama '72 del arte platense' son realmente un amplio espectro que refleja las tendencias sociales e intelectuales que sacuden a la Argentina de hoy. Todos los aspectos de la violencia en sus variadas formas: guerrillerismo, represión, guerra internacional, etc., se encontraban presentes en extenso desfile ante los ojos de los concurrentes. ( 7 y 50, 1/12/72, s/p.)

Seguido, califica a la obra de nuestro artista: “el 'señalamiento' de Edgardo Antonio Vigo, [es] la obra -a nuestro entender- más clara y racional de todas las presentaciones en esta variante" (7 y 50, 1/12/72, s/p.). Así como La civilización occidental... de Ferrari se había convertido en una "imagen-manifiesto" (Giunta, 1997), esta obra de Vigo cumplía la misma función, y tanto en uno como en otro caso, la censura no se hizo esperar.

Otros trabajos expuestos en la muestra dan cuenta de un clima de conjunción artísticopolítico, en donde se hacía evidente el uso de una temática política como forma de denuncia. En la entrada se disponía una gran sábana que parecía haber sido manchada con sangre, de Luis Pazos, en cuya parte superior tenía la frase "No negociaremos con 
la sangre derramada". Ginzburg presentó un colchón con coronas de flores y palmas funerarias y libros sobre ellas: "La muerte tiene permiso", "Yo fui asesinado", "La tortura". La obra de Iacopetti utilizaba fotos de nazis; Alzugaray presentó dos pinturas, en una de las cuales había una foto de Irigoyen con su comitiva; Gutiérrez Marx trabajó sobre la guerra y la patria, con imágenes de granaderos e infantes, y entregaba a los visitantes una tarjeta con la frase "Pacem pueblo" y una palomita. También se encontraban banderitas de Argentina y Estados Unidos.

Las circunstancias que rodearon esta presentación merecen ser mencionadas. El carácter explícitamente político de las obras decidió al dueño del local, Giusti, en el momento de la inauguración a pedir a los expositores -a través de su secretaria- que en una hora sacaran las obras con "tono político", pero sin indicar cuáles eran estas, de modo que eran los propios artistas quienes debían resolverlo. Éstos interpretaron la indicación no solo como censura, sino también una invitación a la "autocensura", al tener que determinar cuáles trabajos debían permanecer y cuáles no. Así, decidieron levantar toda la muestra a solo dos horas de haber sido inaugurada. La repercusión en la prensa escrita fue notable. Una nota en el diario El Argentino titulada “¿La muestra más corta del mundo?" (21/11/72), con una foto de la ambientación de Vigo, informa sobre la clausura de la muestra y menciona el punto de vista de los expositores que decidieron retirar todas las obras, así como aclaraba, además, que muchos de ellos tienen una amplia trayectoria nacional e internacional. Similar contenido tiene la nota del diario $E l$ Día (22/11/72). Se destaca, entre la prensa escrita, el artículo publicado en la revista 7 y 50 (1/12/72). Luego de hacer una descripción de las características de la muestra -citado arriba-, en el que subraya el contenido referido a la violencia y a la política en las obras, menciona también las opiniones de los artistas: "lo peor es que pretenden que nosotros mismos censuremos nuestras obras señalando cuáles sí y cuáles no tienen sentido político”, "esto es el colmo. ¿Habrán creído que íbamos a hacer una exposición tipo 'Peña de las Bellas Artes’?”, “¿por qué no se informaron primero sobre la situación actual del arte?", fueron algunas de las frases recogidas por el diario.

El tercer momento de este señalamiento se dio en el número ce de la revista Hexágono '71. Incorporó allí una afiche doblado al medio con cuatro perforaciones circulares pequeñas. En su interior dice "El 'systema' coagula rápido la sangre del pueblo. Este no" (imagen 40) y contiene dentro tres elementos. El primero es un pequeño papel escrito a máquina que dice “Ármelo!", repetido en inglés y francés. El segundo es la tarjeta "Souvenir del dolor" (imagen 37). El tercer elemento es "El ojo del Che": una 
tarjeta de papel blanco con un hilo color naranja en la parte superior y una xilografía de medio rostro del Che Guevara, el cual en el centro del ojo tiene un círculo calado (imagen 41).

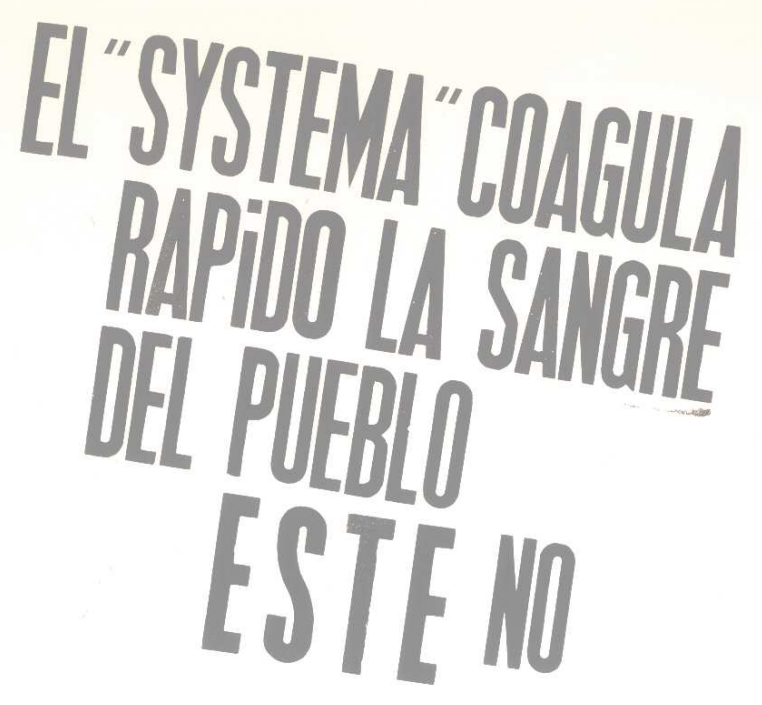

Imagen 40. Vigo, Señalamiento XI.

Afiche. 1973.

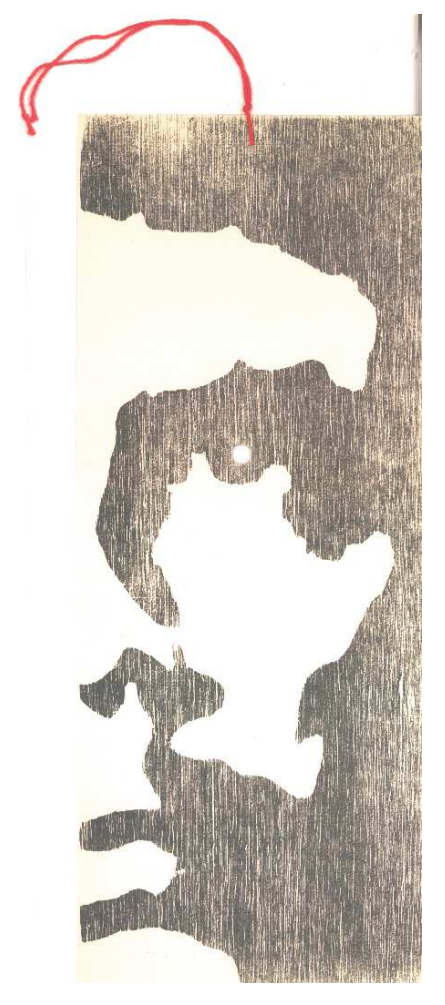

Imagen 41. Vigo, Señalamiento XII.

Tarjeta. 1973. 
La palabra "ármelo" apela claramente a la intención de hacer participar al observador. Este interviene más como colaborador del artista que como creador, ya que sus posibilidades son escasas. Sin embargo, como emana de sus ensayos, Vigo apunta a movilizar, de modo que la acción misma del armado desestructure la idea de un público que recibe el trabajo terminado y solo se dispone a contemplar, y, además, a que manipule con sus propias manos elementos que aluden al "sistema", los asesinatos, la militancia, la guerrilla, el Che. El mismo significante "ármelo", como se dijo arriba, remite a aspectos de la cultura política y de las prácticas literarias y artísticas del momento. Por otro lado, la escritura en tres idiomas se vincula con el interés de que la revista circule internacionalmente.

En apariencia, para "armarlo" se cuelgan de los hilos las dos tarjetas, eligiendo el orden y atándolas en los orificios de la hoja de modo que a la frase que termina "este [el pueblo] no" le sigan las remisiones a la masacre de Trelew y al Che.

Como en otros trabajos, Vigo utiliza la idea de "sistema" de un modo crítico. Posiblemente, el uso de $y$ en lugar de la $i$ se deba a la remisión a la palabra system en inglés, reforzando la idea de que el sistema está digitado o gobernado por los Estados Unidos. "El 'systema' coagula rápido la sangre del pueblo" porque decide ignorar el sufrimiento humano, aún las muertes, tanto, que el proceso le resulta breve. Según el texto, el pueblo no actúa igual, padece a sus víctimas, recuerda los asesinatos de su gente, por ello la sangre no coagula rápido, sino que chorrea recordándoles lo sucedido. Como un modo de explicitar este mensaje, las dos tarjetas ofrecidas para culminar la composición clarifican cuál es la sangre del pueblo y por qué para él no coagula.

El texto "Recuerda! (...) Trece más engrosan la lista" funciona como objetualización que materializa la necesidad de mantener la memoria sobre la experiencia de la masacre. Al mismo tiempo, "Trece más" está indicando que no son los primeros, que antes hubo otros muertos por la represión de las dictaduras.

La cara del Che está realizada en una xilografía que a simple vista podría parece una composición abstracta de manchas negras sobre un fondo blanco. Una observación detenida descubre que allí se encuentra medio rostro del guerrillero argentino. La perforación en el ojo es el centro de la composición, aunque pequeña, moviliza la mirada hacia el otro lado de la hoja, lo que podría funcionar tanto como una mirada hacia el interior del Che, lo que habita en él como conjunto de principios vinculados a la lucha contra las injusticias y a favor de la revolución, así como una mirada inversa, 
desde detrás de la imagen hacia adelante, como una especie de careta que puede calzarse cualquiera y convertirse en él, mirando a través de $s u$ ojo. También implica, desde otro punto de vista, que el Che está traspasado por nuestra realidad, lo que pasa hoy -la masacre de Trelew, por caso- atraviesa su figura en tanto fue un prototipo quien dio su vida por la lucha y que muchos de los militantes argentinos tomaron como modelo ideológico y de acción. Cada uno de los muertos en Trelew o tantos otros militantes movilizados podría ser un Che asesinado, lo ha franqueado a través de su ojo y se ha metido en él.

Vemos que aquí Vigo utiliza un tema de relevancia política para enfocar el objetivo de su obra, la significación simbólica de esa matanza de guerrilleros no puede, para este artista, dejarse de lado. Hay, así, una incorporación de ese tema por lo que su obra se vuelve expresamente política y cuyo objetivo de comunicación de una idea -ambos, la presencia y el recuerdo de la masacre- es claro. Sin embargo, esa asociación directa se vuelve más compleja si se tienen en cuenta dimensiones de la materialidad de las obras. Tanto en la ambientación como en el Souvenir hay un aspecto que Vigo no relega: su carácter de artista que idea y produce obras o acciones que siguen siendo artísticas y rupturistas del sentido común político. No se trata simplemente de panfletos o de la transposición de ideas políticas, es decir, solo la movilización de un lugar discursivo ideológico a otro artístico, sino que a la literalidad de las ideas, le agrega elementos de continuidad con su poética: la flecha que señala, utilizada en todos sus señalamientos, remite a que se trata de un acto artístico inmerso en una cadena de acciones tendientes a desnaturalizar distintos aspectos o hechos del orden social; además, en el caso del Souvenir del dolor, el "recuerdo" -en otros casos será una "prueba"- que Vigo entrega al público lo produjo en otros señalamientos y acciones como indicador de una parte de la acción artística realizada.

Dos años más tarde, en agosto de 1974, Vigo dio una charla en la Facultad de Bellas Artes de la UNLP y llevó -como lo hacía frecuentemente- materiales de su producción, entre los que mostró las tarjetas del Señalamiento XI. Además de este, expuso el Señalamiento XIV - variante uno llamado Del Silencio (1974), el díptico Masacre Homenaje a Trelew-Ezeiza-La Plata y sus caídos (1974), cuatro xilografías y 200 llaves que viajaron de La Plata/Buenos Aires/La Plata. A dos años de la masacre, Vigo insistía en señalar el tema y el hecho de trasladar al ámbito de la universidad los resultados de una acción realizada primero en el zoológico y continuada en la Cueva del 11, implicaba traspasar las limitaciones entre el adentro y el afuera de la institución: del 
espacio público a la galería, de allí a la Universidad. Un itinerario que daba cuenta de los intereses diversos de intervención crítica, no excluyentes. Es decir que si la ocupación del espacio público era una prioridad, también lo era el interior de las instituciones. Cuando se trata de un espacio educativo, Vigo usufructuaba su condición de docente para introducir allí -tanto en la Facultad como en su cargo de profesor del Colegio Nacional- elementos discursivos y creativos que dieran cuenta de que había una realidad múltiple, es decir, diferenciada del orden dominante de percepción y de lectura del mundo.

\subsection{SERIE Y RITUALIZACIÓN}

Una vez que se han analizado los señalamientos realizados en el espacio público, resulta necesario realizar una caracterización más general de los mismos, teniendo en cuenta tanto lo expresado por el propio Vigo, como otras cualidades relevantes que surgieron de esta investigación.

Vigo escribió un texto en el que desarrolla una explicación acerca de los señalamientos:

Comencé aprovechando las creaciones no-artísticas, donde fundamentalmente prevalece el carácter 'funcional', al negar a los elementos los señalé desde el punto de vista estético - vía contemplación- buscando una nueva apertura en el arte.

Di primacía a los elementos que denunciaban el 'anonimato' de su creadorproyectista (...). Sus características han ido variando desde lo público (...) a lo íntimo (...); de carácter gráfico (...) y los que podrían clasificarse dentro de la teoría del 'Arte por correspondencia' (...).

Se puede apreciar a partir de la lectura anterior que la primitiva base de concreción de los 'señalamientos' ha ido sufriendo una metamorfosis de concepción y de elementos utilizados. (Vigo, "Señalamiento", c. 1974)

También publicó en la revista Ghost Dance los fundamentos de su programa en relación con estas acciones:

Por un lado, he querido que el creador vuelva al anonimato, y por otro lado, no quería que la obra sea considerada en sí misma un mero producto de consumo. Traté de variar los señalamientos en sus características e infundirlos con un cierto sabor poético. (Vigo, 1974: 2. Traducción nuestra) 
Se condensan en estos párrafos las intenciones de Vigo en la realización de los señalamientos. En primer lugar, dice que aprovechó "creaciones no artísticas” para ser señaladas, diferenciándose así de la idea general de obra de arte en términos clásicos. Aquello que señalan son lugares o elementos naturales o artificiales (Vigo, Biopsia 1973), a lo que podemos agregar acontecimientos y acciones.

Vigo ya había expresado desde el manifiesto del Señalamiento I, y lo repite aquí, que realiza una separación de la funcionalidad de los elementos que lo conforman para darles un lugar en la experiencia estética. En cuanto a la idea de anonimato de artista, como hemos visto en capítulo 1, puede relacionarse con la premisa de la participación. Así, un artista sin nombre, podría generar las condiciones necesarias para que el público se lanzara a tomar parte de la obra. Sin embargo, cabe preguntarse si esta autodefinición no evita reflexionar con mayor profundidad respecto de su propia posición como artista que parece ser más compleja, en tanto se conserva la "función-autor", como apuntamos antes. Esta idea -el anonimato-, además, forma parte de otro supuesto, que es la negativa a la mercantilización de la obra de arte. La idea del artista anónimo debe ser diferenciada del acto de negar la categoría de autor, ya que en el primer caso, no es el autor inexistente, sino aquel que está ausente y no puede ser identificado o nombrado.

Otra característica que se presenta es que la obra de cada señalamiento no puede materializarse en un objeto que pueda ser vendido o comprado -aunque sí presentado en una exposición, como se ha visto en los casos antes analizados.

Esto último hace referencia a una cualidad de los señalamientos que es su carácter efímero, dado que se trata de una acción. La efimeridad en el arte-que las vanguardias explotaron, especialmente desde la producción de happenings- opera como la función de teatro, donde la obra no es ni el texto dramático ni la puesta, sino, en rigor, cada función, ya que entre una y otra siempre hay diferencias irreductibles. Sin embargo, los objetos materiales utilizados en cada uno de los señalamientos -tarjetas con instrucciones, "souvenirs", votos, urnas, banderola- permanecen. No se trata de que los materiales sean efímeros en todos los casos, sino de lo finito de la acción y de la combinación (la puesta) de esos materiales en un lapso de tiempo. Esto otorgaría una particularidad a las acciones de Vigo, dado que si comparamos con uno de sus antecedentes más importantes, los vivo-dito de Greco prácticamente carecían de existencia material fuera del momento de su acción. La posibilidad de preservar los elementos utilizados en cada acción permitió a Vigo darle una existencia más o menos separada, ya que los presentaba en exposiciones posteriores como constancia del 
señalamiento que había realizado, o bien los reutilizaba, como el caso de la banderola. En este sentido, lo efímero de los señalamientos es relativo, aunque abona a la idea de no mercantilizar su producción creativa $\mathrm{y}$, en términos más generales, a la experimentación con objetos, actos y espacios, fuera de cualquier orden canónico del arte en relación con el concepto de "obra".

En noviembre de 1973 Vigo participó de una exposición de banderas, Festival of Flags, organizada por el Midland Group Gallery en Nottingahm, Inglaterra, donde envió la banderola que utilizaba para la realización de los señalamientos. Agregó al envío una explicación sobre el origen y utilización de la misma, de donde surge una de las claves para pensar los señalamientos como una ritualización de la práctica artística:

A partir de 1968 vengo realizando 'señalamientos' de distintos lugares y elementos naturales o modificatorios de la naturaleza. La acción tiene forma de ritual y a este ritual pertenecen una serie de elementos. Uno de los principales es la bandera de señalamiento cuya función es 'marcar' el lugar que se determina como campo de acción para el futuro desarrollo del 'señalamiento'. (...) [La] utilización de la bandera [funciona] como determinación del lugar geográfico donde transcurre la acción. (Vigo, Biopsia 1973).

Asimismo, en la descripción que hace del Señalamiento XIII, en el mismo año, Vigo se refiere a la puesta en posición de la banderola como un "ritual".

La cuestión de las constantes en su obra parece clara desde los comienzos de su carrera como artista. Ya había dicho unos años antes que se interesaba por las series o la repetición de elementos: la utilización de la madera es el caso más general, pero también menciona el uso de elementos como los agujeros, los números, la geometría, así como una "sistematización temática", dando como ejemplos los trabajos que realizó sobre la televisión (La Tribuna, 25/06/1968). Es decir que asume la reiteración de elementos como una característica particular de su poética. Luego, en más de una ocasión, menciona a los señalamientos como una serie ${ }^{81}$.

¿Qué es lo que convierte a los señalamientos en una serie y cuál es su particularidad? En las series debe haber un elemento o tema que se sostenga. Vigo explicaba para la

${ }^{81}$ Por ejemplo, se refiere a los señalamientos como una serie en una nota publicada en el El Día $(8 / 10 / 72)$. 
revista Ghost Dance: "Empleamos varios elementos que resultan 'constantes' en estas acciones como la banderola con la señal que ha aparecido desde el séptimo señalamiento -un 'paseo' visual por la Plaza Rubén Darío ${ }^{82}$ (...)- y constituye un tipo de 'código elemental' que indica un determinado lugar donde la acción tendrá lugar" (Vigo, 1974: 2. Traducción nuestra). Tenemos aquí una de las características diferenciadoras de los señalamientos: que se trata de una serie cuyo elemento constante es el empleo de una banderola, lo que constituye un "ritual" o "código elemental" repetitivo y que esta banderola tiene una flecha cuya función es la de indicar el lugar en el que llevará a cabo la acción, "fijarlo", dice Vigo (Biopsia 1974).

El uso de las flechas no es nuevo para Vigo: ya en 1966 en uno de sus grabados, Cafishio, aparecen flechas. Asimismo, el uso de la signografía en sus poesías visuales puede verse como parte de un mismo esquema de elementos a ser utilizados en distintas obras, con variados formatos y soportes. En ese sentido, resulta parte de la elaboración material de su poética -aún cuando se trate de poesías visuales- la búsqueda de elementos ajenos a la plástica pura -color, forma, etc.- como indicadores del desbordamiento de aquella.

Por otro lado, resulta interesante pensar en qué medida aquello que Vigo intenta quitarle a la obra de arte -su carácter "religioso, intocable y único" (Vigo, Ritmo, 1970) o, en términos de Benjamin (1989), el aura- se lo devuelve a través del ritual. Como si fuera necesario mantener algún aspecto de la obra de arte que permita calificarla como tal, la negación -en el discurso- de las categorías de autor, público pasivo, obra intocable se vuelve menos simple de lo que Vigo pretende si se da relevancia a la repetición del ritual como medida purificadora que oficie de remedio frente a la desnudez del hecho artístico desauratizado. A esto se suma que quien posee la banderola, la manipula y decide su ubicación es Vigo, lo que constituye un rasgo que fortalece la presencia del artista como autor y, esto último, asegura su condición de obra de arte. Sin embargo, esta relativización de la negación de la idea general de obra de arte, no implica ignorar los esfuerzos realizados por Vigo en desarticular sus elementos y los resultados singulares que alcanzó, sino pensar en el complejo de relaciones establecidas entre ellos que tienden a problematizar de un modo particular y situado la relación entre arte y sociedad o, en la fórmula de las vanguardias, "arte y vida".

\footnotetext{
${ }^{82}$ Aquí Vigo menciona a Un paseo visual... como el señalamiento VII, cuando se trata del número V.
} 


\section{5. "EL 'SEÑALAMIENTO' DESENCADENA, NO LIMITA"}

A modo de conclusión de este capítulo, presentaré algunas reflexiones que vinculan los casos analizados con el contexto artístico y sociopolítico más general, lo que permitirá arribar a una interpretación de los mismos en su conjunto. A fines de los '60 estas acciones en el espacio público se transformaron en parte de la construcción de un lugar que estaba vinculado a la protesta social, a la contestación al poder, tanto del Estado como de las instituciones y a la idea de autoridad en general, elementos que estaban vigentes en el discurso disruptivo de la década. La intervención en el espacio público a partir de acciones de tipo vanguardista, como las de Vigo, implica una forma de apropiación y sobresignificación del mismo, como modos de re-espacialización. Ese espacio se transforma en territorio de vinculación entre el arte y la calle, relación implicada en una de las consignas vigentes en la época y retomada de las vanguardias históricas, que sostenían que era necesario un acercamiento entre el arte y la vida a través de una ruptura de barreras que separaban a ambos. Así, las acciones artísticas allí situadas habilitan el traspaso de los límites que apartan las zonas de la creación y las de la vida cotidiana.

La relación entre creación, participación y espacio público se torna compleja si se tienen en cuenta algunas cuestiones: por un lado, en esa misma década, los museos y galerías iban ampliando la gama de obras aceptadas y promovían artistas de corrientes nuevas ${ }^{83}$, lo que generaba dentro de estas instituciones tensiones y disputas entre el discurso dominante que definía al autor, la obra y el público, y otro que pretendía involucrarse en los procesos de cambio que se estaban experimentando en el campo artístico. La otra cuestión es que las acciones en el espacio público permiten que el transeúnte común participe, o al menos se transforme en testigo imprevisto de un acto creativo; situación imposible en el museo que divide ambos espacios (el adentro y el afuera de la institución) como correlato de la división de esferas en la sociedad, típico de la modernidad. En este sentido, el museo, aún habiendo ampliado la aceptación de estilos, por su propia cualidad institucional, está separado del espacio de la circulación cotidiana, que es el de lo público en su conjunto. Un tercer aspecto, es que deben

\footnotetext{
${ }^{83}$ En el caso de La Plata, al mismo tiempo que comenzaban las acciones en el espacio público, el Museo Provincial de Bellas Artes había avalado exposiciones de artistas vanguardistas locales y de los miembros del Instituto Torcuato Di Tella (Suárez Guerrini, 2010).
} 
distinguirse las acciones artísticas en las instituciones y en el espacio público de acuerdo con una cualidad de este último: existe una diferencia material y simbólica entre la participación del público en una acción artística dentro del museo o del teatro y la que ocurre en un espacio no destinado a la acción artística, sino a la circulación, las acciones y comunicación públicas.

Aparece aquí, nuevamente, la idea de que el público debía cambiar su estatuto para pasar a tener un rol activo. Era convocado con el objetivo de que su participación fuese una experiencia completamente distinta a la del arte de las "elites". En este sentido, confluye con la idea de acercamiento al "pueblo" en tanto era un significante de uso extendido entre los proyectos políticos y militantes de la época, cuyos sentidos fueron pasando desde el pueblo peronista hasta una idea más amplia de "lo popular" como lo opuesto a la "burguesía". El arte asume también que se hace imprescindible realizar tipo de prácticas que impliquen el involucramiento del pueblo y esta intención -lograda o no- se veía como factible desde la utilización de nuevos espacios, especialmente el público, donde la presencia de los elementos específicos e institucionales fuesen anulados. Era especialmente en el espacio público donde el pueblo se había manifestado con la dictadura de Onganía y donde seguía expresando y visibilizando sus descontentos.

El público algunas veces acudía para participar de una invitación realizada por Vigo o por los medios de comunicación. Otras, se encontraba con una irrupción de la que no se había propuesto participar, se topaba con una intervención, es decir, con un corte de la pragmática rutinaria entre él y el espacio público, una nueva espacialización. Como afirma Berardi, "cambiar el orden de las expectativas es una de las principales transformaciones sociales que un movimiento puede producir: este cambio implica una transformación cultural, pero también un cambio en la sensibilidad, en la apertura del ser al mundo y a los demás." (Berardi, 2012: 5. Traducción nuestra). En esos casos en que el público era incorporado de improviso, operaba un carácter impuesto y no previsto ni buscado, en que algunos transeúntes resultaban hechos-parte en el mismo lugar físico de la espacialización convencional y conocido, puestos en una situación otra, es decir, en algo que no es el espacio público según lo conoce y usa, ni es el arte según el imaginario pre-vanguardista, situación en la que, además, se le propone que atraviese una experiencia estética en conexión con una manifestación artística y con los otros con quienes comparte el espacio público. 
El conjunto de las acciones artísticas analizadas contiene implicancias que se desprenden del modo particular en que en ellas se vinculan el espacio público y su politicidad y que actúan en dos niveles. En primer lugar, para la producción de estas acciones, Vigo proyectó su ubicación en ese lugar, de modo que los resultados de las mismas, debían estar en consonancia con esa planificación. La utilización de elementos como el semáforo, el monumento, la vereda, entrañan varios significados. Por un lado, de acuerdo con el tono de la época, la producción de obras con objetos previamente existentes, es decir, no creados materialmente por el artista y que tiene su origen en los ready-made de Duchamp, ponía en cuestión el género de las obras, la idea pieza artística y el rol del autor. Por otro lado, el uso de elementos urbanos, contenía la intención ya plasmada por el autor de desencajarlos del orden cotidiano compartido anónima y colectivamente, de producir un extrañamiento. Implicó, además, la conversión de esos objetos en otra cosa, cuyo mensaje, además de ser artístico, se convierte en político, a veces en consonancia con el tema tratado en las acciones y otras aún por fuera del mismo. Esto se debe a que la apropiación del espacio público y de sus elementos componentes, visibiliza la posibilidad de acción en un espacio en general vedado para la expresión libre, creativa o imprevista, lo que pone en cuestión esa misma imposibilidad. No solo los objetos concretos ubicados en el espacio, sino también los relatos -en los casos analizados: las instrucciones y explicaciones, el manifiesto- son en sí mismos "fabricaciones de espacio" (de Certeau, 2007: 134), formas de describir a través de los señalamientos qué es ese espacio y cómo puede ser utilizado, construido y reconstruido, en el sentido de que "los relatos 'marchan' delante de las prácticas sociales para abrirles un campo" (de Certeau, 2007: 138).

Lo que Vigo está expresando es que no solo se deshace de los cánones artísticos, de acuerdo a su posición vanguardista, sino que, además, la elección y ubicación deliberada de sus acciones contradice un orden político dominante que impone y mantiene un orden social y de usos del espacio público a través de una espacialización represiva. Cuando ocupa espacios y actúa sobre ellos, está desafiando las reglas de la institución arte que regulan los modos de producción, los materiales habilitados, los medios accesibles y los espacios de consagración. Pero, además, está proponiendo un modo de actuar sobre un proceso que, situado históricamente, aunque contenía rasgos de renovación social y cultural, era especialmente represivo.

En segundo lugar, las acciones analizadas implican una contra-construcción del espacio al distorsionar su uso común y cotidiano, oponiendo a las lógicas que determinan sus 
usos y funciones y a las reglas que condicionan la producción artística una ampliación de los márgenes de acción y representación posibles. Todo ello ocurre a través de acciones que más que situarse en el espacio, lo intervienen simbólica y materialmente, lo sobresignifican.

Esa intervención, lejos de concebirse como modificación directa de la vida de las personas o del mismo espacio, se plantea, para Vigo, como la posibilidad de "desencadenar" algo nuevo, en consonancia con lo analizado arriba sobre su idea de revulsión, opuesta a la de revolución. Vigo dice: "La no existencia de la obra, la no necesidad de estar presente, la efimeridad del estar, la posibilidad 'abierta' a concretar disímiles 'actos' a los propuestos nos convierte a todos en 'hacedores' (léase tradicionalmente 'creadores') de situaciones y no consumidores apriorísticamente digitados. El 'señalamiento' desencadena, no limita." (Vigo, "La calle: escenario del arte actual", 1971). En este fragmento, además ofrece una caracterización de los señalamientos, especialmente lo referido a la negación de la obra de arte, del artista y del público en su concepción clásica. El señalamiento puede desencadenar, como elemento liberador no solo del público, sino también del espacio, lo que Lefebvre llamó un "espacio de representación” (1991). Según ese autor, las resistencias que se sitúan en los espacios de representación se componen de elementos imaginarios y simbólicos. Oponen, por ello, a la homogeneización y racionalización, contra-espacios. Puede pensarse que el arte ocupa aquí un lugar particular, por ser uno de los lenguajes que posibilita la operación simbólica de la resistencia y que viene a formar parte de la relación compleja entre hegemonía y emergencia de nuevas representaciones.

En las prácticas aquí analizadas la ocupación del espacio público involucra, por una parte, la búsqueda de contacto con el espacio de lo público-popular, un acercamiento al "pueblo" que los sucesivos gobiernos desde 1955 venían clausurando; además, una vinculación con la idea más general de "la gente", que históricamente había estado alejada de la "alta cultura" elitista de las instituciones artísticas. Si "el espacio es la síntesis, siempre provisional y siempre renovada, de las contradicciones y de la dialéctica social" (Santos 2000: 90), la contradicción dictadura/pueblo se hace patente en el espacio público. La negación del pueblo por parte del gobierno dictatorial es puesta en cuestión a través de las acciones que hacen visible esa negación. Cuando la participación sobre la esfera pública se encontraba vedada de múltiples modos, que iban desde la prohibición de reuniones de personas con cualquier fin hasta la manifestación de ideas políticas, el debate sobre lo público no puede tener lugar en los modos 
habituales de un sistema democrático. Así, estas prácticas desbordan la autonomía de la esfera estética en relación con la pública, porque están inmersas en las luchas por el poder (Achugar, 1991) y, aunque como hemos apuntado antes, se trata de un momento político represivo, "el poder de los aparatos de reproducción ideológica nunca opera de modo absoluto y (...) funciona contradictoriamente", especialmente cuando aparecen prácticas discursivas que no están provistas por la tradición hegemónica (Achugar, 1991: 128). Este tipo de manifestaciones artísticas, al emplazarse en el espacio público, disrumpen el orden que prohíbe su utilización para la expresión libre y, al mismo tiempo, colocan a un arte que contacta con las rutinas cotidianas en otro espacio, afuera de las galerías y museos. Este proceso de doble ruptura, debe leerse especialmente en el contexto histórico tanto del campo artístico como de lo social-político en general. En relación al primero, si bien habían tenido lugar las primeras acciones artísticas en el espacio público en señal de protesta contra el régimen canónico de consagración de artistas y circulación de obras, situados en la ciudad de La Plata, las acciones analizadas, aparecen entre las primeras que cruzan ese borde que limita lo habilitado y lo no habilitado por la institución arte en esa década. Se distinguen del "arte público" cuyo objeto son los monumentos emplazados en el espacio público y que, al contrario de las acciones analizadas, son parte de la "representación del espacio" dominante y racionalizada. Además, las acciones de Vigo son pensadas y proyectadas para ser realizadas en el espacio público, lo que las diferencia de otras que puedan haber tenido lugar en el mismo, pero solo como un traslado de lo que fue producido para el museo o la galería. Es, entonces, la planificación deliberada de que ocurran en el espacio público otro de los aspectos que permite pensar en su potencialidad política de contraconstrucción de ese espacio.

Además de este, otros modos particulares en que se materializó la poética de Vigo, implicaron diversas formas de politicidad. Si aquí es el espacio y su re-espacialización lo que jugaron a favor de una poética de ruptura, veremos seguidamente que también los materiales lingüísticos y formales, dislocados, constituyeron elementos de producción disensual. 


\section{CAPÍTULO 3 \\ USOS Y DISLOCACIONES DEL DISCURSO JUDICIAL}

Se han visto en los capítulos anteriores los modos en que Vigo produjo acciones en el espacio público y se interesó por un arte en que ocupaban un lugar central la participación del público y la utilización de lugares desvinculados de los circuitos tradicionales de circulación y exposición. En esas acciones y manifestaciones artísticas, Vigo propuso tanto la transformación al interior del mundo del arte, en términos de tipo de obras, lugares asignados al autor y al espectador y los espacios utilizados, como una "revulsión" que fuese más allá de ese ámbito, ampliándose a la percepción y significación del espacio público.

Otra de las zonas de su obra que se ha considerado en esta investigación como clave para analizar su poética y que también tiene implicancias más allá del mundo artístico es la utilización del dispositivo judicial-administrativo en el arte. Se trata de procedimientos a los que Vigo recurrió repetidamente y que pueden ubicarse como otro de los aspectos de su poética en que emerge una relación con lo político y la política.

Consiste, por un lado, en un discurso escrito que incorpora elementos propios del lenguaje de las leyes, las disposiciones judiciales y burocráticas. Vigo lo utilizó tanto en su forma declarativa como probatoria, en la narración de los hechos y la constatación de las acciones. Por otro lado, se suma el uso que dio a elementos visuales de ese discurso, como son los sellos personales y fechadores. Asimismo, echó mano a una de las prácticas asociadas al derecho, pero específicamente al ejercicio de la escribanía, como el dar fe, la cual fue una de las formas más excéntricas del uso de este dispositivo por parte del artista.

\section{1. "PUEDO SER UN BURÓCRATA Y SIN EMBARGO SER LIBRE"}

Vigo trabajaba como empleado de los Tribunales Civiles, lo que no solo le dio un sostén económico, sino una materia que incorporaría en su poética para desnaturalizarla de su lugar original.

En su juventud había querido dedicarse a la aviación, razón por la cual se presentó en la Aeronáutica de Córdoba, pero no ingresó. Luego comenzó a trabajar como practicante en los Tribunales de La Plata. Un tiempo más tarde, cuando ya estaba establecido en su 
trabajo, le llegó una nota informándole que se había producido una vacante y que entraba en la Aeronáutica. Sin embargo, Vigo, que había sido un apasionado por los aviones, decidió rechazar la oferta y quedarse en los tribunales. Definió ese lugar de trabajo como un ambiente "muy lindo con gente particular, humanamente muy constructivo, me daban una lección permanente y yo estaba muy integrado", y en el que incluía desde los oficiales hasta el juez. Cuando rechazó la oferta de la aviación, explica que "ahí yo ya había encontrado la canalización, cosía expedientes, empezaba a mover expedientes, una cosa nueva en mi vida”. En su casa no había empleados administrativos, "yo no conocía el lenguaje, ni a través de historia, anécdotas o racconto de cosas, así que para mí era un deslumbramiento, estar en la oficia en tribunales, que es muy particular, que tiene características especiales, (...) me atrapó” (entrevistado por Curell, 1995).

En tribunales, el oficial de justicia Figueroa ("un tipo muy particular, con una gran cultura, le gustaba leer, le gustaban las Bellas Artes") veía a Vigo dibujar, hacer esquemas y le regaló un tomo de la obra del historiador del arte español Josep Pijoan ${ }^{84}$. Entusiasmado con el tema, Vigo decidió inscribirse en unos cursos nocturnos de Bellas Artes. Al año siguiente, dos compañeros de tribunales (Aramburu y Gioa), sin consultarle, lo anotaron en la carrera de la Escuela de Bellas Artes y hasta le pagaron la matrícula. Así, el comienzo de su relación formal con el arte se vinculó estrechamente con el mundo de la justicia, desde un regalo de un oficial, hasta la inscripción a instancias de sus compañeros de tribunales, lo fueron incentivando para el desarrollo de la actividad artística.

Yo rescato mucho de tribunales a nivel humanístico (...)", dice Vigo, "el abogado... que es un hipócrita para la sociedad (que a veces lo es), tiene también pegado un sentido humanista (...)”, [allí hay] "poetas, escritores, plásticos (...): tienen una especie de propensión al cine, o a hacer una lectura distinta; a indagar un poco más. Es interesante escuchar a un abogado, porque aparte del invento de teorías que necesariamente debe hacer para defender casos a veces indefendibles, tiene que trabajar con la ficción, eso a ellos les va dando un mundo muy particular, una visión muy particular, entonces lo encaran desde un punto de vista muy distinto del común de la gente (entrevistado por Curell, 1995).

\footnotetext{
${ }^{84}$ Posiblemente se refiera a Pijoan (1914).
} 
Ese conjunto de cosas a Vigo le entusiasmó: el sentido humanista, el gusto por las artes, la indagación, la inventiva de teorías y lo que llamó "ficción". Tenía largas charlas con abogados que le resultaban muy interesantes. Uno de ellos era Julio Sager con quien forjó una relación en el mundo del arte a través de la Pequeña Galería de Radio Universidad que dirigía y su programa de radio. Vigo comenta que en tribunales hablaba con él de diferentes temas, muchos relacionados con el arte, y que jamás el abogado le solicitó algo relativo a un expediente que estaba en sus manos ni mantuvieron una conversación sobre temas jurídicos, lo que significó para él una actitud de respeto admirable.

Según Vigo, el despacho de tribunales es "muy rico". Pero es "una noria", donde uno precisa tener charlas y allí hay tiempo para eso. "Planificaba el juego dentro de mi trabajo, (...) que se canalizaba por el diálogo, la conversación, totalmente fuera de contexto de lo que específicamente era tribunales" (entrevistado por Curell, 1995).

Resulta estimulante que seguido a este comentario, Vigo manifestara una crítica a la institución donde estudió arte, expresando una oposición entre ambos. En la Escuela de Bellas Artes, "los profesores no tenían pedagogía, no conocían los planes didácticos para verter sus conocimientos, había una falla en la comunicación”. Si bien destaca el nivel humano de la escuela, dice que los cinco años que estuvo en allí, le demandaron el mismo tiempo para "tener que olvidar" y así poder hacer lo que quería. De este modo, el "ambiente muy rico" de Tribunales se contrapone a "hacer tabla rasa" de lo que había aprendido en la Escuela.

Además de su trabajo de oficial de justicia, vivió de cerca la fundación de la Asociación Judicial Bonaerense ${ }^{85}$, en la fue un activista pero sin ocupar un cargo formal. Más tarde, a partir de 1980, se ligó más estrechamente con la revista que editaba la Asociación, En marcha, encargándose de una sección que se vinculaba con la xilografía. A fin de año la revista traía un grabado, la "xilografía finañera", que en el dorso tenía una biografía del artista y dentro de la revista una nota sobre el mismo (entrevistado por Curell, 1995). Así, las distintas oficinas se iban llenando de xilografías y algunos jueces y empleados hasta armaron sus colecciones a instancias de Vigo.

También participó de otras actividades, ya que cuando se constituyó el "Centro de Estudios de Derecho y Economía Internacional Dag Hammarskjold”, dedicado al “estudio, análisis e investigación de los problemas actuales que plantean las relaciones

${ }^{85}$ Fundada el 3 de junio de 1960. 
políticas, económicas y jurídicas en el ámbito internacional" (La Tribuna, 1967), en la designación de autoridades, Vigo ocupó el cargo de vocal.

[Es importante] la libertad que cada uno tuvo, somos beneficiados por estar en el camino de la creatividad. En ese momento no te jode nadie, sos libre, hasta rompés lo que no te gustó, sos hasta juez de lo tuyo... es impresionante. Puedo ser libre en mi taller, en mi lugar de trabajo, en mi escritorio, puedo ser un burócrata y sin embargo ser libre (Vigo, entrevistado por Curell, 1995).

Vigo estimaba el valor de la libertad creativa y sintió que en su trabajo de judicial, también podía ejercerla. La propuesta "revulsiva" en el arte, que pretendía modificar la mirada o la subjetividad desde un posicionamientos anti "burgués", parece contraponerse con el grado de integración que tuvo Vigo a la institución judicial -a pesar de su carácter aristocrático, dominante y garantista del orden social-, aunque el propio artista no demostrara contradicciones entre ambos mundos. En alguna medida, su estrecha vinculación con lo judicial le dio un anclaje tanto económico como social que, a juzgar por sus declaraciones, no generó antinomias. Sin embargo, fue tal vez esa misma adaptación lo que le permitió incorporar elementos y materialidades de lo judicial a su producción artística, que, con diversos matices, van desde la ironía hasta la crítica política.

No solo las relaciones que entabló con sus compañeros fueron gratificantes, también hizo de la oficina donde trabajaba $-y$ de otros despachos- un pequeño espacio de expresión: colgaba objetos y xilografías, los que convirtieron a ese lugar formal en un mundo de arte de vanguardia. Como apunta el artista Carlos Ginzburg

No solo Vigo judicializó su obra (...) sino que también realizó la operación opuesta. La oficina de Vigo en Tribunales, era un tema de comentario, de duda y de sorpresa para sus colegas: pues Vigo metía "obras" de arte (las suyas) en medio del papeleo legal, las cuales interferían (no sé cómo) con las operaciones burocráticas normales. Yo estuve una sola vez en Tribunales y mis recuerdos son muy vagos. Lo seguro, es que de una manera u otra, parasitó el discurso y los comportamientos judiciales, con el discurso y los comportamientos de su vanguardia artística (Ginzburg, comunicación personal, 2012)

En el mismo sentido, dice otro artista amigo, Juan Carlos Romero, que "la oficina estaba llena de obras. El juez era más loco que él, porque tenía toda la obra de él colgada en la oficina" (comunicación personal, 2013). 
Esa oficina, que, según su registro, tenía la forma de un hexágono, fue tan significativa que dio el nombre a una de sus revistas más importantes, Hexágono '71. ${ }^{86}$ Así, la apropiación de distintos aspectos del discurso judicial puede entenderse en el marco de esa idea de libertad, su trabajo en Tribunales, lejos de constreñirla y pesar de las contradicciones, se representó como una disposición a ensancharla.

\subsection{LENGUAJE TÉCNICO Y DISCURSO JUDICIAL}

Antes de adentrarnos en el uso que hizo Vigo del discurso judicial, es necesario precisar algunos conceptos y reseñar brevemente una de las teorías más acabadas y críticas en el análisis de este tipo de discurso, lo que otorgará una base teórica adecuada para el estudio empírico de nuestro caso y posibilitará una interpretación de orden sociológico que conjugue ambos aspectos -teoría y datos.

La primera cuestión a desarrollar aquí es el modo particular que adquiere el lenguaje utilizado en el mundo judicial. Se sabe que en el desenvolvimiento de las profesiones y saberes especializados se han desarrollado lenguajes "técnicos", "especiales" o "tecnolectos" propios de cada ámbito que, tomando como base el lenguaje natural, poseen formas y significados particulares. Éstos son apreciables a través del uso de formas lingüísticas tales como terminología, frases, formas verbales y tratamiento personal característicos. Así, han aparecido variedades de la lengua vinculadas con ámbitos sociales e institucionales y con tipos de relaciones interlocutivas: los “'lenguajes de especialidad' son las variedades que la lengua adopta cuando se la utiliza como un instrumento de comunicación formal y funcional entre especialistas de una materia determinada" (Etxebarría, 1997: 352).

Más allá de las clasificaciones posibles de estos lenguajes (por ejemplo, por el ámbito en: profesionales, técnicos, científicos; o bien por el código, la temática, el destinatario, etc.), lo que nos interesa es destacar que tienen un uso específico dentro de un ámbito particular, con el objetivo de favorecer la comunicación entre sus miembros, dando lugar a un texto especializado. Si bien es dable que se utilice para la comunicación con el público en general, en su función divulgativa (Sevilla y Sevilla, 2003), este no es su

\footnotetext{
${ }^{86}$ En uno de sus registros del archivo anotó: "Implantación en el 'Hexágono' -lugar del Poder Judicial donde trabaja- del objeto 'Suero antiletrado' (1970)”. (El subrayado es mío, Biopsia 1970)
} 
principal objetivo. Es decir que predomina un acuerdo entre emisor y receptor sobre una cierta unidad temática, así como la suposición de un mismo nivel de entendimiento de lo que se dice y de la forma en que se hace. En vistas a favorecer la comunicación, el uso de estos lenguajes se propone minimizar los riesgos de malos entendidos, limitando las posibilidades de ambigüedades, polisemia u otros aspectos abiertos de la lengua natural; así como reducir la necesidad de explicar a cada paso aquello que quiere expresarse. Esto ha dado lugar a los diferentes géneros en el lenguaje científico y técnico, los que se encuentran altamente estructurados y convencionalizados para su uso en una comunidad académica o profesional (Sevilla y Sevilla, 2003).

Las principales características de estos lenguajes son: la formalidad, el predominio de rasgos de neutralidad afectiva y de impersonalidad, la funcionalidad para lograr una comunicación más eficaz, la sintaxis controlada con una tendencia a la secuencia lógica, la concisión y precisión y finalmente, una preeminencia del canal escrito, dado que es el más regulado y con mayores garantías de rigor y permanencia (Etxebarría, 1997).

El lenguaje judicial es claramente uno de los casos de lenguajes especiales. Su uso, extendido al ámbito administrativo, ha dado lugar a lo que se ha llamado el "lenguaje jurídico-administrativo". Siguiendo a Prieto, se puede definir como aquel que "se encuentra presidido por las reglas de economía, seguridad y funcionalidad comunicativas", en el que predominan enunciados prescriptivos, impersonalidad, cortesía, cierta fraseología y formas estructurales como título, preámbulo, articulado, disposiciones adicionales, etc. (Etxebarría, 1997: 342).

Este lenguaje es uno de los que posee una tradición más antigua entre los lenguaje de especialidad - junto con el religioso- y ejemplo escrito de ello en el caso del latín es la Lex Duodecim Tabularum (Ley de las Doce Tablas) del siglo V a. C., llegando a su máximo desarrollo en el siglo XVIII en paralelo al de la administración pública. La necesidad de plasmar las normas en forma de lenguaje, la dependencia entre hecho jurídico y hecho lingüístico, ha sido admitida en la teoría jurídica. Es decir que al concebir el derecho como pautas obligatorias impuestas por las autoridades políticas está formado por un conjunto de normas estrechamente relacionadas con el lenguaje (Vernengo, 1996). Asimismo, estas pautas se han plasmado en el derecho escrito, positivo, por oposición al derecho natural o a las costumbres, en tanto las normas se encarnan en textos. 
Esta relación cercana entre norma y lenguaje ha dado lugar a diferentes teorías que van desde la identificación entre ambos hasta la necesaria diferenciación. ${ }^{87}$ Los debates que se han suscitado, centrados en la formulación de normas, la forma prescriptiva, el énfasis en su especificidad lógica o pragmática, exceden los temas de esta introducción, pero denotan la vinculación entre el mundo jurídico y el lenguaje, lo que ha generado corrientes de pensamiento elaboradas y estables. Así, un ejemplo de la importancia que tiene el lenguaje, además de estos importantes trabajos de la mano de la lingüística, es que se trata de uno de los temas introductorios más recurrentes para el inicio del estudio del derecho ${ }^{88}$.

El carácter predominantemente textual de este lenguaje ha hecho de la palabra escrita una herramienta fundamental para el ejercicio del derecho (Montolío y Samaniego, 2008). Una de las características de este lenguaje es el uso de latinismos y cultismos, lo que le ha dado una matriz arcaizante y estrechamente vinculada a lo ritual. Otra de ellas, el uso de modos verbales poco comunes así como formas sintácticas complejas y oraciones largas. Así, sus características fundamentales son: "amaneramiento", "opacidad", "falta de naturalidad" y "oscurantismo" (Cucatto, 2011: 6). Esas particularidades han hecho de este un lenguaje especialmente intrincado, con una sintaxis artificiosa y muchas veces poco clara ${ }^{89}$, lo que ha fortalecido su carácter de exclusividad en el ámbito judicial y una dificultad generalizada en la comunicación con el público en general. Esta característica será relevante para el análisis de las obras de Vigo que lo utilizan.

El lenguaje judicial-administrativo también puede entenderse como un discurso, especialmente centrado en el orden y el control social. De allí que Michel Foucault haya dedicado parte de su obra a su estudio. Si bien este autor lo ha analizado con otros fines, especialmente para la investigación de los cambios en las formas de búsqueda de la verdad, así como de las sanciones aplicadas (2008), también ha realizado un estudio del discurso en general (2012) que contiene elementos de importancia para nuestra

\footnotetext{
${ }^{87}$ Cfr. von Wright (1979), Kelsen (1974), Cossio (1947), Ross (1977), Soler (1969). Algunas de estas discusiones están recogidas en el artículo de Vernengo (1996).

${ }^{88}$ Véanse, por ejemplo, los programas de la materia Introducción al derecho de diferentes universidades. Uno de los libros clásicos utilizados por los estudiantes que se inician es de Guibourg, Ghigliani y Guarinoni (1984) cuya parte central está dedicada al lenguaje; o bien Carrió $(1979,1973)$.

${ }^{89}$ Montolío y López Samaniego (2008) desarrollan esta problemática y proponen cambios para superarla. También se realiza una propuesta para su modernización y normalización en el citado artículo de Etxebarría (1997).
} 
investigación. Lo que interesa aquí es que no se trata solo de un tipo de lenguaje especial entre otros, sino uno fundamentalmente utilizado como modo de control sobre las sociedades a través del tiempo. En primer lugar, esto se debe a que "en toda sociedad la producción del discurso está a la vez controlada, seleccionada y redistribuida por cierto número de procedimientos que tienen por función conjurar sus poderes y peligros, dominar el acontecimiento aleatorio y esquivar su pesada y temible materialidad" (Foucault, 2012: 14). En el mismo sentido, Rancière (2007) sostiene que el uso de la lengua está sometida a un orden que organiza, jerarquiza y autoriza quiénes pueden usarla y disponer de ella y quiénes no y que algunos usos fuera de esa organización son políticos porque ponen en cuestión la partición de lo sensible. Para Foucault (2012), en la sociedad hay procesos de exclusión externos e internos al discurso que limitan su uso fuera de los lugares e interlocutores apropiados, así como la aparición del azar y el acontecimiento en el mismo, lo que implicaría una ruptura con ese orden establecido ${ }^{90}$. Uno de los discursos que mejor expresa estos procesos de exclusión es el judicial, porque su constitución como discurso del control exagera las limitaciones a través de ritualizaciones, selección de autores autorizados, usos de terminología específica, etcétera.

Siguiendo a Foucault (2012), los procesos de exclusión externos son: en primer lugar, la prohibición sobre lo que se habla, cómo y quién lo hace; segundo, la separación y el rechazo (el aislamiento de loco que solo hace "ruido"); tercero, lo verdadero y lo falso, que se trata de una separación construida históricamente. En los procesos internos al discurso se encuentran el comentario como repetición y reforzamiento de lo dicho, el autor en tanto unidad de significaciones y las disciplinas con sus limitaciones temáticas y teóricas. Finalmente, hay otro grupo de procesos de exclusión centrados en los sujetos, las condiciones y formas de utilización del discurso: el ritual que establece ciertas condiciones para su realización, las sociedades de discursos, cerradas en la producción y difusión, las doctrinas que someten a los individuos y a los discursos mutuamente, la adecuación social, especialmente determinada por la educación.

Entre los procesos de exclusión, uno de los que se destacan para nuestro interés es el de la prohibición: "tabú del objeto, ritual de circunstancia, derecho exclusivo y privilegiado

\footnotetext{
${ }^{90}$ Coincidente con esto, Badiou dice que frente a un estado de situación algo queda fuera de la cuenta (es decir, de la organización del orden social), y es allí donde puede desatarse un acontecimiento, una interrupción de ese orden que genera una verdad y donde interviene el azar. El arte es uno de los cuatro lugares donde pueden producirse esos acontecimientos $(1998 ; 2004 ; 2009)$
} 
de sujeto que habla", es decir que "uno sabe que no tiene derecho a decirlo todo, que no se puede hablar de todo en cualquier circunstancia, que cualquiera, en fin, no puede hablar de cualquier cosa" (Foucault, 2012: 14). Esto denota que en el discurso se ponen en juego cuestiones de poder, lo que implica luchas por su apropiación. Otro grupo de procedimientos de exclusión de los discursos que nos interesa es el que limita a los sujetos y las circunstancias, dado que "se trata de determinar las condiciones de su utilización, de imponer a los individuos que los dicen cierto número de reglas y no permitir de esta forma el acceso a ellos a todo el mundo" (Foucault, 2012: 38-39). Dentro de ellos, el ritual cobra especial relevancia, ya que el discurso judicial es un caso claro de ese dominio: estipula la cualidad de los individuos que hablan, las formas, las circunstancias y la eficacia de las palabras. Una de la de las formas en que Vigo desvirtuó esos límites, es a través de la ironización de ese discurso, dado que al producir sentencias para las que utilizaba géneros, formas y materialidades comunes del mundo jurídico-administrativo, estaba burlándose de esas formalidades y rituales, y demostrando su contrario, la irracionalidad de su uso fuera del espacio "natural" de su utilización. Entendemos aquí que en el uso que le dio Vigo,

La ironía, la forma ética del excesivo poder de la lengua, es el infinito juego de palabras que juega para crear, alterar [disrupt] y enredar el significado. Un movimiento social, al final, debe usar la ironía como la insolvencia semiótica, como un mecanismo para desentrañar el lenguaje, la conducta y la acción desde los límites de la deuda simbólica.” (Berardi, 2012: 8. Traducción nuestra)

En la medida en que el discurso judicial debe atenerse a estas restricciones, su uso fuera de estos parámetros, descolocado de los sujetos, circunstancias, rituales, objetos pertinentes, hace de él un discurso mal-dicho, que, en lugar de repetirse y fijarse, como sucede con el comentario, se desgrana en el ámbito de una experiencia que lo separa de la normalidad. Veremos seguidamente cómo sucede en la poética de Vigo.

\subsection{LA JUSTICIA DESCENTRADA}

Además de su relación de pertenencia y de cierto encantamiento con el mundo judicial, Vigo utilizó elementos que provenían de aquél, un saber que había forjado en su práctica de oficial de justicia, la cercanía cotidiana con los expedientes, sus escritos, sus procedimientos. Conocía aspectos del discurso y de la práctica: una forma de proceder 
en el relato de las acciones, el uso de terminología específica y de algunos símbolos, como los sellos personales y fechadores, las constancias, los certificados, en fin, aspectos que denotan su existencia como un lenguaje especial, técnico. Decidió, entonces, hacer un uso particular de ellos, incorporarlos a la obra de arte.

Esa utilización que realizó Vigo pueden dividirse en dos grandes grupos: el primero, trabajos en los que prevalece la forma del discurso judicial; el segundo, los que hacen hincapié en el contenido, acercándose a una crítica al sistema judicial en sus aspectos más injustos. ${ }^{91}$ Esta clasificación esquemática no debe opacar que aún cuando los trabajos del primer grupo no siempre expresen una acusación al sistema judicial, la utilización descontextualizada, no autorizada o irónica de su lenguaje y sus formas materiales o visuales implica un modo de dislocación general y de ridiculización del funcionamiento de la estructura jurídica.

Como apunta Dolinko (2012b), en el primer número de Diagonal Cero Vigo colocó un texto de Macedonio Fernández, a quien admiraba y cuyos rasgos humorísticos que apuntaban a la ruptura de las convenciones en la escritura y su ubicación fuera de las instituciones más reconocidas, pueden presentarse como una identificación del plástico con el escritor. Además, la autora señala que en la biografía que incluyó en ese número, Vigo agregó que Macedonio había sido secretario de un juzgado, lo cual coincidía con su propio trabajo en Tribunales.

Las acciones realizadas por este artista tienen una particularidad: registraba por escrito o fotográficamente (o ambas cosas) cada paso que realizaba. Algunas veces incorporaba esos registros en distintas obras vinculadas entre sí y, además, formaba con esa documentación carpetas que archivaba cuidadosamente. Este proceso repetido en casi todos los casos, parece contrarrestar el carácter efímero de las acciones artísticas, resguardando un dato conservable que diera cuenta por la vía documental de la efectiva realización de esas acciones. Además de proteger la memoria de las acciones, Vigo le dio un carácter particular a ese registro, utilizando frases, palabras, sellos y procedimientos propios del ámbito judicial.

\footnotetext{
${ }^{91}$ Nota metodológica: es necesario aclarar que la descripción extensa y minuciosa de cada uno de los casos que sigue a este apartado responde al interés particular de mostrar que el conjunto de los trabajos de Vigo referidos al mundo judicial pueden conformar un objeto de estudio en sí mismo. Al ser éste el primer trabajo que los analiza en tal sentido y problematiza su relación con el resto de la obra de Vigo así como con lo social y político, se justifica tal detalle, seguido por el análisis, con el afán de demostrar su relevancia como parte constituyente y rasgo específico de su poética.
} 


\subsubsection{TERMINOLOGÍA, CERTIFICACIÓN Y PRUEBA}

Como se ha dicho en el apartado referido al lenguaje científico y técnico, los géneros constituyen formas comunicativas estandarizadas. En el discurso judicial, el certificado $^{92}$ es uno de ellos. Vigo hizo repetidos usos de ese género, especialmente a partir de 1970, que analizaremos seguidamente.

Ese año en el mencionado negocio Tomatti no solo presentó objetos y acciones o señalamientos, sino que también entregó un trabajo que llamó Certificado de mi nacimiento, el que además envió por vía postal a diversos destinatarios (imagen 42). Más tarde, se publicó traducido al inglés en Enflin Plot $\mathrm{n}^{\circ} 8$ editado en Canadá por Andrew Suknasky (octubre de 1971) y en el mismo mes del año siguiente, se expuso en la Midland Group Postal Exhibition en Nottingham, Inglaterra.

\footnotetext{
${ }^{92}$ En los términos jurídicos, la certificación es un "acto jurídico por medio del cual un funcionario público, en el ejercicio de su cargo, da fe de la existencia de un hecho, acto o calidad personal de alguien, que le consta de manera indubitable, por razón de su oficio. // Documento público, autorizado por persona competente, destinado a hacer constar la existencia de un hecho, acto o calidad, para que surtan los efectos jurídicos en cada caso correspondiente" (Alfaro Jiménez, 2012, s/p).
} 


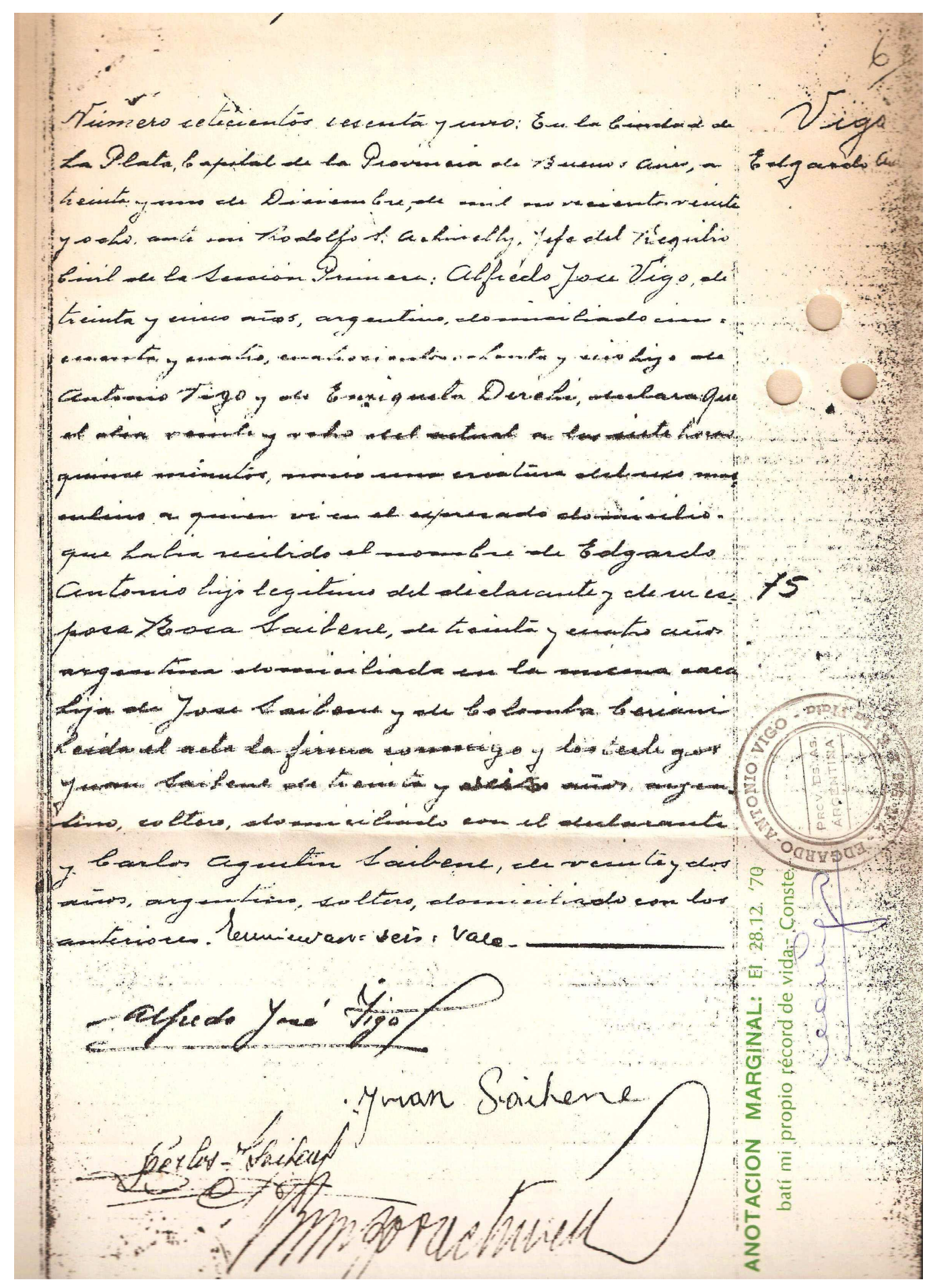

Imagen 42. Vigo, Certificado de mi nacimiento. 1970.

Tomó una copia de su certificado de nacimiento del Registro Civil de La Plata y en la parte derecha de la hoja, agregó con letras impresas en color verde: "Anotación 
marginal: el 28.12 '70 batí mi propio record de vida.- Conste."93 Debajo realizó una firma y colocó un sello con su nombre y otros datos. En la parte superior de la hoja realizó tres perforaciones circulares.

La contextualización de la introducción de esta obra ofrece un dato de la significación que puede adquirir. Ese día realizó en Tomatti la Presentación del (in) instrumento, basada en el Disco (in) sonoro que había producido el año anterior y en esa situación entregó el Certificado. Es decir que el uso de un certificado como obra de arte, muy cercano al gesto duchampiano, se revelaba en el mismo momento en que mostraba un (in) instrumento, es decir, un instrumento que no lo es: ambos se presentan como disfuncionales en relación con lo que son. En el primer caso, un certificado del registro civil puesto a circular no solo extraña por lo que dice: batir un record de vida, que por sí mismo suena irrisorio, tratándose de cuarenta y dos años de edad (y siempre que se cumpla años será su propio "record de vida"), sino también por la dislocación o alteración que significa un certificado fuera de los trámites legales y burocráticos. Asimismo, la firma y sello del artista identifican al certificado como una obra de arte firmada por su autor, es decir, lo convierten en objeto de arte y, al mismo tiempo, suma esa firma a las otras originalmente realizadas en la circunstancia de la confección del documento, localizándola como si fuera una que da validez a lo dicho, tanto como las demás. Sin embargo, de esta aparente congruencia, lo que emerge es su opuesto: frente a las firmas que certifican lo que se dice arriba, se encuentra la del artista que no tiene el mismo efecto jurídico -lesionando así uno de los principios de la firma en el derecho y su función como signo de veracidad- que apunta a una afirmación del texto sobreescrito, y a la intervención en el documento como obra. El sentido que tiene su firma incorporada extemporáneamente al documento pone en tensión la idea de obra firmada: por un lado, decimos que lo convierte en obra de arte porque quien le da ese estatuto es el propio artista (como autor, auctoritas), quien, además, la presenta en espacios vinculados al arte; por otro lado, recordemos que Vigo cuestiona -no sin vacilacionesla idea de autor único y consagrado, pero al mismo tiempo hace de su firma o de su nombre una marca identificatoria.

Otro aspecto que lo coloca en continuidad con sus trabajos previos es la perforación del papel, especialmente el uso de los círculos, interviniendo la materialidad de la hoja y

\footnotetext{
${ }^{93}$ Hasta poco tiempo antes de morir, Vigo continuó produciendo records de vida, aunque en formatos diferentes.
} 
transformando su superficie. Este es otro de los modos por la cuales Vigo deja una impronta de su autoría sobre el documento, provocando una distancia con la formalidad que se presenta.

Hay aquí, como en los casos que se analizan más abajo, una extracción de aspectos, formas, géneros de su lugar asignado en el normal funcionamiento del discurso, y una traslación o incorporación que desdeña las circunstancias y sujetos autorizados para manipularlo, así como los objetos que ese discurso designa.

El Señalamiento VIII, realizado entre 1970 y 1972 consistió en retirar un poco de agua del Río de la Plata, al año siguiente, devolverla al río y tomar cuatro muestras de una nueva toma. Según la descripción que realizó el propio artista, en la primera oportunidad había sumergido trescientas tarjetas en el agua, "a las que previamente había impreso un texto donde se certificaba que las mismas habían estado sumergidas durante un tiempo-horario determinado", seguido de su firma y sello (imagen 43). En el señalamiento, entonces, se devuelve la muestra del agua usada para sumergir esas tarjetas.

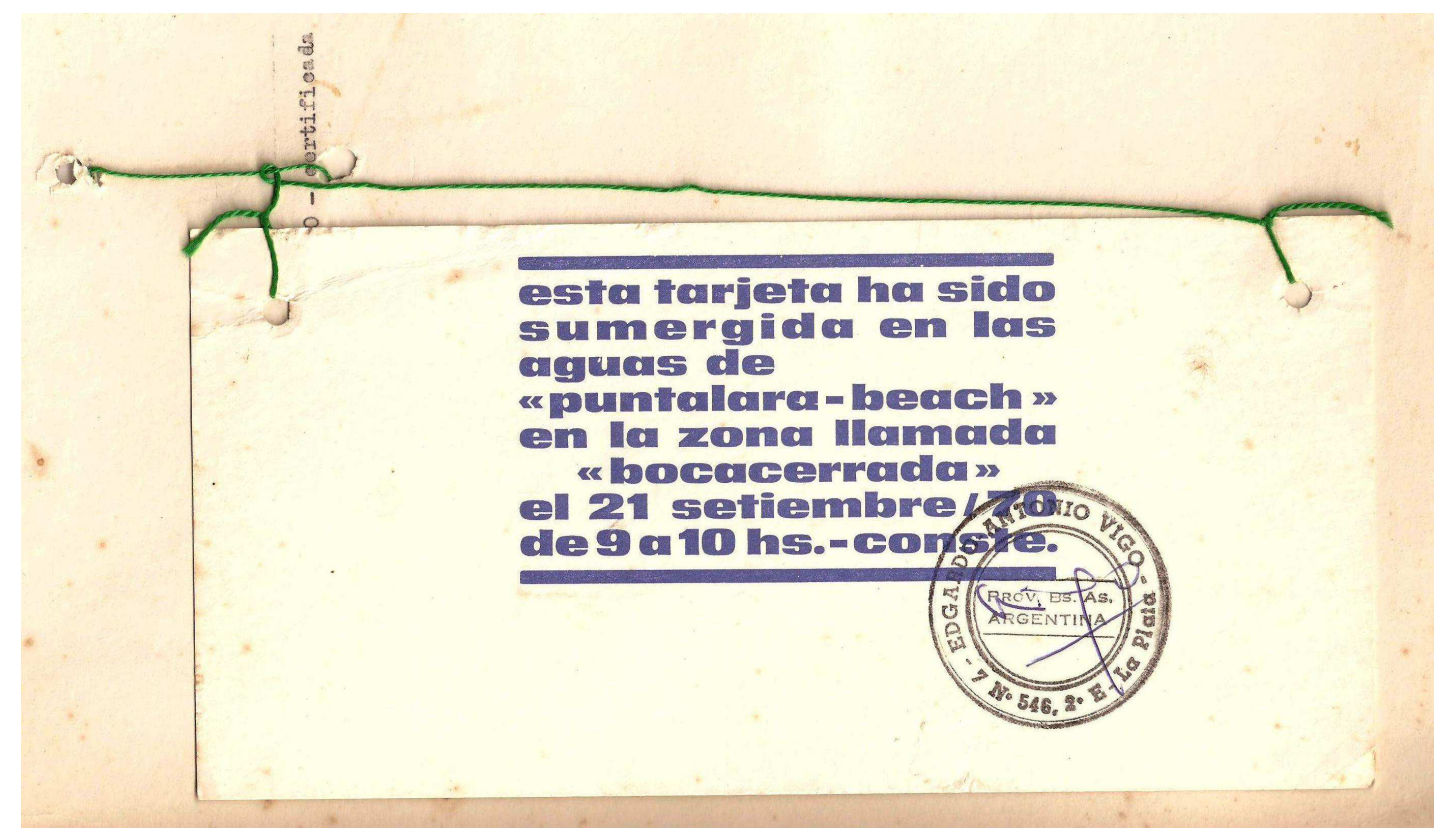

Imagen 43. Vigo, Señalamiento VIII. 1970.

El documento " $\mathrm{H}_{2} \mathrm{O}$ - Relato de la acción" (imagen 44) forma parte del señalamiento, y su título da señales de que recogió la frase que usualmente encabeza en el derecho a la 
descripción de una acción en un escrito legal. Luego, certifica la acción artística, utilizando un lenguaje que obedece al discurso judicial: "prosiguiendo con los actos", "procedî", "conjuntamente se acompaña", así como una descripción de las tareas realizadas, con un detalle de características y una organización temporal cronológica, que adecúan el texto al género de ese tipo de relatos en los escritos judiciales. Finalmente, utiliza un certificado oficial del Ministerio de Obras y Servicios Públicos, Secretaría de Comunicaciones, fechado, firmado y sellado, además de la impresión de un sello fechador.
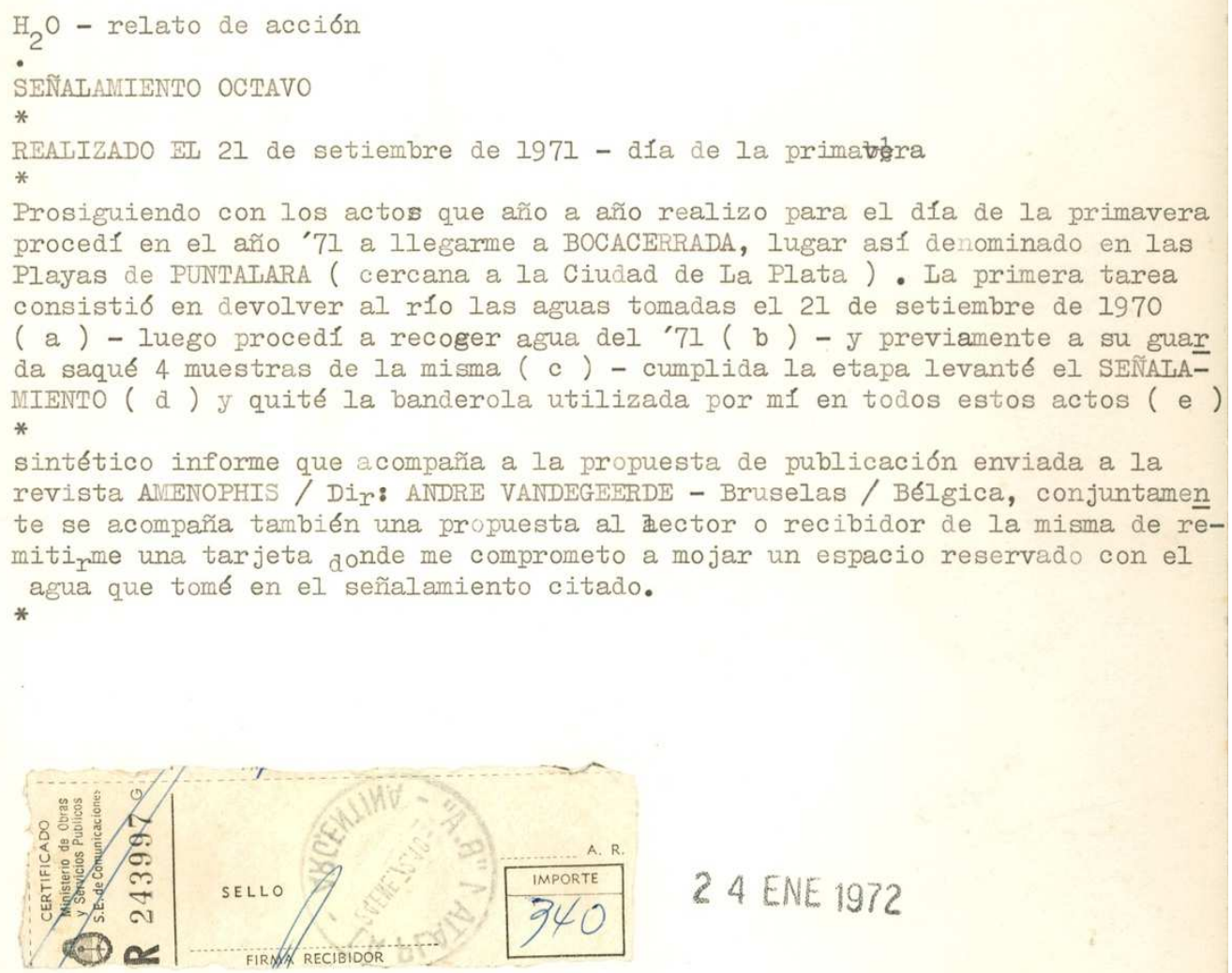

\section{ENE 1972}

Imagen 44. Vigo, Señalamiento VIII.

“ $\mathrm{H}_{2} \mathrm{O}$ - relato de la acción”. 1972.

Esta explicación se publicó en la revista belga Amenophis, en la que se agregó una tarjeta con un espacio especialmente reservado para que quien lo deseara, la enviara a Vigo y él lo mojaría con el agua del señalamiento como prueba de la acción realizada. Luego, la volvería a enviar al receptor de la revista (imagen 45). 
Si vous voulez avoir une PREUVE

de I'eau recueillie à cette

S I G N A L I S A T I O N 8ème

envoyez cette carte $\ddot{\mathrm{a}}$ : *EDGARDO-ANTONIO VIGO HEXAGONO '71

CASILLA DE CORREO 264

LA PLATA / PROV.Bs.As

REPUBLICA ARGENTINA

elle vous sera rétournbémouiliée

( au lieu choisie) avec I'eau

de cet ocassion .

Imagen 45. Vigo, Señalamiento VIII.

Tarjeta. 1972.

Hay aquí dos cuestiones: una certificación y un compromiso reglado. Vigo certifica la veracidad del acto realizado y al mismo tiempo se compromete a realizar otra acción: mojar con agua del señalamiento parte de una tarjeta que se constituye en una "preuve". En cuanto a la certificación, esta aparece de dos maneras. Por un lado, opera la decisión del artista de registrar de forma documental la acción a través del documento "Relato de la acción", y se expresa, por otro lado, la intención de hacer participar al público en otra etapa. Así, este señalamiento consta de varias fases: la primera es la acción propiamente dicha (el momento del señalamiento en sentido estricto); la segunda, la certificación; la tercera, apela a la participación del público y también consta de tres pasos: el envío de una propuesta por parte del artista a través de una revista, la devolución de una tarjeta del receptor al artista y el reenvío de la misma, mojada por el artista con el agua del señalamiento y transformada en una "prueba" de que esa acción efectivamente se produjo. 
Este "trámite" de tinte burocrático, con regulaciones precisas -tal como suele hacerlo el mundo estatal y especialmente judicial- invita al lector a intervenir en el proceso de la acción, apuntando a uno de los leit motiv de la poética de Vigo: la participación del público. Lograda o no, hay aquí al menos un involucramiento de otro que no es el propio artista en la producción del proceso de la obra. La publicación de este documento en una revista apela a la difusión de la acción que, sumada a la invitación a intervenir, implica un ofrecimiento de ese discurso judicial por fuera de los límites de su ámbito natural. Además, ese llamamiento a que cualquiera pueda ser parte de la constitución de una prueba también cuestiona las inclusiones, exclusiones y designación precisa de sujetos autorizados dentro del sistema judicial. Por otro lado, hacer constar este tipo de situaciones parece mostrar el sinsentido de algunas acciones judiciales y de la burocracia en general si se las considera de modo aislado -como en los casos en que las utiliza Vigo- y no como elementos del ritual judicial y de los procedimientos que le otorgan legitimidad, es decir, lo que las hace ser lo que son.

Casi veinte años más tarde, Vigo continuó realizando el mismo señalamiento (imagen 46) y produjo un "certificado" siguiendo el formato de ese tipo de documentos, dando datos rigurosos de lo que se certifica ("fragmento de una de las ocho hojas"), lugar ("Río de la Plata", "Boca Cerrada"), horario ("15 hs. 45' a 15 hs. 55"”) y fecha ("16 de junio de 1900;90"94).

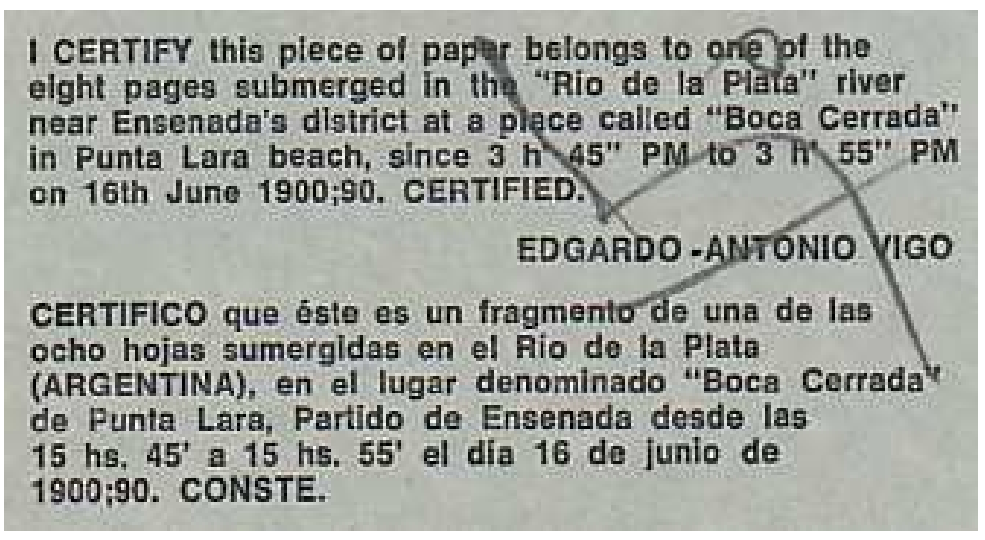

Imagen 46. Vigo, Señalamiento VIII. Certificado. 1990.

El texto, igual que el Certificado de mi nacimiento, finaliza con una palabra resonante en los expedientes judiciales, "conste" y su propia firma. Quien certifica en este caso la

\footnotetext{
${ }^{94}$ En la escritura del año, Vigo ha utilizado desde mediados de los cincuenta con frecuencia una forma particular: el año 1990 es escrito 1900;90. Del mismo modo, lo realiza con el nombre de las calles de la ciudad de La Plata. Es interesante apuntar que en el señalamiento, mientras utiliza el lenguaje judicial más o menos apropiado para un documento formal, en el caso del año, mantiene una marca de su producción en obras de arte y revistas.
} 
validez del contenido del documento es el propio artista. Si, como citábamos al pie, lo central del certificado es que está "autorizado por persona competente" (Alfaro Jiménez, 2012, s/p) la firma de Vigo o, como se verá más abajo, de otro artista o del receptor, se posiciona como elemento impropio e irónico que desajusta tanto el uso normalizado de este tipo de documentos, así como la recepción de un objeto que se presenta como obra y que, por lo tanto, no se espera de él ningún tipo de consecuencia legal (excepto, en el caso de obras de artistas reconocidos, la presencia de la firma como prueba de autoría que le da valor en tanto obra original y cuanto mercancía). Vigo pone en juego aquí estos tres problemas respecto de la firma que rondarán sus otras intervenciones sobre el dispositivo judicial. El nivel de detalle y exactitud excede la simple necesidad de registrar un episodio artístico efímero: Vigo decide dar la forma de documento judicial.

Asociadas a la revista que inició en el año 1971, Vigo produjo "ediciones" con el sello editorial "La Flaca grabada. Hexágono '71”. Una de ellas es el Informe 0’00A de la acción 200 llaves que viajaron de La Plata/Buenos Aires/La Plata, del que realizó una tirada de doscientos ejemplares. Vigo reunió doscientas llaves abrelatas y las transportó desde La Plata hacia Buenos Aires. Allí las llevó hasta al Di Tella, donde el artista Samuel Paz certificó la llegada de las llaves (imagen 47) y luego Vigo regresó a La Plata con ellas.

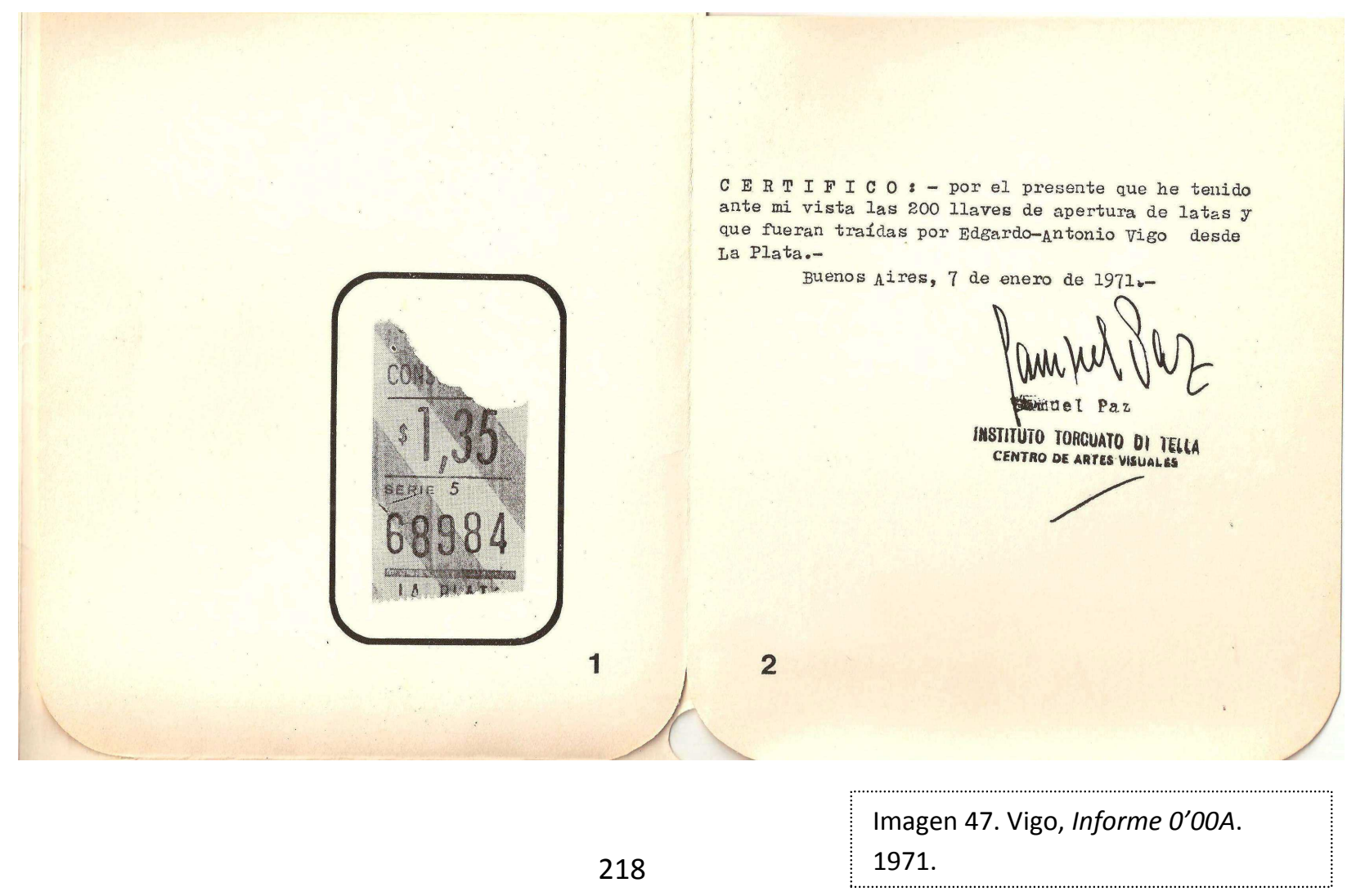


En el trayecto de ida y vuelta, así como en el encuentro con Samuel Paz, Vigo tomó nota de los datos y horas exactas en que ocurrieron los hechos, así como fotografías que lo "documentaron". Todo ello forma parte del Informe. Este es un tríptico que al cerrarse forma un sobre. En la primea solapa dice "Una llave / abrelatas que viajó (junto a 200) desde La Plata/Baires/La Plata en 7 de enero '71', la parte inferior de la solapa está troquelada con un cuarto de círculo. La parte central contiene, suelta, una tarjeta calada con semicírculos, un círculo y el mismo texto. También se encuentra una hoja perforada adosada con dos ganchos de la que cuelga, atada a un hilo, la llave (imagen 48). Al lado, con el número 1, "partida": presenta los datos de la salida (hora, medio de transporte, número de boleto, número de coche); continúa con el número 3 [sic], "documento": describe la foto que se tomó Vigo con las llaves en la Plaza San Martín, la hora en que fue tomada y dice, además, "hora controlada con el reloj de la Torre de los Ingleses; número 2: "certificación” hecha en el Instituto Di Tella por Samuel Paz y la hora correspondiente; número 4: "regreso", da los datos del colectivo, boleto y hora.

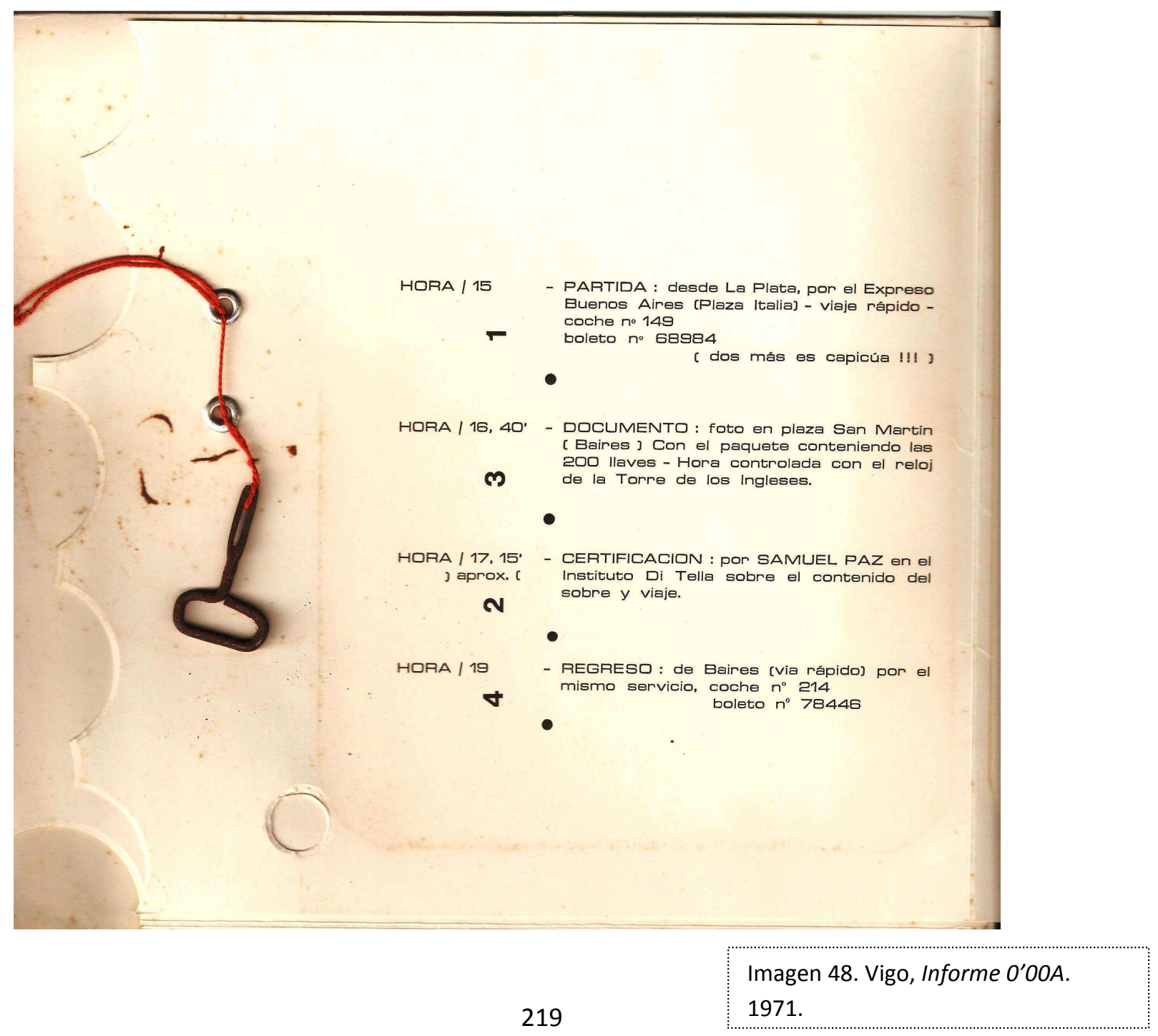


Unida a esta hoja se encuentra otra doblada en cuatro partes, también numeradas, con lo que conformarían las pruebas de lo expresado anteriormente: Número 1: copia del boleto de ida, 2: copia de la certificación, 3: foto de Vigo con las llaves en la Plaza, 4: copia del boleto de regreso. ${ }^{95}$

Tal como lo realizó con los señalamientos, presentó esta acción, es decir la información sobre la misma, la certificación y la prueba de la llave en diferentes ocasiones. Una de ellas fue en marzo de 1973, cuando la envió a Experimenta / 2 realizada en Madrid; otra, en el Poetiche - Festival Internazionale di poesía en Ivrea, Italia.

Vigo realizó una acción -el viaje de ida y vuelta con las doscientas llaves- que termina siendo solo una parte de la obra, ya que (en la forma en que la presenta en las exposiciones) el informe con su certificación, las pruebas ofrecidas, como el boleto y la foto, pasan a ocupar un lugar primordial. Aparecen nuevamente aspectos del discurso judicial, una narración organizada de las acciones, a la que se suma la información pormenorizada de estas y un conjunto de pruebas que aseguran la veracidad de lo relatado. Se advierte en esta obra la presencia de un tercer involucrado, un participante calificado que certifica la acción del viaje realizado por Vigo. La pertenencia a una institución de relevancia en el arte (visible por el uso del sello) y la cualidad de artista del firmante, dan mayor formalidad y credibilidad al uso del certificado (en comparación con una certificación realizada por el propio Vigo), al mismo tiempo que religan la obra y su certificación al mundo del arte.

Dos cuestiones del informe llaman la atención, la numeración no correlativa de los pasos que implicó la acción $(1,3,2,4)$, aunque los horarios en que ocurrieron sí están ordenados y el uso de los paréntesis en forma invertida, por ejemplo en ")aprox.(“. Como una forma de mantener restos de la poesía visual, en las que Vigo utilizaba letras y números dándoles un lugar que se aparta de su función normal, aparecen aquí señales de esos usos. Además, la desorganización de los números y la inversión de los paréntesis se ofrecen como disrupción en un informe que sobresale por la organización formal y el lenguaje técnico, dando cuenta de que se trata de un trabajo artístico y de que esos aspectos que lo asemejan a un documento judicial, solo se encuentran allí para demostrar -de un modo especial- una acción estética.

\footnotetext{
${ }^{95}$ La utilización de boletos no es nueva para Vigo, dado que ya había utilizado un boleto de tren como parte un collage publicado en $D R K W, B, 1960$.
} 
Los trabajos analizados muestran, por un lado, que por la cercanía que implicaba su trabajo diario, Vigo no solo conocía el léxico y las formas del discurso judicial sino que avanzó hasta su apropiación y los involucró en las obras. El uso de ese discurso se convierte así en un elemento ineludible de la conformación de estos trabajos, pasando a ser el aspecto central, tanto porque los textos (producidos en formato judicial) implican una referencia a un hecho que ya no es visible por haber sido efímero (y que Vigo creyó necesario demostrar y documentar), como porque en otros casos es el elemento constitutivo de la propia obra. En las manifestaciones efímeras, Vigo parece apelar en estos trabajos a la frase latina de uso corriente en los expedientes judiciales, y que forma parte de la lógica material de su funcionamiento: Quod no est in actis, non est in hoc mundo, refiriendo a que todo lo alegado y probado, debe constar en autos, de otro modo, no existe. ${ }^{96}$ La trasposición de una máxima de los expedientes a las obras y acciones, impone, nuevamente, un elemento externo y privativo de un uso específico al arte. Esto sucede, además, en una poética que presenta entre una de sus particularidades la proposición de la utilización de materiales "innobles" y la realización de "presentaciones". Esto último contradice o al menos tensiona la opción de probar, como en un caso judicial, la existencia de esos mismos hechos que se proponen distantes de las obras de arte tradicionales. O por el contrario, es por ese carácter vanguardista que se hace necesario, para Vigo, constatar al menos probatoriamente, su existencia. Aquí, como en la ritualización de los señalamientos, la permanencia de un elemento -en aquél caso: la banderola, la flecha; en este: la prueba o el certificado- devuelven simbólicamente la idea de que la obra está allí, tomó cuerpo, como una resistencia a la pérdida total de su entidad.

Por otro lado, el uso de las formas judiciales implica una intervención sobre lo social y político, dado que constituye una dislocación en tanto desubica o transporta modos propios de un ámbito cerrado hacia otro que se propone -al menos en el programa de Vigo- como abierto y disidente con el orden institucional y canónico de las Artes. El artista propone un choque entre ambos: justicia y vanguardia, certificación y sorpresa son elementos que se encuentran en modo conflictivo o controversial. Eso mismo apela a un efecto sobre la lectura y visión que, con la ironía sobre el medio utilizado -el judicial-, deja irresuelta la relación del espectador con lo que se le presenta. Mientras

\footnotetext{
96 "Lo que no consta en actas, no existe en este mundo": esta frase que sustenta la organización del discurso judicial escrito en los expedientes fue acuñada por Guillaume Durand en Speculum iudiciale en 1271.
} 
Vigo propone alejarse de los modos "burgueses" de las Bellas Artes (un arte preparado para un público elitista, una obra intocable, un artista único y un público pasivo), incorpora atributos y materialidad de uno de los espacios donde esa burguesía reconoce una extensión de su posición de poder.

En el Señalamiento IX Vigo enterró un taco de madera en el patio de su casa y al año siguiente lo desenterró ${ }^{97}$. Todo ello fue certificado no solo por la presencia de dos compañeros que llamó "testigos" (la escultora Graciela Gutiérrez Marx y el fotógrafo Estéves), sino por una escribana que formalmente realizó un acta de constatación de lo ocurrido y “protocolizó” las “actas labradas” en ambas acciones (imagen 49).

\footnotetext{
${ }^{97}$ Así como Vigo se encontraba inmerso e informado de un clima de renovación, experimentación vanguardista y crítica no sólo de Argentina sino también del mundo, en el marco de un programa que también apuntaba a desestabilizar las figuras del autor y las instituciones, Christian Boltanski había presentado en el Work in progress del American Center de París en octubre de 1969 la acción de cavar y enterrar estacas de color rosa, titulada Bâtons Roses. Ver DeRoo (2006).
} 


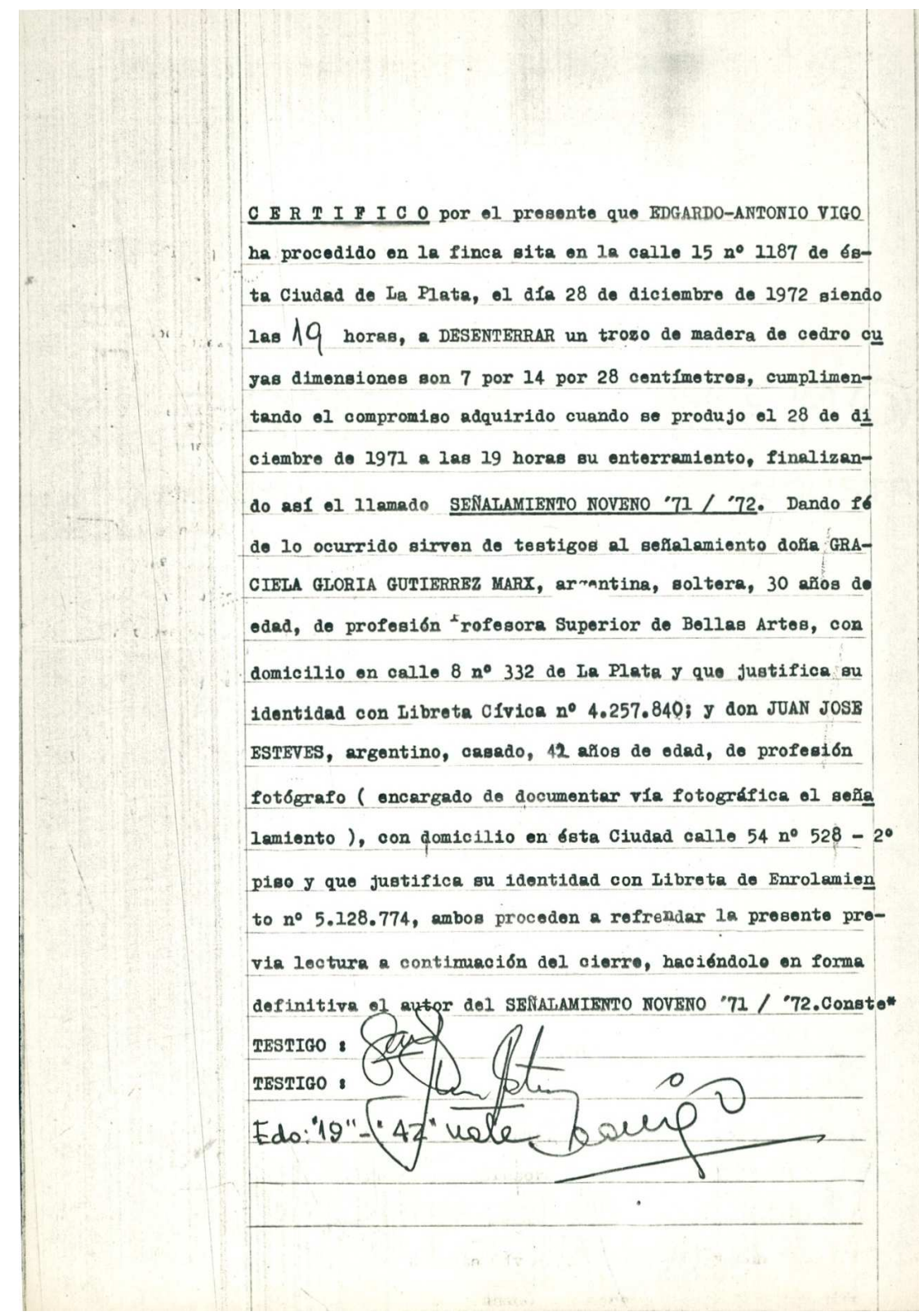

Imagen 49. Vigo, Señalamiento IX.

Acta de constatación. 1971.

Además de las acciones del señalamiento y la constatación por parte de la escribana, Vigo cortó setenta trozos del taco original con los que formó una edición de Múltiples acumulados. Produjo, además, un texto que narra lo realizado en el señalamiento. Allí, luego de explicar con tono administrativo el procedimiento seguido con el taco de madera (enterrado y luego desenterrado), aclara:

Nota 1: del taco de madera original se cortaron 70 trozos de aproximadamente 1.x.2.x.7. cmts. cada uno que se incluyen como testimonio en la presente edición de 'Múltiples acumulados'. 
Nota 2: las actas labradas en ambas acciones fueron protocolizadas ante la escribana Lucía Zulema Ruíz de Galarreta de de Cano bajo escritura pública número 20 de su Registro con fecha 12 de febrero de 1973. (Vigo, Señalamiento IX)

En este caso encontramos nuevamente indicadores de la apropiación del discurso judicial y el uso del término "testimonio" en el sentido que se le da en el orden de la práctica y el lenguaje de la escribanía, es decir una copia del original que queda en manos del escribano. Además, se presenta aquí la máxima configuración de la utilización de ese discurso en la acción artística: no solo la palabra y la imagen de ese lenguaje, sino el procedimiento y la acción concreta de un representante del estado, específicamente, un experto en procedimientos de dar fe que, según la doctrina del derecho, otorga validez y legalidad al acto, además de plasmar todo en un documento público que se convierte en indiscutible.

El uso del acta de constatación de la escribana en la obra de arte se vincula con lo que se ha caracterizado en el mundo judicial como "actos altamente ritualizados" (Montolío y López Samaniego, 2008: 43), en el que una persona investida de un poder delegado por el estado da "fe pública", objetivada a través de su firma en un "instrumento público".98 Así, un escribano da fe de que lo que se ha presentado delante suyo indudablemente ha ocurrido y tiene, por lo tanto, un valor legal pleno y absoluto. Esa ritualización que proviene de la antigüedad pero que llega a nuestros días a través del derecho romano con la idea de fides publica (Fernández de Buján, 2001) se ha realizado aquí con un sentido similar: la escribana da fe de que la acción Señalamiento IX se ha desarrollado delante de sus ojos, así como de los testigos que lo han presenciado. Sin embargo, el uso que dará Vigo a esta certificación no es el de presentarlo para la realización de algún trámite, sino demostrar que esa acción que se encuentra entre las que él mismo ha clasificado como "privadas" (por oposición a las realizadas con la presencia de público, analizadas en el capítulo anterior) efectivamente ha ocurrido. Así, lo efímero de la acción que constituye su sustancia, queda atenuado por el registro fehaciente de su

\footnotetext{
${ }^{98}$ En el acta de constatación, el escribano da "fe de conocimiento" de las personas participantes del hecho o acto jurídico certificado, luego de ello otorga "fe pública" sobre la efectiva realización del mismo, y lo convierte en una "verdad". Asimismo, también otorga "fecha cierta" al acto realizado, es decir que afirma que éste se realizó ese día en ese lugar. Tal es la "verdad" que emana de ese documento que la única manera de atacar el instrumento suscripto es a través de un proceso judicial de "redargución de falsedad" (Couture, 1954). En el caso de Vigo, se han cumplido todos estos pasos.
} 
existencia. Esto permite no solo reforzar la acción frente a otros, sino dar brindar una objetivación más prolongada en el tiempo y mostrarla en diferentes ocasiones. La presencia de una escribana y la veracidad del acto legal (dado que todo ello podría haberse realizado sin la figura de un funcionario real), constituyen el caso más extremo de dislocación de la práctica jurídica. La aplicación de un proceso que posee un alto valor (en su ámbito específico) a una acción artística aparece así como una burla hacia los procedimientos judiciales y una demostración de su ineficacia o insensatez. Asimismo, también ironiza sobre la función del artista, que se ve necesitado de tal suceso para constatar que ha realizado un señalamiento, el cual, a diferencia de las obras de arte tradicionales, no puede ser captado como hecho artístico fuera del momento de su realización.

El texto incluido en cada Múltiple acumulado (que se da al público junto con cada trozo cortado del taco original), también mantiene elementos del discurso formal judicial y allí se informa sobre el registro que realizó la escribana sobre el señalamiento (imagen 50). Cada uno de los que recibe el trozo de madera que formó parte de la acción, adquiere la "prueba" de que ese señalamiento consecuentemente se realizó y que el trozo pertenece a ese taco inicialmente enterrado. Para demostrar todo ello, Vigo incluye este texto que quedará en manos de cada receptor: 
En este documento aparecen elementos discursivos similares a los mencionados arriba en cuanto a la forma de descripción, información brindada, formas verbales y palabras especiales. Como en el caso de la llave, va adjunto el objeto que formó parte de la obra oficiando de prueba concreta y la frase "El trozo que recibes ha sido cortado de la madera original" declara esa función. Sin embargo, a diferencia de la llave, el trozo se entrega a cada uno, asemejándose a la operatoria intentada desde la revista Amenophis para que el público tuviera su prueba en la mano. En el caso del trozo de madera ya no es necesario que este lo solicite, sino que va entregado directamente por el artista, lo cual lo ubica en un lugar más estático que participativo, pero asegura su recepción.

En un proyecto presentado por Vigo al año siguiente para mostrar este señalamiento, además de las "actas protocolizadas" ofrece "doce fotografías que documentan en una serie de seis cada una, las dos acciones desarrolladas" (Vigo, Biopsia 1973). Es decir que a la certificación formal de la escribana, se suman las fotos tomadas en ambas ocasiones como medio de prueba. Aparece aquí, como en otras acciones, la idea de que además de certificar, es posible probar las acciones.

Otros artistas, especialmente aquellos ligados al conceptualismo, también utilizaban dispositivos textuales similares para la producción artística, a través de la elaboración de declaraciones o información documental que se ofrecían a la audiencia en reemplazo del objeto artístico, como parte de la "desmaterialización”. Entre ellos, Yves Klein entregaba "certificados" de su "sensibilidad artística" a orillas del Sena en 1962 y Sol LeWitt produjo en 1970 un documento que "certificaba" la existencia de uno de sus wall drawing y describía sus partes. En el caso de Vigo, las prácticas que venimos analizando se asociaban a esta tendencia conceptual, aunque se particularizan fundamentalmente por los modos en que las combinó con su pertenencia al mundo judicial y porque el objeto artístico no estaba completamente "desmaterializado", sino que -como él mismo señaló en sus diferencias con el conceptualismo- también existía como objetivación de la idea. Además, el uso que hizo Vigo de estos dispositivos, implicó también a la materialidad y al uso de otros elementos como los sellos e hilos, que veremos más adelante. Además, la sistematicidad y repetición con que utilizó los géneros, fórmulas y terminología del discurso judicial y la presencia misma de los objetos a los que hacía referencia, no siempre reemplazados por la palabra aunque en estrecha vinculación con ella, otorgan un rasgo específico a sus trabajos. 
En 1972 el canadiense Andy Suknaski creó la propuesta Barrilete / Poema para realizar en tres países, por la que él mismo en Vancouver, Pedro Xisto en Tokio y Vigo en La Plata, remontarían un barrilete el día domingo 24 de diciembre de 1972 a la misma hora, según sus husos horarios. De acuerdo con el diario platense, los barriletes forman el poema visual con la palabra "pena", refiriéndose a la situación actual del mundo. Así, Vigo colocaba la $p$ y la $n$, Suknaski la $a$ y Xisto la $e$ (El Día, 23/12/72). Sin embargo, Vigo decidió modificar la propuesta ya que agregó dos globos inflados con helio y un sobre plástico que contenía una ficha.

Así, el barrilete montado por Vigo, además de las letras acordadas con los otros artistas, contenía un texto escrito en español en el que explicaba la propuesta de remontar el barrilete y mencionaba que su creador era Andy Suknaski, adjuntando además dos recortes de diarios: "El barrilete de Vigo", publicado en El Argentino (23/12/1972) y "La Plata participará de una experiencia el domingo: significado", en El Día, (22/12/1972) sobre su realización. Agregó en el sobre un tarjetón en el que había que completar los datos personales de quien reciba el barrilete y solicitaba enviarlo devuelta a Vigo. Dice: "lo que se pretende es que el receptor del presente luego de llenar los tarjetones que contiene cada sobre con los datos ahí pedidos, proceda a remitir conjuntamente cada uno de los sobres con cada uno de los tarjetones", con un lenguaje ("proceda a remitir conjuntamente") y una sintaxis específicos de ámbito jurídico que poco tienen que ver con una invitación artística de participación. Finaliza: "esa certificación es importante porque es el fundamento de la experiencia”. Pide, además, si es posible "documentar" por medio de fotografías y otros medios el lugar en que se ha encontrado. Finalmente, coloca los nombres de los tres artistas a modo de firma (Vigo, Biopsia 1972)

El tarjetón para completar está adosado a un sobre con la dirección postal del destinatario, Vigo (imagen 51). En la parte inferior tiene calado un semicírculo. Comienza con la frase "Certifico por la presente que yo..." y finaliza "Conste"; debajo debe ser colocada la firma del receptor. Es decir que reúne los elementos adecuados para un certificado válido en términos legales, utiliza la frase propia del lenguaje especial, ofrece los espacios para que el que certifica pueda colocar sus datos personales y remata, nuevamente, con un término asociado a las disposiciones judiciales, lo que refuerza no solo la apropiación de ese lenguaje, sino un conocimiento de la función de esos significantes en su contexto. 


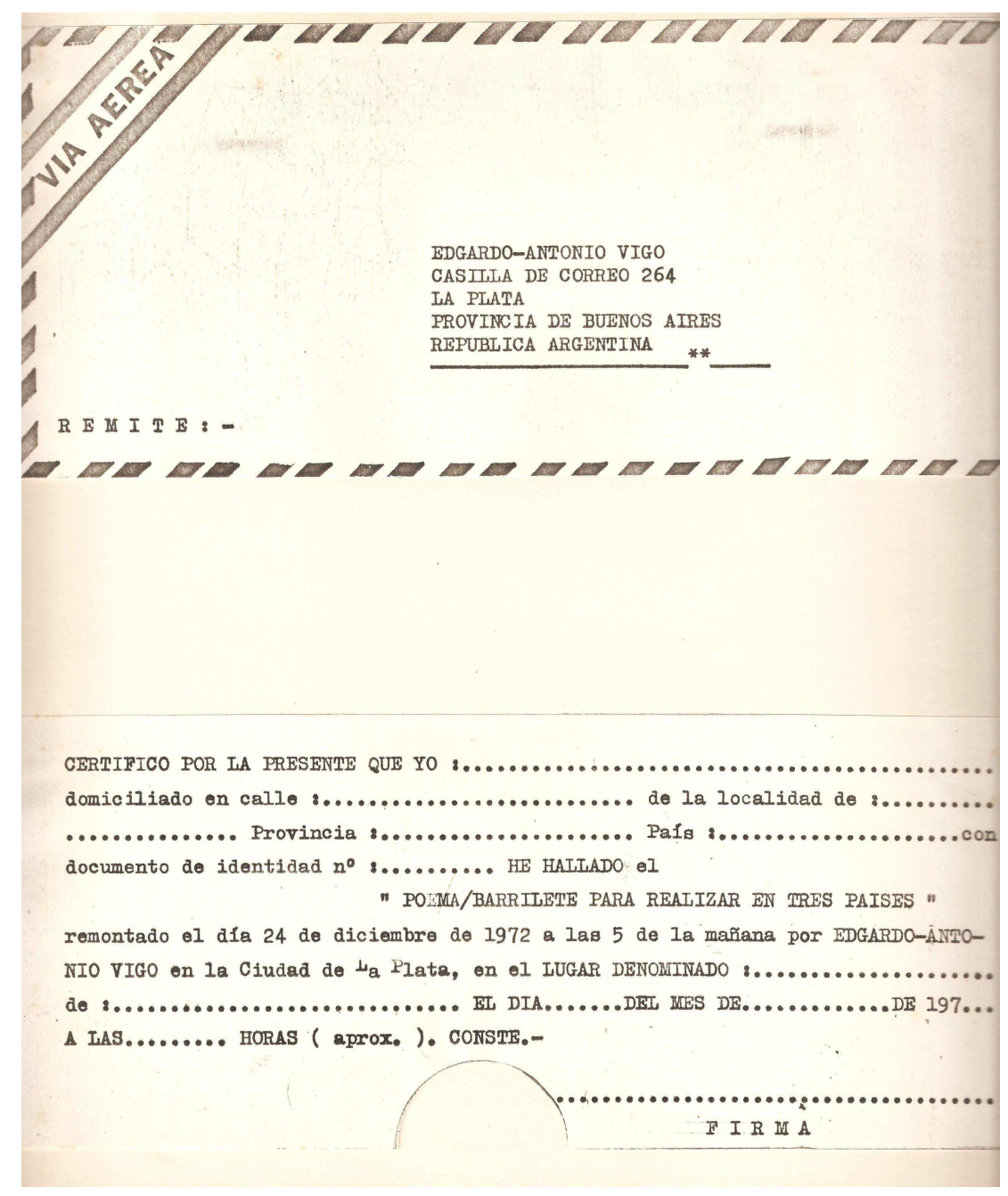

Imagen 51. Vigo, Barrilete / Poema para realizar en tres países. Sobre y tarjeta. 1972.

La idea de que la certificación es el "fundamento" de la experiencia desvirtúa la intención de su autor primigenio que, según el diario, era hacer referencia a la situación mundial como una "pena". Vigo más que un agregado, convierte la acción en otra, hace parte al receptor del barrilete y lo invita -con un acotado margen de libertad- a culminar la obra. Al mismo tiempo, con esa acción, también lo hace partícipe de un acto legal, es decir que además de la propia utilización de Vigo del discurso judicial, hace que el público se convierta en productor de dos acciones de tipo jurídico: certificar y probar. Asimismo, al colocar en la tarjeta los dos recortes de diario que explican el contenido de la acción en los tres países, ofrece pruebas de la veracidad de la propuesta. Como se ve, la lógica del funcionamiento judicial, la inclusión de datos personales, la certificación, la prueba, las frases hechas, la terminología y la sintaxis inundan la acción, sobresignificando y dislocando el discurso. 
Con características semejantes a este trabajo, Viaje de esta tarjeta postal, de enero de 1975, también hace uso del medio postal y, lo que interesa aquí, expresa la necesidad de certificación de un hecho (imagen 52). Cuarenta y cuatro postales fueron entregadas a diferentes destinatarios, los que debían adosar en un recuadro especial algún objeto (boletos de colectivo o metro, estampillas, etcétera) "representativo" y remitirlas a Vigo. La indicación finaliza "la fecha de salida, de la obliteración postal y de llegada, certificarán el viaje de esta tarjeta postal” (Vigo, Biopsia 1975).

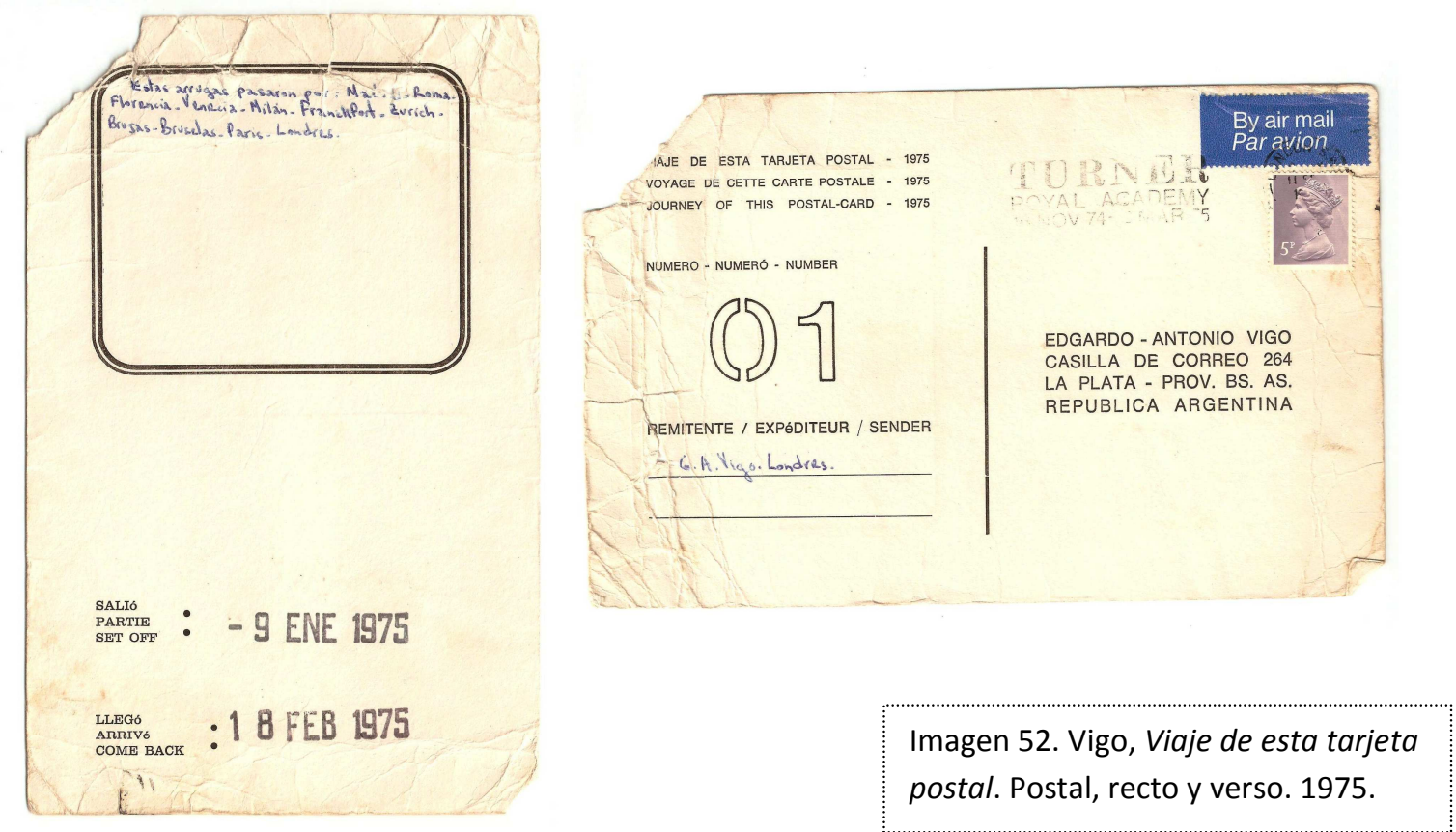

Se evidencia aquí una forma del procedimiento administrativo que certifica las fechas de entrada y salida de un documento y que Vigo realiza, además, con un instrumento típico de esas prácticas, el sello fechador. Así, la salida de la tarjeta postal, como si fuera la entrada de un documento al proceso judicial o administrativo, queda fijada en el sello que imprime la fecha, y lo mismo sucede con su llegada (retorno). En la práctica tribunalicia, cuando se entrega en Mesa de entradas un documento para ser incorporado al expediente, se le aplica un sello con la fecha para dejar constancia del día en que fue realizado. Se llama "cargo" a ese acto procesal que resulta imprescindible para que el documento continúe su tránsito. Vigo se apropia aquí de ese procedimiento y de la imagen visual que resulta de él, acentuándolo al sostener que las fechas “certificarán el viaje". A ello se suma el pedido (realizado al receptor) de incorporar un elemento "representativo", el cual oficia también como prueba de la realización de la acción por 
parte del receptor. Es decir que por un lado, Vigo certifica la fechas, y por el otro, involucra nuevamente al público en la participación a través de un acto que posee características de mundo judicial, probando los lugares por lo que atravesó la tarjeta postal.

En cuando al uso de los sellos en su poética temprana, Vigo explicó:

Hacia 1960 realicé unas series de "composiciones poéticas" utilizando sellos de goma que tenía en la oficina donde trabajaba. Como podrán imaginar aquellos sellos no tenían inscripciones poéticas, pero de alguna manera aquellos sellos me permitieron descubrir el "espacio poético". Es decir, era una manera de liberarse desde una página como un "espacio real", haciendo un libre uso de ella (la página) como soporte de un poema. Además realicé una serie de textos irónicos donde cada palabra (a veces con un artículo) formaba un largo texto escrito en sentido vertical y otras veces colocaba unas cuantas palabras fuera de esta columna para añadir algo de movimiento en la composición visual. (Vigo en Janssen, 1997).

En este párrafo, Vigo no solo implica directamente el uso de los sellos con su actividad laboral, sino que señala que los aprovechó para un uso plástico, claramente desvinculado de su función primordial, la de dar cuenta de un proceso administrativo. Es posible encontrar aquí una familiaridad con el objetivo que expresó en el primer señalamiento en tanto se proponía des-funcionalizar al semáforo para convertirlo en un objeto que brinde goce estético y que provocara un extrañamiento respecto de su normal statu quo. En este caso, el sellado aparece también disyunto respecto de su uso corriente. Más tarde, en el período de nuestro estudio, su aplicación en obras de arte como modo de certificar una acción o de formalizar una firma, excede al uso compositivo plástico para ponerlo a circular como presentación formal pero dislocado de su lugar convencional y funcional.

En el año 1973 presentó cuatro proyectos conjuntos para realizar una muestra de acciones realizadas por él en el Museo de Arte Moderno (MAM). Si bien cada uno de ellos aborda una temática diferente, los cuatro coinciden en que tienen como elemento común la certificación de las acciones realizadas. El primero, ya analizado arriba, presenta el Señalamiento IX, con las actas protocolizadas por la escribana y las doce fotos como prueba de haber realizado las acciones de enterrar y desenterrar un taco de madera. El segundo, Objetivación de la contemplación, según su proyecto, se trataba de "preparar una caja de, aproximadamente, 0.80 de alto por 0.60 de ancho por $1 \mathrm{~m}$. de 
largo, entintada de negro y en la cual se ha pintado de color blanco una cruz no geométrica. Un cartel que se cambia todos los días, indica la fecha de la jornada correspondiente. Todo esto se acompaña con la publicación de un 'souvenir' cuyo texto es el siguiente:

'Hoy: (sello de goma fechador) estuve mirando esta cruz'

MAM, mes de agosto '73 - Vigo

Objetivación de la contemplación" (Vigo, Biopsia 1973)

El tercero, Tierras latinoamericanas era un proyecto que constaba de tres etapas. En la primera, aproximadamente durante siete días, se presentan en recipientes iguales tierras de distintos países latinoamericanos, con un gran recipiente adelante. En la segunda, "proceder" a juntar las tierras en el gran recipiente y mezclarlas. En la última, "repartir en forma de 'souvenir' un tarjetón que señale la mezcla de tierras de los distintos países y que, a su vez, contenga en saquitos transparentes testimonio de esa mezcla." (Vigo, Biopsia 1973).

El cuarto proyecto, llamado Comunicaciones febrero '73, consistía en presentar sobres de correspondencia recibida por Vigo durante el mes de febrero, clasificándolas por día, impreso o epístola, naciones, continentes. "Cada pieza-postal está acompañada por un membrete especial, impreso para correspondencia del año 1973. Previamente a la exposición el MAM deberá dejar debidamente certificado y bajo constancia de su Director que cada una de estas piezas han sido expuestas para la ocasión testimoniando el día de apertura de la muestra, como su cierre." (Vigo, Biopsia 1973).

Las palabras y formas que aparecen en estos proyectos vuelven a vincularse con la terminología del lenguaje técnico: "certificar", "prueba", "actas protocolizadas", “escribana”, "se acompaña”, "sello de goma fechador”, “proceder”, “testimonio”, “bajo constancia”. La necesidad de intensificar la existencia verdadera de las acciones, vinculada con una práctica conceptualista a hacer uso de la expresión lingüística, es expresada por Vigo en forma de actos y lenguaje jurídicos. Si bien, como se decía arriba, las temáticas de estos proyectos son diferentes, encontramos aquí una referencia ineludible al ámbito de su propio trabajo como empleado. En el segundo proyecto, la forma en que se "objetiva" la "contemplación" se produce por el pasaje de la acción a lo escrito, y esto se concreta a través de la impronta de la datación, producida por el sello fechador. En el tercero, funciona la idea de prueba a través de los "souvenirs" de las tierras mezcladas y de la obtención de saquitos con una muestra de esas tierras para que el público pudiera obtener sus propias pruebas. En el último, se destaca la idea de un 
membrete especial como el que suele colocarse en la parte superior de los documentos administrativos, la certificación de las piezas a ser expuestas, en este caso, realizada por el museo como institución y en la figura de su director, y las fechas de apertura y cierre de la muestra.

El Señalamiento XIII, denominado La contemplación, que Vigo realizó el 21 de septiembre de 1974, consistió en marcar los cuatro puntos cardinales en un círculo trazado en la arena de la playa Bocacerrada, ubicada en Punta Lara y señalar el espacio en que se realizó la acción con la banderola. Además, arrojó una botella al río conteniendo una poesía visual de Daniel Culla. Agregó allí un pedido de contestación a Vigo y a Culla por parte de quien encontrara la botella, el que además debía enviar una foto como "documentación” (imagen 53). Asimismo, también Vigo hizo fotografiar “documentar fotográficamente", dice- todo el proceso del señalamiento ${ }^{99}$, como lo solía hacer con varios de ellos.

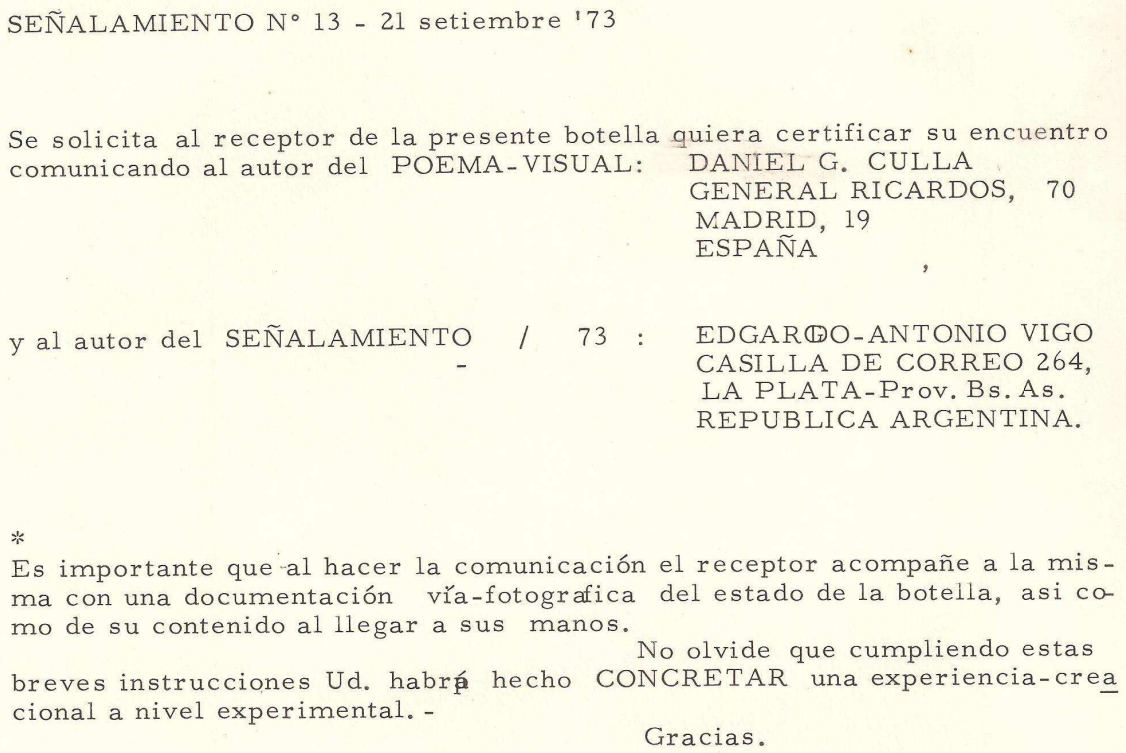

99 En el proyecto escribió las dos formas en que él iba a "documentar" este señalamiento: "Primer variante: trabajar con el concepto de la cámara ojo y documentar fotográficamente haciendo centro en el centro del círculo trazado lo que supuestamente el autor del señalamiento ve. Segunda variante: la cámara fotográfica capta por detrás mi figura como documentando mi presencia ante el paisaje que se capta desde los distintos puntos cardinales." (Vigo, Biopsia 1973) 
Quien encontrase la botella debía "certificar" que la había encontrado, enviando una carta tanto al autor del poema visual como al del señalamiento y se le solicitaba también que "acompañe a la misma con una documentación" sobre el estado en que se encontraba la botella. Nuevamente, el lenguaje especial aparece en el texto escrito por Vigo, así como la lógica probatoria y la certificación. Se agrega aquí, como en los señalamientos $I$ y $I X$ vistos en el capítulo anterior, la expresión de que a través de esta acción por parte del receptor se concretará una "experiencia creacional a nivel experimental".

Si en el lenguaje técnico, "la precisión será un criterio preferente al de la estética, o, como ya hemos señalado, al de la expresividad o emotividad que resultan inapropiadas en la comunicación tecnolectal" (Etxebarría, 1997: 354), Vigo ha podido configurar ambos en una misma obra: tras la organización del texto con formas apropiadas para el lenguaje jurídico, aparece la indicación de mantener una experiencia creacional. Es ahí donde quiebra la normalidad del discurso, sus lógicas internas y externas, dándole un valor artístico o imponiéndolo en un contexto artístico.

Vigo enuncia -en este como en los otros casos citados- que se realizará una experiencia estética, pero no aclara por qué han de concebirse como situaciones complementarias. Para comprenderlo, debe subrayarse que confluyen aquí algunas cuestiones: por un lado, el hecho de que sea un artista quien hace la propuesta parece convertirla en una acción creativa, tanto como su explicitación en el texto del señalamiento, por otro lado, establece una continuidad con sus trabajos artísticos en los que el público debe participar. Finalmente, el envío de este señalamiento o, mejor dicho, de sus elementos escritos y visuales -los textos y las fotografías- a diversas exposiciones, terminan de configurar su existencia como obra de arte y, por ende, la participación del receptor de la botella que certifica y prueba el hallazgo (en el caso en que ocurriera) como una actividad de índole estética. Como se ve, en este caso, depende enteramente de la voluntad del artista ubicar una acción solicitada al espectador como "creacional", apareciendo, nuevamente, las vacilaciones en cuanto a la presencia del autor y su relación como mediador imprescindible en la participación del público.

Finalmente, otro de los usos del discurso judicial, pero diferentes de los anteriores en que su centro ya no es la certificación o la prueba, es el uso de un significante particular. Hemos visto que reiteradamente Vigo utilizó una terminología propia del lenguaje 
técnico y este es uno de esos casos. Se trata de Área de libertad, analizado en el capítulo anterior en relación con el señalamiento realizado en el Jardín Zoológico de La Plata. A lo dicho antes sobre esa intervención del espacio y su paradojal texto con significado político (explícito), se puede agregar que la utilización de la palabra "perimido" también remite a ese discurso. Recordemos que cada tarjeta tenía impreso "Espacio de libertad" y sobre ese texto, sellado "perimido", completando así el sentido del área delimitada por las cadenas y su ubicación espacial (imagen 54).

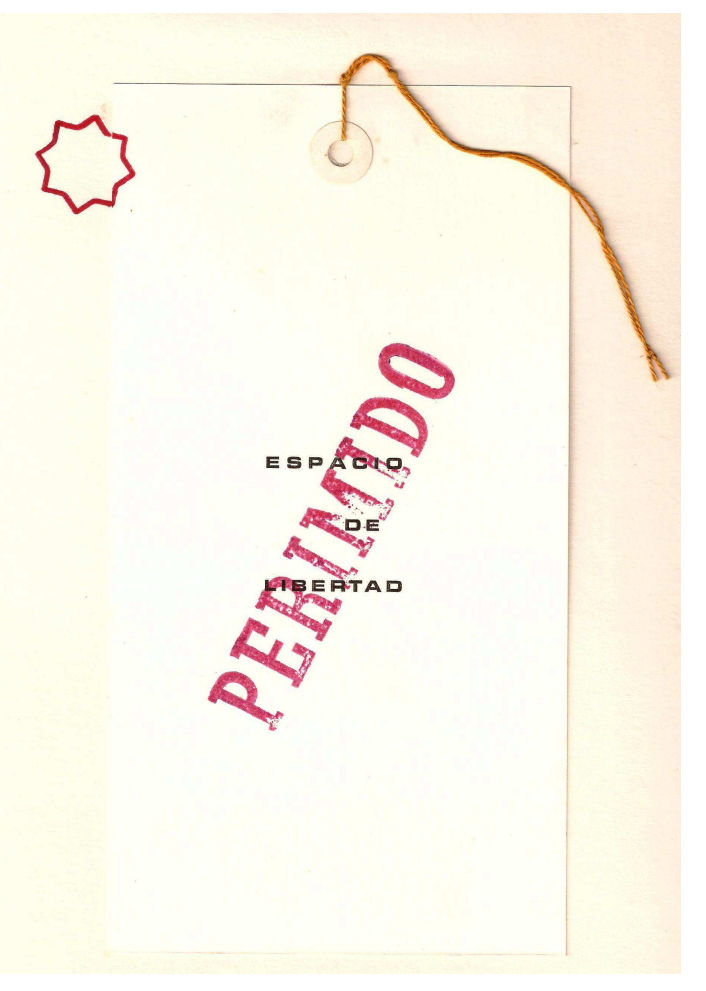

Imagen 54. Vigo, Espacio de libertad.

Tarjeta. 1972.

Ese término designa el efecto de caducar un procedimiento por el transcurso del tiempo fijado por la ley, es decir su finalización. Aquí el uso de uno de los significantes del discurso judicial, mantiene su significado, ya que expresa que el "espacio de libertad", tanto como un proceso legal, ha terminado. Aunque en lugar de referirse a un procedimiento judicial, lo hace en relación con algo que Vigo ha llamado "espacio de libertad" -marcado sobre el suelo como una superficie restringida- por lo que funciona a modo de denuncia sobre la situación política del país, una finalización de la libertad, su perención.

Las apropiaciones dislocadas que ejerce Vigo del discurso judicial -especialmente de sus formas más reconocibles como la certificación, la prueba o la terminología 
particular-, en su aplicación a los trabajos artísticos, desenmarcan tanto el espacio propio de su uso como los autores e interlocutores posibles. En tanto el programa de Vigo implicó un cambio en la concepción de la obra, del autor, del público y de los lugares y modos de exposición (o "presentación”), puede considerarse que en aquellas apropiaciones abre también una forma de obra artística que se desencaja de las expectativas culturales más establecidas. En este sentido, implica una intervención de un mundo ajeno en la práctica artística, donde nuevamente aparecen la sorpresa y la ironía como formas de descontracturar el efecto de la obra.

Al mismo tiempo, provoca una extensión desatinada, por impropia, de las formas judiciales hacia otros espacios. Como decíamos antes, mientras Vigo denostaba las prácticas burguesas en el arte, anexó o constituyó trabajos artísticos con materiales y operatorias que no solo pertenecen a ese sector, sino que permanecen más o menos intocables para otros estratos sociales. Además, la utilización de esas herramientas de un modo irónico, avanza más allá del solo uso para ejercer una crítica al sistema judicial. Si hasta aquí prevalece lo político en el despojo de formas discursivas de su propia normalidad y naturaleza y en su incorporación a obras que no dejan de ser vanguardistas y estéticamente provocativas, se verá que aparecen a la par intervenciones de la política como estrategia denuncialista de las injusticias y violaciones provocadas por el sistema judicial.

\subsubsection{LOS TEMAS JURÍDICOS}

Hemos mencionado que además de la utilización de las formas y procedimientos del discurso judicial, Vigo también captó aspectos que constituyen su contenido, lo que hizo tropezar el "tabú del objeto" que limita los discursos (Foucault, 2012): tomó como tema elementos que forman parte de lo que no puede ser dicho de cualquier modo o circunstancia, de lo que no puede ser hablado en formas ajenas a una constitución adecuada. Esto implicó no solo un tratamiento excéntrico de un objeto intocable o exclusivo, sino también una acusación política que muestra arbitrariedades y atropellos sobre los derechos de las personas. De este modo, al mismo tiempo que se apropió de las formas discursivas, abarcó una crítica social y política sobre el funcionamiento de la estructura judicial. 
En el número $c d$ de Hexágono '71 (1973) Vigo publicó una poesía visual de su autoría que no solo toma un tema jurídico, sino que implica también una crítica al sistema judicial en general.

Allí la palabra "inocente" pasa por un embudo del que sale la palabra "culpable". Debajo se encuentra la frase "La ley del embudo" y un sello de Vigo (imagen 55).

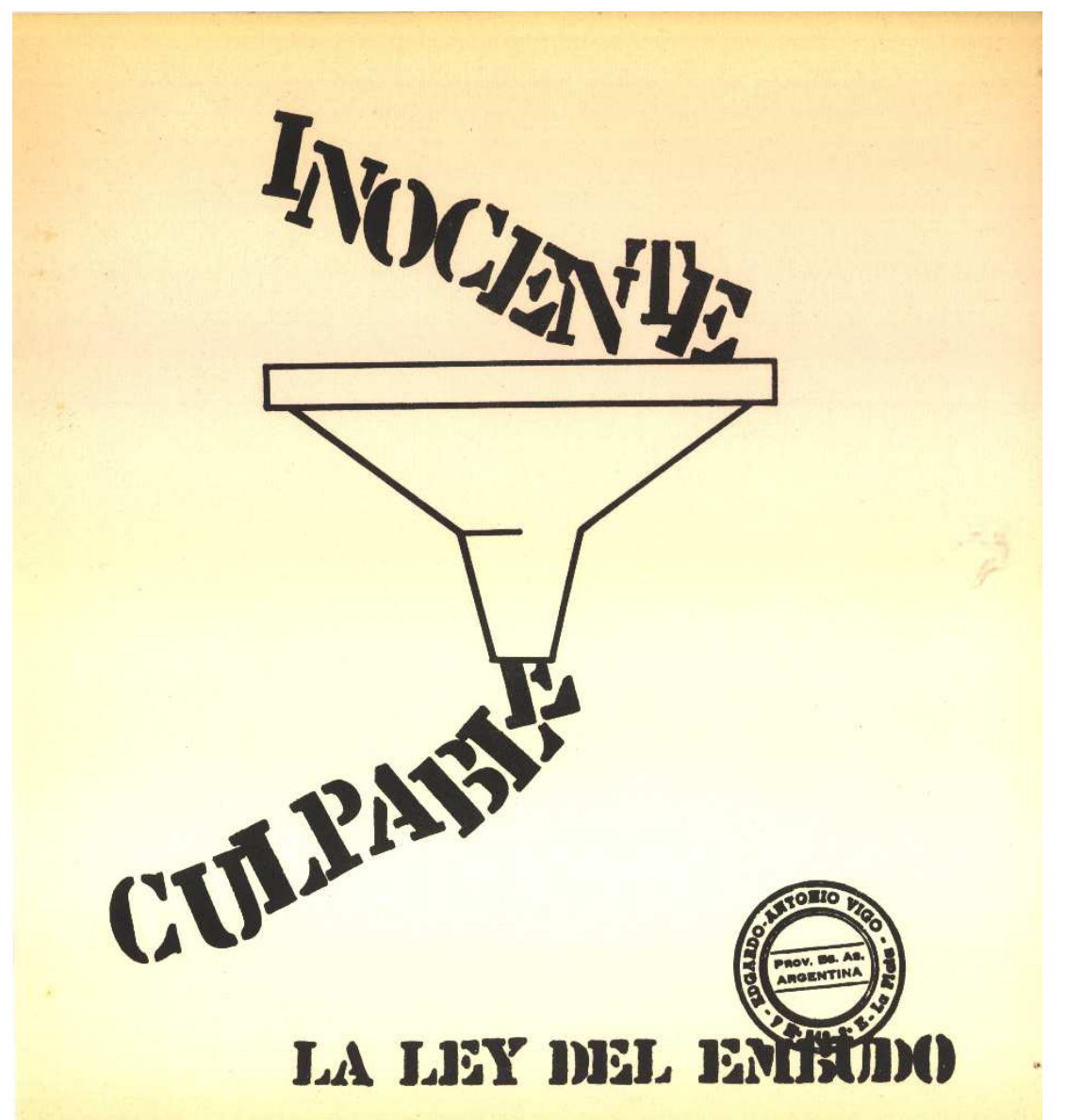

Imagen 55. Vigo, La ley del embudo. 1973.

Anotó en su registro de archivo que “'La ley del embudo' [es un] trabajo a nivel conceptual-objetivo de 1973, en el cual retoma una línea de dichos populares nacionales para aplicarlos al carácter del arte argentino" (Vigo, Biopsia 1973). La idea que aparece aquí es que quien es inocente, al pasar por el sistema (capitalista, dominante, militar, judicial, etc.), se convierte en culpable. Echando mano del principio de presunción de inocencia ("Toda persona es considerada inocente hasta que sea declarada culpable"), Vigo hace que el inocente que pasa por el "embudo", sea considerado culpable. Coincide, así, con el artículo de su autoría publicado en el mismo número de la revista, 
"Por qué un arte de investigación", donde dice que uno de los temas a incorporar en el arte son los "hechos históricos deformados por el "sistema". La idea de utilizar un “dicho popular" en el arte se trata de que la frase "La Ley del embudo" es popularmente una metáfora de la desigualdad o la injusticia, razón por la cual interpretamos que la crítica se asume hacia todo el sistema judicial.

La ley del embudo, puede entenderse como uno de los casos en que Vigo se relaciona con la política, asumiendo una posición denuncialista sobre una realidad que considera injusta. Así como en Área de libertad reprocha la falta de libertad, aquí lo hace en relación con un derecho, y el responsable también es el estado.

Combina su relación con la política y lo político, compone la obra de un modo que conserva la raigambre de su propia poética, a partir de un tipo, como la poesía visual, de por sí desestabilizante para la lectura-visión que utilice los instrumentos de decodificación establecidos tanto para la plástica como para la poesía. Además, no hace explícito el significado de ese embudo. Si bien podemos entender a la luz del contexto de su obra que se trata del "sistema", esto no está dicho por la propia obra, ni hay otras figuras representativas de lo que quiere manifestar más que un embudo -es decir, no hay imágenes, por ejemplo, de militantes encarcelados, trabajadores explotados o campesinos esclavizados.

Emparentado con este, el trabajo Variante jurídica, publicado en el $c f$ de Hexágono '71 (a finales de 1973 o principios del año siguiente) es otro de los que toman como tema algún aspecto del contenido del discurso judicial. Con el subtítulo "Relación: Estado / Individuo", consta de dos columnas, en la izquierda dice "Ayer" y en la derecha, "Hoy". Debajo de la primera dice "Quita de libertad por hecho probado" y al lado, bajo la columna "Hoy", se lee "Quita de libertad por hecho supuesto".

En la segunda fila, bajo la columna "Ayer" dice "Demostración de culpabilidad por el Estado", en "Hoy" dice "Demostración de inocencia por el individuo". También se encuentran la fecha "1970 i 3" y su lado, el sello de Vigo con el número de casilla postal (imagen 56). 


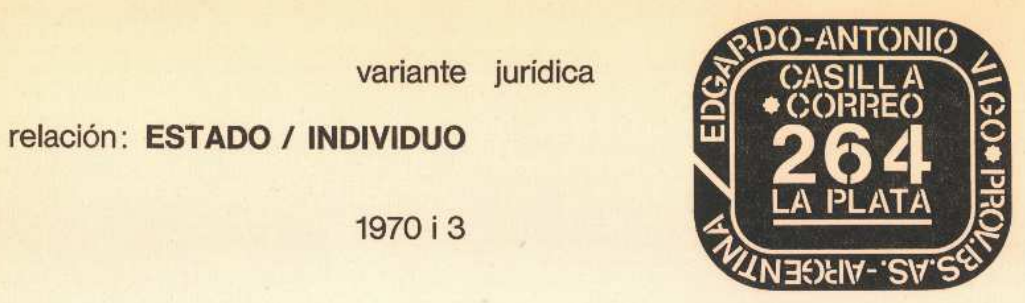

AYER HOY

Este texto, que a simple vista parece una poesía por la forma en que están distribuidas las oraciones como si fueran versos, es una clara denuncia sobre las violaciones a los derechos de las personas por parte del estado en dos de sus aspectos más vinculados a las prácticas judiciales: la condena por un hecho probado y la presunción de inocencia $^{100}$.

En la primera frase hace referencia a lo que en la doctrina del derecho se llama "debido proceso legal”, el cual garantiza un “juicio justo". Seguido, se encuentra su violación, es decir el caso en que no se cumpla el mandato de que nadie puede ser penado sin un juicio previo. El siguiente es el principio de presunción de inocencia, garantía procesal

100 Ambos principios están expresados en el artículo 18 de la Constitución Nacional y también garantizados por tratados internacionales. 
de máxima importancia para el imputado de un delito. De allí se deriva que no sea él quien deba probar su inocencia, sino el estado demostrar su culpabilidad, es decir este que es el titular del onus probando (la carga de la prueba). Esta garantía para Vigo también ha sido transgredida, ya que se ha trasladado esa carga al imputado. Interesa remarcar aquí que ambos principios son la demostración del funcionamiento del estado de derecho, es decir, donde el propio estado tiene limitaciones en sus funciones, determinadas por las garantías y derechos de los individuos.

Aquí no hay imagen plástica en sentido estricto, esta se ha reemplazado por el texto. El centro de la obra está puesto en la literalidad de lo escrito y en la composición de una comparación entre dos momentos, cuya disposición en la hoja tiende a hacer evidente la diferencia entre un antes de respeto a esos principios y un hoy violatorio. Hay tiempo y lugar, aparecen un pasado y un presente contrapuestos y una ubicación posible, Argentina, ya que el sello de Vigo tiene los datos de su localización.

Finalmente, Vigo utilizó una ley en su producción artística. Se trata de la ley 18188, que dio nombre a su Tríptico remarcado (Ley 18188), editado por Diagonal Cero en 1970 (imagen 57).

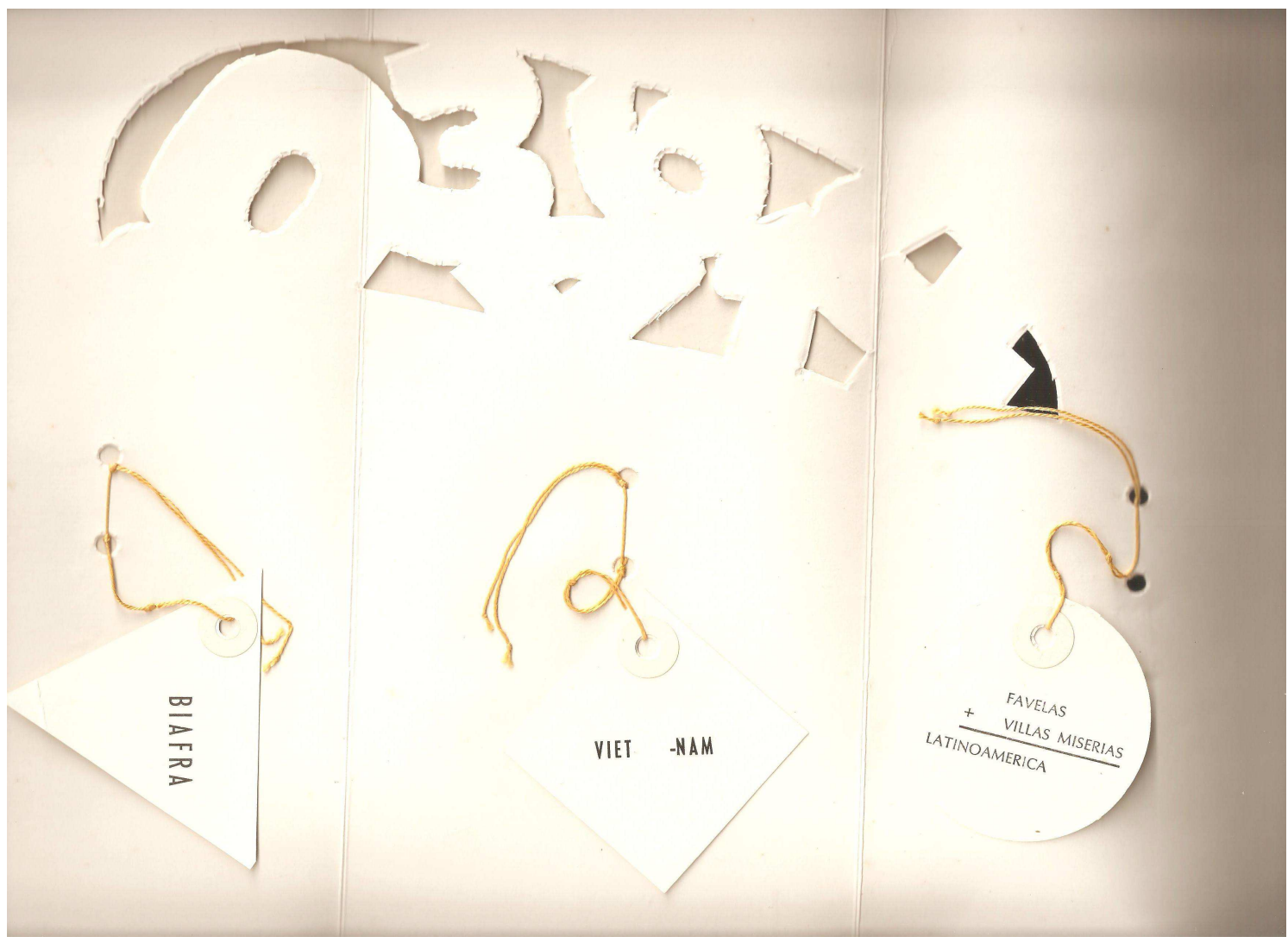


La mencionada ley es la que establece el valor de la moneda local, los "pesos ley 18188”, vigentes entre 1970 y 1983. Vigo utilizó el nombre de esa norma para realizar un tríptico perforado con números - una práctica utilizada también en otras obras- que en su interior contiene tres tarjetas colgadas de hilos. La primera, en forma triangular, dice "Biafra", haciendo referencia a uno de los países de África en que la miseria extrema era difundida por diferentes medios hacia el mundo; la segunda, romboide, dice "Viet-Nam", haciendo clara alusión a la guerra allí desatada y que fuera rechazada por amplios sectores de las sociedades en distintos países, especialmente por los grupos y organizaciones comprometidos con una crítica al imperialismo, la guerra y la intervención de Estados Unidos; la tercera es un círculo - una forma cara a la poética de Vigo- con una suma algebraica: "Favelas + villas miserias = Latinoamérica", es decir, que relaciona la pobreza en la forma de sus asentamientos más conocidos de Brasil y Argentina con la totalidad del subcontinente. Así como la utilización de números en sus poesías visuales proviene de la década anterior, también las fórmulas matemáticas tienen una historia en su poética. El desarrollo más completo se dio en lo que llamó "Poemas matemáticos", una combinación de letras, números, fórmulas y formas plásticas, dispuestos de manera que formaban una poesía visual (imágenes 4 y 5).

Este trabajo se encuentra ligado a lo judicial también por un aspecto de su materialidad. Se dijo arriba que una de las funciones que él cumplía en los tribunales era coser expedientes, un oficio de características artesanales que requiere cierta práctica y algo de destreza, ya que se realiza de un modo pautado sobre cientos de hojas con un hilo especial y agujas de gran tamaño. El objetivo es mantener unido el conjunto de los documentos que forman el expediente, respetando el orden cronológico de su incorporación y evitando la pérdida o suplantación.

La presencia del hilo en las obras de Vigo ha sido una constante a lo largo de su carrera, ya sea uniendo dos elementos o simplemente colgando de una pieza, y se convirtió en un aspecto que rápidamente se identifica con la materialidad de su poética (véanse por ejemplo las imágenes 15, 16, 19, 21, 25, 30, 48 y 57. Es otra de las formas por las que Vigo captó una de las prácticas judiciales -también extendida a otros ámbitos, como la archivística- haciéndolas parte de su poética. Si bien son pocos los casos en que Vigo utiliza el hilo específicamente para coser en sus obras, su incorporación a la obra de 
arte, aún desvinculada temática y discursivamente del mundo judicial, remite a la práctica de los tribunales, hechos en los que asume, nuevamente, un uso dislocado de ese ámbito en el de la creación artística.

Lo que parece estar expresando Vigo en Tríptico enmarcado (Ley 18188) es la relación existente en las políticas económicas de los países, a través de la referencia a su forma monetaria en la mencionada ley, con la pobreza, el hambre y la guerra. Cada continente África, Asia y América Latina, es decir, el "Tercer Mundo", está mostrado a través de un país emblemático por representar esas cualidades.

El carácter contestatario que adquiere este tríptico respecto de un orden injusto, como La ley del embudo y Variante jurídica, incluye una relación con la política en la que un tema jurídico -el principio de inocencia, las garantías del proceso judicial, una ley monetaria- es utilizado como objeto de la obra para destacar sus aspectos negativos, dominantes e injustos. Vigo se involucra así con los sujetos de la época, cuyas conciencias estaban "descreídas de libertades democráticas a las que se pensaba reproductoras del sistema de injusticias extremas; críticas de un humanismo burgués liberal, subjetivista, proclamando sus abstractos derechos y libertades individuales; creyentes en un sujeto colectivo que objetivamente determinaba la historia, los lenguajes y los mundos simbólicos" (Casullo: 2004: 17).

Al mismo tiempo, realiza esto sin recurrir a herramientas de tipo realistas o naturalistas que lo muestren explícitamente, es decir que no presenta fotos o imágenes plásticas ilustrativas de aquello que quiere demostrarse. Sin embargo, aparece un aspecto de tipo explicativo o didáctico -especialmente en los dos primeros- que hacen uso de la palabra para expresar la existencia de una realidad que es necesario mostrar, pero sin apelar a formas de enseñanza sobre cuáles son los medios por los cuales puede ser cambiada. En la misma lógica de la idea de "revulsión”, que no pretende enseñar qué es lo que hay que hacer, sino mostrar u ofrecer críticas a través de formas o experiencias estéticas, estos trabajos hacen circular su politicidad.

\subsection{DESHILVANAR EL ORDEN SOCIAL}

Como conclusión de lo analizado en este capítulo puede afirmarse que la obra de Vigo alude a un orden en el que un cuerpo específico, la corporación judicial, estructura su discurso con un lenguaje propio: en la utilización que realiza Vigo, lúdica o irónica, hace visible que ese lenguaje no pertenece al arte, ni siquiera a la lengua común, 
muestra su privatismo. ${ }^{101}$ Pero no es el de cualquier jerga propia de un ámbito particular, sino de aquel en que toma cuerpo una de las formas más concretas de afirmación de un orden social, donde se aplica la ley. En este sentido, Vigo interceptar un aspecto del funcionamiento del sistema -o como dice Rancière, el orden policialdisociándolo de su lugar normal y al ofrecerlo en una acción artística, permite una apropiación descentrada, fuera de los límites impuestos por su naturaleza.

Vigo hace uso no solo de la forma escrita del lenguaje jurídico, sino que ha conformado un dispositivo, en el que incluye el texto, la imagen, las prácticas y elementos de su materialidad.

En cuanto al discurso escrito, es tomado al menos de dos maneras: en su aspecto retórico - la palabra- y en su forma visual -el sello. El uso del sello en la obra de Vigo puede datarse desde los comienzos de su carrera artística, dado que en los catálogos que realizaba para el "Cine Club" que organizó en 1957, incluía poesías visuales "Matemáticas"-, enteramente realizadas con sellos de letras y números. Si bien la utilización de los sellos fue una práctica extendida por otros artistas más tarde, a partir de la incorporación al arte-correo, en el caso de Vigo esto puede identificarse mucho antes, y directamente ligado a su trabajo tribunalicio.

La práctica del sellado de Vigo que, como vimos, tenía una función plástica, fue adquiriendo importancia desde mediados de los cincuenta y durante los años siguientes, hasta que en 1974 publicó junto con otros artistas (Bercetche, Ginzburg, Leonetti, Pazos, Romero, Zabala y Vigo) el ya mencionado libro Sellado a mano (imagen 25). Para ese entonces, el uso del sello había superado el uso judicial, abarcando otras modalidades y contenidos. Según Vigo, en ese trabajo "impera una clara línea política, elemento común en los investigadores latinoamericanos de hoy, inmersos en una realidad que presenta problemas urticantes, que deben ser contestados también desde el punto de vista creativo" (1975).

\footnotetext{
${ }^{101}$ Es necesario expresar que, tal como fue mencionado en la Parte I, esta investigación no se centra en el estudio de la obra de Vigo en su carácter conceptualista -razón por la cual interesa hacer hincapié en la idea de poética como producción artística y programática- y abarca obras y acciones que exceden esa clasificación. Esta posición no significa ignorar que trabajos anteriores allí referidos han ubicado una serie de obras de este artista en ese amplio grupo de producciones. Es por ello que algunos procedimientos utilizados por Vigo en relación con la prueba o certificación de una acción u objeto artístico -interpretado aquí como apropiación del dispositivo judicial administrativo-, podrán analizarse en relación con algunas de las características más sobresalientes del conceptualismo (aún cuando las investigaciones citadas, interesadas en esa corriente, no han hecho referencia explícita al uso del discurso judicial como operación conceptualista). No es éste, sin embargo, el objeto de nuestro análisis e interpretación y queda abierta la pregunta como vía posible para otras investigaciones.
} 
Al mismo tiempo, en diversos lugares del mundo, otros artistas se encontraban trabajando con sellos. Hervé Fischer publicó en 1974 Art et comunication marginale, un libro en que realiza una recopilación de imágenes de sellos de artistas y un análisis del fenómeno. Este libro interesa particularmente porque fue producido a la par que Vigo estaba trabajando con las impresiones de sellos que hemos analizado, es decir que se encontraba en un contexto más general de su uso en diferentes partes del mundo. Fischer atribuye el uso de los sellos por parte de artistas a un "fenómeno sociológico de comunicación marginal" (1974: 13. Traducción nuestra), que, además de ser un vehículo, recuerda al post-dadaísmo a través del absurdo o lo caprichoso. Realiza una clasificación de los sellos usados por artistas con diversos criterios (comunicacional, contestatario, contra institucional, etcétera). Incluyó allí algunos sellos realizados por argentinos: de Vigo, su sello personal y "Editó Diagonal Cero" (235); de Horacio Zabala, "Explotación es terrorismo" e "Investigación de la realidad nacional" (241); de Juan Carlos Romero, “Arte Argentino de vanguardia - 1973” (194). Si bien ninguno de estos sellos tiene raigambre burocrática, lo que nos resulta más atractivo es que Fischer ofrece también las categorías: "numeraciones", "certificaciones" y "apropiaciones", dando cuenta de que había otros artistas que, como Vigo, también habían asumido prácticas relacionadas con el mundo administrativo o judicial. Así, señala que hay sellos "que son habitualmente privativos de instituciones oficiales de la sociedad", pertenecientes a formularios y documentos administrativos, así como los que garantizan su autenticidad, y afirma que se trata de un "contra-uso" (contre-usage), irónico o lúdico. Luego, Fischer menciona el uso de los sellos numeradores, ligados a la "sociedad burocrática", que en algunos casos pasan a ser texto escrito como forma de datar una obra de arte. La certificación es otra de las clasificaciones posibles para este autor y ubica allí solo cuatro ejemplos (a diferencia de los demás casos, que son mucho más numerosos): sellos con el texto "Artist's proof” de Ken Friedman, “B. V. certifies this to be a work of Fluxart" de Ben Vautier, "Reconstitution historique authentifiée" de Pierre Restany y "Work of art made in Canada by J. Palumbo" de Palumbo.

Vigo leyó este libro y en base a él escribió el artículo (homónimo del libro) "Sellado a mano", publicado en el número $c$ de Hexágono '71. Allí, Vigo dice que en el citado libro de Fischer, "surge de muchos ejemplos que el sello de goma se libera del usocomún-administrativo por el toque que el artista imprime a su 'sello personal' o cuando se vuelca una ironía de uso desarraigado, al ridiculizar ciertos emblemas o textos burocráticos, ejemplos éstos que pueden ser clasificados como el período tardío dadá." 
(Vigo, 1975). Al igual que Fischer, lo relaciona con el uso de materiales "pobres" y la "comunicación marginal". Por otro lado, hace hincapié en que la utilización de los sellos tiene un origen en el mundo administrativo que el artista se encarga de modificar. La descripción que hace Vigo del uso de los sellos de goma, desnaturalizando su lugar "normal" a través de la "ironía" o el "ridículo" se acerca a nuestra hipótesis sobre la utilización particular que hace el mismo artista no solo de los sellos, sino también de otros elementos o procedimientos discursivos y materiales tomados del ámbito judicialadministrativo.

Vigo dice que la utilización del sello se trata de un "medio de comunicación común", que se ha generalizado por ser, además, una forma poco costosa -ideal para los artistas latinoamericanos- y reconoce en Sellado a mano el primer libro producido con sellos.

Del análisis de los casos presentados a lo largo de este capítulo, puede resumirse que los diversos procedimientos utilizados por Vigo responden fundamentalmente a dos tipos de prácticas. El primero es el uso del sello personal, en general seguido de su firma, como modo de certificar o afirmar lo que se dice en el texto. Este es el caso del Certificado de mi nacimiento, el Señalamiento VIII con la firma de la tarjeta sumergida, la Ley del embudo; Variante jurídica.

El segundo tipo, la ridiculización de los procedimientos burocráticos (con o sin uso de sellos), en el que aparecen tanto el uso de géneros específicos del discurso, así como terminología, frases y formas sintácticas, puede verse en: la anotación marginal de Certificado de mi nacimiento, la certificación en el Señalamiento VIII, sumado al pedido de envío de la tarjeta por parte del receptor y reenvío por parte del artista a modo de prueba, la certificación por Samuel Paz con sello del Instituto Di Tella y las pruebas ofrecidas por Vigo, como boletos, fotos y la llave en el Informe 0'00A, la certificación y protocolización por parte de la escribana y luego la prueba de cada trozo de madera entregada al público junto con un certificado en el Señalamiento $I X$, la certificación y prueba fotográfica pedidos al receptor del Barrilete / Poema para realizar en tres países, la certificación de la fecha a través de los sellos con las fechas de salida y llegada, así como la obliteración postal en Viaje de esta tarjeta postal, la utilización del mismo sello en Objetivación de la contemplación, la prueba o "testimonio" de la mezcla de tierras en Tierras latinoamericanas, la certificación del director del MAM sobre las correspondencias exhibidas y clasificadas en Comunicaciones febrero '73, el pedido de certificación y de prueba al receptor del poema de Culla en la botella arrojada al Río de 
la Plata en el Señalamiento XIII, la finalización de un plazo legal con el uso de sello "perimido" en Área de libertad.

En ambos casos, como hemos apuntado a lo largo del capítulo, el uso de la firma como parte de la certificación de la existencia material de una acción o una obra, es una de las operaciones complejas en la poética de Vigo. Por un lado, en consonancia con lo señalado en el capítulo 1, Vigo ha oscilado en una presencia inestable del autor, dado que si bien ha propuesto el "anonimato" del "creador", este no ha sido una pura negación. Vemos en algunos casos la ausencia de la referencia a la persona del artista en tanto individuo y la búsqueda de un espectador que forme parte de los actos creadores de la obra. En otros casos, la presencia de la firma, que, acompañada algunas veces de un sello, parece parte imprescindible de la manifestación artística, tanto porque la completa, cuanto porque certifica su objetividad material. La firma "pretende ser la presencia del 'autor' como 'personal que enuncia' como 'fuente', en la producción del enunciado (...) [e] implica la no-presencia actual o empírica del signatario (...), señala también y recuerda su haber estado presente en un ahora pasado, que será todavía un ahora futuro" (Derrida, 1998: 370). Esta omnipresencia autoral o "forma trascendental de mantenimiento", tensiona la formulación de un autor anónimo ya que, por el contrario, transforma a su firma en dispositivo tanto de la apropiación de aspectos de géneros judiciales, como de la afirmación de su existencia como individuo y genera una identificación única y singular entre la firma y lo que se firma. Una función semejante tiene La marca de Vigo (vista en el capítulo 1), en tanto revalida no solo la singularidad de la tarjeta -como firma- sino de su autor, que necesita ser nombrado como una "marca" colgada en obras de diversos tipos y entregada en acciones, donde "Vigo" no es el tema de la manifestación artística, sino una señal de su "función-autor".

Asimismo, hemos considerado el uso de algunos aspectos de la materialidad del discurso jurídico. Se trata especialmente de la utilización del canal escrito en soporte papel, es decir el que prima por excelencia en el mundo administrativo y judicial. Como artista plástico, Vigo contaba con una variedad de posibilidades en la producción de sus obras, sin embargo, salta a la vista que privilegió -para la comunicación de ideas- esa operatoria. Como se señaló antes, otro aspecto notorio de esa materialidad es el empleo del hilo, material de uso cotidiano en su labor judicial, que pasó a formar parte de sus obras como seña identificatoria de su autoría: hilos colgando o uniendo, remiten a la costura de expedientes. Comenta Juan Carlos Romero que un día lo visitó en su trabajo de Tribunales y pudo comprender el por qué del uso de ese material: "Me acuerdo que 
estaba él atando unos expedientes, con unos hilos, cosiendo (...) Claro, 'y acá es de donde Vigo sacó esto', decía yo. Pero me di cuenta ese día. (...) Los hilitos, tenía todo lleno de obras" (comunicación personal, 2013). Vigo unió, así, un mundo judicial que en su vivencia cotidiana se presentaba como placentero y que abría puertas a amistades y relaciones, con prácticas a las que tenía acceso como empleado pero que describe como ajenas en tanto no habían formado parte de su vida personal ni familiar hasta el momento de su incorporación a los Tribunales. En esa conjunción de compañeros cercanos y discursos extraños, Vigo conformó esta parte de su poética.

En tanto las sentencias judiciales se caracterizan por la ininteligibilidad, con un estilo solemne y períodos sintácticos prolongados, lo que resulta -en los casos en que éstos no son bien manejados- es un "estilo culto impostado, a menudo incomprensible" (Montolío y López Samaniego 2008: 44). Vigo se apropia de ese estilo, hace de lo incomprensible -por específico, técnico y arcaico- algo que exhibe el valor de lo artístico, que se muestra y se ofrece como experiencia estética. Desvirtúa su condición de especialidad solo accesible y comprensible para unos pocos y lo pone a circular, demuestra que la politicidad de sus obras -como configuración interna- se vincula con el medio de un modo particular y ostenta elementos privativos de un modo público. He aquí un tipo de relación con lo político que opera al desestabilizar aspectos del orden social, una organización de los discursos que implica también una distribución de los poderes. Si

La actitud mayoritaria de los ciudadanos (...) es de aceptación de la ininteligibilidad de las resoluciones judiciales y de resignación ante textos que se saben de antemano incomprensibles, dada la desigualdad de conocimientos técnicos que separan al 'ciudadano de a pie' de los profesionales (Montolío y López Samaniego, 2008: 46),

frente a esta generalidad, el artista se posiciona en un lugar incorrecto, no como un "ciudadano de a pie" que no comprende ni utiliza este lenguaje, sino, como un experto sin serlo. Recordemos que Vigo había narrado su vinculación con los tribunales como novedosa, ya que en su casa no había empleados administrativos ni se utilizaba ese lenguaje, así que todo lo que supo lo aprendió en su trabajo de oficial de justicia. Vigo hace fallar, entonces, procedimientos de exclusión del discurso: el que limita el uso por parte de sujetos o en circunstancias ajenas a las originalmente establecidas y el que determina que ciertos objetos del discurso no pueden ser empleados de cualquier modo. 
El uso de ese discurso en las obras de arte no se condice con el sujeto habilitado para hacerlo porque falta la adecuación social y formal para ocupar ese lugar distinguido. Sin embargo, Vigo no solo lo hace, sino que implica a otros en su uso, tanto espectadores o receptores del mismo, como en su función de productores o colaboradores de la obra de arte a través de las acciones de certificación o prueba. En este sentido, encuentra una grieta en el control del discurso, demostrando que es posible evadirlo y hacer ver o leer una voz no permitida.

Esto último puede entenderse también con Rancière (2007), ya que las voces no autorizadas son aquellas que solo producen "ruido" -así también lo anuncia Foucault- y por eso producen un disturbio, una desorganización en el orden de las jerarquías, posiciones y disposiciones del orden policial y sus reparticiones en lo social. En el caso de Vigo, su obra aparece en ese lugar descentrado que hace aparecer una voz en lugares y formas inapropiadas, particularmente movilizando un discurso caracterizado por su relación con la ley, el orden social y la sanción, y en ese sentido su procedimiento es político.

En relación con esto último, habíamos mencionado que hay una relación entre lenguaje y derecho aceptada -aunque con diferentes matices- en la teoría del derecho.

Para el pensamiento [jurídico] teórico clásico, como en Kelsen, (...) hay derecho, hay normas jurídicas, si y solo si los actos ilocucionarios normativos (ordenar, imperar, promulgar, regular, etcétera) son empíricamente satisfechos, si adquieren un efecto perlocucionario satisfactorio, entendiendo por tal el efecto que el acto lingüístico emitido produce sobre el receptor del lenguaje (Vernengo, 1996: 91).

Es decir que para esta teoría hay derecho solo en el caso en que lo dicho a través del lenguaje normativo tenga un efecto concreto en el receptor. La obra de Vigo, sin embargo es capaz de utilizar este lenguaje a pesar de que no tenga el "efecto perlocucionario satisfactorio" en términos legales, porque no se trata de una autoridad capaz de emitir una normativa y, entonces, no asegura que el pedido de certificación o prueba por parte del receptor, o su propia acción de certificar ante escribano un señalamiento, obtengan una consecuencia jurídica. Si en algunos casos el lenguaje jurídico tiene un carácter performativo, porque al solo enunciarlo del modo y en las circunstancias específicas, realiza un hecho -lo cual se protege con las limitaciones señaladas por Foucault- es claro que Vigo quita esa cualidad particular, ya que lo hace 
con fines artísticos o creativos, pero utiliza aspectos de ese discurso de un modo tal que aparecen en forma cerrada o completa dentro aquél.

En ese acto que involucra la materialidad visual y retórica del lenguaje judicial, la obra de Vigo opera en dos sentidos: por un lado, desprende ese lenguaje de su cualidad de "elevado" y niega su carácter de reservado para unos pocos, poniéndolo a disposición de los receptores o participantes de un acto creativo. Recuérdese que Vigo hacía circular sus trabajos por diferentes medios, ya sea Hexágono '71, presentaciones, exposiciones, revistas, etc. En relación con el procedimiento de exclusión de los discursos vinculados con las condiciones y los individuos que hablan ("no todas las partes del discurso son igualmente accesibles e inteligibles; algunas están claramente protegidas (diferenciadas y diferenciantes) mientras que otras parecen casi abiertas", dice Foucault, 2012: 38-39), como venimos diciendo, Vigo interviene en uno de tales discursos que están protegidos, no solo porque se elabora y reproduce en el ámbito específico judicial, sino porque resulta muchas veces un discurso imposible de comprender para el resto de las personas. Por otro lado, Vigo crea algo nuevo, incorporándolo a la obra como se agrega un color o una palabra. En ese acto doble, por un lado, desestructura las reglas que indican qué es propio de una obra de arte -aquí su vanguardismo- y organiza una obra que resulta confusa, inexplicable para los cánones establecidos. Por otro lado, desbarata algo, un punto del tejido que organiza los discursos sociales y sus ámbitos específicos, particularmente, el del espacio judicial. Corre de lugar ese lenguaje reservado, lo desnaturaliza porque lo ofrece. Al descolocarlo de su lugar normal reconoce su carácter previo de exclusividad e identifica que pertenece a un uso específico en el orden de jerarquías sociales, justamente en el estrato que garantiza la dominación. Así, permite una experiencia sensorial que ofrece nuevas configuraciones de lo social, porque interviene en la partición de lo sensible (Rancière 2002) o del estado de la situación (Badiou, 1998; 2000a, 2000b). En este sentido, la obra de Vigo, se vincula con la idea de novedad ya que, como dice Badiou, "una obra de arte real (...) es una indagación que no había tenido lugar, un punto-sujeto inédito de la trama de una verdad" (2009b: 57). Esto es posible porque existen otras formas de actuar de las que ofrece o impone el estado de la situación (2000b).

Siguiendo el mismo razonamiento, si la comunicación -y en nuestro caso, la forma específica del ámbito judicial-administrativo- tiene múltiples limitaciones que determinan un sentido convencionalizado, el lenguaje poético, o el arte en general, 
ofrecen infinitos significados o miradas (Berardi, 2012). Algunas de las formas utilizadas por Vigo, apelan a un desligamiento del lenguaje respecto de esa finitud.

Así, los juegos irónicos del lenguaje judicial de Vigo -en los términos citados de Berardi-, los rituales transformados en performances y su circulación extramuros de los circuitos normales, pueden pensarse como intentos de poner a la vista que hasta los espacios y prácticas más consolidados como excluyentes de los oídos y las voces de los no autorizados, son pasibles de ser alterados, deshilvanados y descolocados como disidencia de la finitud técnica y específica: una politicidad específica que apunta directamente sobre una de las prácticas socioculturales de la dominación.

Es posible que en la apropiación de lo judicial que realizó Vigo, haya también una relación con el público no convencional, en tanto busca provocar, de diferentes maneras, algún tipo de reacción que lo descoloque respecto de los usos corrientes de ese discurso y formas materiales, y también en el seno de su oficina, donde, como apuntamos antes, colgaban tarjetas, obras, xilografías, lo que, como decía Ginzburg, interfería en las operaciones burocráticas normales o, como expresaba el propio Vigo, era un juego que estaba "totalmente fuera de contexto de lo que específicamente era tribunales". Puede pensarse que aquí, la base de este tipo de arte es "lanzar una herramienta" hacia el público, en tanto se "evita la complicidad -porque corrientemente no hay lógica ni realidad [como el realismo socialista] (...); [y] tiende a enfocarse en los efectos beneficiosos de la disrupción" (Lukes, 1991: 70. Traducción nuestra). Es decir, los usos de Vigo, por un lado, presentan, casi sin mediación, una realidad manifiesta -la existencia de un taco de madera o de una acción- pero cuyo objetivo no es la complicidad o la generación de la adhesión a una causa, sino, la distancia, la provocación del desconcierto y la disfuncionalidad de las formas jurídicas trasladadas fuera de su locus, al mismo tiempo que sus obras son puestas a circular dentro de la oficina: "desde su posición separada, este tipo de arte desmantela (¿deconstruye?) los prejuicios e ilusiones" (Lukes, 1991: 72. Traducción nuestra). Esa relación con el público a la que Vigo apunta, es otra de las formas de desarticular las funciones tradicionales de los sujetos de arte.

En la apropiación de lo judicial, la dislocación opera sobre los géneros jurídicoadministrativos, así como en la publicación de Hexágono ' 71 , lo hace sobre el propio género revista. Y así como en el uso de lo judicial Vigo apuntó a una relación disruptiva con respecto al público, veremos que en la revista oscila entre la búsqueda de ese efecto largamente vinculado con el dadaísmo y las vanguardias, y la comunicación de ideas 
políticas reconocibles que mantienen una relación directa con las propuestas y discursos de la nueva izquierda. La complejización de su relación con los receptores de la revista y los modos en que articuló la política y lo político al interior de cada número y a través del tiempo, requieren de un examen exhaustivo y detallado de sus particularidades textuales, visuales, con relación al género y con los acontecimientos histórico-políticos de su tiempo. 


\section{CAPÍTULO 4}

\section{DISTORSIONES DE UN SOPORTE: LA REVISTA HEXÁGONO ‘71}

Entre las diversas politicidades de su poética, además de las intervenciones en el espacio público y la utilización del discurso, la materialidad y las prácticas judiciales en tanto modos de alterar los límites impuestos a los sujetos autorizados, a los objetos restringidos y a los espacios habilitados, Vigo llevó a cabo también a otro tipo de actividad: la edición de la revista Hexágono '71. Allí el propio género y soporte revista fueron trastocados, y su relación con la política y lo político adquirieron preeminencia. Se trata de un artefacto cuya politicidad se encuentra en el entrecruzamiento de vanguardia estética y política radicalizada, las que obtuvieron diferentes pesos a lo largo del tiempo: los modos y proporciones en que se combinaron invalidan cualquier interpretación lineal que identifique el aumento del compromiso político con el abandono de las prácticas específicamente artísticas o de la estética vanguardista. Desarrollaremos aquí un análisis que tiende a reconocer e interpretar los aspectos más sobresalientes en esa dirección ${ }^{102}$, partiendo de sus características materiales y de las modificaciones del soporte y del género, para pasar luego a los trabajos publicados, tanto textuales como artísticos y las variaciones en los autores. Por fin, proponemos enfocar especialmente la relación de la revista con los temas y acontecimientos de la política nacional. Teniendo en cuenta estas variables, hemos dividido el análisis en dos etapas, dado que así lo reclama la propia deriva de la revista.

Hexágono '71 fue una revista ensamblada que creó, dirigió y editó Vigo, asimismo, buena parte de su contenido fue producido también por él. Tomaba las decisiones en soledad, incluyendo poesías, proyectos o textos que le enviaban (o directamente tomaba de) diversos artistas y autores, prácticamente sin consultar con otros compañeros. Se convirtió así en una revista directamente atada a su producción personal (un ejemplo es la publicación de señalamientos que continúan con la numeración de su serie), como una extensión de su labor artística en otros ámbitos, visible también en la elección de

\footnotetext{
${ }^{102}$ Dado que el análisis de la revista estará guiado por el problema de investigación de la tesis y en especial por las variables aquí mencionadas, no se recurrirá a una descripción detallada de cada uno de los trabajos publicados, sino a un estudio que al atravesar diferentes obras o textos, se focalice en las principales preguntas que conducen la investigación. En los Anexos se encontrarán una matriz de datos de cada número de la revista y un índice razonado de la totalidad de la revista, realizados para esta tesis, con el objetivo de completar la información de la misma y ofrecer un panorama para futuros trabajos interesados en ella.
} 
trabajos o textos a publicar, relacionados con sus propios contactos en Argentina y el mundo (volveremos sobre este rasgo más adelante).

Se publicaron trece números entre 1971 y 1975, todos ellos en la ciudad de La Plata, con una periodicidad trimestral y una tirada de quinientos ejemplares. Se trata de una revista de arte dedicada a la publicación de poesías visuales, historietas, propuestas para realizar acciones, comunicaciones, ensayos, partes de textos más largos. A pesar de los cambios que se produjeron a lo largo del tiempo, mantuvo un interés enfocado fundamentalmente en mostrar y debatir sobre las distintas formas de expresiones plásticas.

\subsection{SOPORTE, MATERIALIDAD Y ENSAMBLAJE}

El soporte y la materialidad de Hexágono representan parte de su rareza que consiste, entre otras cosas, en desligarse de las pautas establecidas o corrientes para la elaboración de una revista convencional. Al mismo tiempo que otros artistas editaban revistas ligando vanguardia y experimentación ${ }^{103}$, Vigo produjo una intervención sobre el género-soporte que tenía su propio antecedente en las revistas que había editado en años anteriores: WC (1958), DRKW (1960) y Diagonal Cero (1962 - 1968), así como con otras pequeñas ediciones caseras de escasos o únicos números (ver listado de ediciones de Vigo). Así, en consonancia con su círculo de artistas conocidos, pero imponiéndole un sello propio, Vigo se lanzó a la publicación del artefacto Hexágono '71. La revista presenta una clara ligazón con su precedente, Diagonal Cero, en cuanto al interés por el arte experimental, los textos críticos, las hojas sueltas, caladas, y la publicación de trabajos vanguardistas. ${ }^{104}$ En Hexágono Vigo publicó imágenes, textos, traducciones y aquello a lo que apuntaba en términos de un programa de comunicación tendiente a desestabilizar los sentidos comunes, los materiales y la relación del arte con la política (imagen 58).

\footnotetext{
${ }^{103}$ Vigo estaba conectado, por ejemplo, con las revistas que editaba Clemente Padín en Montevideo: Los huevos del Plata, Ovum 10 y Ovum. Cuenta Padín que "la revista 'Los Huevos del Plata' (17 nros. de 1965 a 1969) nucleó a más de 20 escritores y artistas jóvenes que compartían sus ideas. Gracias a esa revista y a su difusión fue que entramos en contacto con las vanguardias europeas y norteamericanas y tomamos conocimientos de la 'Nueva Poesía' (así se llamaba a la poesía experimental en aquellos años). Fruto de nuestro desarrollo fue que accedimos a nuevas dimensiones de la expresión poética y así nace otra revista que mejor reflejaba esas nuevas tendencias poéticas, 'Ovum 10' (1969-1971) y, luego, ya con carácter cooperativo, 'Ovum' (1971-1975).” (Yto, 2003: s/p).

${ }^{104}$ Análisis de la revista Diagonal Cero pueden encontrarse en Davis (2006), Pérez Balbi (2006), Gradin (2010) y Dolinko (2008, 2010, 2012a, 2012b).
} 


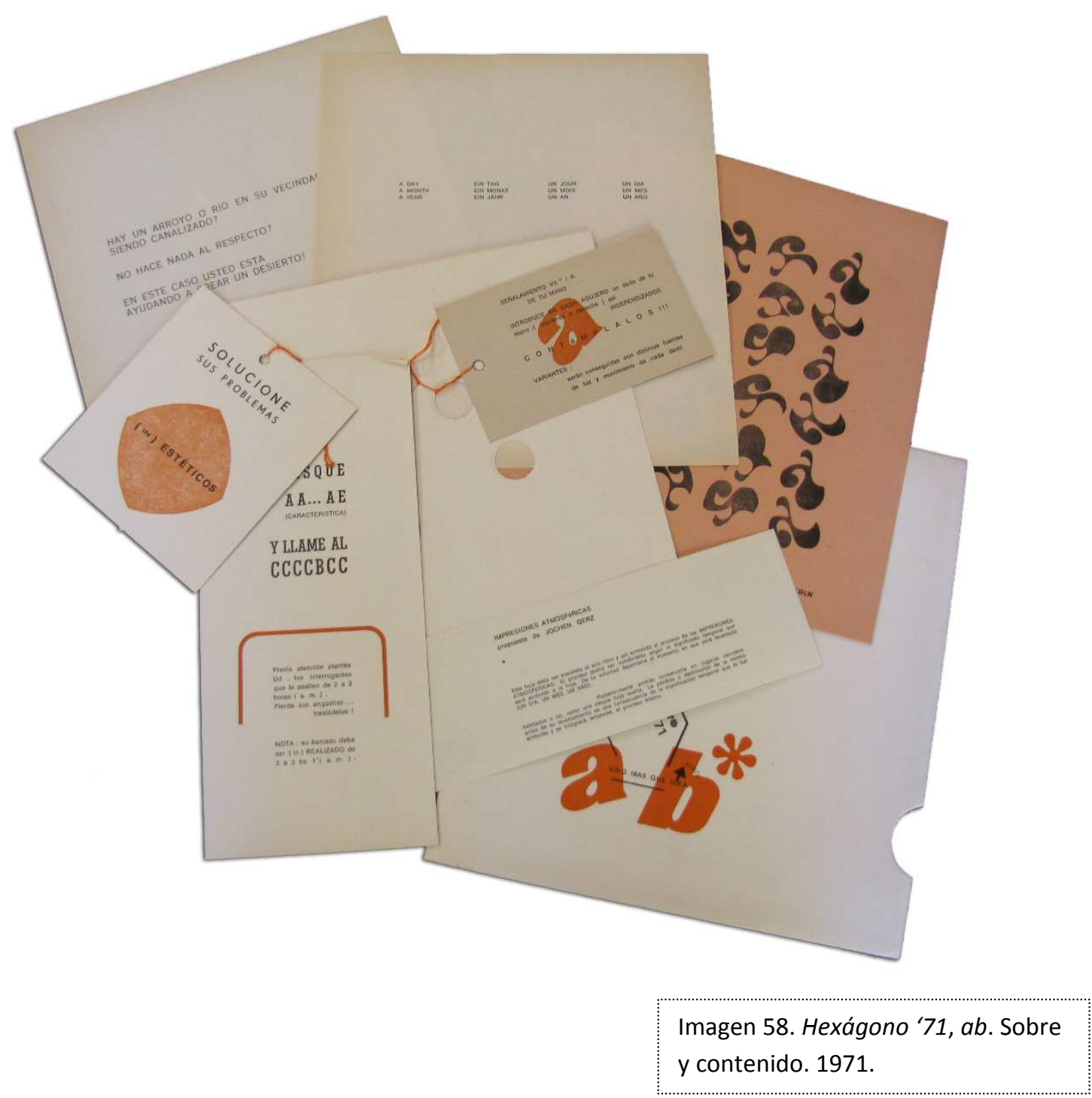

Hexágono es una revista ensamblada (assembling magazine), es decir, un montaje de trabajos de diversos artistas que un editor se encarga se aunar, similar al libro de artista y cuyas estrategias comunicativas se separan de las limitaciones del mundo editorial (Campal, 2001; Murciego, 2008; Méndez Llopis, 2012). En ellas, "la aparición de una obra en forma impresa marca la etapa final de un proceso conceptual y artístico" (Perkins, 2005: 395. Traducción nuestra). Dado que revista está compuesta por páginas aportadas por los artistas, algunos autores han identificado a estas revistas con "museos transportables" (Campal, 2001) o "galerías deslocalizadas" (Murciego, 2008). En el caso de Vigo, esto puede aplicarse dado que solo puede considerarse a Hexágono un museo o una galería en tanto estas instituciones sean desvirtuadas en su papel canónico de consagración y exposición, dado el especial interés que demostró el artista en ponerlas en cuestión, aunque sin abandonar del todo su implicación en ellas (como es el caso de la creación del Museo de la Xilografía, un verdadero “museo transportable”). 
Si bien en las revistas ensambladas el contenido fundamentalmente tiende a ser visual, Vigo propuso también la permanencia de textos propios y de otros autores.

Las revistas ensambladas surgieron a fines de los sesenta con la intención de superar las restricciones editoriales e imposiciones de las revistas normalizadas o convencionales, tanto en su presentación material, la forma en que insertan las hojas, el continente, la tipografía, la calidad del papel, como en el tipo de contenido publicado. Asimismo, carecen del interés comercial y masivo que poseen las que dependen de editoriales (Méndez Llopis, 2012; Gómez, 2007). En general, como Hexágono '71, son cambiantes, volátiles y bordean los materiales precarios.

Las vanguardias de principios del siglo $\mathrm{XX}$, especialmente el futurismo, el dadaísmo y el surrealismo propusieron cambios significativos en los usos de la imagen y el lenguaje que contribuyeron a la creación de nuevas expresiones, de allí que en la segunda mitad del siglo otras corrientes como minimalismo, expresionismo, experimentación deconstructiva, profundizaran las transformaciones y realizaran producciones cada vez más alejadas de las convencionales. Si a partir de Mallarmé el soporte dejó de ser únicamente un receptáculo para convertirse en parte de la propuesta creativa, fue en 1936 que apareció el primer libro-objeto, cuando Marcel Duchamp realizó la Boîte-envalise (caja en maleta), una valija que al abrirla formaba un sostén de pequeñas obras y que también contenía carpetas y soportes con reproducciones en miniatura de sus trabajos (Hopkins, 2000). A esto le siguieron, en los años sesenta, las ediciones en cajas de Fluxus como antecedente de las revistas ensambladas (Murciego, 2008; Perkins, 2005). La reproducción de un texto de Dick Higgins (perteneciente a Fluxus) en el tercer número de Hexágono y las repetidas referencias a Duchamp, especialmente en sus textos tempranos, muestran que Vigo estaba interesado en ambos y que conocía sus trabajos.

Las razones por las cuales comenzaron a publicarse estas revistas, se centran en que eran una respuesta alternativa a las necesidades de algunos artistas de mostrar sus trabajos y, además, se presentaban como estructuras capaces de generar comunidad entre redes de artistas (Perkins, 2005). También funcionaban para los artistas conceptuales a modo de plataforma que permitiera mostrar a un público más amplio ideas, actos u objetos efímeros, de los que habían sido testigo un pequeño número de personas (Webster, 2011). A través de estas revistas, en los setenta, tanto Vigo, como otros artistas 
se acercaron a las revistas con el mismo ingenio con que abrazaron otros medios de comunicación en el 'campo expandido'. Experimentaron con el formato, el diseño y la tipografía, se deleitaban en la materialidad del lenguaje y la impresión, hicieron hincapié en la sensibilidad táctil y la interactividad de la revista, y en primer plano, en los actos de lectura y en el dar vuelta la página (Webster, 2011, Traducción nuestra).

Estas revistas comenzaron a publicarse entre fines de los sesenta y principios de los setenta y se ha considerado que Vigo fue un pionero en este tipo de publicaciones, en tanto se afirma que Hexágono '71 fue una de las primeras de este tipo en el mundo y la de vida más larga en América Latina (Perneczky, 1993; Perkins, 2005). ${ }^{105}$

A diferencia de las revistas normativas, basadas en parámetros industriales y masivos y centradas en el "deber de ceñirse y atenerse a unos cánones editoriales estandarizados por la industria -no digo sin ciertas libertades- para llegar eficazmente a consolidarse en el mercado -sea cual sea su temática, tipo de consumidor, nivel de experimentación gráfica o distribución” (Méndez Llopis, 2012: 198), las ensambladas transgredieron esas normas y habilitaron la creación experimental, lo que permitió tanto la transformación del formato como del contenido, pero limitadas en la tirada y la difusión.

Esto último se debe al tipo de edición que requiere de un trabajo personal, manual o artesanal. En cuanto a la tirada se señala que algunas revistas de este tipo rondan los veinte o treinta ejemplares y, raramente, los trescientos (Campal, 2001), sin embargo cabe destacar que, como se anotó arriba, Hexágono tenía una tirada de quinientos ejemplares, lo cual la coloca en un lugar excepcional respecto a esta cuestión.

La reproductibilidad se hace indispensable en este tipo de publicaciones, ya que es la forma en que pueden hacerse varios ejemplares de la misma obra, apuntando así a una estrategia comunicacional en que el valor de lo auténtico, como lo único, pierda sentido. Si bien esto no fue así en la totalidad de las revistas ensambladas, sí es una característica de la realizada por Vigo.

La función del coordinador en estas publicaciones es fundamental:

\footnotetext{
${ }^{105}$ En su artículo sobre revistas ensambladas, Perkins (2005) sostiene que una de las más notables de Sudamérica es Hexágono '71. Perneczky (1993, 2003) incluyó referencias a las revistas de Vigo y a su relación con el arte-correo, así como con el arte de sellos. El libro de Allen (2011), si bien no incluyó a Hexágono '71 en su estudio, en el listado final de "Revistas de artistas desde 1945 hasta 1989" hizo una breve reseña de Diagonal Cero y Hexágono '71, aunque no específicamente como "revistas ensambladas". Estos casos, sin embargo, no pasan de ser breves referencias sin incluir descripciones más amplias o análisis empíricos e interpretativos. El resto de los trabajos citados en este apartado no mencionan las publicaciones de Vigo, centrados en las revistas publicadas en Estados Unidos y Europa.
} 
El editor se transmuta en una suerte de alquimista/ensamblador de volúmenes en el contenedor elegido (...). Las revistas ensambladas son publicadas por artistas o creadores literarios que buscan, en el placer de editar, una prolongación esencial de su trabajo artístico o literario (Murciego, 2008: s/p).

Así, Vigo ocupó el rol de editor, director y artista, utilizando sus contactos con otros artistas, a quienes convocaba a publicar en su revista. Ellos enviaban vía postal sus trabajos o indicaciones para que Vigo los reprodujera y procedía a incorporarlos a la revista, con lo cual se hace evidente también la relación que tuvieron este tipo de publicaciones con el arte-correo. Según recuerda Juan Carlos Romero, "siempre era a pedido de Vigo, siempre él te decía cuándo tenías que hacer, qué tenías que hacer más o menos para la publicación. Después, la publicación era libre, podía ser una hojita, una grande, chica, mediana, él la plegaba, hacía lo que hacía él: era un artesano del papel y con eso resolvía el problema" (comunicación personal, 2013). En ese sentido decíamos más arriba que Vigo lo hacía en soledad, sin embargo, el resultado de cada una de las revistas era un trabajo colectivo, una nueva obra formada por los trabajos de todos los artistas que habían participado en ese número ${ }^{106}$.

Veremos cómo las características de Hexágono tienden a romper con el sistema habitual del soporte. Primero, la revista carece de numeración de los volúmenes y en su lugar, Vigo utilizó letras (imagen 59). Las letras están repartidas en series de tres $(a, b, c)$ acompañadas por otra letra también en orden alfabético y finalmente una sola letra $e$ (el último número): $a, a b, a c, b c, b d, b e, c d, c e, c f, d e, d g, d f, e$ conforman los trece números publicados ${ }^{107}$.

\footnotetext{
${ }^{106}$ Según el Studienzentrum für Künstlerpublikationen (Centro de Estudios de Publicaciones de Artistas) de Wesergurg - Universität Bremen, las "publicaciones de artistas", entre las que se incluyen los periódicos y revistas de artistas, pueden convertirse en el medio de creación para el artista, por lo que han sido consideradas como "obras de arte", en tanto gozan del mismo estatus y valor que una pintura o una instalación (Studienzentrum für Künstlerpublikationen, s/f. Traducción nuestra).

107 Si bien Vigo puso letras en lugar de números para identificar a cada una de las revistas, para simplificar la lectura nos referiremos a "números", como se utiliza corrientemente.
} 


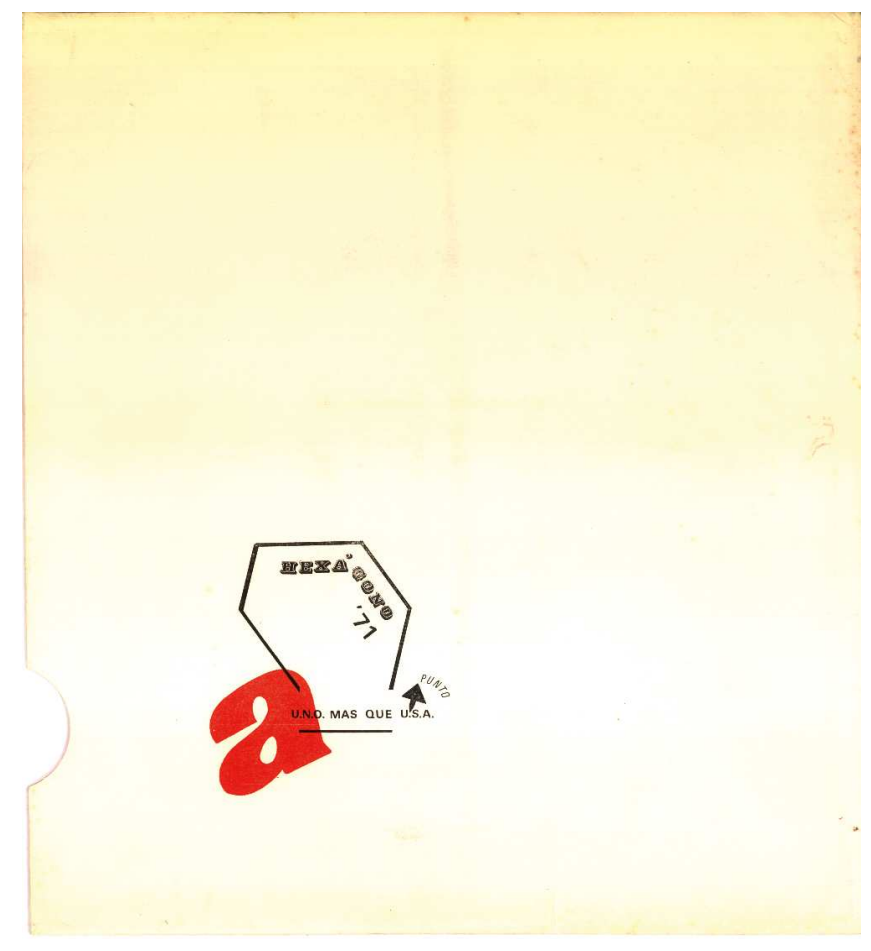

En segundo lugar, las revistas no tienen fecha, por lo que el lector está impedido de identificar plenamente cada número con mes y año. La combinación de esta falta de información con la utilización de letras en lugar de números, implica una forma de desorientación para el lector. Los distintos logos en los que se incluye el año son el único indicador temporal para ubicar al lector, así como las referencias incluidas en los trabajos publicados, pero éstos en muchos casos no son contemporáneos de la fecha de publicación de cada número, sino anteriores. Por ejemplo, como se verá más abajo, en el primer número se publican textos de cuatro y cinco años de antigüedad, lo que desbarajusta criterios de identificación de fechas y contemporaneidad de cada número. Tercero, en cuanto a sus características materiales, apela a un formato diferente del usual, ya que en lugar de tratarse de hojas enganchadas con grampas, ordenadas y cubiertas por tapa y contratapa, la revista está contenida en sobres o carpetas en cuyo interior se encuentran hojas sueltas y sin numerar. La utilización de contenedores en formatos variables y distintos de los de las revistas convencionales es una característica de las ensambladas, incluso la variación de un número a otro, tal como señala Campal (2001). Entre el número $a$ y el $c f$ se utilizan sobres de papel blanco y a partir del número de el continente es una carpeta color verde de dos tapas unidas y una solapa interior en la parte inferior. Las hojas se mantienen a lo largo de todos los números sin ganchos ni referencias de orden, excepto en algunos casos en los que se publican textos largos, los 
que son numerados. El último número también es una carpeta, pero de papel madera (papel de estraza) y tiene la abertura en la mitad de la tapa (imagen 60).

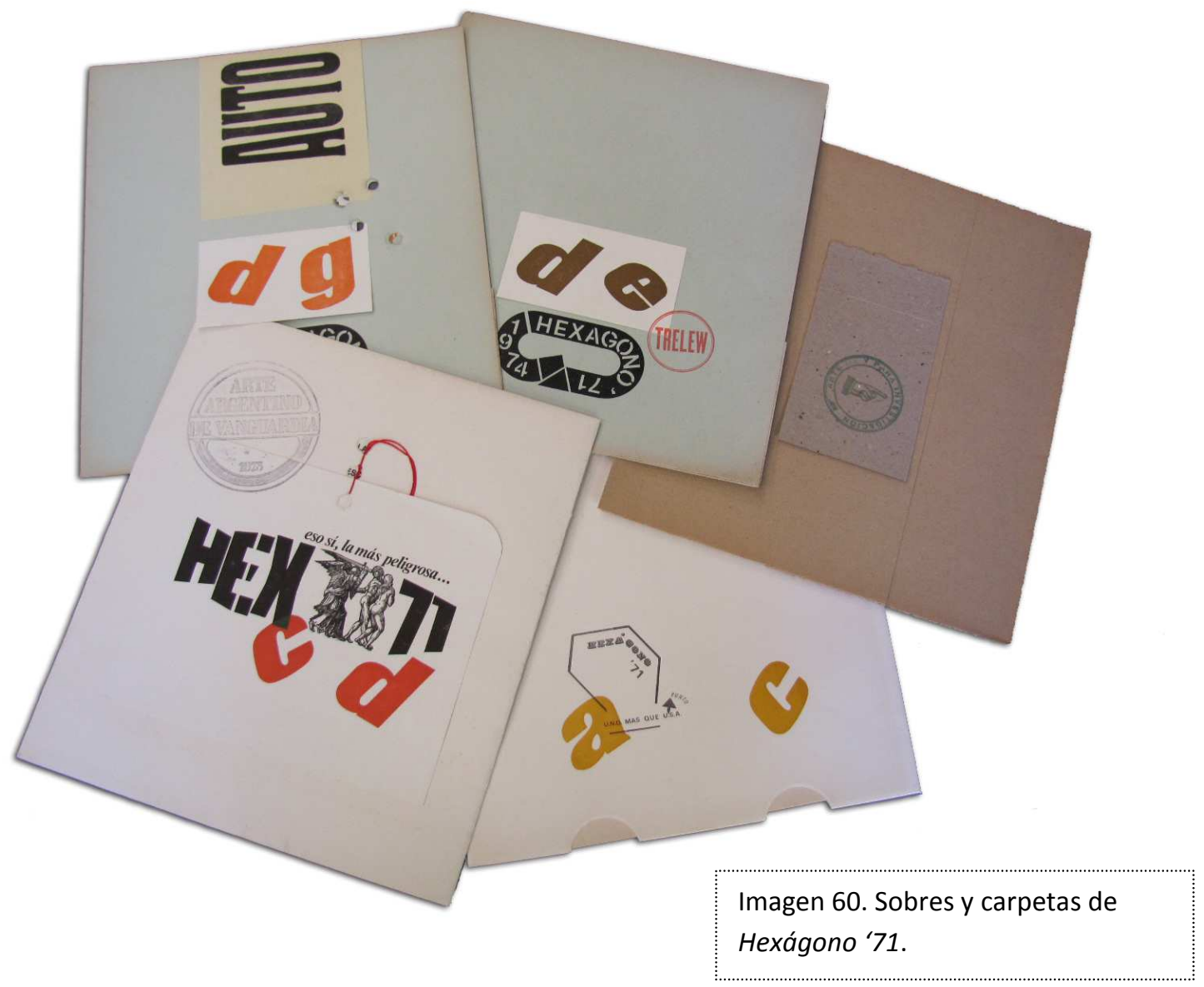

Las perforaciones se encuentran en la mayoría de los números: de los trece números, nueve tienen calado el sobre o la carpeta. Estas perforaciones tienen forma circular y reiteran, como si se tratara de un sello personal, las que se encuentran en grabados y objetos de Vigo. Un ejemplo es el sobre del número bd (imagen 61). Este se encuentra calado con dos círculos de distinto tamaño sobre los que se imprimió la palabra "acceso", y desde los cuales puede observarse parte del contenido de la revista. Estos calados aparecen en distintos trabajos a lo largo de todos los números de la revista. Vigo también los utilizó en otras revistas, poesías visuales, señalamientos, propuestas de acción, y juegan fundamentalmente con lo visual, es decir con la posibilidad de poder ver a través de ellos, mirar de otra manera el mundo. También permiten la acción sensorial, ya que pueden atravesarse los dedos, como en el caso del Señalamiento De tu mano, publicado en Hexágono ab, o de las portadas de la revista, donde el lector puede tocar el contenido que se encuentra en su interior. El troquelado opera además como un procedimiento de ruptura con la ilusión representativa o escritural, es decir que la 
superficie dejar de ser apoyo o soporte de alguna re-presentación y aparece como un cartón u hoja con perforaciones.

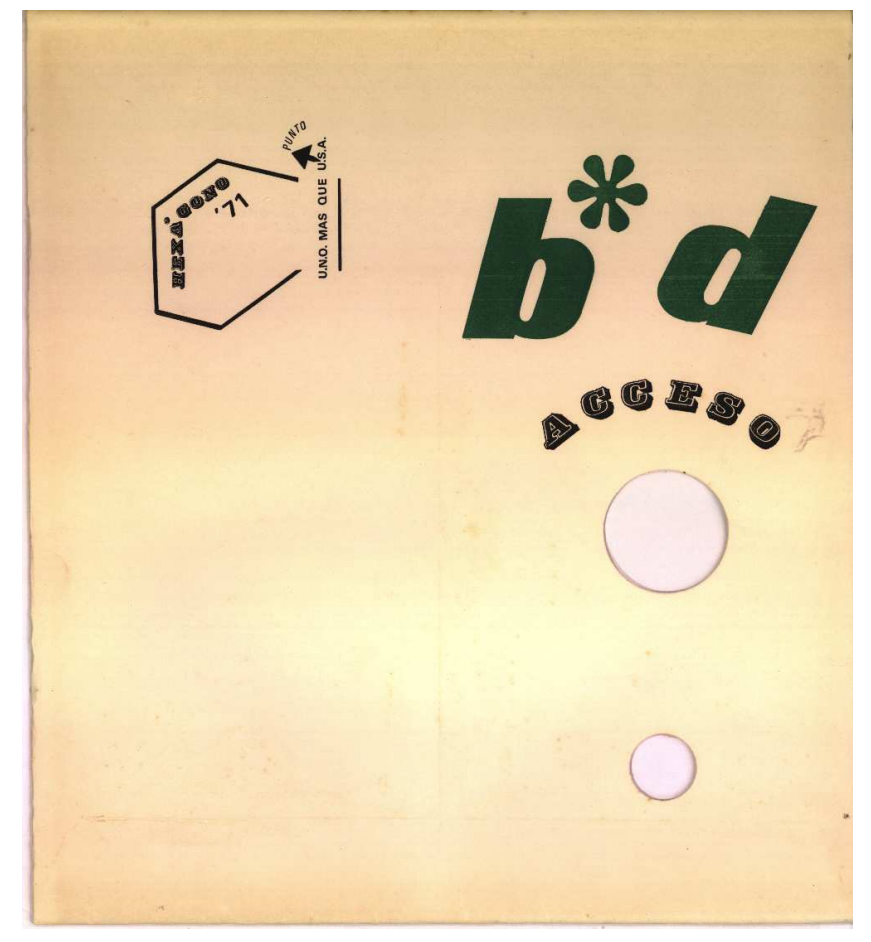

Todas, excepto el último número, poseen en la parte delantera del sobre o carpeta el nombre de la revista, aunque el logo se va modificando. En este aspecto, las primeras seis $(a, a b, a c, b c, b d$ y $b e)$ tienen cierta homogeneidad, ya que el nombre está rodeado por un hexágono abierto en cuya parte inferior dice "U.N.O. MÁS QUE U.S.A.” y del punto que sigue a la "U" de U.S.A. sale una flecha que señala la palabra escrita "punto" (imágenes 59 y 61). Como dijimos en el capítulo anterior, el nombre de la revista surge de la forma que tenía su oficina en el edificio de Tribunales. Así, puede pensarse que también el logo de un hexágono abierto sea una réplica del plano de ese lugar. La frase que le sigue "U.N.O. MÁS QUE U.S.A.”, según Vigo (El Día, 7/1/1973), se debe a que el hexágono tiene un lado más que el pentágono, analogía con el conocido edificio del Departamento de Defensa de los Estados Unidos. Los puntos en la palabra "U.N.O." no permiten que la interpretación del lector sea inmediata y segura, además, el énfasis puesto en el punto de la "U", señalado y escrito, parece ser un recurso tautológico en el que se combinan imagen, letra y palabra. De este modo, Vigo indica, otra vez, que las letras y los signos pueden salirse del rol normalmente asignado en la comunicación para poseer un estatuto estético-visual. 
A partir del número $c d$ se producen cambios significativos en el contenido de la revista, así como también en su materialidad. Así, desde el $c d$ hasta el $c f$ el logo es la palabra Hex seguida por una ilustración que podría haber sido tomada de un grabado de la biblia, donde aparece una pareja desnuda que es empujada por un ángel con una espada, lo que se interpreta rápidamente como Adán y Eva siendo echados del paraíso. Al lado de la imagen sigue el número 71. Por encima del logo se inscribe la frase "eso sí, la más peligrosa...", que analizaremos más abajo (imagen 62).

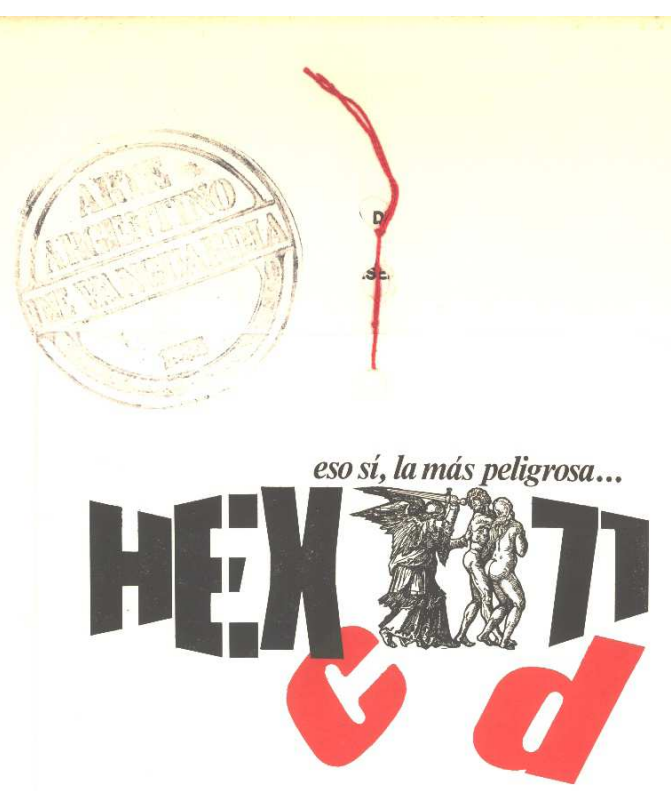

En la serie de las letras $d$ el logo cambia nuevamente: "Hexágono '71 1974” está escrito en una cinta con fondo negro que forma un óvalo (imagen 63). 


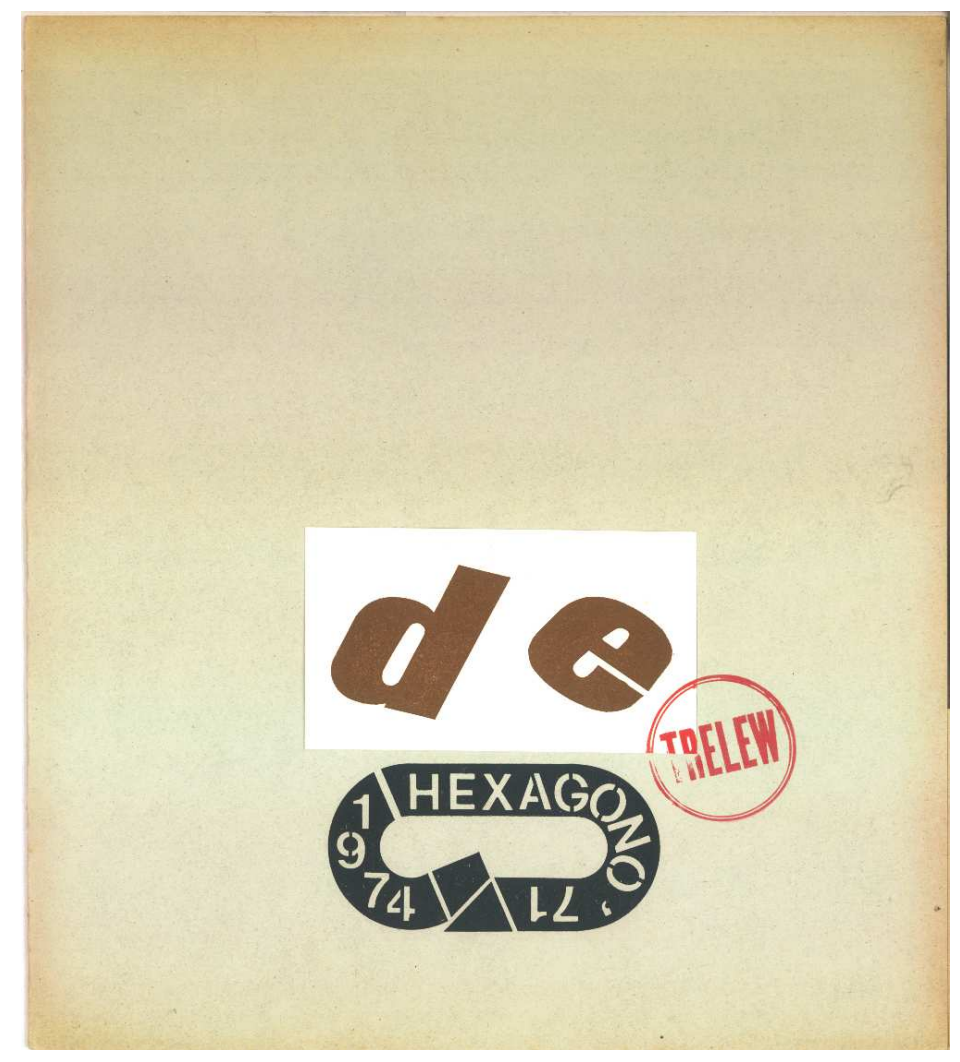

Imagen 63. Vigo, portada de Hexágono '71, de. 1974.

Finalmente, la última revista, $e$, en su portada solo tiene pegado un cartón con un sello circular que dice "Arte de y para investigación". En el centro del sello tiene una mano con el dedo índice que señala. Recién al abrir las solapas, aparece una referencia a la revista: una hoja que dice "Hex 71" y el año 1975 colocado debajo forman la imagen de un hexágono (imagen 64). Tiene un sello que dice "Sellado a mano", adelantando el contenido de este número, centrado en la producción de trabajos con ese instrumento. Sobre el logo y la letra $e$ que identifica al número, se imprimió un cuadro con las letras del abecedario, números y signos, así como imágenes de manos con el dedo índice que apunta hacia ambos lados y una de ellas emergiendo de una trompeta, los cuales componen una poesía visual, reforzando nuevamente la desnaturalización de los signos convencionales. 


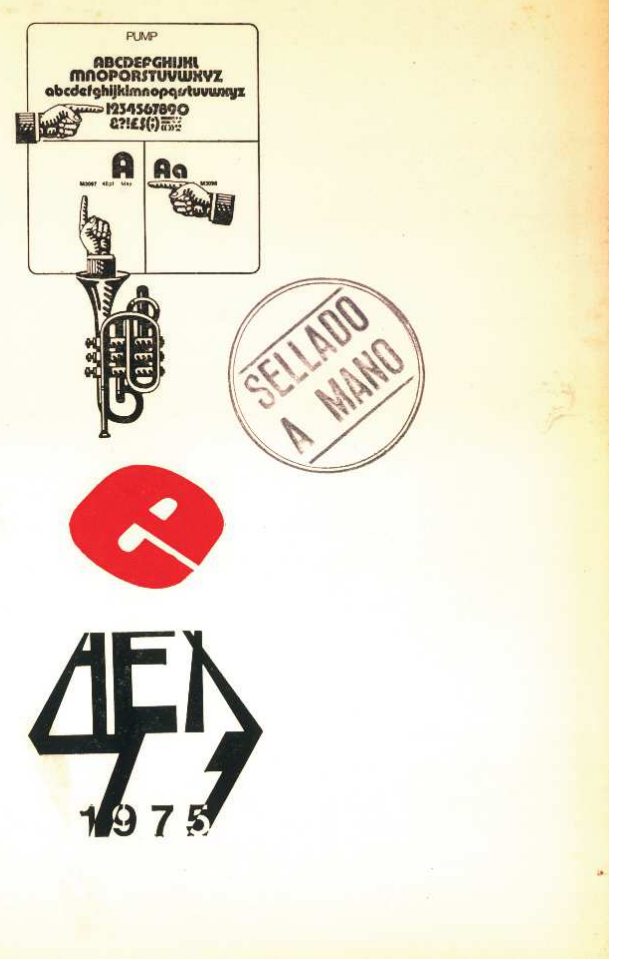

Imagen 64. Vigo, primera página de Hexágono '71, e. 1975.

En cuarto lugar, otros de los modos por los cuales Vigo disrumpe al género revista es a través de la ausencia de información: la estructura y sus puestos tales como director, editor, colaboradores -que en general dan una idea de lo que puede contener la revista en su interior- no se publican en ninguno de los números. Solo aparece la firma de las poesías visuales, de los textos escritos y en el caso de traducciones figura el nombre de Vigo o de su esposa, Elena Comas, quien participaba como activa colaboradora de la revista. Esta falta de información se mantiene a lo largo de todos los números.

Una quinta característica es que no hay secciones o divisiones internas que establezcan un cierto orden y continuidad. Los textos e imágenes se suceden unos a otros, desordenadamente y sin un sistema o estructura que se repita entre los números. A esto coadyuva la falta de numeración de las páginas, permitiendo el intercambio de hojas o su desmembramiento.

En sexto lugar, se observa la falta de avisos o publicidades que contribuyan a su publicación (lo cual también la diferencia de Diagonal Cero ${ }^{108}$ ). Financiada por el bolsillo de su director, la revista carecía de relación con el mercado y se distribuía por

\footnotetext{
${ }^{108}$ Diagonal Cero contiene los datos de director, editor, colaboradores y seguido, una página editorial. En esta revista las páginas en algunos casos están numerada y en otros no.
} 
suscripciones entre los conocidos de Vigo, con lo cual su circulación fue acotada y escasamente referida en la prensa especializada de la época. Una de las formas en que Vigo conseguía suscripciones para costear los gastos de publicación era ubicándola entre amigos, conocidos y personal de los tribunales judiciales. Éstos últimos, que recibían tanto a Hexágono como a otros trabajos de Vigo, se convirtieron en extraños destinatarios de una revista vanguardista, que contenía múltiples referencias especializadas para el mundo estrictamente artístico -como discusiones acerca del estatuto de la historieta en el mundo del arte o sobre problemas de recepción aurática de las obras- en combinación con elementos del mundo de la política radicalizada y críticas al propio sistema jurídico por injusto o ineficaz.

Estas formas de intervenir disruptivamente sobre el género, sumadas al tipo de trabajos publicados, tendientes a la desautomatización o desnaturalización de la lectura y la visión, resultan en una política de la revista, en el mismo sentido que Rancière lo utiliza para nombrar a la diferente repartición de lo sensible que puede provocar el régimen estético (2007) y que en nuestro armado teórico hemos llamado lo político del arte. Esto se da al mismo tiempo que la revista es política (en el sentido expresado más arriba de la política), por su contenido, su intencionalidad comunicativa respecto de los problemas sociales y políticos del momento, dimensión a través de la cual participó de las diferentes formas que adoptó la política en ese período. Además, Vigo interviene sobre un soporte que es por excelencia el medio de comunicación de la política revolucionaria: las revistas, la "prensa" partidaria (junto con volantes) aparecen como uno de los soportes de la propaganda y como herramienta de activismo más utilizado por las diferentes organizaciones. Lo mismo sucede con la comunicación de las vanguardias artísticas, que en general se realizó también a través de revistas. Esto abonar a la idea de que Vigo asumió una posición crítica o de rebeldía, pero que al mismo tiempo desestabilizó los criterios del buen revolucionario, produciendo obras que no siempre intentan comunicar ideas o directivas claras con las que luego el receptor pueda modificar su rumbo de vida o sus posiciones ideológicas en un sentido de cambio social y político.

Finalmente, en la misma lógica que utilizó para los señalamientos y los trabajos con materiales judiciales, Vigo envió trabajos suyos publicados en Hexágono a otras revistas o para ser expuestos en diversas muestras. Es el caso, por ejemplo, de Soluciones económicas ofrecidas por el 'systema' al pueblo y Poema matemático censurado, enviados para exponer en Buenos Aires, así como La ley del embudo y Señalamiento 
VIII "De tu mano", para la exposición "Prospective '74", Museu de Arte Contemporanea de Sao Paulo, entre otros. Para la muestra en Londres que realizó con el "Grupo de los Trece" en noviembre de 1974, envió nuevamente Soluciones... y Souvenir de Viet Nam.

Hexágono funcionó también como editorial con el nombre "Hexágono '71. La flaca grabada". Entre las ediciones podemos nombrar a: Informe O'O0A (1971), Informe O’OOB: 10 ideas de arte pobre de Carlos Ginzburg, la postal Poema matemático censurado (1974), Crozier-Zabala-Vigo (1975) (100 ejemplares de carácter manual), donde incluyó dos pequeñas obras de cada uno de los tres autores y Tres detalles de una obra que no me pertenece (1975).

\section{2. "EL PODER DE LO IMPRESO"}

Si la revista anterior, Diagonal Cero, había tenido una circulación más o menos amplia, Hexágono no solo tuvo un alcance menor, sino que tampoco fue reseñada en la prensa de la época. Entre las escasas referencias publicadas sobre la revista, se encuentran dos notas, una en el diario local y otra en una revista inglesa.

En el diario El Día (7/01/1973), el autor de la nota se pregunta si es o no una revista y se responde "ni sí ni no": "Tiene algunos elementos que la señalarían como tal: cierta periodicidad en la salida (es trimestral), un determinado número de ejemplares (500 por vez), artículos, colaboraciones... La gran ruptura con el género es formal. $\mathrm{Ni}$ en su formato, ni en su estructura, Hexágono se parece a una revista". Explica que se trata de una "cosa" de estilo "underground", retomando un término ("cosa") que Vigo ya había utilizado para nombrar a la revista Diagonal Cero. Según la misma nota, Hexágono se vincula con expresiones vanguardistas: "artículos tipo editorial sobre distintas manifestaciones artísticas, reproducciones de notas aparecidas en el extranjero (...), señalamientos de la producción de artistas locales y nacionales, propuestas, poesía, canciones y hasta historietas". Al ser entrevistado Vigo dice que "colaboradores fijos no hay, el número se va armando a medida que llegan los trabajos", ya que al ser un sobre con hojas sueltas, es posible agregar un trabajo a último momento. La nota finaliza manifestando la ventaja de que el lector pueda separar los trabajos y manejarlos con independencia.

El otro artículo referido a Hexágono está firmado por Felipe Ehrenberg en Kontexts (1974), publicado en Inglaterra y titulado "Hexágono '71 and other tid-bits published by 
Edgardo Antonio Vigo". Ehrenberg describe la revista y hace hincapié en sus hojas sueltas, los sobres, la existencia de arte por correspondencia, instrucciones y "excelentes juegos de palabras". Dice que, además, está impecablemente producida. En cuanto al contenido, Ehrenberg expresa que Vigo muestra fuertes afinidades con las literaturas experimentales italianas, francesas y latinoamericanas. Luego, explica que como fueron producidas en Argentina ("país del 3er. Mundo"), Vigo "se conduce con exquisito margen de tiradas comprometidas con los artistas y su sociedad. Al hacer esto se proponen como niños mimados de la minoría liberal del régimen reaccionario." En cuanto a sus obras, remarca que están respaldadas por el Di Tella y el CAYC, así como son "finas e internacionales". Finaliza diciendo que "Vigo es consciente del poder de lo impreso y la producción múltiple” (Ehrenberg, 1974: s/p. Traducción nuestra).

Ambas notas realizan una caracterización de Hexágono, aunque la primera destaca su ruptura formal y la segunda, la potencialidad política que encarna un proyecto de este tipo. Para conocer qué hizo Vigo con "el poder de lo impreso", es necesario continuar indagando en los aspectos más sobresalientes de la revista, así como en aquellos que pueden pasar desapercibidos. En cuanto a la selección de los artículos e imágenes, no parece haber otra lógica que la del propio gusto e interés de su director. Teniendo en cuenta sus amplias relaciones nacionales e internacionales, Vigo no parecía tener dificultad en reproducir textos hallados en libros o revistas que conseguía por intercambio ${ }^{109}$ o por los amigos que tenía en otros países. Con el antecedente logrado en Diagonal Cero de establecerse en una "trama de revistas latinoamericanas (...) desde el registro contracultural, marginal, 'micro' o artesanal como signo de virtual identidad comunitaria" (Dolinko, 2008: 9), generó, también desde Hexágono, una suerte de red de relaciones entre artistas argentinos y del mundo, que luego aparecerán juntos en exposiciones o publicaciones cruzadas.

\subsection{VOLUNTAD PROGRAMÁTICA}

Si las revistas ensambladas "son una respuesta a la cultura dominante, con una clara actitud activista, que trata de difundir otras maneras de entender la cultura, sus

\footnotetext{
109 Vigo comúnmente enviaba números de sus revistas a diversas bibliotecas y editoriales ubicadas en otros países y solicitaba a cambio que el enviaran libros o revistas con las últimas novedades del arte.
} 
relaciones con la sociedad e, incluso, con uno mismo" (Vidal y Martín: 2010: 3), será necesario indagar cuáles son los modos por los cuales Hexágono practicó esa tensión entre cultura dominante y alternativa y de qué forma lo planteó en sus textos.

El primer número (a) no tiene editorial a modo de presentación, declaración de propósitos o intereses. Allí, además de imágenes, se publicaron dos textos escritos que podría pensarse que ofician de presentación de la revista: el "Prefacio" a Banda Dibujada y Figuración narrativa, escrito por Burne Hogarth en el año 1967 y "Arte pobre" de Germano Celant, de febrero de 1968. Ambos -tardíamente incorporados en la publicación, teniendo en cuenta que se trata de artículos de cuatro y cinco años de antigüedad- se centran en zonas marginales del arte, la tira dibujada y el arte pobre, teorizando sobre sus condiciones e importancia, así como las aspiraciones de los autores sobre la relevancia de ese tipo de producciones en el arte. En el primero, se declara la importancia que ha adquirido la producción de tiras dibujadas o historietas, que sin embargo no ha tenido un consecuente reconocimiento como arte, sino más bien un desprecio entre "los círculos informados (...) que determinan la apreciación de las artes", quienes niegan su riqueza y aptitud para mostrar los aspectos más importantes de la vida. Sobre la ubicación de este texto en la revista, conviene señalar que se la coloca en el anverso de la hoja en la que se publica una de las "historietas herméticas" de Vigo. Es decir, que aparece como una posible explicación o interpretación de la relevancia de ese tipo de producciones al que el mismo Vigo se dedicaba.

El segundo texto, del reconocido teórico del arte pobre, no solo busca un reconocimiento ese tipo de producciones, sino que además de indicar sus características más relevantes, tiene la forma de un ensayo que teoriza sobre el hombre y el arte en general. Dice que a través del arte pobre ("contingencias fónicas y escritas") se desarrolla una aceleración y transformación de la praxis operativa que rompe con lo programado y se convierte en una estrategia socio-cultural de "fragmentación de sistema de dictadura industrial". Frente a la situación de obreros y estudiantes recuérdese que este texto es de 1968-, y la importancia de la colectividad, dice que "el problema no reside ya en ofrecer recetas, tal como pueden resultar los objetos estéticos, sino sensibilizar o agilizar la sensibilidad del público a través de acciones que conduzcan a una nueva intensificación perceptiva, realizada mediante la corporeidad y la conciencia". Por ello, sostiene Celant, deben unirse estudiantes, obreros e intelectuales, eliminando todo corporativismo, en un nuevo tipo de acción con una 
metodología de la ruptura y derivando en una organización donde se identifique la acción, la dimensión psicofísica y el trabajo.

Este texto que pertenece a la forma manifiesto significa para la revista no solo la declaración de su contenido en cuanto a una reivindicación del arte pobre como una de las formas del arte y como un modo de cambiar las relaciones sociales o de incorporarse a los cambios que se estaban sucediendo. Si se observan ambos escritos -más allá de las especificidades de los dos modos artísticos- pueden entenderse como una clave de lectura para la revista: instalarse en los bordes de lo que es digno de ser considerado un buen arte, es decir, las Bellas Artes con sus características formales, materiales, de autoría y circulación. La toma de posición de un lugar marginal podrá recorrerse a lo largo de todos sus números, en algunos casos, asumido como "vanguardia". A ello se suma que la forma de la revista, su materialidad y la intervención sobre el soporte realizada por Vigo, también la ubican en los márgenes del género revista, como prototipo de la comunicación tanto política como vanguardista. Vigo se desvincula así tanto de la idea de Artes aceptadas y académicas, como del género revista, entendido como objeto de comunicación que respeta ciertas regularidades para ser reconocido como tal.

Esto implica, además, involucrarse en los cambios que se venían produciendo en el arte desde la década anterior en cuanto al auge de la experimentación, del uso de nuevos modos de expresión, así como de otros espacios de circulación y exposición, alternativos a los tradicionales. Además, la revista se incluye en otras transformaciones culturales y en la sensación más o menos generalizada de estar viviendo un momento histórico de renovación en todos los sentidos. Esto último se hace evidente en la publicación de textos que hacen referencia a la necesaria adecuación de las expresiones artísticas a las novedades de la época.

Es claro que el centro de atención está puesto en el arte, pero su relación con la sociedad parece ineludible si lo que se pretende es producir cambios o bien incorporarse a las transformaciones sociales en curso. Esta opción inicial operará, entonces, como guía -si bien con matices- del camino que transitará la revista.

En la elección para el primer número de dos autores extranjeros, explicitando esa cualidad (debajo de Hogarth dice "Director de la Escuela de Arte Visuales N.Y.", y en el caso de Celant aclara que se trata de una traducción del italiano), puede estar dando cuenta de un recurso de apelación a lo extranjero como autoridad y al mismo tiempo sentando las bases de un interés internacionalista que se desarrollará a lo largo de la 
revista -aunque por momentos con menor intensidad- al publicar trabajos o textos de autores extranjeros.

Si el primer número de la revista puede convertirse en un indicador de su propuesta, en este de siete trabajos publicados en total, tres tienen conexión con el extranjero. Se trata de los dos únicos textos que se encuentran en ese número (de Burne Hogarth y Germano Celant), a los que se suma una propuesta Jochen Gerz para intervenir la guía telefónica de París, donde la invitación está escrita es francés, inglés y español.

La revista muestra así un interés de vinculación con el extranjero, evidente en la publicación de poesías y textos de artistas o teóricos del mundo que igualan o sobrepasan en número a los nacionales. Además de la procedencia de los autores, los textos o frases incluidos en los trabajos artísticos en varios idiomas son frecuentes.

Esta característica de Hexágono que veremos especialmente en el análisis de su primera etapa, mantiene una continuidad con el mismo interés desplegado por Vigo desde los comienzos de su carrera personal.

Resumiendo, podemos decir que las declaraciones indirectas de la voluntad programática de la revista son:

- vanguardia artística

- textos críticos del arte canónico

- difusión de nuevas formas de expresión

- relación con lo internacional

A estas declaraciones se suma la concreción de sus propósitos a través de la publicación sostenida de trabajos artísticos que involucran tanto la novedad estética como la incorporación de elementos de la realidad social y política del momento. Si bien el énfasis en cada uno de estos dos aspectos va variando a través del tiempo, ambos están presentes en mayor o menor medida.

\subsection{UN PÚBLICO MOVILIZADO}

Al preguntarnos cuál es la relación de la revista con el público, la presencia permanente de obras en que se lo convoca a realizar una acción, como el caso de las propuestas de Carlos Ginzburg, Jochen Gerz y Vigo que se verán más abajo, avalan la idea de que el público, así como ocupa un lugar central en el programa de Vigo, también lo hace en la 
revista. El tipo de receptores ideales a los que se dirige es un público activo, atento, capaz de colaborar con la conclusión de una obra (tanto en términos materiales como intelectuales) o de reflexionar sobre los textos publicados. A esto se suma que, además de la recepción de la revista entre los círculos de conocidos, tanto otros artistas como compañeros de Tribunales, había otros receptores. Cuenta Horacio Zabala que cuando Vigo viajaba en tren, solía dejar un número en el asiento para que pareciera un olvido y cualquier pasajero pudiera acceder a la revista: "es una vieja costumbre transgresiva y subversiva de Edgardo" (entrevistado por Curell, 1995). Este juego entre la intencionalidad y el azar, ampliaba el tipo de destinatarios de Hexágono (aunque podemos suponer que en un número muy reducido), e implicaba una acción casi performática de simular un descuido para obtener un resultado incalculable.

Las revistas ensambladas, a diferencia de las convencionales que buscan "asegurar la legibilidad y comprensión" (Méndez Llopis, 2012: 198), tienden a generar un producto nunca del todo concluido y a establecer con el receptor una relación en la que se considere la posibilidad de distintas interpretaciones o lecturas, llegando hasta una vinculación en la que se exploren las sensibilidades y emociones, "una fuente de sugerencias a experimentar por el lector" (201).

Las historietas de Vigo -nunca del todo claras-, las comunicaciones y poesía visuales publicadas en Hexágono tienden a hacer imprescindible un público que esté dispuesto a reflexionar y prestar atención frente a la sorpresa, la ironía o el descolocamiento. Esto se debe al criterio utilizado por Vigo al escoger los trabajos para publicar, en el que prima un interés por desechar la lectura o mirada convencional. Propone un receptor que pase a ser también productor o intérprete más o menos libre tanto de las imágenes como de la manipulación del artefacto revista, quitando páginas o ubicándolas en otro lugar. Esto último no implica desistir de la incorporación de trabajos -especialmente en la segunda etapa- cuyo mensaje permanece relativamente inalterado luego de su encuentro con el lector y donde la comunicación política se ha privilegiado sobre otras funciones. En la heterogeneidad que permitió esta combinación, Vigo ha conciliado la presencia de intervenciones radicales del receptor con otros casos en los que este se mantiene -tanto en los trabajos más explícitamente políticos como en los textos teóricos- en un rol menos activo y en una relación menos incierta con el sentido. El resultado son revistas en las que se tensiona o distorsiona el rol de receptor, en tanto pasa por distintos momentos de mayor y menor participación en un mismo número, con contenidos más herméticos o más explícitos, lo cual genera un salto permanente que limita una mirada 
única y controlada y que mantiene una vacilación entre sentidos compartidos legibles y otros suspendidos.

En la elección de trabajos y textos para publicar en la revista Vigo siguió desarrollando parte su poética, como continuación de sus trabajos artísticos y teóricos, y con una clara intencionalidad movilizadora.

\subsection{PRIMEROS SEIS NÚMEROS}

Teniendo en cuenta las variables tipo de relación con la política y lo político, condición de extranjeros y nacionales de los autores y tipos de trabajos publicados, es posible considerar que Hexágono tuvo dos etapas: los primeros seis números y los siguientes siete $^{110}$. Si bien hay aspectos centrales que se mantuvieron estables -el más importante es la condición de permanecer en una estética vanguardista- hay otros que se modificaron a través del tiempo y que estimulan en el análisis de la revista la identificación de rupturas, quiebres y diferencias, negando cualquier interpretación como un todo homogéneo e invariable. No es llamativo que ese cambio se manifieste en la publicación al mismo tiempo que avanzaban los acontecimientos políticos más importantes de la época. Vigo, así como sus colaboradores, se encargaron de acentuar una interpretación de esos sucesos en trabajos que los expresaban o complejizaban con una mirada estética desprejuiciada.

En las revistas que van de la $a$ a la be (las primeras seis), se presentan algunas constantes: la presencia estable de imágenes o textos artísticos en cada número es mucho mayor que la de textos teóricos (un $80 \%$ de trabajos artísticos frente a un $20 \%$ de textos), lo que indica que el interés principal está puesto en lo visual. Los tipos de trabajos que representan la mayor parte de lo publicado son poesías visuales, historietas, fotografías, así como comunicaciones. En cuanto a los textos, son, en general, escritos teóricos acerca del arte, especialmente enfocados en una mirada que tiende a desdeñar las Bellas Artes y exaltar formas de expresión no académicas y muchas veces no reconocidas como arte, tales como la historieta, el arte pobre y el uso del espacio público para la producción artística.

\footnotetext{
${ }^{110}$ Tanto De Rueda (2003a) como Davis (2007a) describen los cambios producidos en la revista por una mayor vinculación con los temas políticos.
} 
En esta primera etapa, los trabajos expresamente políticos, es decir cuyo contenido puede remitirse directamente a una comunicación política son solo tres (de un total de treinta y cinco trabajos artísticos y textos publicados en estos seis números). Llama la atención que los tres pertenezcan al propio Vigo, pudiendo interpretarse que solo permitió que él mismo publique ese tipo de producciones. Analizaremos cada uno de ellos.

Al abrir la solapa del primer número de la revista $(a, 1971)$ aparece adosado a la retiración de tapa un sobre de papel transparente debajo del cual se inscribe la siguiente leyenda: "Souvenir de Viet-Nam. Viaja. Busca una trinchera (de cualquier bando), recoge una vida y guárdala en el sobre transparente" (imagen 65). La ubicación de esta obra en la revista, en el primer número y detrás de la portada, le otorga una importancia destacada y da una señal de que la política y lo político, aún de diversos modos -como un entramado- forman parte de la misma, la co-constituyen no como simples agregados. Se sabe que la guerra de Vietnam (1964 - 1975) cobró una relevancia internacional no solo por ser unos de los conflictos más resonantes de la guerra fría, sino también por el rechazo popular que desató en Estados Unidos como consecuencia de su intervención. Se multiplicaron los llamados a la paz y el final de la contienda entre los bloques. Así, también en plena guerra, Vigo decide incorporar la temática de un modo bien evidente. 


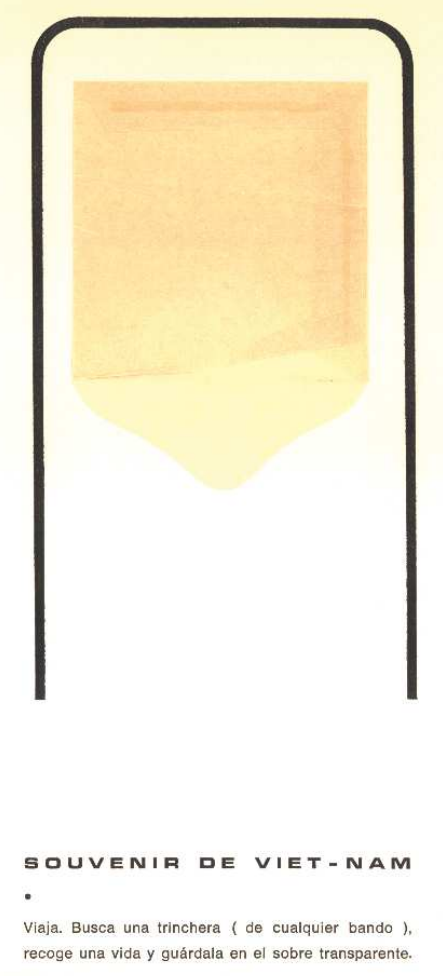

El uso del "souvenir" -tratado en otra parte de la tesis- se aplica aquí a un recuerdo imposible: la búsqueda de "una vida" (¿el alma?, ¿el cuerpo?) y su guarda dentro de un sobre pegado a la revista. Es así como el autor logra la combinación de la política con una estética que continúa siendo extrañificante, no propagandística y que por un lado, toma un tema fácilmente reconocible por los lectores -y de crítica política- pero por otro, lo traduce a una estética que implica un proceso de decodificación más complejo, incompleto o inseguro. Así, se emparenta con la estrategia de las vanguardias de elegir un tema político y no dejar en claro más que cierta intención u orientación denuncialista: corta el curso de la comunicación y el que lee y ve queda detenido. Se requiere la intervención del espectador, de su capacidad de comprensión o de su disposición a abandonar la expectativa de una aprehensión satisfactoria sin una explicación adoctrinadora: en términos de Rancière (2010), un respeto a la inteligencia y autonomía de quien recibe la obra de arte, ya que más allá de las doctrinas sobre la necesidad de participación o no de los espectadores, éstos "son a la vez espectadores distantes e intérpretes activos del espectáculo que se les propone. Este es el punto esencial: los espectadores ven, sienten y comprenden algo en la medida en que componen su propio poema" (2010: 20). Esta idea de que aquellos a quienes se dirige la 
obra tienen capacidad de interpretar y crear más allá de las intencionalidades de los artistas, se convierte en una clave para el análisis de la revista a lo largo de sus dos etapas, así como de los demás trabajos de Vigo vistos a los largo de la tesis. Pero esta cuestión adquiere una importancia particular en la pesquisa sobre Hexágono porque allí se ve con más claridad que esa premisa no se pierde aún en los momentos en que los temas de la radicalización política atraviesan profundamente las decisiones y trabajos de Vigo.

El segundo trabajo que relacionamos con la política es la historieta U.S.A. versus Latin America (imagen 66) que Vigo publicó en $b c$ (1972).

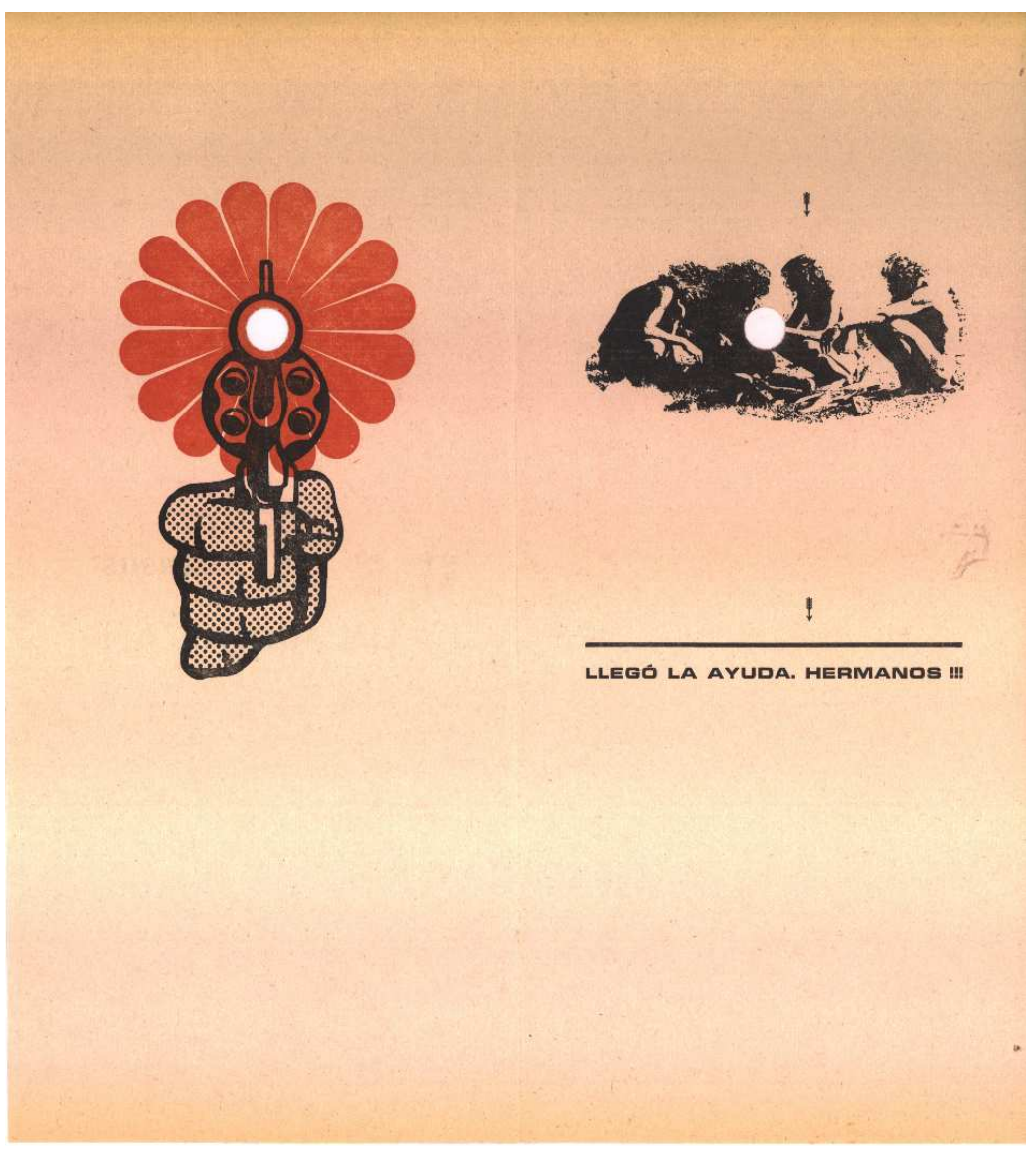

La historieta está impresa en una hoja doblada longitudinalmente. El título (en la cara de hace de tapa), debajo del cual se sitúa un círculo calado, es el que presenta -como en el caso del texto de Vietnam- la temática del trabajo. Aquí es la oposición entre Estados Unidos y América Latina o mejor, el ataque del primero sobre la segunda. El texto en inglés puede ligarse con un uso del idioma de aquél al que se está criticando. Al abrir la hoja, se observa que el calado coincide con el caño de un arma de fuego que apunta 
directamente hacia el espectador, con un tratamiento pop de la imagen extendido en los Estados Unidos, lo cual también puede emparentarse con el uso del inglés en el título. En la página siguiente, el mismo agujero se ubica en medio de una imagen repetidamente utilizada por Vigo -y sin que podamos establecer un único sentido a lo largo de su poética- de cuatro hombres desnudos con apariencia prehistórica, que en uno de sus documentos de archivos llamó "grupo de familia" (Biopsia 1971). Finalmente, el texto "Llegó la ayuda, hermanos!!" alude, posiblemente, al tipo de ayuda que puede brindar Estados Unidos al resto de América: violencia y destrucción de las relaciones humanas. Opera aquí el mismo dispositivo utilizado en el trabajo sobre Vietnam, que deja entender que se trata de una crítica política, pero que vela otra parte de la obra, la hace confusa.

Soluciones económicas ofrecida por el "systema" al pueblo es el tercer trabajo de Vigo que nos interesa analizar aquí. Publicado en el $b d$, durante el año 1972, es un sobre en cuyo interior contiene tres tarjetas ${ }^{111}$ (imágenes 67).

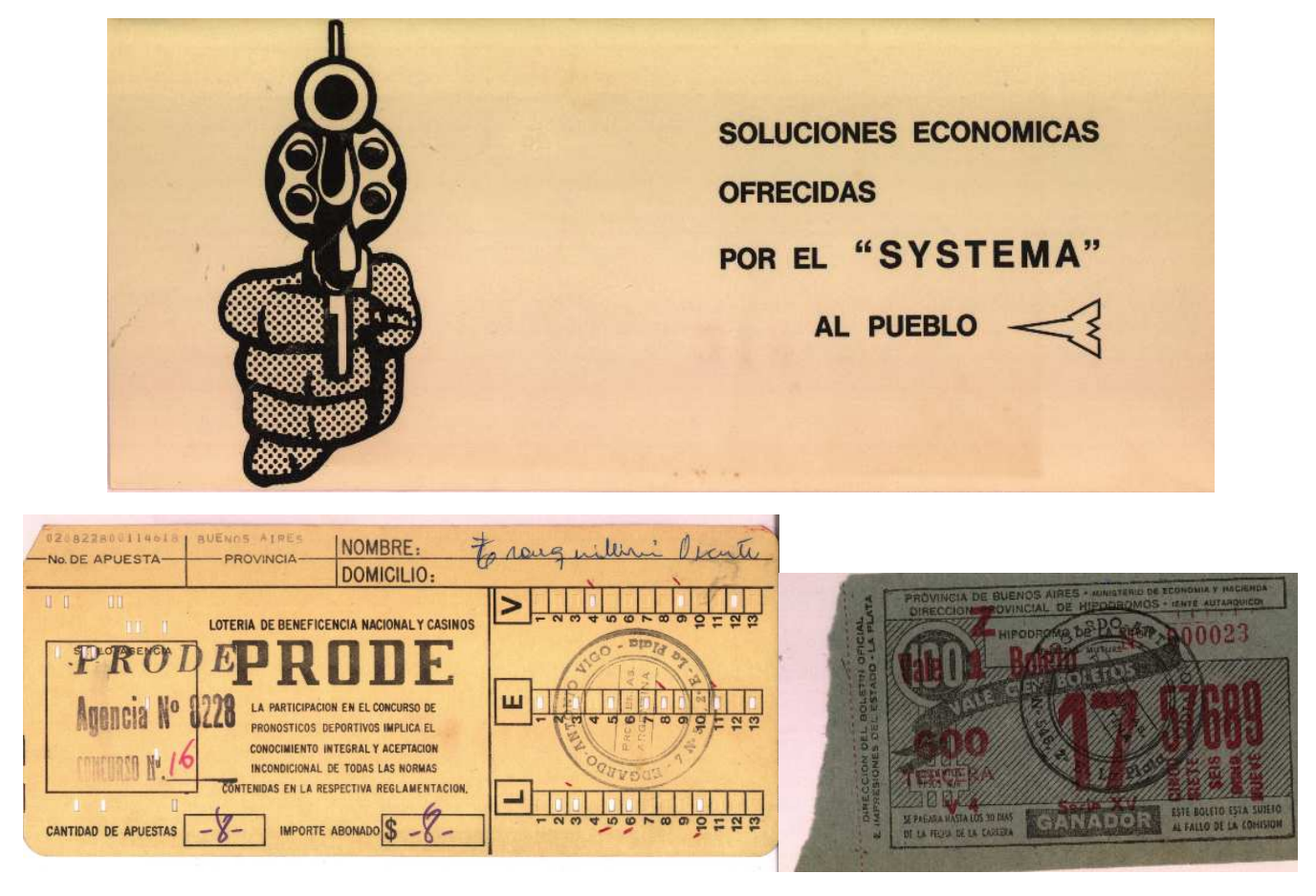

\footnotetext{
${ }^{111}$ También repartió este sobre durante la presentación que hizo Jorge D’Elia de Soledad hay una sola, una guía para un café concert, en abril de 1973 en Chihuahua. El sobre se distribuyó como "souvenir" (Biopsia 1973).
} 


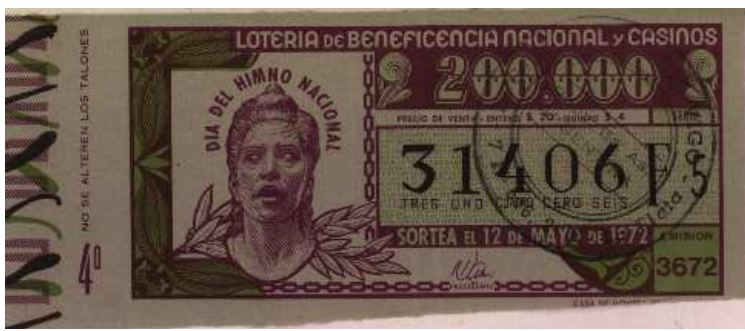

Imágenes 67. Vigo, Soluciones

económicas ofrecidas por el

"systema" al pueblo. 1972.

El sobre tiene impresa la misma imagen del arma de fuego apuntando al frente que en el trabajo anterior, aunque en este caso, sin la perforación. A su lado, el título nuevamente ofrece un dato clave para la comprensión del trabajo. Al igual que en el Señalamiento $I X$, referido a la masacre de Trelew y producido un año más tarde, la palabra "systema" entrecomillada y con la letra y griega, puede atribuirse, como en el caso anterior, al uso del inglés (system), aunque de un modo castellanizado. Al abrir el sobre, el lector se encuentra con tres tarjetas usadas de juegos de azar: el prode, el hipódromo ${ }^{112}$ y la lotería. Los boletos son originales, pero, a modo de intervención sobre esa originalidad -y en consonancia con lo dicho en el apartado sobre el uso de los materiales judicialescada uno tiene impreso un sello personal de Vigo en forma circular que dice "Edgardo Antonio Vigo, $7 \mathrm{~N}^{\circ}$ 526, $2^{\circ}$ E, La Plata. Prov. Bs. As. Argentina". Nuevamente, la búsqueda de la sorpresa y la ironía operan como moduladores de la temática.

La idea de "systema" en este caso es explícita porque está en el texto impreso del sobre -a diferencia del trabajo ya analizado "La ley del embudo", que se publicará unos números más adelante. El contenido del sobre es, por el contrario, una clave de lectura de la realidad: el sistema no ofrece nada consistente para solucionar los problemas de la gente, entonces, lo único que impulsa en este sentido es la ayuda del azar o la suerte. El título es, como decíamos antes, esclarecedor sobre el tipo de interpretación que desea el autor de la obra, una guía y en esto se manifiesta la idea de mantener un lenguaje claro que permita la comunicación. Pero el contenido del sobre requiere al menos cierta astucia para vincular el sentido de esos boletos con la falta de verdaderas resoluciones a los problemas de la gente, digamos, trabajo, bienestar, derechos sociales, etc. La forma de la obra también está en consonancia con un tipo de expresión desarticulada: un sobre

${ }^{112}$ En un collage publicado en $D R K W$, B, 1960 Vigo ya había utilizado un Boleto de Hipódromo, aquí la significación de esa inclusión es otra, pero mantiene la idea de utilizar materiales cotidianos y efímeros en la obra de arte. 
con papeles en su interior desconcierta a quienes deseen contemplar una obra de arte en el sentido tradicional e implica, aunque escueta, una acción por parte del receptor, lo que responde también a la lógica de la participación del público.

A la presencia de estos trabajos que hemos llamado expresamente políticos, es decir relacionados con la política, se suman en este mismo número de Hexágono otros que implican igualmente una crítica al modelo económico o social, aunque de modo menos evidente. Un ejemplo de ello es la (in)hostia (imagen 68), donde Vigo, aprovechando el largo uso que ha hecho de la negación de una palabra (por ejemplo en "(in)comunicación”, “(in)estético" o "(in)conferencia”), apela a un objeto de alto valor religioso y con él, un desafío a la iglesia católica.

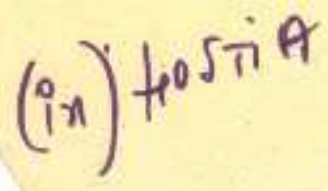

Imagen 68. Vigo, (in) hostia. 1971.

Debe destacarse que en este caso también hace uso de un círculo, una de las formas reiteradas a lo largo de su poética y que hemos mencionado también como relevante en las portadas de las revistas. Asimismo, la presencia desconcertante de un círculo de papel, suelto y sin ninguna otra aclaración que su propio nombre, también permite abonar a la idea de una revista dis-yunta o disensual ${ }^{113}$. En otro caso, las fotografías comparativas entre el Empire State Building y un cohete espacial de Betty Radin pueden implicar no solo una muestra de la similitud entre ambas en su aspecto formal, sino también -en el contexto de la revista- una referencia al poder del imperio norteamericano: un centro simbólico del capitalismo y un cohete que demuestran la puja de poder entre oriente y occidente, el poder también en el espacio estelar. En el mismo número, el montaje de Anna Esposito À la guerre comme à la guerre está formado por fotografías de un trozo de torso humano que forma una celada. En plena guerra de Vietnam, se presenta la idea de que a la guerra se va con el cuerpo y se lo destruye.

\footnotetext{
${ }^{113}$ Encontramos antecedentes de la (in) hostia en los catálogos que Vigo realizaba para el "Cine Club" que organizó en el año 1957. Allí incluía críticas de las películas que proyectaba, poesías visuales y pequeñas tarjetas sueltas, en general, con el sello de una letra. Puede considerarse a la (in) hostia una continuación de aquellas pequeñas tarjetas (Biopsia 1957).
} 
Estos dos montajes refuerzan un carácter denuncialista de la revista, aunque (al menos hasta este número) permanece siempre en un plano más o menos simbólico o metafórico. Asimismo, puede pensarse que se establecen en la búsqueda de un efecto emocional- ideológico sobre los receptores, al ser puestos ante un tema tan controversial de un modo tal como el de estos trabajos. Si bien es claro que el objetivo de la revista es la intervención en el debate sobre el arte actual y su contraposición a los viejos cánones, clasificaciones y definiciones del arte, se mantiene una condición crítica respecto del orden social actual. Ya sea en los textos publicados que aluden más o menos directamente a la necesidad de cambios en el sistema de dominación o en las imágenes artísticas.

En estos primeros seis números los autores de la mayoría de los trabajos (un 85\%) son extranjeros, y solo tres son argentinos: Vigo (quien publica la mayor cantidad de trabajos), Carlos Ginzburg y Lido Iacopetti. Veremos más abajo cómo esta relación se modifica a partir de la entrada de Vigo al CAYC, lo cual se hace evidente desde el número $c d$. Sin embargo, la elevada cantidad de trabajos de Vigo, hace que el número de obras o textos de autores argentinos casi iguale a la de extranjeros.

Los extranjeros que colaboraron en estos seis números son: Burne Hogarth, Dick Higgins (Estados Unidos), Germano Celant, Annalisa Alloatti, Anna Esposito, Mirella Bentivoglio (Italia), Jochen Gerz, Klaus y Renate Groh, Hans Kalkmann (Alemania), Julien Blaine (Francia), Henry Targowski, Robin Crozier, Betty Radin (Inglaterra), Clemente Padín (Uruguay), Moarcy Cirne (Brasil) ${ }^{114}$. Todos ellos, ligados a diferentes tipos de expresión vanguardista o fuera de los cánones del arte tradicional. Algunas de estas relaciones y la forma de comunicación postal que utilizaban para enviar los trabajos fueron adelantando la enorme red de artistas de la que participó Vigo con el

\footnotetext{
${ }^{114}$ Con muchos de ellos -así como con los que aparecen en los demás números de Hexágono- Vigo mantuvo relaciones que le permitieron exponer o publicar en el exterior, por ejemplo, en enero de 1975 el Museo de la Xilografía de La Plata organizó una muestra en la Galería Il Brandale - Centro d'Arte e di cultura, Savona, Italia. Allí Vigo envió cinco xilografías y lo presentó Mirella Bentivoglio. Expusieron también Irma Amato, Raúl Cattelani, Abel Bruno Versacci, Hipólito Veytes. Otro ejemplo es la relación que tenía con Robin Crozier con quien, entre otras actividades, publicó en el libro Portrait of Robin Crozier, Edit. Ceolfrith, Sunderland, 1975, la obra (de Vigo) Crozier's portrait. Este listado, así como el que aparecerá más adelante sobre la segunda etapa de la revista, es un primer mapa para continuar explorando las relaciones y redes que Vigo construyó con sus colegas.
} 
$\operatorname{arte-correo~}^{115}$. Julien Blaine y Robin Crozier mantuvieron con Vigo una relación más larga y estrecha.

Las poesías visuales ocupan un lugar muy reducido en comparación con lo que se publicaba en Diagonal Cero y aparece fuertemente la presencia de comunicaciones. Estas son textos en los que los artistas desean transmitir un pensamiento, una reflexión sobre el arte o el mundo en general (imagen 69). En muchos casos, la disposición de las palabras en la página propone también un sentido visual, o bien a través del uso de sellos (que en este período aún es poco frecuente) o de imágenes.

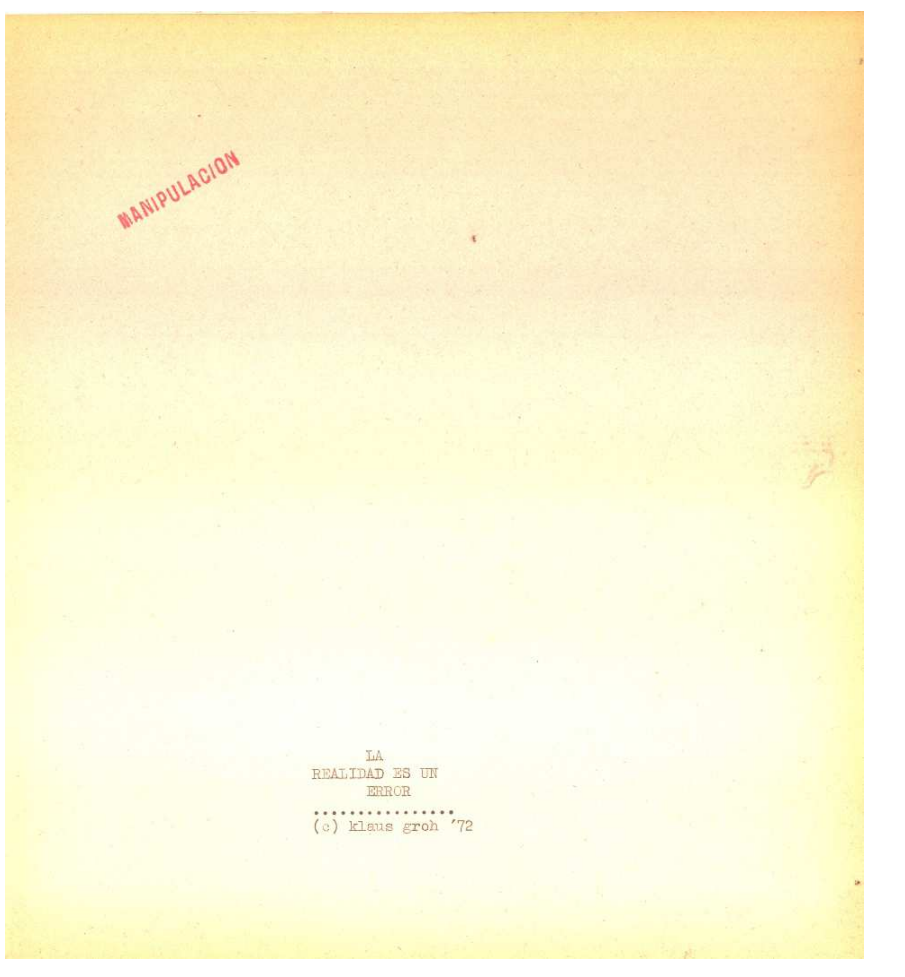

Imagen 69. Klaus Groh, Manipulación. La realidad es un error. 1972.

A partir de la ubicación de letras o textos en las primeras obras vanguardistas de principios del siglo XX, la utilización de frases como parte de la obra, o conformándola, se hicieron cada vez más frecuentes. Esto se mantuvo en las neovanguardias, convertidas en comunicaciones o en proposiciones de acción (aunque algunas fueran irrealizables), y aparece con una presencia alta y estable en los números de Hexágono.

Los textos publicados a lo largo de los trece números marcan el camino que va transitando la revista: en estos primeros seis proponen un estado del mundo del arte, en

\footnotetext{
115 Perneczky $(1993,2003)$ ha incorporado en sus libros un listado de intervenciones de diversos artistas de arte-correo donde muestra esquemáticamente los lazos que mantuvieron. Entre ellos, Vigo aparece mencionado repetidamente, involucrado en decenas de publicaciones y exposiciones de ese tipo de arte y con una intensa actividad en relación con otros artistas.
} 
el que las expresiones y formas alternativas a las artes tradicionales emergen como salida o propuesta crítica.

En cuanto a los textos publicados en esta primera etapa, además de los dos textos ya reseñados aparecido en $a$ (los de Hogarth y Celant sobre banda dibujada y arte pobre), Vigo incorporó en el tercer número $(a c)$ una traducción de "Aburrimiento y peligro" de Dick Higgins, tomada de una publicación de Nueva York de 1966. Como miembro de Fluxus, el autor propone pensar en el empleo del aburrimiento en el arte en tanto se convierte en una de las posibilidades de escapar a lo utilitario, decorativo o entretenido. Ejemplos del uso del aburrimiento, según este autor, son las composiciones de Schoenberg, Erik Satie o las presentaciones de Fluxus. Dice, además, que en algunos casos se trata del involucramiento del público sin siquiera dar las claves de su participación -que llama "estructuras vacías"-, de modo de que se genere una expectativa sobre lo que ocurrirá. También destaca el uso del peligro a través de happenings. Finalmente, dice que la utilización del aburrimiento o el peligro son señales de "buena calidad" y representan la mentalidad de la época, lejos de la búsqueda del éxito total o garantizado. Así, afirma que obras no decorativas ni cómodas resultan interesantes porque abren nuevas experiencias.

En $b c$ Vigo tradujo "La importancia de la tira dibujada", de Moacy Cirne, publicado originalmente en Blum! La explosión creativa de las tiras dibujadas, con la Editora Vozes Limitadas de Petropolis, Brasil. Aparece así el segundo texto sobre historietas y en consonancia con la publicación de historietas del propio Vigo. Cirne destaca el peso de la historieta que, a pesar de haber sido subestimada, es una de las formas de comunicación de la sociedad de masas gracias a su reproductibilidad técnica. Así, en clave benjaminiana, dice que la posibilidad de ser reproducidas amplía su difusión y la capacidad de comunicación, ya que se trata de una continuación histórica de otras reproducciones, como la fotografía y el cine. Las historietas "ampliarán las perspectivas de invención, consumo y radicalidad" y, parafraseando a "La obra de arte en la época de su reproductibilidad técnica" (Benjamin, 1989), dice que el tercer mundo responde a la dominación con la politización de la historieta.

El autor afirma que a pesar de que las historietas representan a la ideología pequeño burguesa -dado que es este sector su principal consumidor- tienen la potencialidad de poner en peligro a la estructura del arte occidental. Además, se han convertido en un nuevo tipo de literatura popular del siglo XX. Finaliza diciendo que lo más importante 
de la historieta no es saber si son arte o no, sino su poder de comunicación y de revitalizar formas expresivas.

En el resto de los textos publicados en estos seis números se encuentra la letra de canción de Dick Higgins dedicada al "Movimiento liberación de las mujeres", titulada Canción de cólera / 10 -en el número ac-, cuyo tema es el cambio de actitud de los hombres en el hogar y en el mundo. Más tarde, en el $b d$, se publicó una invitación a ver presentaciones de Lido Iacopetti llamadas "imágenes imigráficas". Seguido a esto hay una explicación del artista sobre la razón por la cual no se presenta en galerías, salones o museos. Dice que lo hace en lugares no presupuestos para la presentación y que se integran así al medioambiente circundante. Como es claro, se ubica en total correspondencia con lo expresado por Vigo en 1969 sobre la necesidad del abandono de las instituciones y la utilización del espacio público u otros sitios no específicamente artísticos. Este texto de Iacopetti se complementa con el ensayo que Vigo publicó en el número siguiente (be), "La calle: escenario del arte actual" (ya reseñado antes), centrado en un análisis de la situación del arte y las instituciones, frente a las que propone la utilización del espacio público y un cambio en la actitud de los artistas en sus producciones y especialmente en relación con el público.

Los textos teóricos nombrados se corresponden con las intencionalidades, gustos y perspectivas de Vigo sobre el arte, de modo que parecen una presentación de sus propias elecciones para la construcción de su poética. Las prácticas marginales, los medios que proponen y las formas de estimular al espectador se imbrican en la misma búsqueda que realizó Vigo de un tipo de arte vanguardista.

La afirmación de que en las revistas ensambladas prevaleció "la descontextualización de imágenes, mensajes y materiales de uso poco habituales, creando una dinámica red de absoluta actualidad, con altas dosis de ironía y crítica" (Pastor en Méndez Llopis, 2012: 199), coincide con estos primeros seis números de Hexágono. Veremos seguidamente de qué modos esta impronta enriquece también a la segunda etapa, aunque complejizándose y enraizando en otros elementos de la realidad política y social.

\section{6. ÚLTIMOS SIETE NÚMEROS}

A partir de número $c d$ se observa una modificación en la deriva de la revista, una segunda etapa. No solo, como se mencionó antes, del logo e ilustración de la tapa, sino también el contenido. 
Uno de los primeros cambios que saltan a la vista es la masiva presencia de autores nacionales frente a la de extranjeros: si antes la proporción era mucho mayor para los extranjeros, ahora es la inversa. Teniendo en cuenta que el número total de trabajos (artísticos y textos) publicados supera en mucho a los números anteriores (una relación de 35 a 58), la gran mayoría de las obras y la totalidad de los textos teóricos son de autores argentinos. Los trabajos de extranjeros se reemplazaron por trabajos de integrantes del CAYC, quienes se transformaron de hecho en colaboradores de la revista, aunque Vigo mantuvo la autonomía e individualidad de todas las decisiones concernientes a ella.

Como se mencionó en el capítulo 1, Vigo tuvo una intensa relación con el CAYC desde comienzos de 1970. El momento de mayor involucramiento fue a partir de su incorporación al "Grupo de los 13", a principios de 1973 hasta septiembre de 1974. Estas fechas coinciden en esta segunda etapa de la revista, ya que $c d$ se publicó en 1973. En la primera hoja del número que abre esta segunda etapa de Hexágono, dando cuenta de la importancia de la mencionada incorporación de Vigo al CAYC, se publica un texto en papel membretado de dicha institución y sin firma, aunque su autor es el propio Vigo. Su título es "Un arte de sistemas concretado como objeto" y está fechado 19 de marzo de 1973. El artículo -reseñado en el capítulo 1- tiene al comienzo el sello de Vigo utilizado en otras oportunidades y consiste en una reseña crítica de la muestra $E l$ Grupo de los Trece en Arte de sistemas, realizada en el CAYC, así como otras reflexiones acerca del arte de sistemas, el arte conceptual y una caracterización del grupo.

En cuanto a los trabajos de autores extranjeros de la segunda etapa de Hexágono, éstos son Nicola Andreace, Michele Perfetti, Franco Vaccari (Italia), Guillermo Deisler (Chile), Endre Tôt (Hungría), Michael Joseph Phillips, Winsor McKey (Estado Unidos), Clemente Padín (Uruguay), Henry Targowski, Pauline Smith, Genesis Orridge (Inglaterra), Klaus Groh, Roberto Rehfeldt (Alemania), Ops (Andrés Rábago) (España) y la convocatoria de Chuk Stake Enterprizes (Canadá). Artistas visuales, dibujantes, historietistas, artistas de acción, artistas conceptuales, etc. se concentraron en estos números, pero la mayoría de ellos aparecen en el último número (e), dedicado completamente al arte con sellos.

Este giro nacional puede explicarse por la inserción en temáticas más locales y el tono de denuncia política que adquiere la revista a partir de entonces. Además, se muestra en algunos números una posición anti-colonialista (por ejemplo, el "Bando" de la revista 
Barrilete publicado en Hexágono de, 1974). Ligado a esto, se observa un marcado incremento de trabajos de temática política frente a los únicos tres de la primera etapa. Así como en Diagonal Cero Vigo viró desde un interés más centrado en las vanguardias europeas a otro más latinoamericano, lo cual puede relacionarse con el giro latinoamericanista de la cultura en general (Dolinko, 2008, 2012b), el año 1973 también representa un momento de creciente politización general, tanto por la preparación para la vuelta de Perón, como por la polarización que entre derecha e izquierda operó dentro del peronismo y las decisiones que tomaron las diferentes organizaciones frente al inminente regreso del líder y a la presencia ineludible de Cámpora y el Devotazo.

En cuanto a la cara del sobre que hace de portada, el agregado de la inscripción "Eso sí, la más peligrosa..." invitaría a pensar -al receptor de la época- en una revista vinculada al momento de radicalización política que se estaba viviendo. La idea de "peligrosidad" de algo o de alguien, más que una relación con la ruptura estética, aludía, en ese momento, a militantes u organizaciones políticos, sindicales, sociales que se disponían a luchar-de distintos modos- contra el "sistema". ¿Qué implica, entonces, esa leyenda en una revista de arte? Puede interpretarse como una señal de interpenetración más evidente con la situación política y social: la revista se ha vuelto "peligrosa" porque a partir de ese número la masacre de Trelew, el Che y la represión son los temas por excelencia de los trabajos allí publicados. Volveremos sobre este asunto más adelante.

Al menos la mitad del contenido del primer número de esta etapa se concentra en algún tipo de crítica política. Inventario es un trabajo de Bercetche de 1973 (imagen 70) que consiste en una hoja divida longitudinalmente en la que del lado izquierdo se encuentra la palabra "Inventario" y del derecho la siguiente lista: "7 muertos, 13 heridos, 3 desaparecidos, 4 camiones, 1 bar, 1 cabina telefónica, 1 quiosco, 5 viviendas, 1 hospicio, 1 templo". Todas las palabras están seguidas por un tilde, excepto "3 desaparecidos" en el que el 3 está escrito sobre un 2 y luego se ubica una cruz. Si bien tanto el título como el texto no ofrecen un dato certero de la referencia a un acontecimiento político, la ligazón que puede hacer el receptor entre este listado y la realidad política es inevitable. 


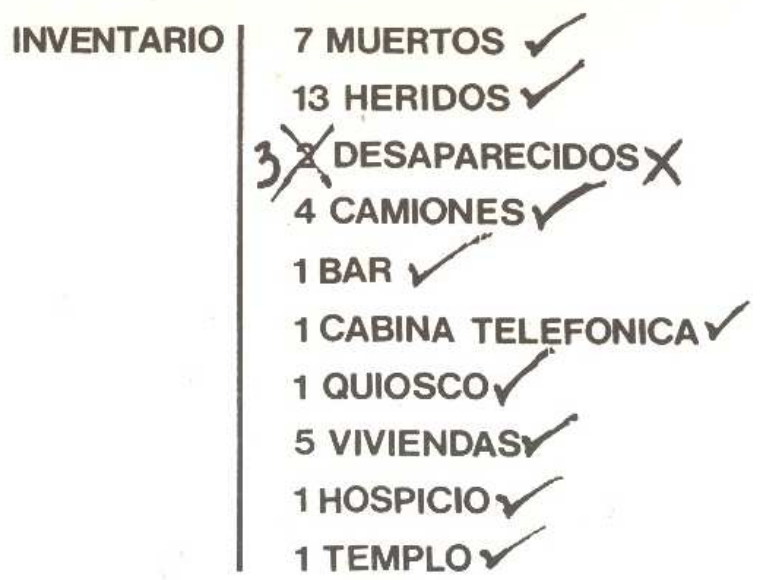

Imagen 70. Juan Bercetche, Inventario. 1973.

Luego, La ley del embudo de Vigo, analizada en el capítulo anterior, da cuenta de una crítica política al sistema jurídico. En vinculación con la cercanía que adquiere la revista con la masacre de Trelew, ese trabajo se reprodujo también en el "Informe sobre Trelew" (agosto de 1974), una publicación organizada por el Grupo Barrilete y el Frente de Trabajadores de la Cultura, bajo el sello editorial COFAPPEG (Comisión Familiares Presos Políticos Estudiantiles y Gremiales).

Herida, de Luis Pazos, es otro de los trabajos publicado en $c d$ : un dibujo en el que la sangre que emana de la silueta de una persona asesinada forma el mapa de América de Sur (imagen 71).

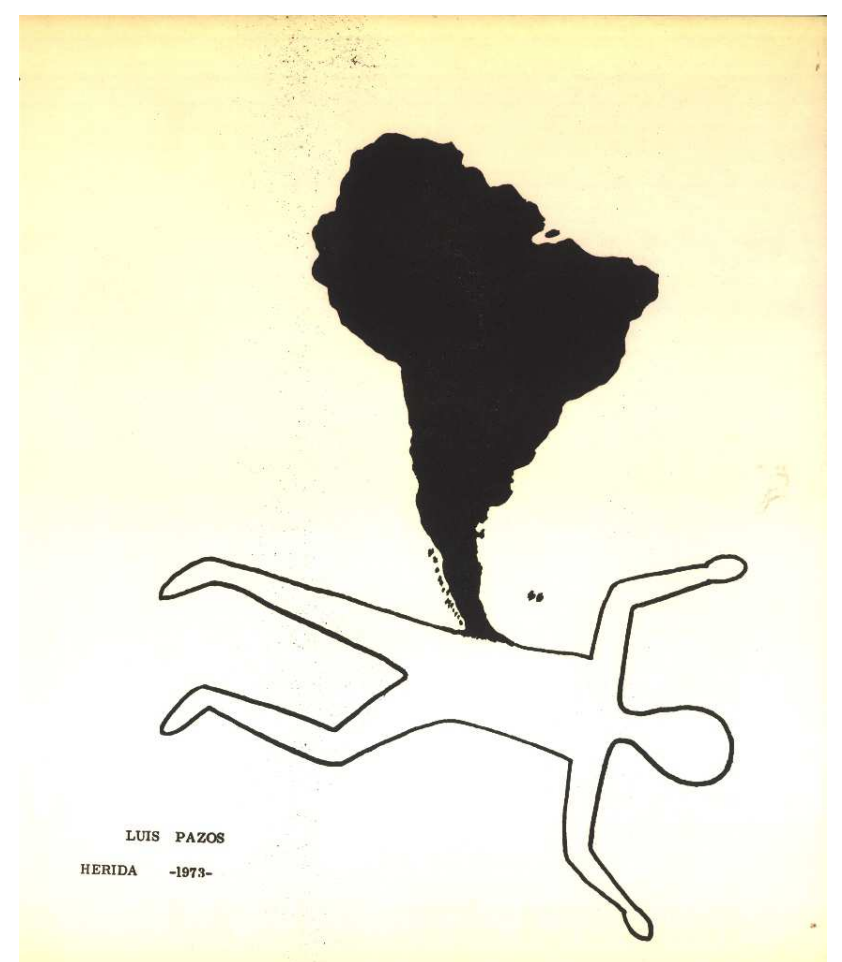


Romero copió dos veces la foto de un cuerpo sin vida yaciente en la calle que tomó de un periódico y lo tituló La violencia, como una explicitación de lo que ella significaba en aquellos tiempos y de los límites a los que se estaba llegando (imagen 72). En el anverso de la hoja, ubicó un texto sobre la violencia que consiste en una descripción de sus características en el plano de la física. El texto tiene al final los nombres de Leonardo Da Vinci (Breviarios) y de J. C. Romero

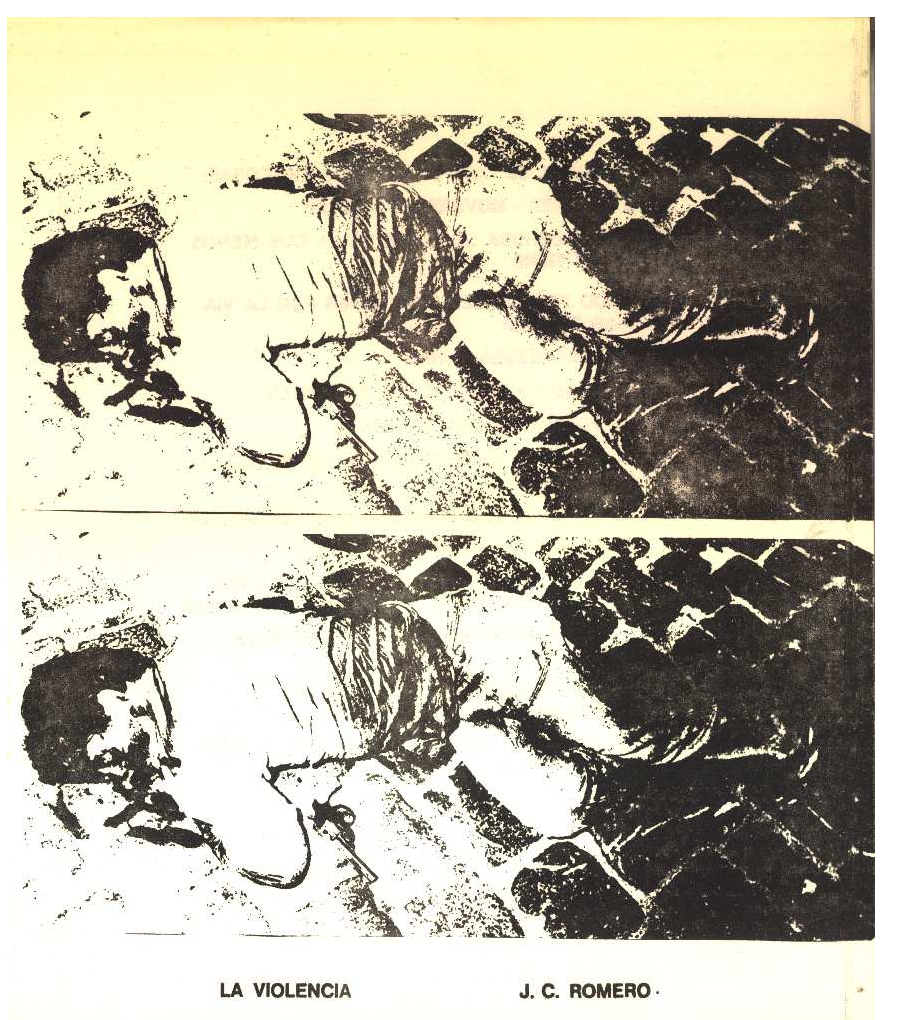

Imagen 72. Juan Carlos Romero, La violencia. 1973.

A éstos su suma el trabajo de Horacio Zabala, Anteproyecto de arquitectura carcelaria para las sierras de Córdoba. Argentina, en el que realiza unos dibujos de tipo arquitectónico, donde la cárcel estaría ubicada directamente bajo tierra y los reclusos se encontrarían conectados con el exterior solo por unos pequeños tubos que salen a la superficie para permitir la entrada de oxígeno.

El tenor de estos trabajos publicado en $c d$, en el contexto de aumento de los niveles de violencia estatal y avance paulatino de la represión política que se venían viviendo desde 1969, ofrece una mirada crítica y claramente preocupada por esa progresión. En general -al igual que otras obras que hemos analizado- el título cumple una función 
primordial para ubicar el lector en el sentido de las imágenes y textos, aunque estas son cada vez más explícitas. Puede pensarse, así, que la comunicabilidad política de la revista ha cambiado al publicar un tipo de trabajos en los que hay mayor claridad, univocidad o decidibilidad de los significantes utilizados. La búsqueda de establecer una posición política de la revista, parece ser desde este número uno de ejes que conducen la selección de trabajos que realizó Vigo. Este cambio involucra también la visibilidad pública de Vigo, antes cuidadosamente centrada en su actitud vanguardista más que en su visión política de modo explícito.

Así como desde este número Hexágono se presenta como una revista involucrada con la política del momento, en la portada de $c d$, además de agregar la leyenda sobre su condición de peligrosa, Vigo puso el sello que dice "Arte argentino de vanguardia". Esto lo lleva nuevamente al terreno estético y recuerda que aquí el cruce del arte y la política va de la mano de lo político del arte, como resultado de una renovación desde sus propios límites.

En el siguiente número, ce, el tenor de los trabajos es similar. Entre ellos, podemos señalar el de Zabala, Explotación. En este colocó un sobre con el sello "Explotación”, y en su interior una tarjeta escrita por el sistema de computación de IBM, quemada en uno de sus lados y con el sello "Explotación es terrorismo". De este modo, utilizando un término ("explotación") caro a la crítica política de izquierdas al capitalismo, es decir, decodificable para un público más o menos conocedor de esa terminología, arma una obra que presenta un grado de novedad al relacionar ese significante con una tarjeta de computación -ligada a la idea de trabajo- y quemarla, rematando con el segundo sello que atribuye la explotación al terrorismo, y no, como solía reproducirse en el discurso estatal y mediático, a las organizaciones de izquierda. Es, entonces, la explotación de los trabajadores lo que se convierte en terrorismo.

En este mismo número Vigo publicó su trabajo El 'systema' coagula rápido la sangre del pueblo. Este no -analizado en el capítulo sobre los señalamientos- con las tarjetas Souvenir del dolor y El ojo del Che para armar un afiche-móvil sobre la masacre de Trelew. Los muertos, el "systema", el Che, el texto "ármelo", forman un conjunto visual, textual y significativo con un importante peso político que reitera aquí aspectos de su poética como la participación del público, el uso de los señalamientos en una serie, la desnaturalización de las palabras -“ármelo", "systema”- y su remisión a un conjunto discursivo presente en la cultura política de la época, una materialidad 
descompuesta y un dispositivo que no termina de cerrar un sentido, que no lo clausura de una sola mirada.

Dentro de este número de la revista viene un afiche realizado por Juan Carlos Romero, doblado, con el siguiente texto: "Fusilados en Trelew el 22 de agosto de 1972. Tribunal popular para los asesinos". Debajo, se ubica una cuadrícula con los dibujos realizados a partir de fotos de los rostros de los dieciséis militantes. En la parte inferior del afiche dice "Acto de conmemoración. 22 de agosto 19hs Plaza Congreso. Adhieren Artistas Plásticos en Lucha” (imagen 73).

\section{FUSIIAJ)OS EN 'TREILEWT EL 22 ]DE A(YOSIO ]DE 19)T2}

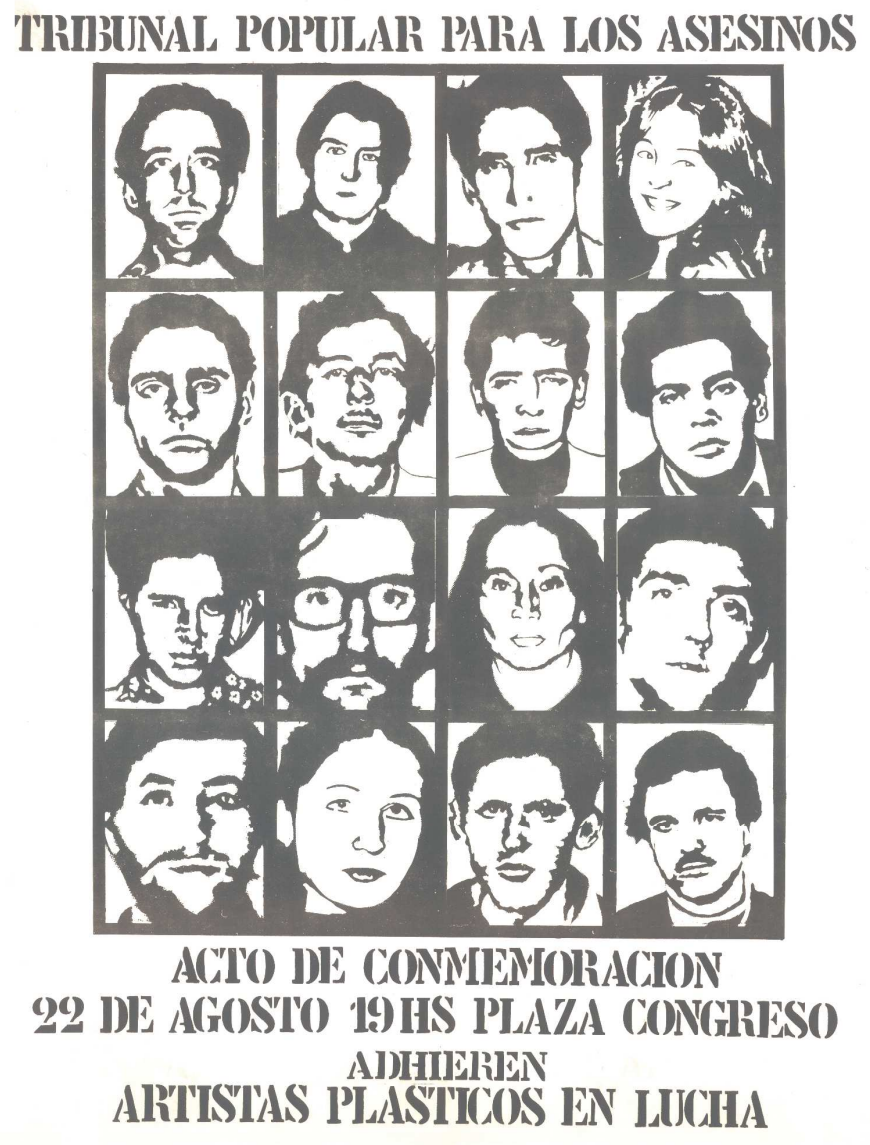

La incorporación de este afiche representa otro modo de sumarse a las distintas formas que aparecen en este número de mencionar o recordar los fusilamientos de Trelew. Se trata de un afiche tal como los que usualmente se colocan en las calles, por lo que dentro de las posibilidades de utilización del mismo está la de efectivamente pegarlo en los muros. Aquí la obra tiene una funcionalidad específica, que es publicitar un llamado a la 
movilización pública en conmemoración de los asesinatos. La revista suma, así, un trabajo de propaganda, pero diferenciado del resto de los que se encuentran en su interior. Éstos, en cambio, sostienen una clave de lectura menos transparente en que, si bien en algunos casos son más explícitos -como "Explotación es terrorismo" o "El 'systema' coagula..."- la búsqueda de comunicabilidad no elimina por completo la innovación estética. El afiche pertenece a otro orden, propone un mensaje claro, directo, pero fundamentalmente se diferencia porque realiza un llamado concreto a la movilización en día y hora determinados.

Si lo comparamos con el trabajo de Vigo, se observarán sus diferencias. En el caso de Vigo, se inscribe un texto más elíptico "El 'systema' coagula rápido la sangre del pueblo. Este no" frente a "Fusilados en Trelew (...) Tribunal popular para los asesinos"; por otro lado, la apelación a la acción de armar el trabajo colgando las tarjetas, si bien puede compararse con la de pegar el afiche en la calle, el primero se presenta como obra y el segundo como propaganda cuya funcionalidad está condicionada por la difusión masiva de un mensaje. Asimismo, como se mencionó arriba, la convocatoria a la movilización es un factor determinante de diferenciación entre ambos, así, mientras "Fusilados de Trelew" insta a la acción política, "El 'systema' (...)" apunta a la experiencia estética e intelectual y a partir de esta queda liberado el camino a la acción que depende de una decisión personal.

En el número siguiente ( $c f)$ Vigo sumó un catálogo de la exposición "Arte argentino de vanguardia", realizada en 1973 en la Galería Arte Nuevo de Buenos Aires por Benveniste, Leonetti, Pazos, Romero, Vigo y Zabala (el grupo que trabajó sobre el muro "Ezeiza es Trelew") y en la que presentaron las imágenes de que lo había sido esa experiencia (ver capítulo 1). Así, Vigo incluye en la revista el resumen de una exposición que recopila una acción artística y política ${ }^{116}$. Una breve reseña del contenido de ese catálogo ayudará a comprender la magnitud política de esa inclusión. Tiene un formato de carpeta y en su interior se encuentran varias hojas sueltas y sin numerar. En la introducción, firmada por Horacio Safons, dice que en apariencia todos estamos de acuerdo con algunas cuestiones vinculadas al rol del artista -se refiere a los cuestionamientos de su posición tradicional-, sin embargo, hay varias diferencias, por

\footnotetext{
${ }^{116}$ Un análisis de estos trabajos puede encontrarse en Longoni (2001) y Davis (2007). La descripción somera que se realiza en esta tesis reitera algunos aspectos ya señalados por estos autores, pero resulta necesaria dada la sobresaliencia que poseen esos elementos para nuestra interpretación.
} 
ejemplo, entre "promover el arte popular" y "popularizar el arte”. Esta última posición, dice, deja intactas las galerías, museos y salones, sin cuestionarse sobre el lugar en que se presentan las obras y favoreciendo el sistema comercial. Por el contrario, lo que interesa para el autor es la búsqueda de un arte popular o de las mayorías a través de un "proceso dialéctico" y ubicar al arte en la "geografía del hombre, se insatisface, se relativiza, hace su entrada en el terreno del cuestionamiento y del compromiso". Safons expresa que la propuesta de este grupo de artistas en aquella galería fortalece el sistema que quiere combatir, pero por el contrario, si estuviera situada en una villa, favorecería un choque entre el lenguaje del arte institucionalizado y la expresión de "una mayoría que no interpreta la realidad, sino que la vive".

El primer trabajo de este catálogo es la letra de la canción Sabino Navarro, de Tono Baez, luego se encuentra el trabajo de Perla Benveniste Debemos organizarnos en cuya parte superior se reproducen fotografías con un marco que aparenta ser un negativo. Las fotos pertenecen al trabajo Proceso a nuestra realidad nacional ("Ezeiza es Trelew") donde aparece la artista trabajando sobre el muro (imagen 74).

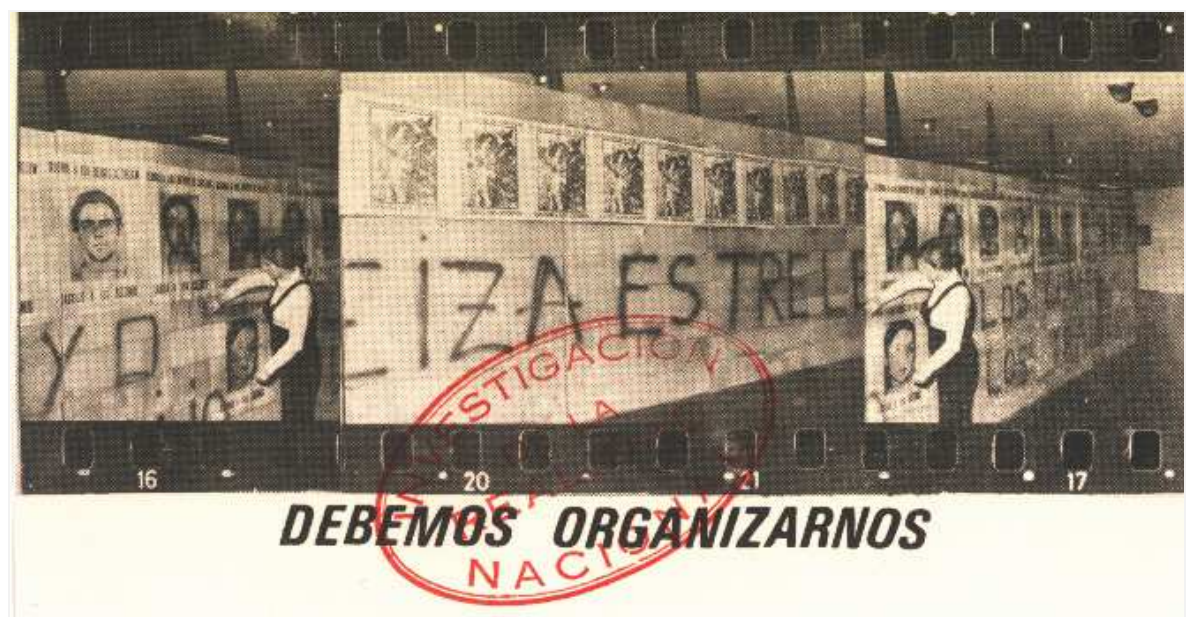

Nosotros, los artistas plásticos, dominados por jerarquías y formalismos burocráticos hemos terminado refugiándonos en el individualismo, que cierra nuestras conciencias y nos impide encontrar, junto al pueblo los caminos para una política cultural popular y nacional. 
Se visualizan las fotos de las víctimas de Trelew y Ezeiza y parte del texto escrito sobre el muro que da nombre a esa presentación. Debajo se encuentra un párrafo que refiere al individualismo en que han caído los artistas, "que cierra nuestras conciencias y nos impide encontrar, junto al pueblo los caminos para una política cultural y nacional." Finalmente, con letras mayúsculas, se lee: "Solamente la unidad y organización de los artistas hará posible un arte que esté al servicio de los verdaderos intereses del pueblo." Este trabajo podría pasar por un panfleto de una organización política: un título que indica un deber, un texto que explica la situación actual y la deseable, finalmente, un cierre que es un llamado a la unidad y la organización.

Le sigue un trabajo de Eduardo Leonetti La oferta y demanda II (El Curso de la Revolución). En la misma línea que venía trabajando el artista en la que identificaba partes de los clasificados que le resultaban llamativas, este trabajo se trata de una copia de los clasificados del diario La Opinión (1/04/1973) en el que se encierra con un trazo de marcador azul un clasificado con el texto "Peronismo y revolución. Análisis crítico de la ideología" y luego los datos del lugar donde se desarrolla el curso.

Una fotografía de Luis Pazos, Perón Vence (1973) tomada desde arriba en el patio del Colegio Nacional de La Plata es otro de los trabajos que forman este catálogo (imagen 75).

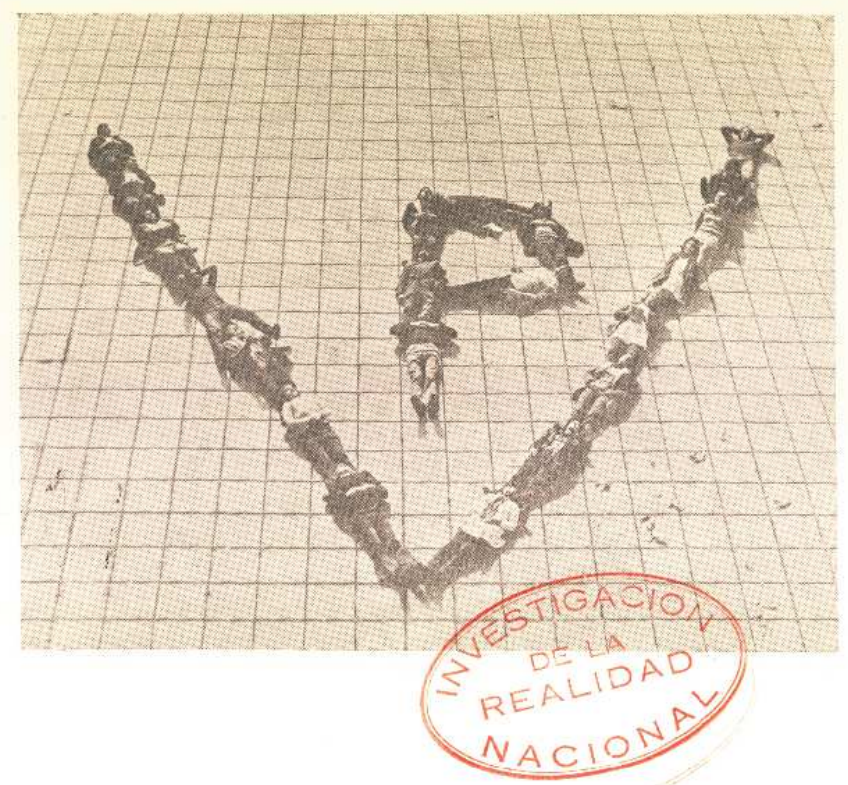


Allí se ve a un grupo de personas que con sus cuerpos forman el símbolo peronista formado por una $V$ y dentro de ella una $P$. Como apunta Longoni (2001), en lugar del esperable "Perón vuelve", Pazos llamó a esta fotografía Perón vence. Interesa especialmente que haya sido realizada en el Colegio y que las personas que participaron fuesen alumnos del establecimiento.

Juan Carlos Romero publicó una reproducción de un collage formado por una foto de una manifestación de Montoneros en la que se ven algunas banderas donde puede verse “José Sabino Navarro”, “Montoneros”, el símbolo de "Perón Vuelve” (imagen 76).

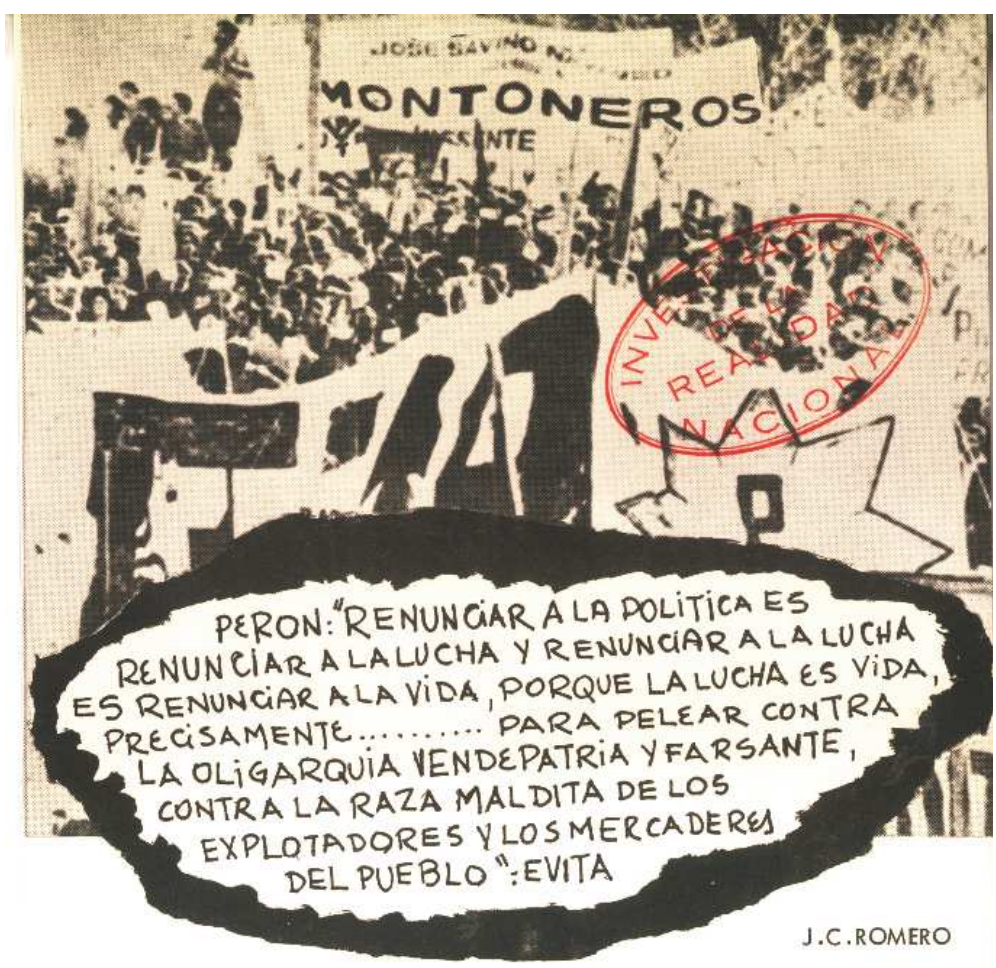

Imagen 76. Juan Carlos Romero. s/t. 1973.

En la parte inferior de la foto se ha superpuesto un texto escrito a mano. La frase comienza con el nombre de Perón seguido por dos puntos, lo que indica que es suya, pero termina con el nombre de Evita: es la unión de dos expresiones. La primera parte es un llamado a la política y la lucha, vinculándolas con la vida; la segunda, dice contra quiénes se debe pelear: la oligarquía, los explotadores y los mercaderes. En este caso, como en el de Benveniste, la línea divisoria entre arte y propaganda política se ha diluido. El texto es una apelación a la participación política con unos fines bien definidos, cuyos autores, además, son los propios líderes políticos del peronismo. A ello se suma que la imagen es la foto de una manifestación política sin intervención del 
autor. Es una conjunción de arte y política en donde la segunda prevalece sobre la primera en tanto el desarrollo de la creatividad del artista ha quedado subsumido bajo las premisas de la transmisión de un mensaje que intenta ser operativo sobre la conciencia de quien lo lea, tal como lo hace la práctica política proselitista. Esto era acorde a la militancia política que mantenía Romero que asegura que era el centro y el objetivo de su producción artística (comunicación personal, 2013).

El trabajo de Vigo es la imagen del contorno de una botella que en su pico tiene una perforación circular. Dentro de la botella se encuentra impreso el siguiente texto: "El propio militante/compañero debe llenar con su sangre esta botella/bomba. Su activación constante hará desparecer el objeto para convertir su circulación sanguínea en detonante" (imagen 77).

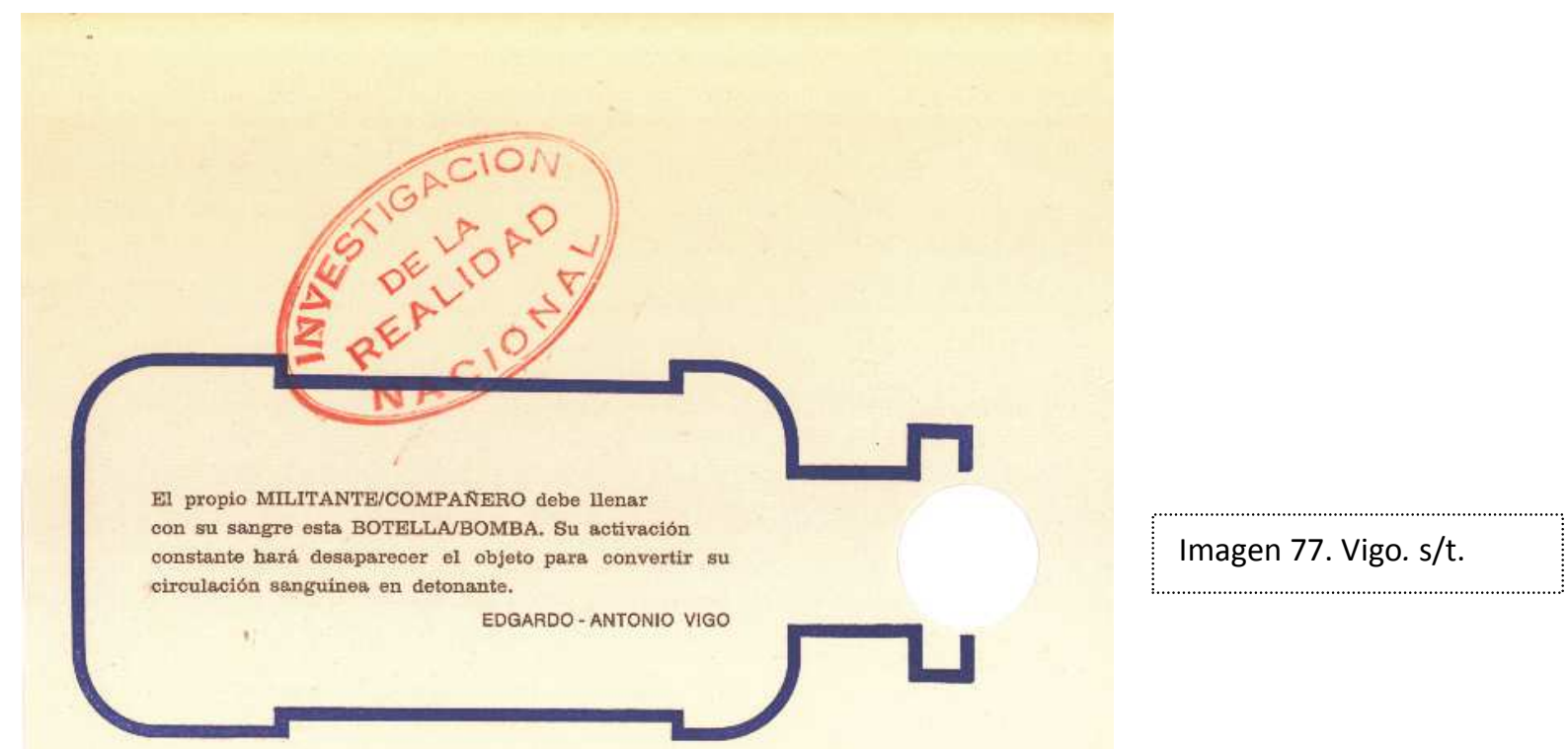

Vigo ya había utilizado botellas como soporte en las Obras (in)completas (1969), tal como vimos anteriormente. Aquí, se suma a la elección del objeto una particularidad relevante, la utilización más o menos difundida de la "Bomba Molotov" entre los militantes por su producción casera y accesible. La indicación de Vigo "el propio militante (...) debe llenar con su sangre..." intersecta dos aspectos. Uno, asociado a la 
ruptura estética y la idea de participación del público en la obra de arte, que ya tenía en Vigo una tradición y que se representa aquí con una prescripción que anuncia lo que "debe" realizar el receptor. Pero ese mandato resulta en este caso -a diferencia de otros como armar un objeto o una poesía visual, realizar una acción en un señalamientofácticamente imposible. El segundo aspecto se hace eco de esa práctica de la utilización de las bombas caseras y de la utilización de un lenguaje vinculado a las formas de expresión escrita de la práctica política de la época: "militante", "compañero", "su sangre", "bomba". El agujero de la botella opera como imagen visual del vacío que puede ser llenado por el observador, así como, en otro plano, a modo de perforación de la realidad política sobre la obra de arte. Aquello que puede traspasar el agujero es el conjunto de prácticas y discursos militantes que se engarzan en la producción artística. Sin embargo, el artista no ha convertido su obra en una propaganda política abandonando una elaboración estética crítica o bien dejando de lado su disconformidad con los cánones clásicos del arte o con el realismo figurativo de tipo socialista. Conserva los elementos característicos de su poética, como las perforaciones y la participación del público, así como las líneas limpias y marcadas a regla y compás que recuerdan a sus poesías visuales matemáticas, es decir, mantiene su interés en los efectos de subjetivación (o, en palabras de Rancière, "repartición") que el trabajo artístico con las formas y las convenciones puede provocar.

Zabala presentó el Texto $N^{\circ} 1$ que trata sobre el arte, lo poético, el producto artístico y sus relaciones con el público participante y las conciencias.

La inclusión de este catálogo en la revista destaca, en primer lugar, la importancia de la exposición original -Proceso a nuestra realidad nacional- y luego, de Arte Argentino de Vanguardia. La centralidad de la temática política que implicó el armado de ambas se traslada así a la revista, que venía tomando a Trelew y otros asuntos políticos como uno de sus ejes principales. Asimismo, contribuye a la publicidad de este tipo de exposiciones $-\mathrm{y}$ de los propios artistas-, controvertidas y no siempre bien comentadas por la prensa. La literalidad política de algunos de los trabajos incluidos en el catálogo refuerza también el cruce de arte y la política, en términos de una temática claramente identificable en el arco de las discusiones, propuestas y discursos políticos de la época, a la que Vigo como editor no escapó.

En ese mismo número de Hexágono se publicaron otros trabajos que continúan en la misma tónica. Bercetche envió una planilla estadística con fondo negro cuyo sello 
"Trelew" ubica inmediatamente al lector acerca del tema de los datos allí brindados (imagen 78) y se liga al trabajo que publicó en $c d$ (Inventario).

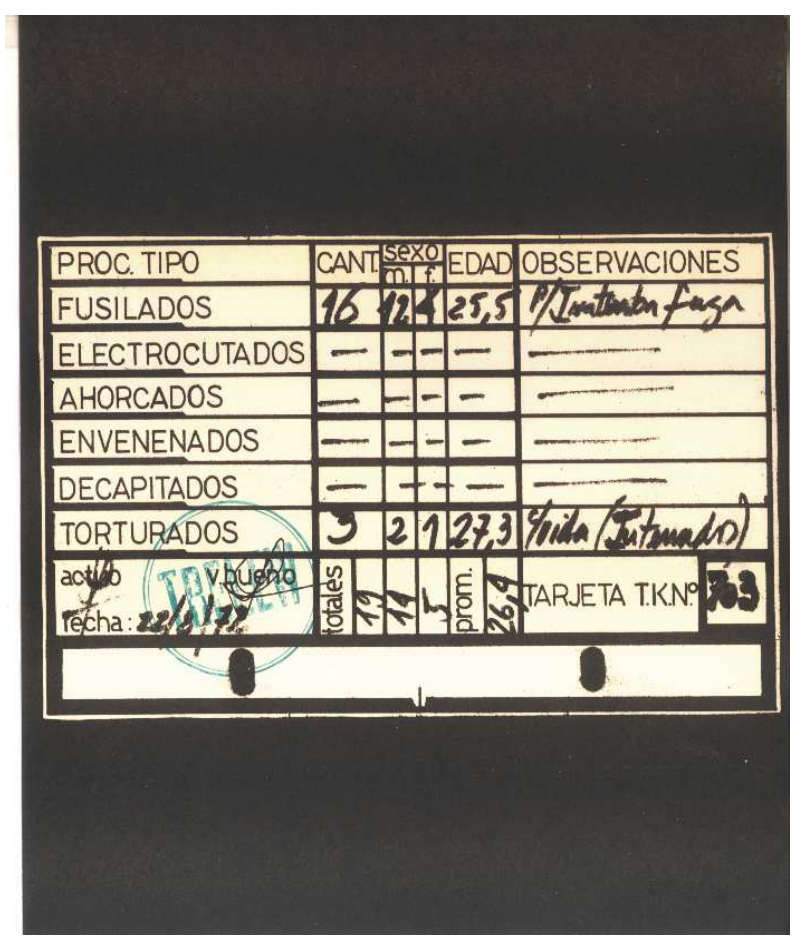

Sus categorías: "fusilados", "electrocutados", "ahorcados", "envenenados", "decapitados" y "torturados", dan cuenta del horror de la violencia estatal represiva a la que el autor quiere aludir. Al lado de "fusilados" aparece en número dieciséis y a continuación de "torturados", el tres, luego "sexo", "edad" y finalmente en “observaciones", en la misma fila, dice "p/ intentar fuga" y en la de "torturados" expone “c/ vida (Internados)". Debajo aparecen las celdas "actuó" y una firma, "fecha" "22/8/72" y número de "tarjeta". Sobre el texto, resalta un sello en color verde circular que dice "Trelew". La parte inferior descripta (con datos de tiempo y espacio, sellos y firma) se asemeja a un documento policial y el conjunto de la obra puede ser el resultado de una estadística del sometimiento de los cuerpos -las categorías de la primer columna ofrecen datos específicos de las formas de la muerte- y no escatima en colocar a los sobrevivientes a partir de su trato corporal y psíquico, en la cuadrado correspondiente a la tortura. Así como Inventario era un listado de los efectos de la realidad política, aparecen en este cuadro la crudeza de la información brindada, lo escrito y su forma de plasmarlo, todo ello sin recurrir a imágenes plásticas. El sello, ubicado como si fuese el de quien firma el documento o la institución, posibilita, por un lado, ubicar el suceso político con claridad, y por otro, excede esa función para remitir a 
la práctica artística del sellado, que unos número más adelante será el centro de la producción de Vigo y sus compañeros.

Horacio Zabala publicó la fotocopia de un collage que cuenta con tres trozos de hojas rasgadas sobre un fondo negro: en el superior, que conserva los agujeros de haber pertenecido a un cuaderno anillado, dice "Ernesto Che Guevara", en el medio, otro trozo que dice "Che Guevara" y en el inferior, "Che". El autor juega así, con una disposición poética y visual, con el nombre de uno de los mayores representantes de la guerrilla revolucionaria (imagen 79). Este trabajo, seguido del anterior, parece mostrar la contracara de la represión, la esperanza de la militancia, o por el contrario, su disminución hasta quedar reducido a un pequeño recorte de papel.

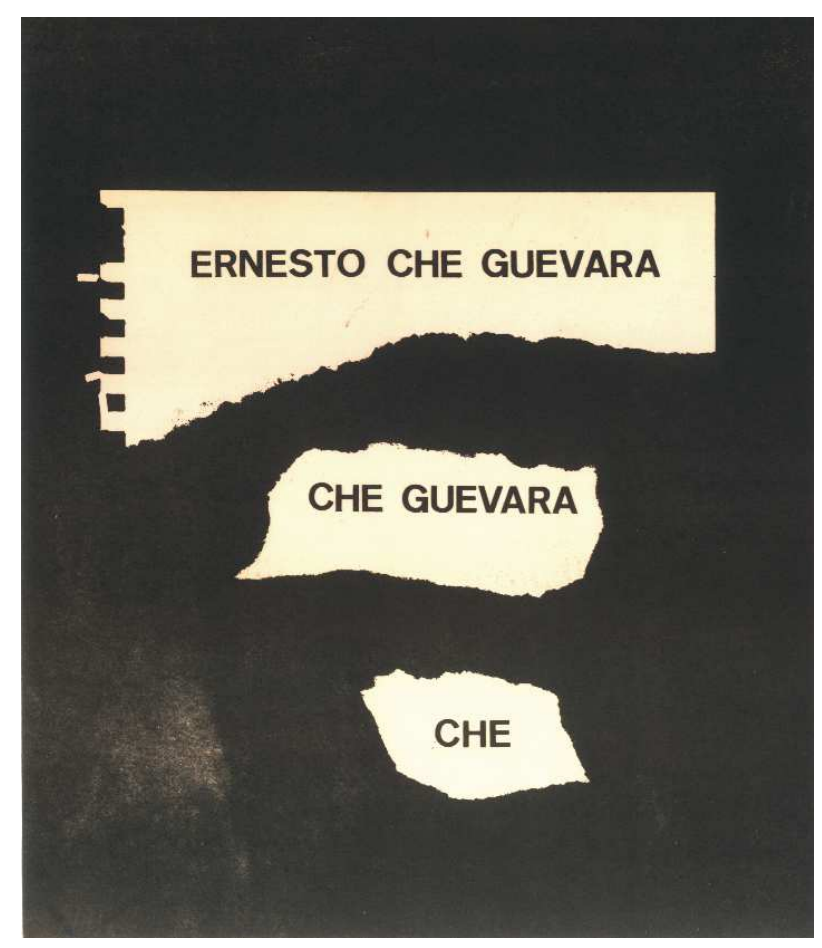

Imagen 79. Horacio Zabala, Ernesto Che Guevara. 1973.

Otro trabajo que se destaca es el de Ginzburg, Pirámide de la muerte, un proyecto presentado para la Octava Bienal de París. Como continuación de la publicación de proyectos, en este caso propone realizar una pirámide de flores extraídas de los tachos de basura de los cementerios de París en la puerta de la Bienal. Luego arrojará allí “esqueletos humanos, arañas, murciélagos y escorpiones”. El último párrafo dice va a colocar "cientos de libros: de terror psicológico, de terror político, de genocidios y guerras, la situación económica y social del Tercer Mundo, de filosofías nihilistas, de culturas desaparecidas, etc.”. La enumeración de tipos de libros, sumada a la idea de la muerte que emerge de una pirámides de flores de cementerios, sintoniza con el resto de 
los trabajos de denuncia política, aunque aquí menos centrado en los problemas de Argentina (el autor se encontraba viviendo en París) y sí más general del "Tercer Mundo".

En ese número Vigo sumó la ya analizada Variante jurídica, una crítica al mal funcionamiento del sistema de derechos y garantías. ${ }^{117}$

A partir de número de (1974) cambia el logo de la revista, así como se ha pasado del sobre a la carpeta y se ha modificado el color, que ahora es verde. Se encuentra en la tapa un sello circular en tinta roja que dice "Trelew" (el mismo que utilizó Bercetche en el cuadro con los datos de la masacre de Trelew).

Este es el primero de los números de la revista en que se ha puesto en la portada un sello que haga una referencia directa a un suceso político y que, además, está cargado de sentido al ligarse a asesinatos de militantes presos por parte de las fuerzas militares. Es decir, se trata de una revista artística en cuya portada aparece una mención a uno de los acontecimientos más violentos que dejan en evidencia la represión del estado. Esto implica una seña particular de la revista y de los cambios que ha sufrido desde su inicio hasta ese momento.

El sello "Trelew” avanza aún más sobre la relación de la revista con la realidad política (imagen 61). No solo es "peligrosa" (“eso sí, la más peligrosa”), sino que le otorga un nombre a eso que le da su condición. Disputa al estado el poder de nominación sobre los hechos políticos. Es la masacre, su necesidad de recordarla, lo que sigue presente en este número editado dos años después del suceso, porque ella representó mucho más que el atroz asesinato: también las muertes de militantes por doquier, fraguadas muchas veces en supuestos enfrentamientos. Mencionar la masacre, entonces, ubica decididamente a Hexágono en una de las veredas ideológicas del momento.

Vigo da lugar a que la realidad política se introduzca llanamente no solo en la temática de la revista, sino también en la forma. Un claro ejemplo de ello es el "Bando" de la revista Barrilete publicado en el número de, en forma de afiche doblado. Este texto realiza, en la primera parte, una descripción de la situación política y de la necesidad que tienen los "trabajadores de la cultura" de incorporarse a las "luchas" contra la

\footnotetext{
${ }^{117}$ Variante jurídica 1970 i 3 se publicó también en Our idiotismo, ${ }^{\circ} 3$, de IAC - FOCKE Edition, una revista alemana publicada en inglés por la Internacional Artist's Cooperation.
} 
"dominación" y el "colonialismo cultural". Por ello, declara reeditar Barrilete e invitar a otras revistas literarias, así como artistas y escritores, a unirse a esa pelea. Todo ello, en un lenguaje militante que se refiere tanto a las "luchas del pueblo" como a la importancia de no medir los riesgos, ya que lo contrario implicaría "no ser dignos del pueblo del que somos parte". El uso de dicha terminología, el llamado a la "unión" de diversos sectores para comprometerse con las "luchas de los trabajadores de la cultura", etc., involucran un contenido y un lenguaje común a otros escritos de las organizaciones políticas, a lo que se suma la forma de la escritura, un tono apelativo que pertenece también a las prácticas militantes.

En ese número (de) Vigo incluyó una postal suya que tiene impresa la poesía visual Poema matemático censurado, en la que predomina el lenguaje matemático y donde las letras cumplen una función en las fórmulas, el típico juego de letras y números que Vigo acostumbraba a hacer como otra señal de que la revista es una continuación de su poética (imagen 80).

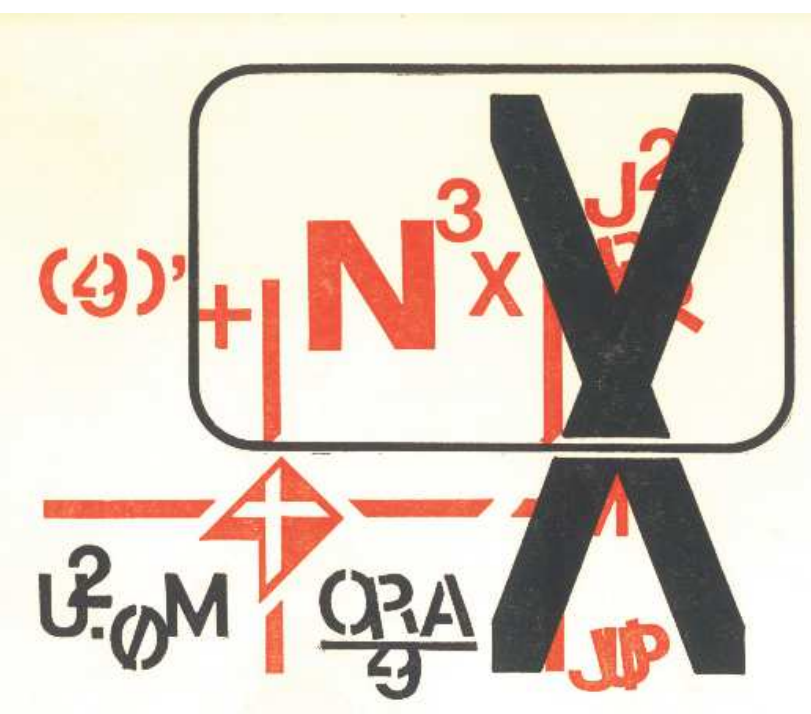

Imagen 80. Vigo, Poema matemático censurado. 1974.

En la parte superior derecha un recuadro ocupa parte de la poesía y está tachado con una cruz negra de mayor tamaño. En el reverso de la postal, está escrito el título y repetido en francés e inglés, el año 1974 y debajo, el sello de Vigo. La postal está editada por “Edición Hexágono '71” y tiene el número 1. 
Resulta sugestivo el título "censurado" y la cruz negra sobre parte de la poesía. Teniendo en cuenta las críticas al "sistema" aparecidas en trabajos suyos en números anteriores, así como Variante jurídica en el número anterior, podría pensarse que alude a la censura en lo político, como también a la de las instituciones artísticas sobre ciertas exposiciones, de las que Vigo también había tenido experiencia.

También sumó a este número un trabajo llamado Argentina 74, que consiste en un afiche en cuya parte superior tiene un cuadro rojo dentro del cual se encuentra a modo de señal de tránsito una flecha que dobla hacia la izquierda, tachada con una banda roja. Debajo de la señal, dice en letras mayúsculas negras "Argentina '74" y luego, el sello de Vigo (imagen 81).

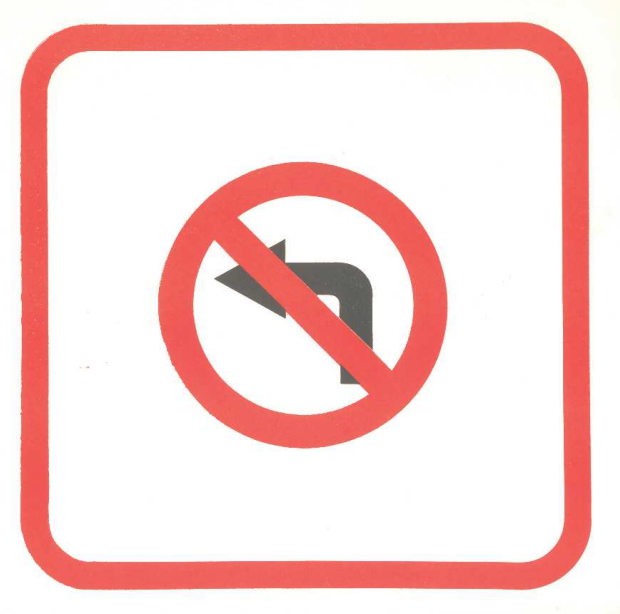

Imagen 81. Vigo, Argentina '74. 1974.

\section{ARGENTINA}
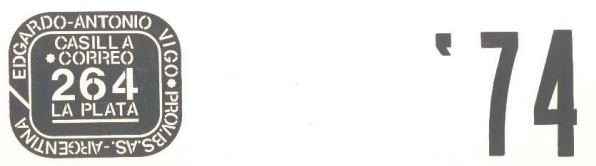
En esta poesía visual, Vigo acude a la señal de tránsito que simboliza "prohibido girar a la izquierda", sugiriendo que en la Argentina del año 1974 no está permitido inclinarse ideológicamente hacia esa tendencia ideológica. Si bien no tenemos certeza del mes en que se publicó este número, es posible que haya sido en la primera mitad del año, con lo que no podemos asegurar si fue anterior o posterior a la muerte de Perón. Si fue anterior, la prohibición de girar a la izquierda, puede estar vinculada al momento político del giro a la derecha de las políticas implantadas por Perón como rechazo a los pedidos de los grupos políticos más radicalizados y en el contexto del conocido discurso en la Plaza de Mayo el $1^{\circ}$ de mayo de 1974. Con José López Rega parado a su derecha, Perón echa a los Montoneros, acusándolos de "estúpidos" e "imberbes" frente a los "sabios y prudentes" sindicalistas, lo que encarnó un quiebre en su relación con aquellos jóvenes. Si, en cambio, este número de Hexágono se publicó posteriormente a la muerte de Perón, ocurrida el $1^{\circ}$ de julio de aquel año, el viraje hacia la derecha es todavía más claro, con la asunción de su esposa como presidenta y el total manejo del poder por el creador de la Triple A.

Interesa destacar la comparación que puede establecerse entre el "Bando" de la revista Barrilete y esta poesía visual de Vigo, ambos publicados en el mismo número. Los dos apelan a un sentido crítico de la política de la época, pero estéticamente sus propuestas divergen casi en su totalidad. En el primero se utiliza un discurso que reproduce los esquemas y términos de las declaraciones de las organizaciones políticas: una descripción de la situación actual de explotación, dominación y colonialismo; la posición de lucha que debe tomar el pueblo frente a eso $\mathrm{y}$, especialmente los "trabajadores de la cultura"; un llamado a la unidad; y, finalmente, una convocatoria a la participación sin medir los riesgos que se asumen, es decir, hasta las últimas consecuencias, lo cual encaja con la posición heroica sustentada por la mayoría de las organizaciones políticas y armadas del momento.

El trabajo de Vigo se diferencia del anterior, en primer lugar, por tratarse de una poesía visual, es decir que hay una búsqueda estética de ruptura. Si bien, por un lado, es claro que propone un símbolo interpretable para todos (la señal de tránsito) y la leyenda “Argentina 74" ubica al espectador en tiempo y lugar, por otro lado, la orientación de la flecha hacia de izquierda y la prohibición de girar requieren de un observador que vincule esa señal con la ubicación témporo-espacial y desde allí realice una decodificación que implique un salto hacia la posición ideológica aludida en la flecha y el por qué de su tachadura. Es decir que aquí hay elementos de una poética que 
demanda un espectador más o menos atento y dispuesto a actuar -aunque sea mentalmente- saliendo de los modelos de interpretación basados en la representación mimética o en la explicación detallada de todo lo que debe entenderse en la obra (Rancière, 2010).

Esta comparación, así como la anterior entre el afiche de Romero y El 'systema' coagula de Vigo, denota por un lado las diferencias que mantuvo Vigo con un tipo de trabajos ligados al estilo y el tono de la propaganda, pero por otro lado, permite complejizar esta misma afirmación, dado que si bien lo anterior es cierto en tanto autor, no lo es como editor. En este último rol, Vigo combinó intermitentemente ambos tipos de trabajos, eliminando contradicciones posibles o únicos caminos a seguir. Si bien Vigo se dedicó predominantemente a las producciones menos propagandísticas, ambas formas cobran importancia en la revista y su convivencia pacífica -es decir, la conjunción de la política y lo político- es una de las particularidades y rareza de Hexágono.

Una poesía visual de Pazos en la que las palaras "dependencia" y "liberación" son las protagonistas de otro trabajo publicado en este número (imagen 82). La primera, en rojo, tiene sobreimpreso en negro la palabra "anulado". Debajo se lee en rojo "liberación" y sobreimpresa la palabra "urgente" en color negro, es decir, que el mensaje puede ser leído como la necesidad de anular la dependencia y la urgencia de la liberación. Dos conceptos clave de discurso crítico de izquierda de la época, convertidos en imagen visual, pero con una tipografía semejante al sello, que va en el mismo sentido que la utilización de sellos por Vigo y otros colaboradores de la revista. 


\section{DERINUDA령|A}

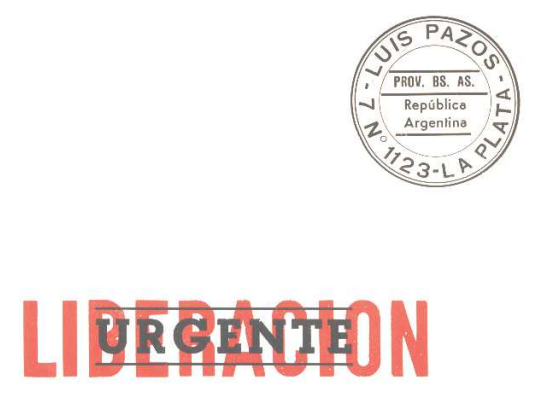

Imagen 82. Luis Pazos, s/t. 1974.

Como se dijo antes, no hay textos teóricos de autores extranjeros desde el número $c d$ hasta el final de la revista. Solo hallamos un relato de Ops (pseudónimo de Andrés Rábago García), titulado "Mitos, ritos y delitos en el país del silencio" y publicado originalmente en Madrid en 1973. De allí Vigo seleccionó unos párrafos en que el autor se relata una situación donde reina el silencio, lo cual favorece a los poderosos, basados en el honor y la tradición, así como también a "sacerdotes de oscuras religiones". Es un lugar de muerte y frío, hasta que finalmente saldrán los locos y los enfermos, liberándose e imponiendo un grito frente al silencio. Este relato que puede ser pura ficción, parece describir a la España franquista y cobra su significado en el marco de la revista.

En el siguiente número, $d f$, Vigo continúa apostando a una portada que inmediatamente transporte un significado claro en términos de posicionamiento político. En la tapa tiene un sello con la consigna que hicieron famosa las FAR y Montoneros: "Libres o muertos jamás esclavos". Al igual que en el caso de la tapa con el sello "Trelew", Vigo produce una intervención de la política en la revista que no solo hace evidente su posición y lade sus colaboradores, sino también la intención explícita de cruzar arte y política. Pegado contra la retiración de tapa, un rectángulo de cartulina tiene el sello "Trelew”, el mismo que se utilizó en el número de. Reforzando la posición mencionada arriba, este sello 
remite, una vez más, a la masacre, en una combinación de consigna política y memoria del terror.

En este número una gran proporción de los trabajos (casi la mitad) refieren más o menos directamente a temas políticos: la censura, la guerra fría, Trelew, la relación entre arte y política. Leonetti y Romero enviaron un recorte de diario sobre la guerra fría en el que aparecen imágenes de misiles estadounidenses y rusos ; Glusberg, la encuesta "Poll-vote on art and political ideology in a country of the third world" ("Votación sobre arte e ideología política en un país del Tercer Mundo") -el mismo que presentó en 1972 en la muestra Arte e ideología en CAYC al aire libre- y donde incluyó preguntas tales como "Do you belive there is a relationship between art and poltics?” (“Cree que hay una relación entre arte y política?"), "Do you belive that these works can become a provoking element in a political sense?” (¿Cree que estas obras pueden convertirse en un elemento provocador en un sentido político?”) y “Would General Perón agree with this exhibition?” (“¿Estaría de acuerdo con esta muestra el General Perón?”), entre otras. Zabala publicó un trozo de mapa político de América del Sur al que le agregó la fórmula: Tension $=$ Force $/$ Area , insinuando el uso de la fuerza que se produce en esa parte del continente y done la elección del inglés puede referir a que esa "tensión" está relacionada con los Estados Unidos. Análisis sumario de la enfermedad del 'putsch' cuyos casos críticos son de lamentar es el trabajo del chileno Guillermo Deisler (imagen 81). 


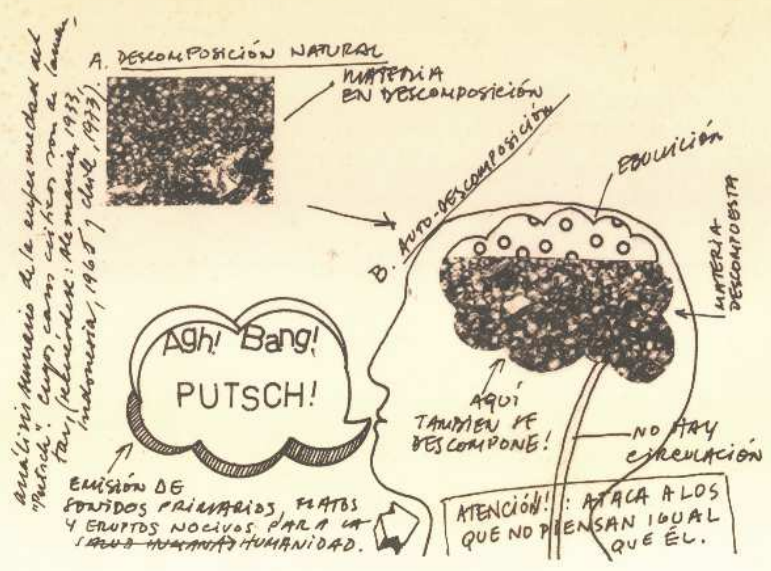

Imagen 83. Guillermo Deisler, Análisis sumario de la enfermedad del "putsch", cuyos casos críticos son de lamentar. 1974.

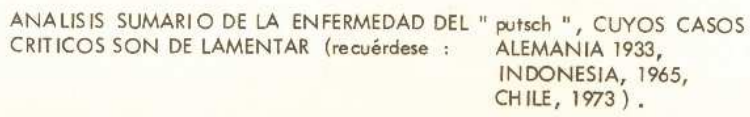

Una cabeza de perfil muestra el modo en que ocurre la "enfermedad": el cerebro en “descomposición", con flechas y textos explicativos, como la frase "Atención!: ataca a los que no piensan igual que él". Debajo del dibujo, una lista de países y fechas de golpes de estado (Alemania, Indonesia, Chile), termina de configurar el tenor denuncialista del trabajo. En clave irónica, Padín envió un esquema de una máquina para censurar llamada "Monocensurex", el cual al modo de una publicidad tiene textos como "censure sin asco" y "Ud. ni siquiera tendrá que leer los textos a censurar! Modernícese!!”.

De la descripción de los trabajos publicados en esta segunda etapa se desprende que hay una heterogeneidad palmaria en cuanto, por un lado, algunos producen reflexiones o proposiciones sobre un mundo que se presenta como injusto, cruel o violento, frente a lo que se realiza un llamado a la concientización o participación política, y por otro lado, 
se sostiene la presencia de poesías visuales, comunicaciones, collages, que buscan un efecto de lectura desautomatizada, conflictiva o plural. Esta disparidad de trabajos, fruto del tipo de revista que, al ser ensamblada, permite la conjunción de diversos autores, artistas, estilos y temas, así como del interés de Vigo más próximo a la definición política pero conservando elementos de la estética vanguardista, continúa hasta el penúltimo número.

Hexágono $d g$, presenta una particularidad: la carpeta tiene pegada sobre la tapa y contratapa una banda de papel que dice "autocensurado". Esta banda impide la apertura completa de la revista, a menos que se la rompa (imagen 84).
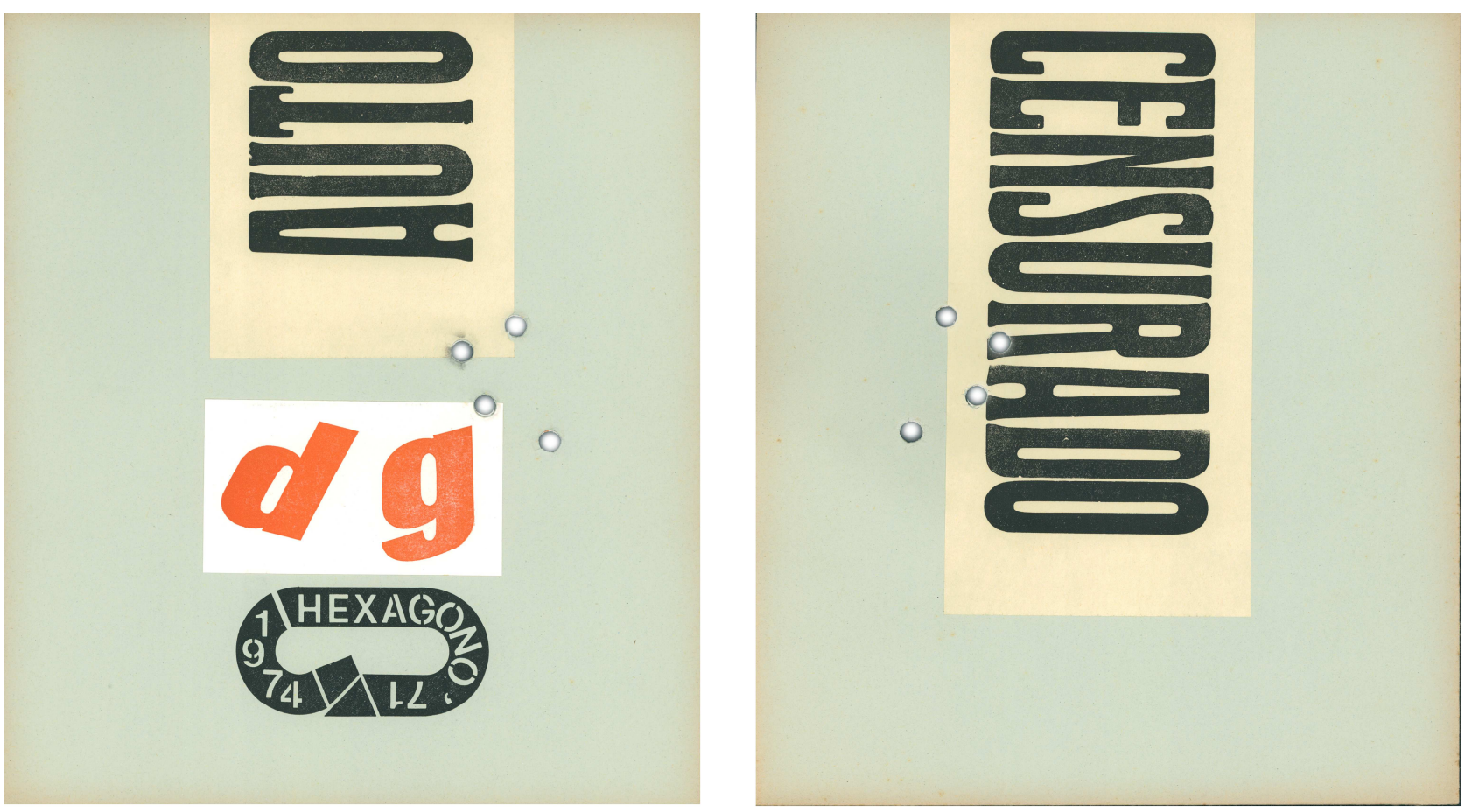

Imagen 84. Vigo, tapa y contratapa de Hexágono '71, dg. 1974.

Sobre parte de la banda y la tapa tiene cuatro perforaciones que abarcan ambas cubiertas e incluyen las hojas que contiene la revista, es decir que la han traspasado en su totalidad -no, como en otros casos en los que las perforaciones solo se encontraban en el sobre o carpeta. La disposición de estos cuatro agujeros circulares es irregular, por lo que, como apunta Davis (2009a) da la sensación de haber sido baleada. También puede interpretarse -como se señaló en relación con Diez días de masaje electoral. (In) forme 
sobre la votación "Tomatti"- que los agujeros implican un lugar por el cual es posible espiar lo que se encuentra clausurado a la vista, a lo inaccesible. En la revista, el término "autocensurado" y en informe, "confidencial", apelan al impedimento de acceso a un contenido o información. ¿Por qué Vigo "autocensura” su revista, si el estado no ha reparado en él ni en el contenido de Hexágono?, además, ¿en qué sentido es una verdadera autocensura si al romper la banda de papel puede accederse a las hojas que se encuentran en su interior?. Tal vez haya creído necesario "presentar" la censura en lugar de "representarla" (Davis, 2009a), o bien, haya sido una forma de adelantarse a lo que podría haber contenido ese número en términos de radicalidad política (a juzgar por el tenor de los trabajos de sus números anteriores) si no hubiera actuado como censor de su propio trabajo editorial. Además, la ubicación temporal de este número, a fines de 1974, permite interpretar que Vigo estaba viviendo los finales del peronismo y el avance de la ultraderecha preocupación.

En el interior de este número solo se encuentran dos hojas. Ambas han quedado perforadas con los mismos agujeros que la tapa. Una es un trabajo de Juan Carlos García Palou, Eduardo Leonetti y Juan Carlos Romero con el título Contaminación o liberación y contiene un extracto de un documento de Perón presentado ante varios países sobre el cuidado ambiental y su vinculación con la justicia social, la soberanía, la independencia económica y la cooperación internacional. Cabe destacar que esta hoja no tiene un tratamiento plástico, sino solo el título, el texto y las firmas (imagen 85).

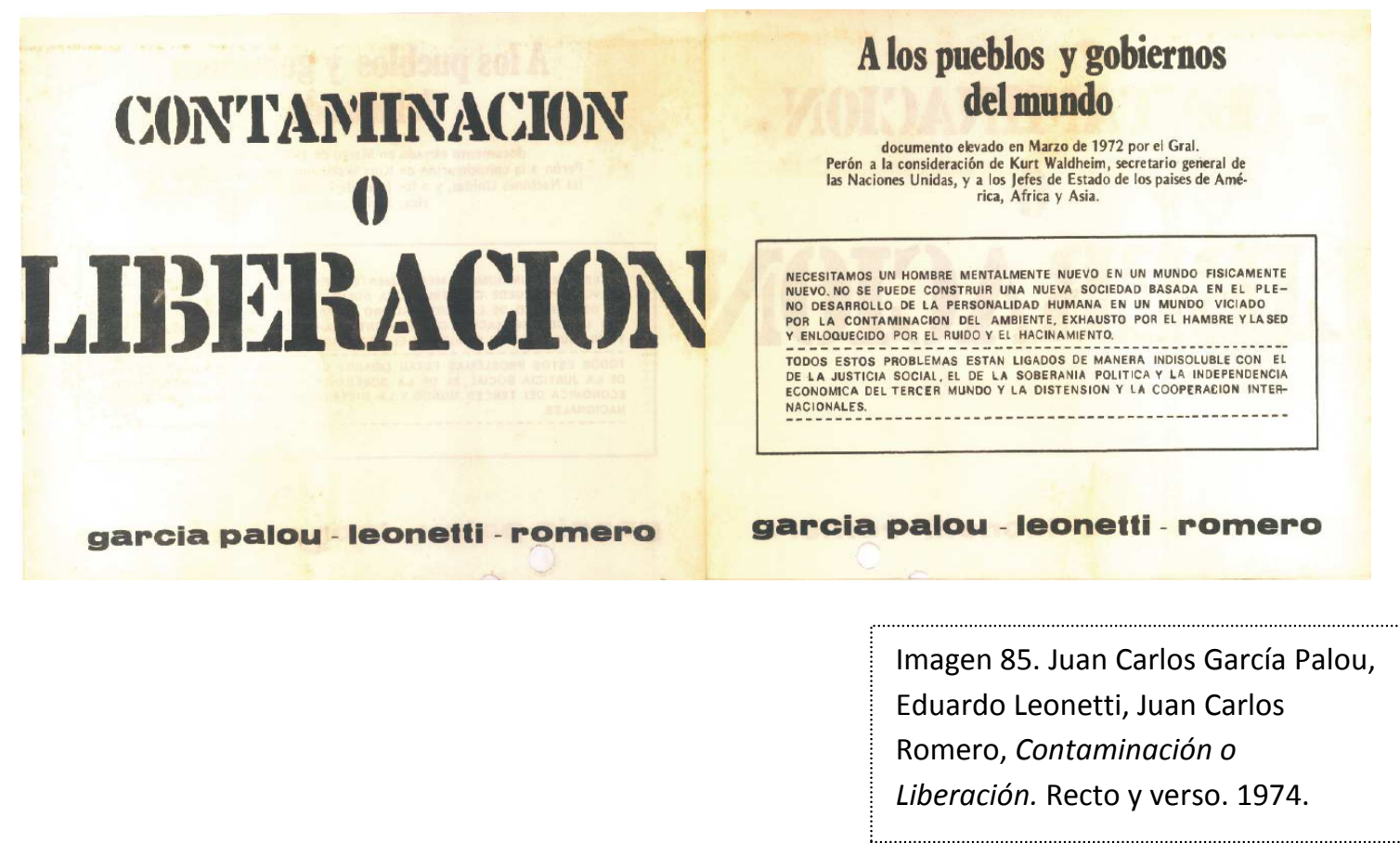


En relación con este trabajo del grupo integrado por Romero, así como los anteriores cercano a la retórica de la propaganda política ${ }^{118}$, este artista señala que se encontraban relacionados con su vida política: "Mucha militancia, pura militancia (...). Yo puse mi arte en función de la militancia. De la revolución, digamos, de lo que podía ser en aquel momento la revolución" (Romero, comunicación personal, 2013). Esta fuerte impronta de la actividad militante que excedía a su labor artística explica en parte la distancia que lo separa de los trabajos de Vigo quien, por el contrario, no se involucró en una actividad política orgánica y privilegió la "revulsión" como herramienta de contradicción con el sistema.

Al incluir este trabajo en Hexágono puede Vigo estaba colocando un volante en manos del receptor y ofreciendo la posibilidad de ser efectivamente arrojado al espacio público o entregado en reuniones políticas tanto como en exposiciones (o el destino que imaginen los receptores de la revista, entre quienes había, recordemos, funcionarios judiciales y artistas vanguardistas). Esto explica también el significado de la faja "autocensura" si remite, entonces, a que la muerte de Perón y las características del poder ejercido por su sucesora y su principal asesor, son una censura sobre las "verdaderas" ideas del líder -en cuyo título los artista pusieron un énfasis en la palabra “Liberación”-, copiadas textualmente.

El segundo es una poesía visual de Vigo (1974) Te deshacen y recomponen tu mente (escrito en español, francés e inglés). Se trata de una imagen de partes separadas de un cuerpo, que tal vez simbolicen la tortura o la muerte, y dentro de la cabeza se encuentran dos cuadros con letras y números a la manera de un teorema. Un sello circular con la palabra "anulada" coincide con el sentido de "autocensurado" de la portada.

En el último número, e (1975), Vigo -ya alejado del CAYC- se volcó hacia el arte con sellos y aumentó decididamente la presencia de autores extranjeros. Como se expresó

\footnotetext{
${ }^{118}$ En relación con este trabajos, el anterior de Romero (imagen 74) y el de Perla Benveniste (imagen 72), como muchos otros de la época, cabría preguntarse con Achugar -en concordancia con lo que plantaba León Ferrari a mediados de los sesenta- : “con qué criterios puede la obra de arte, supuestamente pura, ser considerada tal y no propaganda?. Realmente no sé si existe algún criterio válido para distinguir el arte, cualquier tipo de arte, de la propaganda; más allá de lo que indicaría el 'sentido común'. Incluso se podría ir más lejos y sostener que toda obra de arte es, conciente o inconcientemente, un pronunciamiento político hecho por un ser humano y por lo tanto propaganda" (Achugar, 1991: 125). Esta reflexión que abarca problemas teóricos e ideológicos, puede ser útil para pensar en la heterogeneidad que hemos descripto en la revista, donde tanto la propaganda como la poesía visual más críptica forman parte del conjunto.
} 
más arriba, este número está contenido en una carpeta marrón con el sello "Arte de y para investigación", sin indicación de pertenencia a la revista. Vigo dispuso en primer lugar un texto suyo -al que ya hemos hecho mención-, "Sellado a mano". Allí analiza el fenómeno de la utilización de los sellos, así como lo que considera un "'real' arte pobre" y una fuerte crítica a las instituciones. Frente a ellas propone otros tipos de trabajos alternativos, especialmente para los artistas latinoamericanos, vinculados con una "realidad urticante". Si bien, como mencionamos, se produce un cambio en este número, Vigo no perdió el interés en reflexionar sobre la realidad de los países pobres. En este ensayo utiliza un lenguaje con referencias a Latinoamérica propios de la época, antes no tan frecuentes en los escritos de Vigo, así como directamente sobre la "dominación", el "colonialismo", la "violencia" o la "censura" y sobre los magros recursos de los artistas.

Concordante con la idea de que el giro nacional de la revista se corresponde con un momento político particular y con la incorporación de Vigo al CAYC, el número $e$ denota su retirada de la institución, así como el pasaje a un tipo de práctica plástica vinculada con el arte-correo, como es la utilización de sellos, pero al mismo tiempo basada en sus propios antecedentes de apropiación de uno de los recursos de la práctica judicial, como se destacó antes.

Además del texto de Vigo, el resto de lo publicado en este número son trabajos sellados de distintos autores, esta vez europeos (de Inglaterra, Francia, Holanda, Italia y Alemania), así como argentinos. Algunos instan a la acción del receptor, otros mencionan hechos o personas de relevancia política, como Hitler, la palabra "Venceremos", o realizan una reflexión sobre el propio medio. Zabala, continuando con su trabajo sobre la censura, presentó una hoja de un libro de medicina con el sello "Censurado" seguido por una cruz. Vigo cierra la revista con un trabajo que contiene un sello circular con la palabra "Anulada" -utilizado en el número anterior- sobre el que puso otro en color negro con la frase “Anulé esta hoja el día 1 de abril de 1975”, y debajo, marcando una vez más su presencia personal, uno con sus datos.

\subsection{POLÍTICAS DE LA REVISTA, REVISTA (DE) POLÍTICA}

En 1971 empecé a publicar Hexágono '71 tratando de hacer una revista diferente, algo así como una experimental, de la que se editaron trece números. En 1973 comenzó el período presidencial de Cámpora, lo que parecía una 
primavera en Argentina. El partido "Peronista" trajo una gran esperanza para muchas personas. Todos esos sentimientos también estaban en la revista Hexágono '71, quizás las colaboraciones mostraron ese momento especial. Desgraciadamente, los envíos dan cuenta -Perón regresó al país- de su muerte. Su esposa Isabel Perón [se convirtió en] presidente y [ejerció] una fuerte represión dirigida por una persona malvada, José López Rega, y su "Triple A", una organización similar a los futuros días en el país, también para la cultura, por lo que cada uno ha tratado de transmitir sus mensajes, a divulgarlos camuflados (Vigo en Perneczky, 2003: 457. Traducción nuestra).

Como procuramos mostrar mediante la revisión descriptiva detallada en las páginas precedentes, lo político y la política de la revista Hexágono ' 71 se han manifestado a través de sus particularidades en cuanto a la materialidad, la desfiguración del género y del soporte, su modo de permanecer en la vanguardia estética, en la que el receptor es pensado como activo intérprete o co-constructor de los trabajos, y la especial relación que mantuvo con el momento social y político, mostrando imágenes, poesías, comunicaciones, textos, en los cuales tanto los sucesos políticos como los discursos reconocibles de la nueva izquierda se asumen de modos diversos, heterogéneos, y se expresan con tonos que van de lo propagandístico y divulgativo hasta lo que implica una lectura más reservada o incierta, aunque sugerida. Hexágono no ha sido solo una revista de arte interesada en las discusiones más candentes en los bordes de las Bellas Artes -0 por fuera de ellas-, así como tampoco una pura revista de política. Fue su montaje de temas, modalidades y tonos lo que provocaron su condición de rareza desconcertante, apuntando a la desnaturalización del propio género, de los signos, de la materia, del estatuto de receptor, del lenguaje y de la imagen.

Se han señalado las dos etapas por las que atravesó la revista, entre las cuales hay continuidades y diferencias. Como manifestamos en el marco teórico, el arte puede involucrar politicidad a través de un cuestionamiento al orden de la sensibilidad, lo que implica un desarreglo de las normas que organizan algunas jerarquías y apartarse de marcos de lectura o interpretación disponibles (Rancière, 2010). Además, el arte, aunque pertenezca al conjunto del proceso social, ofrece nuevas formas de decir y experimentar el mundo que otras actividades no logran ya que, como se dijo, produce un disturbio entre la experiencia y el modelo social (Williams, 2003). Es desde esa posibilidad de disenso con el orden o proceso social que Hexágono tiene una politicidad 
-de tipo menos manifiesto-, especialmente en su primera etapa, pero presente en todo el trayecto.

Así como en las revistas ensambladas, a partir de las divergencias con las lecturas convencionales de texto e imagen se conjuga "este incipiente transvase entre la palabra y la imagen [que] facilitará la construcción y el diálogo de nuevos discursos sociales y estéticos, también ideológicos" (Bonet, Tro y otros en Méndez Llopis, 2012: 199), en el caso de Hexágono, Vigo aprovechó productivamente esa potencialidad de combinación entre arte y sociedad, estética y política.

En su segunda etapa, se suma a esa politicidad una incursión decidida en la política de las disputas ideológicas. Se incorporan reclamos y elementos de las luchas que la vinculan con la política de modo más explícito - es decir, se incluyen como temas hechos o personas- sin abandonar una posición interesada en presentar trabajos que innoven estéticamente en relación con el arte tradicional, así como respecto del modo de hacer una publicación del género revista y de sus dispositivos materiales y formales.

Si en la primera etapa las alusiones manifiestas a la política son escasas, esto se revierte en la segunda a partir del número $c d$. Allí, la leyenda "Eso sí la más peligrosa" marca la dirección bien definida que tomará la revista en adelante. Por un lado, es una alusión a la suma de trabajos referidos a la política; por otro, resulta una ironía advertir que la "más peligrosa" es una revista de arte vanguardista, cuando ese término -como decíamos más arriba- significaba la capacidad de utilización de la violencia por parte de las organizaciones armadas. Cuando se agrega el sello "Trelew" esa peligrosidad toma un nombre: un hecho concreto, personas, un lugar. La consigna "Libres o muertos jamás esclavos", también vinculada con la masacre de Trelew y con otras acciones y consignas de organizaciones políticas, las frases de Perón, el catálogo de la muestra donde se lee "Ezeiza es Trelew”, las referencias a la explotación, el sistema, la opresión, ubican la revista en un lugar de cruces múltiples entre el arte y la política.

También parece ser "peligrosa" por la conjunción del arte y la política, es decir, tanto por una toma de posición en las luchas ideológico-políticas del momento, como por la combinación que se produce al tratarse de una revista de arte. No es lo mismo situar temas políticos en una revista de actualidad, ya sea periodística o perteneciente a alguna organización, que en una revista dedicada a problematizar diversos asuntos relacionados con el arte y que apuesta, además, a una ruptura en lo estético y una intervención sobre el soporte revista en tanto des-convencionaliza un género de la comunicación. La peligrosidad se diversifica. Pero ello no como posibilidad concreta de convertirse en un 
movimiento revolucionario, sino en la medida en que los efectos de la publicación potencien o propicien posibles transformaciones de la subjetividad política.

En los cruces de arte y política que conforman la revista, la ruptura de la forma o materia común -usual- y comunicable de las revistas confluye con la otra politización: la temática revolucionaria que se acrecienta. En este sentido, cuando el contenido se hace más propagandístico, pedagógico, agitador o informativo, la legibilidad y manejabilidad del artefacto se mantienen problemáticas y disensuales.

Al mismo tiempo, los cambios que se producen en cuanto al aumento de relación con la política, no implican un progreso lineal y ascendente hacia un mayor "compromiso" social. Vigo puede volver sobre sus pasos y en el mismo número que publica una botella bomba, lo hace con un trozo de afiche que compone una poesía visual al estilo ready made: sin ninguna alusión al mundo social más que las escasas palabras que puedan leerse o suponerse de lo que queda de un texto sobre carreras de automóviles o motos a partir de un trozo de afiche recortado (donde se leen algunos datos, pero escasas palabras completas), sellado con el nombre de Vigo (Hexágono ' $71, c f)$. Ese trabajo se propone como una poesía visual pero realizada a partir de un ready made: en este caso, las palabras, reducidas en su mayoría a letras, forman más una imagen plástica que un texto definido. Para hacerlo, Vigo recurrió a un recorte de afiche, por lo que la factura original no es propia; sin embargo el recorte del papel y la inscripción del sello lo convierten en una poesía visual firmada. Así, entre tantos trabajos referidos a la realidad política de la época, coloca un tipo de producciones más herméticas y con un procedimiento tomado de las vanguardias históricas. Por ello, no hay un mensaje en sentido explícito, sino que se quiere inducir a la reflexión sobre las prácticas estéticas y desnaturalizar la observación. Asimismo, mientras publica la flecha tachada que gira hacia la izquierda, en el mismo número pega en la retiración de tapa de la revista un sobre con la palabra "kitsch" con una figurita infantil dentro.

Resultan algunas conclusiones del análisis de la revista. En primer lugar, que la politización de las vanguardias estéticas no implica siempre ni en todos los casos un abandono de las prácticas artísticas en pos de una dedicación completa a las actividades políticas de la militancia; así como tampoco puede convertirse en un modelo ideal de interpretación de radicalización artística. En el caso de Vigo el mayor peso que tienen los temas políticos en sus trabajos de la segunda etapa, se relaciona con una situación política general de aumento de las disputas ideológicas y objetivas y una polarización social creciente en relación con esos asuntos, así como con un mayor involucramiento 
personal en ellos. Esto no significó una renuncia a la producción artística, así como tampoco la resignación de otro de los elementos de su poética, la ruptura estética y la búsqueda de innovación en la calidad artística.

En segundo lugar, si uno de los ejes de la poética de Vigo a lo largo de todo el período es la participación del público y la utilización del espacio para la realización de acciones, como formas de materializar el acercamiento de arte y vida, en la segunda etapa de la revista esta vinculación con la vida se da también por la utilización de la temática política. En el período trabajado, la politización ocupaba a grandes sectores de la sociedad y el acceso a la información sobre las disputas políticas era generalizado (es decir, se participara o no en las prácticas políticas, lo que allí sucedía era parte de la información de la que cualquiera disponía diariamente), de modo que al integrar ese aspecto en los temas de las obras de arte, Vigo cumplía con una de las aspiraciones de la vanguardia, asociar arte y vida, al mismo tiempo que se implicaba más expresamente en los acontecimientos sociales y políticos del momento.

En tercer lugar, esta cuestión se relaciona también con los modos en que Vigo pivoteó entre trabajos que apuntaban fundamentalmente a la comunicación, de una legibilidad más o menos manifiesta (el caso de la flecha que gira a la izquierda), y otros de interpretación menos evidentes (como el trozo de afiche de una carrera de autos con su sello). En una entrevista dijo que "como el arte en general busca la comunicación, un artista no está en una pompa de jabón, tiene necesidad de mostrar, del diálogo; puede ser muy hermético, pero la obra no tiene por qué ser hermética también" (Vigo, entrevistado por Curell, 1995) y la revista parece ser un ejemplo de ese vaivén. En la selección que trabajos que realizó Vigo, los que utilizan herramientas más comunes a los discursos políticos de la época (por ejemplo: el "Bando", Contaminación o liberación) son de otros autores, mientras que en los que él realiza -desde el armado de una revista sobre con portadas troqueladas hasta una postal llamada Poema matemático censurado- el cruce con el lenguaje, el tono y las formas de comunicación mantienen siempre un aspecto velado, irónico, figurado, enigmático o deliberadamente inesperado. En la estética visual de la revista no aparece el típico conflicto entre arte experimental y pedagogía de las urgencias políticas que obliga a elegir entre uno de los dos. Es decir, sale de la senda que siguieron otros artistas de la época, en que "la política a secas, después reduce y fija las fronteras esa originaria carga estética. La contrae programáticamente, establece los binarismos" (Casullo, 2004: 16). Hexágono va acumulando y combinando diferentes modos de experimentar con los usos del soporte 
papel, los sobres, las tarjetas de un modo bien vanguardista y a partir de cierto momento incorpora el imperativo político en los enunciados y modos de la publicidad, el panfleto, la foto, entre las técnicas de desautomatización. Se va dando una convivencia del trabajo semánticamente plural, incierto y vacilante con las geometrías y las letras y números tratados como materia (no solo ni tanto como signos), por un lado, y los panfletos y afiches de denuncia política, por otro. Más que una dicotomía o una encrucijada en la que se debe elegir un solo camino, Vigo permite la coexistencia, las mezclas y combinaciones, apuntando también con esta estrategia a lo desconcertante. 
PARTE III 
La realidad tangible con su presente pesa sobre los acontecimientos futuros. Si ajustamos ese futuro a ella poco queda para el campo de los "supuestos". La lógica racional impera de tal forma que niega toda posibilidad de re-creación. Pero el acto creativo propone una realidad-abonada basada en ir más allá del hecho-en-sí para suponer la a-rracionalidad a-lógica. La creatividad de la persona pasa entonces por una interpretación del hecho y en base a esa interpretación un nuevo hecho pasa por la realidad-abonada, es decir aquella que se ha concretado a través de una hipótesis tan real como el hecho en sí. 1976 - Abel Luis (a) Palomo, Vive - 1986 Vigo, 1986, “A propósito de las utopías realizables. Realidad tangible / realidad abonada"

El artista no tiene que defender la verdad absoluta, defiende su verdad precaria.

Vigo, 1997 (entrevistado por Curell) 


\section{CONCLUSIONES}

Cuando se le preguntó a Vigo en 1994 si creía que debía haber "un compromiso político del creador", respondió:

Pienso que está el compromiso del militante, que también milita siendo artista; este corre el riesgo y generalmente se produce, sacando casos muy puntuales, de caer en el panfleto. Eso a mí no me interesa porque creo que lo creativo debe cumplimentar ciertos requisitos para ser justamente eso, una creación plástica, para lo cual no se pueden dejar de abordar la estética o los materiales nuevos. Siempre se tiene una posición política, pero eso no quiere decir atada a una militancia, sino para analizar esa complejidad que es la relación hombresociedad.

(...) Hay trabajos que son más abiertamente políticos, por ejemplo la obra "Trelew", un hecho puntual que no firmo porque las obras como esa o "Las Madres de Plaza de Mayo" (tengo hecho un pequeño objeto) no las firmo porque entiendo que están hechas por sus protagonistas, indudablemente son muy fuertes sobre todo en su lectura para la Argentina. Pero en muchas de mis obras, sin ser tan puntuales, hago una crítica también política pero más sutil, porque no intento con mis trabajos dar solución, sino que soy el autor de un interrogante, me interesa crear una situación de la que cada uno saque sus consecuencias, busco la mayor libertad del individuo. Mis trabajos quieren ser un grano de arena con el cual alguien se monta una playa. (Vigo en Tragaluz, 1994)

Si el arte piensa (Badiou 2009b) la obra de Vigo señala, desmitifica, desubica, desestructura, sobresignifica. Vigo produce su poética en clave de rebeldía de su tiempo, fines de los '60 y mediados de los '70. Pero su rebelión transcurre también por fuera del estereotipo más consolidado para la época. Vigo va de la idea de revolución y la ruptura estética al cuestionamiento al orden social. Pero si bien ese vaivén es un movimiento, no conviene pensarlo como una secuencia unidireccional. Vigo no abandona la ruptura estética para ir directamente hacia la fusión idealizada con la vanguardia política, como pareciera ser, en algunos casos, el destino obligado del arte 
de vanguardia de esa época. Más bien, modula, pero no por un cambio temático, sino en un mismo acto, en-el-acto.

En tanto una de las características del arte de vanguardia del siglo $\mathrm{XX}$ ha sido la primacía del acto sobre la obra (Badiou 2009a), podemos reflexionar aquí cómo se produce en la obra de Vigo, en ese acto, una modulación. Posiblemente, la propuesta destructiva del sistema anterior por parte de las vanguardias artísticas, también haya dado lugar a procesos creativos o novedosos más afirmativos, de modo que, en tanto las vanguardias provocaron un acontecimiento en el arte, la obra de Vigo podría ser considerada parte de lo que Badiou llama la "configuración artística" de ese acontecimiento. Pero así como "la obra es una indagación situada sobre la verdad" (2009b: 57), el modo y la forma que eligió Vigo para realizar su obra se corresponde con un momento histórico que le otorga un marco específico para su trabajo creativo.

La obra de Vigo retoma algunos procedimientos de las vanguardias, como la utilización del objeto ya hecho, inaugurada por Duchamp, el uso de espacios alternativos de producción y difusión de sus obras, el abandono casi completo del formato de cuadro, entre otros. Esto no representa, en principio, nada novedoso en los años '60 con el surgimiento de las neovanguardias artísticas. Sin embargo, se analizaron en esta tesis los modos en que esta apropiación de técnicas y procedimientos previos se combina con otra ruptura dirigida no solo al sistema artístico, sino también al orden social. En este sentido la obra de Vigo piensa su tiempo.

¿En qué consistió concretamente esa modulación? Lo que en la música es un cambio de tonalidad, pero en el que quedan huellas de lo anterior -y que, además tiene una continuidad en la misma melodía- es, en la obra de Vigo, ese pasaje no temporal (en-elacto) que va de los procedimientos vanguardistas a la novedad. Esa novedad está impregnada de los rasgos del modelo del artista revolucionario, pero al mismo tiempo, y en virtud de la utilización de técnicas y formas específicas, hace colapsar ese prototipo. Lo hace interfiriendo en la normalidad a través de cuestionamientos del orden social -a veces explícitos en manifiestos o proclamas-, cuyas proposiciones son diversas respecto de las que genera el estado de la situación. A la vez, se orienta a alcanzar el nuevo statu quo que propone la política revolucionaria de izquierda, aunque con materiales y modalidades que se cruzan y se diversifican respecto de los modelos de comunicación política que apuntan a la toma de conciencia con mensajes explícitos.

Lo llamativo, es que si se trata de un tiempo convulsionado política y artísticamente, la obra de Vigo apela a estrategias desestabilizantes del propio discurso disruptivo de la 
época. Esto quiere decir que si agujerea algún saber establecido en la estructura normal, si se transforma en disenso respecto del orden social, lo hace más que por la asunción del rol de artista-revolucionario, por un tipo de obra que opera una articulación entre la utilización de prácticas y discursos rupturistas de vanguardia y elementos tanto de la práctica artística "comprometida" políticamente -digamos, de comunicación de ideas políticas- como otros que resultan ajenos a esas prácticas. En esa combinación, Vigo no rechaza, sino que incorpora elementos de ese prototipo de artista y de obra “comprometidos". Es en esa articulación múltiple que opera una modulación en el acto. Esta conclusión general puede ser particularizada en las zonas de la obra de Vigo sobre las que se ha trabajado en la tesis. Si bien hemos procurado en cada capítulo presentar conclusiones parciales, recordaremos aquí sus resultados más relevantes.

Dado que el espacio está construido socialmente y que en él se disputan sentidos y legitimaciones, razones por las cuales es político, en relación con los señalamientos de Vigo puede sostenerse que estas acciones artísticas en el espacio público se propusieron como forma de efectuación de un desequilibrio en la regimentación y administración del ámbito de circulación y expresión públicas. Allí donde el estado dictatorial organiza las formas y límites de lo público, los señalamientos, en tanto emergencia de lo político, aparecen como oportunidad de reconfiguración de la experiencia sensible. Vigo opera doblemente: por un lado, organiza acciones artísticas de tipo vanguardistas, desligadas de la obra de arte tradicional y sus formas institucionalizadas, donde, además, se prefigura un espectador activo y participante, alejado de la pasividad contemplativa; y por otro lado, esas acciones ocurren en el espacio público, al alcance de los transeúntes y donde esa expresión artística parece no tener sitio por inadecuada o peligrosa, relacionándose también, en algunos casos, con una crítica política a la represión estatal. Las producciones artísticas en el espacio público participan de la construcción de ese espacio como sitio donde confluyen, más o menos descolocados, arte y vida, a lo que se suma que, de acuerdo con el proceso de progresiva politización de amplios sectores sociales, convergen con estos últimos en establecer en el espacio público un ámbito de expresión de la contestación política y social. Las acciones no ocurrían allí, entonces, por una pura oposición institución/espacio público, dado que, además, se jugaba en ese acto una representación de lo público como cercano al "pueblo" (lo cual no significa, sin embargo, la correlación material de aquella representación). Así como desde el peronismo la idea de pueblo adquirió un nuevo sentido, asociado a la clase trabajadora, a medida que transcurrían los sesenta, se transformó en un significante que iba 
adquiriendo un sentido más amplio y complejo: al mismo tiempo que abarcaba al "pueblo peronista" que sufría la proscripción del partido, estaba vinculado más ampliamente a todos aquellos afectados negativamente por el "sistema" capitalista.

Los artistas se pronuncian "a veces sin necesidad de una explicitación de los temas mencionados sino a través de símbolos o de postulaciones imaginarias que implican, de hecho, un pronunciamiento sobre la situación en la que la propia obra es enunciada o presentada" (Achugar, 1991: 126-127). En los señalamientos tanto la operación del extrañamiento con respecto a la espacialización convencional como el hecho de que las producciones de acciones refirieran en algunos casos a problemáticas políticas y se dieran en las particulares condiciones socio-políticas de la época, coadyuvan a otorgarle un sentido disruptivo y político.

La utilización del discurso judicial-administrativo en obras y acciones es otra de las formas en que la poética de Vigo generó una articulación de concurrencias múltiples entre el arte y la política. La apropiación dislocada de ese discurso que realizó Vigo en sus obras constituye una crítica a la organización judicial, tanto desde el punto de vista de la exposición de sus injusticias e inequidades, como en la configuración de un dispositivo que toma aspectos del lenguaje y su materialidad visual u objetual, especialmente los géneros de la certificación y la prueba, los sellos y los hilos, los que marcan una falla en los procedimientos de exclusión que protegen los discursos de un estrato social garante la dominación.

Doblemente rebelde, Vigo no solo actúa como autor y toma como objeto un discurso protegido por formas institucionales, materiales y simbólicas que limitan sus usos, deshilvanando algunas tramas del orden social, sino que se aleja también de los dictámenes de la doctrina del buen artista revolucionario, que significó en esa época el compromiso político, la utilización de temas vinculados con la revolución. Se decía antes que Vigo no excluyó estos temas entre sus trabajos, pero lo hizo, en general, presentando innovaciones que hacían que algo del mensaje permaneciera velado o que no pudiera leerse con los esquemas de interpretación usuales. Lo que interesa aquí, entonces, es ese movimiento oscilante a lo desconocido. La poética de Vigo combina la certeza de la necesidad del cambio radical en su forma más o menos común desde el discurso de la izquierda, con procedimientos estéticos novedosos o basados en los planteos de las vanguardias. En el propio acto provoca una modulación que implica la emergencia de algo que no estaba dicho o mostrado, una propuesta de cambio, pero ya 
fuera del modelo estandarizado, mientras hace conocer que hay un discurso privativo y lo utiliza en la obra desarticulando esa condición. Desarma, así, algo de la organización y la cuenta del orden social, aprovechando elementos que puede manipular gracias a su trabajo diario, pero que corresponden "naturalmente" al ámbito específico de aplicación de la ley, de modo que esas prácticas dan a entender que todos pueden ser usuarios del discurso de la ley y, en definitiva, todos pueden producirlo.

La tercera conclusión apunta a que la revista Hexágono '71, cuya materialidad desarticula el propio género, es uno de los modos en que la mixtura de vanguardia y comunicación política se establece como un particular artefacto donde conviven en tensión las lógicas heterogéneas de la política y lo político. La aparente contraposición entre experimentación estética y compromiso político -uno, centrado en la forma, el otro, en el contenido- es potenciada más que anulada en el desenvolvimiento de la revista. Vigo apostó a la superposición, al montaje de esas lógicas a través de formas, técnicas, tonos, y dispositivos materiales, visuales y textuales como desorganización de los géneros de la comunicación y haciendo uso de las formas estéticas y culturales tanto de la vanguardia como de los discursos reconocibles de la izquierda.

Es, entonces, este proceso de cruces múltiples, que se hace más evidente a partir de número $c d$, lo que se asume como una "peligrosidad". En este sentido, es posible pensar en la existencia de diversas peligrosidades, desde aquellas que implican la posibilidad de la lucha armada hasta las aperturas subjetivas sobre las miradas del mundo: los cruces heterogéneos entre arte y política que permitió Hexágono '71. Ambas involucran diversos modos de apartarse del proceso social como un modelo único y monolítico. Esto demuestra que una mayor participación de la realidad política no implicó para Vigo un abandono de las premisas que venía desarrollando desde los orígenes de su carrera. Hexágono '71 se produce en la intersección de tres elementos: la ruptura estética, la comunicabilidad y los temas de la vida social, y desde una mirada diacrónica, las modificaciones en el peso que adquiere cada uno en distintos momentos le otorgan flexibilidad y versatilidad. Así, si en una primera etapa tiene mayor gravedad la ruptura estética, y por ello parece necesario publicar trabajos y textos que avalen esa mirada; en la segunda, pesa más que antes una temática política, que, sin embargo, no provoca el abandono de las disyunciones y dislocamientos de convenciones, formas y expectativas culturales de la primera. En cuanto a la presentación de trabajos menos herméticos, es dable que la comunicabilidad de la revista aumente a medida que lo 
hacen también los temas de la vida social, junto con las interpelaciones a la toma de posición sobre la actualidad política o pública. Sin embargo, esto ocurre al mismo tiempo que la posibilidad de manipulación del objeto revista, su rareza como artefacto problemático, por ejemplo para ser identificado -no hay fechas, editorial, ni estructurase mantiene inalterable hasta el final de su publicación.

En su programa poético Vigo apostó también a la desorganización de los lugares y roles tradicionalmente asignados al artista, el espectador, la obra y las instituciones. Obras, acciones, propuestas, manifiestos y teorías se combinaron de un modo tal que la "revulsión" ocurriera también en el mundo del arte. Las ideas de construir un arte "tocable", de "materiales innobles" y especialmente "contradictorio" basaron su proyecto artístico que incluía desde la elaboración de objetos, xilografía y poesía visuales, hasta las performances, las ediciones de revistas y la intervención tanto en el espacio público como las instituciones artísticas. Hemos visto cómo en esa diversidad hubo no solo coincidencias, sino también contradicciones, vaivenes y tensiones.

Como sostiene Basualdo en relación con Vigo, "su trabajo tiende a desnaturalizar las reglas del juego del arte, a mostrar al código en tanto sistema arbitrario sancionado por el consenso, o sea, a demostrar efectivamente su historicidad" (1994: 12). En cuanto a la relación que estableció Vigo en sus obras con la política como temática, puede sostenerse que no se transformó en un artista panfletario o didactista, es decir, un promotor de propaganda política que intentaba convencer con un mensaje unívoco y directo sobre las bondades de un modelo político. Sino que, al tiempo que hace referencia a alguna cuestión de la política, conserva una poética opaca, a través de configuraciones propias que no es posible decodificar según recursos y herramientas disponibles.

En tanto, como afirma Negash, los artistas e intelectuales "asumen un rol crítico en la sociedad por su posición privilegiada, y poseen la imaginación y las habilidades para crear narrativas, pinturas e imágenes que construyen y reconstruyen las ideas y significados políticos" (2004: 191. Traducción nuestra), Vigo potenció esa productividad y permaneció siempre en el campo del arte. Defendió la posición de reconocimiento que había logrado en ciertos ámbitos de la ciudad de La Plata y en conexiones constantes y crecientes con el mundo. La intervención que produce en lo político y social se da en tanto permanece instalado en el lugar del artista, es decir, si bien en Hexágono '71, algunos señalamientos y otras obras se vincula con aspectos, 
acontecimientos e ideologías políticos, no abandona esa posición dentro del campo. Esto abreva en la confirmación de que en su poética hay una doble conexión con la política y lo político. Es, justamente, porque mantiene su producción en el mundo del arte que puede conectarte con la política del momento y al mismo tiempo, mantener la politicidad interna a las obras.

Esta idea sugiere que es posible concebir la acción de artistas vanguardistas vinculados con su tiempo histórico que no necesitaron o no optaron por un abandono de las prácticas específicas para pasar a la participación política plena ni por un arte concebido como instrumento pedagógico y comunicacional al servicio de la política.

En el acento que puso Vigo en la idea de "revulsión" en lugar de "revolución", no solo a través de sus textos, sino también de sus obras y acciones artísticas, proponía una discusión con la posición que supone que la función del artista revolucionario es modificar las relaciones sociales de producción y, por consiguiente, que debe ocuparse de su rol estrictamente en el proceso productivo, más que de su práctica particular. Vigo expresó que su objetivo no era modificar el rumbo de la gente, no forzar hacia una toma de conciencia para la revolución, sino "inducir" de un modo más sutil o velado, utilizando mediaciones que inciten a una actitud crítica hacia el contexto inmediato (señalamientos), su comunidad (Hexágono '71), o el sistema jurídico y legal (discurso judicial). Estos artefactos objetuales y discursivos vendrían, más que a conciliar una conciencia revolucionaria y consustanciada con "el" sujeto de la historia, el proletariado, a preparar a una subjetividad de la experiencia crítica, movilizada, dislocada. A partir de allí, si esos sujetos se convierten o no en hombres y mujeres revolucionarios, excede a la propuesta poética. Vigo reconoce sus limitaciones y si bien pretende estimular a un sujeto crítico, no puede convencerlo de que vaya a modificar el orden social de una forma en especial. Él mismo había decidido, desde su posición anarquista, no participar de organizaciones políticas porque sostenía que no podía soportar que le indicaran una línea de acción.

Esta particularización de politicidades ha sido clave tanto para profundizar en el discurso de Vigo como para observar los vaivenes, yuxtaposiciones, combinaciones de ambas que se producen en sus trabajos y, lejos de cristalizar una mirada sobre ellos (o de imponer un único patrón de lectura), permite comprender las complejidades y contradicciones que se presentan entre lo dicho, lo escrito, lo deseado y lo realizado.

Richard ha caracterizado un tipo de movimiento artístico vanguardista, cuya construcción difiera tanto de "la lengua del poder oficial" como del "modelo ideológico 
del arte militante" (2000). En el mismo sentido, no se trata para Vigo de la dicotomía que se presenta entre ser experimental y lúdico ó producir al servicio de la política, sino de un arte que tiende a dislocar, desviar o romper con aspectos del sistema del arte tradicional y del orden social dominante. Así, Vigo se ubicó fuera del marco de lo que Richard llama "cultura militante", caracterizada por un tono emotivo y referencial e intentó desbordar las prácticas que aparecían como modelos de activismo políticoartístico. Su apuesta fue por un camino complejo y heterogéneo de quebrantamiento de algunos signos de la cultura compartida y de ciertos pactos comunicativos que funcionan como normalización de las relaciones e instituciones sociales.

Si en un momento el arte puesto en función de la política parecía adquirir mayor legitimidad que otras manifestaciones, porque era a través de él que se podía coadyuvar, instrumentalmente, a los fines de la revolución, Vigo, tanto en sus señalamientos y en Hexágono '71 como en las apropiaciones que hizo del discurso judicial administrativo, operó desjerarquizando y poniendo en un pie de igualdad sus producciones ligadas con el trabajo sobre los lenguajes, los signos, los espacios y aquéllas que aludían a los problemas políticos. Si bien por momentos privilegió unas sobre otras, no construyó un orden de jerarquías definitivo en el que las obras se valorizaran más a medida que avanzaban en su politicidad manifiesta, es decir que se propusiera aumentar progresiva y sistemáticamente una función de compromiso entendido como producción intelectual y material a los fines pragmáticos de la revolución. Aún en momentos en que en Hexágono "71 publica trabajos de contenido político con mayor frecuencia, continúa apostando desde la misma revista a la participación del público en la búsqueda del desconcierto o la acción, con temáticas y modalidades no vinculadas expresamente a los acontecimientos políticos. Lo mismo sucede con los señalamientos y con las obras que se apropian del lenguaje y las formas materiales de lo judicial. Ello no implica, como se ha demostrado a lo largo de la tesis, que Vigo desdeñara los procesos socio-políticos que se estaban viviendo, sino, por el contrario, que trabajó políticamente desde la "revulsión" de los lenguajes, los sentidos, las costumbres, en combinación -en mayor o menos medida- con la crítica política explícita.

Esta reflexión no puede llevarnos, como es claro, a la pregunta sobre la eficacia, muchas veces realizada por los propios artistas de la época. No podemos responder en qué medida la política y lo político de Vigo fueron efectivos en la producción de cambios, como tampoco si sus prácticas ligadas a la política fueron más válidas para esos fines 
que lo político o viceversa. No se trata de una medida racional de la utilización de medios para ciertos fines, sino de la elaboración de una programa disidente, disensual y de la producción de experiencia vivida en momentos en que las subjetividades estaban siendo interpeladas para la generación de un mundo nuevo. Es en ese sentido que las politicidades del arte participan del proceso social general de cuestionamientos institucionales, religiosos, sexuales y políticos. No como el reflejo de un campo sobre otro, sino en concurrencia histórica de prácticas diversas.

Como apuntamos antes, la idea de que la política era la clave de la producción artística, parece ser una traslación directa de la imagen que transmitieron los intelectuales de la época. Así como empírica y metodológicamente no puede asumirse esa afirmación sin tener en cuenta el grado de diferenciación que tenían los artistas respecto de los intelectuales -aunque por momentos fuese muy bajo- la especificidad de la práctica artística no implica per se un involucramiento directo y necesario con los espacios y discursos públicos, como sucede con tantas actividades intelectuales. La indagación puntual de diversos casos de artistas seguramente dará, a partir de investigaciones futuras, un panorama más exacto de lo que ocurría en el arte.

Es posible que esta ampliación sea útil para analizar otros casos de artistas o escritores. Por ejemplo, en 1965 Ricardo Piglia había escrito en Literatura y sociedad que "es luchando por una nueva cultura y no violentando los 'contenidos' o alienando a la literatura en la inmediatez de lo político como podemos responder a la realidad de nuestro tiempo" (Piglia en Giunta 2008: 279). Asimismo, León Ferrari y Juan Pablo Renzi planteaban diferencias sobre la relación entre arte y política, en la que el primero sostenía la existencia de una relación de subordinación del arte respecto de la política y el segundo afirmaba que "si uno quería transformaciones en el arte es porque quería transformaciones en la sociedad (...). Nuestra intención desde la vanguardia era tomar la ideología, no poníamos el arte al servicio de la ideología, como mero mensajero (...), sino que tenía que ser una confluencia dialéctica, creativa y creadora de una nueva situación formal (Fantoni, 1998: 59).

No se trata de negar que los artistas se involucraron en los procesos sociales y políticos, sino de pensar que las formas de intervención que protagonizaron para producir cambios, especialmente en el plano cultural y a través de la convergencia de prácticas estéticas y sus múltiples politicidades, incluyeron, como en el caso de Vigo, una participación mixta e híbrida que iba desde la apropiación lisa y llana del discurso de la 
izquierda a la provocación del desconcierto en el uso de los lenguajes, géneros y modalidades comunicativas que salían de los bordes normalizados o dominantes.

Otra de las vías que la tesis pretende abrir se vincula más específicamente con el estudio de la poética de Vigo y la incorporación de una perspectiva sociológica para el estudio de las redes artísticas -y tal vez intelectuales- de las que Vigo formó parte, interesado durante décadas en el contacto con artistas del otros países, tanto latinoamericanos como europeos. El estudio de ese tema, en el que Dolinko avanzó en relación con la etapa de Diagonal Cero, y que hemos esbozado en el capítulo referido a Hexágono '71, puede ser profundizado en ese y otros momentos de la poética de Vigo.

Este tema se vincula, además, con otra de las cuestiones que no se han trabajado en la tesis, que es la particular forma en que Vigo pensó la internacionalización de su obra. Vigo participa del interés por la internacionalización del arte, pero a diferencia de lo que ocurría desde el Di Tella o de lo que proponía Romero Brest, más que convertir a Buenos Aires en un centro de arte mundial (Giunta: 2008), lo que le interesaba era permanecer actualizado en lo que sucedía en Europa, Estados Unidos y Latinoamérica, en continuo intercambio de trabajos e ideas, a través de una labor de hormiga, personal y a veces microscópica, que diera a conocer las producciones artísticas y textuales de sus contemporáneos y al mismo tiempo le posibilitara ser conocido y reconocido en el mundo. Así, lo internacional para Vigo funcionó como una meta personal que comenzó en 1953 con su viaje a París, y, al mismo tiempo, como medio para divulgar nuevas ideas y teorías que se estaban produciendo en el mundo. Es en este sentido que su interés por lo internacional fue más un objetivo personal como receptor, divulgador y artista. Acompañó estos objetivos con una teorización que diferenciaba entre un arte "internacional" y uno "universal", donde el primero tenía un objetivo mercantil y cuya poética sería "lavada" para evitar posicionamientos políticos o vanguardistas, y el segundo, se vinculaba con los múltiples trabajos de diversos artistas del mundo conectados en una red de intercambios paralelos y alejados de los medios de circulación y comercialización del arte. Desde allí hasta el arte-correo que utilizó especialmente durante la última dictadura como modo de expresión alternativo y en ciertos casos, críptico, reaparece, una vez más, la búsqueda de la conmoción, la disrupción, una articulación particular entre arte y política. 
ANEXOS 


\section{SÍNTESIS BIOGRÁFICA DE EDGARDO ANTONIO VIGO}

Esta biografía fue preparada por el equipo del Centro de Arte Experimental Vigo. Se reproduce aquí para simplificar las referencias a momentos clave de su carrera durante la lectura de la tesis.

1928: Nace en La Plata

1953: Egresa de la Escuela de Bellas Artes de La Plata

1953-54: Viaja a Francia donde se relaciona con Jesús Soto.

$\mathrm{Al}$ regresar realiza objetos móviles de técnica mixta que enfocan el hecho artístico con la problemática de la participación.

Realiza la primera exposición con su futura esposa, Elena Comas, en la Asociación Sarmiento de La Plata. Expone estructuras e instalaciones. El público destruyó casi la totalidad de las obras expuestas a los tres días de apertura de la muestra.

Algunas piezas expuestas en la Asociación Sarmiento necesitan el aporte del público para su plena concreción.

1955-56: Elabora sus primeros Poemas matemáticos que tienen una variante participativa.

1958-1960: Publica las revistas W.C. y $D R K W^{\prime} 60$.

Desarrolla sus tesis denominadas "Relativuzgir's" que asocian un espíritu Dadá con un arte no representativo (arte concreto).

1959: Publica en el diario El Argentino de La Plata el texto "Máquinas Inútiles Solteras Imposibles".

1960: Construye la Bi-tricicleta Ingenua (con ruedas incapaces de rodar).

1962: Crea la revista Diagonal Cero $\left(n^{\circ} 1,1962\right.$ - $\left.n^{\circ} 28,1968\right)$.

Publica carpetas de grabadores contemporáneos que serán la base del fondo del Museo de la Xilografía.

Comienza su permanente intercambio con el movimiento internacional de arte experimental vía correo.

1967: Edita en París sus Poemas Matemáticos Barrocos.

Funda el Museo de la Xilografía de La Plata. 
1968: Plantea la recuperación de la calle como lugar de expresión y espacio abierto. Realiza su primer señalamiento (1968), Manojo de Semáforos en La Plata.

1969: Realiza el film Blanco sobre blanco: homenaje a Kasimir Malevich y multiplica sus "proyectos a realizar".

Organiza la Expo / Internacional de Novísima Poesía /69, en el Instituto Di Tella de Buenos Aires. La presentación reunió 120 trabajos de las distintas ramificaciones de la poesía experimental (poesía concreta, espacialismo, poesía visiva, poesía semiótica, poesía-acción, poesía sonora, poesía-objeto, poesía-proceso, etc.).

Entrega Angel O. Nessi la declaración "Hacia un arte tocable" que amplía un primer artículo publicado en 1959.

1971: Organiza la primera Expo/Internacional de proposiciones a realizar, llevada a cabo en el CAYC de Buenos Aires.

Publica el libro-manifiesto De la Poesía/proceso a la poesía para y/o a realizar en 1970.

Crea la cuarta revista de Edgardo Antonio Vigo, Hexágono '71. Publicará 13 números hasta 1975.

1975: Organiza junto a Horacio Zabala la Última Exposición de Arte Correo.

Durante la década del '70 y ' 80 se constituye en el artista internacional del cono sur de mayor relevancia en el circuito del arte-correo.

1977-1983: Comparte su trabajo con Graciela Gutiérrez Marx, acuñando la firma conjunta "GE-MARXVIGO".

1991: Realiza una muestra retrospectiva denominada Anteproyecto de proyecto de un pretendido panorama abarcativo en la Fundación San Telmo de Bs. As.

1993: Participa de la muestra en el Centro Cultural Victoria Ocampo de Mar del Plata, con Claudia del Río y Mario D. Gemin, denominada Sras. y Sres.

1994: Es seleccionado junto a Pablo Suárez y Líbero Badii para integrar la delegación argentina en la Bienal de San Pablo, Brasil.

Realiza la muestra individual 1954-1994 en la Fundación Centro de Artes Visuales de La Plata.

1997: Realiza la muestra individual realizada en el Instituto de Cooperación Iberoamericana (I.C.I.) en Capital Federal, Vigo- poeta de la distancia.

4-11-1997: Fallece en la ciudad de La Plata, Argentina. 
2. MATRIZ DE DATOS DE SEÑALAMIENTOS

\begin{tabular}{|c|c|c|c|c|}
\hline \multicolumn{5}{|c|}{ Señalamientos } \\
\hline $\mathbf{N}^{\circ}$ & Nombre & Fecha & Lugar & Descripción \\
\hline 1 & Manojo de semáforos & 25/10/1968 & Calles 1 y 60 & $\begin{array}{l}\text { Convocatoria a } 1 \text { y } 60 \text { a observar el semáforo. Invitación con } \\
\text { Manifiesto - Primera no presentación Blanca. Publicada en } \\
\text { diversos medios, también en Diagonal Cero. }\end{array}$ \\
\hline II & Remember Grupo Sí & $27 / 10 / 1968$ & Alianza Francesa, La Plata & Tarjeta: "Colgar el presente membrete donde guste" \\
\hline III & No va más & $12 / 1968$ & Portada de Diagonal Cero n ${ }^{\circ} 28$ & $\begin{array}{l}\text { Tarjeta: "Señalamiento IIIํ realizado por Edgardo Antonio } \\
\text { Vigo. No va más!!!" }\end{array}$ \\
\hline IV & Poema demagógico & 1969 a 1971 & $\begin{array}{l}\text { Negocio Tomati; Uruguay (Padín); } \\
\text { Colegio Nacional; etc. }\end{array}$ & $\begin{array}{l}\text { Tres urnas con diferentes ranuras para realizar un "voto } \\
\text { demagógico" (poesía, dibujo, tachar una palabra, etc.) }\end{array}$ \\
\hline V & $\begin{array}{l}\text { Un paseo visual a la plaza } \\
\text { Rubén Darío }\end{array}$ & 08/11/1970 & $\begin{array}{l}\text { Plaza Rubén Darío (Cap. Fed.) en la } \\
\text { muestra Escultura, follaje y ruidos } \\
\text { organizada por el CAYC }\end{array}$ & $\begin{array}{l}\text { Propone marcar una superficie con una tiza, dar un giro de } \\
360^{\circ} \text { y componer un "paseo visual". }\end{array}$ \\
\hline VI & $\begin{array}{l}\text { 5' de filmación en el } \\
\text { monumento de } B \text {. Mitre }\end{array}$ & $06 / 06 / 1971$ & Calle 5 entre 56 y 57 & Filmación alrededor del monumento con cita al público \\
\hline VII & De tu mano & 1971 & $\begin{array}{l}\text { Hexágono, ab y en la muestra Arte Joven } \\
\text { Platense, Museo Provincial de Bellas } \\
\text { Artes de La Plata. }\end{array}$ & Tarjetón perforada para colocar la mano a través de orificios \\
\hline VIII & $\begin{array}{l}\text { Devolución del agua del } \\
\text { '70 }\end{array}$ & $21 / 09 / 1971$ & Bocacerrada, Punta Lara & Se devuelve al río el agua tomada el 21/09/70 \\
\hline IX & $\begin{array}{l}\text { Enterramiento y } \\
\text { desenterramiento de un } \\
\text { taco de madera de cedro }\end{array}$ & $\begin{array}{l}28 / 12 / 1971 \text { al } \\
28 / 12 / 1972\end{array}$ & Domicilio particular: $15 n^{\circ} 1187$, La Plata & $\begin{array}{l}\text { Se entierra un taco de madera y se desentierra al año. Una } \\
\text { escribana produce un certificado ( Actas protocolizadas). }\end{array}$ \\
\hline IX bis & $\begin{array}{l}\text { Tres actos interconectados } \\
\text { ' } 71\end{array}$ & 24/05/1971 & $\begin{array}{l}\text { Calle } 7 \text { y } 50, \text { La Plata. Distribuido por } \\
\text { carta y en la vía pública. }\end{array}$ & $\begin{array}{l}\text { Tres tarjetas que indican donde orinar, defecar y entrar en } \\
\text { "trance poético". }\end{array}$ \\
\hline $\mathrm{X}$ & Llamado del limonero & $\begin{array}{l}22 \text { al } \\
27 / 7 / 1972\end{array}$ & Domicilio particular & Se extrae jugo de limón y luego se reinyecta. \\
\hline $\mathrm{XI}$ & Souvenir del dolor & 1972 & $\begin{array}{l}\text { Muestra Arte integración (Zoológico de } \\
\text { La Plata); exposición Arte Platense } \\
\text { Panorama '72; Hexágono '71. }\end{array}$ & $\begin{array}{l}\text { En el zoológico: sobre el suelo, señala recorte del diario } \\
\text { sobre la masacre de Trelew. En Panorama ' } 72 \text {, emula un } \\
\text { stand de tiro con ametralladora, nombres de los muertos, } \\
\text { imagen del Che. En Hexágono ' } 71 \text { publica un afiche con } \\
\text { tarjetas para armar. }\end{array}$ \\
\hline XII & Almácigo de arena & $21 / 09 / 1972$ & [Punta Lara] & Recolección de arena. \\
\hline XIII & Los puntos cardinales & $21 / 09 / 1973$ & Punta Lara & $\begin{array}{l}\text { Marca los puntos cardinales, mira en dirección de cada uno, } \\
\text { arroja una botella. }\end{array}$ \\
\hline XIV & Llamado del silencio & Julio 1974 & [Domicilio particular] & Consiste en tres tarjetas: "Señalamientos de un texto", \\
\hline
\end{tabular}




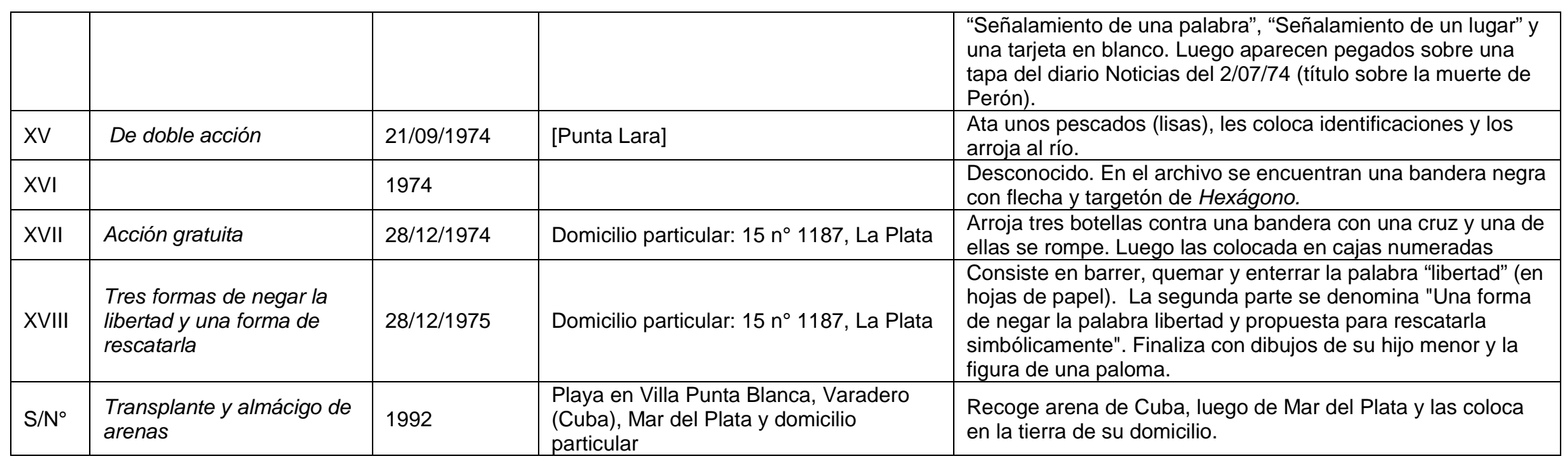


3. MATRIZ DE DATOS DE HEXÁGONO '71

\begin{tabular}{|c|c|c|c|c|c|c|c|c|}
\hline \multicolumn{9}{|c|}{ Revistas Hexágono '71 } \\
\hline$N^{\circ}$ y año & Portada & Elem. & Textos & Trabajos & Tipo & Nacional & Extranjero & País \\
\hline $\begin{array}{l}a \\
{[1971]}\end{array}$ & $\begin{array}{l}\text { "U.N.O. más } \\
\text { que U.S.A." }\end{array}$ & 1 & & $\begin{array}{l}\text { "Souvenir de Viet- } \\
\text { Nam" }\end{array}$ & Sobre e instrucción & Edgardo Vigo & & \\
\hline (1) & & 2 & & Historieta & Historieta & Vigo & & \\
\hline & & 3 & "Banda dibujada" & & Texto & & Burne Hogarth & EE.UU. \\
\hline & & 4 & "Arte pobre" & & Texto & & Germano Celant & Italia \\
\hline & & 6 & & "In (hostia)" & Círculo & Vigo & & \\
\hline & & 7 & & Guía telefónica & $\begin{array}{l}\text { Propuesta de } \\
\text { intervención }\end{array}$ & & Jochen Gerz & Alemania \\
\hline Total & & 7 & 2 & 5 & & 2 & 3 & \\
\hline
\end{tabular}

\begin{tabular}{|c|c|c|c|c|c|c|c|c|}
\hline$a b$ & $\begin{array}{l}\text { "U.N.O. más } \\
\text { que U.S.A." }\end{array}$ & 1 & & $\begin{array}{l}\text { "Soluciones sus } \\
\text { problemas } \\
\text { (in)estéticos" }\end{array}$ & $\begin{array}{l}\text { Trajetas } \\
\text { troqueladas }\end{array}$ & Vigo & & \\
\hline \multirow[t]{4}{*}{ (2) } & & 2 & & "Signografía VII" & Poesía visual & & Clemente Padín & Uruguay \\
\hline & & 3 & & $\begin{array}{l}\text { Señalamiento VII : } \\
\text { "De tu mano" }\end{array}$ & $\begin{array}{l}\text { Señalamiento, } \\
\text { tarjeta, hoja. }\end{array}$ & Vigo & & \\
\hline & & 4 & & "Hay un arroyo..." & Arte ecológico & & $\begin{array}{l}\text { Klaus Y Renate } \\
\text { Groh }\end{array}$ & Alemania \\
\hline & & 5 & & $\begin{array}{l}\text { "Impresiones } \\
\text { atmosféricas" }\end{array}$ & $\begin{array}{l}\text { Propuesta (arte } \\
\text { ecol.) }\end{array}$ & & Jochen Gerz & Alemania \\
\hline Total & & 5 & 0 & 5 & & 1 & 3 & \\
\hline
\end{tabular}

\begin{tabular}{|l|l|l|l|l|l|l|l|}
\hline ac & $\begin{array}{l}\text { "U.N.O. más } \\
\text { que U.S.A." }\end{array}$ & 1 & & "Haz tu body works" & Instrucciones & Vigo \\
\hline (3) & & 2 & $\begin{array}{l}\text { "Aburrimiento y } \\
\text { peligro" }\end{array}$ & & Texto & \\
\hline & & 3 & & $\begin{array}{l}\text { "Canción de cólera } \\
10 "\end{array}$ & Letra de canción & Dick Higgins & DE.UU. \\
\hline
\end{tabular}




\begin{tabular}{|l|l|l|l|l|l|l|l|l|}
\hline & & 4 & & Historieta erótica & Historieta & Vigo \\
\hline & & 5 & & Hoja envasadora & Collage & Vigo & \\
\hline Total & & 5 & 1 & 4 & & 1 & 1 \\
\hline
\end{tabular}

\begin{tabular}{|c|c|c|c|c|c|c|c|c|}
\hline $\begin{array}{l}b c \\
{[1972]}\end{array}$ & $\begin{array}{l}\text { "U.N.O. más } \\
\text { que U.S.A." }\end{array}$ & 1 & & $\begin{array}{l}\text { "El artista es el opio } \\
\text { del arte" }\end{array}$ & Tarjeta & Vigo & & \\
\hline \multirow[t]{6}{*}{ (4) } & & 2 & & $\begin{array}{l}\text { "Este año no escribí } \\
\text { a Noel para } \\
\text { Navidad" }\end{array}$ & Comunicación & & Hans Kalkmann & Alemania \\
\hline & & 3 & & $\begin{array}{l}\text { "Nos tratan de } \\
\text { anartistas" }\end{array}$ & Comunicación & & Julien Blaine & Francia \\
\hline & & 4 & & $\begin{array}{l}\text { "Manipulación . La } \\
\text { realidad es un error" }\end{array}$ & Comunicación & & Klaus Groh & Alemania \\
\hline & & 5 & & "The universal" & $\begin{array}{l}\text { Poesía visual } \\
\text { erótica }\end{array}$ & & Henry Targowski & Inglaterra \\
\hline & & 6 & & $\begin{array}{l}\text { "U.S.A. versus Latin } \\
\text { America" }\end{array}$ & Historieta & Vigo & & \\
\hline & & 7 & $\begin{array}{l}\text { "La importancia } \\
\text { de la tira dibujada" }\end{array}$ & & Texto & & Cirne Moacy & Brasil \\
\hline Total & & 7 & 1 & 6 & & 1 & 5 & \\
\hline
\end{tabular}

\begin{tabular}{|l|l|l|l|l|l|l|l|}
\hline $\begin{array}{l}\text { bd } \\
\text { [1972] }\end{array}$ & $\begin{array}{l}\text { "U.N.O. más } \\
\text { que U.S.A." }\end{array}$ & 1 & & $\begin{array}{l}\text { "Soluciones } \\
\text { económicas } \\
\text { ofrecidas por el } \\
\text { systema" }\end{array}$ & Sobre con tarjetas & Vigo \\
\hline (5) & Acceso & 2 & $\begin{array}{l}\text { "Múltiples } \\
\text { manuales" }\end{array}$ & $\begin{array}{l}\text { Hojas con números } \\
\text { y palabras }\end{array}$ & Texto. Invitación y \\
\hline & & 3 & $\begin{array}{l}\text { "Múltiples } \\
\text { presentaciones de } \\
\text { Imágenes } \\
\text { Imigráficas" }\end{array}$ & Lido lacopetti & Robin Crozier \\
\hline & & 4 & & $\begin{array}{l}\text { Imágenes } \\
\text { Imigráficas }\end{array}$ & Imagen & Lido lacopetti \\
\hline & & 5 & & "Autorritratto" & Poesía visual & \\
\hline & & 6 & & $\begin{array}{l}\text { "Análisis de } \\
\text { espacios poéticos }\end{array}$ & Hojas perforadas & Vigo \\
\hline
\end{tabular}




\begin{tabular}{|c|c|c|c|c|c|}
\hline & & & '72' & & \\
\hline Total & 6 & 1 & 5 & 2 & 2 \\
\hline
\end{tabular}

\begin{tabular}{|c|c|c|c|c|c|c|c|c|}
\hline be & $\begin{array}{l}\text { "U.N.O. más } \\
\text { que U.S.A." }\end{array}$ & 1 & & $\begin{array}{l}\text { "La } \\
\text { (in)comunicación de } \\
\text { los medios de } \\
\text { comunicación } \\
\text { masivos" }\end{array}$ & Historieta & Vigo & & \\
\hline \multirow[t]{4}{*}{ (6) } & & 2 & $\begin{array}{l}\text { "La calle: } \\
\text { escenario del arte } \\
\text { actual" }\end{array}$ & & Texto & Vigo & & \\
\hline & & 3 & & $\begin{array}{l}\text { Empire State y } \\
\text { cohete }\end{array}$ & Fotografías & & Betty Radin & Inglaterra \\
\hline & & 4 & & $\begin{array}{l}\text { "À la guerre comme } \\
\text { à la guerre" }\end{array}$ & Fotografías & & Anna Esposito & Italia \\
\hline & & 5 & & "Vuoto al centro" & Poesía visual & & Mirella Bentivoglio & Italia \\
\hline Total & & 5 & 1 & 4 & & 1 & 3 & \\
\hline
\end{tabular}

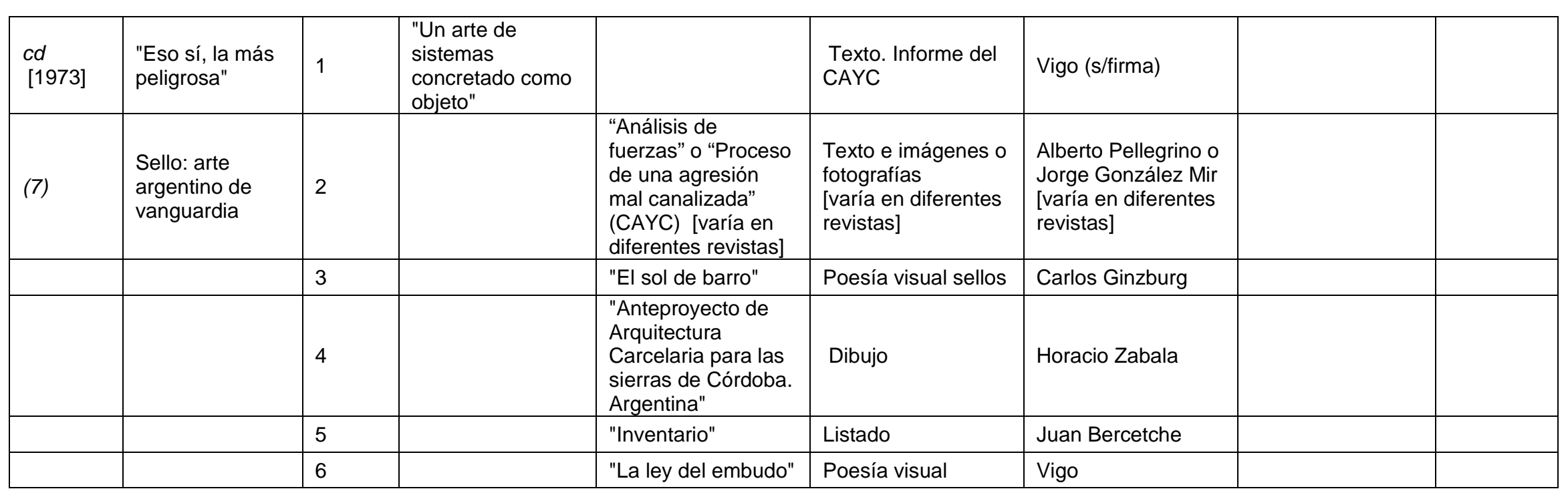




\begin{tabular}{|l|l|l|l|l|l|l|l|}
\hline & 7 & & "Herida" & Dibujo & Luis Pazos \\
\hline & & 8 & & Poesía & Poesía e imagen & Marcos Paley \\
\hline & & 9 & & $\begin{array}{l}\text { "La ofera y la } \\
\text { demanda" }\end{array}$ & $\begin{array}{l}\text { Recorte de diario } \\
\text { intervenido }\end{array}$ & Eduardo Leonetti \\
\hline Total & & 10 & & "La violencia" & Fotografías y texto & $\begin{array}{l}\text { Juan Carlos } \\
\text { Romero }\end{array}$ \\
\hline
\end{tabular}

\begin{tabular}{|c|c|c|c|c|c|c|c|c|}
\hline $\begin{array}{l}c e \\
{[1973]}\end{array}$ & $\begin{array}{l}\text { "Eso sí, la más } \\
\text { peligrosa" }\end{array}$ & 1 & $\begin{array}{l}\text { "Por qué un arte } \\
\text { de investigación" }\end{array}$ & & Texto & Vigo & & \\
\hline (8) & $\begin{array}{l}\text { (en tarjeta } \\
\text { colgando) }\end{array}$ & 2 & & "Large \& far..." & Poesía visual & & $\begin{array}{l}\text { Nicholas } \\
\text { Zurbrugg }\end{array}$ & Inglaterra \\
\hline & & \multirow[t]{4}{*}{3} & & $\begin{array}{l}\text { "El 'systema' } \\
\text { coagula rápido la } \\
\text { sangre del pueblo. } \\
\text { Este no" }\end{array}$ & $\begin{array}{l}\text { Poesía visual } \\
\text { (señalamiento) }\end{array}$ & \multirow[t]{4}{*}{ Vigo } & & \\
\hline & & & & "Ojo del che" & Xilog, tarjeta & & & \\
\hline & & & & "Souvenir del dolor" & Xilog, tarjeta & & & \\
\hline & & & & "Ármelo" & Instrucciones & & & \\
\hline & & 4 & & $\begin{array}{l}\text { "Explotación es } \\
\text { terrorismo" }\end{array}$ & $\begin{array}{l}\text { Sobre con tarjeta } \\
\text { IBM }\end{array}$ & Horacio Zabala & & \\
\hline & & 5 & & $\begin{array}{l}\text { "Fusilados en } \\
\text { Trelew..." }\end{array}$ & Afiche & $\begin{array}{l}\text { Juan Carlos } \\
\text { Romero (s/firma) }\end{array}$ & & \\
\hline & & 6 & & $\begin{array}{l}\text { "Al boom. } \\
\text { Burocrazia e } \\
\text { computer" }\end{array}$ & $\begin{array}{l}\text { Fotocopia de } \\
\text { collage }\end{array}$ & & $\begin{array}{l}\text { Nicola Andreace y } \\
\text { Michele Perfetti }\end{array}$ & Italia \\
\hline & & 7 & & $\begin{array}{l}\text { "Envíe una idea en } \\
200 \text { copias" }\end{array}$ & Propuesta & & Guillermo Deisler & Chile \\
\hline & & 8 & & Historieta & Automóvil & Vigo & & \\
\hline Total & & 8 & 1 & 7 & & 3 & 3 & \\
\hline
\end{tabular}

\begin{tabular}{|l|l|l|l|l|l|l|l|}
\hline $\begin{array}{l}\text { cf } \\
\text { [finales } \\
\text { de } 1973 \\
\text { o }\end{array}$ & $\begin{array}{l}\text { "Eso sí, la más } \\
\text { peligrosa" }\end{array}$ & 1 & $\begin{array}{l}\text { "Arte argentino de } \\
\text { vanguardia" }\end{array}$ & & Catálogo & $\begin{array}{l}\text { Perla Benveniste, } \\
\text { Eduardo Leonetti, } \\
\text { Luis Pazos, Juan C. } \\
\text { Romero, Vigo, }\end{array}$ & \\
\hline
\end{tabular}




\begin{tabular}{|c|c|c|c|c|c|c|c|c|}
\hline $\begin{array}{l}\text { principios } \\
\text { de 1974] }\end{array}$ & & & & & & Horacio Zabala & & \\
\hline \multirow[t]{6}{*}{ (9) } & & 2 & & "Trelew" & Planilla estadística & Juan Bercetche & & \\
\hline & & 3 & & $\begin{array}{l}\text { "Ernesto Che } \\
\text { Guevara" }\end{array}$ & Collage & Horacio Zabala & & \\
\hline & $\begin{array}{l}\text { Sello: } \\
\text { investigación de } \\
\text { la realidad } \\
\text { nacional }\end{array}$ & 4 & & Ruta $2 \mathrm{~km} \mathrm{...} \mathrm{cc}$ & Poesía visual & Vigo & & \\
\hline & & 5 & & "Variante jurídica" & Poesía visual & Vigo & & \\
\hline & & 6 & & "Tierra cúbica" & Proyecto & Carlos Ginzburg & & \\
\hline & & 7 & & $\begin{array}{l}\text { "La pirámide de la } \\
\text { muerte" }\end{array}$ & Proyecto & Carlos Ginzburg & & \\
\hline Total & & 7 & 1 & $\begin{array}{l}6 \\
\text { (no se incluyen la } \\
\text { obras contenidas en } \\
\text { el catálogo) }\end{array}$ & & 7 & 0 & \\
\hline
\end{tabular}

\begin{tabular}{|c|c|c|c|c|c|c|c|c|}
\hline $\begin{array}{l}d e \\
{[1974]}\end{array}$ & Sello: "Trelew" & 1 & & "Kitsch" & $\begin{array}{l}\text { Sobre, tarjeta con } \\
\text { sello y figurita }\end{array}$ & Vigo & & \\
\hline \multirow[t]{7}{*}{ (10) } & & 2 & "Bando" & & $\begin{array}{l}\text { Declaración revista } \\
\text { Barrilete }\end{array}$ & Barrilete & & \\
\hline & & 3 & & $\begin{array}{l}\text { "Poema matemático } \\
\text { censurado" }\end{array}$ & $\begin{array}{l}\text { Poesía visual, } \\
\text { postal }\end{array}$ & Vigo & & \\
\hline & & 4 & & "Revisado" & $\begin{array}{l}\text { Recorte diario y } \\
\text { sello }\end{array}$ & Horacio Zabala & & \\
\hline & & 5 & & "Argentina ‘74" & Poesía visual & Vigo & & \\
\hline & & 6 & $\begin{array}{l}\text { "Mitos, ritos y } \\
\text { delitos en el país } \\
\text { del silencio" }\end{array}$ & & Texto & & $\begin{array}{l}\text { Ops (Andrés } \\
\text { Rábago) }\end{array}$ & España \\
\hline & & 7 & $\begin{array}{l}\text { "Introducción a } \\
\text { Arte de Sistemas } \\
\text { en Latinoamérica" }\end{array}$ & & Texto. CAYC & Jorge Glusberg & & \\
\hline & & 8 & & $\begin{array}{l}\text { Dependencia } \\
\text { anulado... }\end{array}$ & Poesía visual & Luis Pazos & & \\
\hline Total & & 8 & 3 & 5 & & 5 & 1 & \\
\hline
\end{tabular}




\begin{tabular}{|c|c|c|c|c|c|c|c|c|}
\hline $\begin{array}{l}d f \\
{[1974]}\end{array}$ & $\begin{array}{l}\text { Sello: "Libres o } \\
\text { muertos jamás } \\
\text { esclavos" }\end{array}$ & 1 & & "Trelew" & Tarjeta con sello & Vigo & & \\
\hline \multirow[t]{12}{*}{ (11) } & & 2 & & $\begin{array}{l}\text { "Acción de } \\
\text { transplante de un } \\
\text { agujero existente en } \\
\text { el papel al cartón" }\end{array}$ & Collage & Vigo & & \\
\hline & & 3 & & "Frente y... dorso" & Recorte de diario & $\begin{array}{l}\text { Eduardo Leonetti y } \\
\text { Juan C. Romero }\end{array}$ & & \\
\hline & & 4 & & "Political ideology" & Encuesta & Jorge Glusberg & & \\
\hline & & 5 & & $\begin{array}{l}\text { Carta de Endre Tôt } \\
\text { a Jorge Glusberg }\end{array}$ & "Carta audiovisual" & & Endre Tôt & Hungría \\
\hline & & 6 & & "Tension = force..." & $\begin{array}{l}\text { Fotocopia de } \\
\text { collage }\end{array}$ & Horacio Zabala & & \\
\hline & & 7 & & $\begin{array}{l}\text { Esbarrando } \\
\text { mecanismos... }\end{array}$ & Telegrama CAYC & Amelia Toledo & & \\
\hline & & 8 & & "Lorcaesque" & Poesía & & $\begin{array}{l}\text { Michael Joseph } \\
\text { Phillips }\end{array}$ & EE.UU. \\
\hline & & 9 & & $\begin{array}{l}\text { "Análisis sumario de } \\
\text { la enfermedad del } \\
\text { 'putsch' cuyos } \\
\text { casos críticos son } \\
\text { de lamentar" }\end{array}$ & $\begin{array}{l}\text { Poesía visual - } \\
\text { dibujo }\end{array}$ & & Guillermo Deisler & Chile \\
\hline & & 10 & & "Monocensurex" & Poesía visual & & Clemente Padín & Uruguay \\
\hline & & 11 & & "Espejo" & $\begin{array}{l}\text { Poesía visual - } \\
\text { poema matemático }\end{array}$ & Vigo & & \\
\hline & & 12 & & $\begin{array}{l}\text { "Little Nemo in } \\
\text { Slumberland" }\end{array}$ & $\begin{array}{l}\text { Historieta y síntesis } \\
\text { histórica }\end{array}$ & & Windsor Mckey & EE.UU. \\
\hline & & 13 & $\begin{array}{l}\text { "Homage to } \\
\text { Boredom contest } \\
\text { number two" }\end{array}$ & & $\begin{array}{l}\text { Convocatoria para } \\
\text { arte-correo }\end{array}$ & & $\begin{array}{l}\text { Chuck Stake } \\
\text { Enterprizes }\end{array}$ & Canadá \\
\hline Total & & 13 & 1 & 12 & & 6 & 6 & \\
\hline $\begin{array}{l}d g \\
{[1974]}\end{array}$ & $\begin{array}{l}\text { Faja: } \\
\text { "Autocensurado" }\end{array}$ & 1 & & $\begin{array}{l}\text { "Contaminación o } \\
\text { liberación". "A los } \\
\text { pueblos y gobiernos }\end{array}$ & & $\begin{array}{l}\text { Juan Carlos García } \\
\text { Palou, Eduardo } \\
\text { Leonetti, Juan }\end{array}$ & & \\
\hline
\end{tabular}




\begin{tabular}{|l|l|l|l|l|l|l|l|}
\hline & & & & del mundo" & & Carlos Romero \\
\hline$(12)$ & & 2 & $\begin{array}{l}\text { "Te deshacen y } \\
\text { recomponen tu } \\
\text { mente" }\end{array}$ & Poesía visual & Vigo \\
\hdashline Total & & 2 & 2 & 4 & 0 \\
\hline
\end{tabular}

\begin{tabular}{|c|c|c|c|c|c|c|c|c|}
\hline $\begin{array}{l}e \\
{[1975]}\end{array}$ & $\begin{array}{l}\text { Sello: "Arte de y } \\
\text { para } \\
\text { investigación" }\end{array}$ & 1 & "Sellado a mano" & & Texto sobre sellos & Vigo & & \\
\hline \multirow[t]{11}{*}{ (13) } & & 2 & & $\begin{array}{l}\text { "Poesia non } \\
\text { transferibile" }\end{array}$ & Sellos & & Franco Vaccari & Italia \\
\hline & & 3 & & $\begin{array}{l}\text { "El medio es el } \\
\text { mensaje" }\end{array}$ & Sellos & Carlos Ginzburg & & \\
\hline & & 4 & & $\begin{array}{l}\text { "Composite } \\
\text { Message" }\end{array}$ & Sellos & & Henry Targowski & Inglaterra \\
\hline & & 5 & & $\begin{array}{l}\text { "Adolf Hitler } \\
\text { Commemorative } \\
\text { Stamp" }\end{array}$ & Sellos & & Pauline Smith & Inglaterra \\
\hline & & 6 & & "End of an empire" & Sellos & & Genesis Orridge & Inglaterra \\
\hline & & 7 & & Censurado & $\begin{array}{l}\text { Hoja de libro con } \\
\text { sello }\end{array}$ & Horacio Zabala & & \\
\hline & & 8 & & Paloma & Sellos & $\begin{array}{l}\text { Graciela Gutiérrez } \\
\text { Marx }\end{array}$ & & \\
\hline & & 9 & & "Try= life" & Sellos & & Klaus Groh & Alemania \\
\hline & & 10 & & $\begin{array}{l}\text { "Señale su paso por } \\
\text { la historia" }\end{array}$ & $\begin{array}{l}\text { Hoja para completar } \\
\text { y sellos }\end{array}$ & Luis lurcovich & & \\
\hline & & 11 & & "Venceremos" & Sellos & & Robert Rehfeldt & Alemania \\
\hline & & 12 & & "Anulada" & Sellos & Vigo & & \\
\hline Total & & 12 & 1 & 11 & & 5 & 6 & \\
\hline
\end{tabular}




\section{4. ÍNDICE RAZONADO DE HEXÁGONO '71119}

$\mathrm{N}^{\circ} a(1)^{120}$

Portada: "U.N.O. más que U.S.A."

1. "Souvenir de Viet-Nam". Sobre de papel transparente adosado a la retiración de tapa. Texto: "Viaja. Busca una trinchera (de cualquier bando), recoge una vida y guárdala en el sobre transparente". [Vigo] (sin firma).

2. Historieta: serie de cuatro dibujos, sello de Vigo, Vigo.

3. "Prefacio" a Banda Dibujada y Figuración narrativa, Burne Hogarth (Director de la Escuela de Artes Visuales de Nueva York), 1967.

4. “Arte pobre”, Germano Celant, febrero de 1968. Traducción: Elena Comas.

5. "Arte ecológico", Carlos Ginzburg. Propuestas: "Flor", "Hoguera hacia la autora boreal", "Hogueras nocturnas en la costa patagónica".

6. “(in) hostia”. Círculo pequeño de papel: escrito a mano "(in) hostia”.

7. Fotocopia de hojas de la guía de París y una propuesta a intervenir en la codificación organizada de la misma. Jochen Gerz (CAYC).

\section{$\mathbf{N}^{\circ} a b(2)$}

Portada: "U.N.O. más que U.S.A."

1. "Solucione sus problemas (in) estéticos", Vigo. Dos tarjetas troqueladas unidas por un hilo con instrucciones.

2. "Signografía VII", Clemente Padín. Trabajo sobre cartulina de color.

3. "Señalamiento VII. De tu mano", Vigo. Hoja con cinco perforaciones circulares y una tarjeta con instrucciones.

4. Comunicación de H. W. Kalkman, Klaus y Renate Groh (Alemania), Art Agency. Arte ecológico. Texto "Hay un arroyo o río en su vecindad que está siendo canalizado? No hace nada al respecto? En este caso Usted está ayudando a crear un desierto! H. W. Kalkmann”.

\footnotetext{
${ }^{119}$ Este índice fue cotejado con el realizado por Ana María Gualtieri (2010 -2011) en el Centro de Arte Experimental Vigo (inédito).

${ }^{120}$ Seguido a la identificación original de cada letra se coloca entre paréntesis el número correspondiente.
} 
5. "Impresiones atmosféricas", Jochen Gerz. Propuesta en dos hojas: "un día un mes un año".

\section{$\mathbf{N}^{\circ} a c(3)$}

Portada: "U.N.O. más que U.S.A."

1. "Haz tu body works", Vigo. Hoja con instrucciones para realizar la acción. Texto: "escultura con el cuerpo" "Frota la parte elegida de tu cuerpo dentro o fuera de la zona delimitada".

2. “Aburrimiento y peligro”, Dick Higgins, Nueva York, verano de 1966. Ensayo sobre el aburrimiento y el peligro empleados en el arte como oposición a lo utilitario, decorativo o entretenido. Cuatro páginas numeradas y pequeña tarjeta colgada con dos agujeros.

3. "Canción de cólera 10. Para el movimiento 'Liberación de las mujeres"”, Dick Higgins. Texto.

4. Historieta, Vigo. Características eróticas; con perforaciones. Foto de cuatro hombres desnudos, sale a modo de viñeta una imagen de dos mujeres.

5. "Hoja envasadora", Vigo. Texto: "X-9 (side)" "Oblea en caso de reclamo citar este número"

\section{$\mathbf{N}^{\circ} b c(4)$}

Portada: "U.N.O. más que U.S.A."

1. "El artista es el opio del arte". Cartulina verde perforada de la que cuelga una tarjeta de un hilo y contiene el texto.

2. "Cet année je n'envoye pas des cartes de Noël”, Hans Kalkman, Alemania. Comunicación.

3. "Nos tratan de anartistas", Julien Blaine, Francia.

4. "Manipulación”, Klaus Groh. Hoja sellada con la palabra "Manipulación”. Debajo, escrito a máquina se lee: "La realidad es un error".

5. "The universal”, Henry Targowski, 1970. Poesía visual, características eróticas: cuadro con el título "Cópula ideal”.

6. "U.S.A. versus Latin American", Vigo. Hoja doblada longitudinalmente: la tapa tiene el título, perforada en el centro. Al abrir se ve: pistola disparando de frente, agujero en el caño; en la página siguiente, foto de los hombres desnudos con una perforación central y debajo el texto "Llegó la ayuda. Hermanos!!!". 
7. "La importancia de la tira dibujada", Moacy Cirne, en Blum! La explosión creativa de las tiras dibujadas. Editora Vozes Limitadas, Petropolis, Brasil. Traducción: Vigo. Ocho páginas. Cirne destaca el peso de la historieta que, a pesar de haber sido subestimada, es una de las formas de comunicación de la sociedad de masas gracias a su reproductibilidad técnica.

\section{$\mathbf{N}^{\circ} b d(5)$}

Portada: "U.N.O. más que U.S.A."

1. "Soluciones económicas ofrecidas por el 'systema' al pueblo", Vigo. Sobre con el texto; a la izquierda, una mano que apunta hacia adelante con un revólver. Dentro del sobre se encuentran: un boleto del hipódromo, un boleto de lotería, un boleto del Prode. Los tres boletos son originales y cada uno tiene impreso un sello circular que dice "Edgardo Antonio Vigo, $7 \mathrm{~N}^{\circ}$ 526, $2^{\circ}$ E, La Plata. Prov. Bs. As. Argentina".

2. "Múltiples manuales", Robin Crozier. Sobre con papeles en su interior, con números, palabras y perforaciones.

3. "Múltiples presentaciones de Imágenes Imigráficas". Invitación a ver presentaciones de Lido Iacopetti llamadas “Imágenes imigráficas”. Seguido se publica “Un arte para y por el pueblo" Lido Iacopetti, La Plata, agosto de 1972. Explicación del artista sobre la razón por la cual no se presenta en galerías, salones, museos, dado que en esas instituciones no hay lugar para un tipo de presentaciones no convencionales: son instituciones "muertas" que no se relacionan con el tipo de hombre al que el autor aspira. Así, en lugar de "arrastrarse" tras los premios, prefiere estar "de pie frente al mundo". Dice que sueña con un mundo de "hombres libres y justos" y para ello el arte es el medio más indicado, cumpliendo así su "suprema función liberadora". En hoja aparte, dibujo realizado con fibras. Tres hojas.

4. "Autorritratto", Annalisa Alloati. Dos letras "A" en espejo.

5. “Análisis de espacios poéticos '72”, Vigo. Poesías visuales: hojas blancas caladas con forma de círculos dispuestos de diferentes maneras sobre las hojas. Texto: "Código". Cinco hojas.

\section{$\mathbf{N}^{\circ}$ be (6)}

Portada: "U.N.O. más que U.S.A."

1. "La (in) comunicación de los medios de comunicación masivos. Por caso la TV", Vigo. "Comic Strip". Historieta en seis cuadros. 
2. "La calle: escenario del arte actual". Vigo, 1971. Ensayo. Vigo desarrolla su teoría sobre la utilización del espacio público para la producción artística. Propone que el autor se convierta en "proyectista", "salir a la calle" y generar una "revulsión", así como reemplazar la "representación" por la "presentación". 7 hojas.

3. Montaje: fotografía del Empire State Building y fotografía de un cohete despegando. Betty Radin.

4. "À la guerre comme à la guerre", Anna Esposito. Montaje de fotografías de un trozo de torso humano que forma una celada.

5. "Vuoto al centro", Mirella Bentivoglio. Poesía visual.

\section{$\mathbf{N}^{\circ} \boldsymbol{c d}(\mathbf{7})$}

Portada del sobre: hay un nuevo logo

HEX (ilustración) 71

“eso sí, la más peligrosa..."

Este logo, la leyenda, la ilustración y el número de la revista se encuentran en una tarjeta pegada al sobre y al mismo tiempo sostenida por un hilo atado a la tarjeta y al sobre, a través de los orificios calados.

Se agrega en la tapa un sello en forma circular que dice "Arte argentino de vanguardia 1973”. Además, el papel del sobre está calado.

1. "Un arte de sistemas concretado como objeto", sin firma [Vigo], 19 de marzo de 1973. Texto en papel membretado del CAYC. En la primera hoja se encuentra el sello de Vigo (Edgardo Antonio Vigo $7 \mathrm{~N}^{\circ}$...) utilizado en otras oportunidades. El artículo consiste en una reseña crítica de la muestra "El Grupo de los trece en Arte de sistemas", realizada en el CAYC. Al final del texto, se presenta un trabajo de diversos autores, variando entre revistas del mismo número. En un caso, “Análisis de fuerzas", de Alberto Pellegrino, consiste en tres cuadros acompañados de texto sobre la presión ejercidas por distintas fuerzas y su posible resultado final. En otro, "Proceso de una agresión mal canalizada”, de Jorge González Mir, es una serie de seis fotos de flores y arena.

2. "El sol de barro", Carlos Ginzburg. Trabajo conformado por una hoja sellada en el centro con un texto sobre el sol, las culturas precolombinas y la antropología de la pobreza. Otros sellos idénticos ubicados en las cuatro esquinas de la hoja contienen un texto que se refiere al origen del hombre, el mono y un libro de Darwin. 
3. "Anteproyecto de Arquitectura Carcelaria para las Sierras de Córdoba. Argentina", Horacio Zabala, 1973. Dibujos de tipo arquitectónico sobre un proyecto de cárcel subterránea.

4. "Inventario", Juan Bercetche, 1973. Hoja divida longitudinalmente, del lado izquierdo la palabra "inventario", del lado derecho la siguiente lista: "7 muertos, 13 heridos, 3 desaparecidos, 4 camiones, 1 bar, 1 cabina telefónica, 1 quiosco, 5 viviendas, 1 hospicio, 1 templo".

5. "La ley del embudo", Vigo. Poesía visual. La palabra "inocente" pasa por un embudo del que sale la palabra "culpable". Debajo se encuentran la frase "La ley del embudo" y el sello de Vigo.

6. "Herida", Luis Pazos, 1973. Poesía visual. Se trata de la silueta de una persona (del tipo de las que se realizan en un procedimiento policial sobre un cadáver en el suelo). De la silueta se desprende a modo de sangre un mapa de Sudamérica.

7. Fotocopia de fotografía sobre la que se inscribe una poesía de Marcos Paley.

8. "La oferta y la demanda", Eduardo Leonetti. Página del diario La Opinión, 22 de agosto de 1972. Entre los clasificados se encuentra encerrado en un círculo, realizado a mano con marcador, un cuadro que dice "Se vende riñón. Absoluta reserva", la dirección y el teléfono.

9. "La violencia", Juan Carlos Romero. Montaje de dos fotos idénticas colocadas una al lado de la otra, de un cadáver que yace en el suelo. En el anverso de la hoja, un texto sobre la violencia que consiste en una descripción de sus características en el plano de la física. El texto tiene al final el nombre de Leonardo Da Vinci (Breviarios) y de J. C. Romero.

\section{$\mathbf{N}^{\circ}$ ce (8)}

Portada del sobre: mismo logo que el anterior, también en formato tarjeta, en ese caso está atada pero no pegada al sobre. Sin sellos ni perforaciones.

1. "Por qué un arte de investigación". Vigo, 1973. Ensayo. Establece diferencias entre el arte de investigación y el arte popular. Sostiene que la clave de la comunicación está en el diálogo silencioso entre el "trabajador plástico de investigación” y el espectador. Propone "establecer un lenguaje accesible y a la vez cargado de problemáticas nuevas" y la incorporación de cuestiones cotidianas. Reflexiona sobre la relación entre los acontecimientos políticos y el arte. Ocho páginas.

2. "Large \& far. Small \& near", Nicholas Zurbrugg. Poesía visual. 
3. "Souvenir del dolor", Vigo, 1972. Hoja doblada al medio con cuatro perforaciones circulares pequeñas. Dice: "El 'systema' coagula rápido la sangre del pueblo. Este no". En el interior de la hoja se encuentran 1) Un pequeño papel escrito a máquina que dice "Ármelo! Make yourself. Ensemblez-vous". 2) Una tarjeta rectangular de cartulina blanca que dice "Souvenir del dolor", debajo se encuentra una cruz en forma de $x$ xilografiada en color rojo y luego la frase "Recuerda!. El 22 de agosto del '72 trece más engrosan la lista”. Superpuesto a este texto el número once en color rojo. La tarjeta tiene una pequeña perforación de la que se ata un hilo rojo. 3) Una tarjeta de papel blanco con un hilo color naranja en la parte superior. Tiene una xilografía de medio rostro del "Che" Guevara que en la parte central del ojo está troquelado con un círculo. En el anverso dice "El ojo del Che". 4 hojas.

4. "Explotación es terrorismo", Horacio Zabala. Sobre sellado con la frase del título, contiene en su interior una tarjeta de IBM quemada.

5. "Fusilados en Trelew el 22 de agosto de 1972. Tribunal popular para los asesinos", Artistas Plásticos en Lucha [el diseño es de Juan Carlos Romero]. Afiche doblado con el título mencionado. Debajo, una cuadrícula con las fotos de los rostros de los dieciséis militantes. En la parte inferior del afiche dice "Acto de conmemoración. 22 de agosto 19hs Plaza Congreso. Adhieren Artistas Plásticos en Lucha”

6. "Al boom. Burocrazia e computer", Nicola Andreacci y Michele Perfetti. Fotocopia de collage.

7. "Envíe una idea en 200 copias a: G. Deisler - Casilla 487. Antofagasta - Chile." Guillermo Deiler. Propuesta.

8. Vigo. Historieta con automóvil. Cuatro páginas numeradas.

\section{$\mathbf{N}^{\circ} \boldsymbol{c f}(\mathbf{9})$}

Portada del sobre: la tarjeta con el texto "Eso sí, la más peligrosa" y el logo está pegada y atada. Tiene un sello en la parte superior que dice "Investigación de la realidad nacional".

1. Catálogo "Arte argentino de vanguardia", N 1, 1973. Edita: Galería Arte Nuevo de Buenos Aires. Tiene un formato de carpeta y en su interior se encuentran hojas sueltas y sin numerar. En la primera hoja aparecen los nombres de los que produjeron su contenido: Benveniste, Leonetti, Pazos, Romero, Vigo y Zabala, así como el lugar y el año. El catálogo contiene una introducción firmada por Horacio Safons, done dice que debe cuestionarse sobre el lugar en que se presentan las obras, favoreciendo el sistema 
comercial, por eso propone la búsqueda de un arte popular. El contenido del catálogo es el siguiente:

a. Letra de la canción "Sabino Navarro", Tono Baez. En la parte superior dice "Canta: Mario Alberto Costa (Integrante de Canto Popular Urbano)".

b. "Debemos organizarnos", Perla Benveniste. En la parte superior de la hoja se reproducen fotos con un marco con forma de un negativo de fotografía. Las fotos pertenecen al trabajo "Proceso a nuestra realidad" en el que aparece la artista trabajando sobre el muro. Se visualizan las fotos de los asesinados en Trelew y de Ezeiza, además de parte del texto que da nombre a esa presentación. Debajo se encuentra un texto que se refiere al individualismo en que han caído los artistas, "que cierra nuestras conciencias y nos impide encontrar, junto al pueblo los caminos para una política cultural y nacional." Con letras mayúsculas, dice debajo: "Solamente la unidad y organización de los artistas hará posible un arte que esté al servicio de los verdaderos intereses del pueblo." Finaliza con un llamado a la unidad y organización.

c. "La oferta y demanda II (El Curso de la Revolución)", Eduardo Leonetti. Fotocopia de los clasificados del Diario La Opinión, 1 de abril de 1973, en el que se encierra con una marcador azul un clasificado con el texto: "Peronismo y revolución. Análisis crítico de la ideología" y luego, los datos del lugar.

d. "Perón Vence", Luis Pazos, 1973. Fotografía de "escultura viviente", tomada desde arriba por Pazos en el patio del Colegio Nacional de La Plata. Se ve a un grupo de personas que con sus cuerpos forman el símbolo peronista formado por una $V$ y dentro de ella una $P$.

e. Fotocopia, Juan Carlos Romero. Reproducción de un collage formado por la fotografía de una manifestación de Montoneros en la que se ven algunas banderas con el texto: "José Sabino Navarro", "Montoneros", el símbolo de "Perón Vuelve". En la parte inferior de la fotografía se ha superpuesto un texto escrito a mano. La frase comienza con el nombre de Perón y finaliza con el nombre de Evita. La primera parte es un llamado a la política y la lucha, vinculando vida con lucha; la 
segunda, dice contra quiénes de debe pelear: la oligarquía, los explotadores y los mercaderes.

f. Poesía visual, Vigo. Consiste en el contorno de una botella que en su pico tiene una perforación circular. Dentro de la botella se encuentra impreso el siguiente texto: "El propio militante/compañero debe llenar con su sangre esta botella/bomba. Su activación constante hará desparecer el objeto para convertir su circulación sanguínea en detonante". Tiene un sello que dice: "Investigación de la realidad nacional".

g. “Texto $\mathrm{N}^{\circ}$ 1”, Zabala. Texto sobre el arte, lo poético, el producto artístico y sus relaciones con el público participante y las conciencias.

2. "Trelew", Juan Bercetche: una hoja negra con un cuadro blanco de doble entrada. El cuadro tiene cinco columnas en las que se inscriben los datos: "procedimiento tipo" (“fusilados", “electrocutados”, “ahorcados", “envenenados”, “decapitados”, "torturados"). En la siguiente columna, al lado de fusilados se encuentra el número dieciséis y al lado de fusilados, un tres, luego sexo, edad. La última columna es "observaciones": en la fila de "fusilados" dice "p/ intentar fuga" y en la de "torturados" dice “c/ vida (Internados)". Debajo aparecen los datos "actuó" y una firma, fecha "22/8/72" y número de tarjeta. Sobre la parte inferior se colocó un sello en color verde circular con la palabra "Trelew".

3. "Ernesto Che Guevara", Horacio Zabala, 1973. Fotocopia de un collage que cuenta con tres trozos de hojas rasgadas: en el superior, que conserva los agujeros de haber pertenecido a un cuaderno anillado, dice "Ernesto Che Guevara", en el medio, otro trozo que dice "Che Guevara" y en el inferior, dice "Che".

4. Trozo de afiche, Vigo. Un trozo de afiche recortado, aparentemente sobre una carrera de automóviles o motos, donde se ven letras y partes de palabras. Hay variaciones entre revistas del mismo número. Está sellado con el nombre de Vigo y el número de su casilla postal.

5. "Variante jurídica", Vigo, 1973. Subtítulo "Relación: Estado / Individuo". Debajo se ubica la fecha "1970 i 3". Al lado, el sello de Vigo con el número de casilla postal. Consta de dos columnas, en la izquierda dice "Ayer" y en la derecha, "Hoy". Debajo de la primera dice "Quita de libertad por hecho probado" y al lado, bajo la columna "Hoy", se lee "Quita de libertad por hecho supuesto". En la segunda fila, bajo la 
columna "Ayer" dice "Demostración de culpabilidad por el Estado", en "Hoy" dice "Demostración de inocencia por el individuo".

6. "La pirámide de la muerte", Carlos Ginzburg, proyecto presentado para la 8va. Bienal de París y “Tierra cúbica”, presentado para la Beca Guggenheim.

\section{$\mathrm{N}^{\circ} \mathrm{de}(\mathbf{1 0})$}

Portada: nuevo logo de la revista. El contenedor es una carpeta verde. Se encuentra en sello circular en tinta roja que dice "Trelew".

1. "Kitsch", Vigo. Adosado a la retiración de tapa, hay un sobre que tiene impresa la palabra "Kitsch". En su interior se encuentra una tarjeta con el sello de Vigo y una figurita infantil de colores con brillantina.

2. "Bando" de la revista Barrilete. Afiche doblado. Declaración en la que realiza una descripción de la situación política del momento y la necesidad que tienen los trabajadores de la cultura de incorporarse a las luchas contra la dominación y el colonialismo cultural. Por ello, declara reeditar la revista Barrilete e invitar a otras revistas literarias, así como a artistas y escritores a unirse en esas luchas.

3. "Poema matemático censurado", Vigo, 1974. Postal: de un lado, se encuentra una poesía visual con números y letras. En la parte superior derecha, un recuadro ocupa parte de la fórmula y se encuentra tachado con una cruz negra de mayor tamaño. En el anverso de la postal está escrito el título en español, francés e inglés, el año y debajo el sello de Vigo. En el medio dice "postal" y de manera longitudinal, "Edición Hexágono '71 - $\mathrm{N}^{\circ} 1$ / 1974”. En la mitad derecha de la postal se encuentran renglones.

4. "Revisado", Horacio Zabala. Hoja de periódico sellada.

5. “Argentina '74”, Vigo. Poesía visual. Afiche. En la parte superior hay un cuadro rojo dentro del cual se encuentra flecha que dobla hacia la izquierda tachada con una banda roja. Debajo de la flecha dice en letras mayúsculas negras "Argentina "74" y luego se encuentra el sello de Vigo.

6. Reproducción de parte del texto "Mitos, ritos y delitos en el país del silencio", OPS, Ed. Fundamentos, Madrid, 1973.

7. "Introducción a Arte de Sistemas en Latinoamérica", Jorge Glusberg, febrero de 1974, publicado en Bélgica en el mismo año. Texto en hoja membretada del CAYC. Ensayo sobre la relación entre el arte en América Latina y la situación política. Para liberarse debe destruir la dominación colonizadora y el "arte nuevo" es aquel que 
pretende alcanzar este objetivo a través de "estrategias de liberación" que provienen de lo político y social pero que se explicitan en lo cultural y artístico. Cuatro páginas. 8. Poesía visual, Luis Pazos. La palabra "Dependencia", en rojo, tiene sobreimpreso en negro, “Anulado". Debajo, "Liberación” en rojo y sobreimpresa la palabra "Urgente" en color negro.

\section{$\mathbf{N}^{\circ} d f(11)$}

Portada: sello que dice "Libres o muertos jamás esclavos".

1. Adosado en la retiración de tapa, un rectángulo de cartulina tiene el sello "Trelew", [Vigo].

2. “Acción de transplante de un agujero existente en el papel de cartón (1974)”, Vigo. Poesía visual - collage: hoja sobre la que se ha adosado un cuadrado de cartón con una perforación circular en el centro. Debajo dice "Acción de transplante de un agujero existente en el papel de cartón (1974)". En la parte inferior de la hoja, se encuentra el sello de Vigo.

3. "Frente y... dorso", Juan Carlos Romero y Eduardo Leonetti. Material de la muestra Nuestro tercer mundo. 1974. Fotocopia de recorte periodístico impresa de ambos lados con el título "Europa frente a las dos potencias. En medio de la presión mundial, los países del MCE intentan defender el estilo de vida que han creado" (Diario de Buenos Aires, 29/12/1973). Agregado en letras negras, "Frente y... dorso". 4. "Political ideology", Glusberg. Encuesta en inglés sobre la relación entre arte, ideología y política. Dos hojas.

5. Carta de Endre Tôt a Glusberg. "Carta-audio-visual”.

6. "América del Sur - Mapa político: Tension = Force/Area", Zabala. Fotocopia de collage sobre un mapa de esa parte del continente. Texto escrito con letras negras.

7. Telegrama de Amelia Toledo a Mario Pedrosa, CAYC. Texto: "Esbarrando mecanismos itinerante tacteio descomunicada emoçao"

8. "Lorcaesque", Michael Joseph Phillips. Poesía.

9. “Análisis sumario de la enfermedad del 'putsch' cuyos casos críticos son de lamentar (recuérdese: Alemania, 1933; Indonesia, 1965; Chile, 1973)", Guillermo Deisler, julio de 1974. Poesía visual, dibujo. Imágenes y texto sobre los golpes de estado.

10. "Monocensurex", Clemente Padín. "Productora Padín S en C/ 74 - 'Dedicado a H. Zabala"’. Imágenes y texto irónico sobre la censura. 
11. "Espejo", Vigo, 1972. Poesía visual. "Poema matemático".

12. "Little Nemo in Slumberland". Tira de historieta y síntesis histórica de la misma.

13. "Homage to Boredom contest number two". Convocatoria de arte-correo de Chuck Stake Enterprozes, Canadá.

\section{$\mathrm{N}^{\circ} \operatorname{dg}(\mathbf{1 2})$}

La carpeta tiene adosada sobre la tapa y contratapa una banda de papel que dice "autocensurada". Esta banda impide la apertura completa de la revista. Sobre parte de la banda y la tapa tiene cuatro perforaciones que abarcan ambas tapas e incluyen las hojas que contiene la revista.

1. "Contaminación o liberación”, “A los pueblos y gobiernos del mundo", Juan Carlos García Palou, Eduardo Leonetti, Juan Carlos Romero. Extracto de un documento de Perón presentado ante varios países sobre el cuidado ambiental y su vinculación con la justicia social, la soberanía, la independencia económica y la cooperación internacional. La hoja está perforada.

2. “Te deshacen y recomponen tu mente”, Vigo, 1974. Poesía visual. Xilografía. Imagen de partes de un cuerpo desordenadas y dentro de la cabeza dos cuadros con letras y números a la manera de una fórmula matemática. La hoja está perforada.

$\mathbf{N}^{\circ} \boldsymbol{e}(\mathbf{1 3})$

Carpeta marrón, sin indicación de pertenencia a la revista. Sello "Arte de y para investigación".

Hoja con logo "Hex 71 1975" formando un hexágono. Tiene un sello que dice "Sellado a mano". Sobre el logo y la letra $e$ que identifica al número, hay un cuadro con las letras del abecedario en su orden, números sucesivos y signos, así como imágenes de manos con el dedo índice señalando y una de ellas emergiendo de una trompeta.

1. "Sellado a mano", Vigo, La Plata, 1975. Ensayo sobre la utilización de sellos en el arte como "medio de comunicación común" y económico, accesible a los ingresos de los artistas. Permite despegarlo del uso administrativo e ironizar o ridiculizar emblemas o textos burocráticos. Opone la "internacionalización" del arte -hace referencia a la posición de Romero Brest- y la universalización, por la que brega. El texto está ilustrado por algunos sellos: el título está escrito en un sello, en la hoja 
siguiente se halla impreso un sello que dice "29 de mayo de 1969. Insurrección popular en Córdoba. 29 de mayo 'Día del Ejército Argentino"”, asimismo las hojas están numeradas con sellos y en el final se encuentra un sello con las letras $A B C$ y el año 1975. Seis páginas numeradas.

2. "Poesia non transferibile", Franco Vaccari, 1973. Sellos

3. "El medio es el mensaje", Carlos Ginzburg. Sellos sobre "el mensaje"

4. "Composite Message", Hernry Targowski. Sellos.

5. "Adolf Hitler Commemorative Stamp", Pauline Smith, 1975. Sellos

6. "End of an empire", Génesis Orridge. Sellos

7. "Censurado", Horacio Zabala. Sobre una página perteneciente a un libro de medicina, están impuestos los sellos: "Censurado", una cruz y el suyo personal. [Las páginas del libro varían en las diferentes revistas del mismo número].

8. Sello con paloma, Graciela Gutiérrez Marx.

9. "Try = Life”, Klaus Groh. Sellos

10. "Señale su paso por la historia”, Luis Iurcovich. Sobre una hoja impresa con renglones, se colocaron huella digital y un sello con la palabra "implicado".

11. "Venceremos", Roberto Rehfeldt. Sellos en negro y rojo.

12. "Anulada", Vigo. Sello circular que dice "Anulada" sobre el que se ha puesto otro en color negro con la frase "Anulé este hoja el día 1 de abril de 1975", debajo se encuentra un sello con los datos de Vigo. 


\section{ARCHIVO DEL CENTRO DE ARTE EXPERIMENTAL VIGO}

En la producción de datos para la tesis se ha recurrido fundamentalmente a la información contenida en el archivo que dejó Vigo y que hoy forma el Archivo del Centro de Arte Experimental Vigo (CAEV), de la Fundación Artes Visuales.

Para el relevamiento de la información se realizó un detallado estudio de cada una de las cajas que incluyen nuestro período de estudio, así como uno menos exhaustivo para los años anteriores y posteriores. Además de las notas y selección de segmentos significativos, se recurrió en algunos casos a la técnica de la digitalización para retener imágenes en alta calidad que permitieran recurrir a ellas con mayor comodidad y evitar la manipulación de los originales.

Además del trabajo individual sobre la digitalización de los documentos, he considerado la importancia de realizar un aporte al desarrollo de la institución que cuenta con dicho fondo, por lo que elaboré y actualmente dirijo un proyecto de mejora en la accesibilidad pública, el servicio y la difusión de la serie Archivo Personal Edgardo Antonio Vigo con un subsidio de Harvard University - David Rockefeller Center for Latin American Studies a la Fundación Artes Visuales - Centro de Arte Experimental Vigo. El proyecto fue aprobado por el Program for Latin American Libraries and Archives (PLALA) y puede considerarse, en algún modo, un resultado de la tesis, una extensión de sus productividades fuera del ámbito académico y en vinculación directa con la sociedad. Dicho proyecto involucra, someramente, la digitalización completa de la Serie Archivo Personal de Edgardo Antonio Vigo con escáneres especialmente adquiridos para esta actividad, generación de un archivo con las imágenes en alta calidad para acceso público en la institución, producción de un catálogo virtual de imágenes para difusión de la serie completa a través de la WEB y elaboración de un catálogo descriptivo archivístico a nivel de serie que mejore el acceso a la información, permita la difusión y funcione como ayuda de búsqueda para investigadores.

En relación con dicho proyecto, realicé junto al equipo del CAEV una caracterización del Archivo del Centro de Arte Experimental Vigo siguiendo las normas internacionales $I S A D(G)$. Si bien el equipo del CAEV había producido algunos datos, no se contaba con una descripción de este tipo, por lo cual consideré relevante elaborarla a partir del trabajo de investigación que realicé para esta tesis en dicho archivo. 
Para esta tarea colaboraron la Museóloga Mariana Santamaría y la Arq. Ana María Gualtieri, del equipo de dicho centro.

Nombre del Archivo: Centro de Arte Experimental Vigo (CAEV)

Dirección: Calle 15 n 1187 (1900) La Plata, Buenos Aires, Argentina.

Nombre del Director: Arquitecta Ana María Gualtieri. Presidente del Consejo de Administración de la Fundación Centro de Artes Visuales de La Plata. Directora General del Centro de Arte Experimental Vigo.

\section{A. ARCHIVO}

El Centro de Arte Experimental Vigo (CAEV) es una pequeña institución dedicada a preservar y difundir la obra del artista Edgardo Antonio Vigo. El fondo documental del Centro cuenta con tres áreas: Biblioteca, Hemeroteca y Archivo.

- La Biblioteca cuenta con 2.500 volúmenes, todos ellos pertenecientes a EAV y consiste en una biblioteca especializada en artes plásticas contemporáneas, poesía visual y arte-correo.

- La Hemeroteca posee colecciones de revistas de arte de EAV que datan desde 1951 hasta fines de la década del 90. Esta incluye números de difícil acceso en otros puntos del país y del mundo. Actualmente personal bibliotecario se encuentra organizando y preparando un índice temático de su contenido.

- El Archivo contiene un fondo documental producido a lo largo de la vida de EAV.

El Archivo se clasifica en series:

Serie Documentos personales de EAV.

Serie de Exposiciones organizadas por EAV.

Serie Arte Correo.

Serie obra artística (objetos, xilografía, poesía visual, arte-correo).

Serie Fotografías, diapositivas y videos.

Serie Publicaciones (revistas experimentales, libros de estampillas, cajas de poesía visual).

Serie documentos, obras y publicaciones de otros artistas.

Sub fondo: Museo de la Xilografía. 
Esta descripción se centrará en la Serie Documentos personales de Edgardo Antonio Vigo. El propio Vigo desde los comienzos de su carrera como artista se dedicó a registrar de forma documental todos sus pasos: recortes periodísticos sobre exposiciones, reportajes, ensayos escritos por él mismo, críticas y comentarios a sus obras, catálogos, invitaciones, actuaciones como jurado, comunicaciones vía postal, fotografías, grabados, pruebas, diseños. Estos documentos se encuentran hoy en las cajas que él mismo procuró y en el orden en que se dispusieron originalmente.

Esta serie posee un valor incalculable, dado que se poseen ejemplares únicos de documentos y trabajos de Edgardo Antonio Vigo, así como de otros artistas de Argentina y del mundo, entre ellos: Julien Blaine, Paulo Brusky, Horacio Zabala, Carlos Ginzburg, Jochen Herz, Luigi Ferro, Fernando Millan, Juan Carlos Romero, Luis Benedit, Clemente Padin, Klaus Groh, etc.

\section{B. DESCRIPCIÓN TÉCNICA:}

A continuación se realiza la descripción técnica únicamente de la Serie Documental "Documentos personales de EAV" ("Cajas Biopsia").

\section{1. Área de identificación:}

Fondo: Archivo Edgardo Antonio Vigo

Serie: Documentos personales de EAV

Fechas extremas: 1953 - 1997

Nivel de descripción: Serie

Volumen: 37 cajas que contienen hojas sueltas.

Soporte: papel, cartulina, cartón.

CAJA 1 (1953 - 1957): Caja de madera artesanal. Medidas: 36,5 x 31,5 x 8,5 cm. Contiene 110 hojas de cartulina de 33 x 27,8 con dibujos, grabados, témperas, collages, textos, publicaciones personales y bocetos.

CAJA 2 (1958): Caja artesanal de madera. Medidas: 30,1 x 34,6 x 8,4. Contiene 113 hojas de 32,8 x 27,7 de cartulina con trabajos en tinta, textos, colaboraciones en publicaciones, fotos, artículos periodísticos, revista $W C$, obra original. 
CAJA 3 (1959): Caja artesanal de madera. Medidas: 40,8 x 30 x 6,8. Contiene 117 páginas de cartulina de 28 x 37,5 con artículos periodísticos, bocetos, fotografías, entrevistas.

CAJA 4 (1960): Caja artesanal de madera. Medidas: 40,8 x 30 x 6,8. Contiene 76 páginas de cartulina con dibujos a tinta, collages, cartas a embajadas y bibliotecas, revistas $D R K W^{\prime} 60$.

CAJA 5 (1955-57): Caja de cartón. Medidas: 24,5 x 27. Contiene 72 páginas de cartulina con fotografías, escritos a mano, manifiestos, dibujos y collages.

CAJA 6 (1961-1965): Medida: 26,5 x 32,5 x 5. Contiene aprox. 76 páginas sueltas de cartulina sin numerar con documentación de ambos lados.

CAJA 7 (1966/67): Medida: 25,5 x 32,5 x 8. Contiene aprox. 130 páginas sueltas de cartulina sin numerar con documentación de ambos lados.

CAJA 8 (1968): Medida: 27 x 29,5 x75. Contiene aprox. 107 páginas sueltas de cartulina sin numerar con documentación de ambos lados.

CAJA 9 (1969): Medida: 27 x 29,5 x 7. Contiene aprox. 100 páginas sueltas de cartulina sin numerar con documentación de ambos lados.

CAJA 10 (1970): Medida: 27 x 30 x 5. Contiene aprox. 70 páginas sueltas de cartulina sin numerar con documentación de ambos lados.

CAJA 11 (1971): Medida: 27 x 30 x6, 5. Contiene aprox. 90 páginas sueltas de cartulina sin numerar con documentación de ambos lados.

CAJA 12 (1972): Medida: 27,5 x 30 x 5. Contiene aprox. 50 páginas sueltas de cartulina sin numerar con documentación de ambos lados.

CAJA 13 (1973): Medida: 27 x 29,5 x 7. Contiene aprox. 100 páginas sueltas de cartulina sin numerar con documentación de ambos lados.

CAJA 14-15 (1974): Medida: 27 x 30 x5. Contiene aprox. 86 páginas sueltas (cada caja)de cartulina sin numerar con documentación de ambos lados.

CAJA 16-17 (1975): Medida: 27 x 30 x 5. Contiene aprox. 80 páginas sueltas de cartulina (cada caja) sin numerar con documentación de ambos lados.

CAJA 18 (1976): Medida: 27 x 30 x 5,5. Contiene aprox. 120 páginas sueltas de cartulina sin numerar con documentación de ambos lados.

CAJA 19 (1977/78): Medida: 27 x 30 x 5,5. Contiene aprox. 120 páginas sueltas de cartulina sin numerar con documentación de ambos lados.

CAJA 20 (1979): Medida: 27 x 30 x 6. Contiene aprox. 90 páginas sueltas de cartulina sin numerar con documentación de ambos lados. 
CAJA 21 (1980): Medida: 26,5 x 30 x 8. Contiene aprox. 120 páginas sueltas de cartulina sin numerar con documentación de ambos lados.

CAJA 22 (1981): Medida: 27 x 30 x 6. Contiene aprox. 100 páginas sueltas de cartulina sin numerar con documentación de ambos lados.

CAJA 23 (1982): Medida: 26,5 x 30 x 7. Contiene aprox. 110 páginas sueltas de cartulina sin numerar con documentación de ambos lados.

CAJA 24 (1983): Medida: 26 x 28,5 x 10. Contiene aprox. 180 páginas sueltas de cartulina sin numerar con documentación de ambos lados.

CAJA 25 (1984): Medida: 26 x 28,5 x 4,5. Contiene aprox. 60 páginas sueltas de cartulina sin numerar con documentación de ambos lados.

CAJA 26 (1985): Medida: 26 x 28,5 x 8,5. Contiene aprox. 120 páginas sueltas de cartulina sin numerar con documentación de ambos lados.

CAJA 27 (1986): Medida: 26 x 28 x 8. Contiene aprox. 120 páginas sueltas de cartulina sin numerar con documentación de ambos lados.

CAJA 28 (1987): Medida: 26 x 28 x 6,5. Contiene aprox. 100 páginas sueltas de cartulina sin numerar con documentación de ambos lados.

CAJA 29 (1988-89): Medida: 26 x 28 x 9,5. Contiene aprox. 150 páginas sueltas de cartulina sin numerar con documentación de ambos lados.

CAJA 30 (1990): Medida: 26 x 29 x 9,5. Contiene aprox. 160 páginas sueltas de cartulina sin numerar con documentación de ambos lados.

CAJA 31 (1991): Medida: 26 x 28,5 x 9. Contiene aprox. 160 páginas sueltas de cartulina sin numerar con documentación de ambos lados.

CAJA 32 (1992): Medida: 26 x 29 x 10,5. Contiene aprox. 190 páginas sueltas de cartulina sin numerar con documentación de ambos lados.

CAJA 33 (1993): Medida: 25 x 28 x 7,5. Contiene aprox. 90 páginas sueltas de cartulina sin numerar con documentación de ambos lados.

CAJA 34 (1994): Medida: 25,5 x 29 x 7,5. Contiene aprox. 90 páginas sueltas de cartulina sin numerar con documentación de ambos lados.

CAJA 35 (1995): Medida: 26 x 29 x 11. Contiene aprox. 190 páginas sueltas de cartulina sin numerar con documentación de ambos lados.

CAJA 36 (1996): Medida: 26 x 28 x 7. Contiene aprox. 90 páginas sueltas de cartulina sin numerar con documentación de ambos lados.

CAJA 37 (1997): Medida: 26 x 29 x 12,5. Contiene aprox. 250 páginas sueltas de cartulina sin numerar con documentación de ambos lados. 
Las cajas 6 a la 37 fueron denominadas por Vigo bajo el título "Biopsia". Todas estas cajas son de cartón corrugado y contienen páginas sueltas con detalles de la actividad del artista año por año.

\section{2. Área de Contenido:}

Productor: Edgardo Antonio Vigo (1928 - 1997)

Biografía: ver aparte

\section{3. Área de contenido y estructura:}

Esta serie está compuesta por los siguientes tipos documentales:

Manuscritos, catálogos, folletos, afiches e invitaciones y convocatorias a exposiciones nacionales e internacionales de grabado, arte conceptual, poesía visual y arte-correo; dibujos y grabados originales; fotografías; artículos periodísticos; cartas e invitaciones a bienales; entrevistas, textos y otros documentos.

La el soporte principal es el papel y el cartón; el conjunto contiene documentos desde fines de la década del '50 y décadas del '60, '70, '80 y '90.

Valoración, selección y eliminación: No se realizan.

Nuevos ingresos: No están previstos dado que se trata de un fondo cerrado. Aunque el Centro de Arte Experimental Vigo recibe en guarda los mismos tipos documentales complementando el fondo documental original.

Organización: La ordenación de la unidad de descripción está organizada cronológicamente por años (1953 a 1997).

\section{4. Área de condiciones de acceso y utilización:}

Acceso irrestricto, utilización libre.

Condiciones de reproducción: Condición de citar a la fuente de la información. Los derechos de la reproducción de imágenes o textos son reservados y exclusivos del CAEV.

Lengua/escrituras de los documentos: Español, también hay documentos en francés, italiano, inglés, alemán y portugués, checo y japonés. 
Características físicas y requisitos técnicos: Los materiales solo se pueden consultar en la Institución. Una vez finalizado el proyecto se podrá consultar la serie completa en formal digital a través de la WEB de la institución y de la Facultad de Humanidades y Ciencias de la Educación (proyecto ARCAS).

Instrumentos de descripción: Se carecen. Se producirán en el transcurso del proyecto.

\section{5. Área de documentación asociada:}

Existencia y localización de documentos originales: Colección Jorge Helft y Marion Helft, Fundación Espigas, Museo de Arte Moderno de Buenos Aires, Museo Nacional de Bellas Artes de Buenos Aires, Museo Arte Contemporáneo Barcelona, MOMA Museum of Modern Art de Nueva York, Colección Sackner (EEUU): estas instituciones solo poseen algunas obras y ediciones. Muchas de estas fueron entregadas como donaciones desde el CAEV. 


\section{BIBLIOGRAFÍA}

\section{A. BIBLIOGRAFÍA TEÓRICA Y GENERAL}

Achugar, H. (1991). "La política de los estético”. Nueva Sociedad, 116: 122-129.

Adorno, T. (2003). Beethoven. Filosofía de la música. Barcelona :Akal.

Adorno, T. (2005). Teoría estética. Madrid: Akal.

Alfaro Jiménez, V. Glosario de términos de derecho civil. México: Universidad Nacional Autónoma de México. Disponible en http://www.paginaspersonales.unam.mx/files/358/GLOSARIO_DE_DERECHO_CIVIL .pdf [acceso 22/07/12].

Alonso, L. (1998). La mirada cualitativa en sociología. Madrid: Fundamentos.

Allen, G. (2011). Artists’ Magazines. An Alternative Space of Art. Cambridge: MIT Press.

Aznar Almazán, Y e Iñigo Clavo, M. (2007). “Arte, política y activismo”. Concinnitas, v. $8,1(10)$.

Badiou A. (1998). "Conferencia sobre El ser y el acontecimiento y el Manifiesto por la filosofía”. Revista Acontecimiento, VIII, 15, pp. 21 - 49.

Badiou, A. (2000a). El ser y el acontecimiento.

Badiou, A. (2000b). "Movimiento Social y Representación Política". Buenos Aires: Instituto de Estudios y Formación de CTA. Disponible en http://www.grupoacontecimiento.com.ar/documentos/documentos.htm [acceso 6/10/11]

Badiou, A. (2004). "Ser, acontecimiento, verdad, sujeto”. La ética. México: Herder.

Badiou, A. (2007). "Destruction, negation, subtraction - on Pier Paolo Pasolini". Graduate Seminar - Art Center College of Design in Pasadena - February 62007. Disponible en http://www.lacan.com/badpas.htm [acceso 20/12/2010]

Badiou, A. (2009a). El siglo. Buenos Aires: Manantial.

Badiou, A. (2009b). Pequeño manual de inestética. Buenos Aires: Prometeo.

Bajtín, M. (2002). "El problema de los géneros discursivos". Estética de la creación verbal. Buenos Aires: Siglo XXI Editores.

Barthes, R. (1987). “La muerte del autor”. El susurro del lenguaje. Barcelona: Paidós.

Benjamin, W. (1989). Discursos interrumpidos. Buenos Aires: Taurus.

Benjamin, W. (1989). "La obra de arte en la época de su reproductibilidad técnica".

Discursos interrumpidos I. Buenos Aires: Taurus.

Benjamin, W. (1990). El origen del drama barroco alemán. Madrid: Taurus. 
Berardi, F. (2012). "Emancipation of the Sign: Poetry and Finance During the Twentieth Century". E-flux journal, 39.

Bokina, J. (1991). “The Politics of Art: An introduction”. International Political Science Review, 12 (1): 3-4.

Bourdieu, P. (1971). "Elementos de una teoría sociológica de la percepción artística". En A. Silbermann y otros. Sociología del arte. Buenos Aires: Nueva Visión.

Bourdieu, P. (1983). Campo del poder y campo intelectual. Buenos Aires: Folios.

Bourdieu, P. (1990). Sociología y cultura. México: Grijalbo.

Bourdieu, P. (1995). "La objetivación del sujeto objetivante". P. Bourdieu y Loïc J. D. Wacquant. Respuestas. Por una antropología reflexiva. México: Grijalbo.

Bourdieu, P. (2005). Las reglas del arte. Barcelona: Anagrama.

Buchloh, B. (1990). "Conceptual Art 1962-1969: From the Aesthetic of Administration to the Critique of Institutions". October, 55: 105-143.

Bürger, P. (2010). Teoría de la vanguardia. Buenos Aires: Las cuarenta.

Carrió, G. (1973). Sobre los límites del lenguaje normativo. Buenos Aires: Astrea.

Carrió, G. (1979) Notas sobre derecho y lenguaje. Buenos Aires: Abeledo-Perrot.

Cossio, C. (1947). La plenitud del ordenamiento jurídico. Buenos Aires: Editorial Losada.

Couture, E. (1954). El concepto de fe pública. Montevideo: Universidad de Montevideo.

Cucatto, M. (2011). "Algunas reflexiones sobre lenguaje jurídico como lenguaje de especialidad: más expresión que verdadera comunicación”. Revista virtual intercambios, 15. Disponible en http://intercambios.jursoc.unlp.edu.ar/ [acceso 10/10/2012].

Dalmaroni, M. (2004). "Conflictos culturales: notas para leer a Raymond Williams". Punto de vista, XXVII (79).

Dalmaroni, M. (2009). "Lo que resta (un montaje)", en Miguel Dalmaroni y Geraldine Rogers (editores). Contratiempos de la memoria en la literatura argentina. La Plata: EDULP.

Dalmaroni, M. (2011). "Violencia (un paso errático entre algunos libros)". Jorge Monteleone (Ed.), La Argentina como narración, Buenos Aires: Fondo Nacional de las Artes.

de Certeau, M. (2007). La invención de lo cotidiano. I. Artes de hacer. México: Universidad Iberoamericana.

Del Río, V. (2006). "El concepto de neovanguardia en el origen de las teorías del arte postmoderno". En D. Hernández Sánchez et alia. Octavas falsas. Materiales de arte y estética 2. Salamanca: Luso-Española de Ediciones. 
De la Fuente, E. (2000). "Sociology and Aesthetics". European Journal of Social Theory, 3 (2): 235 - 247.

De la Fuente, E. (2007). "The 'New Sociology of Art': Putting Art Back into Social Science Approaches to the Arts". Cultural Sociology, 1 (3): 409 - 425.

Derrida, J. (1998). "Firma, acontecimiento, contexto". En J. Derrida. Márgenes de la filosofía. Madrid: Cátedra.

Didi-Huberman, G. (2006). Ante el tiempo. Buenos Aires: Adriana Hidalgo.

Erlich, V. (1974). El formalismo ruso. Historia y doctrina. Barcelona: Seix barral.

Etxebarría Arostegui, M. (1997). "El lenguaje jurídico-administrativo. Propuestas para su modernización y normalización”. Revista Española de Lingüística, 27 (2), pp. 341 380.

Fernández de Buján, A. (2001). "Fides publica e instrumenta publice confecta en Derecho Romano". Revista de estudios latinos: RELat, No. 1, 2001, pp. 189-202

Fischer, H. (1974). Art et comunication marginale. Tampons d'artistes. Paris: Balland.

Freire, C. y Longoni, A. (orgs.) (2009). Conceptualismos del Sur/Sul, São Paulo: Annablume.

Foster, H. (2003). "Recodificaciones: hacia una noción de lo político en el arte contemporáneo". En Blanco, P., J. Carrillo, J. Claramonte y M. Expósito (Eds.). Modos de hacer. Arte crítico, esfera pública y acción directa. Salamanca: Universidad de Salamanca.

Foster, H. (2001). “¿Quién teme a la neovanguardia?”. En: El retorno de lo real. La vanguardia a finales de siglo, Madrid: Akal.

Foucault, M. (2000). Qué es un autor. ElSeminario.com.ar. Disponible en http://www.elseminario.com.ar/ [Acceso 25/07/2010].

Foucault, M. (2008). La verdad y las formas jurídicas. Buenos Aires: Gedisa [1978]

Foucault, M. (2012). El orden de discurso. Buenos Aires: Tusquets [1970]

García Canclini, N. (1977). Arte popular y sociedad en América Latina. Teorías estéticas y ensayos de transformación. México DF: Grijalbo.

García Canclini, N. (1979). La producción simbólica. Teoría y método en sociología del arte. México: Siglo XXI.

Geertz, C. (1992). "Descripción densa: hacia una teoría interpretativa de la cultura". La interpretación de las culturas. Barcelona: Gedisa, 19-40.

Giordano, A. (2001). Manuel Puig. La conversación infinita. Buenos Aires: Beatriz Viterbo.

Gómez Aguilera, F. (2004) "Arte, ciudadanía y espacio público". On the waterfront. Universitat de Barcelona, $\mathrm{n}^{\circ}$ 5, marzo de 2004. 
Guibourg, R, Ghigliani, A y Guarinoni, R. (1984) Introducción al conocimiento jurídico. Buenos Aires: Astrea.

Habermas, J. (1988). "La modernidad, un proyecto incompleto". En H. Foster (Ed.). La posmodernidad. México, Kairós.

Heinich, N. (2010). La sociología del arte. Buenos Aires: Nueva Visión.

Iregui, J. (2008) “Los espacios del espacio público”, Revista Zehar. Arteleku. № 62. Disponible en www.arteleku.net

Kelsen, H. (1974). Teoría Pura del derecho, Buenos Aires: Eudeba.

Lefebvre, H. (1974) “La producción del espacio”, Papers Revista de Sociología, n 3.

Lefebvre, H. (1976). "Reflections on the politics of space", Antipode, 8 (2).

Lefebvre, H. (1991). 1974, The production of space. Oxford: Blackwell.

Lukes, T. (1991). "Prepositional Phases: The Political Effects of Art on Audience". International Political Science Review, 12 (1): 67 - 86.

MacDonald, K. y Tipton, C. (1996). "Using documents". Researching Social Life. N. Gilbert (ed.) London: Sage.

Marcuse, H. (1978). La dimensión estética. Barcelona: Materiales.

Margulis, M. (2001) "La ciudad y sus signos", Revista Sociedad, n 19 , diciembre de 2001.

Marrero Guillamón, I. (2008) "La producción del espacio público", (con)textos. Revista D’Antropología i Investigació social, $\mathrm{n}^{\circ} 1$.

Núñez, A. (2009) "De la alienación, al derecho a la ciudad. Una lectura (posible) sobre Henri Lefebvre". Revista Theomai. Estudios sobre sociedad y desarrollo, $\mathrm{n}^{\circ} 20$, segundo semestre de 2009.

Milner, A. (2010). "It's the Conscience Collective, Stupid: Philosophical Aesthetics and the Sociology of Art". Thesis Eleven, 103(1): 26-34.

Montolío, E. y López Samaniego, A. (2008). "La escritura en el quehacer judicial. Estado de la cuestión y presentación de la propuesta aplicada en la Escuela Judicial de España”. Revista signos, 41 (16), pp. 33 - 64.

Muñoz, M. A. (2006). "Laclau y Rancière: algunas coordenadas para la lectura de lo político”. Andamios, 2 (4), 119-144.

Negash, G. (2004). “Art Invoked: A Mode of Undestanding and Shaping the Political”. International Political Science Review, 25 (2): 185 - 201.

Oslender, U. (2002) "Espacio, lugar y movimientos sociales: hacia una 'espacialidad de resistencia'". Scripta Nova. Revista electrónica de Geografía y Ciencias Sociales, vol. VI, ${ }^{\circ} 115$. 
Parcerisas, P. (2007) "Arte y contexto. Hacia una redefinición del espacio público y el arte político”. En: Ramón Parramón (dir.) Arte, experiencias y territorios en proceso. Calaf: Idensitat, Associació d'Art Contemporani.

Parramón, R. (2003) “Arte, participación y espacio público”, Jornada d'innovació estratégica. Models de participació en xarxa. Disponible en www.vegga.org [acceso 02/09/2009]

Parramón, R. (2007) “Arte, experiencias y territorios en proceso”. En: Ramón Parramón (dir.) Arte, experiencias y territorios en proceso. Calaf: Idensitat, Associació d'Art Contemporani.

Phillips, J. (2010). “Art, Politics and Philosophy: Alain Badiou and Jacques Rancière”. Theory Culture Society, 27 (4): 146 - 160.

Pollak, M. y Heinch, N. (2006). "El testimonio", en Michael Pollak, Memoria, silencio y olvido, La Plata: Al Margen.

Rabotnikof, N. (1995) "El espacio público: variaciones en torno a un concepto" en Rabotnikof, N., Velasco, A., e Yturbe, C. La tenacidad de la política, IIF-UNAM, México.

Rabotnikof, N. (2005) En busca de un lugar común. El espacio público en la teoría política contemporánea. Instituto de Investigaciones filosóficas, Universidad Autónoma Nacional de México, México.

Rancière, J. (2000). "Política, identificación y subjetivación”. En: Benjamin Artidi (ed.) El reverso de la diferencia: identidad y política. Caracas: Nueva Sociedad, pp. 145 152.

Rancière, J. (2002a). La división de lo sensible. Estética y Política. Salamanca: Consorcio Salamanca. Disponible en http://mesetas.net/?q=node/5 (acceso 28/11/ 2007)

Rancière, J. (2002b). "La revolución estética y sus resultados". New Left Review, 14, pp. $118-134$.

Rancière, J. (2005). Sobre políticas estéticas. Barcelona: Museu d'Art Contemporani de Barcelona.

Rancière, J. (2006a). "El uso de las distinciones". Failles, 2. Disponible en http://mesetas.net/?q=node/19 [accceso 01/08/2008]

Rancière, J. (2006b). "La política de la estética". Otra Parte, 9, pp. 1 - 15.

Rancière, J. (2007a). El desacuerdo. Política y filosofía. Buenos Aires: Nueva Visión.

Rancière, J. (2007b). "Estética y política: las paradojas del arte político". Arte y política. Argentina, Brasil, Chile y España. Universidad Complutense de Madrid. Disponible en http://www.ucm.es/info/artepltk/textos.html [acceso 15/05/2008]. También en José Larrañaga Altuna y Aurora Fernández Polanco. Las imágenes del arte, todavía. Cuenca: Diputación Provincial de Cuenca.

Ranciére, J. (2007c) Politique de la littérature. Paris: Galilée. 
Rancière, J. (2008). "Aesthetic Separation, Aesthetic Community: Scenes from the Aesthetic Regime of Art". Art\&Research. A Journal of Ideas, Contexts and Methods, 2 (1): $1-15$.

Rancière, J. (2010). El espectador emancipado. Buenos Aires: Manantial.

Red Conceptualismos del Sur (2009). "Declaración instituyente Red Conceptualismos del Sur". En

http://conceptual.inexistente.net/index.php?option=com_content\&view=article\&id=56:d eclaracion [acceso 10/08/2010].

Richard, N. (1990) "Neovanguardia y postvanguardia: el filo de la Sospecha". En Ana María De Morales Belluzzo (ed.) Modemidade: Vanguardias Artisticas na America Latina. Fundação Memorial da América Latina: São Paulo.

Richard, N. (2005). “'Arte y política'; lo político en el arte.” En Pablo Oyarzún, Nelly Richard y Claudia Zaldívar (Eds.)..Arte y Política. Santiago de Chile: Consejo Nacional de la Cultura y las Artes y Universidad Arcis.

Rolnik, S. (2010). "Furor de archivo". Estudios visuales, 7, pp. 116-130.

Ross, A. (1977) Sobre el derecho y la justicia. Buenos Aires: Edudeba.

Santos, M. (2000). La naturaleza del espacio. Barcelona: Ariel Geografía.

Schmitt, C. (1999). El concepto de lo político. Madrid: Alianza Editorial.

Sevilla Muñoz, M y Sevilla Muñoz, J. (2003). "Una clasificación del texto científicotécnico desde un enfoque multidireccional". Language Design, 5, pp. 19 - 38.

Shklovski, V. (2004). "El arte como artificio". Todorov, T. (ed.). Teoría de la literatura de los formalistas rusos. Buenos Aires: Siglo XXI.

Soler, S. (1969) Las palabras de la ley. México: Fondo de cultura económica.

Suárez Guerrini, F. (2010). "A la deriva del arte moderno. Una lectura sobre la irrupción del MAN y sus repercusiones”. Boletín de arte, 11 (12).

Taylor S. J. y Bogdan, R. (1986). Introducción a los métodos cualitativos de investigación. Buenos Aires: Paidós.

Valles, M. (1997). Técnicas cualitativas de investigación social. Reflexión metodológica y práctica profesional. Madrid: Síntesis.

Vattimo, G. (1993). Poesía y ontología. Valencia: Universitat de València.

Vázquez Romero, A. (2009). "Los aportes de Henri Lefebvre a la Geografía urbana. Un corpus Teórico para entender las nuevas espacialidades". $12^{\circ}$ Encuentro de Geógrafos de América Latina, Montevideo, Uruguay.

Vernengo, R. (1996). "El discurso jurídico y el lenguaje normativo”. Isonomía, 6, pp. 87 -95 .

Weber, M. (2000). “La política como profesión”. En Ciencia y política. Elaleph.com. Disponible en www.elaleph.com [acceso 01/04/2011] 
Wilson, S. y Lack, J. (2008). The Tate Guide to Modern Art Terms. Londres: Tate Publishing.

Williams, R. (2009). Marxismo y literatura. Buenos Aires: Las cuarenta.

Williams, R. (1982). Cultura. Sociología de la comunicación y del arte. Barcelona: Paidós.

Williams, R. (2001). El campo y la ciudad. Buenos Aires: Paidós Ibérica.

Williams, R. (2002). La política del modernismo. Contra los nuevos conformistas. Buenos Aires: Manantial.

Williams, R. (2003). La larga revolución. Buenos Aires: Nueva Visión.

Wolin, R. (1994). Walter Benjamin, an aesthetic of redemption. California: University of Californa Press.

Wright, G. von (1979) Norma y acción. Una investigación lógica. Madrid: Tecnos.

Zangwill, N. (2002). "Against the Sociology of Art". Philosophy of the Social Sciences, 32 (2): $206-218$.

\section{B. BIBLIOGRAFÍA HISTÓRICA Y CRÍTICA:}

Ades, D. Arte en Iberoamérica. Madrid: Ed. Turner, 1990.

Alonso, R. (1999) “En torno a la acción”. En: Arte de acción (cat. exp.). Buenos Aires: Museo de Arte Moderno.

Alonso, R. (Ed.). (2010). Imán: Nueva York. Arte argentino de los años 60. Buenos Aires: Fundación Proa.

Altamirano, C. (2001). Bajo el signo de las masas (1943 - 1973). Buenos Aires: Ariel.

Brett, G. "Un salto radical”. En Ades, Dawn. Arte en Iberoamérica. Madrid: Ed. Turner, 1990.

Bugnone, A. (2012). "Poesía descentrada en los sesenta: el Grupo de los elefantes". Boletín de arte, 13.

Campal, J. L. (2001). "Una ojeada a las revistas ensambladas”. Edita 2001. VIII

Encuentro Internacional de Editores Independientes y Ediciones Alternativas. 30 de abril, Punta Umbría. Disponible en http://www.merzmail.net/campalrevista.htm (10 - 42013)

Casullo, N. (2004). Pensar entre épocas. Memoria, sujetos y crítica intelectual. Buenos Aires: Norma.

Cavarozzi, M. (2004). Autoritarismo y democracia. Buenos Aires: Eudeba.

Cervantes, B. (2000). "Happening: La acción efímera como actividad artística". DC Papers, revista de crítica y teoría de la arquitectura, 4, p. 104-113. 
Davis, F. (2005). "Proyectos, estrategias y debates en la difusión del grabado argentino. Hacia un "arte para todos" (1960-1973)". IX Jornadas Nacionales de Investigadores en Comunicación, Villa María. Disponible http://www.redcomunicacion.org/memorias/pdf/2005dadavisii.pdf [acceso 10/03/2008].

De Riz, L. (2000). La política en suspenso. 1966- 1976. Buenos Aires: Paidós.

DeRoo, R. (2006). The Museum Establishment and Contemporary Art: The Politics of Artistic Display in France after 1968. New York: Cambridge University Press.

Dolinko, S. (2004). "Cronología". En Mercedes Casanegra (Coord.). Entre el silencio y la violencia. Arte contemporáneo argentino. Buenos Aires: Espacio Fundación Telefónica.

Fantoni, G. (1994). Tres visiones sobre el arte crítico de los años sesenta. Conversaciones con Pablo Suárez, Roberto Jacoby y Margarita Paksa, Rosario: Escuela Editora/ UNR.

Fantoni, G. (1998). Arte, vanguardia y política en los años sesenta. Conversaciones con Juan Pablo Renzi. Buenos Aires: El Cielo por Asalto.

Fundación Proa (2001). Sol LeWitt. Wall Drawings. Making of. Textos e imágenes de la exposición. Disponible en:

http://www.proa.org/exhibiciones/pasadas/lewitt/exhibicion_fr.html [acceso $18 / 06 / 2013]$

Funes, P. (2007a). “Ingenieros del alma. Los informes de los Servicios de Inteligencia de la dictadura militar argentina sobre América Latina: canción popular, ensayo y ciencias sociales", Varia Historia, 23 (38): 418438.

Funes, P. (2007b). "Los libros y la noche. Censura, cultura y represión en Argentina a través de los servicios de inteligencia del Estado". Dimensões, 19: 133-155.

Gilman, C. (2003). Entre la pluma y el fusil. Debate y dilema del escritor revolucionario en América Latina. Buenos Aires: Siglo Veintiuno.

Giunta, A. (1994a). "Arte y (re)presión: Cultura crítica y prácticas conceptuales en Argentina”. En G. Curiel Méndez, R. González Mello y J. Gutiérrez Haces (Coords.). Arte, historia e identidad en América Latina: Visiones comparativas. México: Instituto de Investigaciones Estéticas, UNAM.

Giunta, A. (1994b). "Utopía y disolución: Arte crítico en la década del sesenta". Artes Plásticas na América Latina Contemporánea. Maria Amélia Bulhoes y Maria Lúcia Bastos Kern, orgs. Porto Alegre: Editora da Universidade Federal do Rio Grande do Sul.

Giunta, A. (1995). "Destrucción-creación en la vanguardia artística del sesenta: entre Arte Destructivo y 'Ezeiza es Trelew”'. VV.AA. Arte y violencia, México: Instituto de Investigaciones Estéticas-UNAM.

Giunta, A. (1997). "La política del montaje: León Ferrari y La civilización occidental y cristiana". Oteiza, E. (coord.). Cultura y política en los años sesenta. Buenos Aires: Universidad de Buenos Aires. 
Giunta, A. (1999). “Cuerpos de la historia: Vanguardia, política y violencia en el arte argentino contemporáneo”. En M. C. Ramírez (Ed.). Cantos paralelos. La parodia plástica en el arte argentino contemporáneo. Austin: Jack Blanton Museum of Art The University of Texas at Austin - Fondo Nacional de las Artes.

Giunta, A. (2004). "Vanguardias y arte contemporáneo". En Farina, F; Echen, R. y Rojas, N. (Eds.). Arte Argentino Contemporáneo. Macro. Rosario: Museo de Arte Contemporáneo de Rosario.

Giunta, A. (2008). Vanguardia, internacionalismo y política. Arte argentino en los años sesenta, Buenos Aires: Siglo XXI.

Gómez, A. (2007). "Libro objeto y revistas ensambladas. El lenguaje y la comunicación en los libros". Actas del Simposio de Archivos y Fondos Documentales para el Arte Contemporáneo. 30 de noviembre de 2007, Cáceres. Disponible en http://boek861.com/proartista/pry/0\%20LA\%20AG.pdf (10- 4- 2013)

Hobsbawm, E. (2009). A la zaga. Decadencia y fracaso de las vanguardias del siglo $X X$. Barcelona: Crítica.

Hopkins, D. (2000). After modern art. 1945 - 2000. Oxford: Oxford University Press.

Katzenstein, I. (ed) (2007). Escritos de vanguardia. Arte argentino en los años sesenta. Buenos Aires: Fundación Espigas - Fundación Proa - The Museum of Modern Art.

King, J. (1985). El Di Tella y el desarrollo cultural argentino en la década del sesenta. Buenos Aires: Gaglianone.

Lenci, L. (2013). "Violencia política y terrorismo de estado (1955 - 1983)". En Barreneche, O. (comp). Historia de la Provincia de Buenos Aires, Tomo 6. Buenos Aires: EDHASA, en prensa.

Link, D. (2004). "Los setenta: crisis de la literatura y algunos nombres propios". En M. Casanegra (Coord.). Entre el silencio y la violencia. Arte contemporáneo argentino. Buenos Aires: Espacio Fundación Telefónica.

Longoni, A. (1995). “Acciones de arte, acciones de violencia.” El Rodaballo 2.

Longoni, A. (1999). "Investigaciones Visuales en el Salón Nacional (1968-1971): la historia de un atisbo de modernización que terminó en clausura", en Marta Penhos y Diana Wechsler (ed.), Tras los pasos de la norma. Salones Nacionales de Bellas Artes (1911-1989). Buenos Aires: Ediciones del Jilguero, pp. 192-215.

Longoni, A. (2001). "El arte, cuando la violencia tomó la calle. Apuntes para una estética de la violencia", en: "Poderes de la imagen". I Congreso Internacional de Teoría e Historia de las Artes. IX Jornadas del CAIA, Buenos Aires, CAIA, CD-Rom.

Longoni, Ana (2005a). "Oscar Masotta: vanguardia y revolución en los años sesenta". Séptimas jornadas de artes y medios digitales, Centro Cultural España, Córdoba. Disponible en http://www.liminar.com.ar/pdf05/longoni.pdf [acceso 25/07/2008].

Longoni, A. (2005b). "Vanguardia y revolución. Ideas y prácticas artístico-políticas en la Argentina de los sesenta y setenta." Arte y Política. Pablo Oyarzún, Nelly Richard y 
Claudia Zaldívar, eds. Santiago de Chile: Consejo Nacional de la Cultura y las Artes y Universidad Arcis.

Longoni, A. (2006). "La teoría de la vanguardia como corset. Algunas aristas de la idea de 'vanguardia' en el arte argentino de los 60/70", Confines 18.

Longoni, A. (2007) "Otros inicios del conceptualismo (argentino y latinoamericano)". Papers d'Art, 93: 156.

Longoni, A. (2008). "Respuesta a Jaime Vindel”. Ramona, 82.

Longoni, Ana (2011). "Copar el museo". Ideas Visuales. Disponible en http://www.centrocultural.coop/blogs/ideasvisuales/2011/07/copar-el-museo-analongoni/ [acceso 1/02/2012].

Longoni, A. y Mestman M. (2000). Del Di Tella a "Tucumán Arde”. Vanguardia artística y política en el '68 argentin., Buenos Aires: El Cielo por Asalto.

Marchán Fiz, Simón (1997). Del arte objetual al arte del concepto. Madrid: Akal.

Méndez Llopis, C. (2012). "Revistas ensambladas. Conceptualización de las publicaciones periódicas”. Arte, Individuo y sociedad, 24 (2) 195 - 209.

Murciego, P. (2008). "Sobre las revistas ensambladas". Antequltura. Disponible en http://www.antequltura.es/art-287-ensamblados-revistas-ensambladas-1977-2008.html $(10-4-2013)$

Museum of Contemporary Art de Masssachusetts (2007). Sol LeWitt: A Wall Drawing Retrospective. Catálogo, fotografías video y audioguía de la exposición. Disponible en http://www.massmoca.org/lewitt/ [acceso 18/06/2013]

Museum of Modern Art de New York (2011). Thing/Thought: Fluxus Editiones / 1962 - 1968. Catálogo online de la exposición homónima. Disponible en http://www.moma.org/interactives/exhibitions/2011/fluxus_editions/ [acceso 30/01/2012].

O’ Donnell, G. (1977). “Estado y alianzas en la Argentina” Desarrollo económico, 64.

O’ Donnell, G. (1982). El Estado Burocrático Autoritario. Buenos Aires: Ed. de Belgrano.

Oteiza, E. (coord.) (1997). Cultura y política en los años sesenta. Buenos Aires: Universidad de Buenos Aires.

Pacheco, M. (1999). "Movimientos artísticos en Argentina desde las vanguardias históricas". Lápiz, 158/159: 31-37.

Padín, C. (1990). "Breve panorama de la poesía experimental en Argentina, Chile y Uruguay” III Bienal de Poesía Visual Experimental y alternativa. Sección Cono Sur Latinoamericano: Argentina, Chile y Uruguay, Goethe Institut Montevideo y Núcleo Post Arte México- 4 a $1 \quad 8$ de Junio 1990. Disponible en http://boek861.com/padin/br_dic/pd_dict_frame.htm [acceso 01/08/2008] 
Pérez Carreño, F. (2001). “'Institución-arte’ e intencionalidad artística”. Enrahonar, 32/33, p. 151-167.

Pijoan, J. (1914) Historia del arte: el arte al través de la historia. Barcelona: Salvat.

Portantiero, J.C. (1977). "Economía y política en la crisis argentina”. Revista Mexicana de Sociología, 2.

Pucciarelli, A. (Ed.) (1999). La primacía de la política. Buenos Aires: Eudeba.

Richard, N. (2000). La insubordinación de los signos (cambio político, transformaciones culturales y políticas de la crisis), Santiago de Chile: Cuarto Propio.

Sarlo, B. (1998). La máquina cultural, Buenos Aires: Ariel.

Sarlo, B. (2007). La batalla de la ideas (1943 - 1973). Buenos Aires: Emecé.

Sigal, S. (2002). Intelectuales y poder en Argentina. La década del sesenta. Buenos Aires: Siglo Veintiuno.

Studienzentrum für Künstlerpublikationen (s/f). "What Are Artists' Publications?”.

Weserburg - Universität Bremen. Disponible en

http://www.weserburg.de/index.php?id=81 (10 -4 - 2013)

Terán, O. (1991). Nuestros años sesentas. La formación de la nueva izquierda intelectual en la Argentina 1956 - 1966. Buenos Aires: Puntosur.

Terán, O. (2004). “Cultura y política en la década de 1970”. En M. Casanegra (Coord.). Entre el silencio y la violencia. Arte contemporáneo argentino. Buenos Aires: Espacio Fundación Telefónica.

Terán O. (2007). “Cultura, intelectuales y política en los 60”. En I. Katzenstein (ed.) Escritos de vanguardia. Arte argentino de los años '60. Buenos Aires: The Museum of Modern Art, Fundación Proa, Fundación Espigas.

Tortti, C. (1999). "Protesta social y Nueva Izquierda durante el Gran Acuerdo Nacional", en Pucciarelli, Alfredo (ed.) La primacía de la política. Lanusse, Perón y la Nueva Izquierda en tiempos del GAN. Buenos Aires: Eudeba.

Tortti, C. (2006). "La Nueva Izquierda en la historia reciente de la Argentina". Cuestiones de Sociología 3, Dpto. de Sociología, FAHCE, UNLP, La Plata, agosto 2006.

Vidal, R.; Martín, O. (2010). De Zines. Madrid: Caja Madrid.

Webster, N. (2011). "The expectation of failure is connected with the very name of a Magazine". En G. Allen. Artists' Magazines. An Alternative Space of Art. Cambridge: MIT Press.

Yoko Ono (1970). Pomelo. Buenos Aires: Ediciones de La Flor.

Yto (2003). "Clemente Padín. Artista alternativo por naturaleza". Escáner cultural, año $5, \mathrm{n}^{\circ}$ 52. Disponbile en http://www.escaner.cl/escaner52/entrevista.htm [acceso $15 / 3 / 2013]$. 


\section{BIBLIOGRAFÍA SOBRE EDGARDO VIGO Y SU OBRA:}

Aarons, P. y Roth, A. (Ed.) (2009). In numbers: Serial Publications by Artists since 1955. New York: PPP Editions y Andrew Roth Inc.

Alonso, R. (Ed.). (2011). Sistemas, acciones y procesos. 1965 - 1975. Buenos Aires: Fundación Proa.

Álvarez, L. (1997). "Vigo: hacia el tercer milenio". En Segundo Salón de la Crítica "Basilio Uribe”. Buenos Aires: Asociación Argentina de Críticos de Arte.

Álvarez Marín, R. (1991). “El circuito marginal. La vivificación del verdadero arte”. En Helft, J. (Ed.). Anteproyecto de proyecto de un pretendido panorama abarcativo. Buenos Aires: Fundación San Telmo.

Barisone, O. (2012). "Vigo y la Expo Internacional Novísima Poesía/69 (CAV-ITDT, 1969) como materialización del intercambio. Posibilidades del concretismo". Actas del VIII Congreso Internacional de Teoría y Crítica Literaria Orbis Tertius, La Plata: Centro de Estudios de Teoría y Crítica Literaria.

Basualdo, C. (1994). "Prologo a la Novela de Vigo". En Helft, J. (Ed.). Argentina. XXII Bienal Internacional de São Paulo. Buenos Aires: Fundación Banco Crédito Argentino. Publicado también en Besoytaorube, D. (2004). Edgardo-Antonio Vigo. Buenos Aires: Espacio Fundación Telefónica.

Battistozzi, A. M. (2008, 30 de agosto). "El anti arte de Edgardo Vigo". N. Revista de cultura. Disponible en http://edant.revistaenie.clarin.com/notas/2008/08/30/_01748985.htm [acceso 10/12/2008].

Battistozzi, A. M. y Giudici, A. (Ed.). (2010). Un recorrido por el arte contemporáneo argentino. Buenos Aires: Papers Editores.

Besoytaorube, D. (2004). Edgardo-Antonio Vigo. Buenos Aires: Espacio Fundación Telefónica.

Carrera, A. (1981). “Tejidos esponjosos”. Xul, 3: 29-33.

Casanegra, M. (Ed.). (2004). Entre el silencio y la violencia: arte contemporáneo argentino. Buenos Aires: ArteBA Fundación.

Centro de Arte Experimental Vigo (2007). "Un tal Vigo", Revista ramona:

http://www.ramona.org.ar/node/18175

Centro de Arte Experimental Vigo (2008). Maquinaciones. Edgardo Antonio Vigo:

trabajos 1953 - 1962. Centro Cultural de España en Buenos Aires: Museo Provincial de Bellas Artes, Córdoba; Museo Castagnino + macro, Rosario; Museo Provincial de Bellas Artes, La Plata.

Cignoni, R. (1999). "Edgardo Antonio Vigo: El fulgor de lo impensable". Tse-Tse, 6: 22-32.

Davidson, V. (2009). "From Margin to Margin and Back Again: Paulo Bruscky, Leonhard Frank Duch, and Edgardo Antonio Vigo's Mail Art Practice”. Transnational 
Latin American Art from 1950 to Present Day. The University of Texas at Austin. 6-8 de noviembre de 2009.

Davidson V. (2010). "Edgardo Antonio Vigo's Proyectos a Realizar". Anamesa an interdisciplinariy journal, 8 (1), Primavera de 2010.

Davidson, V. (2011). Paulo Bruscky and Edgardo Antonio Vigo: Pioneers in Alternative Communication Networks, Conceptualism, and Performance (1960s-1980s). Tesis doctoral, New York University. New York: UMI - Proquest.

Davis, F. (2002). "El Museo de la Xilografía de La Plata y la poética de un 'arte a realizar' en Edgardo Antonio Vigo" Muestra acervo del Museo de la Xilografía de la Plata. Re-vuelta, cat. exp. Fundación Centro de las Artes Visuales, La Plata.

Davis, F. (2004). "Edgardo-Antonio Vigo. Xilografías y ediciones (1962 - 1972)". En Edgardo-Antonio Vigo. Xilografías y ediciones (1962 - 1972) (catálogo). Buenos Aires: Museo Nacional del Grabado.

Davis, F. (2006). "Poéticas oblicuas. Diagonal Cero y la 'poesía para y/o a realizar' en Edgardo Antonio Vigo (1962-1970)", en: VV. AA. 2das. Jornadas de Investigación en Disciplinas Artísticas y Proyectuales, La Plata, Facultad de Bellas Artes - UNLP [CDRom]

Davis, Fernando (2007a) "Edgardo Antonio Vigo y las poéticas de la 'revulsión"”. Inédito.

Davis, F. (2007b). "Reencontrarse con Vigo". Ramona, 76: 10-20.

Davis, F. (2007c). "Señalar y revulsionar. Edgardo Antonio Vigo en los márgenes de la poesía" en: VV. AA. V Jornadas sobre Arte y Arquitectura en Argentina, La Plata, Instituto de Historia del Arte Argentino y Americano, Facultad de Bellas Artes - UNLP [CD-Rom]

Davis, F. (2008). “El conceptualismo como categoría táctica”. Ramona, 82.

Davis, F. (2009a). "Dispositivos tácticos. Notas para pensar los conceptualismos en argentina en los 60/ 70" Territorio Teatral, $\mathrm{n}^{\circ}$ 4. Disponible en: http://territorioteatral.org.ar/html.2/dossier/n4_02.html

Davis, F. (2009b). "La poesía fuera de sí. La Expo/ Internacional de Novísima Poesía en el Instituto Torcuato Di Tella" El Surmenage. Capítulo II, Año 2, Número 3, Buenos Aires.

Davis, F. (2009c). "Prácticas 'revulsivas'. Edgardo Antonio Vigo en el escena crítica del conceptualismo" en: Cristina Freire y Ana Longoni (orgs.). Conceitualismos do Sul/ Conceptualismos del Sur, São Paulo, Annablume.

Davis, F. (2010). "Political bodies, territories in conflict". En Hans Christ e Iris Dressler (Eds.). Subversive Practices. Art under Conditions of Political Repression: 60s-80s / South America / Europe. Stuttgart: Hatje Cantz y Württembeirgischer Kunstverein Stuttgart.

Davis, F. "Otro encuentro con Edgardo Antonio Vigo". Http://www.ramona.org.ar/node/19186 
De Rueda, M. (1997). "La exaltación del objeto y sus tendencias en el Arte Argentino, E. A. Vigo y Parte X" en: V.V.A.A. Nuevos ensayos de arte, Federico Jorge Klemm, Buenos Aires.

De Rueda, M. (2003a). "La incorporación de artistas platenses al conceptualismo latinoamericano (De Vigo y el Movimiento Diagonal Cero al Grupo de La Plata y Escombros)". Disponible en: http://www.fba.unlp.edu.ar/visuales3

De Rueda, M. (coord.) (2003b). Arte y utopía. La ciudad desde las artes visuales. Buenos Aires: Asunto impreso.

De Rueda, M. (2007). "Preludio a la avanzada artística en La Plata: armando el campo a comienzos de los 60" en: VV. AA. V Jornadas sobre Arte y Arquitectura en Argentina, La Plata, Instituto de Historia del Arte Argentino y Americano, Facultad de Bellas Artes - UNLP [CD-Rom]

Dolinko, S. (2008). "Circulación de xilografías y poesías latinoamericanas a través de la Diagonal Cero de Edgardo Antonio Vigo". Marcela Drien, Fernando Guzmán y Juan Manuel Martínez (ed.), América: territorio de transferencias, Valparaíso, Facultad de Humanidades de la Universidad Adolfo Ibáñez y Museo Histórico Nacional, pp. 245 254.

Dolinko, S. (2009). "Gráfica con dinámica latinoamericana: Edgado Antonio Vigo y Diagonal Cero". En Giunta, A. (comp.), Metrópolis de papel. Revistas y redes internacionales en la modernidad artística latinoamericana, Buenos Aires: Biblos.

Dolinko, S. (2010a). "Edgardo-Antonio Vigo. Sin título". En Museo Nacional de Bellas Artes, Colección. 2. vol. II. Buenos Aires; Asociación Amigos del MNBA.

Dolinko, S. (2010b). "Poesía, gráfica y compromiso. Edgardo Vigo y la red contracultural de los años “60s”. Actas del XXX Colóquio do Comitê Brasileiro de História da Arte, Rio de Janeiro.

Dolinko, S. (2012a). "Edgardo Antonio Vigo, vanguardia y contracultura en los años sesenta". Pós, 2, p. 98 - 113.

Dolinko, S. (2012b). Arte plural. El grabado entre la tradición y la experimentación. Buenos Aires: Edhasa.

Dolinko, S. (2013). Cooperativa gráfica. Buenos Aires: Fondo Nacional de las Artes.

Fajole, F. (2002). "Edgardo Antonio Vigo. Poétique à bascule”. Manglar, 1: s/p.

Fajole, F. (2003). "Poética de Edgardo-Antonio Vigo en la segunda/tercera dimensión de la no-linealidad: las condiciones espaciales de un arte contradictorio". Movimiento Actual, 131, p. 25-32.

Farina, F. (1995). "Un arte a realizar". En Retrospectiva de Edgardo A. Vigo. Rosario: Museo Municipal Juan B. Castagnino. También publicado en Espacio de Arte, 2 (5).

Farina, F; Echen, R. y Rojas, N. (Eds.). (2004). Arte Argentino Contemporáneo. Macro. Rosario: Museo de Arte Contemporáneo de Rosario. 
García Canclini, N. (1973). García Canclini, N. (1973). "Vanguardias artísticas y cultura popular". En Enciclopedia Transformaciones. Buenos Aires: Centro Editor de América Latina: 253-280.

García Canclini, N. (1977). Arte popular y sociedad en América Latina. México: Grijalbo.

García Delgado, F. (1999). "Arte correo. Comunicación a distancia". Tsé-Tsé, 6.

García Delgado, F. y Romero, J. C. (2005). El arte correo en Argentina. Buenos Aires: Vórtice Argentina.

Giudici, A. (Ed.). (2002). Arte y política en los '60. Buenos Aires: Palais de Glace Fundación Banco Ciudad.

Glusberg, J (1985). Arte en la Argentina. Del pop-art a la nueva imagen. Buenos Aires: Ediciones de Arte Gaglianone.

Gradin, C. (2010). "Poesía, imágenes y medios de comunicación en la revista Diagonal Cero (1962 -1969)". IV Congreso Internacional de letras. Buenos Aires: Universidad de Buenos Aires.

Gradin, C. (2011). "Un foco en la selva de los medios. Revista Hexágono (1971-1975)". Laboratorio, 4. Disponible en http://www.revistalaboratorio.cl/2011/06/un-foco-en-laselva-de-los-medios-revista-hexagono-1971-1975/ [acceso 23/05/2013]

Gradowczyk, M. (2008). "Edgardo Antonio Vigo: Maquinaciones (1953 - 1962)" Maquinaciones. Edgardo Antonio Vigo: trabajos 1953 - 1962, cat. exp., Centro Cultural de España en Buenos Aires: Museo Provincial de Bellas Artes, Córdoba; Museo Castagnino + macro, Rosario; Museo Provincial de Bellas Artes, La Plata.

Gutiérrez, P. J. (2004). “El Juego de Vigo”. En Centro de Arte Experimental Vigo (Ed.). El Juego de Vigo. La Plata: Teatro Argentino.

Gutiérrez Marx, G. (2002). "Un teorema no formulado = La marca de Vigo". En A. M. Gualtieri (Ed.). Record-ando a Vigo. Buenos Aires: Fondo Nacional de las Artes Espacio Ojo al país.

Herrera, M. J. (2004). "Vigo en (con) texto". En Besoytaorube, D. (Ed). EdgardoAntonio Vigo. Buenos Aires: Espacio Fundación Telefónica.

Kozak, C. (2007). "Construcción y exploración de lenguajes. Del poema proceso a la tecnopoesía". II Jornadas Internacionales "Poesía y Experimentación, Córdoba:

Universidad Nacional de Córdoba. Disponible en: www.exposeia.com.ar/j07_kozak.html [acceso 2/07/08]

Kozak, C. (Ed.) (2012). Tecnopoéticas argentinas. Archivo blando y tecnología. Buenos Aires: Caja Negra.

Longoni, A. (2008). "Arte de acción en Argentina desde 1960: (Ex)poner el cuerpo". En Deborah Cullen (Ed.). Arte $\neq$ Vida. Actions by Artists of the Americas. 1960-2000. New York: El Museo del Barrio. 
López, M. (2010). "How Do We Know What Latin American Conceptualism Looks Like?”. Afterall, 23.

López Anaya, J. (1997, 16 de agosto). "Vigo y la contradicción”. La Nación, sección II, p. 6.

López Anaya, J. (1999). “Conceptualismo en Argentina”. Lápiz, 158/159: 83-91.

Marín, M. (2012). Discursos gráficos: artistas y grupos de producción gráfica entre 1960 y 1990 . Buenos Aires : Fundación OSDE.

Monteleone, J. (2010). 200 años de poesía argentina. Buenos Aires: Alfaguara.

Morais, F. (Ed.). (1997). I Bienal de Artes Visuales del Mercosur. Porto Alegre:

Fundacão Bienal de Artes Visuais do Mercosul.

Nessi, Á. (dir.). (1982). Diccionario Temático de las Artes en La Plata. La Plata:

Instituto de Historia del Arte Argentino y Americano, Facultad de Bellas Artes - UNLP.

Nessi, Á. (1994). "Edgardo-Antonio Vigo. Cuarenta años de (in) obras de arte". En 1954 - 1994. Edgardo-Antonio Vigo. La Plata: Fundación Artes Visuales.

Noorthoorn V. y Yáñez, C. (Eds.). (2009). $7^{a}$ Bienal do Mercosul: Grito e escuta. Porto Alegre: Fundaçao Bienal do Mercosul.

Pacheco, M. (1997). "Edgardo Vigo, vía aérea". Magazine Literario, 3:15.

Padín, C. (1997). "Edgardo Antonio Vigo: Vocación Libertaria". Merzmail. Disponible en http://www.merzmail.net/edgardo.htm [acceso 15/09/08]

Padín, C. (2007). "Recordando a Edgardo Antonio Vigo en los 10 años de su fallecimiento". Escáner Cultural. Disponible en http://revista.escaner.cl/node/180 [acceso 25/10/2008]

Pérez Balbi, M. (2006). "Movimiento Diagonal Cero: poesía experimental desde La Plata (1966-1969)", Escaner cultural. Disponible en: http://revista.escaner.cl/node/277 [acceso 10/07/2008].

Perkins, S. (1997). Assembling Magazines. International Networking Collaborations. Iowa City: Half-legal.

Perkins, S. (2005). “Assembling Magazines and Alternative Artists' Networks". En A. Chandler y N. Neumark (Eds.). At a distance. Cambridge: MIT Press.

Perneczky, G. (1993). The magazine network. The trends of alternative art in the light of their periodicals. 1968 - 1988. Köln: Soft Geometry.

Perneczky, G. (2003). Network Atlas. Works and Publications by the People of the First Network . Vol. 2: O - Z. Cologne: Geza Perneczky Soft Geometry.

Plante, I. (2013). Argentinos de París. Arte y viajes culturales durante los años sesenta. Buenos Aires: Edhasa.

Rivero, Á. (1981). “Poesía concreta: una introducción”. Xul, 2, p. 33-46. 
Romero, J. C. (1999). "Edgardo A.Vigo: En definitiva, un arte contradictorio". Disponible en http://www.eavigo.com.ar/ [acceso 16/08/2010]

Romero, J. C., Davis, F. y Longoni, A. (2010). Romero. Buenos Aires: Fundación Espigas.

Santanera, C. (2009). "CC 264 Vía postal. Edgardo Antonio Vigo". En CC 264 Vía postal. Edgardo Antonio Vigo (catálogo) Córdoba: Centro Cultural España Córdoba.

Sarmiento, J. A. (2009). "La poesía total". En Sarmiento, J. A. (Ed.). Escrituras en libertad. Poesía experimental española e hispanoamericana del siglo XX. Madrid: Instituto Cervantes, Sociedad Estatal de Conmemoraciones Culturales, Agencia Española de Cooperación Internacional para el Desarrollo.

Storr, R. (2010). "Post Script". Frieze. Contemporary Art and Culture, 132: 15.

Xul. (1993) "Edgardo Vigo: La zona visual de la poesía argentina”. Xul, 10: 51-53.

Zabala, H. (1987). "Las obras de Edgardo-Antonio Vigo: transgresión, irregularidad, incertidumbre”. En E. Vigo (Ed.). Off; Off... La Plata: Fundación Artes Visuales. Publicado también en Besoytaorube, D. (Ed). (2004). Edgardo-Antonio Vigo. Buenos Aires: Espacio Fundación Telefónica.

\section{FUENTES CITADAS}

\section{A. TEXTOS ESCRITOS POR EDGARDO VIGO}

Vigo, E. (1968). “Manifiesto”. En Manojo de semáforos. La Plata: Ed. Diagonal Cero.Vigo, E. (15/12/68). "La revolución en el arte”. El Día,

Vigo, E. (15/12/68). "La revolución en el arte”. El Día.

Vigo, E. (1969). "Plebiscito gratuito Señalamiento IV". Carpeta: Señalamiento IV

Vigo, E. (21/01/69). 'Ipotesi per una rassegna di poesia. L' 'Expo internacional' di Buenos Aires"; Corriere del Giorno.

Vigo, E. (25/06/69). “Un arte a realizar”, Ritmo n³, La Plata

Vigo, E. (7/7/69). “Exp. 69-I / Di Tella”. Ritmo, s/d.

Vigo, E. (25/08/69). "No-arte-Si”. Ritmo, 5.

Vigo, E. (1970). De la poesía/proceso a la poesía para y/o a realizar. La Plata: Diagonal Cero.

Vigo, E. (1970). Correspondencia dirigida a Jorge Romero Brest como director de la Asociación Argentina de Críticos de Arte. Caja Biopsia 1970.

Vigo, E. (23/10/70). "Desde la poesía-proceso a la poesía para realizar. La vanguardia poética”. El Popular, Montevideo.

Vigo, E. (1971). “Acción de señalar”. Manuscrito, Carpeta: Señalamiento VIII. 
Vigo, E. (1971). “La calle: escenario del arte actual”. Hexágono '71, be.

Vigo, E. (1972). "La (in)comunicación de los medios de comunicación masivos (por caso la TV)”. Manuscrito, Caja Biopsia 1972

Vigo, E. (19/03/73). “Arte de sistemas”. Gacetilla del CAYC, GT-212.

Vigo, E. (25/03/73) “Arte de sistemas”. El Día.

Vigo, E. (1974). "Museo de la Xilografía de La Plata". Tríptico. La Plata: Museo de la Xilografía de La Plata.

Vigo, E. (1974) “Tenth happening also called From the lemon tree”, Ghost Dance, 18.

Vigo, E. [c.1974]. “Señalamiento”, Carpeta Señalamientos.

Vigo, E. (1975). "Sellado a mano". Hexágono '71, e.

Vigo, E. (s/f). "Hacia una nueva terminología". Carpeta Poesía visual. Archivo CAEV.

Vigo, E. (s/f). "Publicaciones". Archivo CAEV.

\section{B. EDICIONES Y PUBLICACIONES DE EDGARDO VIGO}

Revistón clandestino envasado

Revista visual clandestina

Biblia Relativuzgir's

Diagonal Cero (28 números), 1 al 28, 1962 - 1968.

Hexágono '71 (13 números), a al e, 1971 - 1975.

DRKW (3 números) A, B, C. 1960.

WC, (5 números) 1, 2, 3, 4, 5. 1958 - 1960

Poemes Mathematiques Barroques. París, Contexte, 1967. 2da. edición: París, Agentzia, 1968.

De la poesía proceso a la poesía para y/o a realizar. La Plata, Editorial Diagonal Cero, 1969.

Sellado a mano. La Plata, Editorial Hexágono ‘71, 1974.

Carpeta Sonidos (Che, vida)

Ediciones de grabados de Diagonal Cero

Edición de cuentos En esta orilla de Lejama Lapidus.

Edición 20 hilos de tamaños diferentes y 1 estampilla anulada

Edición Tres detalles de una obra que no me pertenece 


\section{ARTÍCULOS PERIODÍSTICOS}

Análisis, (1 al 7/04/1969) “Avioncitos y poetas”, IX (420).

Clarín, (20/03/69). "Exposición Internacional de Novísima Poesía 69”

De Sá, Á. (1969). "Poesia de vanguarda na Argentina". Jornal do escritor. Octubre 1969.

Diario Tribuna de América (1967, enero). "Centro de Estudio 'Dag Hammarskjold",, La Plata.

El Argentino. (21/11/1972). “¿La muestra más corta del mundo?”.

El Argentino (23/12/1972). "El barrilete de Vigo".

El Civismo (18/10/1975). “Galería del pequeño formato". Luján.

El Día. (09/06/1968). "Experiencias 68 en el Di Tella”.

El Día. (19/10/1968) "Manojo de semáforos”.

El Día. (25/10/1968) “"Experiencia artística’ en 1 y 60”.

El Día, (16/03/1969). "Donde mueren las palabras".

El Día, (13/04/1969). “La poesía loca”.

El Día. (14/03/1970). "Edgardo A. Vigo inaugurará hoy una exposición”.

El Día. (8/10/1972). “¿La máxima! Nuestro Zoológico se transformó en un salón de exposiciones".

El Día. (22/11/1972). "Fue clausurada una muestra de arte platense".

El Día (22/12/1972). "La Plata participará de una experiencia el domingo: significado".

El Día. (07/01/1973). "Hexágono: U.N.O. más que U.S.A.”.

El Día (13/05/73). “Grabadores exponen”. Sección Artes, libros y espectáculos, p. 14.

El Día. (14/03/74). "Artistas platenses en el Museo de Arte de N. York”.

El Diario, (22/04/69). "Maestría en el impacto". Montevideo.

Ehrenberg, F. (1974) "Hexágono '71 and other tid-bits published by Edgardo Antonio Vigo". Kontexts, 5, ed. Michael Gobbs, Devon.

El popular (1969). “Las 'Obras (in) completas’ de Edgardo Antonio Vigo”. Sección La nueva poesía, Uruguay.

El Popular. (9/10/70). "La nueva poesía", Uruguay.

Fox, H. (1970). [s/título]. The pan american review, Texas, 1 (1). 
Gaceta de la tarde. (6/10/68). "Manojo de semáforos".

La Nación (29/03/69). "Poesía, a pesar de todo".

La Razón (19/03/69). "Estalló la Revolución en la Poesía".

La Razón. (9/11/70). "Triste fin tuvo una experiencia.

La Tribuna (25/06/1968). "Edgardo Antonio Vigo habla de su arte", Asunción.

Primera Plana. (24/09/1968). "No tanta risa".

Primera Plana (1 al 7/04/69) "Expo/Internacional de Novísima Poesía".

Primera Plana (1969, 13 al 19 de mayo), VII (333).

Revista 7 y 50. (1/12/72). "Panorama 72 (clausurado) de arte platense". Revista 7 y 50, 4.

Ritmo. (1970). “Arte, Boutique y Votos”, Ritmo, 7.

Saez, H. (23/05/69). "Expo de Novísima Poesía”. Los Andes.

\section{VARIOS}

$2^{\circ}$ Incontro Internazionale d'avanguardia "Parole sui muri”, Fiumalbo, 1968.

Boletín informativo (1969), Expo/Internacional de novísima poesía /69, Instituto Torcuato Di Tella, Centro de Artes Visuales, 1.

COFAPPEG (Comision Familiares Presos Políticos Estudiantiles y Gremiales) (Ed.). (1974). Informe sobre Trelew.

\section{ENTREVISTAS CITADAS}

\section{A. PUBLICADAS:}

En Marcha (1994). “Un judicial en la Bienal de San Pablo” [entrevista a Edgardo Vigo]. Tragaluz 1 (1), 4- 5.

Janssen, R. (1998). Correo-Entrevista con Edgardo Antonio Vigo. TAM -

Publicaciones, TAM-980184.

La Grieta (1997). "Debate. 'Pero Juanito sigue ahî” [conversación entre Edgardo Vigo, Alfredo Benavídez Bedoya y público]. La Náusea, 2.

La Grieta (1997). “Islas comunitarias” [conversación con Edgardo Vigo]. La Náusea, 2.

Nessi, Á. (1994). "Edgardo-Antonio Vigo. Cuarenta años de (in) obras de arte" [entrevista a Edgardo Vigo]. En 1954 - 1994. Edgardo-Antonio Vigo. La Plata: Fundación Artes Visuales. 
Noé, L. F. (1973). El arte de América Latina es la revolución [entrevista a Luis Felipe Noé]. Santiago de Chile: Ed. Andrés Bello.

\section{B. INÉDITAS}

Entrevistas a Vigo realizadas por Mónica Curell, 1995. (Grabaciones en VHS) CAEV.

Entrevista a Luis Pazos realizada por Ana María Gualtieri. 2004. CAEV.

Entrevista a Jorge D’Elía realizada por Ana María Gualtieri, 2005. CAEV.

Entrevista a Carlos Ginzburg por Ana María Gualtieri, 2010. CAEV

Entrevista personal a Graciela Gutiérrez Marx, 2010.

Entrevista personal a Clemente Padín, 2012.

Entrevista a Carlos Ginzburg, 2012.

Entrevista a Juan Carlos Romero, 2013. 